Portland State University

PDXScholar

\title{
The Geology of Parrett Mountain, Oregon, and its Influences on the Local Groundwater Systems
}

\author{
Brett Todd Brodersen \\ Portland State University
}

Follow this and additional works at: https://pdxscholar.library.pdx.edu/open_access_etds

Part of the Geology Commons

Let us know how access to this document benefits you.

\section{Recommended Citation}

Brodersen, Brett Todd, "The Geology of Parrett Mountain, Oregon, and its Influences on the Local Groundwater Systems" (1994). Dissertations and Theses. Paper 5245.

https://doi.org/10.15760/etd.7118

This Thesis is brought to you for free and open access. It has been accepted for inclusion in Dissertations and Theses by an authorized administrator of PDXScholar. Please contact us if we can make this document more accessible: pdxscholar@pdx.edu. 


\section{THESIS APPROVAL}

The abstract and thesis of Brett Todd Brodersen for the Master of Science in Geology, specializing in Geohydrology were presented on september 20, 1994 and accepted by the thesis committee and the department. COMMITTEE APPROVALS :

DEPARTMENT APPROVAL:
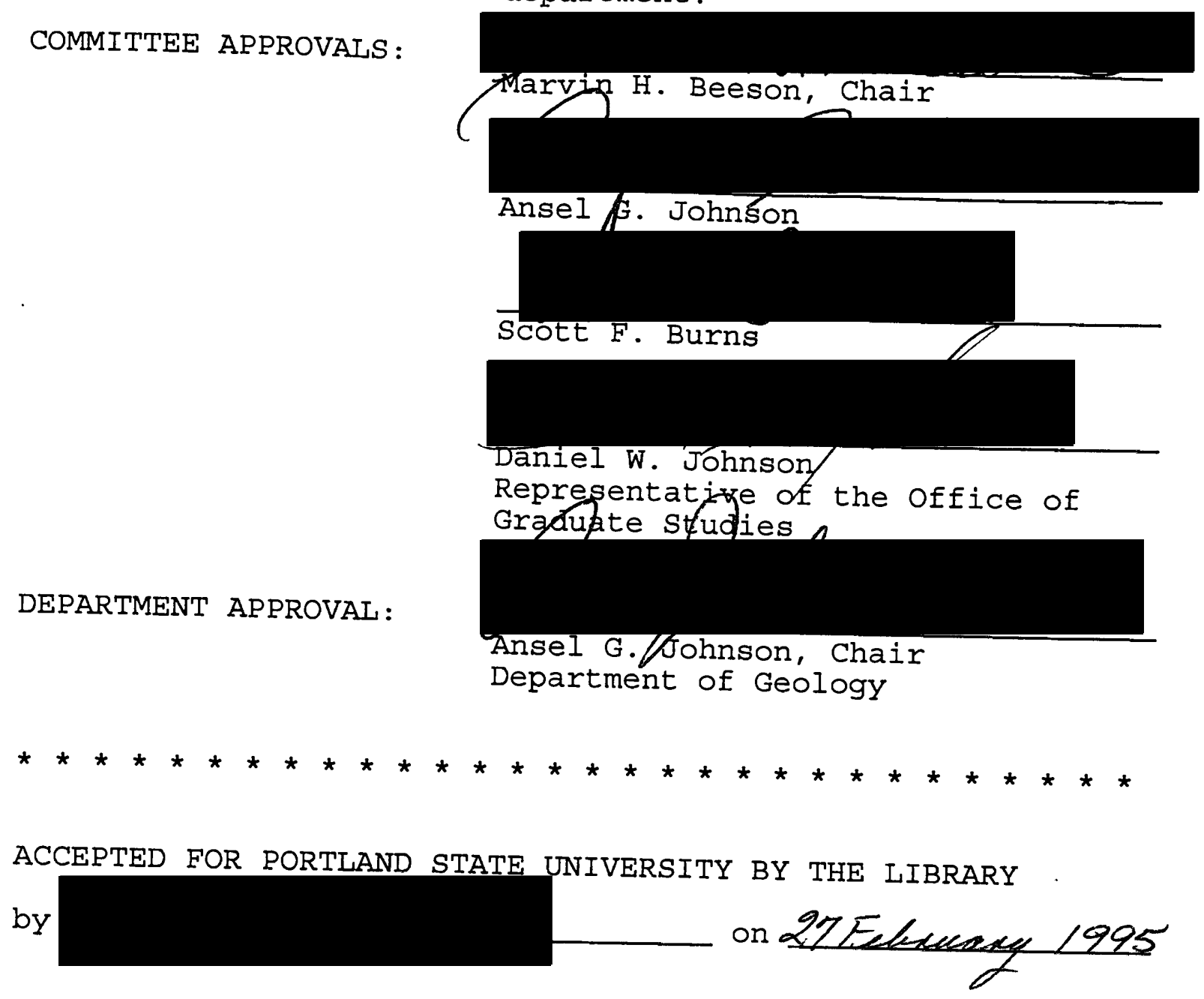
Representative of the office of Gradupte studies 


\section{ABSTRȦCT}

An abstract of the thesis of Brett Todd Bxodersen for the Master of Science in Geology specializing in Geohydrology presented September 20, 1994.

Title: The Geology of Parrett Mountain, Oregon, and its Influences on the Local Groundwater systems.

A geologic study of the Parrett Mountain area, located twenty miles (32 kms) south-southwest of Portland, Oregon, was initiated by the Oregon Water Resources Department. The main goal was to create a stratigraphic and structural model of Parrett Mountain in order to better understand the local basalt aquifers present there.

Previous geologic studies of the area revealed the mountain to be composed of Columbia River basalt. Field mapping and hand lithologic and geochemical analyses allowed the basalt to be subdivided into eleven basalt flows. These flows are as follows: (from oldest to youngest) the Wapshilla Ridge (WpR), the Ortley-Grouse Creek (undifferentiated) (OGC), the Umtanum (U), the Winter Water (WW), and the sentinel Bluffs (SB) basalt units of the Grande Ronde Basalt and the Ginkgo (Gk) flow of the Frenchman Springs Member of the Wanapum Basalt. All the basalt flows were found to be laterally extensive throughout 
the entire area creating a stacked pancake-layered structure.

Thickness variations in the Wapshilla Ridge, OrtleyGrouse Creek and Ginkgo basalt flows reflect paleotopographic relief present during the emplacement of the basalt flows. Sedimentary interbeds appear to be highly localized, occurring sporadically throughout the entire area stratigraphic column.

Faults were identified based on geologic map compilation, cross section analysis, and topographic linear features. They trend N-S, E-W, NE and NW and are believed to dissect the entire basalt column. All faults have been designated with a normal sense of displacement, except those known to be thrust or reverse. Cross-cutting relationnships suggest the NS-trending faults are the youngest and the NWtrending faults are the oldest. The faulting created twenty-four separate basalt blocks, each represented by a distinct strike and dip.

Flowtop morphology, stratigraphic layering, and the local geologic structures influence local groundwater systems. All flow boundaries yield water to at least one well on the mountain. The most commonly used aquifers are the U/OGC boundary, interflow zones within the OGC, the OGC/WpR boundary and permeable zones within the WpR. Faulting is believed to promote recharge of the groundwater systems by increasing the vertical infiltration of 
percolating precipitation through the highly fractured fault zone. 
THE GEOLOGY OF PARRETT MOUNTAIN, OREGON, AND ITS INFLUENCES ON THE LOCAL GROUNDWATER SYSTEMS

by

BRETT TODD BRODERSEN

A thesis submitted in partial fulfillment of the requirements for the degree of

\author{
MASTER OF SCIENCE \\ in \\ GEOLOGY \\ specializing in \\ GEOHYDROLOGY
}

Portland State University

1995 


\section{ACKNOWLEDGEMENTS}

I would like to thank my family for the love and support they provided for me during this study.

Second, I would like to thank the Oregon water Resources Department, especially Donn Miller, Sara Gates, and Mike Zwort. Without their help and data, this thesis would not have been possible.

Finally, I would like to thank all of the residents of Parrett Mountain, and the members of C.A.R.E. and Friends of Parrett Mountain (FOPM) for providing background history and knowledge of the area. 
TABLE OF CONTENTS

ACKNOWLEDGEMENTS. . . . . . . . . . . . . . . . . . . . . i

TABLE OF CONTENTS. . . . . . . . . . . . . . . . . . ii

LIST OF FIGURES. . . . . . . . . . . . . . . . . . . .viii

LIST OF TABLES. . . . . . . . . . . . . . . . . . . xiii

LIST OF PLATES . . . . . . . . . . . . . . . . . . XIV

INTRODUCTION . . . . . . . . . . . . . . . . . . . 1

TOPOGRAPHY . . . . . . . . . . . . . . . . 3

Parrett Mountain . . . . . . . . . 5

The Tonquin area . . . . . . . . . 6

The Hess Creek-Spring Brook Area . . . . . 6

CLIMATE . . . . . . . . . . . . . . . . . . 7

REGIONAL GEOLOGY . . . . . . . . . . . . . . 10

GEOLOGIC SETTING . . . . . . . . . . . . . . 10

REGIONAL STRATIGRAPHY . . . . . . . . . . . . 14

Oligocene-Miocene Sedimentary Rocks . . . . 14

Columbia River Basalt Group . . . . . . . 15

Helvetia Formation . . . . . . . . . 18

Troutdale Formation . . . . . . . . . 19

Willamette Silt............ . 19

Alluvium . . . . . . . . . . . . 20

REGIONAL STRUCTURE . . . . . . . . . . . . 21

Gales Creek-Mount Angel Structural Zone . . . 22

Gales Creek Fault . . . . . . . . 22 
Newberg Fault . . . . . . . . . 22

Mount Angel Fault . . . . . . . 25

Seismicity . . . . . . . . . 25

Sherwood Fault . . . . . . . . . . 26

HYDROGEOLOGIC UNITS . . . . . . . . . . . 27

Oligocene-Miocene Sedimentary Rocks . . . . 27

Columbia River Basalt Group . . . . . . . 28

Troutdale Formation . . . . . . . . . . 29

Willamette Silt............. . 29

METHODOLOGY . . . . . . . . . . . . . . . 30

FIELD MAPPING ............... . 30

Springs . . . . . . . . . . . . 33

STRATIGRAPHY . . . . . . . . . . . . . . . 33

Stratigraphy Based on Well Reports . . . . 33

Stratigraphy based on Drilling Chips . . . . 34

Cross Sections . . . . . . . . . . 35

GEOCHEMICAL ANALYSIS . . . . . . . . . . 36.

X-ray Fluorescence . . . . . . . . . . 36

Instrumental Neutron Activation Analysis . . 38

POTENTIOMETRIC HEAD ANALYSIS . . . . . . . . . 41

BASALT STRATIGRAPHY . . . . . . . . . . . . . . 45

GRANDE RONDE BASALT . . . . . . . . . . . . . 45

Wapshilla Ridge Basalt Unit . . . . . . . 45

Ortley-Grouse Creek (undifferentiated) Basalt

Unit . . . . . . . . . . . . . . 49

Umtanum Basalt Unit . . . . . . . . . 51 
Winter Water Basalt Unit . . . . . . . . 54

Sentinel Bluffs Basalt Unit . . . . . . . . 55 WANAPUM . . . . . . . . . . . . . . . . . . . 58

Frenchman Springs Member: Ginkgo flow . . . 58 INTERBEDS . . . . . . . . . . . . . . . . . . 60

The Vantage Horizon . . . . . . . . . 60

Other Interflow Deposits . . . . . . . . 62 PALEOTOPOGRAPHY • • . . . . . . . . . . . . . 62

Wapshilla Ridge Basalt Unit . . . . . . . 63

Ortley-Grouse Creek (undifferentiated) Basalt Unit . . . . . . . . . . . . . . 64

Ginkgo Basalt Flow . . . . . . . . . . 65

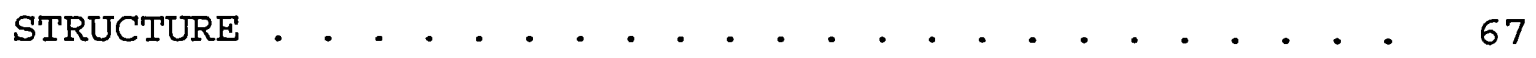

FAULTS . • • • . • . . . . . . . . . . . . . . 67

North/South-Trending Faults . . . . . . . . 74

East/West-Trending Faults . . . . . . . . 75

Northeast-Trending Faults . . . . . . . . 76

Sherwood Fault . . . . . . . . . . 77

Corral Creek-Earlwood Fault . . . . . . 77

Manke and Rim Faults . . . . . . . . 78

Pleasant Hill Fault . . . . . . . . 79

Dammasch Fault . . . . . . . . . . 79

Willamette Fault . . . . . . . . . . 79

The Northwest-Trending Faults . . . . . . 80

Mill Creek, Ladd Hill, and Heater

Faults . . . . . . . . . . . 80 
Middle Fork of Corral Creek Lineation . . 80 Roberts Hills Fault . . . . . . . . 81 Seely Ditch Fault . . . . . . . . 81 STRIKE AND DIP................. . . 82 STRUCTURAL CONTOUR MAPS ............ 83 GROUNDWATER . . . . . . . . . . . . . . . . 91 GROUNDWATER OCCURRENCE . . . . . . . . . . . . . 91 Alluvial/Colluvial Aquifers . . . . . . . 91 Basalt Aquifers . . . . . . . . . . . 93 GEOLOGIC INFLUENCES ON GROUNDWATER MIGRATION . . . 96 Stratigraphy . . . . . . . . . . . . 96 Lateral . . . . . . . . . . . . 96 Vertical . . . . . . . . . . . 97 Morphology . . . . . . . . . . . . . 100 Flowtop . . . . . . . . . . . 100 Basalt Flow Interior. . . . . . 100 Faulting . . . . . . . . . . . . 101 The Rim and Manke Faults . . . . . 101 Sherwood Fault. . . . . . . . 103 GROUNDWATER BARRIERS . . . . . . . . . . . 103 PARRETT MOUNTAIN GROUNDWATER MODEL . . . . . . 104 Aquifers . . . . . . . . . . . . 104 Interflow Zones . . . . . . . . . 104 The Wapshilla Ridge Aquifer . . . . . 104 Recharge ............... 106

Exposed Flowtops . . . . . . . . 108 
Faults . . . . . . . . . . 106

Landslides . . . . . . . . . . 109

Vertical Infiltration . . . . . . . 111

Discharge . . . . . . . . . . . . 111

Groundwater Pumpage . . . . . . . 111

Vertical Seepage......... . 112

Springs . . . . . . . . . . 116

GROUNDWATER CHEMISTRY . . . . . . . . . . 118

Tritium . . . . . . . . . . . 118

Groundwater Geochemistry . . . . . . . 122

Saline Water .......... . . . 123

Occurrence of Saline Water . . . . . 123

QUATERNARY GEOLOGY . . . . . . . . . . . . . 127

GLACIAL FLOOD EFFECTS . . . . . . . . . . 127

Tonquin Scablands . . . . . . . . . . 129

Parrett Mountain ............ 132

The Helvetia Formation . . . . . . 132

Loess . . . . . . . . . . . 133

LANDSLIDES . . . . . . . . . . . . . . . . 133

FUTURE WORK . . . . . . . . . . . . . . . . . 140

GEOLOGY . . . . . . . . . . . . . . . . 140

Stratigraphy . . . . . . . . . . . . . 140

structure . . . . . . . . . . . 140

Landslides . . . . . . . . . . . . 141

HYDROGEOLOGY . . . . . . . . . . . . . . . . 141

Basalt Aquifers . . . . . . . . . . . 141 
CONCLUSION AND SUMMARY . . . . . . . . . . . . . . . . 143 GEOLOGY • • • • • . . . . . . . . . . . . . 143

Stratigraphy . . . . . . . . . . . . . 143

Structure . . . . . . . . . . . . . . . 145

Quaternary Processes . . . . . . . . . 146

GROUNDWATER . . . . . . . . . . . . . . . . 146

REFERENCES

APPENDIX A

APPENDIX B . . . . . . . . . . . . . . . . . . . 183

APPENDIX C . . . . . . . . . . . . . . . . . . . . . . . . . 256 


\section{LIST OF FIGURES}

Figure 1. Topographic view of the geologic study area. . 2 Figure 2. The three distinct physiographic provinces comprising the study area. . . . . . . . 4

Figure 3. Regional geologic map encompassing the

Parrett Mountain area (Schlicker and Deacon, 1967). . . . . . . . . .

Figure 4. A generalized stratigraphic column representative of the Parrett Mountain study area (Modified from Schlicker and Deacon, 1967). . . . . . . . . . .

Figure 5. Stratigraphic framework of the Columbia River Basalt Group (Modified from Beeson and others, 1989). . . . . . . . . . .

Figure 6. The convergence and subduction of the Juan de Fuca Plate against the North American Plate (Yeats and others, 1991). . . .

Figure 7. Regional view of the tectonic features comprising the northern willamette Valley.

Figure 8 . Cross section of a basalt flow showing the distinct jointing patterns and lithologic features in regards to occurrence with in a basalt flow. . . . . . . . . . 32 
Figure 9. Location of wells where XRF and INAA

samples were collected. . . . . . . 40

Figure 10. Diagram representing the quarter- quarter-

averaging system used to define a

potentiometric surface map. . . . . .

Figure 11. A representative stratigraphic column of the

Columbia River basalt comprising Parrett

Mountain. . . . . . . . . . . 46

Figure 12. Exposure of the Wapshilla Ridge basalt along

the Fernwood Road. . . . . . . . . . 48

Figure 13. Exposure of the Sentinel Bluffs basalt along

highway 99 W. . . . . . . . . . . 57

Figure 14. Typical appearance of the Vantage Horizon

on Parrett Mountain. . . . . . . . 61

Figure 15. Cross section $\mathrm{AA}^{\prime}$. . . . . . . . . . 68

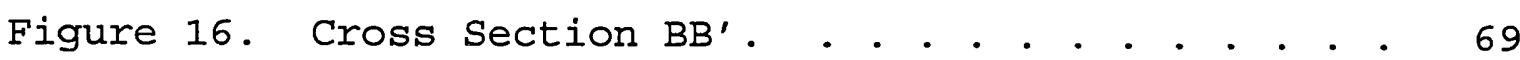

Figure 17. Cross Section $\mathrm{CC}^{\prime}$. . . . . . . . . . 70

Figure 18. Cross Section $\mathrm{C}^{\prime} \mathrm{C}^{\prime \prime}$. . . . . . . . . 71

Figure 19. Basalt block designation. . . . . . . . . 73

Figure 20a. Contour elevations of the Ginkgo flow/

Sentinel Bluffs basalt unit boundary. . . 84

Figure 20b. Contour elevation of the Sentinel Bluffs/

Winter Water basalt units boundary. . . 85

Figure 20c. Contour elevation of the Winter Water/

Umtanum basalt boundary. . . . . . . 86 
Figure 20d. Contour elevation of the Umtanum/ortleyGrouse Creek basalt boundary . . . . . 87

Figure 20e. Contour elevation of the Ortley-Grouse Creek/Wapshilla Ridge basalt boundary. . . 88

Figure 21. Idealized groundwater flow through several vertically stack basalt flows (Modified from Lite (1988). . . . . . . . . . . . 994

Figure 22. Schematic drawing of an idealized vertical gradient occurring in a stacked basalt flow system. . . . . . . . . . . . 98 Figure 23. A map view of the Pleasant Hill basalt block showing the heads of individual wells throught the area. . . . . . . . . . 99

Figure 24. A generalized diagram showing the effects on a potentiometric surface depending upon the thickness of the interflow zone and amount of fault offset. . . . . . 102

Figure 25. The graph shows the difference in lag time between precipitation and recharge based on distance away from a recharge zone. . 107 Figure 26. Comparison of hydrographs, Bach vs. Cogger and Rilee School House vs. Mills, to determine basalt recharge zones. . . . 108 Figure 27. View of the potentiometric surface of the Columbia River basalt aquifer decreasing away from mapped fault zones. . . . . 110 
Figure 28. Cascading water from an uncased or unlined well creating a composite head (Heath, 1984). . . . . . . . . . . . 114

Figure 29. A generalized diagram of a composite head. 116 Figure 30. Location of springs observed on Parrett Mountain. . . . . . . . . . 117

Figure 31. A generalized representation of spring

development on the northwestern slopes of Parrett Mountain with respect to the presence of landslide material. . . .

Figure 32. Location of the five wells where the groundwater geochemistry was analyzed (Driscoll and Titus, 1991). . . . . . 121

Figure 33. Location of saline wells within the Parrett Mountain area. . . . . . . . . 124

Figure 34. Three possible processes in which saline water can occur in basalt aquifers. . . . . 125

Figure 35. Flood scour channel cut into the upper flow of the Sentinel Bluffs. . . . . . . 128

Figure 36. Position of erratics found within the study boundaries.

Figure 37. Twenty erratics found within one hundred square feet (Black dot \#1 in Figure 36). . . 131 Figure 38. Areas showing landslide features. . . . . 134 Figure 39. Location of a landslide (T3S RIW Sect. 4) mapped by Schlicker and Deacon (1967). . . . 135 
Figure 40. Location of one landslide (T3S R2W Sect. 14)

on the northwestern slope of Parrett Mountain. . . . . . . . . . 137

Figure 41. Location of the other landslide (T3S RIW

Sect. 7 and 12) on the northwestern

slope of Parrett Mountain. . . . . . 138

Figure 41. Stratigraphic column of the Thacker well. . 157

Figure 42. Stratigraphic column of the Severine well. 158

Figure 43. Stratigraphic column of the Manke \#l well. 159

Figure 44. Stratigraphic column of the Adams well. . 160

Figure 45. Stratigraphic column of the Kurisa well. . 161 


\section{LIST OF TABLES}

TABLE I. PRECIPITATION DATA FROM REX IS

STATION, PARRETT MOUNTAIN . . . . 8

TABLE II. SEISMIC ACTIVITY ALONG THE GALES

CREEK-MOUNT ANGEL STRUCTURAL ZONE • 26

TABLE III. GEOCHEMICAL COMPOSITION OF THE LOW-

MG GRANDE RONDE BASALT DEFINED BY

XRF ANALYSIS . . . . . . . . . . . 37

TABLE IV. INAA ANALYSIS OF DRILLING CHIPS AND

FIELD SAMPLES • . . . . . . . . . 39

TABLE V. STRIKE AND DIP OF THE BASALT BLOCKS

COMPRISING PARRETT MOUNTAIN . . . . 82

TABLE VI. AQUIFER CHARACTERISTICS OF VARIOUS

ROCK TYPES •. • . . . . . . . . 95

TABLE VII. AQUIFER CHARACTERISTICS FOR BASALT

AQUIFERS . . . . . . . . . . . 96

TABLE VIII. PRINCIPAL AQUIFER(S) OF STUDY WELLS 105 TABLE IX. ESTIMATED BASALT GROUNDWATER

WITHDRAWALS ON PARRETT MOUNTAIN. • 112

TABLE X. GROUNDWATER CHEMISTRY • . • • • . . . . 120

TABLE XI. STRATIGRAPHIC DIVISIONS BASED ON

BASALT DRILLING CHIPS . . . . . 162

TABLE XII. STRATIGRAPHIC DIVISIONS OF WELLS

MEASURED BY THE OWRD . . . . . . . 164 
TABLE XIII. DESIGNATION OF BASALT UNIT PENETRATION BY A WATER WELL . . . 182

TABLE XIV. LIST OF INITIALS FOR BASALT UNIT BOUNDARIES • . . . . . . . . . . 182

TABLE XV. PARRETT MOUNTAIN HYDROLOGIC DATA • • • 184

TABLE XVI. QUARTER- QUARTER- POTENTIOMETRIC

HEAD VALUES FOR PARRETT MOUNTAIN • 251

\section{LIST OF PLATES}

Plate 1. Well locations studied on Parrett in pocket Mountain

Plate 2. Geologic map for the Parrett in pocket Mountain - Tonquin area

Plate 3. Potentiometric surface map of the in pocket Columbia River Basalt aquifer comprising Parrett Mountain 


\section{INTRODUCTION}

Concern over declining water levels on Parrett Mountain prompted a two year study by the Oregon water Resources Department (OWRD) on the Parrett Mountain aquifer system(s). The groundwater study boundaries are: Cedar Creek, the Rock Creek-Seely Ditch lowland, the Willamette River, and the western portions of Corral Creek Road and Wilsonville Road (Figure 1). The objectives of the groundwater study, stated by Donn Miller of the OWRD (1992, written commun.) are the following:

1) to thoroughly characterize the stratigraphy and local structures present on Parrett Mountain;

2) to ascertain the geologic and hydrologic characteristics of the basalt aquifers;

3 ) to determine the magnitude and areal extent of present groundwater development;

4) to ascertain the rate of recharge;

5) to evaluate the effect of development (use) on the perennial supply of groundwater;

6) to evaluate the effect of well construction practices and climate on water levels in wells;

7) to identify areas where supplies are adequate for additional development; and

8) to describe the groundwater chemistry.

These objectives were answered in the Oregon Water Resources Groundwater Report \#40 by Miller and others (1994).

The OWRD initially recommended the Parrett Mountain area be placed under a groundwater moratorium, eliminating all but exempt uses and precluding the construction of any new water wells. However, only Sections 5, 7, and 8 of T3S RIW, referred to as "Northern Parrett Mountain" by OWRD 

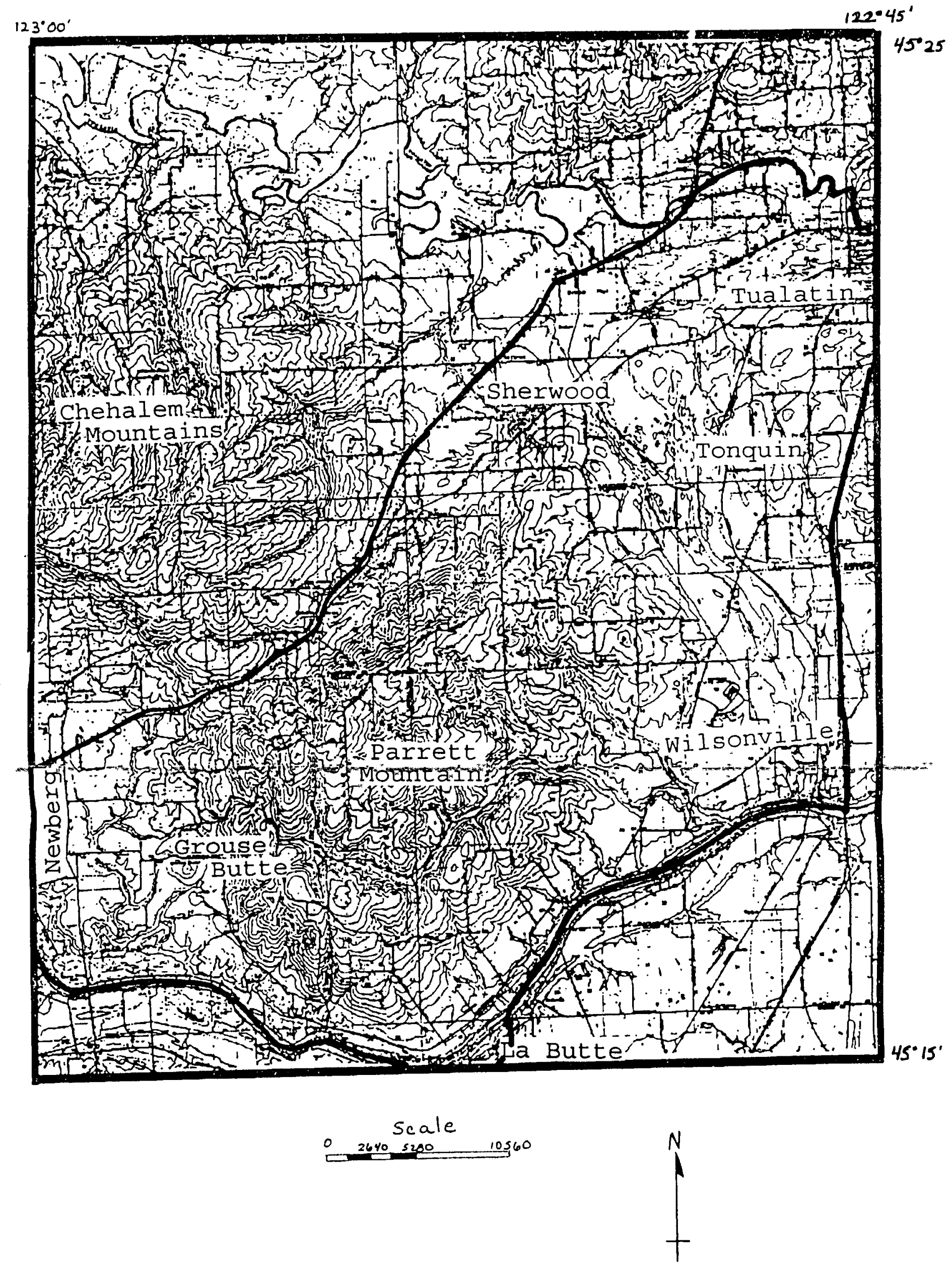

Figure 1. Topographic view of the geologic study area. The bold line represets the study's boundaries. 
staff, was deemed necessary for a withdraw order.

A secondary study, on the geology of Parrett Mountain, was initiated due to a lack of adequate geologic data needed to address objectives one and two of the OWRD study. The goal of this smaller study and the object of this thesis is to create a geologic map as well as develop a stratigraphic model of the mountain. Ultimately the structural and stratigraphic data will be used to help identify groundwater systems occurring on Parrett Mountain, and the geologic controls influencing them.

\section{TOPOGRAPHY}

Boundaries for the geologic study area have been designated as the Tualatin River, Oregon highway 99 West (99 W), the Willamette River, and Interstate 5 (Figure 1). The study area lies roughly twenty miles $(32 \mathrm{~km})$ south southwest of downtown Portland, Oregon, along the Interstate 5 corridor. The boundaries were designed to embody three distinct physiographic provinces: Parrett Mountain, the Tonquin area, and the Hess Creek-Spring Brook (HC-SP) area (Figure 2).

Four cities, Newberg, Wilsonville, Tualatin, and Sherwood, occur within or on the study boundaries. Population for the four cities has been documented in 1994 as 14,065 for Newberg, 10,000 residents in Wilsonville, 16,640 people in Tualatin, and 4,000 residents in Sherwood. 


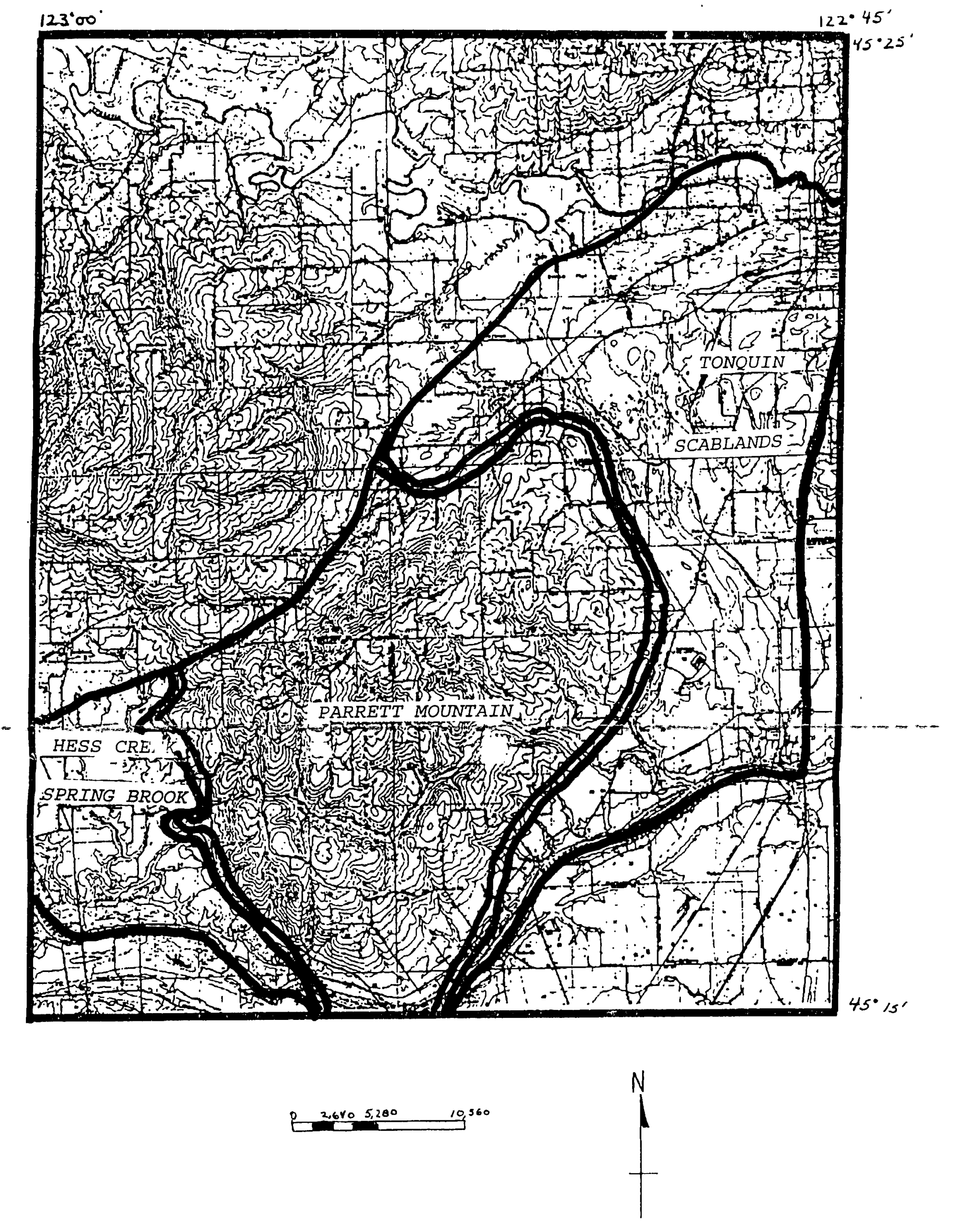

Figure 2. The three distinct physiographic provinces comprising the study area. 
Within the Parrett Mountain groundwater study area Miller and others (1994) estimated at least 4,500 people with 3,500 as rural residents.

Groundwater is the sole source of water for the residents living in the study area. Four of the most heavily pumped wells are the sherwood wells \#3 and \#5 and the two Dammasch wells. Miller and others (1994) estimated that roughly 558 million gallons per year is withdrawn from the basalt aquifers on Parrett Mountain.

\section{Parrett Mountain}

Parrett Mountain is centrally located in the study area, reaching a maximum elevation of 1,247 feet $(380 \mathrm{~m})$. The study area contains over 18,100 acres $(7,325$ hectares) of land of which 12,300 acres $(4,978$ hectares) were set aside for agricultural and forestry uses while the remaining 5,800 acres $(2,347$ hectares) have been zoned for rural residential development (Donn Miller, 1992, written commun.). Agricultural uses within the region include the development of orchards, timber, and nurseries plus the husbandry of sheep, cattle, horses and llamas.

Parrett Mountain is part of the Chehalem Mountain range separating the Tualatin and Willamette drainage basins. The mountain was described as "... a gently southeasterly dipping cuesta composed solely of Columbia River basalt and dissected by deeply incised, linear stream valleys." (Schlicker and Deacon, 1967) For this study Grouse Butte 
and La Butte, two basalt knobs located on the flanks of Parrett Mountain, will be included in the Parrett Mountain province due to similar geologic factors (Figure 2).

\section{The Tonquin area}

The Tonquin area includes the northeastern portion of the study area using the Rocky Creek-Seely Ditch lowland as a physiographic boundary (Figure 2). Thin soils and alluvium mantling the $C R B$ are characteristic for the central portion of the Tonquin area. The remaining area is covered by a thick blanket of alluvium.

Primary uses within this region include the quarrying of rock aggregate and agricultural development. Agricultural uses include the development of orchards and nurseries. Quarrying occurs only in the central portion of the Tonquin area, near the town of Tonquin. Residential population is expected to increase in this area as the cities of Wilsonville, Sherwood, Tualatin, and Portland continue to expand.

\section{The Hess Creek-Spring Brook Area}

The Hess Creek-Spring Brook area (Figure 2), located between Parrett Mountain and the city of Newberg, is characterized by a nearly flat-lying alluvial plain dissected by Hess Creek and Spring Brook. The local geology of the area is comprised of the willamette silt, the Troutdale Formation, and the Oligocene-Miocene sedimentary 
rocks at depth. Basalt is exposed at the surface only around Parrett Mountain and at shallow depths near Grouse Butte. This region supports both an agricultural industry and residential sections of Newberg.

\section{CLIMATE}

Monthly and yearly precipitation averages, since 1948, are presented in Table I. The climate data were collected from the REX IS station, which lies within the study boundaries. Monthly numbers in italics represent partial values, reflecting one to nine daily values missing, while monthly values, in bold, represent values taken from McMinnville. The Parrett Mountain area averages roughly 42 inches $(1,067 \mathrm{~mm})$ of precipitation with $75 \%$ occurring between October to March. 
TABLE I

PRECIPITATION DATA FROM REX IS STATION, PARRETT MOUNTAIN

YEAR JAN. FEB. MAR. APR. MAY JUNE JULY AUG. SEPT. OCT. NOV. DEC. ANNUAL

\begin{tabular}{|c|c|c|c|c|c|c|c|c|c|c|c|c|c|}
\hline 1992 & 5.33 & 4.83 & 1.03 & 5.08 & 0.06 & 0.59 & 0.68 & 0.60 & 1.88 & 4.28 & 5.29 & 5.99 & 35.64 \\
\hline 1991 & 3.41 & 5.04 & 4.53 & 5.43 & 3.38 & 2.59 & 0.24 & 1.83 & 0.16 & 2.83 & 7.67 & 5.26 & 42.37 \\
\hline 1990 & 9.07 & 4.28 & 2.66 & 1.73 & 1.97 & 2.09 & 0.39 & 1.46 & 0.72 & 4.44 & 4.58 & 3.11 & 36.50 \\
\hline 1989 & 4.24 & 3.29 & 7.58 & 0.87 & 2.13 & 1.26 & .0 .30 & 0.98 & 1.06 & 1.80 & 4.21 & 3.85 & 31.57 \\
\hline 1988 & 7.53 & 1.29 & 3.72 & 4.13 & 3.43 & 2.14 & 0.12 & 0.09 & 1.42 & 0.14 & 9.69 & 3.14 & 36.84 \\
\hline 1987 & 8.40 & 4.55 & 6.11 & 1.83 & 1.39 & 0.20 & 1.50 & 0.27 & 37 & 0.34 & 2.75 & 10.77 & 38.48 \\
\hline 1986 & 6.73 & 6.81 & 3.06 & 1.78 & 2.76 & 0.48 & 1.15 & 0.00 & 3.39 & 3.06 & 6.81 & 4.34 & 40.37 \\
\hline 1985 & 0.25 & 2.60 & 4.38 & 1.14 & 0.82 & 2.42 & 0.54 & 0.44 & 1.72 & 3.54 & 4.66 & 2.52 & 25.03 \\
\hline 1984 & 2.84 & 4.88 & 4.63 & 4.17 & 4.61 & 4.67 & 0.03 & 0.16 & 1.89 & 5.62 & 12.87 & 3.40 & 49.77 \\
\hline 1983 & 7.26 & 10.49 & 7.66 & 2.60 & 1.94 & 2.05 & 2.82 & 2.29 & 0.23 & 2.06 & 10.47 & 6.10 & 55.97 \\
\hline 1982 & 6.85 & 7.88 & 3.51 & 5.12 & 0.86 & 1.56 & 0.42 & 0.72 & 3.51 & 3.81 & 5.11 & 9.26 & 48.61 \\
\hline 1981 & 1.97 & 4.00 & 3.65 & 2.18 & 2.35 & 3.74 & 0.16 & 0.02 & 2.61 & 4.48 & 5.61 & 11.01 & 41.78 \\
\hline 1980 & 11.16 & 4.46 & 3.87 & 4.18 & 1.57 & 3.08 & 0.20 & 0.32 & 1.80 & 2.14 & 6.81 & 11.60 & 51.19 \\
\hline 1979 & 2.99 & 6.87 & 2.65 & 2.55 & 2.25 & 0.57 & 0.14 & 1.03 & 2.70 & 5.99 & 3.92 & 8.09 & 39.75 \\
\hline 1978 & 6.32 & 3.73 & 1.65 & 3.72 & 4.09 & 0.79 & 1.28 & 2.49 & 3.50 & 0.37 & 4.63 & 3.10 & 35.67 \\
\hline 1977 & 1.03 & 2.86 & 3.41 & 0.62 & 4.03 & 1.24 & 0.94 & 3.03 & 3.22 & 2.95 & 6.75 & 12.30 & 42.38 \\
\hline 1976 & 6.19 & 7.30 & 3.21 & 1.89 & 2.15 & 0.46 & 0.98 & 2.93 & 1.30 & 1.45 & 1.09 & 1.33 & 30.28 \\
\hline 1975 & 7.09 & 4.88 & 4.69 & 2.19 & 1.81 & 1.52 & 0.52 & 2.66 & 0.00 & 6.09 & 5.41 & 6.17 & 43.03 \\
\hline 1974 & 9.13 & 5.35 & 6.63 & 1.97 & 2.21 & 0.70 & 2.16 & 0.03 & 0.20 & 1.90 & 7.24 & 7.18 & 44.70 \\
\hline 1973 & 5.03 & 1.55 & 3.75 & 1.56 & 1.44 & 1.27 & 0.04 & 0.80 & 2.70 & 3.85 & 14.27 & 10.85 & 47.11 \\
\hline 1972 & 10.20 & 5.73 & 6.59 & 3.63 & 2.35 & 0.60 & 0.27 & 0.27 & 3.46 & 0.88 & 4.24 & 8.93 & 47.15 \\
\hline 1971 & 8.92 & 3.81 & 6.13 & 3.44 & 1.36 & 2.62 & 0.21 & $0.90^{\circ}$ & 2.99 & 3.90 & 7.05 & 8.74 & 50.07 \\
\hline 1970 & 12.08 & 4.38 & 2.33 & 2.53 & 1.18 & 0.55 & 0.10 & 0.00 & 1.75 & 3.74 & 6.46 & 9.60 & 44.70 \\
\hline 1969 & 6.73 & 3.01 & 1.24 & 2.84 & 1.66 & 3.35 & 0.06 & 0.04 & 3.64 & 4.51 & 2.97 & 8.98 & 39.03 \\
\hline 1968 & 5.20 & 7.96 & 3.55 & 2.18 & 3.57 & 2.41 & 0.49 & 3.76 & 2.36 & 6.16 & 7.11 & 10.33 & 55.08 \\
\hline 1967 & 7.85 & 1.83 & 3.99 & 2.29 & 1.42 & 0.80 & 0.00 & 0.20 & 0.83 & 5.21 & 2.70 & 4.83 & 31.95 \\
\hline 966 & 7.22 & 1.95 & 5.47 & 1.08 & 1.20 & 1.35 & 1.40 & 0.29 & 1.71 & 2.72 & 5.24 & 7.82 & 37.45 \\
\hline & 8.60 & 1.54 & 0.94 & 3.08 & 1.30 & 0.99 & 0.33 & 0.98 & 0.00 & 2.14 & 6.74 & 6.98 & 33.62 \\
\hline
\end{tabular}


TABLE I

PRECIPITATION DATA FROM REX 1S STATION, PARRETT MOUNTAIN

CONTINUED

\begin{tabular}{|c|c|c|c|c|c|c|c|c|c|c|c|c|c|}
\hline 1964 & 12.32 & 0.72 & 3.47 & 1.37 & 0.77 & 1.49 & 0.88 & 0.70 & 1.45 & 0.87 & 8.87 & 12.58 & 45.49 \\
\hline 1963 & 1.84 & 4.83 & 6.06 & 3.87 & 3.71 & 1.26 & 0.97 & $0.8 v$ & 1.24 & 3.18 & 6.57 & 4.35 & 38.68 \\
\hline 1962 & 1.75 & 3.40 & 4.91 & 3.59 & 2.03 & 0.76 & 0.01 & 1.65 & 2.06 & 4.18 & 12.02 & 2.96 & 39.32 \\
\hline 1961 & 5.56 & 9.74 & 7.05 & 3.46 & 3.12 & 0.51 & 0.54 & 0.63 & 0.91 & 3.85 & 5.33 & 6.40 & 47.10 \\
\hline 1960 & 4.00 & 4.52 & 5.83 & 4.37 & 4.38 & 0.46 & 0.00 & 0.71 & 0.72 & 3.70 & 10.23 & 3.43 & 42.35 \\
\hline 1959 & 10.20 & 4.91 & 4.86 & 1.26 & 2.78 & 2.40 & 0.88 & 0.09 & 2.83 & 3.14 & 3.17 & 3.31 & 39.83 \\
\hline 1958 & 7.93 & 7.18 & 2.34 & 4.24 & 0.68 & 3.30 & 0.00 & 0.04 & 0.97 & 2.21 & 8.00 & 5.64 & 42.53 \\
\hline 1957 & 2.35 & 4.66 & 7.56 & 1.66 & 3.58 & 1.30 & 0.09 & 0.96 & 0.71 & 3.27 & 3.36 & 8.85 & 38.35 \\
\hline 1956 & 12.87 & 3.87 & 5.99 & 0.63 & 1.35 & 1.37 & 0.02 & 1.82 & 1.26 & 6.76 & 1.60 & 4.29 & 41.83 \\
\hline 1955 & 2.71 & 3.11 & 3.98 & 4.55 & 1.21 & 1.24 & 1.16 & 0.00 & 3.51 & 7.48 & 9.48 & 11.72 & 50.15 \\
\hline 1954 & 10.19 & 5.79 & 2.71 & 3.57 & 1.21 & 3.00 & 0.53 & 1.29 & 1.71 & 4.32 & 5.56 & 5.88 & 45.76 \\
\hline 1953 & 14.91 & 3.99 & 4.58 & 2.23 & 2.69 & 1.99 & 0.00 & 1.78 & 1.13 & 3.26 & 6.84 & 7.88 & 51.28 \\
\hline 1952 & 6.09 & 4.34 & 2.91 & 1.73 & 0.49 & 3.51 & 0.00 & 0.20 & 0.33 & 1.05 & 0.97 & 7.15 & 28.77 \\
\hline 1951 & 8.80 & 5.11 & 4.66 & 1.27 & 1.69 & 0.05 & 0.24 & 0.42 & 2 . & 7.24 & 7.63 & 9.22 & 49.27 \\
\hline 1950 & 9.30 & 6.10 & 5.52 & 1.61 & 0.63 & 2.47 & 0.53 & 0.58 & 1. & 9.24 & 9.77 & 6.20 & 53.75 \\
\hline 1949 & 1.04 & 11.58 & 3.60 & 0.85 & 1.94 & 0.51 & 0.57 & 0.17 & 0.94 & 2.90 & 6.42 & 5.11 & 34.63 \\
\hline 1948 & 6.81 & 5.95 & 4.35 & 3.50 & 4.87 & 0.64 & 0.59 & 0.74 & 2.96 & 2.96 & 7.14 & 9.33 & 48.96 \\
\hline
\end{tabular}




\section{REGIONAL GEOLOGY}

\section{GEOLOGIC SETTING}

The geology of the study area has been described by Schlicker and Deacon (1967); Hart and Newcomb (1967), and by Frank and Collins (1978) (Figure 3). A generalized stratigraphic column (Figure 4) has the oligocene-Miocene sedimentary rocks unconformably overlain by Columbia River basalt. The basalt is also unconformably overlain by the Helvetia Formation, when present, and by the Miocene Pliocene Troutdale Formation in the valleys. The Troutdale Formation is unconformably overlain, when present, by the Willamette silt deposit, which is in turn overlain by recent alluvium along the local drainages.

The lithology of the oligocene-Miocene sedimentary units depicts a forearc depositional basin environment that deepened to the west (Yeats and others, 1991). The basin in which the Oligocene and Miocene sedimentary rocks were deposited was subsequently uplifted during the early Miocene period to form a gently south dipping subaerial plane (Frank and Collins, 1978).

During the middle Miocene the low lying elevations of northwestern Oregon were covered by the basalt flows of the Columbia River basalt. These basalt flows crossed the 


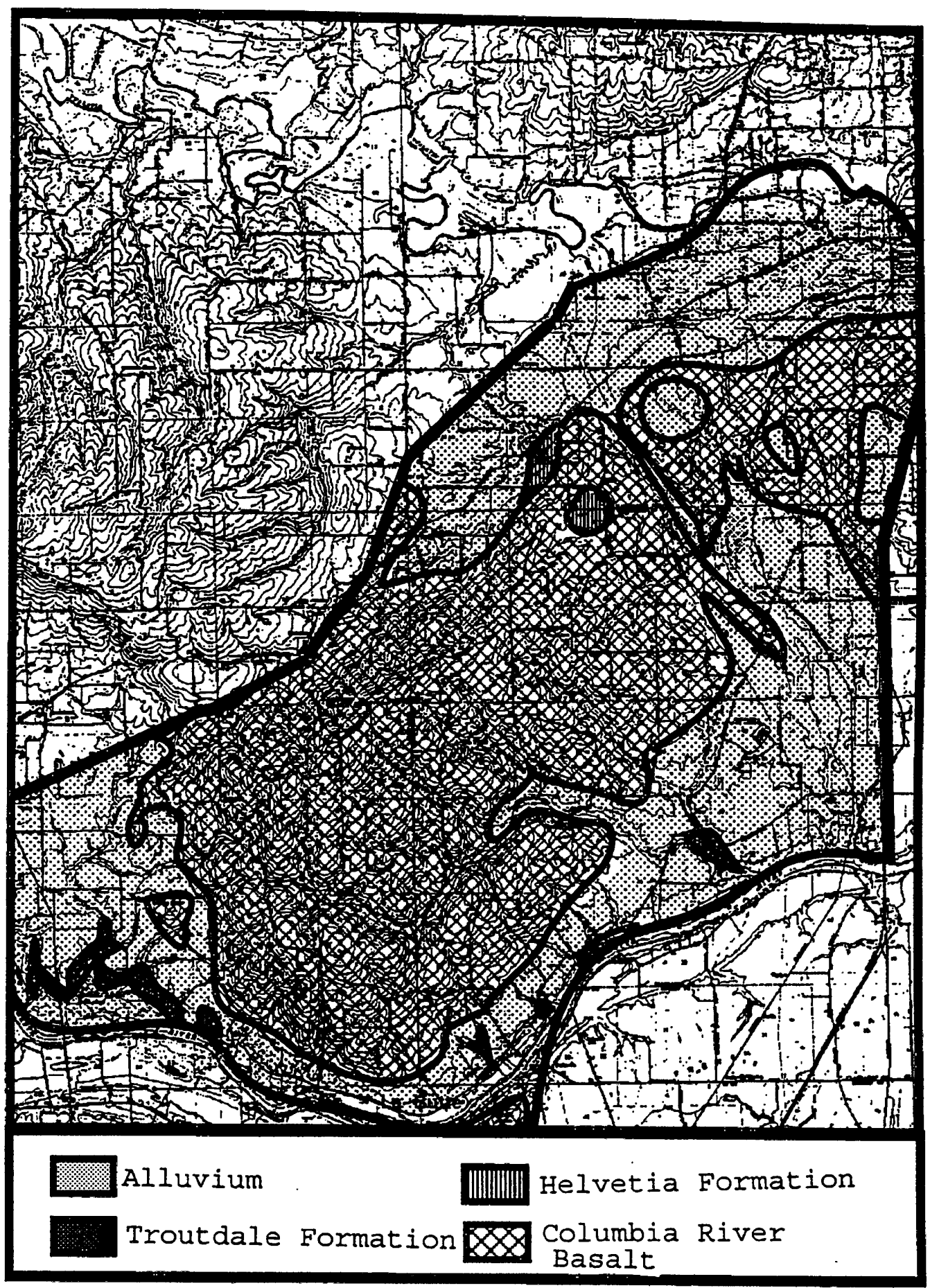

Figure 3. Regional geologic map encompassing the Parrett Mountain area (Schlicker and Deacon, 1967). 


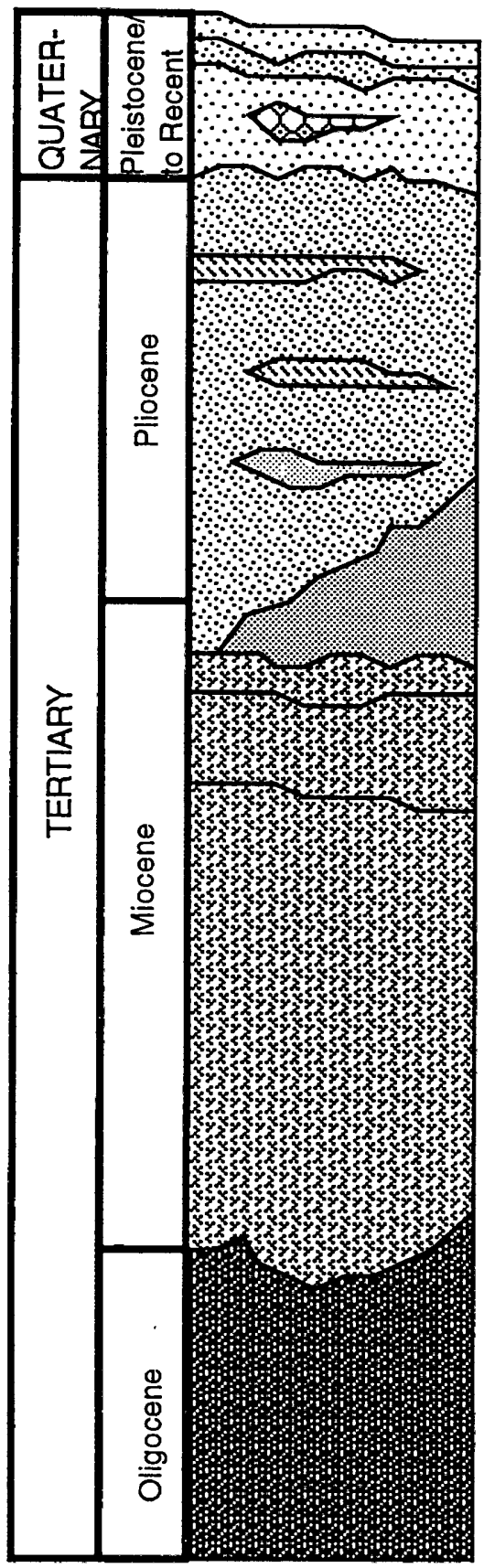

\section{Alluvium}

* Willamette Silt and recent alluvium. Composed of unconsolidated silt, clay, sand, and gravel

\section{Troutdale Formation}

* Poorly indurated, gray brown silt and clay with fine silty sand and lenes or pebble conglomerate and clay horizons

\section{Helvetia Formation}

* Reddish-brown, poorly indurated sand, sandy silt, and silty clay deposits with local thin beds of quartzite and basalt pebbles

unconformity

\section{Columbia River Basalt (CRB)}

- Miocene to Pliocene tholeiitic basalt flows. Previous mapping of Parrett Mountain has separated the CRB into (from oldest to youngest) the Low-Mg N2 Grande Ronde, the High-Mg N2 Grande Ronde, and the Ginkgo flow of the Frenchmen Springs Member of Wanapum Basalt.

\section{unconformity \\ Oligocene-Miocene Sedimentary Deposits}

- Tuffaceous, quartzitic and granitic silt and clay deposits with lenses of fine sands, gravel, and carbonaceous siltstones and claystones

Figure 4. A generalized stratigraphic column representative of the Parrett Mountain study area (Modified from Schlicker and Deacon, 1967). 
ancestral Cascades through the Columbia Trans Arc Lowland (Beeson and others, 1989) and into the Portland basin and paleo-Willamette valley.

Tectonic deformation of northwestern Oregon resulted in the development of several fault-bounded, asymmetrical anticlines. Development of these anticlines along the Portland Hills-Clackamas River and Gales Creek-Mount Angel structural zones resulted in the obstruction of several basalt flows.

After the basalt emplacement, a period of quiescence, from late Miocene to early Quaternary, occurred. This period is marked by the deposition of lacustrine and fluvial sedimentary deposits from the ancestral willamette and Columbia Rivers. This sedimentary material has been formally designated as the Troutdale Formation.

The lower ancestral Willamette Valley was affected by localized cinder cones and volcanic vents of the Boring Lava. This volcanic episode occurred from the upper Pliocene to lower Pleistocene along with the deposition of the Troutdale Formation. The Boring Lava has been found to be a massive, blocky, gray porphyritic olivine basalt (Schlicker and Deacon, 1967). Mount Sylvania, Mount Tabor and Mount scott are all examples of Boring Lava cinder cones and volcanic vents. Since the Boring Lava does not occur within the study's boundaries it will not be discussed further. 
During the Quaternary period, the entire willamette Valley was affected by the glacial flood waters of Lake Missoula. It is believed that over 90 floods occurred, with most occurring between 15,300 and 12,700 BP (Waitt, 1985).

\section{REGIONAL STRATIGRAPHY}

\section{Oligocene-Miocene Sedimentary Rocks}

The oligocene-Miocene sedimentary rocks are composed of tuffaceous, quartzitic and granitic silt and clay deposits with lenses of fine sands, gravel, and carbonaceous siltstones and claystones (Frank and Collins, 1978; Hart and Newcomb, 1965). Schlicker and Deacon (1967) stated that "[a] lthough the oligocene rocks are distinct in gross character, no persistent lithology has been recognized in the map area to permit recognition of separate formations." These deposits depict a marine depositional environment with some brackish near shore and fresh water characteristics (Hart and Newcomb, 1965). A maximum thickness of 5,000 feet (1524 m) was determined by Frank and Collins (1978) with several portions of the unit corresponding to Schlicker and Deacon's (1967) Yamhill and Spencer formations mapped to the south.

Exposures occur throughout the Newberg valley on the southwest flanks of the Chehalem Mountains and the northern and northwestern flanks of the Red Hills of Dundee. These deposits occur underneath the Columbia River basalt 
comprising Parrett Mountain and the Chehalem Mountains, as seen in water well reports and corings (this report; Marvin Beeson, 1992, personal commun.). Near the central region of the Newberg valley, the marine sedimentary rocks are overlain by 10 to 15 feet $(3 \mathrm{~m}$ to $4.6 \mathrm{~m}$ ) of Willamette silt with an additional 10 to 200 feet $(3 \mathrm{~m}$ to $61 \mathrm{~m}$ ) of Troutdale closer to the Willamette River (Hart and Newcomb, 1965; Frank and Collins, 1978).

\section{Columbia River Basalt Group}

The Columbia River Basalt Group is a series of Miocene to Pliocene tholeiitic basalt flows that erupted from fissures in eastern Washington and Oregon, and parts western Idaho. The total area covered by the basalt flows has been calculated to be $164,000 \mathrm{~km}^{2}$ including central and southern Washington, parts of western Idaho, northcentral and eastern Oregon, the northern portion of the willamette valley, and parts of the northern oregon coast. The total volume of the basalt group has been estimated to be roughly $173 \mathrm{~km}^{3}$ (Tolan and others, 1989). The thickest known section of CRB occurs in the Pasco Basin, where subsidence occurred penecontemporaneously with basalt emplacement. Average thicknesses of individual basalt flows range from 650 to a few feet $(<200 \mathrm{~m})$. Interbeds developed during hiatuses between basalt outpourings and have been designated as part of the Ellensburg Formation. The frequency and thickness of these interbeds increases as you get higher in the $\mathrm{CRB}^{\prime} \mathbf{s}$ 
stratigraphic column and as you get to the edge of the CRB's maximum extent.

A stratigraphy has been created for the Columbia River basalt using geochemistry, magnetic-stratigraphy, and lithologic characteristics. Using the above methods, the $\mathrm{CRB}$ has been divided into five formations which have been further subdivided into distinct units, members, and flows (Beeson and others, 1989) (Figure 5). The five formations are the Imnaha, the Picture Gorge, the Grande Ronde, the Wanapum, and the Saddle Mountains Basalts.

Both the Imnaha and Picture Gorge formations occur in central and eastern oregon and were erupted into basins that remained topographically separate from the Columbia Plateau. The Grande Ronde Basalt is a series of seventeen basalt units that were erupted between 17 to $15 \mathrm{Ma} \mathrm{bp}$. This formation is the most voluminous formation of the Columbia River basalt group, containing several "great flows" with individual volumes ranging up to 2,000 or $3,000 \mathrm{~km}^{3}$ (Tolan and others, 1989). The Wanapum Basalt is separated from the Grande Ronde by a highly distinctive interbed/paleosol, the Vantage Interbed, which formed during a 100,000 to 300,000 year hiatus in basalt outpouring. This horizon is highly distinctive, occurring throughout most of the Columbia Plateau. The Wanapum Basalt is composed of a series of highly distinctive basalt flows in terms of geochemistry and lithology. The last formation, the Saddle Mountains Basalt, 


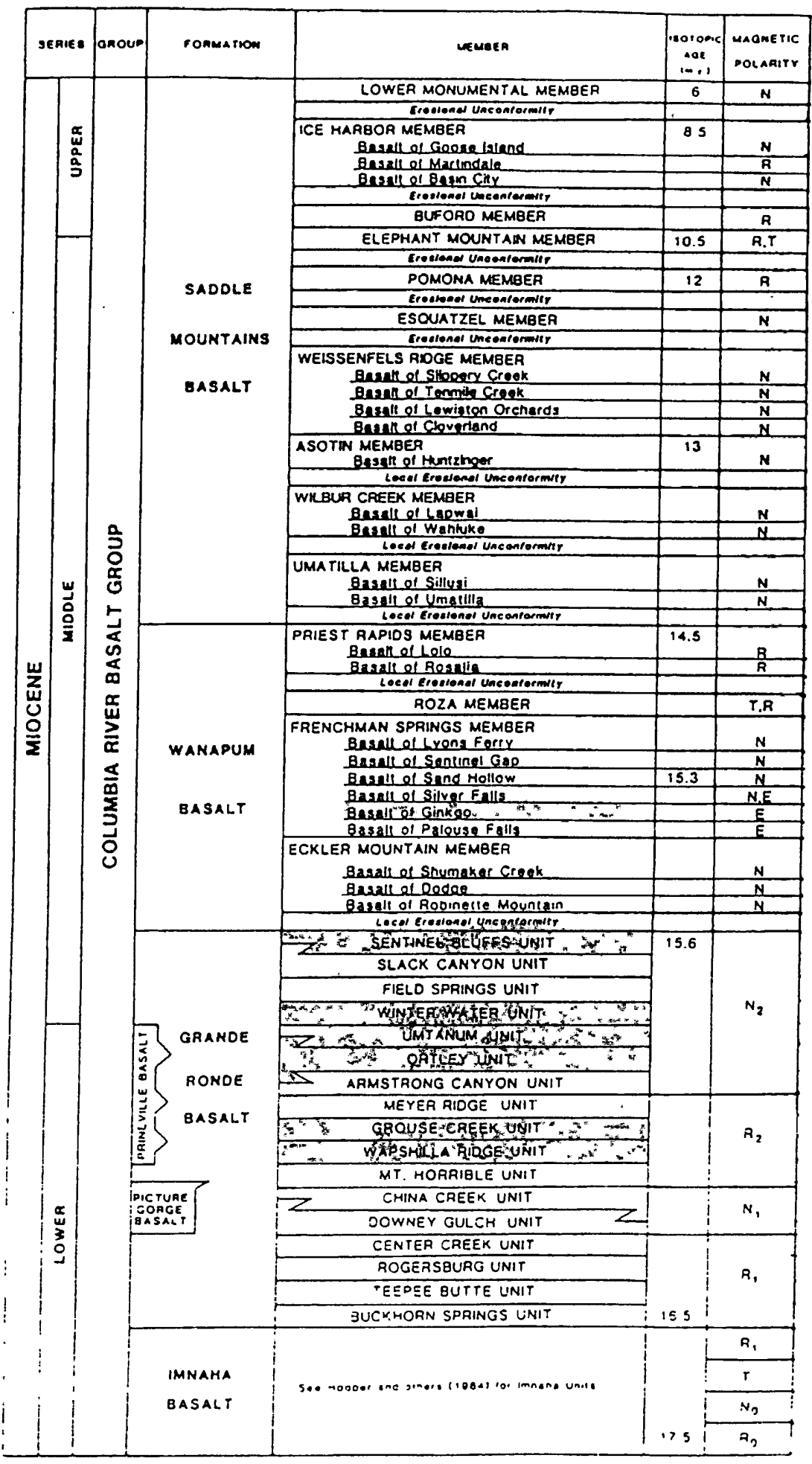

Figure 5. Stratigraphic framework of the Columbia River Basalt Group (Modified from Beeson and others, 1989). Yellow shading indicates the basalt units composing Parrett Mountain. 
comprises a series of basalt flows marking the waning of fissure eruptive activity.

Outcrops of Columbia River basalt occur throughout the study area, including the entire Parrett Mountain area, Grouse Butte, La Butte, and parts of the Tonquin area. Weathering depths vary from location to location on Parrett Mountain but typically range from 0 to 18 feet $(0$ to $6 \mathrm{~m}$ ). Two distinct groups of soil series, mapped by Gerig (1985), are the Jory, Saum, and Laurelwood soils for the upland regions and the Helvetia and Willamette soils in the low lying areas. Both the Helvetia and Willamette soils occur on the Missoula flood deposits.

\section{Helvetia Formation}

Schlicker and Deacon (1967) describe the Helvetia Formation as a reddish-brown, poorly indurated sand, sandy silt, and silty clay deposit with local thin beds of quartzite and basalt pebbles unconformably overlying the Columbia River basalt. The type locality for this formation is a road cut exposure north of the town of Helvetia in T1N R2W, section 3 where a minimum thickness of 25 feet $(7.5 \mathrm{~m})$ is exposed around the town of Helvetia (Schlicker and Deacon, 1967). This formation was mapped as occurring throughout the entire Tualatin Valley ranging in elevation from 200 to roughly 900 feet $(61$ to $275 \mathrm{~m}$ ) and was believed to be correlated to the earliest Troutdale Formation sediments. Currently, the Helvetia Formation is believed to 
be a mixture of weathered basalt and sediment and should therefore lose its designated title of 'formation' (Marvin Beeson, 1994, personnel commun.). The Helvetia Formation is not considered to be an aquifer (Frank and Collins, 1978).

\section{Troutdale Formation}

The Miocene to Pliocene Troutdale Formation is a moderately- to well-indurated depositional unit (Yeats and others, 1991) composed of gravel, sands, silts, and clays of a lacustrine and riparian environment. Within the Tualatin and Newberg valleys, Schlicker and Deacon (1967) describe the formation as a poorly indurated, gray brown silt and clay with fine silty sand and lenses of pebble conglomerate and clay horizons. The Troutdale Formation unconformably overlies the Columbia River basalt with a varying thickness of 10 to 200 feet $(3$ to $61 \mathrm{~m}$ ) in the Newberg area to over 400 feet $(>122 \mathrm{~m})$ near the city of Wilsonville and the Tualatin River (Frank and Collins, 1978). This unit extends throughout the Tualatin and Newberg valleys up to 700 feet $(213 \mathrm{~m})$ in elevation, save for a few locations where the unit is thin or nonexistent and the marine sediments underlie the Willamette Silt (Frank and Collins, 1978). Within the study boundaries, the Troutdale Formation is only exposed along the deep ravines along the Willamette River between the cities of Wilsonville and Newberg (Figure 2).

\section{Willamette silt}


The Willamette silt unit is a depositional layer composed of unconsolidated silt, clay, sand, and gravel originating from the deposition of Missoula flood's debris. This unit varies from a few feet to 50 feet $(15 \mathrm{~m})$ in thickness and underlies most of the basin lowlands up to the 250 foot (84 meters) elevation (Frank and Collins, 1978). However, the unit is only 5 to 10 feet $(1.5$ to $3 \mathrm{~m})$ in thickness around the cities of Newberg and Wilsonville (Frank and Collins, 1978). Most of the material deposited in the lower elevations is basaltic in composition with some granitic and quartzitic sand and silt material. In addition, deposits of basaltic, granitic, and quartzitic gravel to boulder size rock fragments were ice rafted down the ancestral Columbia River on flood waters thereby marking water access and escape channels as well as the maximum elevation of ponded flood waters. Schlicker and Deacon (1967) have reported a maximum thickness of 50 feet (15 m) for these coarser-sized materials in the Rocky Creek-Seely Ditch area.

\section{Alluvium}

Since the last glacial flooding of the willamette Valley, 12,700 years BP (Waitt, 1985), alluvium and colluvium have been collecting in the local drainages (Figure 3). This material is essentially composed of peat and reworked flood material in the northeastern sections of the study area, with a reworking of the willamette silt, 
marine sediments, basalt, and Troutdale deposits in the Newberg flat region (Schlicker and Deacon, 1967). Locations of active deposition mapped by Schlicker and Deacon (1967) are the Seely Ditch - Rock Creek area, Corral Creek and along its tributaries, along the Willamette River, and in Hess Creek and Spring Brook. Schlicker and Deacon (1967) further estimated that the alluvial material had a maximum thickness of 20 to 30 feet $(6$ to $9 \mathrm{~m})$.

\section{REGIONAL STRUCTURE}

Northwest Oregon is composed of three physiographic provinces, the Coast Range, the Willamette Valley, and the Cascade Range. Development of these provinces began during the Tertiary period when the convergence rate between the Farallon Plate and the North American Plate decreased while the strike-slip component of the subduction increased (Figure 6) (Yeats and others, 1991).

Areal photographs and Landsat images of northwestern Oregon and southwestern Washington, indicate the presence of three northwest trending lineations (Balsillie and Benson, 1971, Beeson and others, 1989). Subsequently these lineations have been designated as the Frontal Fault Zone (Yelin and Patton, 1991), the Portland Hills - Clackamas River structural Zone and the Gales Creek - Mount Angel Structural Zone (Beeson and others, 1989) (Figure 7). Beeson and others (1989) have proposed and designated these 
lineations to be structural zones with a dominant right lateral strike-slip sense of motion with a subordinate vertical sense of motion.

Gales Creek-Mount Angel Structural Zone

Beeson and others (1985, 1989) have depicted the Gales Creek-Mount Angel (GC-MA) structural zone as a series of en echelon faults rather than one continuous fault. Three fault segments, the Gales Creek Fault, the Newberg Fault, and the Mount Angel Fault were identified by Werner and others (1993) (Figure 7).

Gales Creek Fault. Seismic lines and gravity modeling showed that the Gales Creek Fault was composed of three fault segments extending from the town of Gaston to the base of the Chehalem Mountain range. A total southeast downdrop of $3 \mathrm{~km}$ was recorded along the Gales Creek Fault segment (Yeats and others, 1991) (Figure 7).

This downdropping has been postulated by Yeats and others (1991) to have occurred before the Columbia River basalt emplacement.

Newberg Fault. Identification of the Newberg Fault (Figure 7) was accomplished using water well data (Werner, 1990) and supported by aeromagnetic and gravity data (Yeats and others, 1991). Unlike the Gales Creek Fault, there is an apparent downdropping to the south (Yeats and others, 1991) based on the CRB and pre-basalt emplacement sediment boundary. 


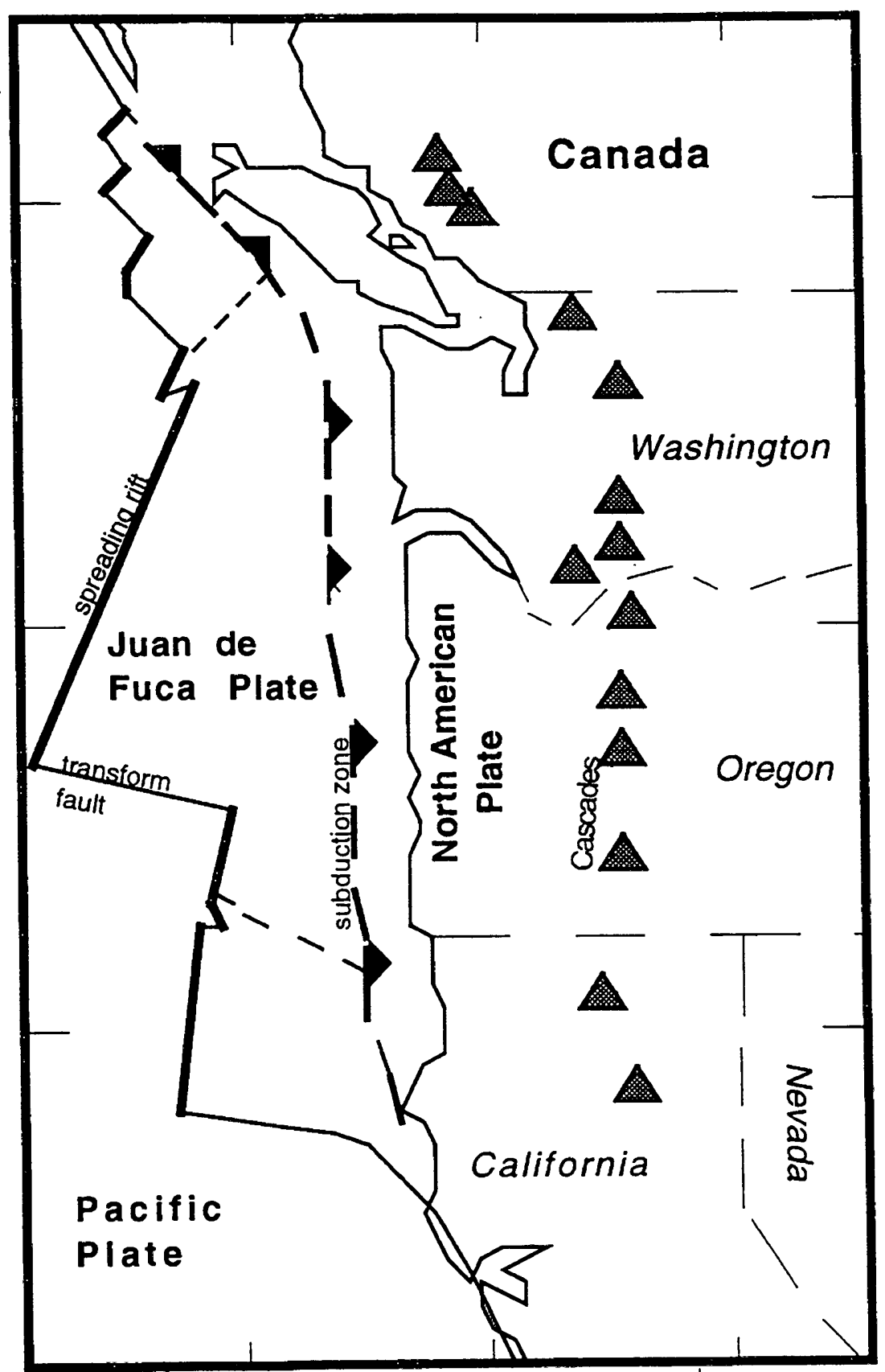

Figure 6. The convergence and subduction of the Juan de Fuca Plate against the North American Plate (Yeats and others, 1991). 

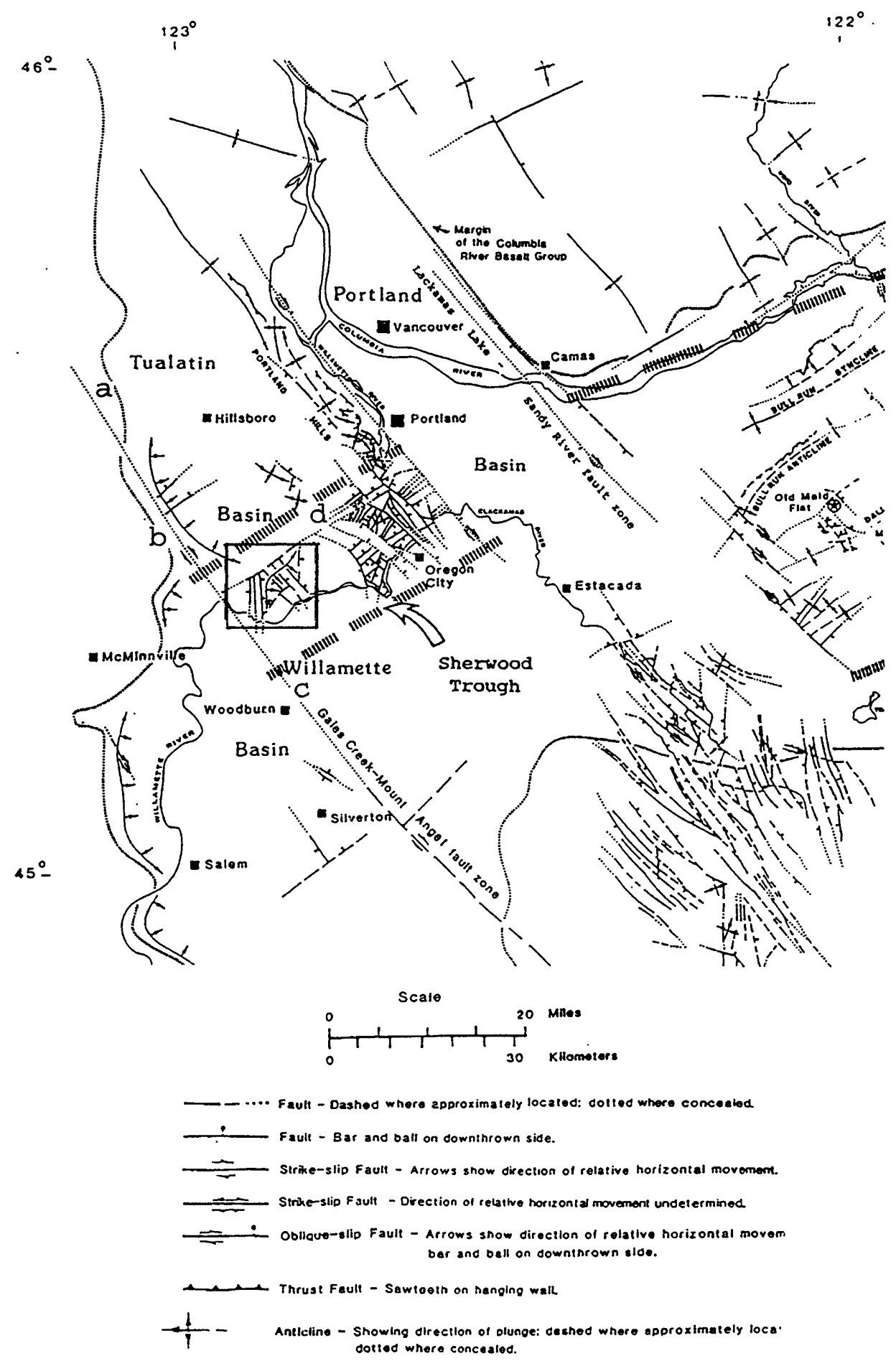

Figure 7. Regional view of the tectonic features comprising the northern Willamette Valley. Boxed area represents the location of Parrett Mountain. (a) represents Gales Creek Fault; (b) represents the Newberg Fault, (c) represents the Mount Angel Fault, (d) represents the sherwood Fault. (Modified from Tolan and Reidel, (1989) 
The nature of the boundary between the Gales Creek and Newberg Faults remains unknown. At the boundary between the Gales Creek and Newberg Fault, seismic modeling failed to reveal any vertical displacement of the CRB's upper boundary (Yeats and others, 1991).

Mount Angel Fault. The Mount Angel Fault (Figure 7) was extended from the Waldo Hills to the city of Woodburn based on seismic lines and water well data (Werner and others, 1993). Displacement along the fault increases to the southeast with 100 feet $(30.5 \mathrm{~m})$ of vertical displacement observed near Woodburn to a vertical displacement of $250+$ feet $(76.2+\mathrm{m})$ by the town of Mount Angel (Werner and others, 1993; Yeats and others, 1991). A possible $1 \mathrm{~km}$ dextral offset of a channelized Ginkgo basalt flow was also recorded near the town of silverton (Marvin Beeson, 1994, personnel commun.).

Seismicity. Seismic activity along the Gales CreekMount Angel structural zone is recorded in Table II. As observed in Table II, the Woodburn segment is the most active segment along the Gales Creek - Mount Angel structural zones, with an average magnitude of a 2.3 .

The Scotts Mills earthquake, depicted as earthquake \#10 in Table II, had a 5.6 magnitude and showed a right lateral sense of motion. Although the earthquake occurred some distance away from the believed GC-MA structural zone some geologists believe that the sense of motion and the location 
of the epicenter suggests some type of connection.

\section{TABLE II}

\section{SEISMIC ACTIVITY ALONG THE GALES CREEK-MOUNT ANGEL STRUCTURAL ZONE}

$\begin{array}{cllcc}\text { Earthquake } & \text { Latitude } & \text { Longitude } & \text { Date } & \text { Magnitude } \\ 1 & 45.133 & -122.886 & 07 / 03 / 80 & 1.7 \\ 2 & 45.142 & -122.874 & 08 / 20 / 83 & 1.2 \\ 3 & 45.165 & -122.871 & 09 / 17 / 90 & 1.6 \\ 4 & 45.153 & -122.847 & 08 / 14 / 90 & 2.0 \\ 5 & 45.113 & -122.877 & 08 / 14 / 90 & 2.5 \\ 6 & 45.118 & -122.86 & 08 / 22 / 90 & 2.4 \\ 7 & 45.132 & -122.867 & 08 / 22 / 90 & 2.2 \\ 8 & 45.12 & -122.871 & 08 / 23 / 90 & 2.4 \\ 9 & 45.107 & -122.866 & 08 / 23 / 90 & 1.4 \\ 10 & 45.02 & -122.364 & 05 / 25 / 93 & 5.6\end{array}$

\section{Sherwood Fault}

The Sherwood Fault (Figure 7) separates the Chehalem Mountain range from Parrett Mountain. This fault is one of the most pronounced features occurring in northwestern Oregon (Schlicker and Deacon, 1967). The style of faulting proposed for the sherwood Fault has been postulated to be 1) a high-angle, north dipping, normal fault (Driscoll and Titus, 1991), or 2) a high-angle, south dipping, reverse fault, or 3) a low-angle, south dipping, thrust fault. Aeromagnetic and gravity studies have yielded little information into the nature of faulting, though a 330 to 495 foot ( 100 to $150 \mathrm{~m}$ ) vertical separation of the CRB can be discerned (Beeson and others, 1989). Given the parallel trends of the Sherwood Fault and the postulated Columbia 
Trans Arc Lowland it is possible that both features are related to each other (Beeson and others, 1989).

\section{HYDROGEOLOGIC UNITS}

Groundwater occurs in unconfined, confined and perched conditions within the study boundaries (Frank and Collins, 1978). These conditions are primarily governed by the bedrock material, and their lithologic characteristics.

\section{Oligocene-Miocene Sedimentary Rocks}

The Oligocene - Miocene sedimentary rock unit is considered to be a poor aquiler due to the low permeability and yields of the material. Yields typically average around $5 \mathrm{gal} / \mathrm{min}$ (.002 acre-feet/day) though some that tap into the shale and sandstone layers may obtain yields ranging from 10 to greater than $200 \mathrm{gal} / \mathrm{min}$ (.04 to .9 acre-feet/day) (Frank and collins, 1978). The water typically shows an unconfined nature with the water table fluctuating with seasonal changes (Frank and Collins, 1978). Confined and perched aquifers can occur within this unit due to clay or silt lenses and layers (Frank and Collins, 1978).

Water quality tends to be the largest problem in developing the oligocene and Miocene sedimentary aquifers. Typically, the water taken from this unit is high in sodium or calcium ions. Typically, the deeper the sedimentary units are penetrated the more likely the groundwater will be unusable (Frank and Collins, 1978). 


\section{Columbia River Basalt Group}

One of the main characteristics of basalt aquifers, is that groundwater storage is largely limited to interflow zones within the basalt flow. These interflow zones occur only on the top and sides of an individual flow, near the flowtop. Because the flowtops are generally highly porous, it makes a natural groundwater source. Flowtops generally range from 3 to 24 feet ( 1 to 8 meters) thick, roughly $10 \%$ of the total basalt flow (Heath, 1984).

A basalt aquifer can also be replenished through the vertical movement of water along cooling joints and stress fractures in the basalt flow. Baker (1978) showed that only a small amount of water migrates through the vertical fractures and joints due to the their small joint spacing. This observation means that the vertical infiltration rate is negligible compared to the lateral groundwater flow.

The groundwater present on Parrett Mountain was found to be in an unconfined and confined state (Frank and Collins, 1978). Average annual yields were found to be 15 $\mathrm{gal} / \mathrm{min}$ (.06 acre-feet/day) in the uplands, and 1,000 gal/min (4.4 acre-feet/day) in the lowlands (Frank and Collins, 1978). Within the Rocky Creek-Seely Ditch area, yields of 100 to $1,000 \mathrm{gal} / \mathrm{min}$ (.4 to 4.4 acre-feet/day) were observed. A yearly decline of 1 foot $(.3 \mathrm{~m})$ in the groundwater table has been observed near the Dammasch water wells (Frank and Collins, 1978). 


\section{Troutdale Formation}

The well yields taken from the Troutdale Formation range from 4 to $360 \mathrm{gal} / \mathrm{min}$ (.02 to 1.6 acre-feet/day) (Frank and Collins, 1978) with specific capacities ranging from 0.08 to $0.27 \mathrm{gal} / \mathrm{min} / \mathrm{ft}$. These ranges are due to variations in lithology, grain size, and lateral extent of the beds or lenses. Because of the lateral variation in deposition, unconfined, confined, and perched aquifers can and do occur (Frank and Collins, 1978). The most productive well, located in T3S R2W Sect. 33, yields $360 \mathrm{gal} / \mathrm{min}$ with a drawdown of 23 feet $(7 \mathrm{~m})$ and a specific capacity of 16 gal/min/ft (Frank and Collins, 1978).

\section{Willamette silt}

The willamette silt is composed of clay, silt, sands, and a lenses of gravels. Aquifers range from unconfined to confined in nature due to the type of the material comprising the sedimentary unit, the depositional layering, the anisotropic characteristics within individual beds, along with the development of fragipans.

Typically the willamette silt has a low permeability and yields water slowly to wells. The low permeability, however, does not inhibit the infiltration of surface water into the underlying rock material (Frank and Collins, 1978). Areas where this unit is exposed at the surface are predominately wet, marked with high water tables (Frank and Collins, 1978). 


\section{METHODOLOGY}

To accurately characterize the geology of Parrett Mountain, four avenues of investigation were conducted. The first task was to create a geologic map of the Parrett Mountain and Tonquin areas (Plate 2) in order to ascertain. the location of the basalt units. Second, a stratigraphic model emphasizing the individual basalt flows was developed using well reports and lithologic analysis of basalt chips taken from newly drilled water wells (Plate 1; Figures 41 45, Tables XI and XII, Appendix A). Identification of the basalt units was based upon methods described by Holmgren (1969). The third avenue of investigation was a geochemical analysis, using $\mathrm{x}$-ray fluorescence (XRF) and instrumental neutron activation analysis (INAA) on the basalt flows in order to obtain a geochemical signature for the various basalt units present as well as corroborate the hand lithologic analysis. Finally, the fourth investigation was the use of potentiometric surface map (Plate 3), collected by OWRD, to correlate head value changes to local geologic features.

\section{FIELD MAPPING}

The goal of the field mapping project, conducted during the summer and fall of 1992, was to create an accurate and 
detailed surficial geologic map of the Columbia River Basalt Group (CRBG). Identification of the individual basalt units was accomplished using criteria specified by Reidel and others (1989). Obvious basalt characteristics used were jointing patterns expressed in outcrops (Figure 8), the presence and character of plagioclase phenocrysts, and to a smaller extent, the color on weathered surfaces. Care was taken to note whether the rock was exposed bedrock, colluvium, or flood deposits, as well as noting the presence of any exposed flowtops.

In May of 1992, an initial reconnaissance of the study area revealed a significant number of basalt exposures present on the local road systems. To take advantage of this fact, each road was designated as a traverse line across the study area. Each transect was then walked. The outcrops were studied, sampled, and marked on a $7^{1 / 2}$ minute quadrangle. Samples were collected at every outcrop, except when the basalt was either too weathered or there was no question as to the identity of the basalt unit. Labeling of the samples was accomplished using one to two letters representing the road followed by a letter-number-letter combination that designated the location of the sampled outcrop.

Several streams/creeks were also investigated. Each drainage hiked was one that appeared to have stream beds of bedrock and was readily accessible. Little information was 


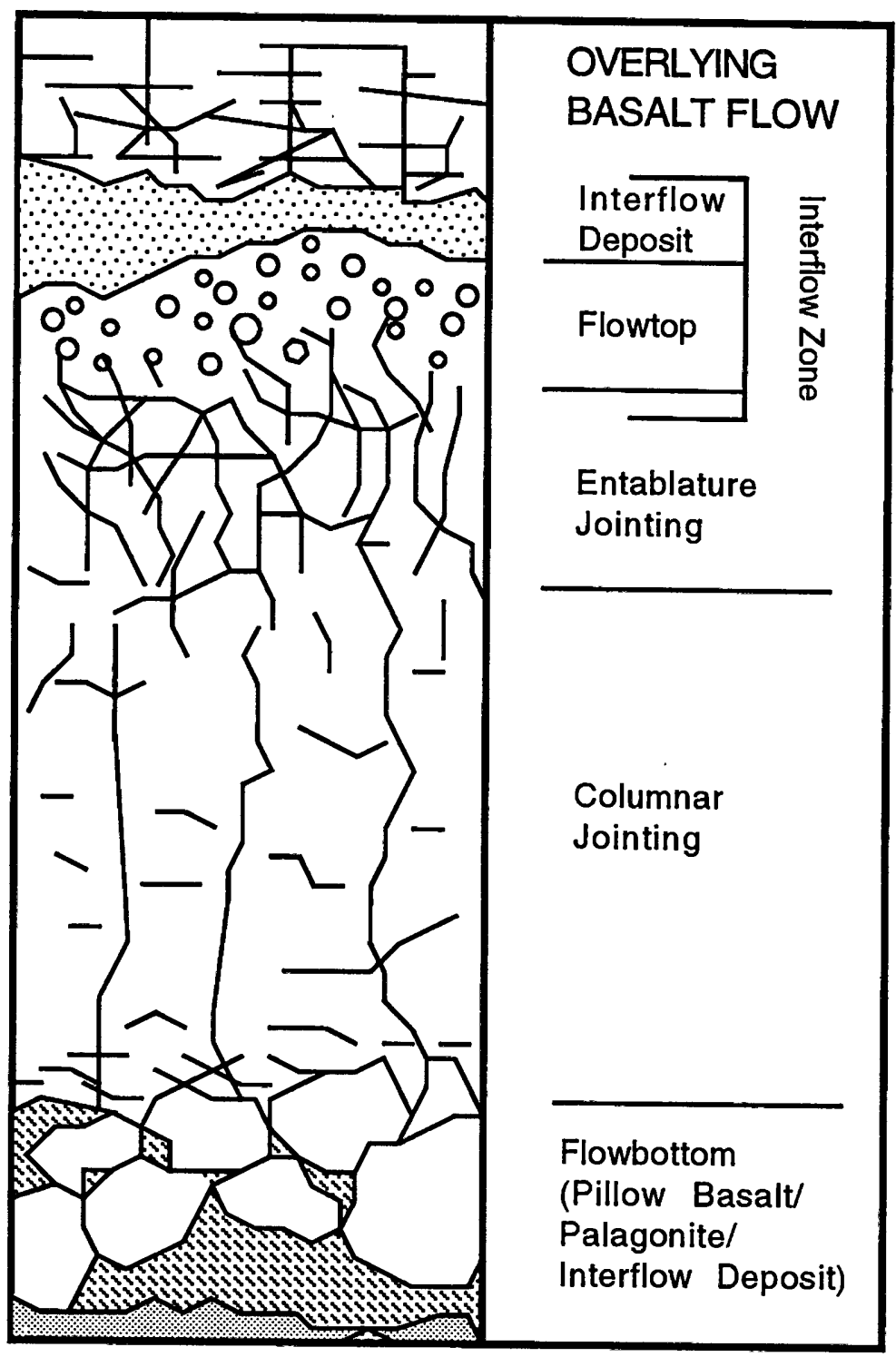

Figure 8. Cross section of a basalt flow showing the distinct jointing patterns and lithologic features in regards to occurrence within a basalt flow. 
obtained from the stream beds due to thick soil and organic litter covering the stream beds. Basalt float encountered in the stream beds was studied and sampled, however, some uncertainty exists for this material since the original location of the basalt boulders is unknown.

\section{Springs}

Naturally occurring springs, observed in the field or mentioned by local residents were also mapped. Since few springs were indicated on previous geologic maps, this small study was accomplished to help delineate flowtops, faults, and highly fractured zones.

\section{BASALT STRATIGRAPHY}

A three dimensional stratigraphic basalt model was essential to characterize the local groundwater aquifers. The stratigraphic model was based upon data from well reports along with hand lithologic and geochemical analysis of basalt chips.

\section{Stratigraphy Based on Well Reports}

The first step in determining the subsurface stratigraphy was completed using well reports that had a detailed lithologic column. A well report is a written document submitted to the OWRD by the well driller after a water well has been completed. Each report describes the location and owner of the well, specific information about 
the construction of the well, the determined use of the well, and a generalized lithologic column of the penetrated material. Any changes to a well require a new well report to be submitted to the OWRD.

Depending upon the quality of the available lithologic log, individual flowtops can be inferred. Flowtops were used as stratigraphic markers due to their highly visible nature and their being natural basalt flow boundaries. Words used to describe a flowtop were 'red', porous', 'cinder', 'lava', and 'scoriaceous'. Interbeds and the underlying oligocene and Miocene marine sediments were also depicted in the well reports with words such as 'interbed', 'shale', 'ash', 'conglomerate', and 'sandstone'. A conservative approach in analyzing the well reports was taken due to variations between drillers in terms of their interpretations and observations.

These data and their subsequent depths are presented in Table XII, Appendix A. Well locations are indicated on Plate 1.

\section{Stratigraphy based on Drilling Chips}

A lithologic description was made of chip samples collected at 5,10 or 20 feet $(1.5,3,6 \mathrm{~m})$ intervals from 34 newly drilled water wells (Plate 1; Table XI, Appendix A). This set of data includes chip samples previously analyzed by Al-Eisa (1981) and Marvin Beeson (unpub. data) .

Criteria used to define the identification of the 
basalt units were delineated by Reidel and others (1989). Specifically, grain size, presence and character of plagioclase phenocrysts, presence and abundance of a microphyric texture, along with the presence and concentration of any glass, were used to define the identity of the basalt units. Furthermore, the proximity to a flowtop was inferred based on vesiculation and/or the amount of weathering and oxidation.

\section{Cross Sections}

A comparison between the flowtop elevations determined from the well report lithologic logs and from the detailed stratigraphic logs showed a good association. The degree of association was dependent upon the number of well reports used. Associations were best when a few highly detailed Iithologic logs were used or when there were many moderately detailed well report logs available. Individual flowtop dips were drawn as close to the dip of the topography that the welI log data would support.

This method related well with the surface geology mapped during the summer. Three-point problems were then conducted on the flowtops in order to ascertain the strike and dip of the various basalt units and faults were identified based on changes in dip and distinct elevation changes of the basalt units. 


\section{GEOCHEMICAL ANALYSIS}

$\mathrm{X}$-ray fluorescence (XRF) and instrumental neutron activation analysis (INAA) were the two geochemical analytical methods used to help delineate the basalt stratigraphy of Parrett Mountain. The ultimate goal using the geochemical analyses was to obtain a geochemical signature for all of the basalt units present on the mountain and to compare these values to those obtained from the Lake Oswego Quadrangle (Beeson and others, 1989b).

\section{$\underline{x-r a y}$ Fluorescence}

The XRF analysis measures the concentration of the major oxides along with several trace elements. This process has been used extensively in determining the stratigraphy of the Columbia River basalt since the late $1970^{\prime} \mathrm{s}$.

Eleven basalt chip samples were sent to Washington State University for XRF analysis. This geochemical data can be observed under Table III. Eight of these samples were collected from the Thacker well near the intersection between Heater Road and Parrett Mountain Road. Each of the eight samples represents the occurrence of a distinct basalt flow, identified lithologically, in the well. This well was selected for sampling because it appeared to the penetrate most of the basalt units comprising Parrett Mountain.

Two of the eleven samples were taken from the Manke \#I 


\section{GEOCHEMICAL COMPOSITION OF THE LOW-MG GRANDE RONDE BASALT DEFINED BY XRF ANALYSIS}

Winter Water Umtanum O-GC Wapshilla Ridge

\begin{tabular}{|c|c|c|c|c|c|c|c|c|}
\hline \# of Samp & 2 & & 4 & & 7 & & 5 & \\
\hline Elements & Average & Std. Dev. & Average & std. Dev. & Average & Std. Dev. & Average & std. Dev. \\
\hline SiO2 & 56.68 & 0.39 & 57 & 0.36 & 56.13 & 0.78 & 55.37 & 0.84 \\
\hline Al203 & 13.48 & 0.11 & 14.33 & 0.6 & 14 & 0.11 & 13.99 & 0.38 \\
\hline TiO2 & 2.11 & 0.018 & 2.21 & 0.13 & 1.92 & 0.16 & 2.33 & 0.11 \\
\hline $\mathrm{FeO}$ & 11.58 & 0.61 & 11.31 & 1.66 & 11.27 & 0.97 & 12.21 & 0.59 \\
\hline MnO & 0.2 & & 0.18 & 0.02 & 0.19 & 0.001 & 0.18 & 0.003 \\
\hline $\mathrm{CaO}$ & 7.02 & 0.035 & 0.68 & 1.09 & 7.38 & 0.44 & 7.13 & 0.14 \\
\hline $\mathrm{MgO}$ & 3.4 & 0.02 & 3.04 & 0.68 & 3.85 & 0.46 & 3.514 & 0.1 \\
\hline $\mathrm{K} 2 \mathrm{O}$ & 1.9 & 0.21 & 1.76 & 0.08 & 1.84 & 0.26 & 1.81 & 0.2 \\
\hline $\mathrm{Na} 2 \mathrm{O}$ & 3.27 & 0.13 & 3.27 & 0.21 & 3.08 & 0.081 & 3.11 & 0.22 \\
\hline P2O5 & 0.36 & & 0.378 & 0.021 & 0.32 & 0.041 & 0.35 & 0.009 \\
\hline $\mathrm{Ni}$ & & & & & 6 & 6.67 & 4 & 3.39 \\
\hline $\mathrm{Cr}$ & 14.5 & 2.12 & 15 & 2.45 & 22.14 & 13.15 & 18.2 & 8.76 \\
\hline Sc & 36 & & 35 & 2.31 & 33.57 & 4.44 & 34.4 & 2.07 \\
\hline V & 326.5 & 13.44 & 358 & 15.34 & 324.7 & 28.9 & 365.6 & 14.91 \\
\hline $\mathrm{Ba}$ & 611 & 4.24 & 679.75 & 58.43 & 623.3 & 61.7 & 672.2 & 25.34 \\
\hline$(k)$ & 47.5 & 0.71 & 49.5 & 5.97 & 46 & 8.13 & 49.2 & 3.03 \\
\hline $\mathrm{Sr}$ & 310.5 & 0.71 & 241.25 & 142.74 & 311.4 & 16.8 & 313.6 & 7.23 \\
\hline $2 r$ & 181 & 1.41 & 185.25 & 9.28 & 167 & 17.7 & 187 & 4.69 \\
\hline Yt & 39 & & 39.75 & 3.2 & 34.86 & 2.84 & 38 & 0.707 \\
\hline N\}, & 310.5 & 0.07 & 15.02 & 0.92 & 13.1 & 1.8 & 15.02 & 0.64 \\
\hline Cu & & & 5.75 & 3.86 & 14.7 & 12.2 & 13.6 & 1.95 \\
\hline $\mathrm{Zn}$ & 128.5 & 2.12 & 141.25 & 7.97 & 120.3 & 5 & 130.6 & 5.27 \\
\hline $\mathrm{Pb}$ & 6 & & 9.5 & 2.38 & 9.86 & 4.37 & 9 & 2.55 \\
\hline Lad & 12 & 1. 41 & 20.5 & 8.38 & 28.3 & 18.38 & 24 & 16.86 \\
\hline Ce & 66 & 14.14 & 20.92 & 4.57 & 44.57 & 17.5 & 56 & 9.62 \\
\hline Th & 5.5 & 0.71 & 5.75 & 0.96 & 56.43 & 2.. 3 & 5.8 & 2.17 \\
\hline
\end{tabular}


and Adam's wells, in which a distinct basalt flow not occurring in the Thacker well was present. The last sample was collected from a small rock quarry on the southeastern side of La Butte. XRF data from the previously analyzed Cedar Creek well (Al-Eisa, 1981; Dr. Beeson, 1993, personal commun.), Sherwood well \# 5, and the Woodburn well (Marvin Beeson, 1993, personal commun.) 'were reexamined in order to obtain more geochemical data on an individual basalt unit.

\section{Instrumental Neutron Activation Analysis}

The INAA process measures trace and several major element concentrations for rock samples, by measuring the gamma ray activity given off by a sample after it has been irradiated. When a sample is irradiated, the stable isotopes of some elements that composed the rock sample are converted to unstable isotopes and give off gamma rays as they decay. These gamma rays are then measured by a high purity germanium detector used by Portland State University.

Delineating the stratigraphy of the Columbia River basalt was attempted by INAA in the late 1970's to early 1980's (e.g. Nathan and Fruchter, 1974) but was then set aside due to the success of x-ray fluorescence. Therefore, the success of INAA as a definitive method of separating out Columbia River basalt units is very limited.

INAA was conducted on thirty-eight hand and well chip samples collected from the study area (Table IV). In an attempt to ascertain the usefulness of INAA in the 
TABLE IV

INAA ANALYSIS OF DRILLING CHIPS

AND FIELD SAMPLES
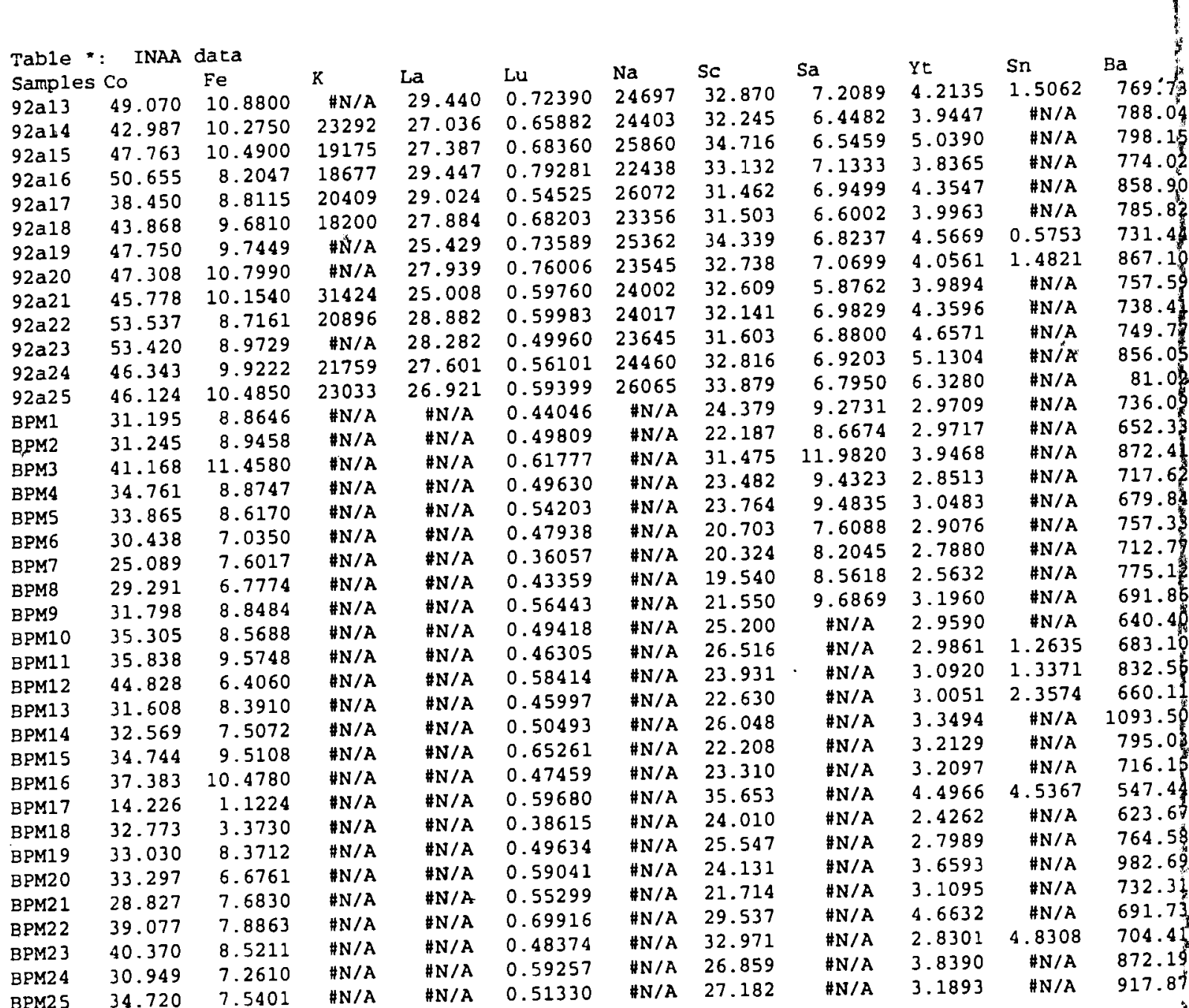

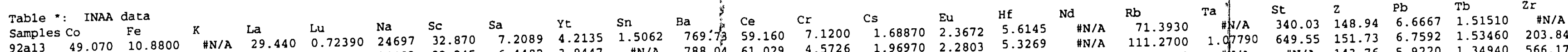

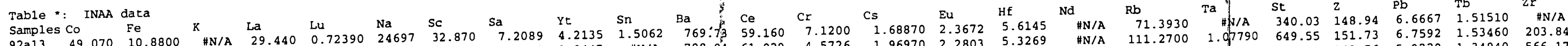

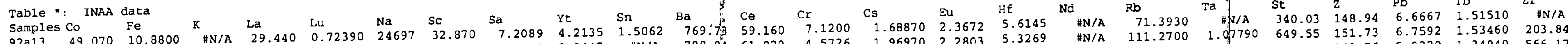

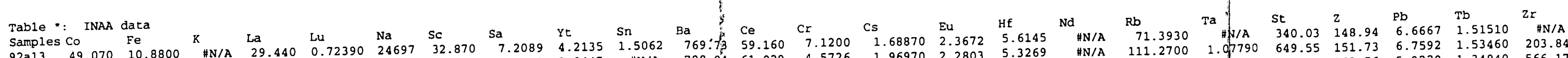

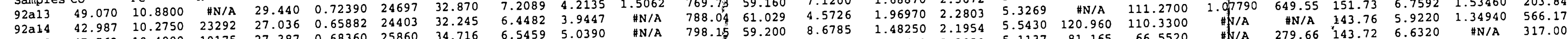
$\begin{array}{lllllllllllllllllllll} & \end{array}$

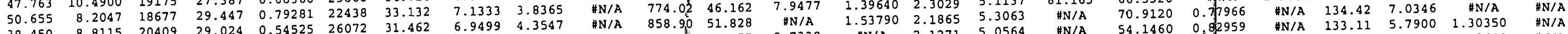

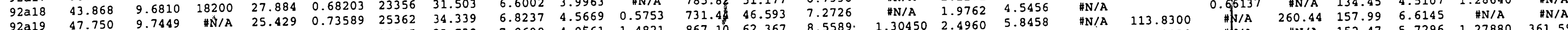

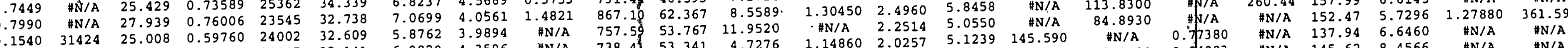
$\begin{array}{lllllllllll}92 \mathrm{a} 23 & 53.420 & 8.9729 & \text { \#N/A } & 28.282 & 0.49960 & 23645 & 31.603 & 6.8800 & 4.6571 \\ & 46.343 & 0.922 & 2303 & 26.921 & 0.5301 & 2460 & 32.816 & 6.9203 & 5.1304\end{array}$

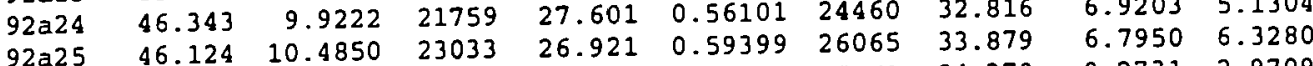
$\begin{array}{llllll}\text { \#N/A } & 0.44046 & \text { \#N/A } & 24.379 & 9.2731 & 2.9709\end{array}$

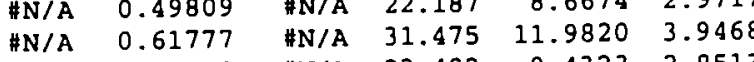

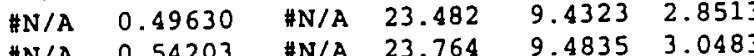
$\begin{array}{lllllll}\text { \#N/A } & 0.54203 & \text { \#N/A } & 23.764 & 9.4835 & 3.0483 \\ \text { NN/A } & 0.47938 & \text { \#N/A } & 20.703 & 7.6088 & 2.9076\end{array}$

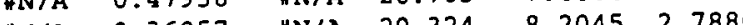

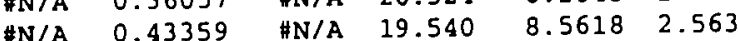
$\begin{array}{llllll}\text { \#N/A } & 0.56443 & \text { \#N/A } & 21.550 & 9.6869 & 3.1960 \\ \text { \#N/A } & 0.4610 & \text { W/A } & 25.200 & \text { \#N/A } & 2.9596\end{array}$ \#N/A $0.49418 \quad$ \#N/A 25.200 NN/A 0.46305 AN/A 26.516 \#N/A $0.45997 \quad$ \#N/A 22.630 $\begin{array}{lllll}\text { \#N/A } & 0.50493 & \text { \#N/A } & 22.048 \\ \text { NW } & 0.65261 & \text { \#N/A } & 22.208\end{array}$ $\begin{array}{llll}\# \mathrm{~N} / \mathrm{A} & 0.65261 & \# \mathrm{~N} / \mathrm{A} & 22.208 \\ \sharp \mathrm{N} / \mathrm{A} & 0.47459 & \# \mathrm{~N} / \mathrm{A} & 23.310\end{array}$ \#N/A $0.59680 \quad \# N / A \quad 35.65$ \#N/A 0.38615 \#N/A 24.010 $\begin{array}{llll}\# \mathrm{~N} / \mathrm{A} & 0.49634 & \# \mathrm{~N} / \mathrm{A} & 25.54 \\ & 0.59041 & \# \mathrm{~N} / \mathrm{A} & 24.131 \\ \mathrm{~N} / \mathrm{A} & 0.5599 & \mathrm{~N} / \mathrm{A} & 21.714\end{array}$

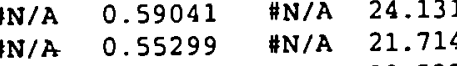
$\begin{array}{lllll} & \text { NN/A } & 0.69916 & \text { \#N/A } & 29.537\end{array}$ \#N/A $0.48374 \quad$ \#N/A 32.971

$\begin{array}{llll}\text { \#N/A } & 0.59257 & \text { \#N/A } & 26.859 \\ \text { \#N/A } & 0.51330 & \text { \#N/A } & 27.182\end{array}$ $\begin{array}{rrrrrrr}\# N / A & 2.9590 & \# N / A & 640.4 p^{*} & 46.560 & 13.2180 \\ \# N / A & 2.9861 & 1.2635 & 683.10 & 49.001 & 15.3560 \\ \text { \#N }\end{array}$ $\begin{array}{llll}\text { \#N/A } & 3.0920 & 1.3371 & 832.5\end{array}$ $\begin{array}{llllll}* N / A & 3.0051 & 2.3574 & 660.11 & 45.219 & 12.1460\end{array}$ NN/A $3.3494 \quad$ HN/A $1093.5038 .147 \quad 20.3950$ $\begin{array}{llll}\# N / A & 3.2097 & \# N / A & 716.1\end{array}$

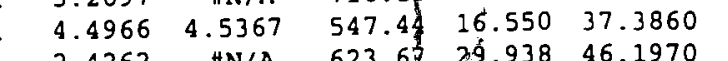

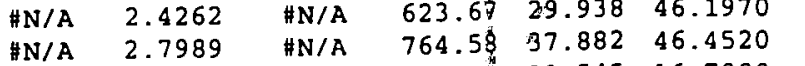
$\begin{array}{llllllll}\text { \#N/A } & 3.6593 & \text { \#N/A } & 982.69 & 39.545 & 16.7080 \\ \text { \#N/A } & 3.1095 & \text { \#N/A } & 732.31 & 47.380 & 9.3253\end{array}$ $\begin{array}{lll} & \\ & \end{array}$

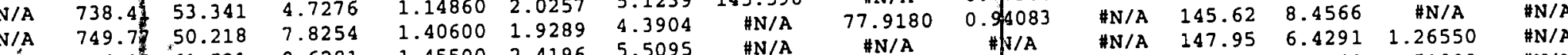
$\begin{array}{ccccccccccccccc} & & & \end{array}$ $\begin{array}{lllllllllllllll} & & & \end{array}$

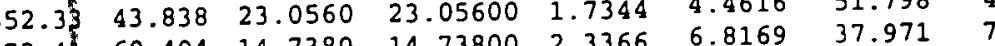
$55.7730 \quad 0.55968$ $\begin{array}{lllllll}58.0386 & 0.63027 & 390.72 & 145.18 & 5.4920 & 0.93754 & 302.71\end{array}$ $\begin{array}{lllllll}69.4140 & 0.9615 & 312.57 & 145.98 & 5.4920 & 0.93754 & 302.71\end{array}$ $\begin{array}{lllllll}39.0570 & 0.61710 & 413.45 & 104.06 & 5.6076 & 0.89270 & 221.52\end{array}$

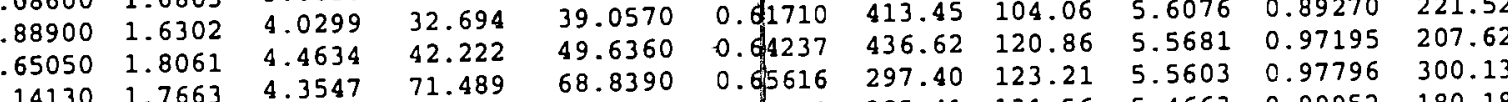

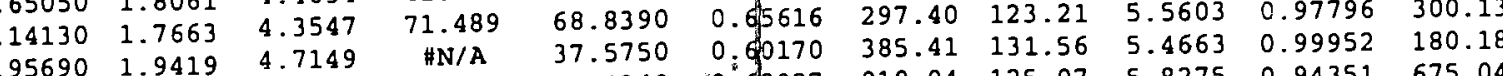

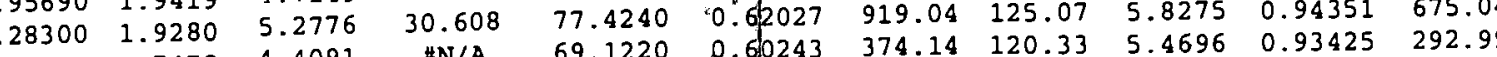
$\begin{array}{llllllllllll} & \end{array}$ $\begin{array}{llllllllllll}39720 & 1.7777 & 5.0381 & 30.459 & 55.2290 & 0.56465 & 492.53 & 115.88 & 5.3297 & 0.91135 & 352.92\end{array}$

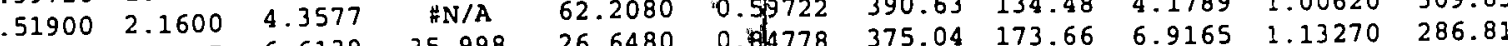
$\begin{array}{lllllllllll}1.27 & & & \end{array}$ $\begin{array}{lllllllllll}24090 & 1.7979 & 4.2635 & 26.097 & 35.2770 & 0.599818 & 476.50 & 134.79 & 3.3789 & 0.80483 & 362.12\end{array}$ $\begin{array}{llllllllllll}1.58320 & 2.0867 & 4.6636 & \text { \#N/A } & 42.3530 & 0.83020 & 334.01 & 132.00 & 5.0995 & 1.02280 & 342.85 \\ 0.952 .3270 & 0.7064 & 388.11 & 119.09 & 6.5189 & 1.4060 & 262.41\end{array}$

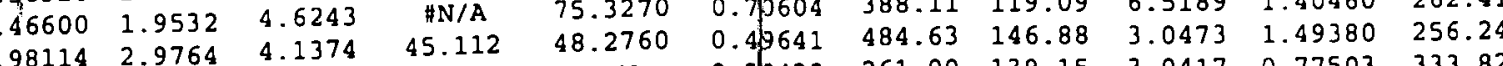
$\begin{array}{lllllllllll}0.98114 & 2.9764 & 4.1374 & 45.1 / \mathrm{A} & \text { \#N/A } & 0.55438 & 261.00 & 139.15 & 3.0417 & 0.77503 & 333.82\end{array}$ 1 


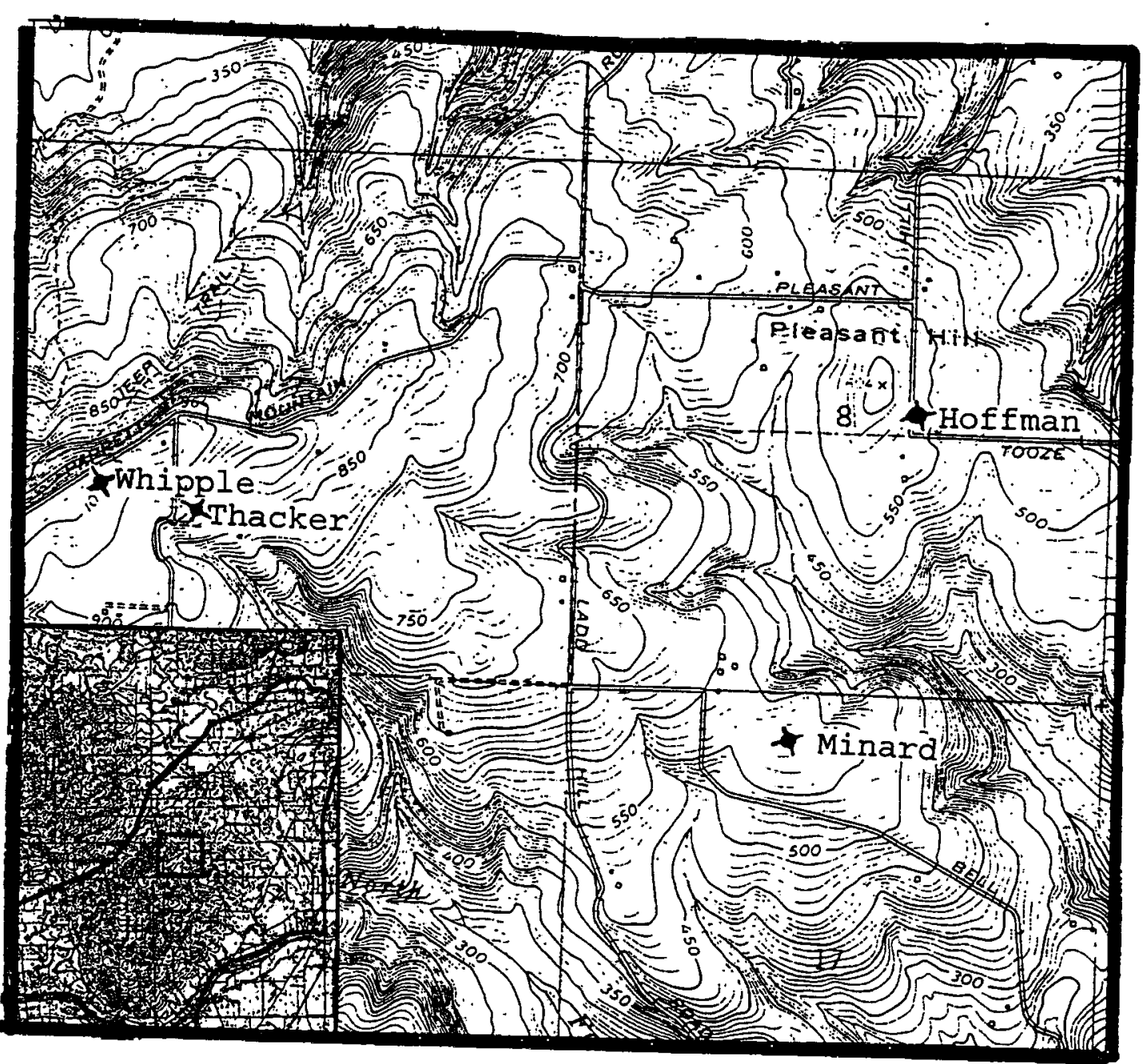

Figure 9. Location of wells where XRF and INAA samples were collected. The inset shows the location of the figure within the study area. 
separation of the basalt units, thirteen of the thirty-eight basalt chip samples, were analyzed prior to the initiation of the Parrett Mountain study. These thirteen samples where taken from the Wipple, Hoffman, and Minard wells (Table XI, Appendix A) at various depths in order to correlate basalt units over a distance (Figure 9). The results of the smaller INAA project showed that several elements, $\mathrm{Cr}, \mathrm{Ba}$, and $\mathrm{Ce}$, could be used to separate individual basalt units within a given water well, but that correlation of these units based on trace element concentrations over some distance was tenuous at best.

The remaining 25 samples were basalt chips collected from water wells along with basalt hand samples collected during field mapping. These samples underwent the INAA process solely to identify the $\mathrm{Cr}$ concentration in each sample. Cr concentrations have been known to delineate the high-magnesium ( $\mathrm{Cr}>25 \mathrm{ppm})$ and low-magnesium $\mathrm{N}_{2}$ unit $(\mathrm{Cr}<$ 25) of the Grande Ronde Basalt. Therefore, by using INAA, a stratigraphic division can be accomplished.

\section{POTENTIOMETRIC HEAD ANALYSIS}

The potentiometric surface map (Plate 3) was devised for the entire Parrett Mountain area using the head data obtained from Miller and others (1994). The key problem in creating a potentiometric surface map, for the study area, was identifying which aquifer to map. This aquifer would 
have to be regional in extent in order to obtain the most amount of information for the entire study area. Second, the aquifer had to have enough water well data, collected by OWRD, to make as accurate a map as possible. Using these two criteria, only the Ortley-Grouse Creek (undifferentiated) / Wapshilla Ridge basalt boundary was usable. However, several areas on Parrett Mountain had no data for this boundary. Therefore, it was necessary to designate the entire Columbia River basalt, comprising Parrett Mountain, as one aquifer.

Designation of the CRB as one aquifer allows for the possibility of composite heads. A composite head is an averaged water level, within a well, of several potentiometric heads. This typically can occur when a water well is uncased or unlined and penetrates several aquifers.

For the development of the potentiometric surface map, each head value was mapped with respect to the well's location. Each township and range section was divided into quarters $(a, b, c, d)$ which were further subdivided into quarters $(a, b, c, d)$. Every head value located in a quartered quartered section was then averaged giving and a head value representative for that part of the section (Figure 10; Table XVI, Appendix B). Individual head values obtained from Miller and others (1994) are found in Table XI in Appendix $B$ while the compiled head data for the potentiometric surface map can be observed on Plate 3 . 


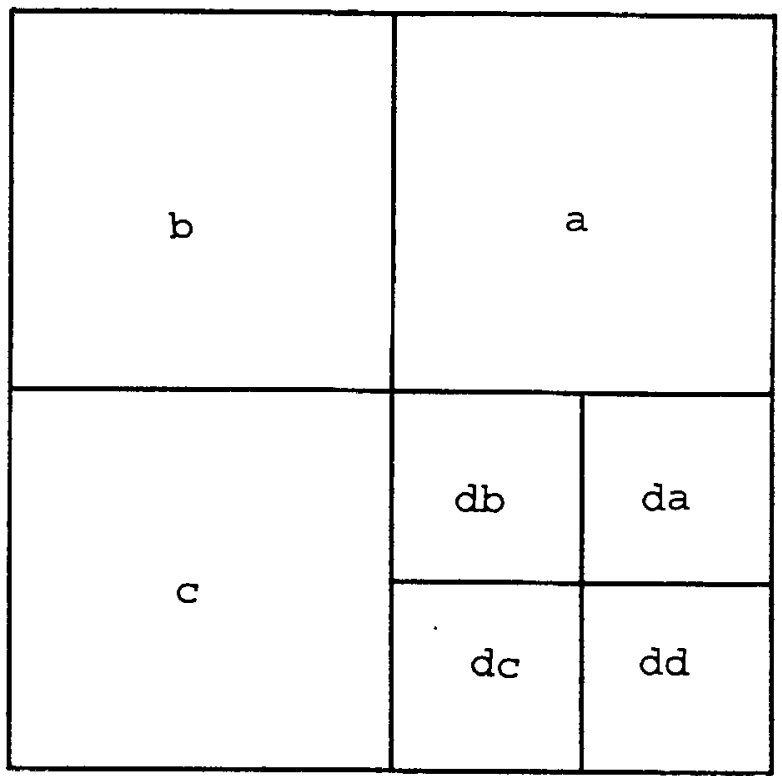

Figure 10. Diagram representing the quarter- quarteraveraging system used to define a potentiometric surface map. 
Creation of the potentiometric surface map showed large head changes occurring within the quarter- quartersections. Through a comparison of the stratigraphic and hydrologic data (Tables XI and XII, Appendix A; Table XV, Appendix B) each large head change was related to 1) penetration into differing interflow zones or 2) groundwater barriers. If the head change was due to the penetration of differing flowtops then the difference was essentially ignored since the entire CRB has been considered to be one aquifer. However, if the head change was due to the presence of a groundwater barrier, then both head values were plotted with respect to approximate well locations in order to essentially approximate the location of the groundwater barrier. 


\section{BASALT STRATIGRAPHY}

Field mapping and laboratory analysis revealed that the Columbia River basalt in the Parrett Mountain and Tonquin area is comprised of the Grande Ronde Basalt and the Wanapum Basalt formations. The Grande Ronde Basalt is composed of the following basalt units, from oldest to youngest: the Wapshilla Ridge, the Ortley-Grouse Creek, the Umtanum, the Winter Water, and the Sentinel Bluffs. The Wanapum basalt is represented by a single Ginkgo flow of the Frenchmen Springs Member. A maximum thickness of 900 feet $(274 \mathrm{~m})$ was measured for the CRB at Rex Hill. Figure 11 is a representative stratigraphic column of the basalt flows comprising Parrett Mountain.

Laboratory analysis included hand lithologic examination of basalt chips, XRF, and INAA techniques while the field analyses included field mapping and magnetic polarity measurements. These analyses have proven to be useful in identifying and correlating individual CRB basalt units at a local level (Holmgren, 1969).

GRANDE RONDE BASALT

\section{Wapshilla Ridge Basalt Unit}

The Wapshilla Ridge basalt unit, the oldest unit present in the area, uncomformably overlies the Oligocene - 


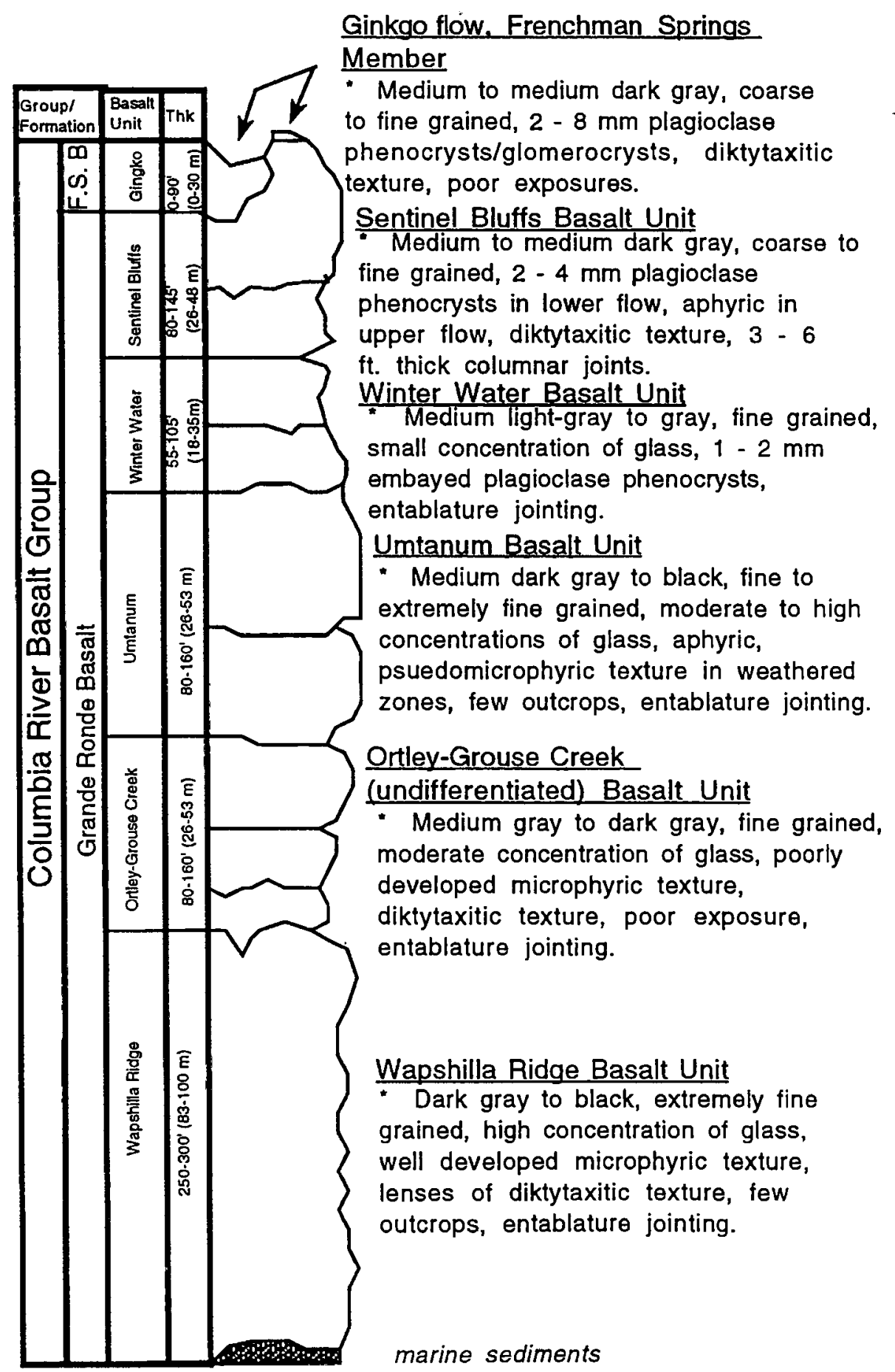

Figure 11. A representative stratigraphic column of the Columbia River basalt comprising Parrett Mountain. 
Miocene sedimentary deposits. Exposures occur on the western side of Parrett Mountain, within the Fernwood Quarry (both the upper and lower quarries), as well as along Fernwood road (Figure 12). Of the wells studied, most on the western portions of Parrett Mountain penetrate the Wapshilla Ridge basalt while only a small percentage of the wells on the eastern half of the mountain actually reach the Wapshilla Ridge.

Only one Wapshilla Ridge basalt flow has been discovered in the study area with an approximate thickness of 250 to 300 feet $(76.2$ to $91.4 \mathrm{~m})$. The maximum thickness is observed for the Rex Hill and the old Parrett Mountain Parrett Mountain Road junction area (Plate 2).

The Wapshilla Ridge basalt unit is easily distinguishable by its polarity and lithologic characteristics. Polarity was determined to be reverse using a portable field magnetometer. Typically a reverse reading is considered to be reverse while a normal reading should be questioned since a normal overprinting is possible due to the current normal polarity expressed by the Earth's magnetic field.

The most distinctive lithologic characteristics are the extremely fine-grained groundmass, a high glass content and a highly developed microphyric texture. The basalt unit is typically dense textured though several diktytaxitic zones have been observed within all of the Manke wells, the 


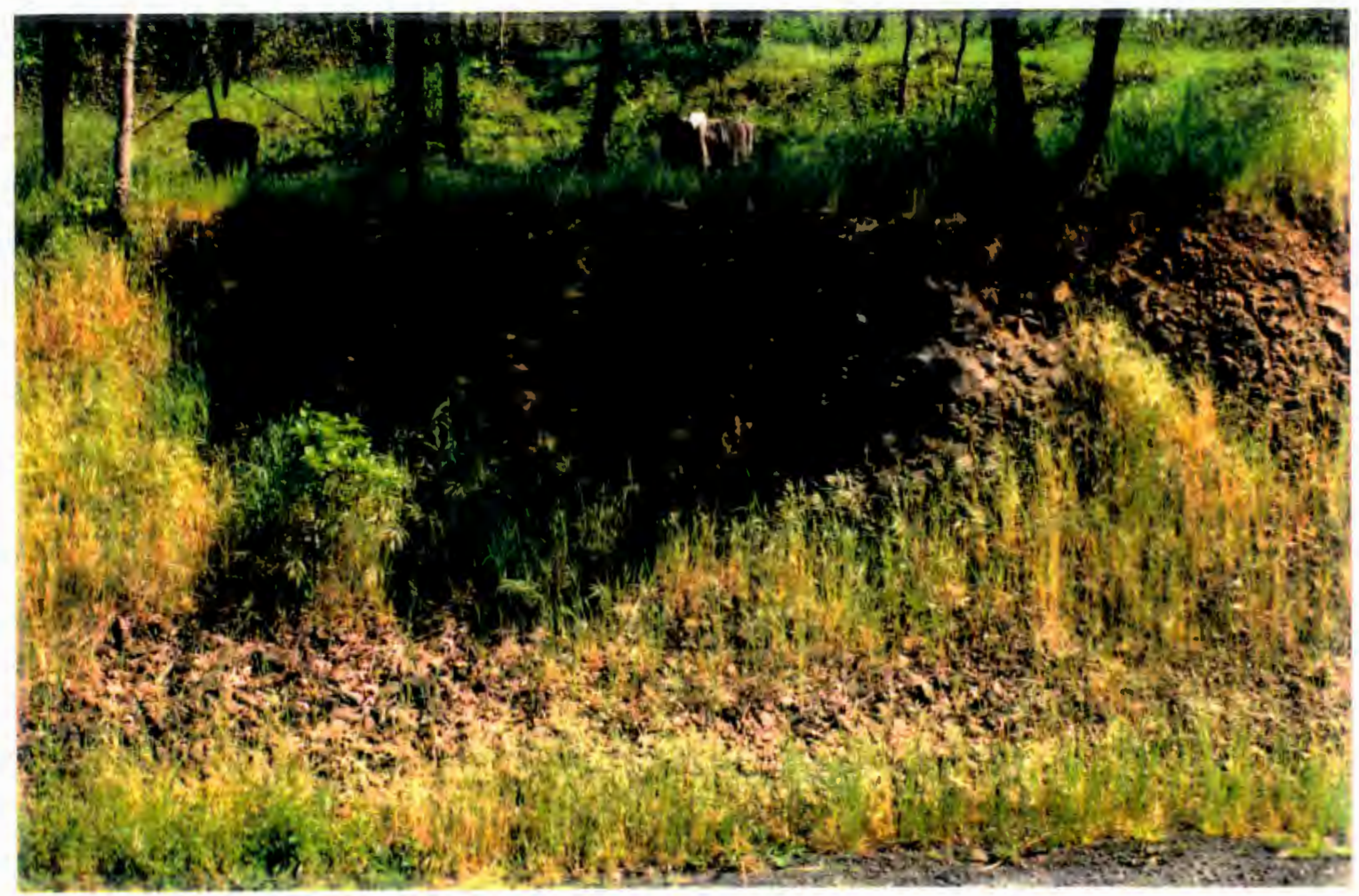

Figure 12. Exposure of the Wapshilla Ridge basalt along the Fernwood Road. 
Thacker well, and the Puderbaugh well (Plate 1; Figure 41, 42, Tables XI, Appendix B). The microphyric texture present in this unit is easily observed in a fresh to moderately weathered state. These microphyric plagioclase laths are typically one to two millimeters long and less than $1 / 2$ millimeter thick. Difficulty in observing this texture occurs in the highly weathered zones where oxidation and basalt alteration or diktytaxitic zones mask a plagioclase phenocryst's presence. Jointing, seen best in the Fernwood Quarry, is an entablature jointing pattern with the columnar section either suppressed or unexposed. The Wapshilla Ridge unit has a well developed oxidized and weathered flow top in many of the newly drilled wells analyzed.

Geochemically the Wapshilla Ridge unit has a lower $\mathrm{SiO}_{2}$ content with high $\mathrm{TiO}_{2}$ while the trace elements show higher concentrations of vanadium, barium, rubidium, zinc, and cesium and a lower concentration of lanthanum compared to the Ortley-Grouse Creek unit (Table III).

\section{Ortley-Grouse Creek (undifferentiated) Basalt Unit}

Ortley and Grouse Creek basalt units are separated based on distinct lithologic characteristics and chemical compositions. However, in the study area, the Ortley and Grouse Creek units could not be differentiated from one another based on the above criteria. Magnetic signatures proved ineffectual in separating out the Ortley and Grouse Creek units due to poor quality, highly weathered basalt 
exposures. Due to the difficulty in separating the ortley and Grouse Creek basalt units, they have for the purposes of this report been combined into the undifferentiated ortleyGrouse Creek basalt unit.

Hand lithologic and geochemical analyses of the basalt chips identified three flows comprising the ortley-Grouse Creek (undifferentiated) basalt unit. Exposures occur on the western side of Parrett Mountain, on the northwest side of Parrett Mountain, and along the north facing valley wall of the South Fork of Corral Creek. Typically the exposures of the Ortley-Grouse Creek (ụdifferentiated) basalt are covered by colluvium and alluvium.

The thickness of the unit varies from 80 to 160 feet $(24.4$ to $48.8 \mathrm{~m})$ with an average of 100 feet $(30.5 \mathrm{~m})$. The maximum thickness occurs on the southwest side of Parrett Mountain near the junction of Corral Creek Road and Fernwood Road. The unit thickens to the northeast and west with a thinning occurring near the Parrett Mountain and old Parrett Mountain Road junction. Thicknesses of the individual basalt flows generally range from 25 to 30 feet $(7.6$ to 9.1 $m$ ), the middle flow showing the most variability, from 20 to 35 feet $(6.1$ to $10.7 \mathrm{~m})$.

Lithologic traits characteristic of the ortley-Grouse Creek (undifferentiated) basalt are: a fine-grained groundmass, rare to moderate amount of glass, and a poorly developed microphyric texture. The microphyric texture is 
composed of a small concentration of large plagioclase laths, two to three millimeters long, or a moderate abundance of very small plagioclase laths, equal or less than one millimeter in length, or both. Moderate amounts of weathering often mask the presence of the microphyric texture. Weathered surfaces range in color from green, white, to blue clay films. Only the upper basalt flow shows an oxidized flowtop, while all three are weathered. The lithologic columns, provided in the well reports, typically do not identify the flowtops of the two lower flows, suggesting that the flowtop characteristics are difficult to discern, very thin, or eroded away.

The jointing patterns, of this unit, are impossible to discern due to a lack of bedrock exposures. Work by Riedel and others (1989) discusses the jointing pattern of the Ortley and Grouse Creek units as being entablature in nature.

Based on XRF data, the Ortley-Grouse Creek (undifferentiated) basalt has a higher $\mathrm{SiO}_{2}$ and $\mathrm{MgO}_{2}$ with a lower $\mathrm{TiO}_{2}$ content. The trace elements rubidium, barium, and zirconium tend to be lower in concentration while the chromium content is higher than either the Umtanum or Wapshilla Ridge units.

\section{Umtanum Basalt Unit}

Analysis of the well chips from the newly constructed water wells reveals the Umtanum unit to be composed of two 
laterally extensive basalt flows. Thickness of the unit varies from 80 to 160 feet $(24.4$ to $48.8 \mathrm{~m})$, with the maximum occurring at the Parrett Mountain-old Parrett Mountain (PM/OPM) road junction area. A general thinning of the unit, to 80 feet $(24.4 \mathrm{~m})$, occurs in the northern Parrett Mountain region with a subsequent thickening away from that locale. A third flow, highly distinctive in its lithologic and geochemical characteristics, was identified along Cedar Creek, beneath the city of Sherwood, and exposed in a rock quarry at La Butte (Marvin Beeson, 1993, written commun.). The exact stratigraphic position appears to lie between the Umtanum and winter water units. For this report, this third flow has been grouped into the Umtanum basalt unit based on similar lithologic characteristics.

Generally water well reports do not recognize the boundary between the upper and lower Umtanum basalt flows in terms of a recognizable flow top. Hand lithologic analysis of the well chips show some flowtop development, though in several wells, e.g. Manke \#1 and \#3, the lower flow's flowtop is difficult to discern. Several possible explanations can be suggested for this phenomenon. First, the flowtop could possibly be very thin and poorly developed, second, the flowtop was not recovered due to the drilling techniques, or third it could have been eroded away before burial by later flows.

The Umtanum unit is difficult to discern from the 
Winter Water unit due to similar lithologic characteristics and chemical compositions. Identification of the unit is based on aphyric fine-grained groundmass with minor amounts of glass. The main lithologic distinction between the Umtanum unit and the winter water unit is the lack of plagioclase phenocrysts in the Umtanum flows. Three wells, the Thacker, Brentano, and Pelling wells (Table X, Appendix $A ;$ and Plate 1) showed plagioclase phenocrysts within the designated Umtanum basalt flows. The basalt containing the plagioclase phenocrysts was designated as Umtanum basalt due to 1) possible contamination of drilling chips due to the sample collection process, 2) stratigraphic positioning, and 3) the lack of data supporting more than two flows of the Winter Water basalt unit within the study area. Weathering of the Umtanum unit will cause a psuedomicrophyric texture to develop on the basalt fragments. This typically does not occur in the winter Water basalt. A honey golden brown weathering color was observed solely with the Umtanum basalt unit. The Umtanum unit expresses an entablature jointing pattern with the colonnade portion suppressed or poorly exposed. Other weathering colors possible are blue, green, gray, and white. The third flow, observed on the fringes of the study area has very distinctive lithologic characteristics. This flow has extremely fine grained aphanitic groundmass with a significant amount of glass. No plagioclase phenocrysts 
were observed in the groundmass.

As stated above, the Umtanum and Winter Water units are similar geochemically (Table III). This similarity made a basalt unit division, based on geochemical composition, tenuous. However, some differentiation can be accomplished. The Umtanum unit typically shows a higher $\mathrm{SiO}_{2}, \mathrm{Al}_{2} \mathrm{O}_{3}$, and Feo with a corresponding smaller concentration of $\mathrm{MgO}_{2}$ than the winter Water and Ortley-Grouse Creek (undifferentiated) basalt units. Some specific differences in the trace element concentrations are also apparent. These differences are a lower barium concentration corresponding to higher concentrations of strontium and cesium.

\section{Winter Water Basalt Unit}

The winter water unit contains two basalt flows that are laterally extensive. Exposures of the winter water occur within the drainages. These flows are generally thinner than the other units, varying from 55 to 105 feet $(16.8$ to $32 \mathrm{~m})$. The winter water unit thickens in the northeastern and northwestern direction while thinning to the southeast. Typically the upper flow has a constant thickness of 50 feet $(15.2 \mathrm{~m})$ while the lower flow varies from 45 to 55 feet $(13.8$ to $16.8 \mathrm{~m})$. A thinning of the unit is seen at Roberts Hill where the upper flow is 25 feet $(7.6$ $\mathrm{m})$ and the lower flow is 30 feet $(9.1 \mathrm{~m})$ thick.

This unit can be identified from the other units based on lithologic and geochemical characteristics. The winter 
Water unit has a fine-grained groundmass with a moderate to low abundance of plagioclase phenocrysts. These phenocrysts are typically one to two millimeter subhedral solitary crystals sometimes occurring in glomerocrysts. The edges of the plagioclase crystals typically appear rounded to slightly embayed, a characteristic uncommon in the sentinel Bluffs unit (discussed below). Within the study area, the plagioclase phenocrysts are typically rare, encountered only once to a few times within any given chip sample and very rarely encountered in the field, The winter water unit is seen to have an entablature/colonnade jointing pattern with the colonnade being suppressed or poorly exposed.

The geochemical signature for the winter water unit given by XRF analysis shows that this unit differs from the Umtanum unit based on a lower $\mathrm{SiO}_{2}, \mathrm{Al}_{2} \mathrm{O}_{3}, \mathrm{TiO}_{2}$ concentrations and a corresponding increase in $\mathrm{CaO}$ and $\mathrm{MgO}$ content. Trace element concentrations show the winter Water unit to have lower barium, rubidium, lanthanum, and zinc concentrations while elevated concentrations of strontium and cesium occur.

\section{Sentinel Bluffs Basalt Unit}

The Sentinel Bluffs unit is easily distinguishable from the other basalt units based on its lithologic characteristics and geochemical signature. Two sentinel Bluffs flows have been mapped within the study area's boundaries with thickness ranging from 40 to 65 feet (12.2 
to $20 \mathrm{~m})$ for the upper flow and from 45 to 75 feet $(13.8$ to $23 \mathrm{~m})$ for the lower flow. A generalized thickness trend for the unit shows a thickening towards the northeast and northwest corresponding to a thinning to the southeast and near Pleasant Hill. Field mapping reveals that most of eastern Parrett Mountain and the Tonquin area is covered by the two flows of Sentinel Bluffs. Identification of these flows, within the study area is fairly well constrained; however, well reports generally do not recognize the lower flow's flowtop thereby grouping the two flows together. The most identifiable lithologic characteristic, of the Sentinel Bluffs unit, is a coarse-grained, dense to diktytaxitic texture expressed throughout most of the unit's thickness. The lower flow is phyric with euhedral plagioclase phenocrysts while the upper flow is aphyric. The basalt unit shows a columnar jointing pattern, expressed best in the Tonquin region where the columns are roughly 6 feet $(2 \mathrm{~m}$ ) in width (Figure 13 ). It is this jointing pattern that allows the sentinel Bluffs basalt unit to weather into spheroidal shaped boulders. Weathering typically causes a greenish tint characteristic of the Sentinel Bluffs. Care must be taken in identifying this unit from the winter water unit, for weathering can cause a fine-grained diktytaxitic textured basalt to appear to be coarse grained. However, weathering of the winter water unit will also typically cause the development of a 


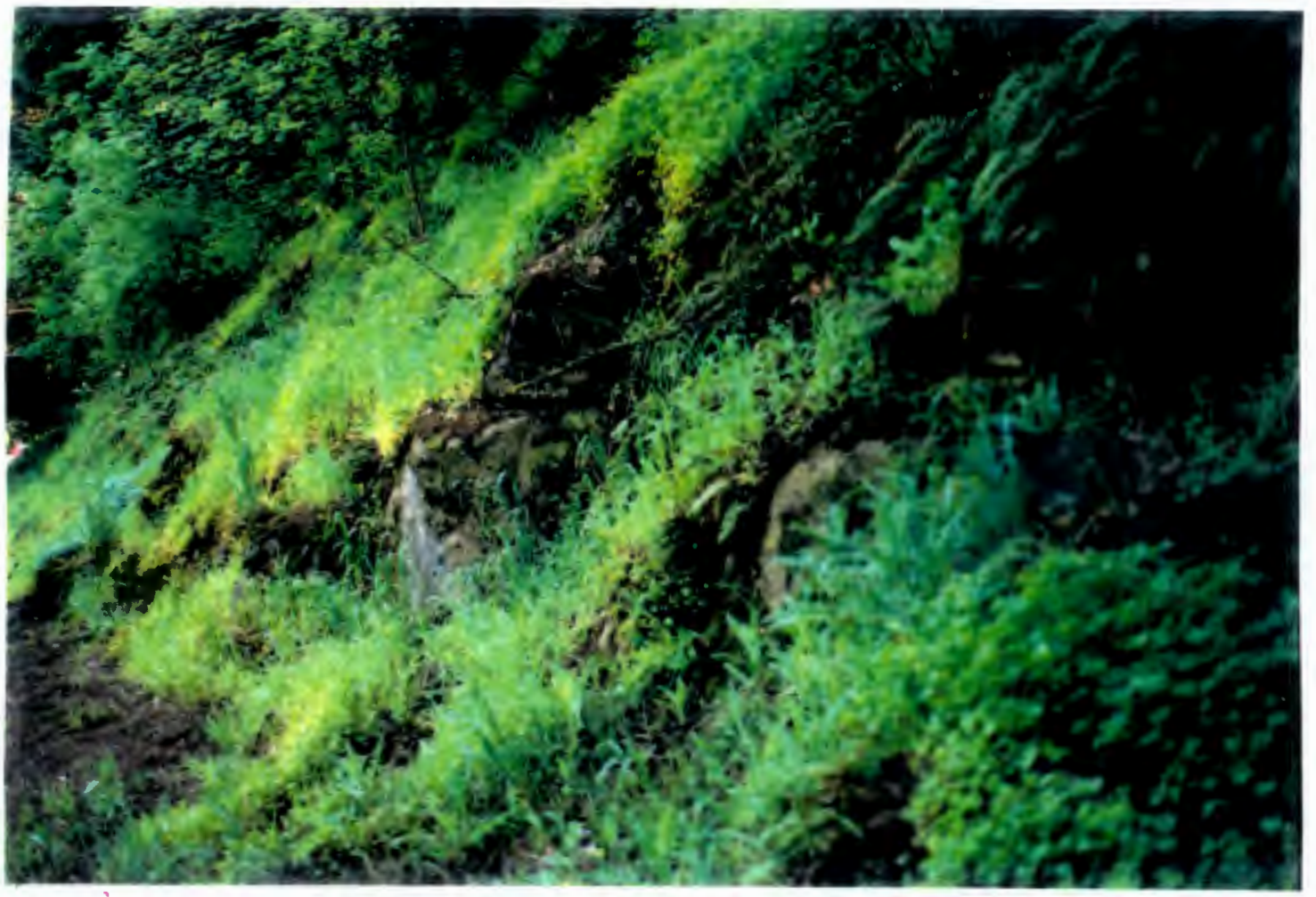

Figure 13. Exposure of the Sentinel Bluffs basalt along highway $99 \mathrm{~W}$. 
hydration rind, that migrates from the surface to the core of the basalt fragment.

XRF and INAA analyzes can be used to distinguish this unit from the other Grande Ronde Basalt units. No XRF data of the sentinel bluffs unit were collected for this study and therefore, not listed in Table III. Major oxide concentrations are provided by Beeson and others (1989b).

Some INAA data were collected on the sentinel Bluffs unit. Examination of the data showed that the sentinel Bluffs basalt unit is distinguishable, based on the chromium content, from the other basalt units. The data show that the unit generally has a chromium content equal to or greater than 40 ppm (Table IV).

\section{WANAPUM}

\section{Frenchman Springs Member: Ginkgo flow}

The Ginkgo flow is the sole representative of the Wanapum Basalt within the study boundaries. This flow is observed only along the tops of the ridges and along the southeasterly dipping slopes. The basalt thickness varies from 0 to 90 feet ( 0 to $27.4 \mathrm{~m}$ ), with the maximum thickness occurring along the old Parrett Mountain - Parrett Mountain Road junction. The large difference in the flow thickness could be a result of the large hiatus between the sentinel Bluffs and Ginkgo flow. This large hiatus, the largest known for Parrett Mountian, could have allowed a greater 
topographic development to occur as discussed on page 62 .

The large thickness of the Ginkgo flow on Rex Hill and Parrett Mountain can be explained by either the inflation of the basalt flow or the stacking of two individual Ginkgo flows. Unfortunately there has been no observable data to support either hypothesis.

The Ginkgo flow of the Frenchmen Springs Member of the Wanapum Basalt is highly distinctive in terms of lithologic characteristics. This unit is coarse-grained, containing an abundance of euhedral to subhedral plagioclase phenocrysts one to three centimeters long. These phenocrysts vary in color from a reddish tint to a creamy white to clear translucent color.

As with the Sentinel Bluffs unit, the jointing pattern is typically columnar. This is inferred from the number of spheroidal Ginkgo basalt boulders excavated from the subsurface. There were no bedrock exposures of the Ginkgo flow on Parrett Mountain. Soils developed on this unit are typically a blood red color. This is very distinctive for the Ginkgo flow because the soils derived from the other basalt units tend to develop a reddish brown color.

Due to the highly weathered yet distinctive texture of the Ginkgo flow, no samples of this unit were analyzed for a geochemical concentrations. Published data for this flow are included with the Geologic Map of the Lake Oswego Quadrangle by Beeson and others (1989). 
INTERBEDS

An interbed is a regional to local sedimentary or ash layer deposited during a hiatus between basalt flow eruptions. The type of material, occurrence and thickness of an interbed are dependent upon the source of the sediments, the type of depositional and erosional processes occurring, and the length of time between basalt eruptions.

\section{The Vantage Horizon}

The Vantage Member is a sedimentary layer seen throughout the Columbia River Plateau. This layer was deposited during a 100,000 to 300,000 year hiatus between the Grande Ronde Basalt and the Wanapum Basalt eruptions. The type of material composing the vantage layer varies throughout the entire Columbia Plateau, from a sandstone to a shale, to an erosional surface.

Within the study area, the Vantage Member is unexposed. Two possible reasons are given. The first is that the Vantage Member is covered by soil and organic litter, masking its appearance. This is a plausible hypothesis due to the weathering depth and thick soil development where the Ginkgo flow is present. The second possibility, is that the Vantage Member is represented, in this area, as an erosional surface on the uppermost sentinel Bluffs flow (Figure 14).

The Vantage interbed is not reported in the analyzed wells that penetrate the Ginkgo flow. One possible 


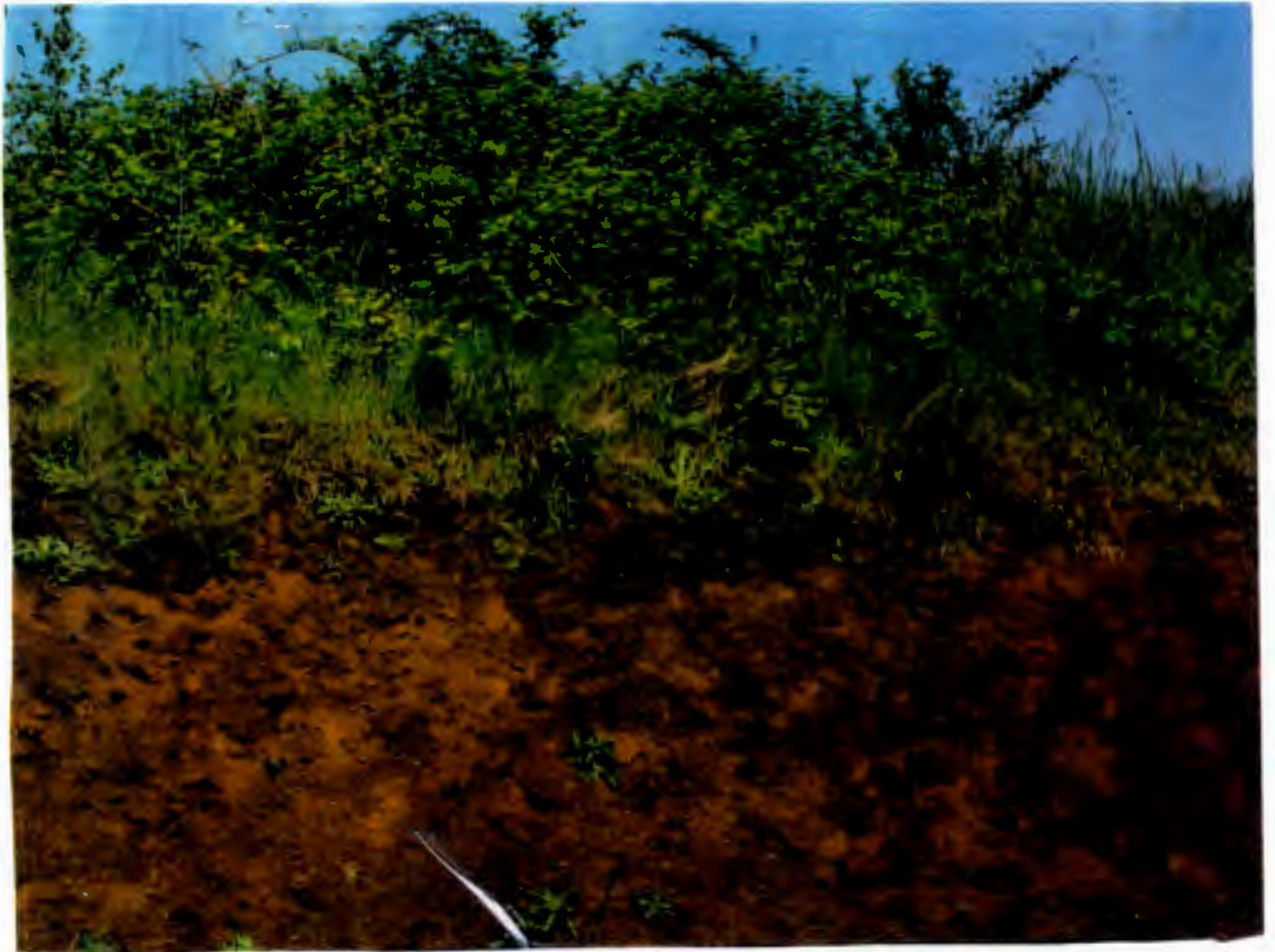

Figure 14. Typical appearance of the Vantage Horizon on Parrett Mountain. Picture taken along Xanthus Court. 
explanation for this apparent absence is the well drilling process itself, that is air rotary drilling. Air rotary may have caused the disaggregation of any material that may be contained in the Vantage horizon. Only within a few lithologic well reports, e.g. the Gordon well (T3S R2W section 14), was there a mention of an interbed that may represent the Vantage Horizon. However, most of the Vantage horizon appears to be a paleosol developed on the upper flow of the Sentinel Bluffs basalt unit.

\section{other Interflow Deposits}

Interbeds have been mentioned in well reports throughout the entire study region. The lithology of these interbeds has varied from sandstone to shale to claystone to ash deposits. However, these interbeds mentioned by the well drillers must be taken with skepticism due to highly weathered basalt being identified as sedimentary material (Marvin Beeson, 1992, personal commun.).

\section{PALEOTOPOGRAPHY}

Three of the basalt units present on Parrett Mountain, the Wapshilla Ridge, the Ortley-Grouse Creek (undifferentiated), and the Ginkgo flow were influenced by paleotopography during emplacement. Identification of paleotopography has been primarily based on sizable thickness variations over relatively short distances where no faults have been identified. 
One very significant interflow deposit was found within the Hansen well. The deposit appears as a white ash/clay layer at the Umtanum and Ortley-Grouse Creek (undifferentiated) boundary. Several well reports throughout the western portions of Parrett Mountain also mention a white ash or white clay layer (Table XII, Appendix A). Based on the lithologic data and the stratigraphic data obtained from field mapping the white ash or clay layer mentioned in the well reports is assumed to be the white ash/clay found in the Hansen well. This assumption allows for a stratigraphic datum line and boundary between the Umtanum and the Ortley-Grouse Creek basalt units.

\section{Wapshilla Ridge Basalt Unit}

Since the Wapshilla Ridge basalt unit was the first basalt flow to enter this region, it seems reasonable that it flowed upon a gently dipping, well-developed topography. Paleotopgraphy was identified in Manke wells \#1 and \#6 (Plate 1) for the Wapshilla Ridge basalt due to a nearly 100 foot $(30.5 \mathrm{~m})$ difference in the basalt/sediment boundary. The elevation difference could not be correlated to fault offset or dip of the beds. Besides the Manke wells, only a few other wells penetrate the basalt/sediment boundary especially on the upper elevations and western portion of Parrett Mountain. Therefore, a quantification of the position of the basalt/sediment boundary is tenuous at best. The variation in the basalt/sediment boundary elevation over 
a distance makes the use of this boundary as a datum for defining fault offset impossible though it does pose a potential problem for saline migration into the basalt aquifers.

Ortley-Grouse Creek (undifferentiated) Basalt Unit

The lowest flow of the Ortley-Grouse Creek (undifferentiated) basalt unit also appears to have been affected similarly by paleotopographic relief. This observation comes primarily from T3S RIW Sec. 7. Drilling chips collected from the deepening of the Puderbaugh well (Plate 1) revealed the OGC/Wapshilla Ridge basalt boundary to be roughly 70 feet $(21.3 \mathrm{~m})$ lower than expected from the structural contour maps. Analysis of well reports for water wells located near the Puderbaugh well and a discussion with Douglas Delano (personnel commun., 1993), a well driller who works on Parrett Mountain, identified a highly localized depression of the Ortley-Grouse Creek (undifferentiated) / Wapshilla Ridge unit boundary around the Puderbaugh well. Three possible explanations, fault offset, erosional paleotopography or constructional topography, have been postulated to explain the boundary offset.

Of the three explanations, erosional topography is believed to be the least probable. The erosional processes, in order to create the 70 foot $(21.3 \mathrm{~m})$ offset in less than a quarter mile, needed a substrate easily erodible. since there appears to be very little topographic development 
visible along this boundary elsewhere on Parrett Mountain, the hiatus between the Wapshilla Ridge and the Ortley-Grouse Creek (undifferentiated) basalt flows must have been short.

The hypothesis of fault offset is a distinct possibility due the structural complexity in the northern Parrett Mountain area. Lack of fault exposure could be used as an argument against this hypothesis, however, it is possible that the fault was active during the emplacement of the Wapshilla Ridge basalt and was then covered by the Ortley-Grouse Creek and younger basalt units.

Constructional topography, the last hypothesis, relates to the primary flow features developed on a basalt flow. Constructional features result when a lava flow's surface cools while the interior is still molten. Movement of the molten interior causes the development of inflationary features such as: inflation ridges, pressure plateaus, residual depressions, inflation clefts, and rotated crust (Chitwood, 1991). Since it has been theorized that the Wapshilla Ridge basalt tongued (lobated) into the region, it is conceivable that such features pock mark its surface. Therefore, the offset could be explained as a residual depression or a depression created by the merging of two basalt lobes.

\section{Ginkgo Basalt Flow}

The Ginkgo flow is believed to be influenced by paleotopography that developed during the 100,000 to 300,000 
year hiatus. This hiatus, as discussed previously, allowed for the development of a sedimentary interbed, the vantage Interbed, through much of the Columbia Plateau. However, in the study area, only an erosional surface has been identified for this hiatus.

Because of the hiatus and erosional surface it is probable that some topographic development occurred within the study boundaries. Field mapping revealed the presence of the Ginkgo flow on the southern flanks of the EarlwoodRoberts Hill portion of Parrett Mountain. The outcrop of Ginkgo flow near the Earlwood road suggests a small channel eroded into the upper flow of the sentinel Bluffs basalt unit filled in with the Ginkgo flow. Other small topographic depressions are suggested, by field mapping, in the Parrett Mountain and Tonquin areas. 
STRUCTURE

FAULTS

Parrett Mountain is considered by Schlicker and Deacon (1967) to be a gently southeast dipping cuesta composed of Columbia River basalt. Topographic maps, of the Parrett Mountain area, show the mountain to be highly dissected by linear streams valleys. Many of these stream valleys have been identified by Hart and Newcomb (1965) and Schlicker and Deacon (1967) as faults based solely on topographic expression.

Cross sections $A A^{\prime}, B^{\prime}, C C^{\prime}, C^{\prime} C^{\prime} \prime$ (Figures 15 - 18) depict the local tectonic features expressed during map compilation and cross sectional analysis. Locations of these cross sections are found on Plate 2 .

Weathering and erosion of the basalt have preferentially attacked fault planes and fracture zones producing linear stream valleys and ridges. To assume that every linear stream is a weathered fault having measurable displacement would be erroneous, for an easily weathered zone may also result from a fractured zone. Weathering and deposition of thick alluvial/colluvial material made the mapping of the local faults tenuous in the field. Therefore, interpretation of a fault was based on the obvious vertical or lateral displacement of basalt 
Map View Along Section A-A'

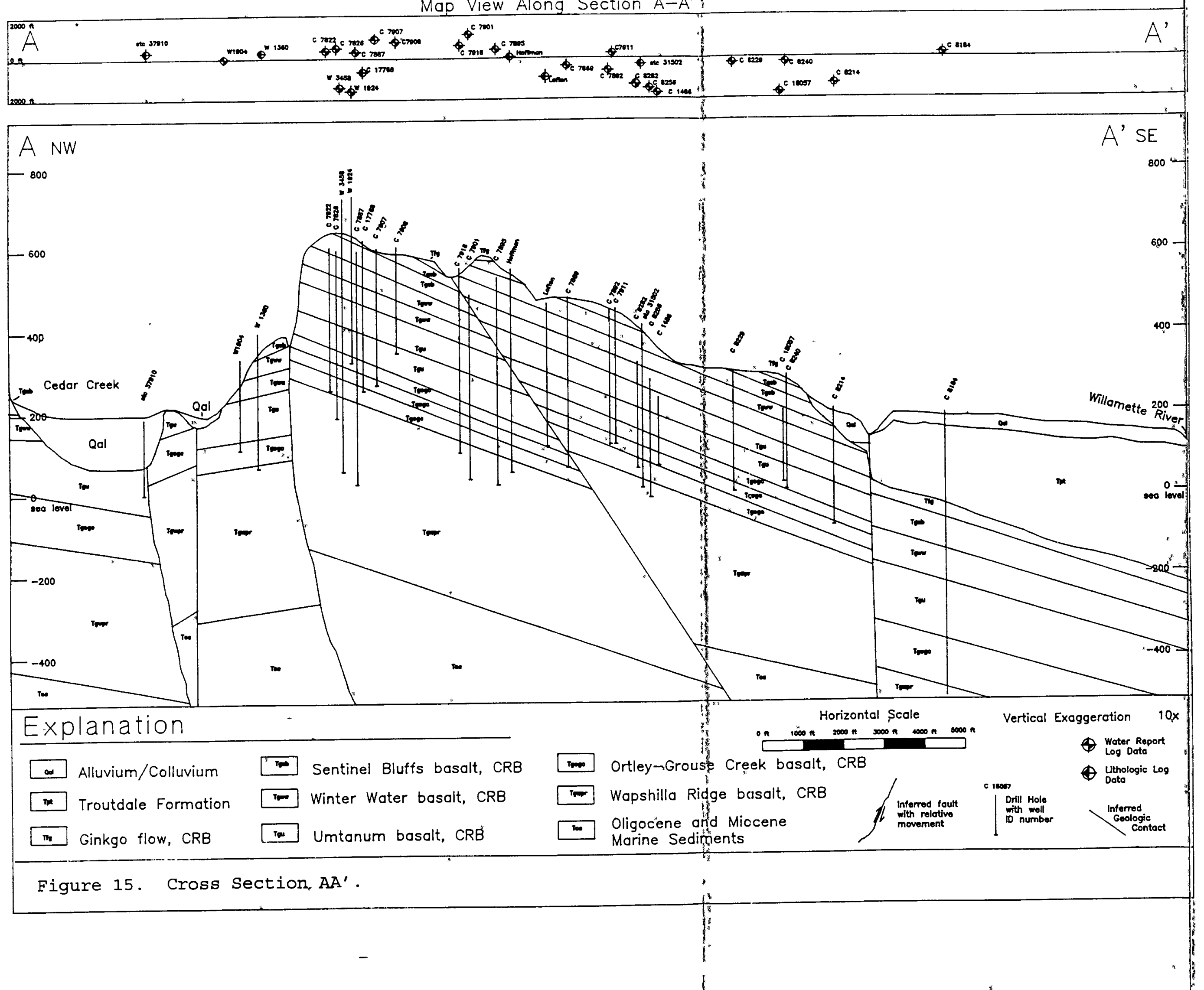




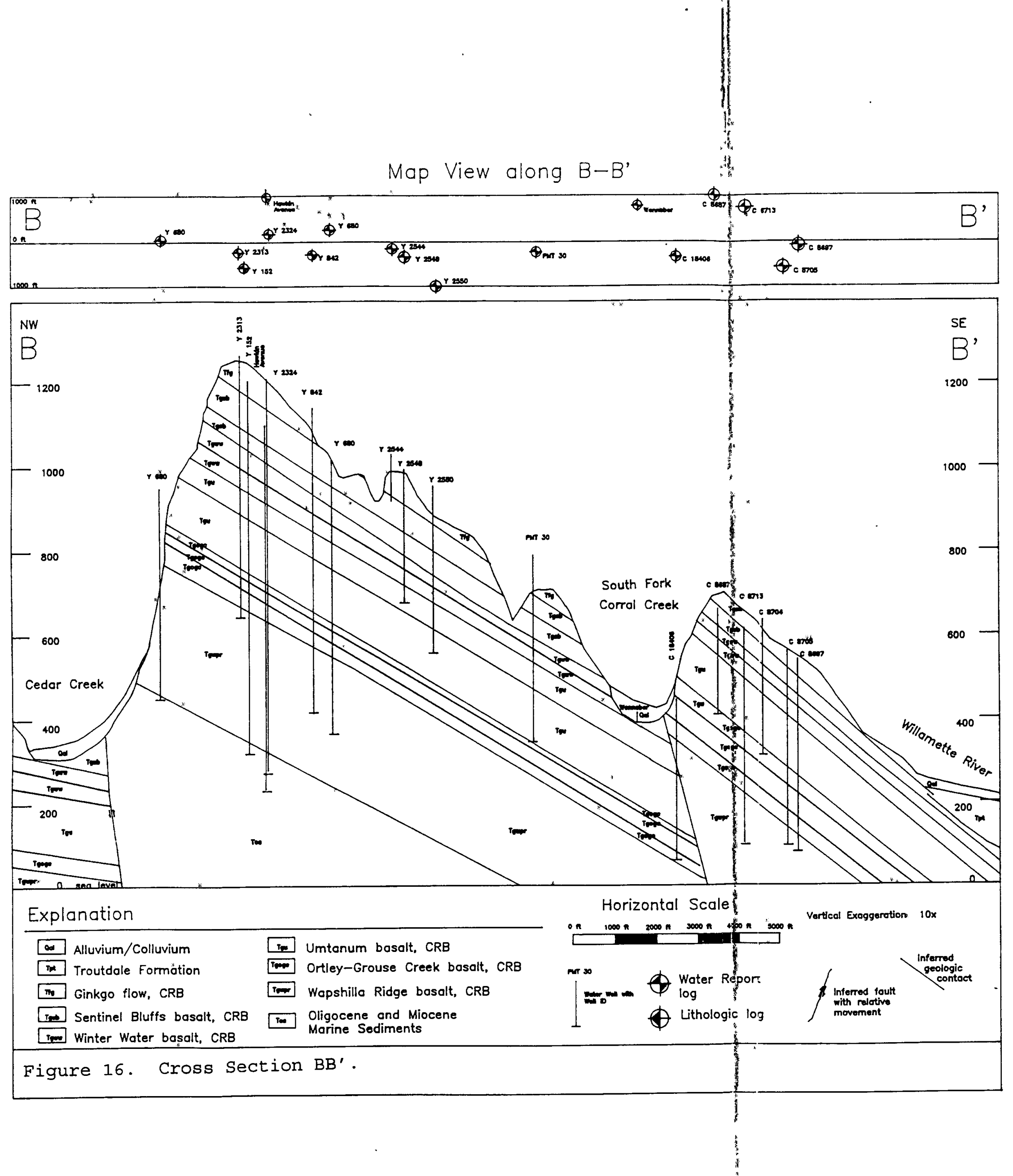




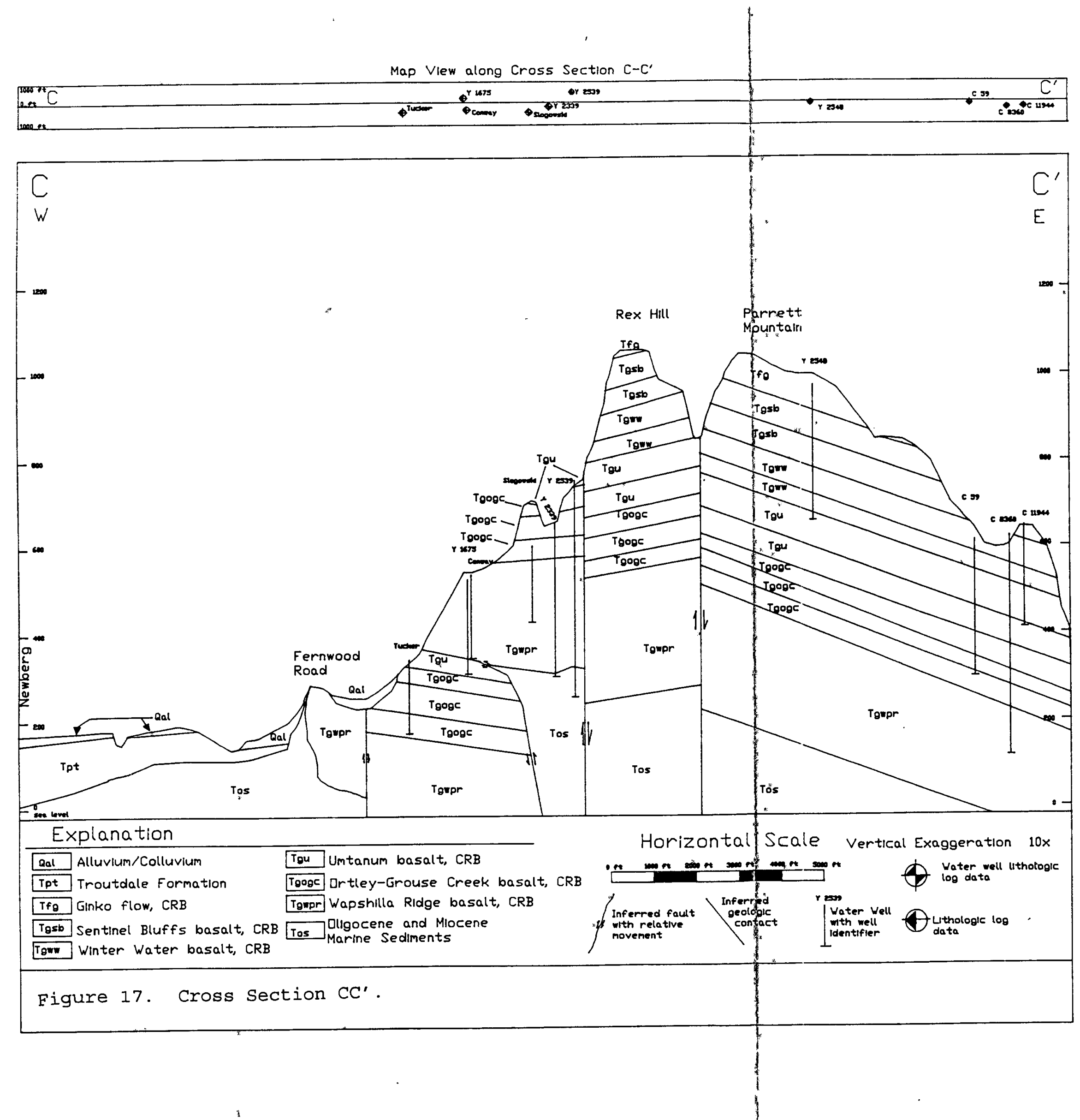


stratigraphic units in map compilation and cross sectional analysis. Fault features, such as slickenslides and cataclastic material, were not observed in the few drill chips collected from designated fault zones, the one exception being the Tucker well. The basalt chips, taken throughout the entire well, are highly weathered and containing some silica banding.

Because slickenslides and cataclastic material are common within fault zones, the absence of these features is probably related more to the preservation by the drilling technique than to the actual presence of the fault features.

Using the above criteria in the designation of a 'fault', several north/south-, northeast-, northwest-, and east/west-trending faults were identified. All faults were classified as 'normal', as a conservative method, unless otherwise known. For simplicity, the designated faults were inferred to cut through the entire basalt column, though this was not based upon any observations. There is a possibility that a few faults, active during the early stages of basalt emplacement, were buried by later basalt flows.

Map compilation and cross sectional analysis have produced the approximate location of the faults identified in this study. Based on the location of the faults, individual basalt blocks were identified (Figure 19). A basalt block, as defined for this report, is a body of rock 

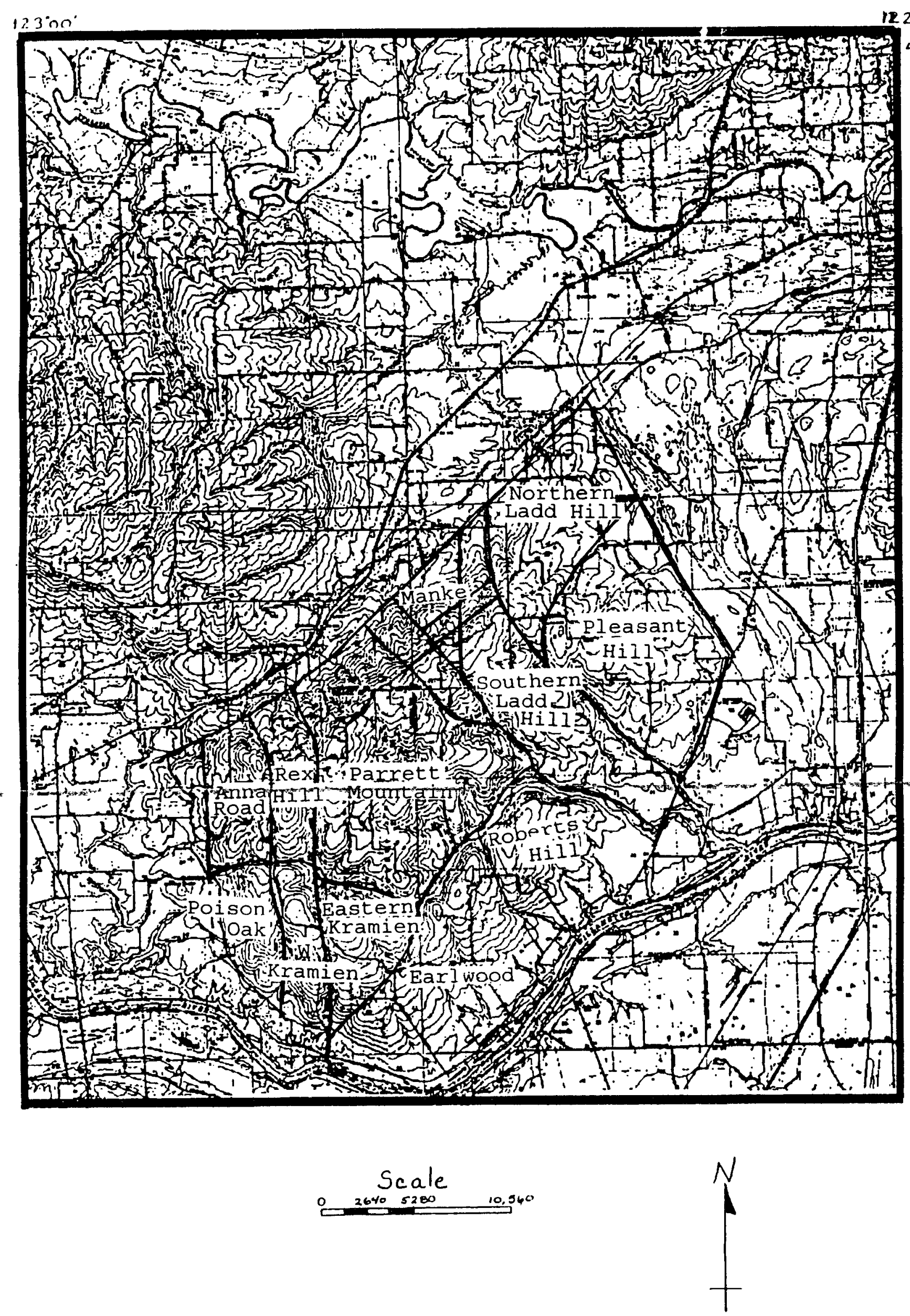

Figure 19. Basalt block designation. 
that is bounded on all sides by faults. Strike and dips were then established for each individual basalt block. Three general strike and dip trends are observed for the Parrett Mountain complex.

The faults mapped within this study were based on strict observations and conclusions. This does not negate the possible existence of other faults present within the Parrett Mountain study area.

\section{North/South-Trending Faults}

The north/south-trending faults (Plate 2) are the most prominent features observed within the study area. All four north/south-trending faults have been designated as highangle normal faults and occur on the west side of Parrett Mountain. The fault traces are visible for 3,200 to 20,000 feet $(975$ to $6,096 \mathrm{~m})$. Termination of the north/southtrending faults occurs to the north by the Cedar Creek Fault, while to the south the faults are buried by thick alluvial deposits. The eastern two north/south-trending faults (NS\#3 and NS\#4) show a minor stratigraphic displacement of 20 to 30 feet $(6.1$ to $9.1 \mathrm{~m})$ along with minor dip variations while NS\#1 shows 500 feet $(152 \mathrm{~m})$ and NS\#2 shows 100 to 200 feet $(30.5$ to $61 \mathrm{~m})$ of displacement.

The Western Kramien basalt block (Figure 19) forms a horst with the basalt blocks to the east and west being down dropped. The Rex Hill block is down dropped with respect to the Anna block but upthrown with respect to the Parrett 
Mountain block (Figure 19). The region lying between NS\#I and NS\#2 faults forms a graben that appears to be part of a flower structure along the NS\#2 fault (Figure 17; Plate 2).

A fifth north/south-trending fault, the Oberst Fault, was observed during field mapping. Seven feet of displacement was recorded for the oberst Fault due to an exposed flowtop on either sided of a small gulley, the designated fault plane. The seven feet $(2.1 \mathrm{~m})$ is an approximate amount of displacement since the thickness of the flowtop is unknown and boundary between the overlying flow and the flowtop was not observed. Map compilation and cross section analysis infers the oberst Fault to be highly inclined to vertical.

Although the north/south-trending features are most prominent in the western portion of the mountain, there is a definite north/south lineation overprinting the entire Parrett Mountain area (Plate 2).

\section{East/West-Trending Faults}

The east/west-trending faults (Plate 2) occur only in the western portion of Parrett Mountain. Only one distinct fault has been identified, though the relationship between this fault trend and the other fault trends remains unknown. This east/west-trending fault is transected by the NS\#3 and NS\#4 faults. Extension of the east/west fault is probable to the west based on the local basalt stratigraphy expressed by Grouse Butte and the Fernwood outcrop. Between the NS\#3 
and NS\#4 faults, the east/west fault is believed to be a high angle reverse to thrust fault. To the west, the east/west fault appears to change its style of faulting from the high-angle reverse to a high angle normal fault. The normal style of faulting is supported by the stratigraphic placement of the Ginkgo flow to the Wapshilla Ridge basalt unit, a total displacement of approximately 600 feet $(200 \mathrm{~m})$ (Plate 2).

An east/west overprinting is observed over the entire Parrett Mountain area (Plate 2). This overprinting is not as pronounced or prominent as the north/south lineation and is typically masked by the northwest-trending structures. Cross cutting relationships suggest that the east/west trending fault are syn- or pre-tectonic to the north/southtrending faults, but post-tectonic to the northeast-trending faults.

\section{Northeast-Trending Faults}

Seven faults have been mapped in this fault category (Plate 2). These faults have been named informally for clarity. The designated faults are the sherwood Fault (Cedar Creek Fault), the Pleasant Hill fault, the Dammasch fault, the willamette fault, the Corral Creek-Earlwood fault, the Rim fault, and the Manke fault. Only the Sherwood and Corral Creek faults have been mapped by previous authors. All of the seven faults, save for Pleasant $\mathrm{Hill}$ and Corral, Creek faults, have been mapped as 
normal, though the true style and sense of faulting remains unknown.

Sherwood Fault. The Sherwood fault (Cedar Creek fault), was mapped based on the separation of Parrett Mountain from the Chehalem Mountains (Hart and Newcomb, 1965; Schlicker and Deacon, 1967). Studies on this fault (Werner, 1991) still have not found the exact fault position and style of faulting due to the thick alluvial and colluvial material covering most of the fault trace.

Detailed field mapping of the basalt units allowed for an approximate fault position to be identified, though the exact orientation, plane angle, and style of faulting remain unknown. Drilling chips collected from the Rolfs, the Cedar Creek, and the Hamness' wells, located slightly south of the fault trace, were examined in order to help identify the position of the fault plane. Examination of the drill chips revealed little cataclastic development and no recognizable, repeated basalt sections. A maximum of 1000 feet $(305 \mathrm{~m})$ total vertical displacement was measured at Rex Hill. The amount of displacement along the fault decreased away from Rex Hill in a general stair-step manner.

Corral Creek-Earlwood Fault. The Corral Creek-Earlwood fault lies along the South Fork of Corral Creek and divides the Roberts Hill-Earlwood basalt block from the Parrett Mountain and Eastern Kramien basalt blocks (Figure 19). A maximum vertical offset of 400 feet $(122 \mathrm{~m})$ was observed 
across the fault (Figure 16; Plate 2).

The Corral Creek-Earlwood fault is unique for the area, expressing a thrusting component to the northeast and a normal style of faulting to the southwest. Three possible styles of faulting may explain this phenomena. The first, is that the Corral Creek-Earlwood fault represents a hinge fault where the basalt block is allowed to rotate in the vertical plane along a hinge lying close to the parrett Mountain and Kramien road intersection. Second, the Corral Creek-Earlwood fault could represent a thrust fault that has been modified by several northwest trending faults, e.g. Roberts Hill fault. Each northwest fault would allow for a progressive downdrop to the southwest, resulting in the Earlwood segment being expressed as a 'normal fault'. The third possibility is that the Corral Creek and Earlwood basalt segment may actually represent two independent faults, separated by a undesignated fault.

Manke and Rim Faults. In the northern portion of Section 7 T3S RIW, two faults were mapped based on the obvious offset of stratigraphic units observed from basalt chip analysis and map compilation. The Rim fault is observed at the base of a basalt ridge that separates the northwestern slope from the southeastern slope of Parrett Mountain. The Manke fault was mapped based on water level data (Luzier, 1992) along with a linear topographic trace expressed by several stream pathways. 
Both faults trend parallel to each other and subparallel to the Cedar Creek fault. Northwest downdropping of 30 feet $(9.1 \mathrm{~m})$ occurs for both faults. The faults are terminated on the southwest by the Ladd Hill Fault and by the Mill Creek fault to the northeast. Both faults may actually extend farther to the southwest and northeast.

Pleasant Hill Fault. The Pleasant Hill fault was identified in cross sectional analysis (Figure 15; Plate 2) due to a drastic decrease in basalt flow dips. The fault is believed to be bounded by the Mill Creek Fault to the southwest and the Seely Ditch Fault to the northeast. Approximately 200 feet $(61 \mathrm{~m})$ of vertical offset has been inferred from cross section $A^{\prime}$ (Figure 15). Analysis of drilling chips and numerous well reports allow the Pleasant Hill Fault to be identified as a low angle thrust fault.

Dammasch Fault. The Dammasch fault was mapped based on a linear stream valley and the vertical displacement of the Ginkgo flow. On the northwest side of the Dammasch Fault the Ginkgo flow is exposed at the 250 foot $(76.2 \mathrm{~m}$ ) elevation, while it is buried by sediment 110 feet $(33.5 \mathrm{~m})$ below the surface on the southeast side of the fault. The fault is believed to terminate against the seely Ditch Fault to the north and to be the possible extension of the implied Willamette Fault.

Willamette Fault. The exact position of this fault is 
difficult to discern due to the thick alluvial material covering the entire area between Parrett Mountain and La Butte. The fault was mapped based solely on the distinct elevation change of the Umtanum and Winter Water basalt boundary from Parrett Mountain to La Butte. The exact style of faulting, fault plane angle, and number of the faults buried beneath the alluvium is unknown.

The Northwest-Trending Faults

The northwest trending faults (Plate 2) have been informally named for clarity in this report. The NW trending faults mapped are the Mill Creek fault, the Ladd Hill fault, the Heater fault, the Roberts Hill fault, the Seely Ditch fault, and the Kramien fault.

Mill Creek, Ladd Hill, and Heater Faults. The Mill Creek and Ladd Hill Faults are the most topographically distinct of all the northwest-trending faults. Both show nearly 100 feet $(30.5 \mathrm{~m})$ of vertical displacement. The Heater Fault is an extension of the Ladd Hill fault. A change in the strike and dip direction for the basalt flows was the main criterion used to designate the occurrence of the Heater Fault. The strike and dip variation suggests a lateral component to the sense of motion along the northwest-trending faults.

Middle Fork of Corral Creek Lineation. The Middle Fork of Corral Creek may represent a northwest-trending fault similar to the Ladd Hill, Mill Creek and Heater Faults based 
on the topographic similarity between Middle Fork and North Fork. However, map compilation and cross sectional analysis do not indicate any lateral or vertical displacement. Therefore, the Middle Fork has not been designated as a fault.

Roberts Hills Fault. The nature of the Roberts Hill fault was discussed under the Corral Creek-Earlwood fault in the northeast trending fault section (discussed above). The fault is observed as a semi-linear feature that separates Roberts Hill block from the Earlwood block (Figure 19). An approximate 50 feet $(15.2 \mathrm{~m})$ of offset was observed in cross sectional analysis and map compilation. Similar northwest Iinear stream gullies dissect the Earlwood-Roberts Hill basalt block. Although, the Roberts Hill Fault dissects the Earlwood-Roberts Hill basalt block, there are no observable strike and dip changes between the two independent blocks, implying that there was no rotational component to the style of faulting along the Roberts Hill fault.

Seely Ditch Fault. The Seely Ditch Fault is based on 1) significant offset of the basalt stratigraphy, 2) a change in the dip of the basalt unit across this line, and 3) a highly linear topographic ridge. Offset of 100 feet $(30.5 \mathrm{~m})$ is inferred in the cross sectional analysis. This fault is inferred to terminate the Pleasant Hill and Dammasch faults while being terminated by the sherwood Fault. The surface trace of the fault coincides with a 
linear trough cut out by the Missoula flood waters.

\section{STRIKE AND DIP}

Cross sectional analysis of the Parrett Mountain area assumes a pancake layered stratigraphy composed of basalt flows (Figures 15 - 18). Due to the nature of basalt emplacement, primary dips are typically horizontal to a few degrees. Therefore, changes in the primary dips will reflect the amount of structural activity that occurred after the emplacement of the basalt flows. Thus, the overall southeasterly and southwesterly topographic dips of Parrett Mountain (Table V) are a reflection of the fault activity along the Sherwood and Corral Creek faults.

TABLE V

STRIKE AND DIP OF THE BASALT BLOCKS COMPRISING PARRETT MOUNTAIN

$\begin{array}{lrr}\text { Basalt Block } & \text { Strike } & \text { Dip } \\ \text { Anna Road } & \mathrm{N} 24^{\circ} \mathrm{W} & 2^{\circ} \mathrm{SW} \\ \text { Eastern Kramien } & \mathrm{N} 86^{\circ} \mathrm{E} & 2^{\circ} \mathrm{SE} \\ \text { Manke (maximum) } \quad \text { (minimum) } & \mathrm{N} 81^{\circ} \mathrm{E} & 10^{\circ} \mathrm{NW} \\ \text { Northern Ladd Hill } & \mathrm{N} 81^{\circ} \mathrm{E} & 6^{\circ} \mathrm{NW} \\ \text { Parrett Mountain } & 5^{\circ} \mathrm{SE} \\ \text { Pleasant Hill } & \mathrm{N} 53^{\circ} \mathrm{E} & 4^{\circ} \mathrm{SE} \\ \text { Poison Oak } & \mathrm{N} 13^{\circ} \mathrm{E} & 2^{\circ} \mathrm{SE} \\ \text { Rex Hill } & \mathrm{N} 15^{\circ} \mathrm{W} & 4^{\circ} \mathrm{NE} \\ \text { Roberts Hill - Earlwood } & \mathrm{N} 33^{\circ} \mathrm{W} & 2^{\circ} \mathrm{SW} \\ \text { Southern Ladd Hill } & \mathrm{N} 42^{\circ} \mathrm{E} & 5^{\circ} \mathrm{SE} \\ \text { Western Kramien } & \mathrm{N} 65^{\circ} \mathrm{E} & 3^{\circ} \mathrm{SE} \\ & \mathrm{N} 50^{\circ} \mathrm{W} & 2^{\circ} \mathrm{SW} \\ \text { @ : maximum and minimum dip values are given due } \\ \text { to a missing section of drill chips taken from } \\ \text { Manke well \#4. }\end{array}$


In the northeastern portion of Parrett Mountain, the strike is approximately north/south, a northeast strike was observed for the central portion of the mountain complex; and, a northwest strike was observed for the western portion of Parrett Mountain forming an apparent anticline.

\section{STRUCTURAL CONTOUR MAPS}

Structural contour maps (Figures 20a - 20e) were created to illustrate the approximate elevation of a basalt unit's top and bottom. These maps were drawn using strike and dip measurements taken from the compiled geologic map. Cross sections $A A^{\prime}$ through $C^{\prime} C^{\prime \prime}$ (Figures 15 - 18), exposed flowtops, outcrops, and collected basalt drill chips were used as qualifiers to check and modify the structural contour maps.

In order to construct and use these structural contour maps, several assumptions are necessary. The structural contour maps produced represent an ideal situation. The first assumption is that each basalt block is represented by only one strike and dip, i.e. each basalt unit, within a designated basalt block, yields the same strike and dip as the unit above and below it in the stratigraphic column. This ignores the possibility of secondary strike and dips occurring from lobe structures or other flow emplacement features. This assumption creates a basalt sheet (layer), or pancake layered structure, with little deviation in 

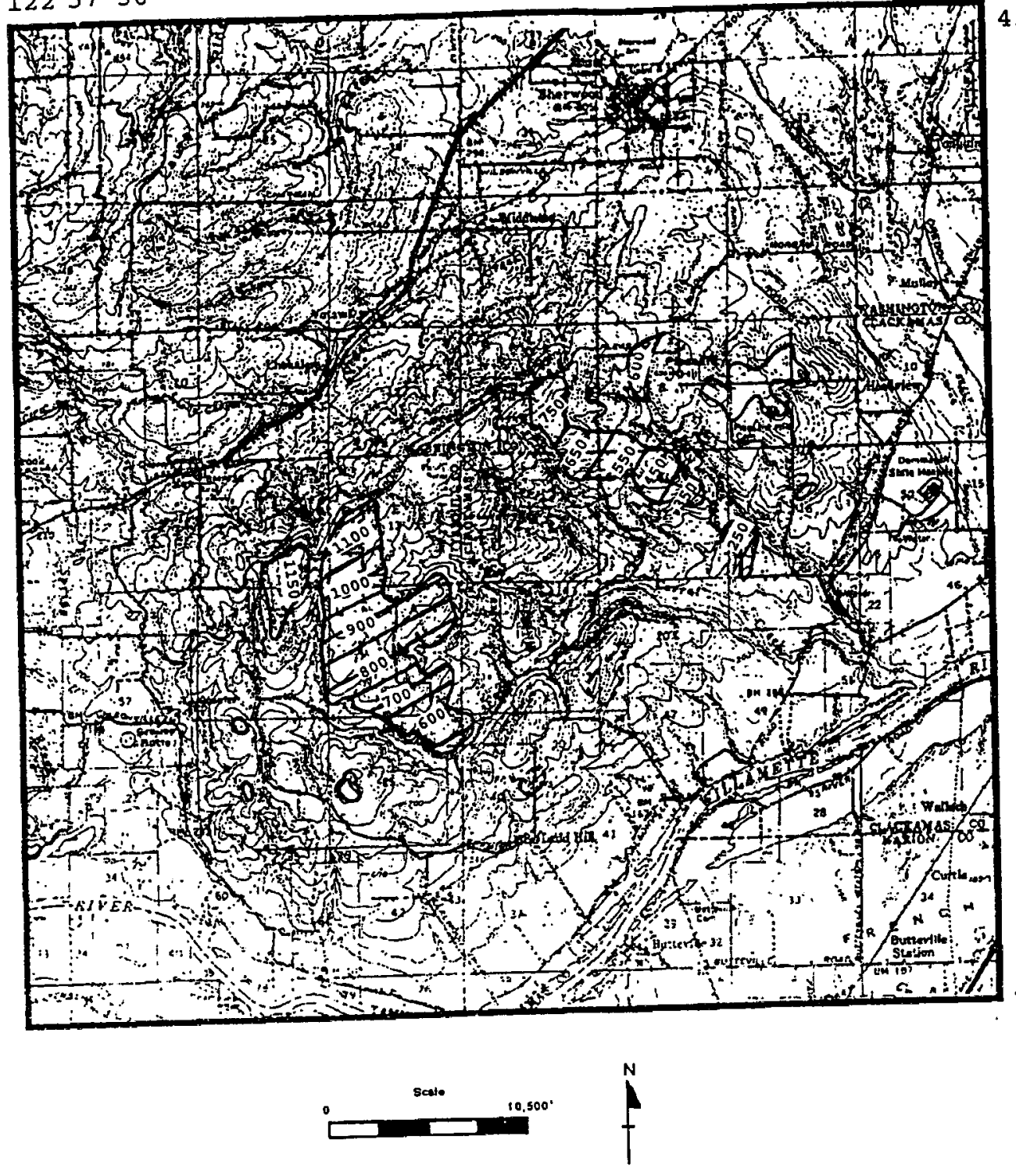

Figure 20a. Contour elevations of the Ginkgo flow/sentinel Bluffs basalt unit boundary. Contour interval is 50 feet. 


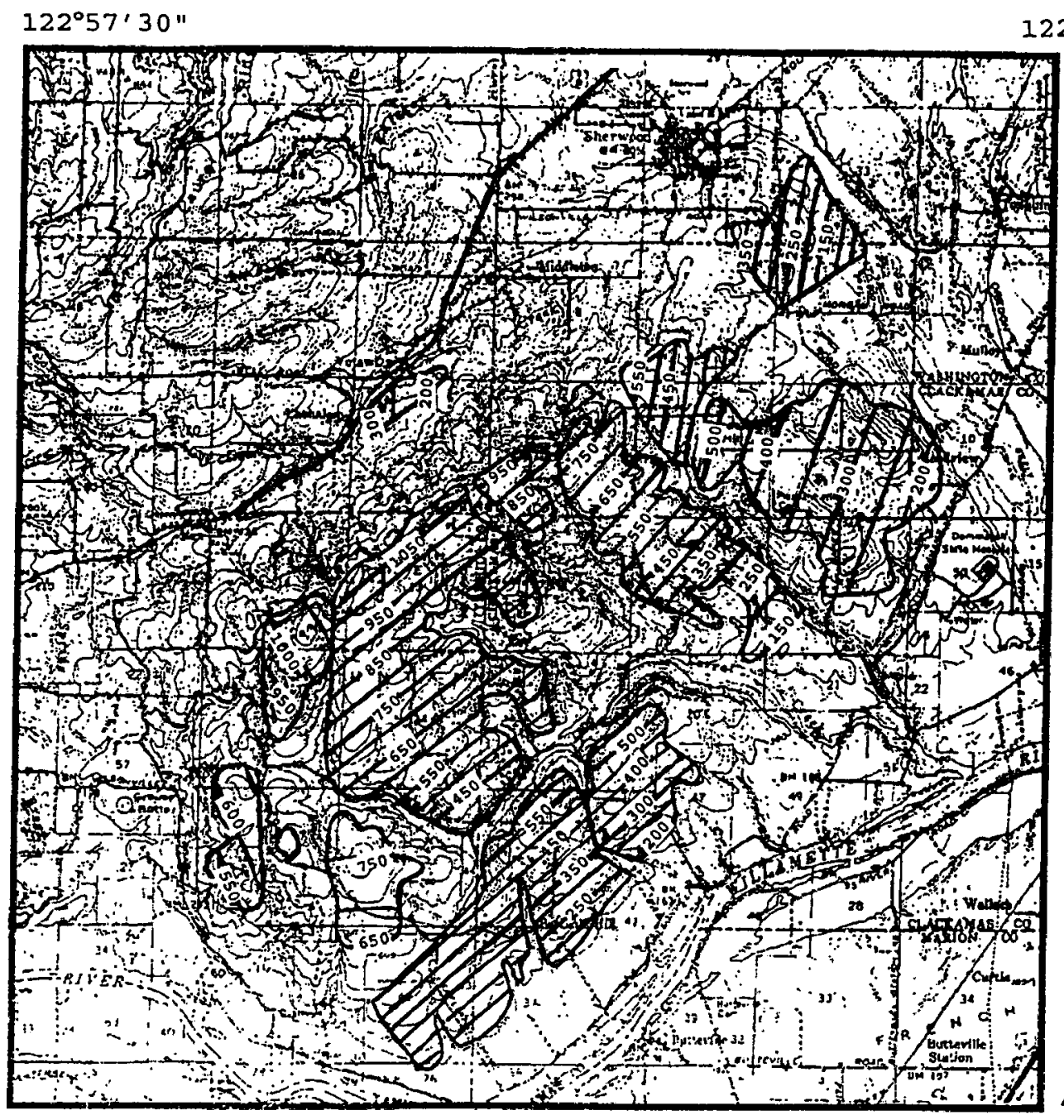

$122^{\circ} 45^{\prime}$

$45^{\circ} 22^{\prime} 30^{\prime \prime}$

$45^{\circ} 15^{\prime}$

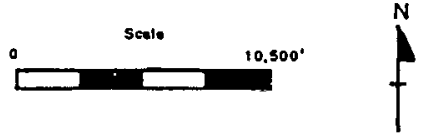

Figure 20b. Contour elevation of the sentinel Bluffs/Winter Water basalt units boundary. Contour interval is 50 feet. 


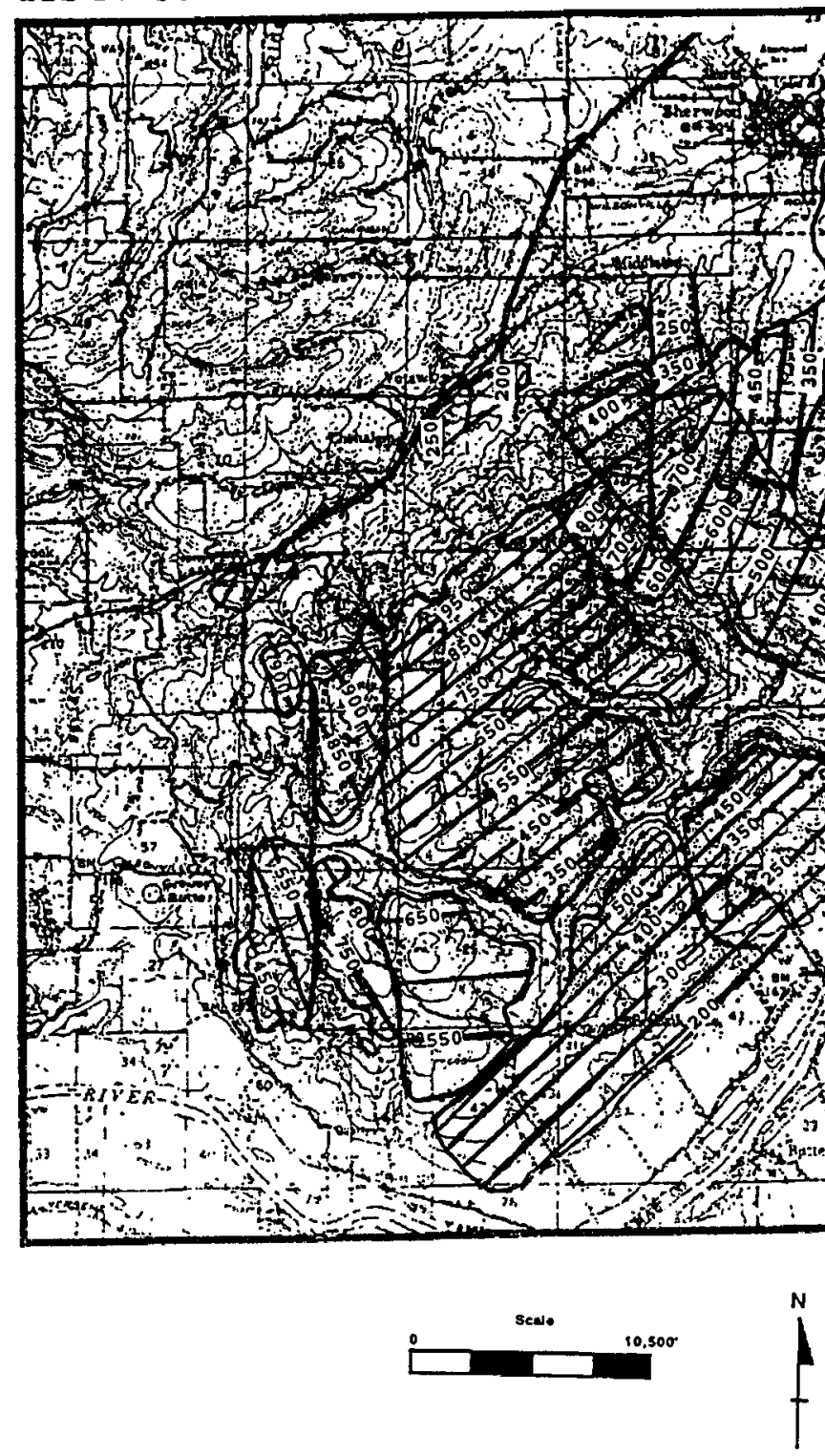

Figure 20c. Contour elevation of the Winter water/Umtanum basalt boundary. Contour interval is 50 feet. 


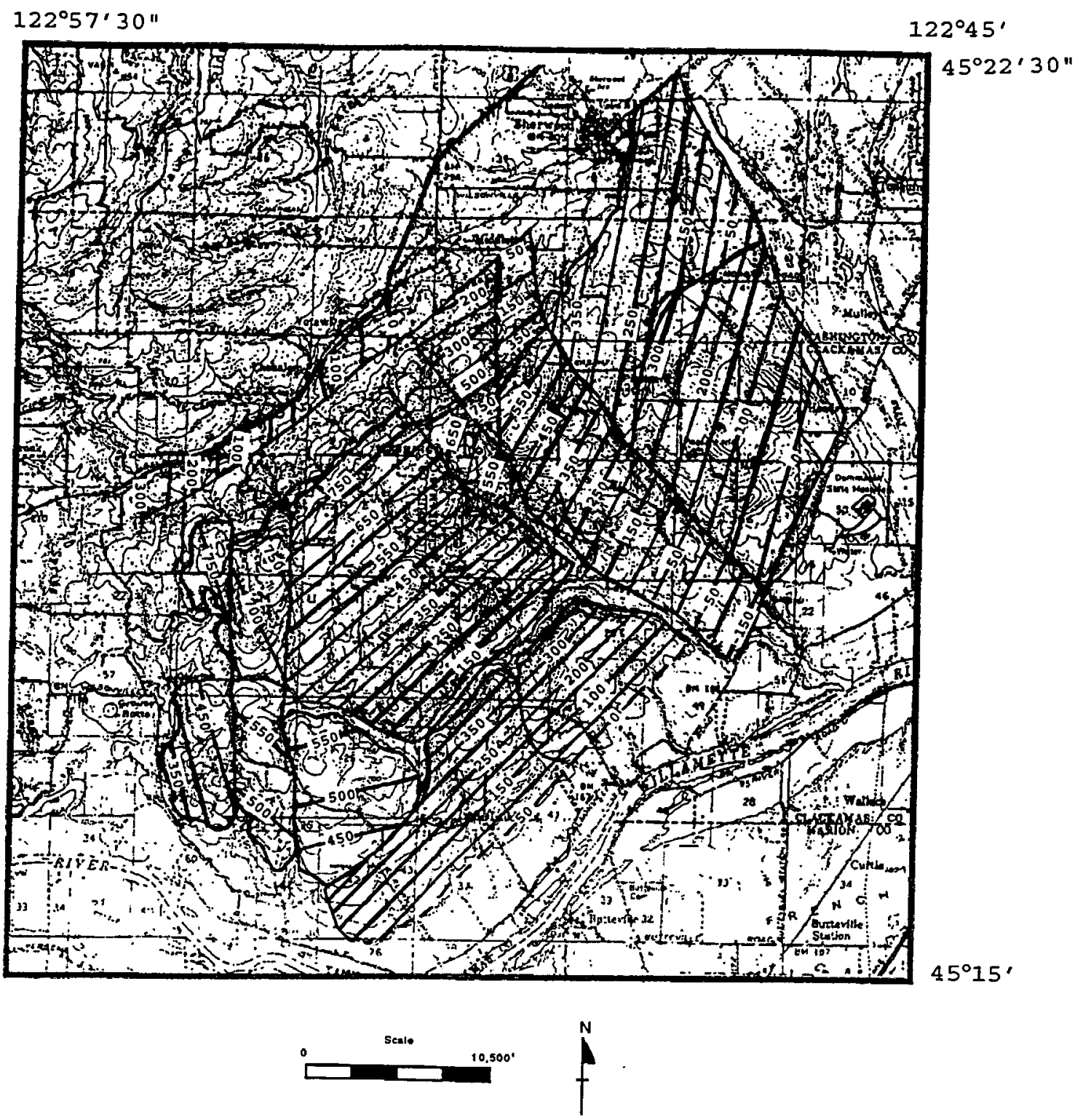

Figure 20d. Contour elevation of the Umtanum/Ortley-Grouse Creek basalt boundary. Contour interval is 50 feet. 


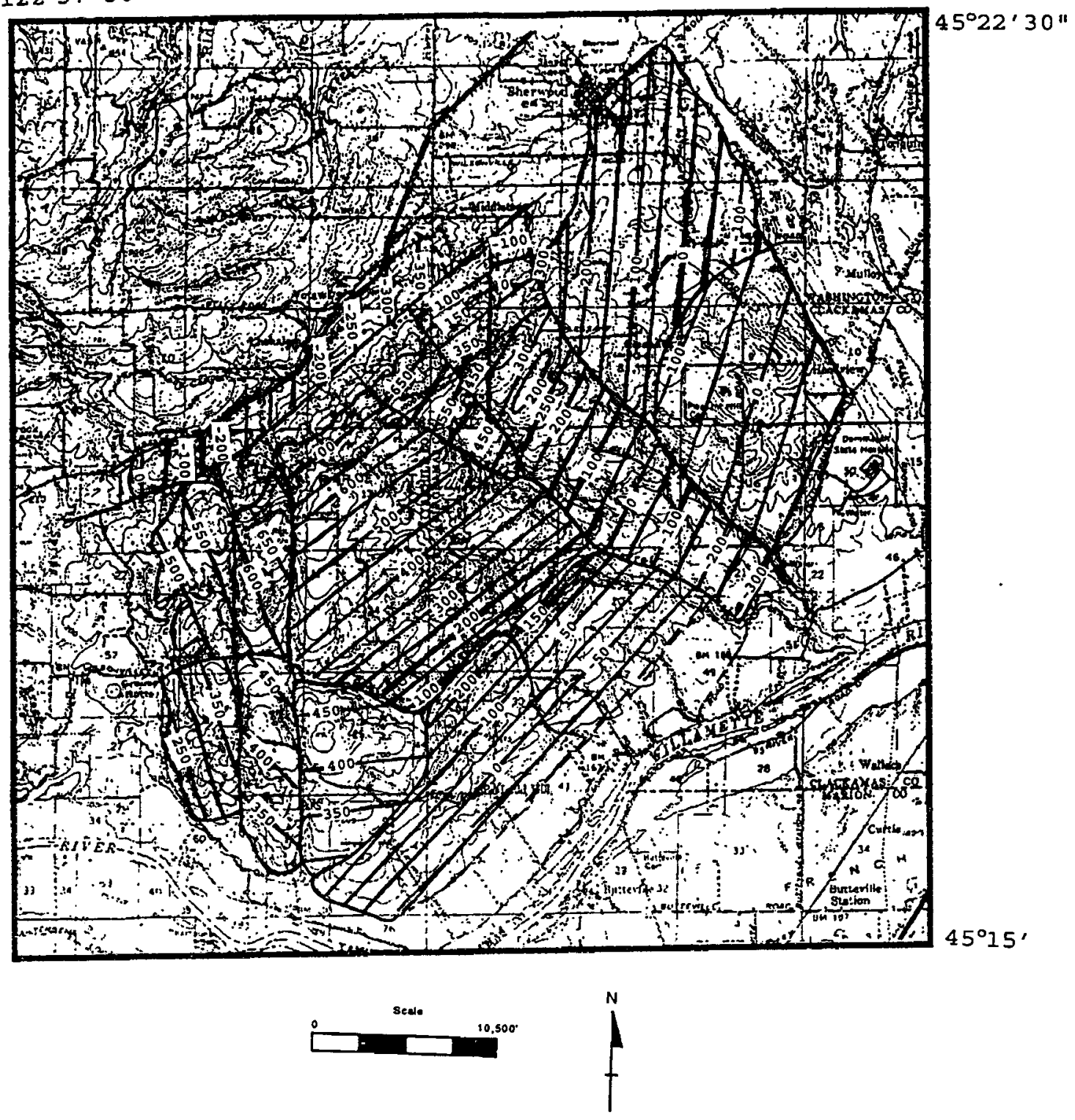

Figure 20e. Contour elevation of the ortley-Grouse Creek/Wapshilla Ridge basalt boundary. Contour interval is 50 feet. 
thicknesses from the bending or folding of the individual basalt units by tectonic forces. A pancake layer structure is transposed from the cross sectional analysis (Figures 15 - 18). Such folding and bending of the units would be difficult to discern in the cross sections with the available data.

The second assumption takes into account thickness variations. General thickening and thinning of the basalt flows, identified from cross sectional analysis, were incorporated into the structural contour maps. These thickness changes reflect changes occurring along the cross sections and are assumed to be standard for the entire basalt block. Therefore, some thickness variations due to paleotopographic influences have been ignored. Paleotopography was found only to influence the Wapshilla Ridge basalt unit, the lower flow of the Ortley-Grouse Creek (undifferentiated) basalt unit, and the Ginkgo flow and therefore essentially disavows this assumption.

The third assumption, used in the creation of these maps, was that the designated basalt blocks were not dissected by unidentified faults. This assumption also assumes that there was no sporadic faulting occurring during the emplacement of the basalt units. If there is an unrecognized fault within a designated basalt block, then the designated strike and dip of the basalt block would most likely be inaccurate. 
Using the above assumptions, the structural contour maps were constructed. Qualifiers; flowtops, outcrops, and analyzed drill chips, were used to check and improve the constructed maps. In areas where little surface or subsurface data existed, topographic analysis was used to infer the unit boundaries. Gently inclined slopes were typically assumed to be flowtops of the basalt units while the steeply-to-moderately inclined slopes were inferred to represent a basalt flow's interior. Such topographic evidence helped in the interpretation of the western side of Parrett Mountain, where subsurface and surface data were scarce to nonexistent.

The structural contour maps concurred with all the qualifiers, taking into account the uncertainty existing in locating the analyzed wells and the sampling procedure. Two wells, however, did not agree with the constructed structural contour maps. The first well, the Puderbaugh well (Plate 1; Table XI, Appendix A), is located in the Southern Ladd Hill basalt block (T3S RIW Section 7). This anomaly has already been discussed under "Paleotopography" and therefore will not be discussed further.

The second well that does not agree with the structural contour maps is the Metcalf well (Plate I; Table XI, Appendix A), located in the Pleasant Hill block, (T3S RIW Section 8). The basalt unit boundaries occurring in this well have an elevation lower than expected compared to the 
Severine well (T3S RIW Section 8), located near the Metcalf well. The elevation changes from the two wells are the most pronounced at the Wapshilla Ridge/Ortley-Grouse Creek (undifferentiated) boundary and decrease in sequential order to the sentinel Bluffs/Winter water boundary. This elevation difference would suggest that at least one of the three assumptions listed is incorrect. Several other wells, Hoffman, Loften, Carraher, and Severine, located within the Pleasant Hill block, agree with little uncertainty with the derived structural contour map. Therefore, it is likely that the cause of the anomaly occurs locally around the Metcalf well. 


\section{GROUNDWATER}

Groundwater systems located on Parrett Mountain were delineated and studied through static water level measurements, groundwater conductivity and groundwater temperature measurements. These measurements were taken by the OWRD from domestic and irrigation wells located throughout the study area. This groundwater data set was then plotted on the geologic map in order to discern the effects stratigraphy and structure have on the groundwater systems.

\section{GROUNDWATER OCCURRENCE}

\section{Alluvial/Colluvial Aquifers}

Alluvial/colluvial aquifers occur in the Tonquin and Hess Creek-Spring Brook area as well as within the Cedar Creek and Corral Creek drainages (Plate 3). The geologic formations associated with the alluvial/colluvial aquifers are the oligocene and Miocene sedimentary deposits, the Troutdale Formation, the willamette silt and coarse flood deposits, and recent alluvium. Because the groundwater problem affecting Parrett Mountain occurs solely in the basalt aquifers the alluvial aquifers will not be discussed in this report.

One very important alluvial aquifer needs to be 
addressed. This aquifer, identified solely through well reports, exists as a perched aquifer at the alluvium/basalt boundary. The aquifer develops due to a decrease in the infiltration rate of the vertically migrating groundwater across the alluvial/basalt boundary.

Future studies into groundwater recharge of basalt aquifers should include the role alluvial aquifers play as potential (basalt) groundwater recharge reservoirs.

\section{Basalt Aquifers}

Basalt aquifers occur within flowtops, flow-bottoms, and flow-margins of individual lava flows. These zones are typically highly porous, marked by a scoriaceous crust, numerous vesicles, and primary (cooling) joints. Primarily, an aquifer will develop within the flowtop since the thickness of the flowbottom and flow-margins is relatively small compared to the flowtop.

Interflow sedimentary deposits, if present, usually have lower permeability than the flowtop and may result in a hydraulic separation of a flowbottom from the underlying flowtop. Since there appears to be no extensive interflow sedimentary deposits, a hydraulic connection between the overlying flowbottom and the underlying flowtop will be assumed under the term 'interflow zone' unless otherwise stated.

Groundwater migrates through a basalt flow both vertically and laterally (Figure 21). The lateral 


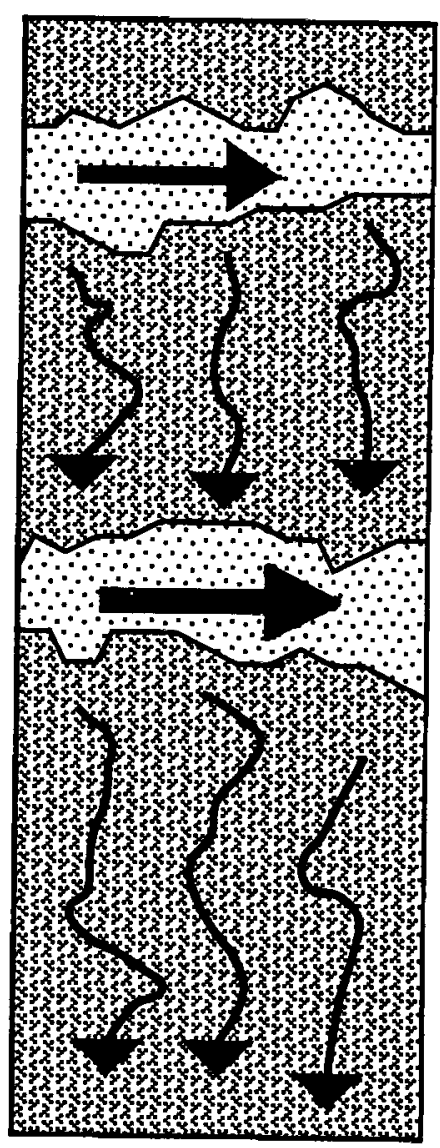

\section{Interflow Deposit}

Basalt

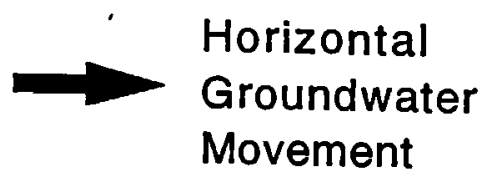

$\left\{\begin{array}{l}\text { Vertical } \\ \text { Groundwater } \\ \text { Movement }\end{array}\right.$

Figure 21. Idealized groundwater flow through several vertically stacked basalt flows (Modified from Lite (1988). 1976; Baker, 1979). 
groundwater transmission occurs primarily through the flowtop due to the porosity and permeability of this zone. If the flowtop is inclined it will allow for an easier pathway for the water to travel allowing for pressure differences to occur creating a hydraulic gradient. the vertically migrating groundwater travels through the primary and secondary joints, if present. However, the opening of the primary joints is typically very small and hinders a large vertical migration of groundwater. Because of the impermeable nature of the basalt flow's interior, the ratio between the lateral and vertical groundwater transmissions is very high (McNish and Baker, 1976.) Table VI compares two hydrogeologic characteristics, porosity and hydraulic conductivity, as a function of the aquifer's lithology. Table VII compares the same aquifer characteristics as a function of a basalt flow's morphology.

\section{TABLE VI}

AQUIFER CHARACTERISTICS OF VARIOUS ROCK TYPES

Rock Type

Permeable Basalt

Karst Limestone

Sandstone

Unfract. crystalline rock

Unweath. marine clay
Hydraulic Conductivity

$$
\begin{gathered}
\mathrm{K}(\mathrm{m} / \mathrm{s}) \\
10^{-2} \text { to } 10^{-7} \\
10^{-2} \text { to } 10^{-6} \\
10^{-6} \text { to } 10^{-10} \\
10^{-10} \text { to } 10^{-14}
\end{gathered}
$$$$
10^{-9} \text { to } 10^{-12}
$$

* Data taken from Freeze and Cherry (1979)
Porosity

(\%)

5 to 50

5 to 50

5 to 30

0 to 5

0 to 10

For the Parrett Mountain area, the porosity and 
hydraulic conductivity, is probably on the low side of the data range given in Tables VI and VII. This is most likely due to a lack of pillow basalt complexes (Marvin Beeson, 1993, personnel commun.), lack of adequate recharge zones, and thin basalt flows.

\section{TABLE VII}

AQUIFER CHARACTERISTICS FOR BASALT AQUIFERS

$\begin{array}{lcc}\text { Type of Basalt } & \text { Hydraulic Conductivity } & \text { Porosity } \\ \text { Dense Basalt } & 10^{-11} \text { to } 10^{-8} & 0.1 \text { to } 1 \\ \text { Vesicu. Basalt } & 10^{-9} \text { to } 10^{-8} & 5 \\ \text { Fract, weath/, } & 10^{-9} \text { to } 10^{-5} & 10 \\ \text { brecciated basalt } & 20 \\ \text { Interbeds/flowtops } 10^{-8} \text { to } 10^{-5} & \\ \text { * Data taken from Freeze and Cherry (1979) }\end{array}$

GEOLOGIC INFLUENCES ON GROUNDWATER MIGRATION

\section{Stratigraphy}

Lateral. Since the lateral groundwater transmission is greater than the vertical, the direction of groundwater movement will be dependent upon the primary and secondary dips of the basalt flows. Examination of the potentiometric surface map shows a southeasterly flow direction. This suggests that lateral groundwater gradient is governed by the secondary (structural) dips since the primary dips, inferred from thickness variations, are to dip to the northeast and northwest.

Intraflow and primary dips have resulted in small variations in the dip directions for the individual basalt 
flows. The effects these small dip variations play in the migration of groundwater systems remains unknown.

Vertical. Since a basalt flow's interior is relatively impermeable, the aquifer developed in the flowtop will generally be isolated. Stacking basalt flows vertically, will result in development of several isolated to semiisolated aquifers (interflow zones). Each aquifer can be identified by a specific potentiometric head value (head) if there is little communication between the aquifers.

Typically these head values will decrease with increasing depth, reflecting a vertical groundwater gradient (Figure 22). Figure 23 depicts one small area on Parrett Mountain where the head decreases with depth.

An example of a stratigraphic control over the groundwater system can be observed in T3S RIW Section 4 . Three wells, Axelson, Nielson, and Phil, lie within four hundred feet of one other and at nearly the same surface elevation. Current head values are 197 feet $(60 \mathrm{~m})$ for Axelson, 212 feet $(64.6 \mathrm{~m})$ for Phil and 242 feet $(73.8 \mathrm{~m})$ for Nielson. The only notable difference, among the three wells, is that the Nielsen well is twenty feet shallower than the other two wells. Well reports record that half of the well's yield, for both Phil and Axelson, occurs in the bottom 10 feet $(3 \mathrm{~m})$. It can be concluded, from this comparison, that by penetrating the lower aquifer both Axelson and Phil have obtained 1) a larger groundwater 


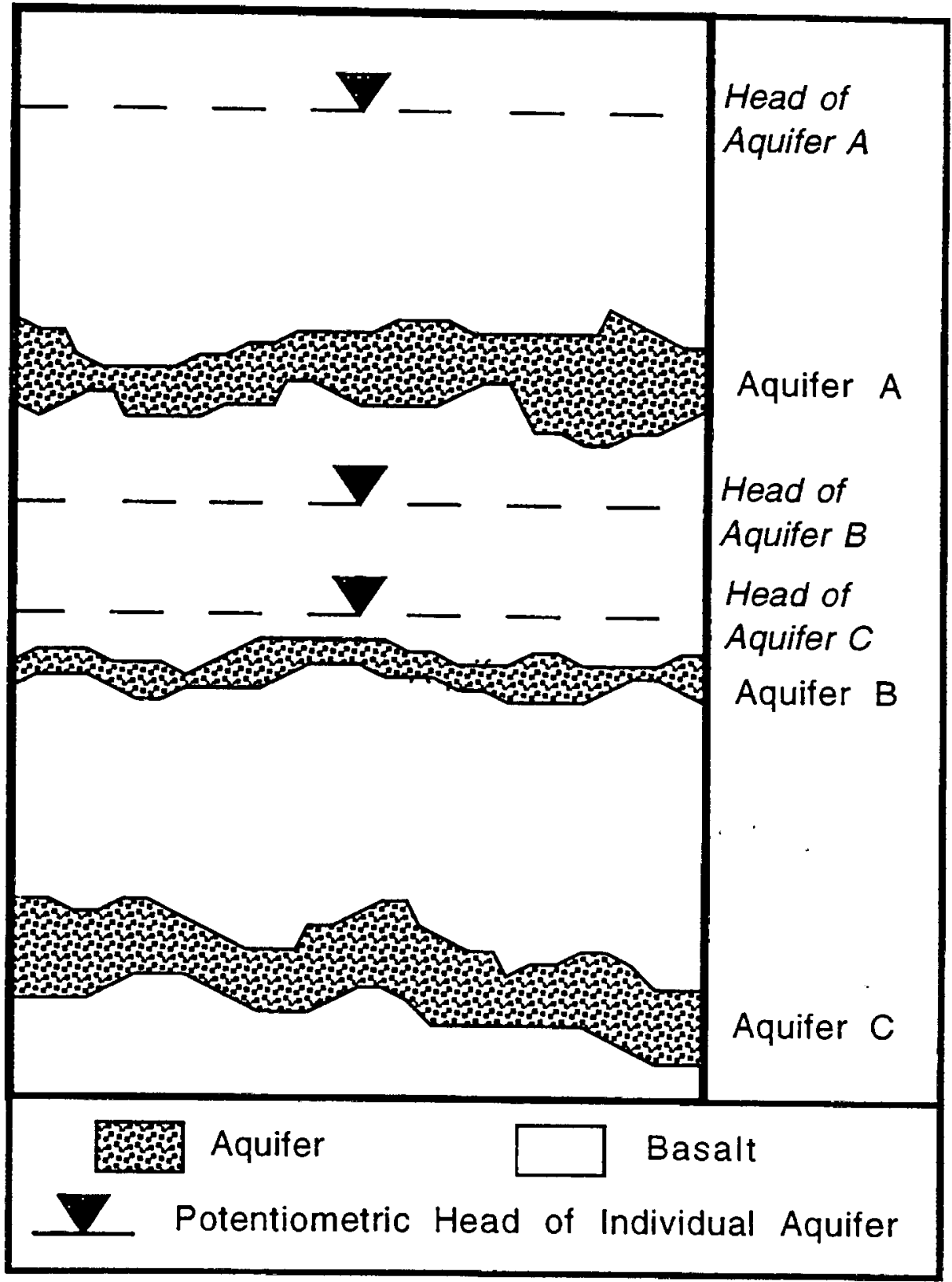

Figure 22. Schematic drawing of an idealized vertical gradient occurring in a stacked basalt flow system. Black triangles represent potentiometric surface of the individual interflow zones. 


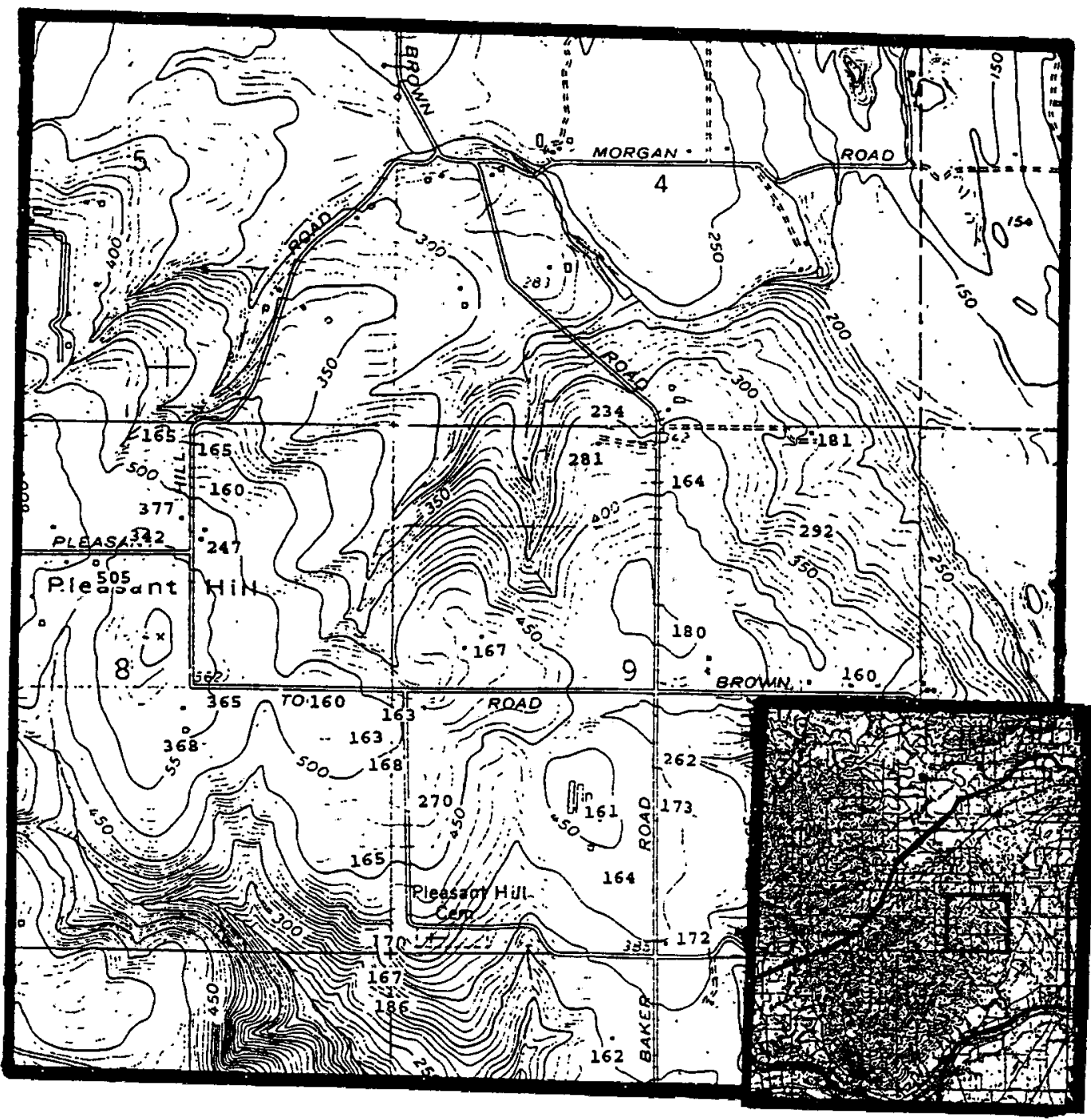

Figure 23. A map view of the Pleasant Hill basalt block showing the heads of individual wells throughout the area. Essentially, the lower the hydraulic head the deeper the aquifer. The inset shows the location of the figure within 
and 2) a smaller hydraulic head.

\section{Morphology}

Flowtop. The thickness of the scoriaceous crust, the concentration of vesicles and primary joints, and the degree of weathering of the flowtop will all directly influence the ability of an aquifer to yield groundwater to individual wells. This geologic influence was extremely difficult to quantify using the available data, since neither the transmissivity and storativity coefficients govern the hydraulic head.

The effect of the flowtop's morphology on the local aquifers is known solely through discussions with local residents and inferred from the analyzed basalt chips. Variations in the flowtop's morphology appears to affect the groundwater systems over a small distance, perhaps a few to tens of feet.

Basalt Flow Interior. Analysis of the collected drilling chips shows that in some locations the winter water and Umtanum basalt flows are highly vesicular throughout the thickness of the flows. In such cases, weathering was observed throughout the basalt flow.

The drilling chips and water well data also suggest that the Wapshilla Ridge is highly porous for most of its thickness over the entire Parrett Mountain area. The exact cause of this high porosity, whether due to permeable lenses/layers or from primary jointing, remains unknown. 


\section{Faulting}

Newcomb (1961) postulated that a fault may cause a groundwater barrier to form. One possible way for the barrier to form results from the offset of a fault. When the interflow zone is relatively thin, little offset is needed to abut the interflow zone to an impermeable flow interior (Figure 24a). When an interflow zone is relatively thick, or if the entire flow yields groundwater, e.g. the Wapshilla Ridge, the offset has to be great enough to offset the entire flowtop or flow (Figure 24b). Because of the changing interflow zone thicknesses, a groundwater barrier may exist from one interflow zone but not for another. Second, the development of fault gouge due to tectonic activity, alteration of basalt fragments, and the build up of silica and other precipitates may clog the fractures and pores providing a groundwater barrier. The examination of well chips has not revealed the presence of fault gouge or significant amount of weathering at mapped fault planes. One exception occurs in the Conway well, were banded silica was noted along the North/South \#2 fault.

The Rim and Manke Faults. In a hydrogeologic study of the Manke property, Jim Luzier studied the hydrogeologic effects of the area (1993, written commun.). Using pump test data, Dr. Luzier created a structural model of the Manke property. He designated two faults that dissected the property. For this report these faults have been informally 

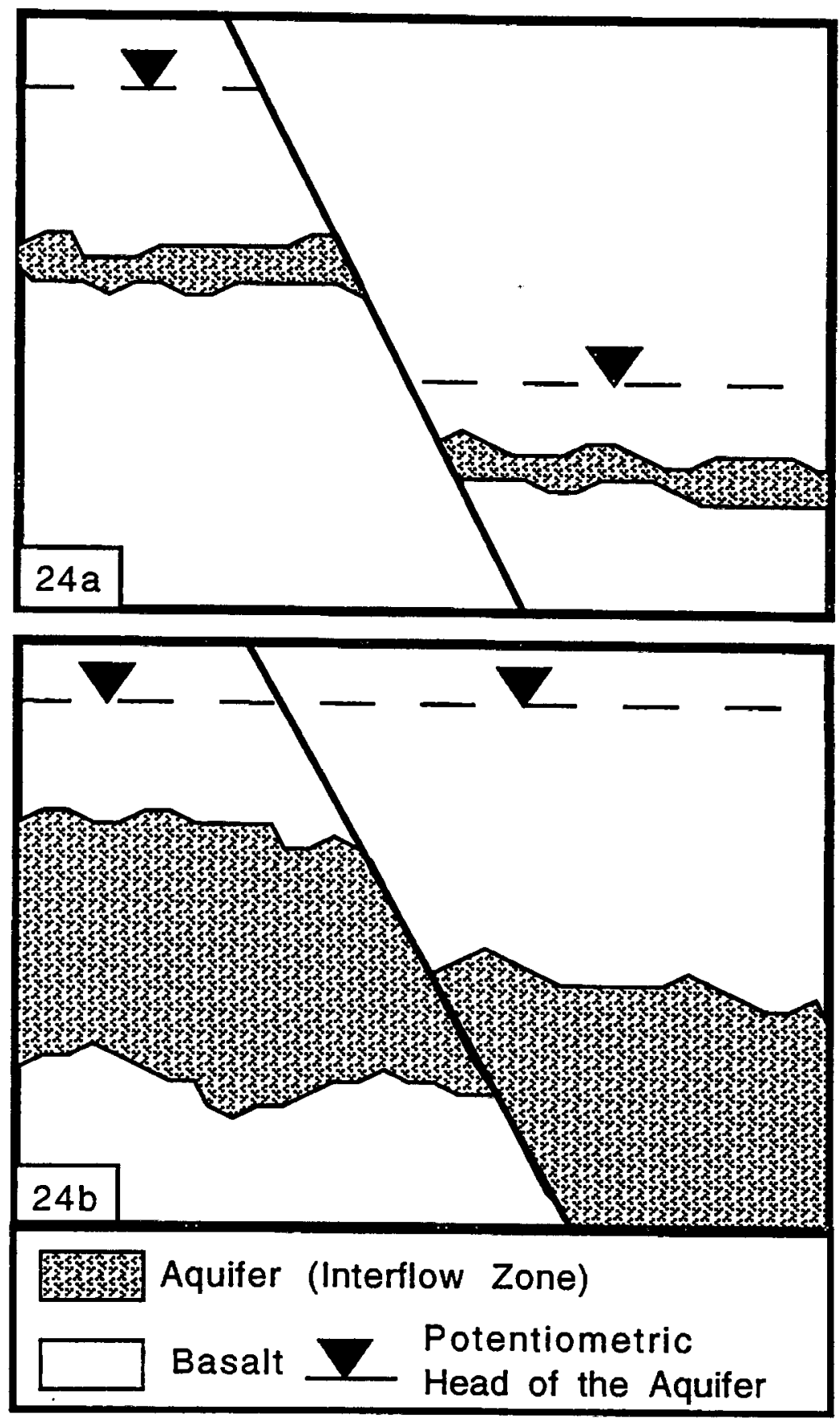

Figure 24. A generalized diagram showing the effects on a potentiometric surface depending upon the thickness of the interflow zone and amount of fault offset. 24 a represents a thin interflow zone or large offset while $24 \mathrm{~b}$ represents a thick interflow zone or small fault offset. 
named as the Rim and Manke Faults (this report). Based on his data, both faults acted as groundwater barriers, separating the aquifers occurring to the south and to the north.

Sherwood Fault. The potential of the sherwood Fault to act as a groundwater barrier has been studied by the City of Sherwood (David Driscoll, P.E., and Willard Titus, P.G., 1991, written commun.). Since the amount of offset, the exact fault position, and the dip of the fault plane remain unknown, it is tenuous at best to assume this fault to be an effective hydrologic barrier.

\section{GROUNDWATER BARRIERS}

Examination of the potentiometric surface map (Plate 3) shows the presence of several groundwater barriers. A few of the barriers coincide with mapped faults. This shows that a few of the faults on Parrett Mountain are acting as groundwater barriers.

Some of the barriers do not have a mapped fault counter part. This may be explained by the conservative approach used in mapping a fault. This is apparent in the Anna and Earlwood-Roberts basalt blocks. Several groundwater barriers (Plate 3 ) are seen throughout these two basalt blocks where no mapped faults have been designated.

One of the most important observations made from the potentiometric surface map exists near the Pleasant Hill 
Fault (Plate 3). Within this area, the groundwater's potentiometric surface dropped 200 feet $(61 \mathrm{~m})$ across the Pleasant Hill Fault. A similar drop, 100 feet $(30 \mathrm{~m})$ occurs in the Southern Ladd Hill basalt block in roughly the same trend and area as the Pleasant Hill Fault. This suggests that the Pleasant Hill Fault crosses the northwest trending Mill Creek Fault.

One other important observation occurs around the Sherwood Fault, along the Cedar Creek drainage. The local head for wells penetrating the basalt show no deviation across the inferred fault trace. Therefore, the sherwood Fault does not act as a groundwater barrier.

PARRETT MOUNTAIN GROUNDWATER MODEL

\section{Aguifers}

The term 'aquifer' has a variety of definitions. For the purpose of this study, an aquifer will be any layer of strata that yields an economic source of water for a individual well. This definition allows for the following basalt units in Table VIII to be considered aquifers.

Interflow Zones. Comparison between the stratigraphic model of Parrett Mountain and the groundwater data taken from water well reports reveals that every basalt flow boundary contributes some water to at least one water well investigated (Table VIII). Further groundwater data are presented in Table XV in Appendix B. 
The Wapshilla Ridge Aguifer. The data in Table VIII and Table XV (Appendix B) show that the Wapshilla Ridge aquifer (WpR) is the most extensively used aquifer on Parrett Mountain. The existence and nature of this aquifer most likely corresponds to the emplacement features present within the Wapshilla Ridge basalt. In analyzing the drilling chips, the vesicular flowtop was found to range from roughly 10 to over 40 feet $(3.1$ to $>12.2 \mathrm{~m}$ ) in thickness. Repeated zones of diktytaxitic textures may represent vesicular zones and/or lenses which may have led to the development of perched or layered aquifers.

TABLE VIII

PRINCIPAL AQUIFER(S) OF STUDY WELLS

Principal Aquifer

winter water

Winter Water/Umtanum

Umtanum

Umtanum/Ortley-Grouse Creek

Ortley-Grouse Creek (OGC)

oGC/Wapshilla Ridge

Wapshilla Ridge
Number of Wells Single Aquifer Two Aquifers ${ }^{\circledR}$ 4

32

14

41

24

52

110
. 0

4

0

6

5

11

@ number aligned between named units indicates the number of wells that apparently draw water from both units.

* Table taken from Miller and others, 1994. 


\section{Recharge}

Groundwater recharge of the basalt aquifers occurs through exposed flowtops, fault zones, along the alluvium/ basalt or colluvium/basalt boundaries, and by vertical migration through a basalt flow. Figure 25 is a generalized graph showing the relationship between the length of lag time and the distance from the measuring point to a recharge zone. This is a simplified model of the aquifer system, essentially ignoring the anisotropic characteristics of the basalt aquifers, yet relates importance of distance as a function of recharge. Well \#A in figure 25 is closer to the recharge pattern, ignoring anisotropic characteristics than well \#B since the lag time between precipitation/infiltration and recharge at well \#1 is shorter than the lag time for well \#2. Hydrographs (Figure 26) were examined to reveal the local and regional recharge patterns.

Exposed Flowtops. Because of the highly permeable nature of the basalt flowtops, the infiltration rate will be greater along an exposed flowtop as opposed to the basalt flow's interior. Flowtops are exposed throughout the entire Parrett Mountain area. Because of the southeasterly dip, the flowtops exposed along the northwestern slopes of Parrett Mountain, Roberts Hill, and along the local drainages will act as groundwater recharge zones. Faults. Newcomb (1961) discussed the possible effects 


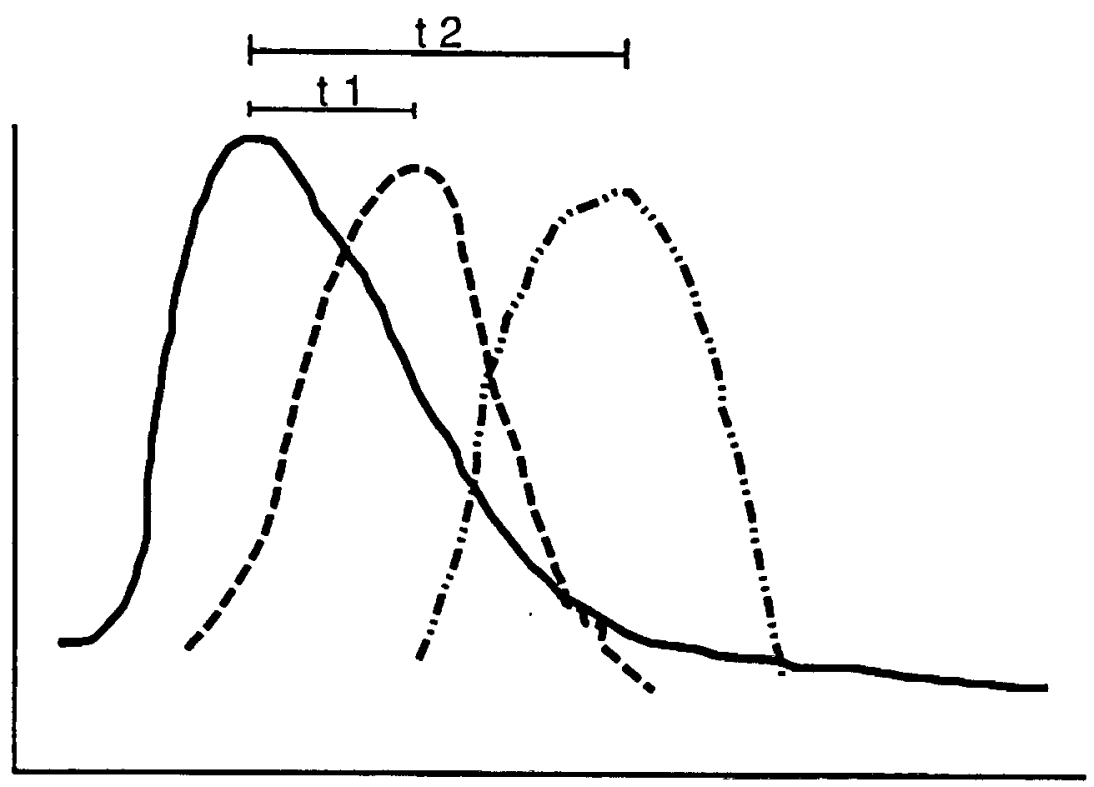

Distance

- Precipitation

--- Hydrograph of Well A

-..- Hydrograph of Well B

Figure 25. The graph shows the difference in lag time between precipitation and recharge based on distance away from a recharge zone. The time duration for recharge of well A (t1) is shorter than the time duration for well B $(t 2)$. 

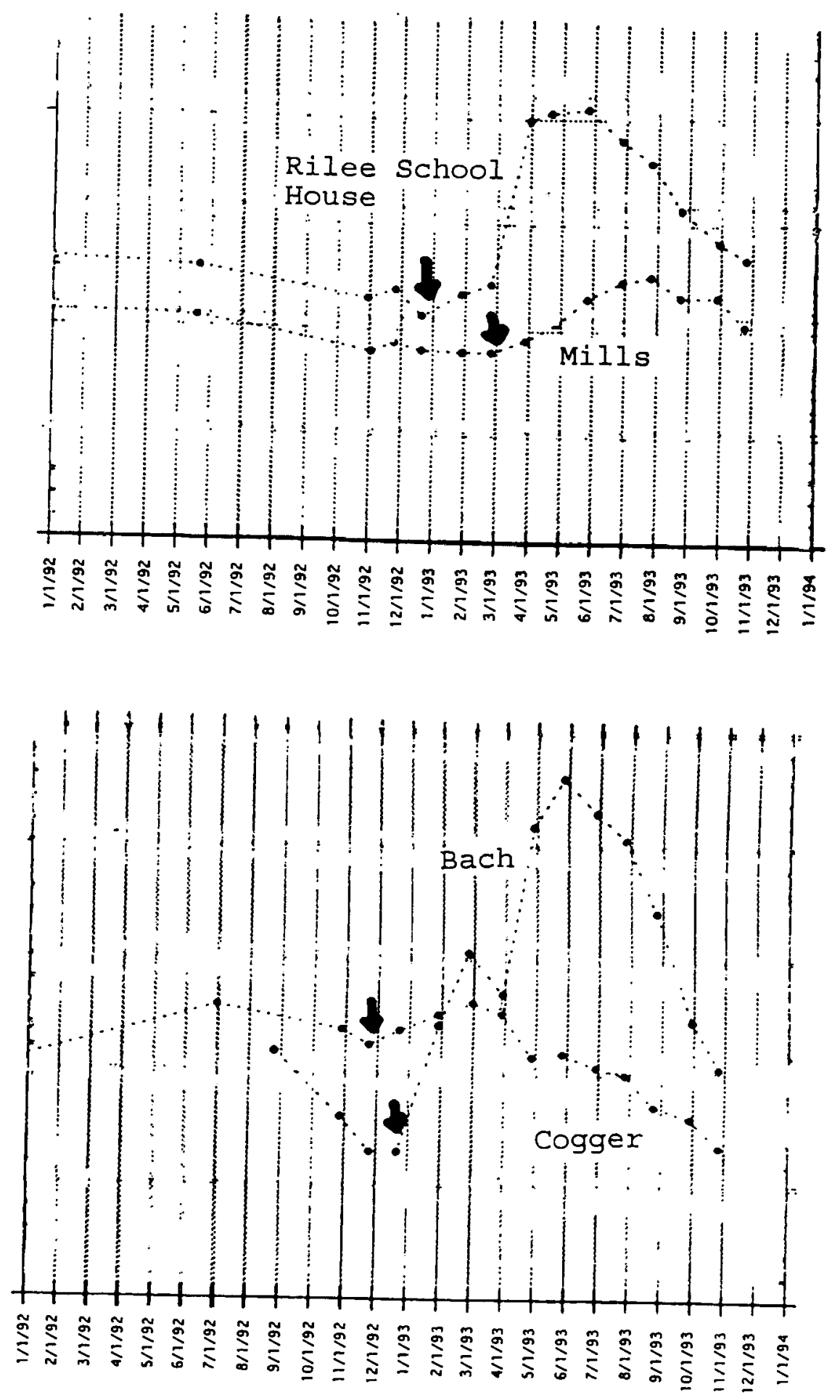

Figure 26. Comparison of hydrographs, Bach vs. Cogger and Rilee School House vs. Mills, to determine basalt recharge zones. Arrow designates the beginning of Seasonal Recharge. 
faults may have on the aquifer systems. He postulated that faults could aid in the recharge of the groundwater systems because of the higher permeability associated with the numerous secondary joints surrounding the fault plane. This allows for an easy vertical transmission of groundwater from the surface and shallow aquifers into the deeper aquifers.

Examination of the potentiometric surface map shows the head values are highest near and decrease away from the mapped faults (Figure 27). This implies that the faults aid in groundwater recharge. Further evidence to support this observation is seen in several hydrographs (Figure 26, Bach vs Cogger) obtained from the OWRD. These hydrographs show that there is a natural lag time between the period of precipitation and the maximum head value. The lag time appears to be smallest near and longest away from mapped faults.

Landslides. The steep slopes on the northwestern face of Parrett Mountain hampers the amount of recharge to the flowtop aquifers by decreasing the time precipitation has to vertically infiltrate into the soil and flowtops. The landslides on the northwestern face of Parrett Mountain have decrease the northwestern slopes and thereby increase the time precipitation has to infiltrate. Second, the physical movement of the landslide material has created a more permeable substrate for groundwater infiltration. The infiltrating groundwater will migrate vertically through the 


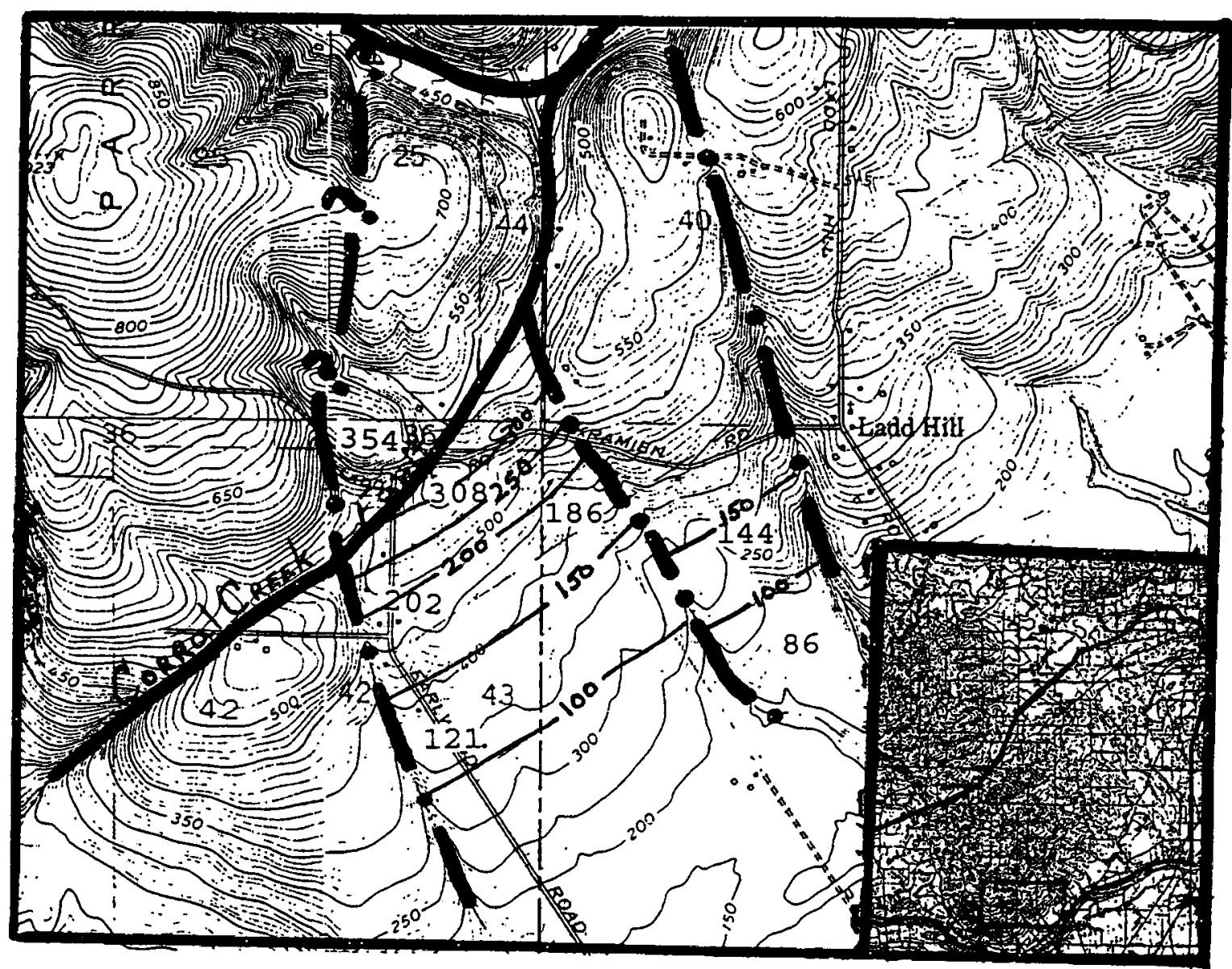

Figure 27. View of the potentiometric surface of the Columbia River basalt aquifer decreasing away from mapped
fault zones. 
landslide colluvial material. Eventually, this infiltrating groundwater will reach the colluvial/basalt boundary, at the base of the landslide, where it will pond forming a perched aquifer. This perched aquifer will slowly yield groundwater into the basalt bedrock over a longer period of time than would occur without the presence of the landslide.

Vertical Infiltration. The infiltration of precipitation through the soil is classified, for this study, under the term 'vertical infiltration'. Groundwater infiltration occurs through a basalt flow's impermeable interior. Both of these infiltration processes recharge the underlying basalt interflow zones. The amount of infiltration was not discerned in either case.

\section{Discharge}

Groundwater discharge from the aquifer systems occurs through groundwater pumpage, vertical seepage, and spring discharge.

Groundwater Pumpage. Withdraw of the basalt aquifers is related to permitted and non-permitted (domestic) uses. The largest groundwater withdraws from the study area are from the City of Sherwood and Dammasch State Hospital. "Current annual water use as reported by these users is about 227.7 million gallons per year (mgy)." (Miller and others 1994) Table IX depicts the estimated basalt groundwater withdraw for the Parrett Mountain area from 1960 to 1993. Further data on the amount of groundwater pumpage 
and uses can be obtained from Miller and others, 1994.

Vertical Seepage. Within the study area, vertical migration of groundwater, represented as changes in the vertical heads, can occur through a basalt flow's interior and/or along fault planes. Figures 22,23 and Plate 3 reveal a generally positive vertical head gradient for Parrett Mountain. Whether this vertical head gradient is caused by groundwater migration through a basalt flow's interior, along a fault plane, or some combination of the two pathways is unknown.

\section{TABLE IX}

ESTIMATED BASALT GROUNDWATER WITHDRAWALS ON PARRETT MOUNTAIN. (in million gallons per year (mgY) from 1960 to 1993)

1960

$1970 \quad 1980$

1990

1993

Domestic Permitted $48 \mathrm{mgy}$ $66 \mathrm{mgy}$ $111 \mathrm{mgy}$ $197 \mathrm{mgy}$

$141 \mathrm{mgy}$ $237 \mathrm{mgy}$

$187 \mathrm{mgy}$ $367 \mathrm{mgy}$ $193 \mathrm{mgy}$ Total $159 \mathrm{mgy}$ $263 \mathrm{mgy}$ 378 mgy 554 mgy 365 mgy * Taken from Miller and others (1994).

Many wells in the Parrett Mountain study area artificially increase the yield of a well in order to obtain more water from the well. This artificial increase, commingling, is created by the penetration of two or more aquifers, allowing their groundwater to co-mingle.

Commingling was noted during field measurements when the sound of flowing to dripping water in the well or the 
generation of an intermittent sound from the electrical measuring tape was heard. The list of wells where commingling was noted as occurring can be found in Miller and others (1994). At least half of the basalt wells existing on Parrett Mountain have some amount of commingling occurring (Miller and others, 1994).

To understand the effects of commingling it is first necessary to understand how an aquifer develops. Within an aquifer, water enters as infiltrating groundwater and leaves as groundwater flow, well discharge, and vertical seepage to underlying rock strata. If the vertical seepage is increased, through commingling, and the other variables remain constant, the effect is to drain the aquifer. Commingling will also overshadow any effects the vertical transmission of groundwater will have (Davies-Smith, 1988). Figure $28 \mathrm{a}$ is a schematic drawing of the effects commingling has on several penetrated aquifers.

Typically, it is believed that if commingling occurs it will develop the lower aquifers due to groundwater migration driven by gravity. However, groundwater migration is not driven by gravity, rather it is driven by head potentials. If the head potential is lower in a overlying aquifer then commingling will cause a upward decreasing vertical gradient through the well to occur. This will develop the upper aquifer at the expense of the lower aquifer (Figure 28b).

Several other effects caused by commingling should be 


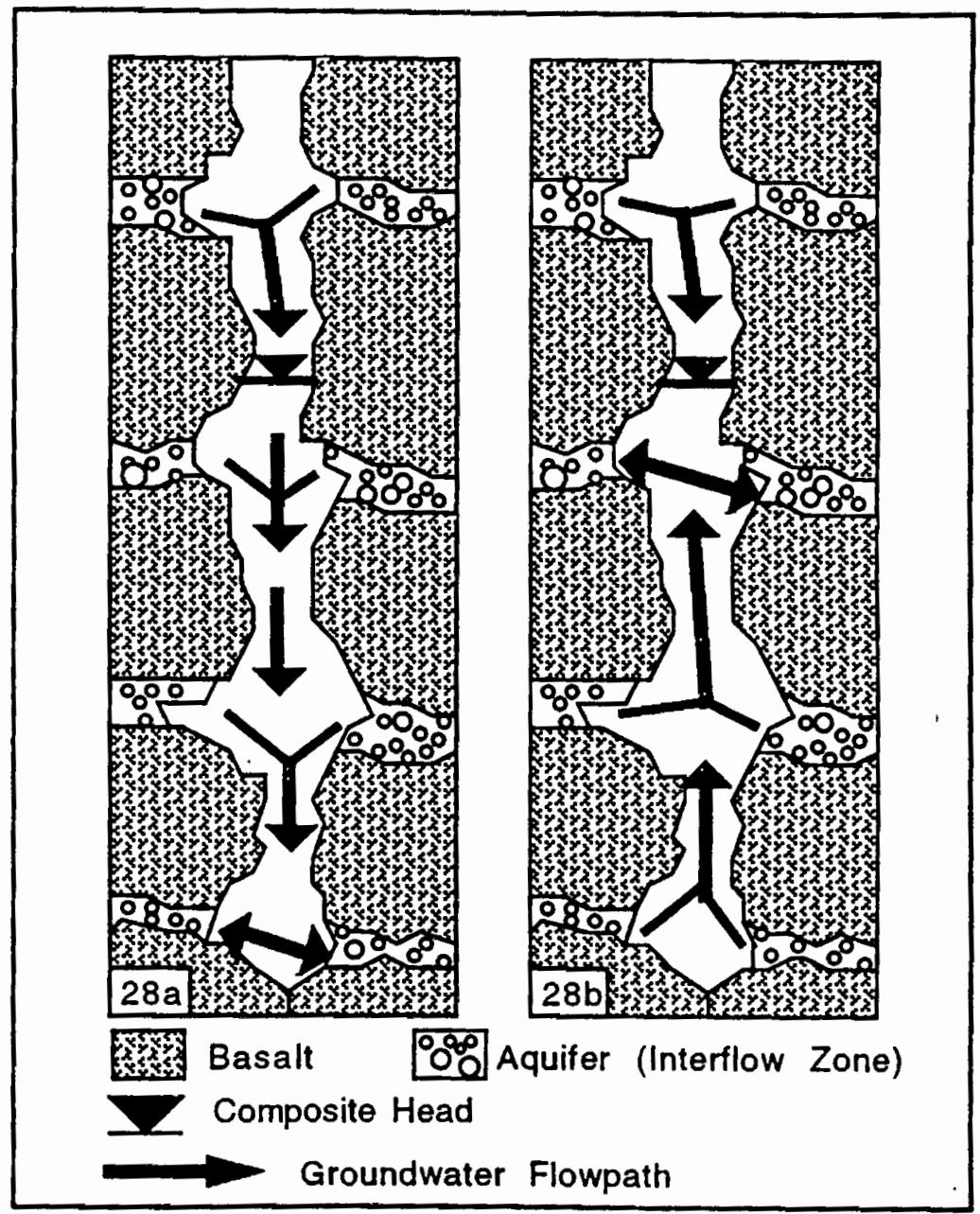

Figure 28. Cascading water from an uncased or unlined well creating a composite head (Heath, 1984). The schematic drawing showing the two forms of cascading water. represents the migration of groundwater down the well-hole, depleting the upper aquifer(s); while (b) represents groundwater migration up the well-hole depleting the lower aquifer(s). 
noted. First, several of the heads measured by OWRD (Table XIII, Appendix B) are actually composite heads. A composite head is a representative head value of the aquifers penetrated by a well (Figure 29). Second, groundwater chemistry becomes questionable as a means of identifying different aquifers due to groundwater mixing. Finally, contaminates, if present in one aquifer, have a greater chance of migrating to other aquifers in the study area.

Springs. Figure 30 depicts the locations of springs encountered during the study. Field mapping has revealed that the springs encountered on the southeastern slope resulted from the daylighting of the interflow zones. Examples are the Ginkgo/Sentinel Bluffs and Sentinel Bluffs/Sentinel Bluffs' interflow zones which were observed to yield water to several springs.

On the northwestern slope, springs were observed to be associated with the landslides. Due to the enhanced permeability and the low slope angle of the landslides infiltrating groundwater will migrate vertically and laterally through the colluvium. Anisotropic characteristics and varying hydraulic conductivities within the landslide colluvium will create the ponding and lateral stratification of the infiltrating groundwater if the landslide is of a thickness to allow hydrologic stratification. The most prominent boundary, the colluvium/basalt boundary, at the base of the landslide, 


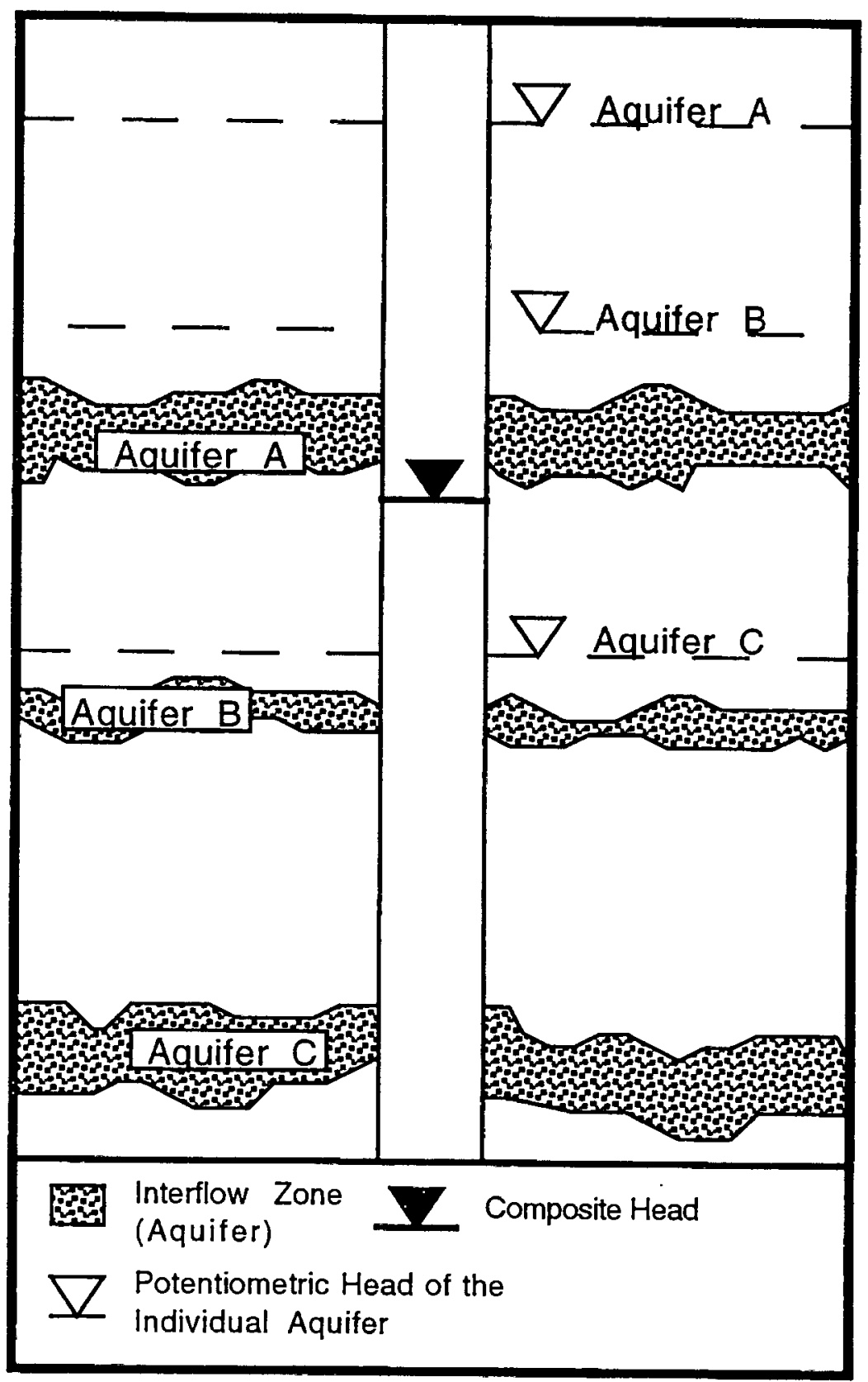

Figure 29. A generalized diagram of a composite head. The water table in the well represents an equilibrated system between the interflows penetrated by the well. 


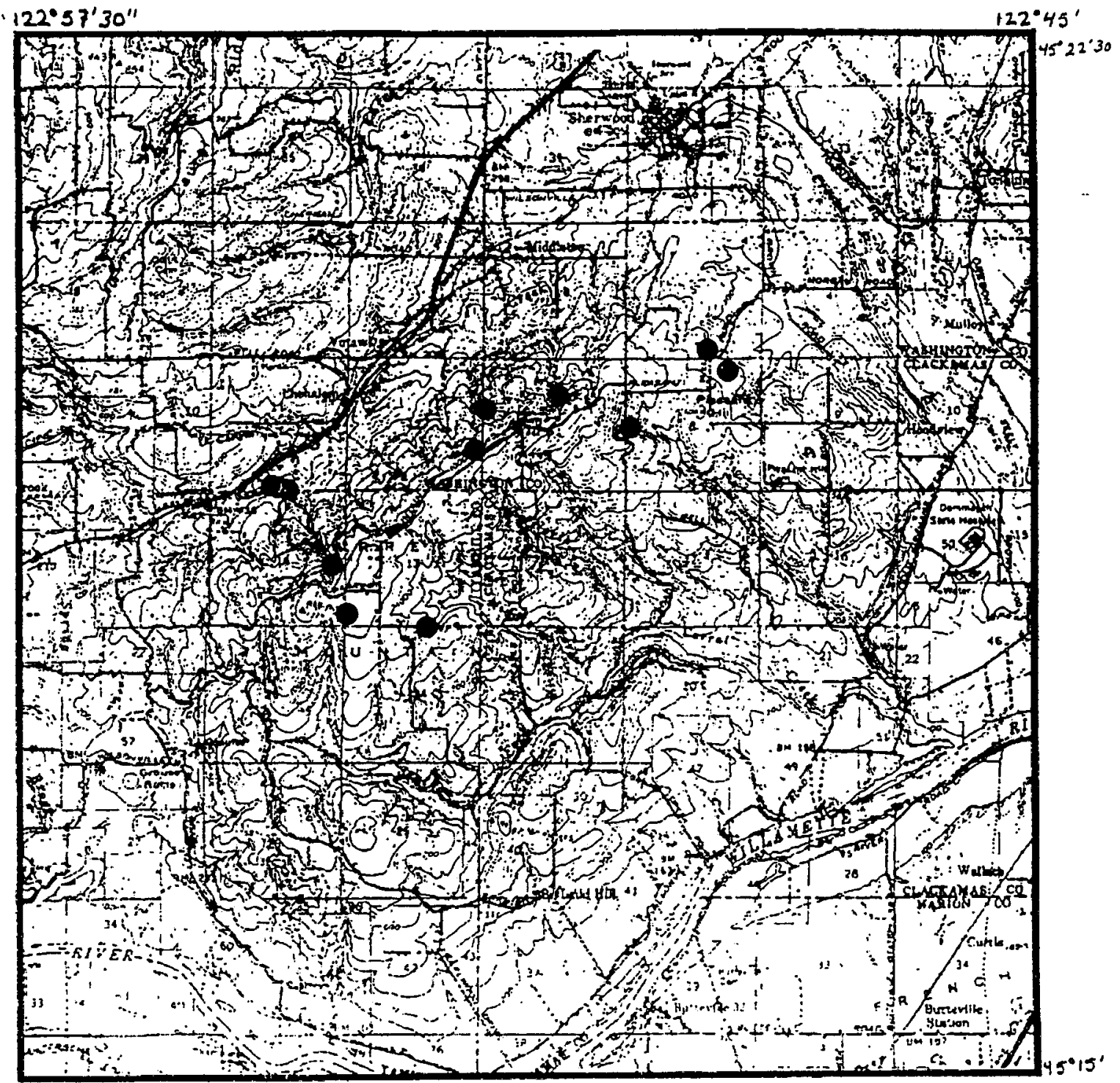

Figure 30. Location of springs observed on Parrett Mountain. 
will cause a ponding of the infiltrating groundwater. If the colluvium/basalt boundary is exposed at the surface then springs will occur, outlining the boundary of the landslide. Such an example can be observed in Figure 31. Several other springs were mapped within the landslide areas. These springs occur due to the anisotropic nature of the landslide colluvium.

Along with the springs associated with the landslide areas a few others were mapped within fault zones, e.g. the NS\#4 and the Oberst Fault.

\section{GROUNDWATER CHEMISTRY}

Groundwater geochemical data were obtained from Driscoll and Titus (1991) and supplemented with the Sherwood and Dammasch well reports. Further geochemical data, generally temperature and salinity, were supplied in a few well reports.

Table $\mathrm{x}$ compares the groundwater chemistry of the City of Sherwood wells \#3 and \#5 to three Parrett Mountain wells: Bach, Langston, and Owens. Figure 32 shows the locations of the five wells sampled in Table $x$.

Tritium. Tritium $\left(\mathrm{H}^{3}\right)$, a radioactive isotope of hydrogen, is naturally and artificially created in the atmosphere. Artificial creation of tritium occurred in the early 1950's due to atmospheric testing of thermonuclear bombs (Freeze and Cherry, 1979). Because of this artificial 


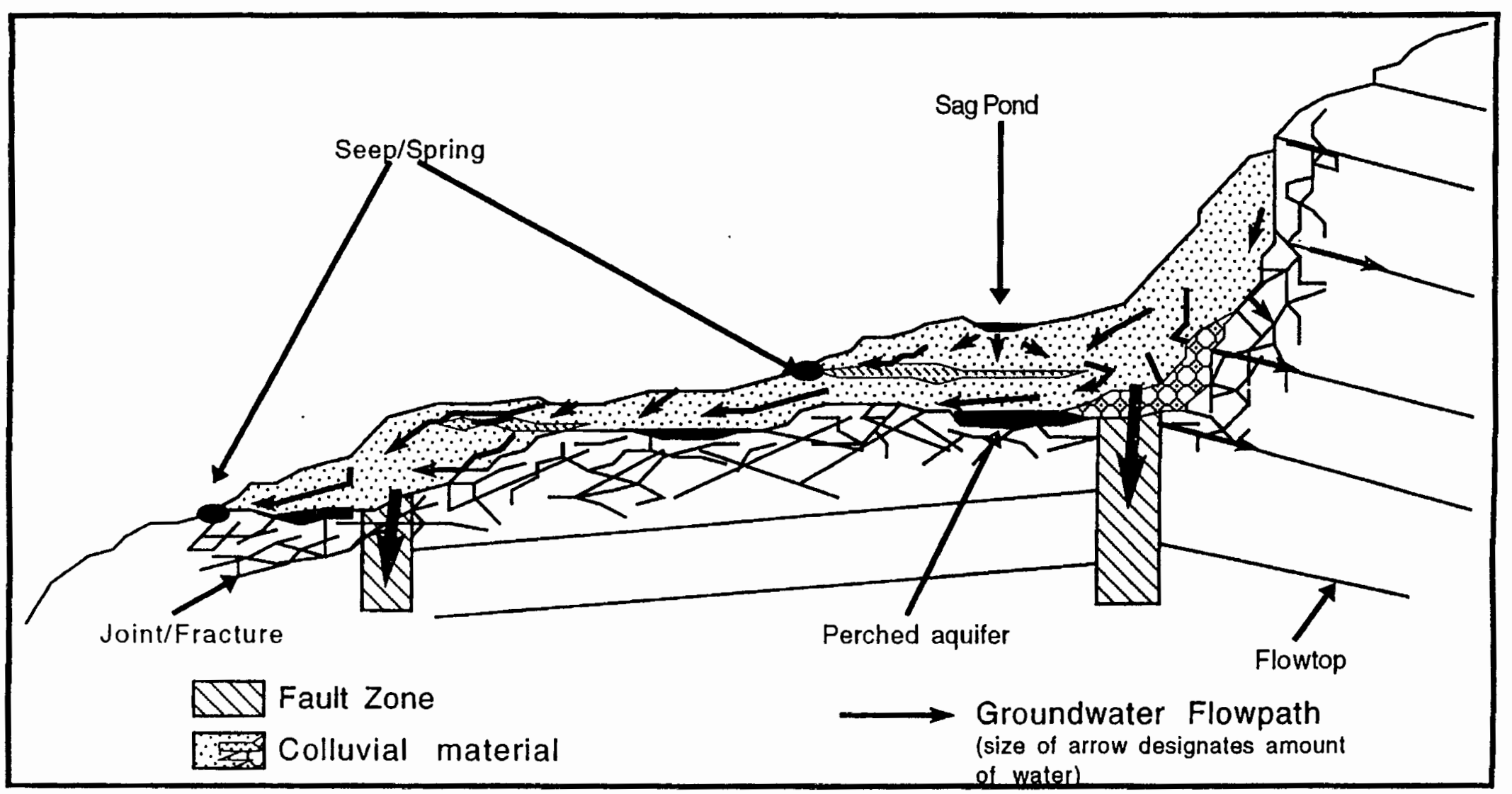

Figure 31. A generalized representation of spring development on the northwestern slopes of Parrett Mountain with respect to the presence of landslide material. 
increase in tritium, this isotope a good time indicator for dating groundwater systems. If the tritium concentration (TU) is roughly 5 to $10 \mathrm{TU}$ then the groundwater must have originated before 1953 (Freeze and Cherry, 1979). The above statement does not take into account groundwater mixing. If very old groundwater ( $\mathrm{TU}<2$ ) mixes with groundwater fed from recent to near recent precipitation ( $\mathrm{TU}>25$ ) then the resulting $T U$ would be a representation of how much old groundwater mixed with the recent precipitation.

Table $\mathrm{X}$ shows the amount of tritium detected in the analysis of three Parrett Mountain wells and two Sherwood wells as pci/L. Under the conditions of the analysis, one

\section{TABLE X}

\section{GROUNDWATER CHEMISTRY}

\begin{tabular}{|c|c|c|c|c|c|}
\hline City of she & rwood W & lls & & Private & \\
\hline Analyte & No. 3 & No. 5 & Bach & Langston & Owens \\
\hline Hardness, mg/L & 88.0 & 81.0 & 49.0 & 60.0 & 45.0 \\
\hline Chloride, mg/L & 1.5 & 2.0 & 2.0 & $<0.10$ & $<0.50$ \\
\hline Nitrate, mg/L & 0.1 & $<0.01$ & 0.8 & 0.7 & 1.3 \\
\hline $\begin{array}{l}\text { Conductivity } \\
\text { (umho/cm) }\end{array}$ & 192.0 & 210.0 & 120.0 & 150.0 & 110.0 \\
\hline $\begin{array}{l}\text { Total Dissolved } \\
\text { Solids, ma/L }\end{array}$ & 134.0 & 147.0 & 84.0 & 105.0 & 116.0 \\
\hline Tritium, $\quad \mathrm{pci} / \mathrm{L}$ & $\begin{array}{l}\text { ND } \\
t \text { ana }\end{array}$ & zed & 5.9 & 32.0 & 19.0 \\
\hline
\end{tabular}

pci/L equals one TU.

Due to the uncertainty in the amount of groundwater mixing resulting from commingling the tritium concentration 


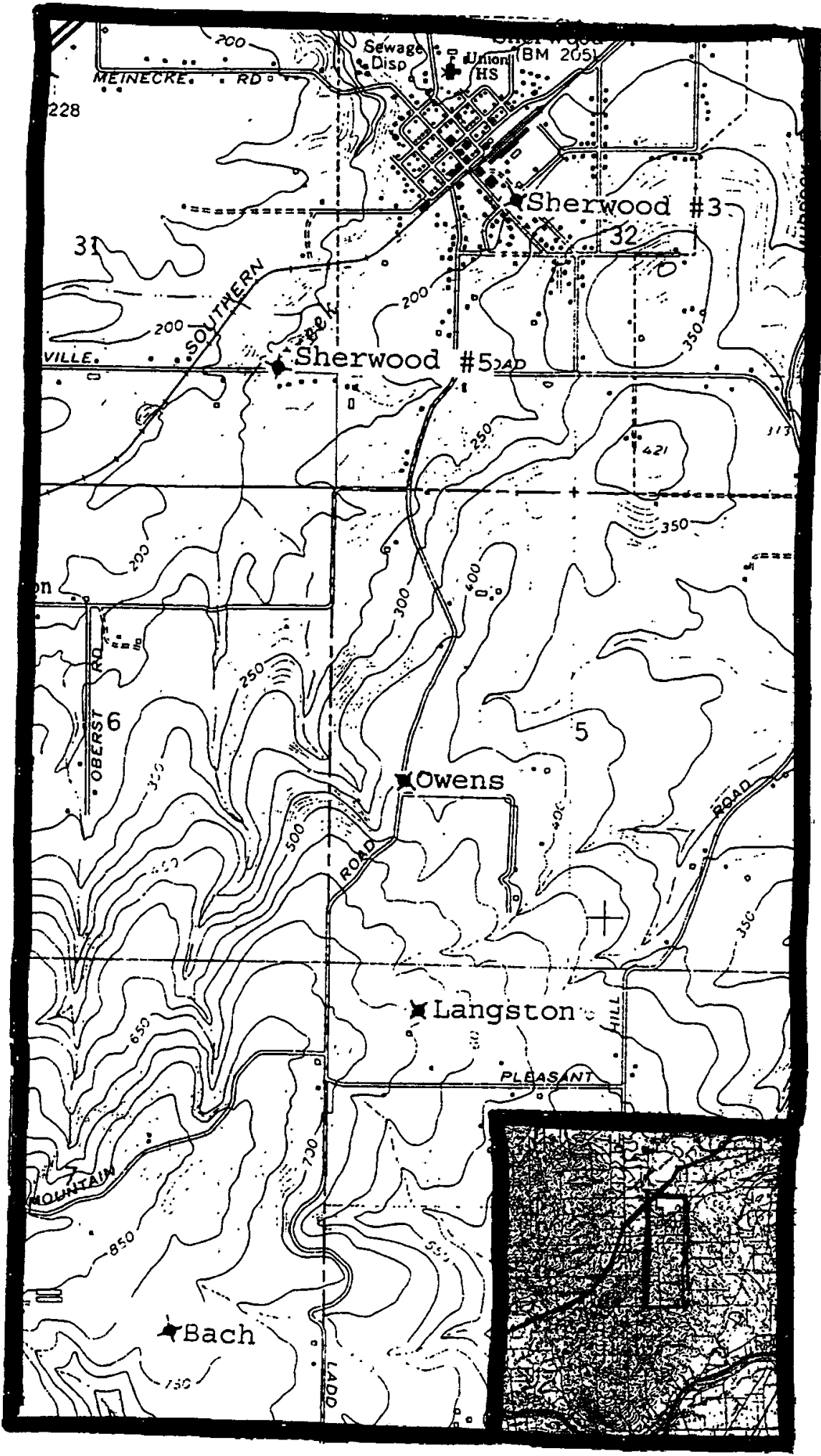

121

Figure 32. Location of the five wells where the groundwater geochemistry was analyzed (Driscoll and Titus, 1991). The inset shows the location of the figure within the study 
should be held questionable.

Groundwater Geochemistry. Based solely on a visual analysis of the geochemical data (Table $\mathrm{X}$ ), comparing Sherwood well \#5 and the three Parrett Mountain wells, it appears that sherwood well \#5 obtains its groundwater from a separate aquifer system. This observation is based solely on apparent differences in hardness, nitrate, total dissolved solids, and conductivity. This separation should be suspected due to the occurrence of groundwater mixing from commingling wells. Since the amount and extent of groundwater mixing remains unknown variations in the groundwater chemistry from site to site should be expected.

Additional groundwater chemical data were extracted from the OWRD and the well reports. Groundwater temperature and conductivity values for wells measured are reported in Miller and others (1994) and are not included in this study. Typically the groundwater temperature was between 50 to $54^{\circ} \mathrm{C}$ while the conductivity range from 35 to $900 \mathrm{micromhos} / \mathrm{cm}$ with most occurring between 100 to $200 \mathrm{microhmos} / \mathrm{cm}$. Based on collected geochemical data, separation of aquifer systems was impossible due to similar values throughout the study area (Miller and others, 1994).

Although very similar in characteristics, the groundwater geochemistry does not prove or disprove the separation of aquifer systems. Given the small variation in the geochemical parameters over the entire study area, a 
larger sample base is deemed necessary to differentiate between aquifers.

\section{Saline Water}

Saline water was recorded in only three wells within the study area. No well reports were found for these three saline wells so a measure of how deep the saline water is encounter is unknown. Their approximate locations were given by Schlicker and Deacon (1967) and discussions with local landowners. Figure 33 shows the approximate locations of the three wells.

Occurrence of Saline Water. Hart and Newcomb (1965) discussed three plausible explanations for the occurrence of the saline water within the basalt aquifers. The first process (Figure 34a) involves the bending and flexing of the basalt layers during folding. The bending and flexing cause tension cracks to develop which allow the saline water to travel upward into the basalt aquifers. The second process (Figure $34 \mathrm{~b}$ ) results from the positioning of a basalt interflow zone adjacent to the marine sediments by faulting. Groundwater from the marine sediments will flow into the interflow zone due to diffusion. The third method (Figure 34c) involves the onlapping of the basalt flow onto a paleohigh composed of marine sediments. This onlapping creates a permeable boundary between the CRB and the marine sediments allowing groundwater easier passage from the marine sediments into the basalt aquifers. 


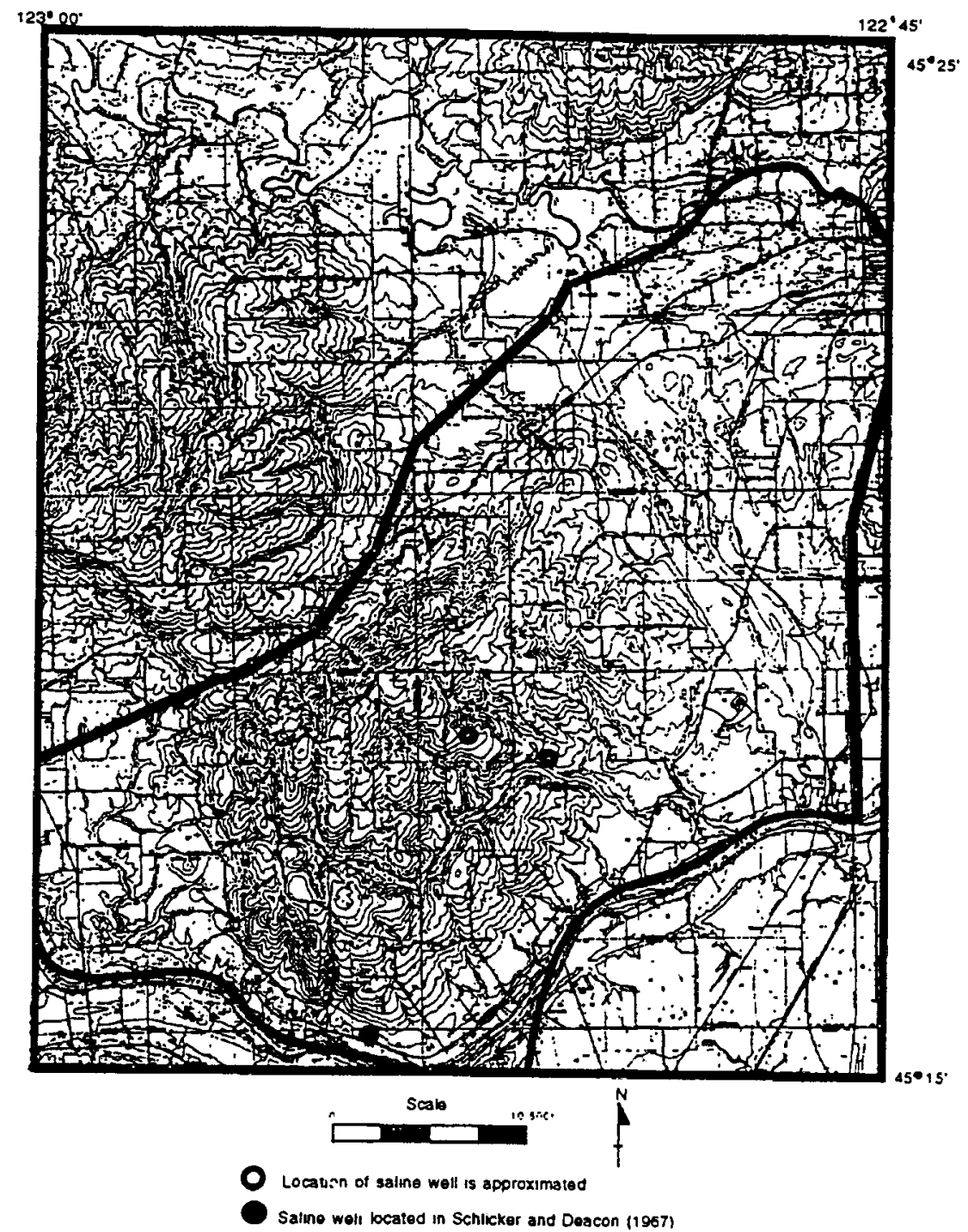

Figure 33. Location of saline wells within the Parrett Mountain area. 

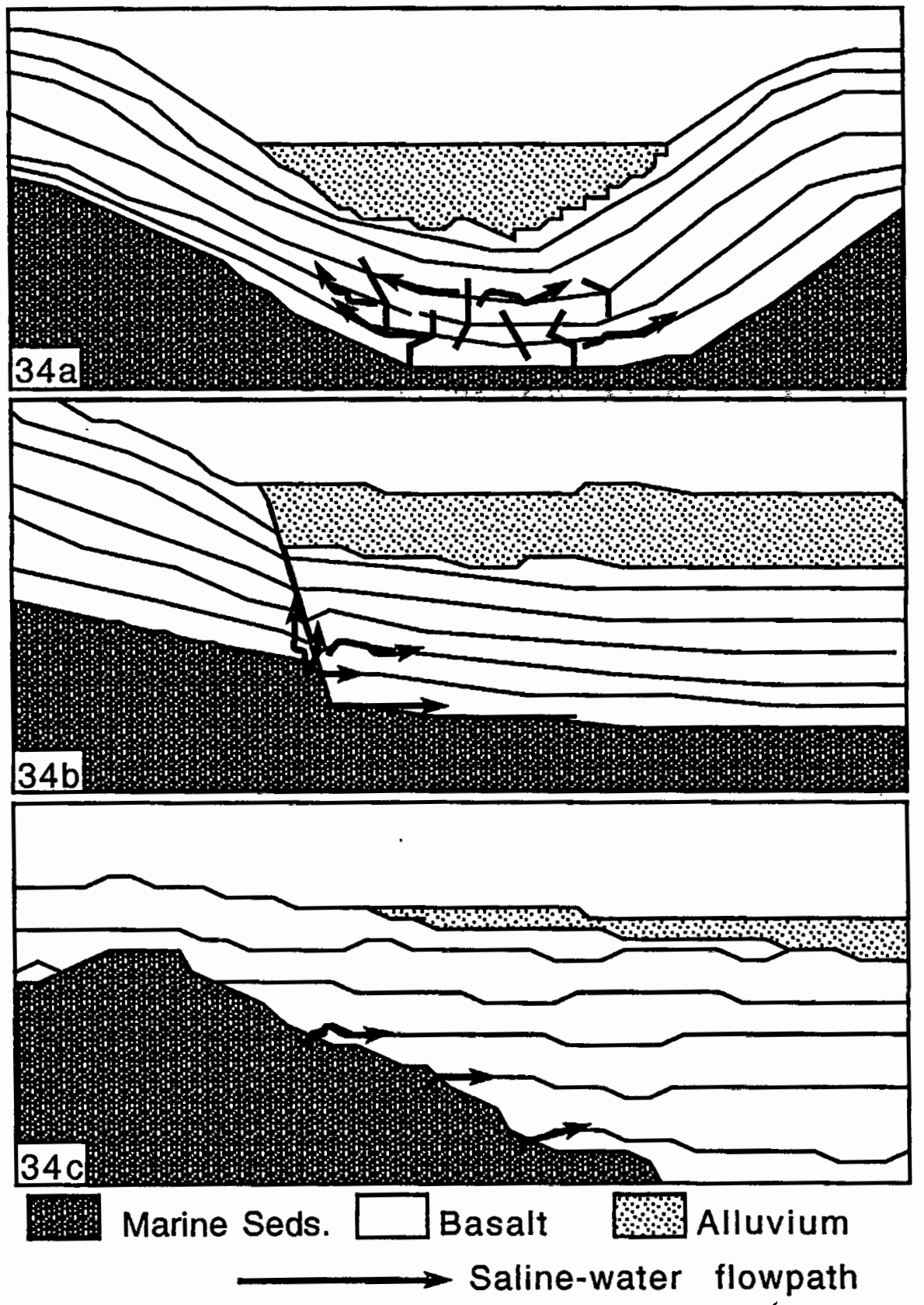

Figure 34. Three possible processes in which saline water can occur in basalt aquifers. a) Tensional cracks developed due to bending of the basalt, b) fault acting as a flow path into a now exposed flowtop, and c) exposed flowtops along a paleohigh composed of marine sediment. paleohigh composed of marine sediments. 
The exact process governing the presence of the saline water remains unknown but it does appear that hypothesis two (Figure 34b) and three (Figure 34c) occur. The saline well near the Willamette River and the one at the junction of the North and South Forks of Corral Creek both occur near or in fault zones. Possibly the presence of saline water is due to fluid flow along the faults. The saline water in the third well, located in Section $18 \mathrm{~T} 3 \mathrm{~S}$ RIW by Heater Road, is probably caused by a saline water flow from a paleohigh into an exposed basalt interflow zone. This is not unexpected given the variable paleotopography observed in the Wapshilla Ridge. 
QUATERNARY GEOLOGY

GLACIAL FLOOD EFFECTS

The flood waters from glacial Lake Missoula inundated both the Tualatin and Willamette valleys forming Lake Allison (Allen and others, 1985). These flood waters eroded the soil and bedrock and then redeposited it as sediment. This deposited material is a combination of clay, silt, sand, cobbles, and boulders of mostly basaltic, granitic, and quartzitic composition. Basaltic boulders deposited within the study area's boundaries are typically from the Ginkgo, Sentinel Bluffs, and Winter water basalt flows, though some boulders of Umtanum and Ortley-Grouse Creek (undifferentiated) units are also present (Figure 35).

Erratics, cobbles and boulders of granitic or quartzitic composition, were used to define the maximum elevation affected by the flood waters. Previous workers (e.g. Allen, 1986) have identified the maximum elevation in the willamette Valley as 400 feet $(122 \mathrm{~m})$. This elevation was based on erratic boulder locations and erosional features. Within the confines of this study, all the erratics were found near the 300 to 310 foot $(91.4$ to 94.5 m) elevation on Parrett Mountain and around 320 to 330 feet $(97.5$ to $100.6 \mathrm{~m}$ ) elevation in the Tonquin area (Figures 36 


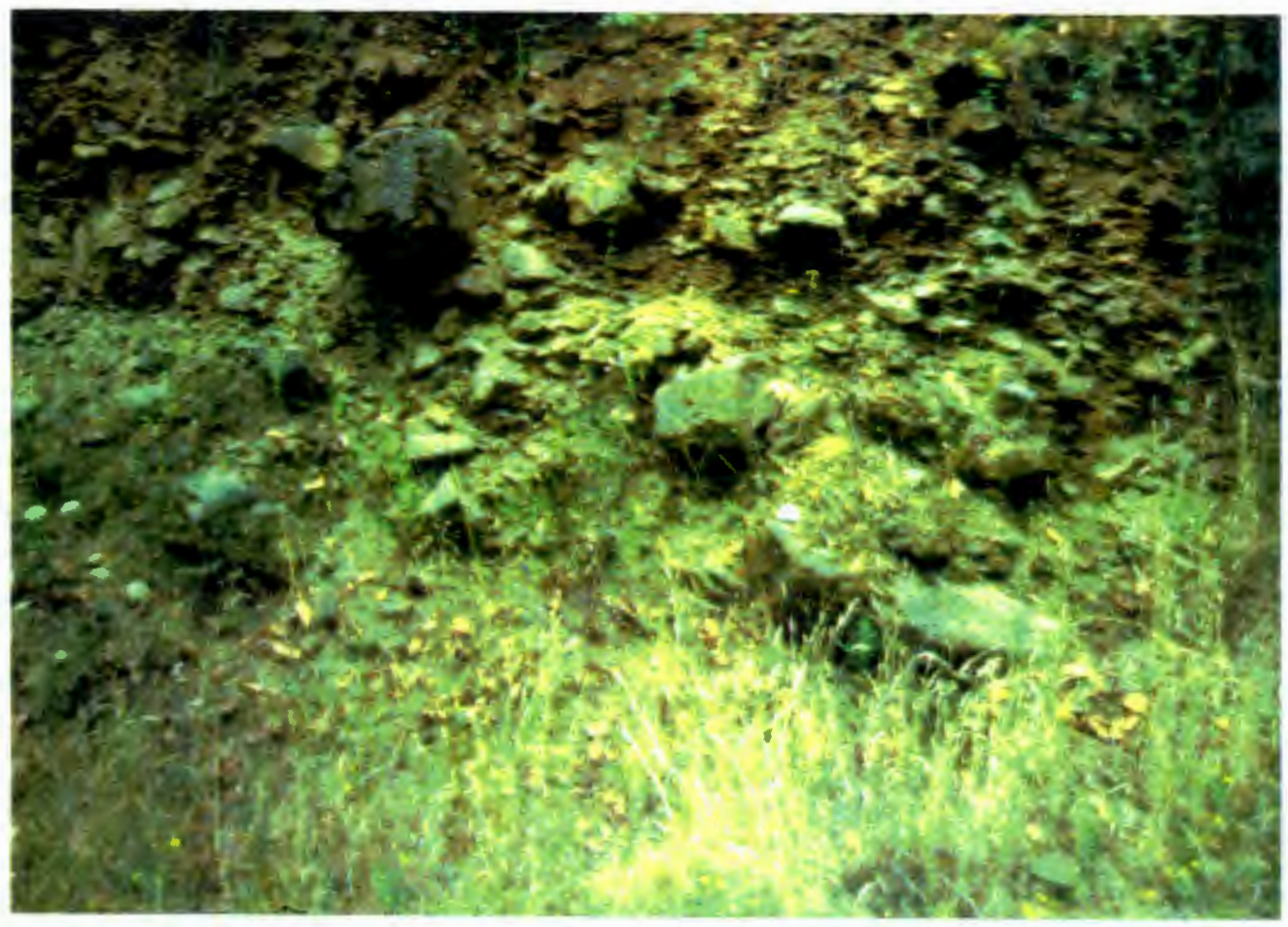

Figure 35. Flood scour channel cut into the upper flow of the sentinel Bluffs. Boulders are basalt typically of Ginkgo, sentinel Bluffs, and winter water basalt lithology. 
and 37). The locations of the erratics were used to delineate the maximum extent of flood water deposits on the flanks of Parrett Mountain and in the Tonquin area.

\section{Tonquin Scablands}

The Tonquin area was severely affected by the glacial flood waters. Erosional features similar to those seen in eastern Washington have allowed this area to be named the Tonquin Scablands (Allen, 1986). The Tonquin scablands area was one of the three main water escape zones where flood waters that filled the Tualatin valley emptied back into the Willamette Valley.

The basalt exposed belongs to the youngest flow of the Sentinel Bluffs basalt, though the Ginkgo flow crops out in a few locations (Plate 2). The basalt has an apparent dip of 1 to 2 degrees to the north northeast. Erosion, by the Missoula floods, appears to have concentrated on the flow boundaries. The few outcrops of the Ginkgo flow as opposed to the upper Sentinel Bluffs basalt flow suggest that the Vantage Horizon was the most easily eroded zone in this area.

Alluvial deposits range from less than one to over three hundred feet $(92 \mathrm{~m})$ in thickness. A general thickness of the alluvial material mantling the basalt, including recent alluvium, flood deposits, and Troutdale Formation, can be obtained from Schlicker and Deacon (1967). Within the Tonquin region, the flood deposits were mapped to 


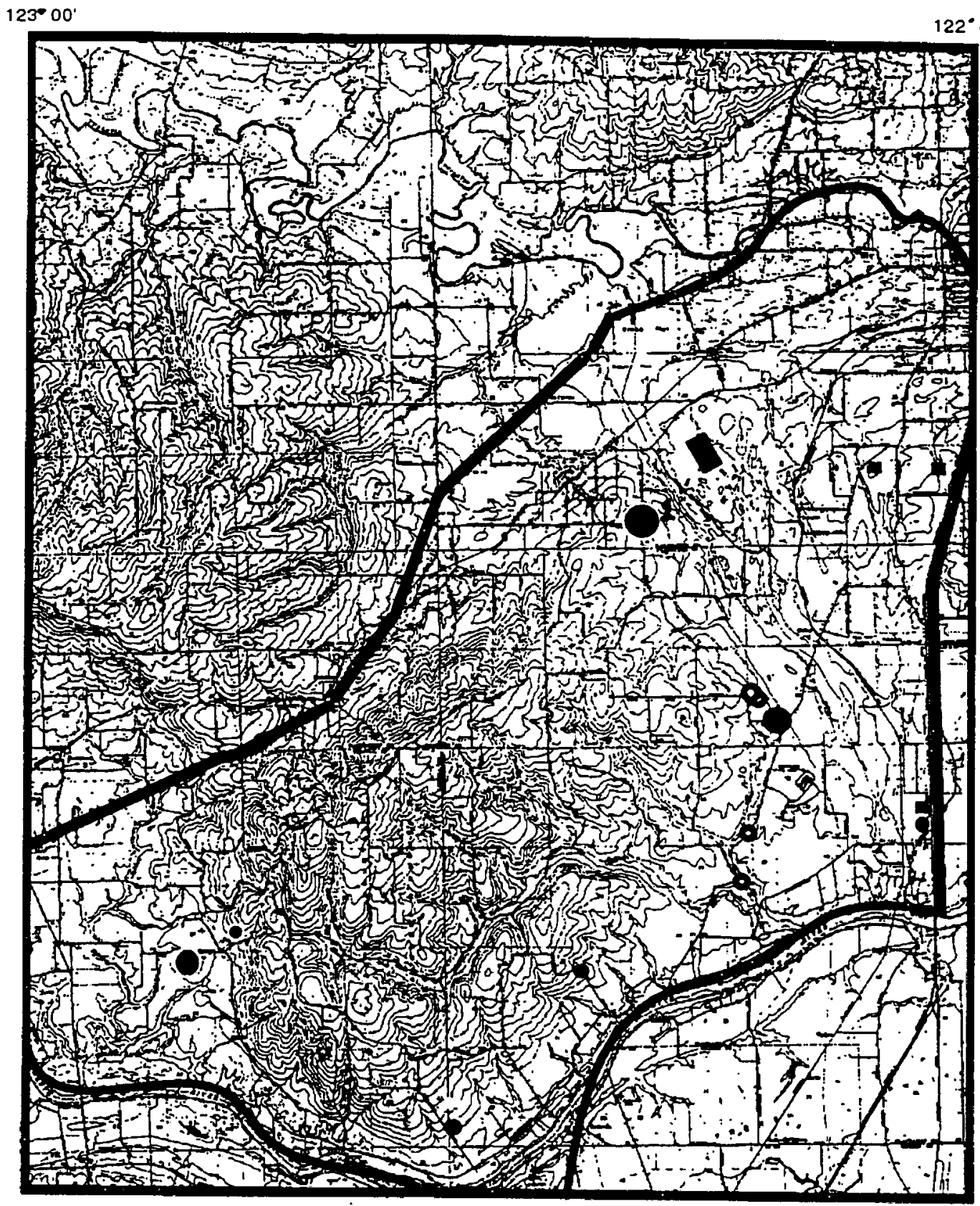

$122^{\circ} 45^{\prime}$

$45^{\circ} 25^{\prime}$

$45^{*} 15$

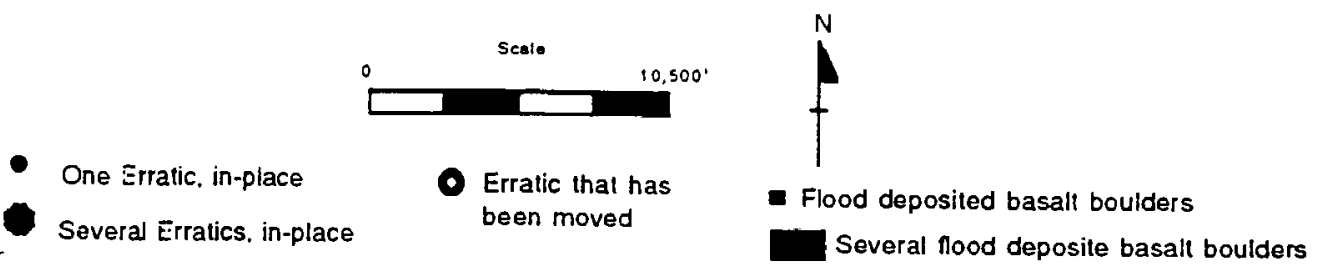

Figure 36. Position of erratics found within the study boundaries. 

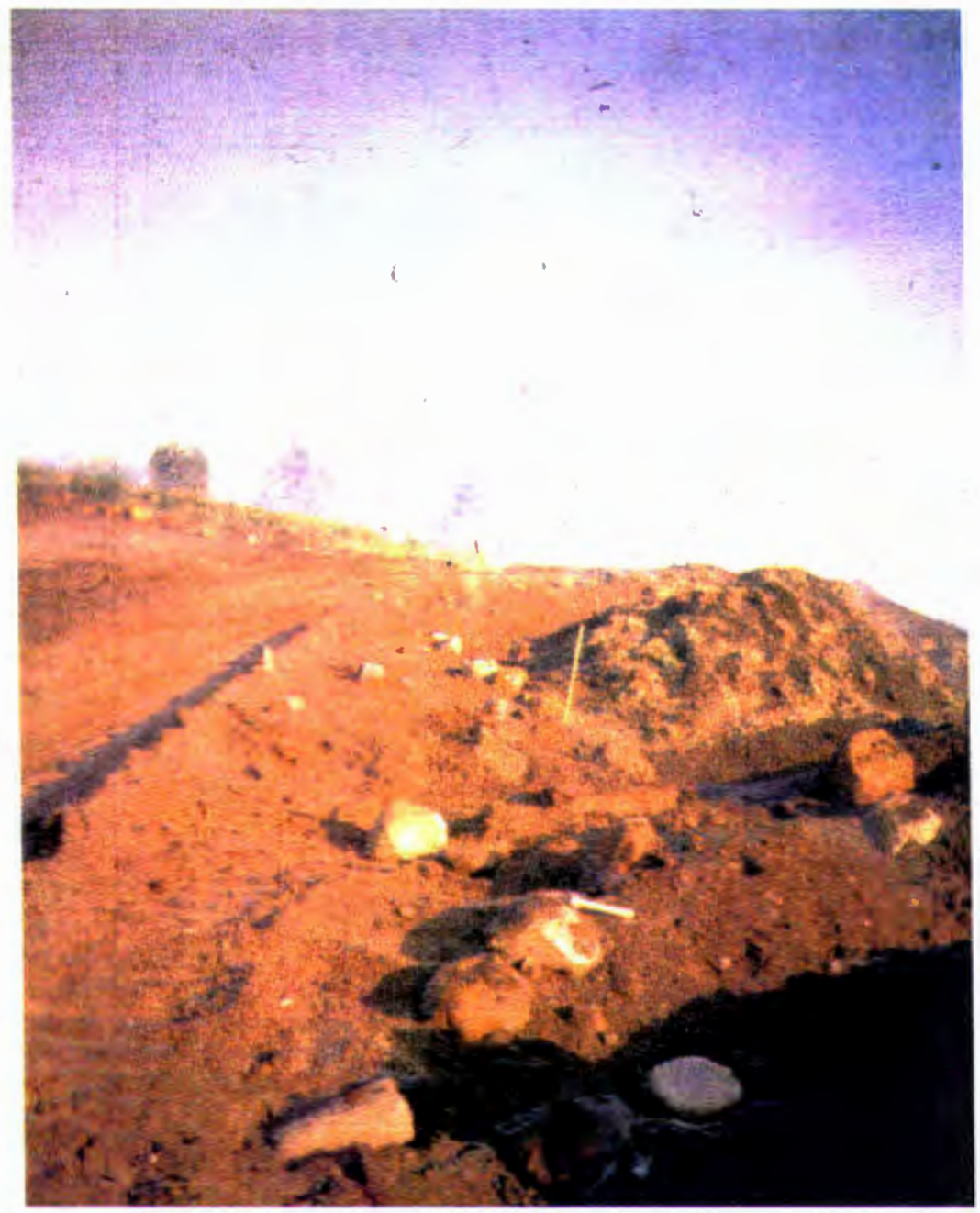

Figure 37. Twenty erratics found within one hundred square feet (Black dot \#1 in Figure 36). 
the maximum elevation of 340 feet $(104 \mathrm{~m})$, due to erratic and basalt flood material positions. Subsequent erosion after the Missoula Floods has revealed portions of the basalt bedrock. The approximated alluvium/basalt boundary is based on the soil surveys for Washington and clackamas Counties unless otherwise known.

\section{Parrett Mountain}

The Helvetia Formation. Two lobes of the Helvetia Formation have been mapped on the northeastern fringe of Parrett Mountain near the city of sherwood (Figure 3). Several questions have arisen on the status and origin of the Helvetia Formation occurring within the study boundaries. Twenty or more erratics (Figure 36 and 37) were discovered adjacent to the designated Helvetia Formation. The erratics were found at roughly 310 to 320 feet $(94.5$ to $97.5 \mathrm{~m})$ in elevation. This places the lower lobe of the Helvetia Formation below the maximum elevation affected by the Missoula Floods. Therefore, the material designated as belonging to the Helvetia Formation should actually be classified as Missoula flood deposits over a lateritic soil on the basalt. In the upper Helvetia Formation lobe highly weathered basalt was recently excavated from newly constructed foundations. Examination of the new excavations and of the surface revealed a lateritic soil with highly-toslightly weathered, in-place basalt cobbles only half a foot $(.15 \mathrm{~m})$ below the surface. The Helvetia Formation, as 
mapped by schlicker and Deacon (1967), for this area, is actually flood deposits, given its color by the residual soils on the Columbia River basalt.

Loess. Wind blown silt deposits, loess, does not exist or is very thinly deposited on the flanks of Parrett Mountain. If thinly deposited, the loess is more than likely masked by the lateritic coloring developed on the Columbia River basalt. This observation corresponds with Lentz's (1977) regional mapping of these deposits.

\section{LANDSLIDES}

Several areas showing landslide features have been mapped on Parrett Mountain (Figure 38). Schlicker and Deacon (1967) mapped one landslide on the northeastern portion of Section 4, T3S RIW, (Figure 39). The landslide occurs in the flood deposits.

Two landslides were mapped on the steeply dipping northwestern face of Parrett Mountain. These landslides were also mentioned by Schlicker and Deacon (1967) but not noted on their geologic hazards map. Topographic analysis was used to determine landslide features. These questionable sites were then field checked for landslide features, such as pressure ridges, seeps, sag ponds, and landslide scarps. Designation of a landslide does not evaluate the stability of the designated area under present conditions. 


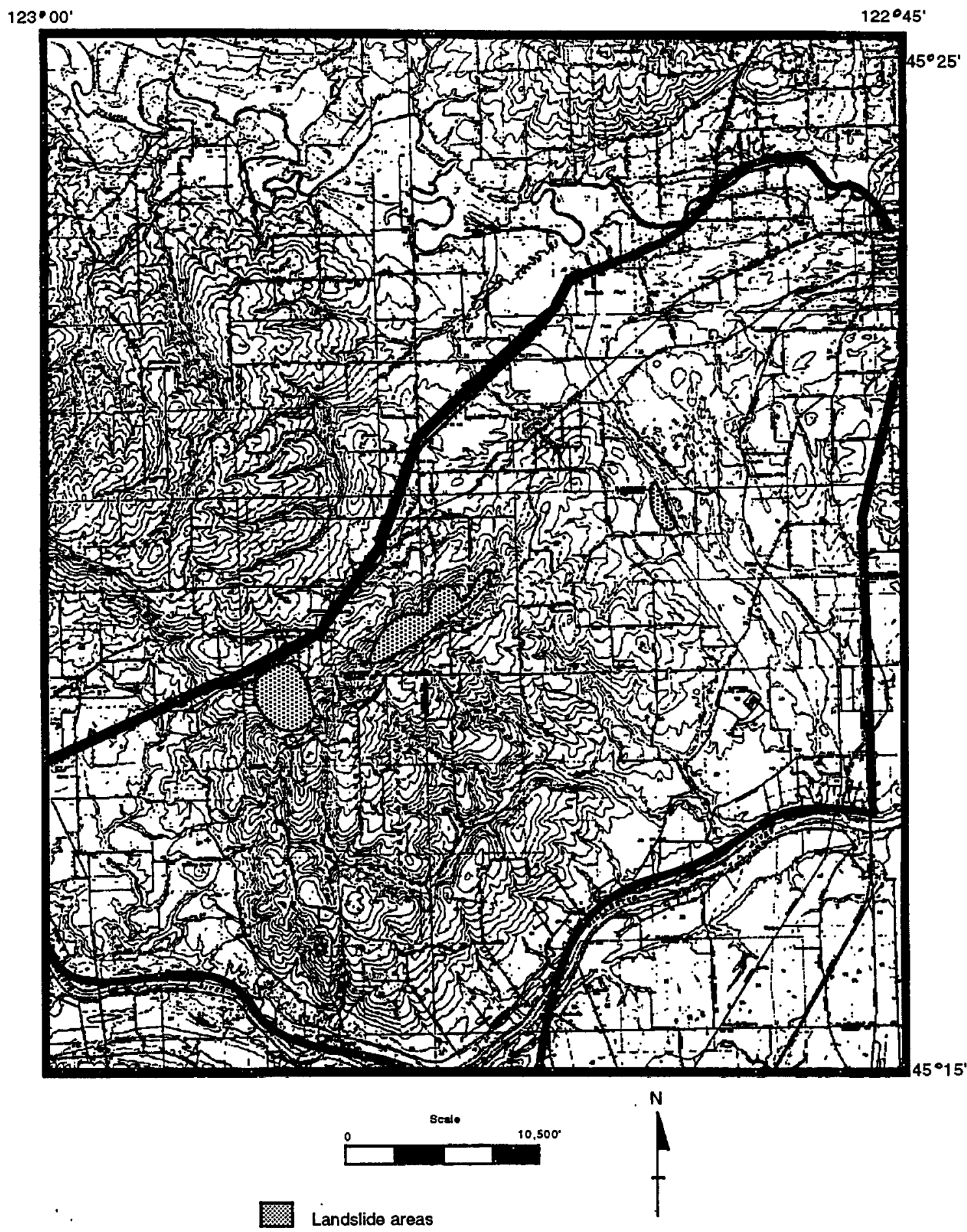

Figure 38. Location of designated landslide areas. 


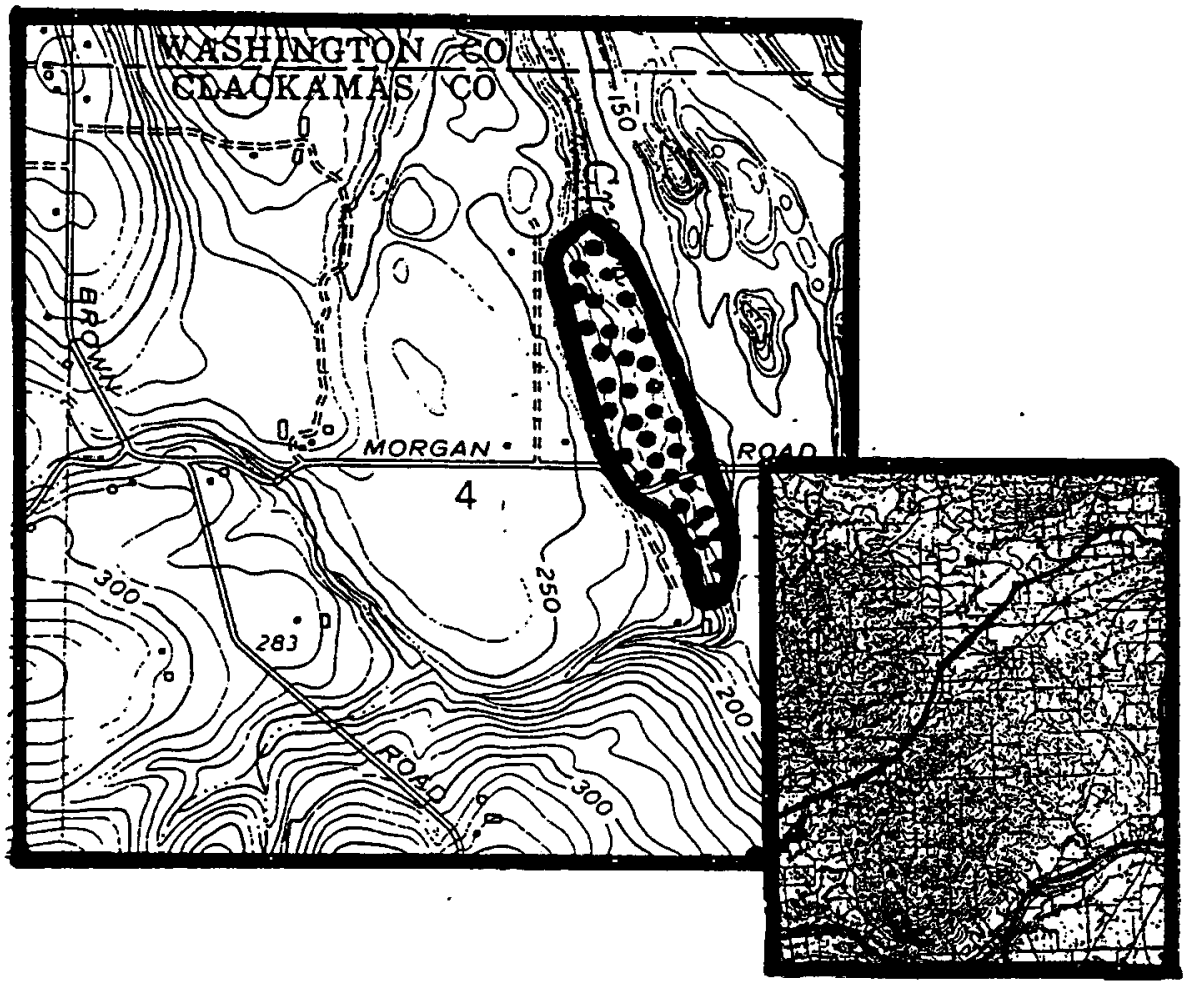

Figure 39. Location of a landslide (T3S R1W Sect. 4) mapped by Schlicker and Deacon (1967). The inset shows the location of the figure within the study area. 
One of two landslides is located in the central portion of Section 14 T3S R2W (Figure 40; Plate 2) and covers an estimated 320 acres. Field evidence used to evaluate this landslide is the numerous small earthflows and slump features present along Haugen Road. Second, a hummocky topography was noted and verified in the field. Downhole caliper logs taken from the Rolfs \#1 well shows the upper 200 feet $(61 \mathrm{~m})$ to be highly fractured (Marvin Beeson, 1992, personal commun.) suggesting that the landslide might be deep seated.

The second landslide complex (Figure 41; Plate 2) was found in the northern portion of section 7 T3S RIW and continues into the northeastern portion of section 12 T3S R2W. This landslide covers an estimated 640 acres and appears to be a combination of several slump and translational slides (Scott Burns, 1993, personal commun.) with an average depth of roughly 30 feet $(9.1 \mathrm{~m})$. The timing relationship of the landslides is unknown, though it is the belief of Scott Burns (1993, personal commun.) that the landslides occurred at various intervals of time and not as one large failure. Although the entire area has been designated as a landslide, the region is actually characterized by a series of landslides separated by stable land ridges. The larger landslides have smaller failures superimposed on them. Designation of this area as a landslide complex by no means refers to the stability of the 


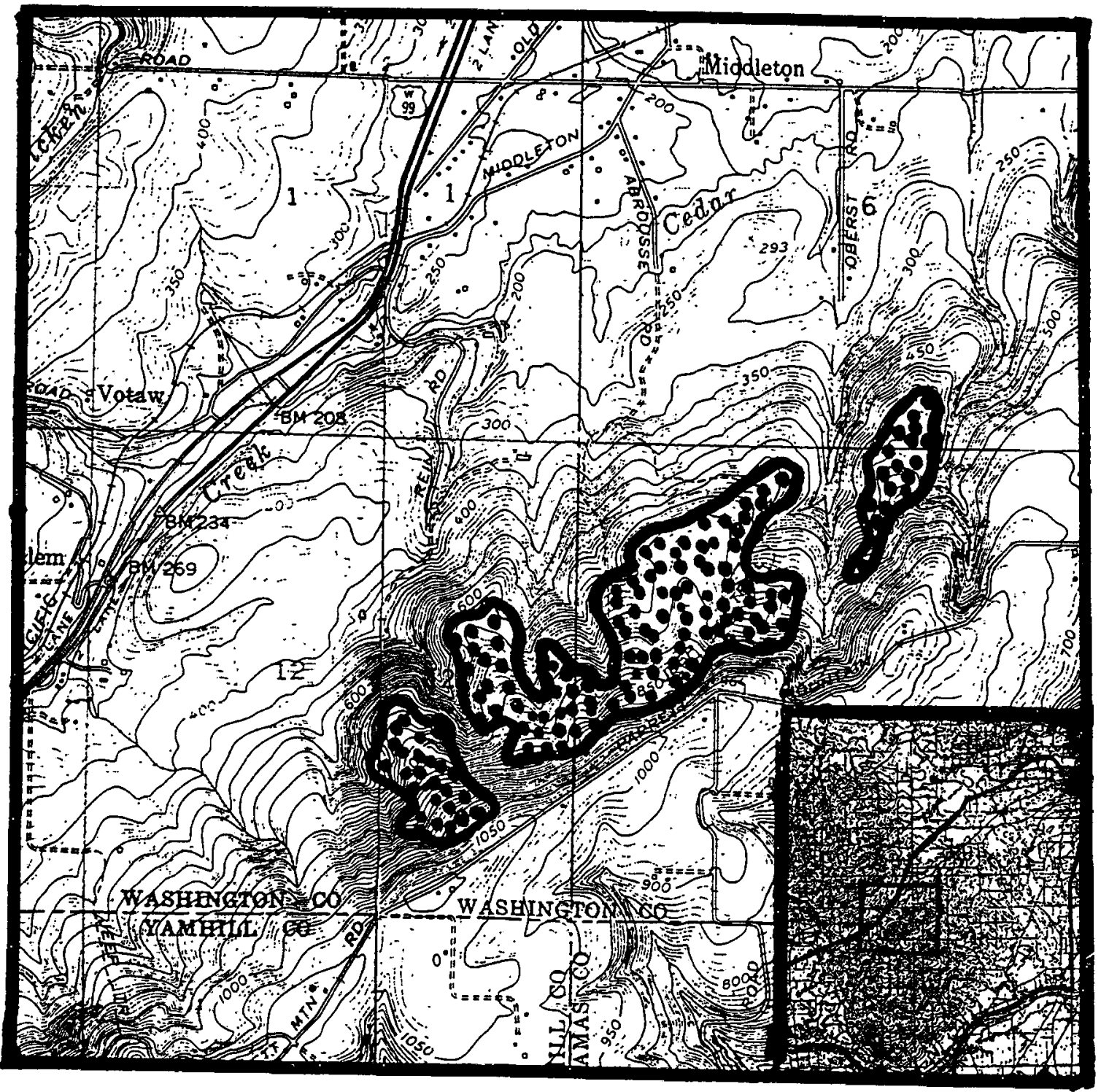

Figure 40. Location of one landslide (T3S R2W Sect. 14) on the northwestern slope of Parrett Mountain. The inset shows the location of the figure within the study area. 


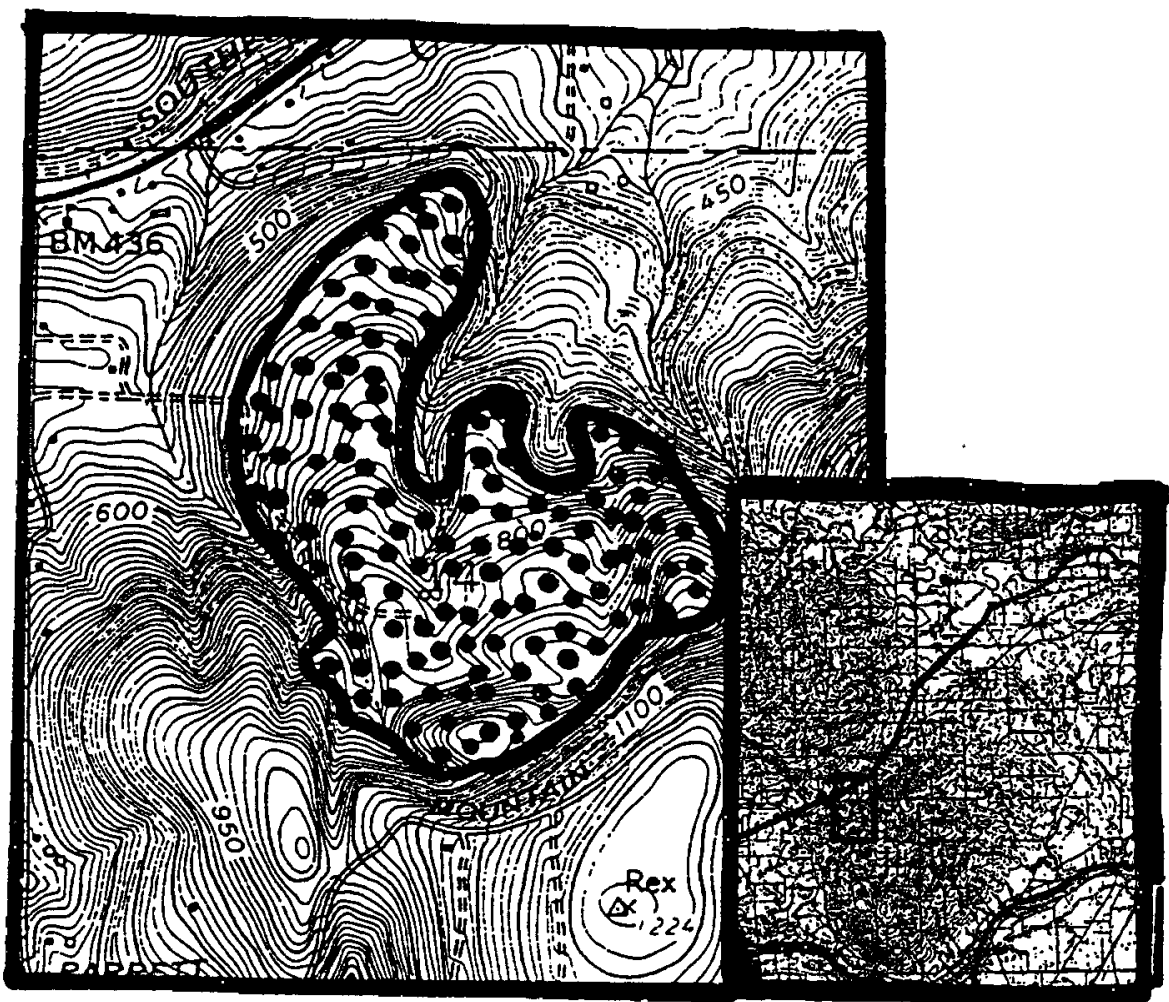

Figure 41. Location of the other landslide (T3S RIW sect. 7 and 12 ) on the northwestern slope of Parrett Mountain. The inset shows the location of the figure within the study area. 
area under present conditions.

Field mapping along the south facing wall of the South Fork of Corral Creek showed the existence of several small earth slumps. Several factors contributing to these small failures are 1) steep slopes, 2) daylighting of a failure plane, the basalt/soil boundary, and 3) groundwater seepage. All three of the above factors were observed in the field. Areas with similar geologic conditions are present and should be looked at carefully in order to discern stability. 
FUTURE WORK

GEOLOGY

\section{Stratigraphy}

First, the overall basalt stratigraphy is known for most of the study area, however several large sections in the south and central portions of Parrett Mountain and the Tonquin area remained essentially unknown. Therefore basalt chips should be collected for any new water wells constructed in these areas. Second, several more XRF analyses should be conducted in hopes to separate the ortley and Grouse Creek basalt units from the Ortley-Grouse Creek basalt unit. Also further XRF analyses would help further differentiate the geochemical compositions of the Umtanum and Winter Water basalt flows.

\section{Structure}

The location of any of the fault planes, at depth, would help in the understanding of the tectonic development of the area as well as help in the understanding of the local hydrogeology. Only three methods can truely help in identifying the fault planes. Being on site during the drilling of a water well is the best method for obtaining fault plane locations. This method allows an individual to note changes in the drilling rate and in the amount of 
basalt chips collected to the depth of the drill, thereby identifying potential fault planes. Second, interviews with the drillers can yield some information but this method is subjective to their interpretations. The last method that can help is hand analyzing the drilling chips. The reliability of this method for recognizing fault zones is still in question but should not be ruled out.

\section{Landslides}

No work was done on the landslides located within this study area. Any data on these landslides will prove useful. Several questions that should be answered are the activity of the landslides, when did the landslide complexes occur, what is the failure plane, and depth of the colluvium/alluvium comprising the landslide complexes.

\section{HYDROGEOLOGY}

\section{Basalt Aguifers}

The main question that needs to be addressed is whether the Columbia River basalt comprising Parrett Mountain is acting as one or more aquifers in non-faulted areas. Several methods should be employed to study this question. First several pump tests could be conducted within the centers of known non-faulted basalt blocks. Second, piezometers could be placed within each of the interflow zones to identify the heads of the individual aquifers. Third, and the most important, a geochemical analysis of the 
groundwater systems should be conducted. Sampling should be conducted using wells that are known to draw water from only one interflow zone. The groundwater chemistry from one interflow zone should be compared analytically to other interflow zones. Samples should also be collected from wells known to penetrate several interflow zones.

Another important area of study is the alluvial aquifers. The role of these aquifers to the basalt aquifers is still unknown. Do these aquifers act as recharge sources to the basalt aquifers should be answered. Special emphasis should be taken with the landslides on the northwestern slope of Parrett Mountain. Their role in the hydrogeology of the mountain needs to be understood. 


\section{CONCLUSION AND SUMMARY}

\section{GEOLOGY}

\section{Stratigraphy}

Eleven basalt flows of the Columbia River Basalt Group comprise Parrett Mountain. These basalt flows were identified as, from oldest to youngest: the Wapshilla Ridge, the undifferentiated Ortley-Grouse Creek, the Umtanum, the winter water, and the sentinel Bluffs basalt units of the Grande Ronde Basalt along with one Ginkgo flow of the Frenchman Springs Member of the Wanapum Basalt. The maximum basalt thickness of 900 feet $(274 \mathrm{~m})$ was measured at Rex Hill.

The Wapshilla Ridge basalt unit is the thickest basalt unit present on Parrett Mountain. This unit is exposed on the western, northwestern, and a few southern slopes of Parrett Mountain. The unit is laterally extensive throughout Parrett Mountain, but terminates near the Fernwood Road exposure. This basalt unit appears to have lobated into the paleo-Willamette Valley during emplacement. As a result the flow's thickness varies to a maximum thickness of 350 feet $(113 \mathrm{~m})$ due to a highly variable lower and upper boundary.

The Ortley-Grouse Creek basalt unit is a combination of 
the Ortley and Grouse Creek basalt units mapped to the north. This combination was necessary due to an inability in separating the two units based on geochemical or lithologic signatures. The unit is comprised of three laterally extensive basalt flows with their individual thicknesses highly variable.

The Umtanum basalt unit occurs as two thick basalt flows extending over the Parrett Mountain area. A third Umtanum flow was observed on the fringes of Parrett Mountain, beneath the city of sherwood and exposed in a rock quarry at La Butte. The thickness of the entire unit appears to be rather constant; however, this unit thins towards the southeast.

Both the winter Water and Sentinel Bluffs basalt units are represented by two laterally extensive basalt flows. The winter water basalt unit is the thinnest of all the basalt units comprising Parrett Mountain and decreases in thickness towards the southeast.

The sentinel Bluffs basalt units changes across the entire area. The upper basalt flow appears to have undergone some erosion before the emplacement of the Ginkgo basalt flow. Field observations show most of the basalt exposed in the Tonquin area to belong to the sentinel Bluffs basalt unit.

The Ginkgo flow is observed in only a few locations on Parrett Mountain and the Tonquin area. Only one flow has 
been observed within the study area and its thickness varies from 0 to 90 feet $(0$ to $30 \mathrm{~m}$ ). This basalt flow appears to have been slightly channelled in the initial stages of emplacement.

\section{Structure}

Tectonic deformation, based on basalt flow thickness variations and cross cutting relationships, occurred during and after the emplacement of the basalt flows. Based on the termination of the Wapshilla Ridge basalt flow in the Newberg Valley and the missing Umtanum basalt flow on Parrett Mountain the extent of the deformation appears to have occurred through most if not the entire study area.

Cross-cutting relationships allow for the relative age dating of the fault trends. The north/south (and possibly the east/west) trending faults are the youngest in terms of relative age. This is based on the cross-cutting of the northeast and northwest trending faults, and the lack of surficial weathering along the fault traces. Next are the northeast-trending faults. Again this is inferred from the cross-cutting relationships with the northwest-trending faults. This leaves the northwest-trending faults as the oldest. Absolute age dating of these faults has proved unsuccessful.

The faults on Parrett Mountain are more than likely an expression of activity on the Gales Creek-Mount Angel structural zone. The northeast and northwest trending 
faults probably were active during and after the emplacement of the basalt in a roughly north/south and east/west trend. Subsequent rotation of northwestern Oregon has rotated these active faults into the observed northeast and northwest trending faults. Further activity along the Gales CreekMount Angel structural Zone has resulted in the development of the newer north/south and east/west trending faults.

\section{Quaternary Processes}

Several key points have been addressed within this section. First, based on erratic locations, the minimum height of the Missoula Flood water within the Tonquin area should be raised to an elevation of 330 to 335 feet ( 100 to $102 \mathrm{~m})$. Second, the material listed as the Helvetia Formation should be redesignated as willamette silt.

\section{GROUNDWATER}

The groundwater systems that have developed within the Parrett Mountain area appear to be controlled by the local geology. Each fault block appears to have a separate groundwater system. Faults appear to act as recharge paths for infiltrating groundwater as well as barriers to lateral groundwater migration.

Every basalt flow boundary was found to yield groundwater to water wells and springs throughout the study area. Thickness variations in the interflow zones as well as the presence of interflow sediments affect the local 
transmissivity and storativity factors for the individual basalt flows. Variations in these coefficients can be noted from the large variations in groundwater yield from the same basalt flows.

The primary aquifers used by the residents of Parrett Mountain are the following interflow zones: Umtanum/OrtleyGrouse Creek and the Ortley-Grouse Creek/Wapshilla Ridge, along with the Wapshilla Ridge basalt aquifer. Each aquifer is separated from one another resulting in distinct head values, though some vertical communication occurs along fault planes, due to commingling, and possibly through a basalt flows's interior. 


\section{REFERENCES}

Allen, J.E. and Beaulieu, J.D., 1976, Plate tectonic structures in Oregon, The Ore Bin, Vol. 38, n. 6, p.8799 .

Allen, J.E., Burns, M., and Sargent, S.C., 1985, Cataclysms on the Columbia: A Layman's Guide to the Features Produced by the Catastrophic Bretz Floods in the Pacific Northwest. p.174-189, 196-200.

Allison, I.S., 1978, Late Pleistocene sediments and floods in the Willamette valley, The Ore Bin, Vol. 40, n. 11, p.177-191.

-.--, 1978b, Late Pleistocene sediments and floods in the Willamette Valley, The ore Bin, Vol. 40, n. 12, p.193202 .

Anderson, J.L., 1978, The structure and stratigraphy of the Columbia River Basin in the Clackamas River drainage: Portland State University, Oregon, M.S. thesis, 136p.

Armstrong, R.L. and Ward, P., 1991, Evolving geographic patterns of Cenozoic magmatism in the North American Cordillera: The temporal and spatial association of magmatism and metamorphic core complexes: Journal of Geophysical Research, b. 96, no. B8, pgs.13, 201-213, 224 .

Augustithis, S.S., 1978, Atlas of the textural patterns of basalts and their genetic significance, Elsevier Scientific Publishing Company, Amsterdam, pgs.6-8, 6566 .

Baker, R.A., 1979, Computer Simulation and Geohydrology of a Basalt Aquifer System in the Pullman-Moscow Basin, Washington and Idaho, U.S. Geological Survey WaterSupply Bulletin \#48, 119p.

Baksi, A.K., 1989, Reevaluation of the timing and duration of extrusion of the Imnaha, Picture Gorge, and Grande Ronde Basalts, Columbia River Basalt Group, Geological Society of America Special Paper 239., p.105-111.

Balsille, J.H. and Benson, G.T., 1971, Evidence for the Portland Hills Fault, The ore Bin, Vol. 33, n. 6, p.109-118. 
Beaulieu, J.D., 1971, Geologic formations of western Oregon (West of longitude $121^{\circ} 30^{\prime}$ ): Oregon Department of Geologic and Mineral Industries Bulletin 70, 72p.

Beeson, M.H., Fecht, K.R., Reidel, S.P., and Tolan, T.L., 1985, Regional correlations within the Frenchman Springs Member of the Columbia River Basalt Group: New insights into the middle Miocene tectonics of northwestern Oregon: Oregon Geology, v. 47, no. 8, p. 87-96.

Beeson, M.H., Tolan, T.L., and Anderson, J.L., 1989, The Columbia River Basalt Group in western Oregon; Geologic structures and other factors that controlled flow emplacement patterns, Geological Society of America Special Paper 239, p.223-246.

Beeson, M.H., Tolan, T.L., and Madin, I.P., 1989b, Geologic Map of the Lake Oswego Quadrangle, Clackamas, Multnomah and Washington Counties, Oregon, Department of Geology and Mineral Industries, GMS-59.

Beeson, M.H. and Tolan, T.L., 1990, The Columbia River Basalt Group in the Cascade Range: A Middle Miocene reference datum for structural analysis: Journal of Geophysical Research, v. 95, no. B12, p.19, 547-49, 559 .

Bingham, J.W. and Grolier, M.J., 1966, The Yakima Basalt and Ellensburg Formation of south-central Washington: Geological Survey Bulletin 1224-G, 15p.

Boggs, Sam Jr., 1970, A Report on the Geology and Ground Water of a Portion of Section 14 Township 3 South, Range 2 West, Yamhill County, Oregon. Eugene, Oregon: University of Oregon, unpublished report, $13 p$

Botros, M. and Johnson, H.P., 1988, Tectonic evolution of the Explorer-Northern Juan de Fuca region from $8 \mathrm{Ma}$ to the present, Journal of Geophysical Research, v. 93, no. B9, p.10, 421-10, 437 .

Bromery, R.W., and Snavely, P.D. Jr., 1964, Geologic interpretation of reconnaissance gravity and aeromagnetic surveys in northwestern oregon, Geological Survey Bulletin 1181-N, 13p.

Bull, W.B., 1984, Tectonic geomorphology, Journal of Geological Education, v. 32, p.310-324. 
Campbell, C.D. and Runcorn, S.K., 1956, Magnetization of the Columbia River Basalts in washington and northern Oregon, Journal of Geophysical Research, v. 61, no. 3, p.449-458.

Campbell, N.P. and Reidel, S.P., 1991, Geologic guide for state routes 240 and 243 in south-central washington: Washington Geology, v. 19, no. 3, p.3-17.

Church, S.E., 1985, Genetic interpretation of lead-isotopic data from the Columbia River Basalt Group, Oregon, Washington, and Idaho, Geological Society of America Bulletin, v. 96, p.676-690.

Crecraft, S., 1991, Compilation of records for several hundred wells on Parrett Mountain. Sherwood, Oregon: Friends of Parrett Mountain, unpublished report, n.p.

Davies-Smith, A., Bolke, E.I., and Collins, C.A., 1988, Geohydrology and Digital Simulation of the Ground-Water Flow System in the Umatilla Plateau and Horse Heaven Hills, Area, Oregon and Washington, U.S. Geological Survey Water-Resources Investigation Report 87-4268, $72 \mathrm{p}$.

Diery, H.D., and McKee, B., 1969, Stratigraphy of the Yakima Basalt in the type area: Northwest Science, v. 43, no. 2 , p. 47-64.

Driscoll, D.D, and Titus, W.S., 1991, Executive Summary: Potential Impacts Induced by Proposed City of Sherwood Groundwater Extraction Well, Sherwood, Oregon: Geotechnical Resources, Inc., unpublished report, n.p.

Frank, F.J, 1983, Water Supplies for Peasant Hill West. Oregon: unpublished report, 16p.

Frank, F.J. and Collins, C.A., 1978, Groundwater in the Newberg area, northern Willamette Valley, Oregon: Water Resources Department Ground Water Report No. 27, 31p.

Foxworthy, B.I., 1975, Summary appraisals of the nations's ground-water resources- Pacific Northwest Region, U.S. Geological Survey Professional paper no 813-S, 39p.

Freeze, R.A. and Cherry, J.A., 1979, Groundwater, Prentice Hall, INC., Englewood Cliffs, N.J., 604p.

Fuller, R.E., 1931, The aqueous chilling of basaltic lava on the Columbia River Plateau, American Journal of Science, V.XXI no. 124, p.281-300. 
Fuller, R.E., 1950, Structural features in the Columbia River Basalt, Northwest Science, v. XXIV, p.65-73.

Gerig, A.J., 1985, Soil survey of Clackamas county, Area, Oregon, Soil Conservation Service.

Gerstel, W.J., 1992, Effects of Holocene and modern earthquakes in northern California: Washington Geology, v. 20, no. 4, p.10-15.

Gonthier, J.B., 1985, National water Summary 1984: Hydrologic Events Selected Water-Quality Trends and Ground-water resources: U.S. Geological Survey WaterSupply Paper 2275, p.355-360.

Green, G.I., 1982, Soil Survey of Washington County, Soil Conservation Service.

Hart, D.H. and Newcomb, R.C., 1965, Geology and ground water of the Tualatin Valley, Oregon: U.S. Geological Survey Water-supply Paper 1697, .

Heath, R.C., 1984, Ground-water regions of the United States: Geological Survey Water-Supply Paper 2242, p. 28-31.

Holmgren, D.A., 1969, Columbia River Basalt patterns from central washington to northern Oregon, PhD, University of Washington, Seattle, $56 \mathrm{p}$.

Hooper, P.R., 1982, The Columbia River Basalts, in Ragland, P.C., and Rogers, J.J.W. (eds.), Basalts, Van Nostrand Reinhold Company, p.353-358.

Hooper, P.R., 1988, The Columbia River Basalt, in Macdougall, J.D. (ed.), Continental Flood Basalts, Kluwer Academic Publishers, p.1-33.

Jones, D.I., Silberling, N.J., and Coney, P.J., 1986, Collision tectonics in the Cordillera of western $N$ America: examples from Alaska, in Coward, M.P. and Ries, A.C. (eds) Collision Tectonics, Geological Society Special Publication No. 19, p.367-387.

Landon, R.D. and Long, P.E, 1989, Detailed stratigraphy of the $\mathrm{N}_{2}$ Grande Ronde Basalt, Columbia River Basalt Group, in the central Columbia Plateau, Geological Society of America Special Paper 239, p.55-66.

Lawrence, R.D., 1976, Strike-slip faulting terminates the Basin and Range province in Oregon, Geological Society of America Bulletin, v.87, p.846-850. 
Lentz, R.T., 1977, The Petrology and stratigraphy of the Portland Hills Silt: Portland State University, Oregon, M.S. thesis, 144p.

Lite, K.E., 1988, Hydrolgeology of the basalt aquifers near Mosier, Oregon: A groundwater resource assessment, Salem, Oregon: State of Oregon Water Resources Department Groundwater Report No. 40, 119p.

Luzier, J.E., 1992, Parrett Mountain Groundwater Withdrawal Technical Comments and hydrogeology Report. Iake Oswego, Oregon: Luzier Hydrosciences, unpublished report, n.p.

-.-., 1992, Northern Parrett Mountain - Presentation of New Findings from Manke Aquifer Testing Program at Public Hearing, July 15, 1992. Lake Oswego, Oregon: Luzier Hydrosciences, unpublished report, n.p.

MacNish, R.D. and Baker, R.A., 1976, Digital Simulation of a Basalt Aquifer System, Walla Walla River Basin, Washington and oregon, U.S. Geological Water-Supply Bulletin \#44, $51 \mathrm{p}$.

Magil1, J. and Cox, A., 1980, Tectonic rotation of the. Oregon Western Cascades, State of Oregon Department of Geology and Mineral Industries Special Paper 10, 67p.

Marsh, J.S., 1987, Basalt geochemistry and tectonic discrimination within continental flood basalt provinces, Journal of Volcanology and Geothermal Research, v. 32, p.35-49.

McDougall, I., 1976, Geochemistry and origin of basalt of the Columbia River Group, Oregon and Washington, Geological Society of America Bulletin, v. 87, p.777792 .

McMillan, K., Long, P.E., and Cross, R.W, 1989, Vesiculation in Columbia River basalts, Geological society of America Special Paper 239, p 157-167.

Miller, D.W., Gates, S.M., Brodersen, B.T., and Zwart, M.J., 1994, Groundwater conditions of basalt aquifers, Parrett Mountain, Northern Willamette Valley, Oregon: State of Oregon Water Resources Department Groundwater Report No. 40, 144p.

Miller, P.R., 1986, The Scotts Mills Formation: Mid-Tertiary geologic history and paleogeography of the central Western Cascade Range, Oregon, Oregon Geology, v. 48, no. $12, \mathrm{p} .139-151$. 
Moore, G.W., 1994, Geologic catastrophes in the Pacific Northwest, Oregon Geology, vol. 56, no. 1, p.3-6.

Nathan, S. and Fruchter, J.S., 1974, Geochemical and paleomagnetic stratigraphy of the Picture Gorge and Yakima Basalts (Columbia River Group) in central Oregon, Geological Society of America Bulletin, v. 85, p. $63-76$.

Newcomb, R.C., 1961, storage of Groundwater Behind Subsurface Dams in the Columbia River Basalt, Washington, Oregon, and Idaho, U.S. Geological Survey Professional Paper 383-A, 15p.

----, 1969, Effect of Tectonic structure on the occurrence of ground water in the basalt of the Columbia River Group of The Dalles area Oregon and Washington, Geological Survey Professional Paper 383-C, 33p.

Otte, G.E., Setness, D.K., Anderson, W.A., Herbert, F.J., and Knezevich, C.A., 1974, Soil Survey of Yamhill Area, Oregon, Soil Conservation Service.

Reidel, S.P., 1983, Stratigraphy and petrogenesis of the Grande Ronde Basalt from the deep canyon country of Washington, Oregon, and Idaho, Geological Society of America Bulletin, v. 94, p.519-542.

Reidel, S.P., Fecht, K.R., Hagood, M.C., and Tolan, T.L, 1989, The geologic evolution of the central Columbia Plateau: Geological Society of America Special Paper 239, p.247-264.

Reidel, S.P., Tolan, T.L., Hooper, P.R., Beeson, M.H., Fecht, K.R., Bently, R.D., and Anderson, J.L., 1989, The Grande Ronde Basalt, Columbia River Basalt Group; Stratigraphic descriptions and correlations in Washington, Oregon, and Idaho, Geological Society of America Special Paper 239, p.21-53.

Schlicker, H.G., 1954, Columbia River Basalt in relation to stratigraphy of northwestern Oregon, M.S. thesis, Oregon State University, Corvalis, $93 \mathrm{p}$.

Schlicker, G.H., Deacon, J.R., Newhouse, C.J., 1967, Engineering geology of the Tualatin Valley region, Oregon: Oregon State Department of Geologic and Mineral Industries Bulletin, v. 60, 103p. 
Siems, B.A., Bush, J.H., and Crosby, J.W. III, 1974, $\mathrm{TiO}_{2}$ and geophysical logging criteria for Yakima Basalt correlation, Columbia Plateau, Geological Society of America Bulletin, v. 85, p.1061-1068.

Snavely, P.D. and Wells, R.E, 1991, Cenozoic evolution of the continental margin of Oregon and Washington, U.S. Department of the Interior Geological Survey Open-File Report 91-44I-B, 34p.

Timm, S., 1979, The structure and stratigraphy of the Columbia River basalt in the Hood River Valley, Oregon: M.S. thesis, Portland State University, Portland, 56p.

Tolan, T.L., Beeson, M.H., and Vogt, B.F., 1984, Exploring the Neogene history of the Columbia River: Discussion and geologic field trip guide to the Columbia River Gorge, Part I. Discussion: Oregon Geology, v. 46 no. 8, p.87-97.

Tolan, T.L., Beeson, M.H., and Vogt, B.F., 1984, Exploring the Neogene history of the Columbia River: Discussion and geologic field trip guide to the Columbia River Gorge, Part II. Road log and comments: Oregon Geology, v. 46 no. 9, p.103-112.

Tolan T.L. and Reidel,S.P., 1989, Structure map of a portion of the Columbia River flood-basalt Province, Geological Society of America Special Paper 239, plate

Tolan, T.L., Reidel, S.P., Beeson, M.H., Anderson, J.L., Fecht, K.R., and Swanson, D.A., 1989, Revisions to the estimates of the areal extent and volume of the Columbia River Basalt Group, Geological Society of America Special Paper 239, p.1-20.

Vogt, B.F., 1981, The stratigraphy and structure of the Columbia River Basalt Group in the Bull Run watershed, Oregon: M.S. thesis, Portland State University, Portland, 151p.

Waitt, R.B. Jr., 1984, Periodic jokulhlaups from Pleistocene glacial Lake Missoula-New evidence from varved sediment in northern Idaho and Washington, Quaternary Research v. 22, p. 46-58.

Waitt, R.B. Jr., 1985, Case for periodic, colossal jokulhlaups from Pleistocene glacial Lake Missoula: Geological Society of America Bulletin, v. 96, p.12711286 . 
Waters, A.C., 1960, Determining direction of flow in basalts, American Journal of Science, v. 258-A, p. 350366 .

Waters, A.C., 1961, Stratigraphic and lithologic variations in the Columbia River Basalt, American Journal of Science, v. 259, p.583-611.

Wells, R.E., 1990, Paleomagnetic rotations and the Cenozoic tectonics of the Cascade Arc, Washington, Oregon, and California, Journal of Geophysical Research, v. 95, no. 12 , 19,409-19,417.

Wells, R.E, Simpson, R.W., Bentley, R.D., Beeson, M.H., Mangan, M.T., and Wright, T.L., 1989, Correlation of Miocene flows of the Columbia River Basalt Group from the central Columbia River Plateau to the coast of Oregon and Washington, Geological Society of America Special Paper 239, p.113-129.

Werner, K., Nubelek, J., Yeats, R., and Malone, S., 1992, The Mount Angel fault: Implications of seismicreflection data and the Woodburn, Oregon, earthquake sequence of August 1990: Oregon Geology, v. 54, no. 5, p. $112-117$.

Wood, W.W., and Fernadez, L.A., 1988, Volcanic Rocks, in Back, W., Rosenshein, J.S., and Seaber, P.R. (eds.), The geology of North America Vol 0-2, Hydrogeology, The Geological Society of America, p. 353-365.

Woodcock, N.H., 1986, Strike-Slip duplexes, Journal of Structural Geology, V.8 n.7, p. 725-735.

Wright, T.L., Grolier, M.J., Swanson, D.A., 1973, Chemical variation related to the stratigraphy of the Columbia River Basalt, Geological Society of America Bulletin, v. 84, p.371-386.

Yates, R.S., Graven, E.P., Werner, K.S., Goldfinger, C., and Popowski, T., 1991, Tectonics of the Willamette Valley, Oregon, U.S. Geological Survey Open-File Report, 91$441-\mathrm{P}, 47 \mathrm{p}$.

Yelin, T.S. and Patton, H.J., 1991, Seismotectonics of the Portland, Oregon, region: Bulletin of the Seismological Society of America, v. 81, no. 1 p.109-130. 
APPENDIX A

LITHOLOGIC AND STRATIGRAPHIC DATA 


\section{Thacker WeII}

Thk. Iithology

Description

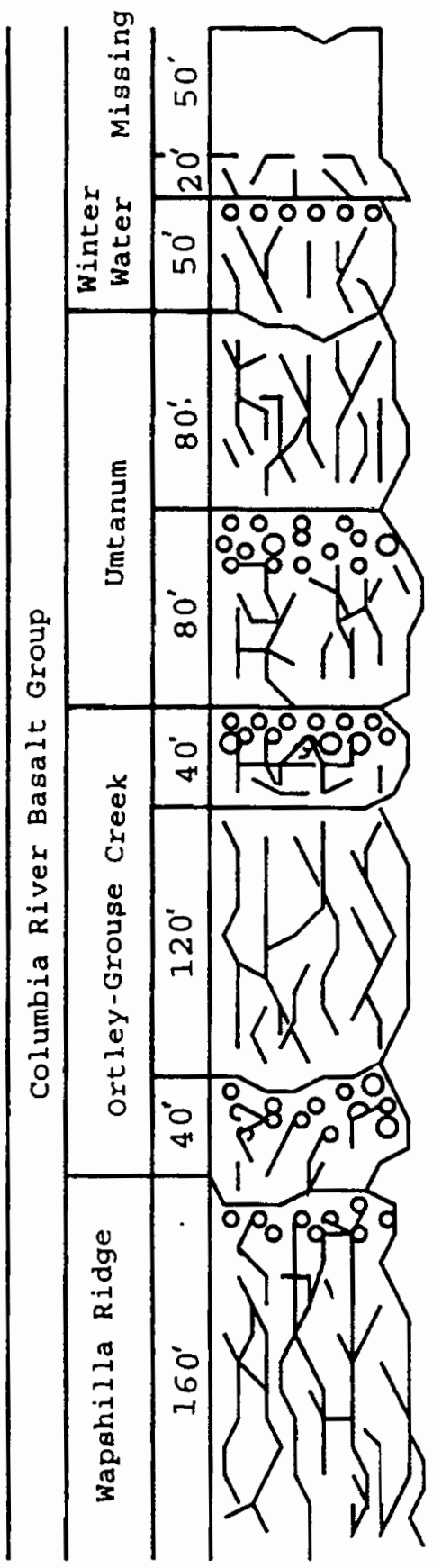

-Fine grained; dense textured; phyric; slightly to moderately weathered, brown coloration; Sampled at $50^{\prime}$.

- Fine grained; dense texture; aphyric; flowtop roughly 10'; moderately to moderately high weathered, brown coloration and alteration; Sampled at $120^{\circ}$.

- Fine grained; dense textured; one phenocryst observed, flowtop difficult to discern; moderately to moderately high weathered, reddish to white clay coloration; Sampled at $170^{\circ}$.

- Fine grained; dense textured, phyric; flowtop roughly $30^{\prime}$ thick, highly weathered and oxidized, scoria at flowtop and flowbottom; moderately weathered, brown to yellow to green coloring; Sampled at $270^{\prime}$.

- Fine grained; dense textured; poorly microphyric, glassy, flowtop roughly $20^{\prime}$ thick, highly weathered and oxidized; slightly weathered; Sampled at $300^{\prime}$

- Medium to fine grained; dense textured to diktytaxitic; small glass content; poorly microphyric near flowbottom, one plagioclase phenocryst observed, roughly $2 \mathrm{~mm}$ long; slightly weathered, Sampled at $390^{\prime}$

- Medium to fine grained:

diktytaxitic; slightly microphyric near flowbottom; flowtop roughly $20^{\prime}$ thick, well developed and oxidized; moderately weathered; Sampled at $470^{\circ}$.

-Very fine grained, dense textured, several dikcytaxitic zones, 500 to $510^{\circ}$ and 610 to $620^{\circ}$; glassy, very microphyric; slightly weathered; Sampled at $630^{\circ}$.

Figure 41. Stratigraphic column of the Thacker well. 


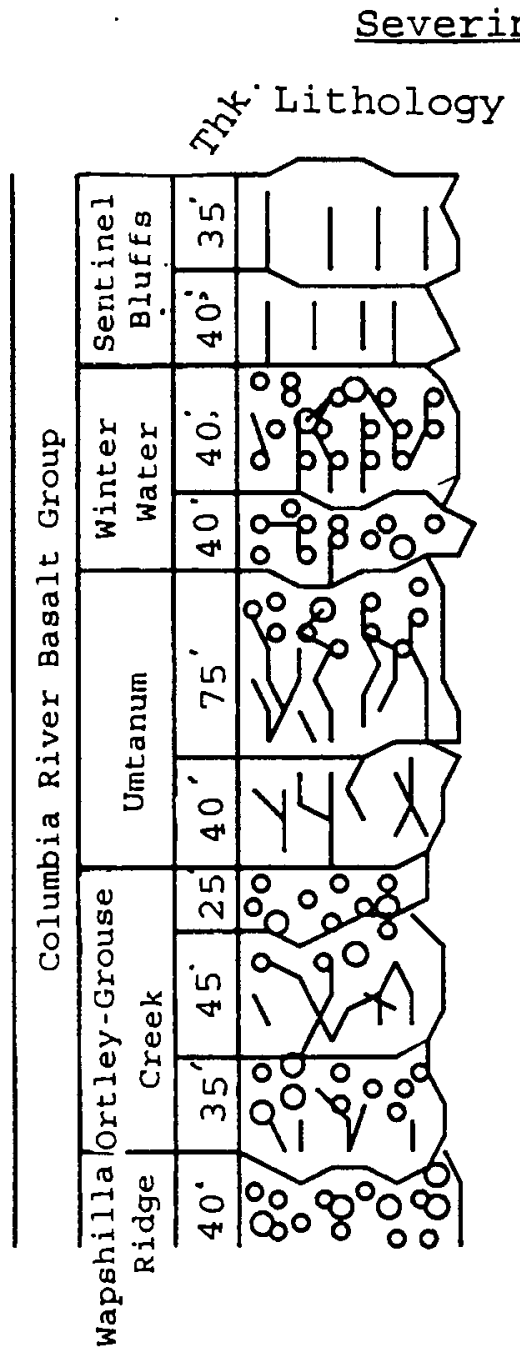

WeII

Description

- Medium grained; dense textured to diktytaxitic; moderately weathered.

- Medium to coarse grained; dense textured to diktytaxitic; no Elowtop discerned, weathered and oxidized boundary; moderately to moderately high weathered.

- Fine grained; dense textured to diktytaxitic; flowtop roughly 30' thick, upper 20' highly oxidized; one small plagioclase lath observed; moderately high to hiqhly weathered.

- Fine grained; dense textured; highly vesicular throughout; several small laths (<lmm) observed at $143^{\prime} ;$ flowtop roughly 10' thick, highly weathered and oxidized; highly weathered decreasing save near the flowbottom.

- Fine grained; diktytaxitic; slightly microphyric; upper 25' highly weathered and oxidized; moderately high weathered.

- Fine to medium grained; dense textured to diktytaxitic; slightly weathered, clay is fluorescent green color; upper flow boundary appears to erosional.

- Fine grained; dense textured; flowtop roughly $20^{\circ}$ thick, upper 15' oxidized; highly weathered.

- Fine grained; diktytaxitic: slightly microphyric. plagioclase laths are few and very small (<lmm); Elowtop roughly 5' thick, highly weathered and oxidized; moderately to less moderateiy weathered.

- Fine to medium grained; diktytaxitic; flowtop roughly 15' thick, highly weathered and oxidized; moderately weathered. Fine grained; dense textured; flowtop roughly $40^{\circ}$ thick, highly weathered and oxidized.

Figure 42., Stratigraphic column of the severine well. 


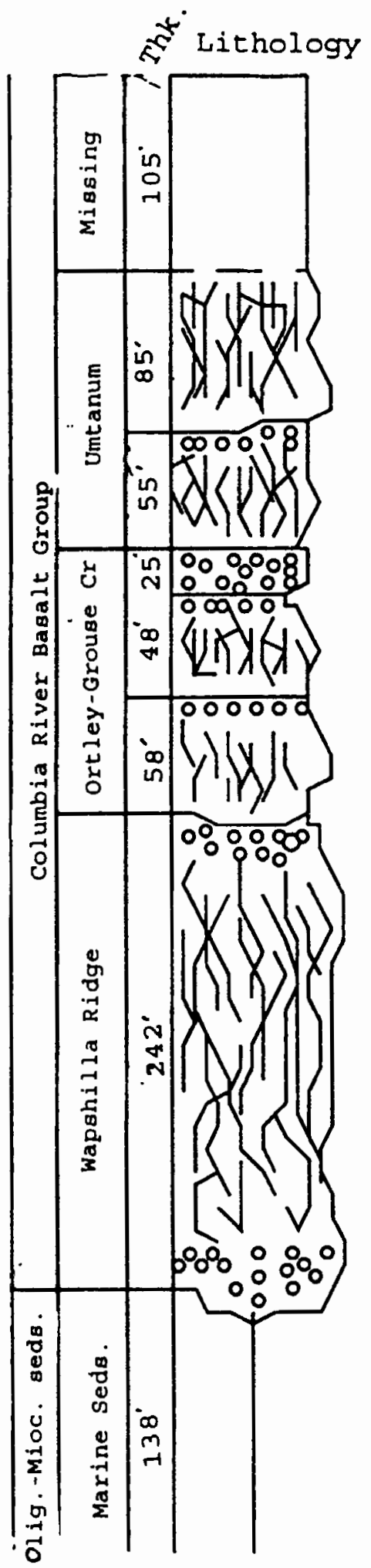

Description

- Fine to medium grained; Dense textured to slightly diktytaxitic; moderately to moderately high weathered.

- Fine to medium grained; diktytaxitic; flowtop roughly 10' thick; moderately high weathered.

- Fine grained; dense texture; slightly microphyric; flowtop roughly 30' thick; moderately weathered.

- Fine grained; dense textured; slightly microphyric: flowtop roughly $10^{\circ}$ thick, highly weathered and oxidized; less than moderately weathered.

- Fine grained; dense textured; poorly developed microphyric texture, few laths roughly $2 \mathrm{~mm}$ long; flowtop roughly 10'

thick; moderately weathered.

Extremely fine grained to slightly medium grained; dense textured with several

diktytaxitic zones; glassy; highly microphyric. laths were observed to be small but very abundant: flowtop roughly 10 " thick, flowbottom roughly 50. thick; moderately weathered. erosional flow surface.

Figure 43. Stratigraphic column of the Manke \#1 well. 


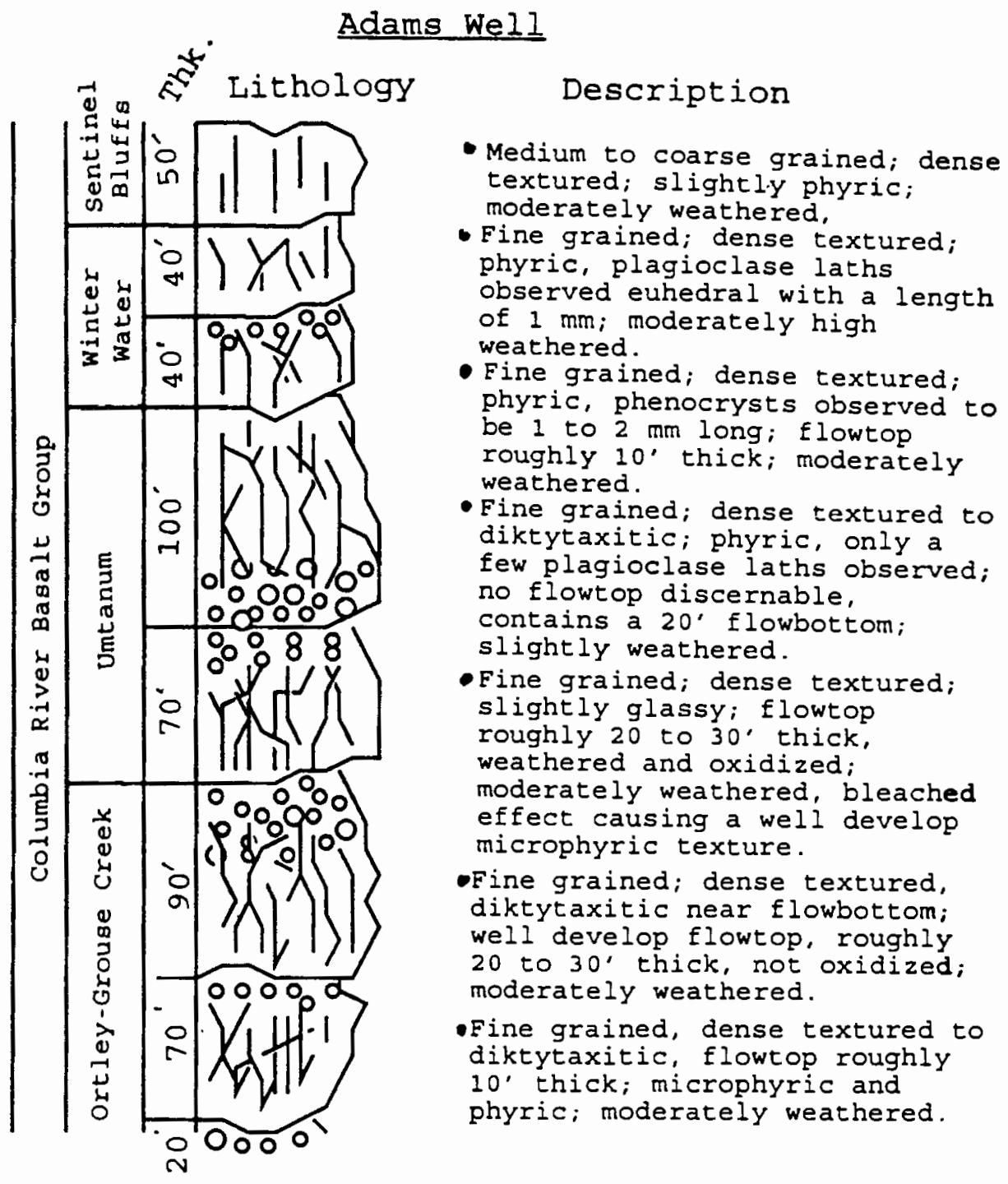

Figure 44. Stratigraphic column of the Adams well. 


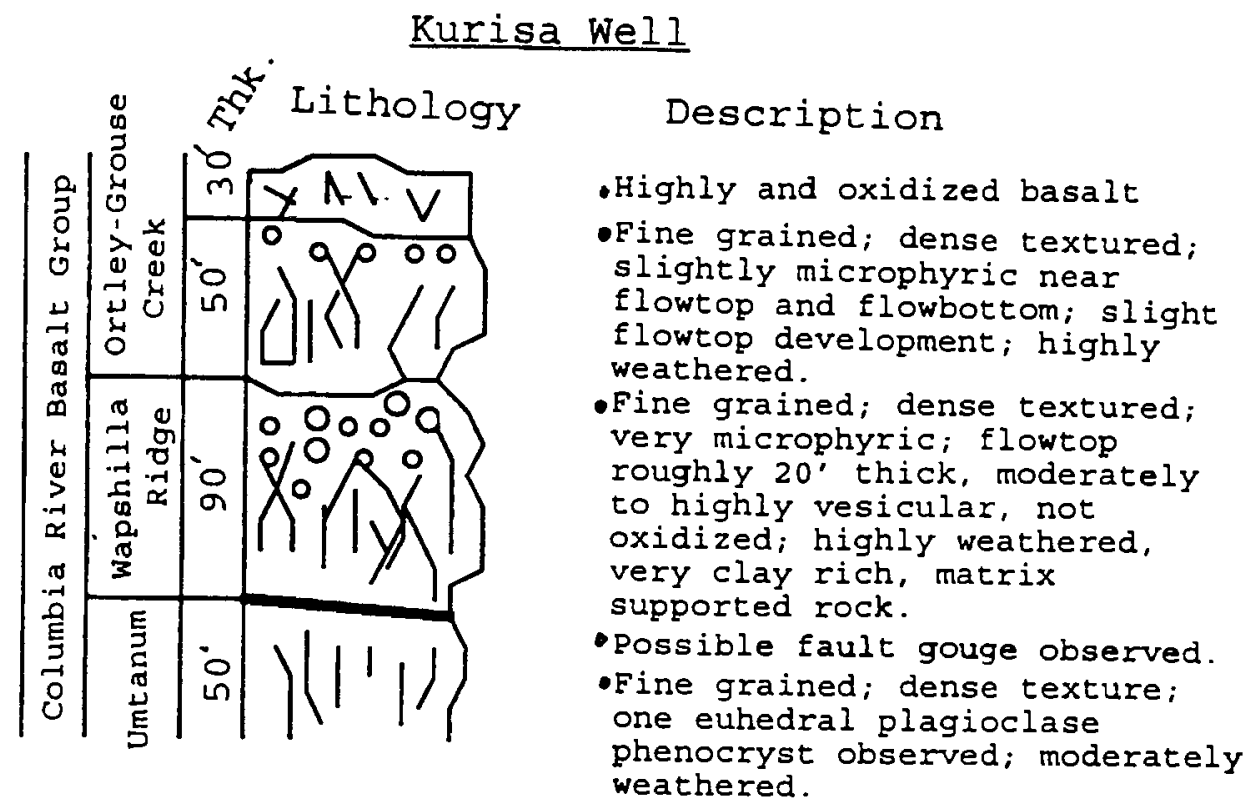

Figure 45. Stratigraphic column of the Kurisa well. 
TABLE XI

STRATIGRAPHIC DIVISIONS BASED ON BASALT DRILLING CHIPS

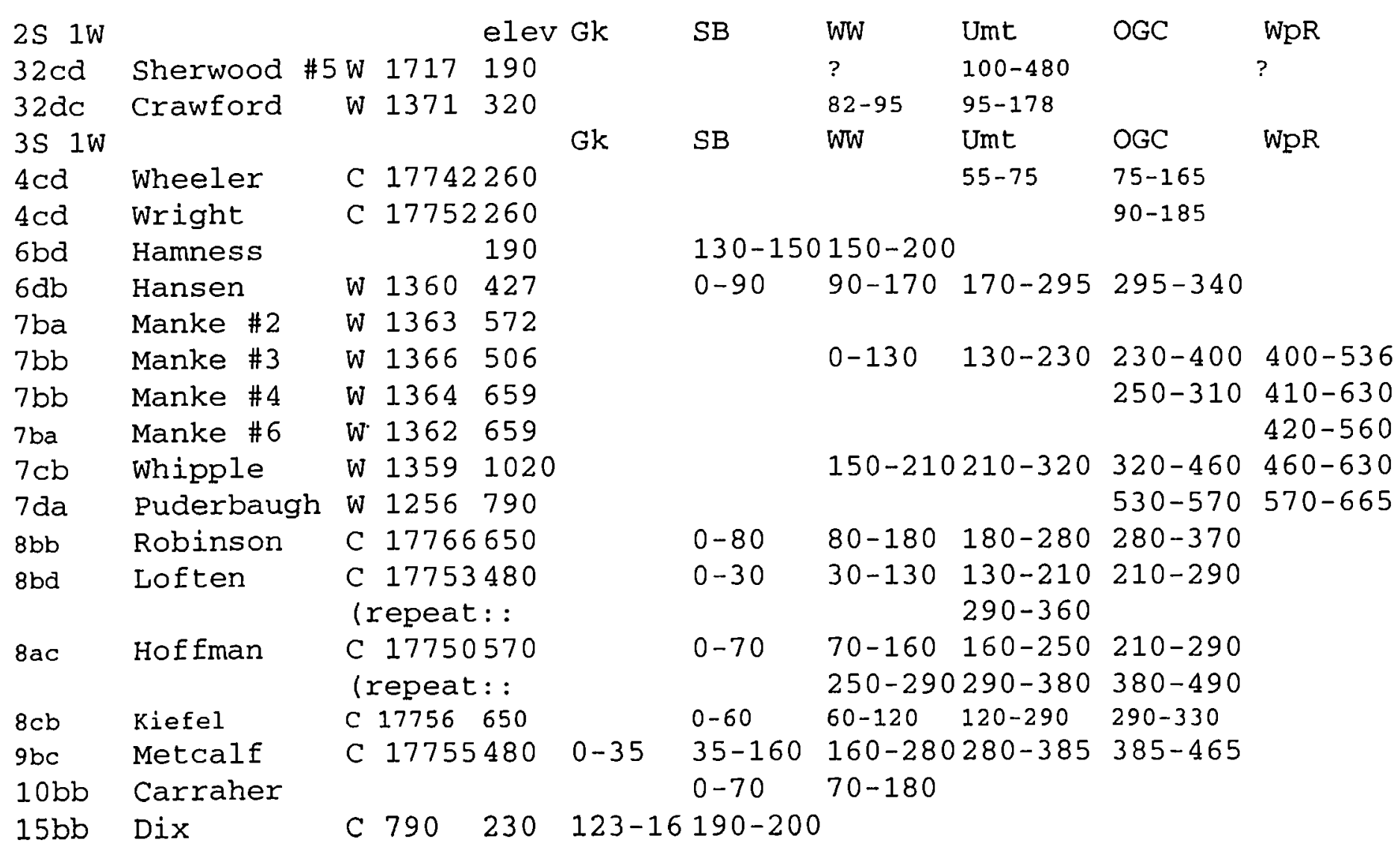


TABLE XI

STRATIGRAPHIC DIVISIONS BASED ON BASALT DRILLING CHIPS CONTINUED

\begin{tabular}{|c|c|c|c|c|c|c|c|c|}
\hline $29 \mathrm{bb}$ & Brentano & & 350 & $50-70$ & $50-70$ & $70-140$ & & \\
\hline $17 \mathrm{ba}$ & Minard & C 17743 & 575 & & & & $460-470$ & \\
\hline $29 \mathrm{bb}$ & Blondeau & & 320 & & $0-130$ & $130-250$ & $250-400$ & \\
\hline $3 S 2 W$ & & & Gk & SB & WW & Umt & OGC & WpR \\
\hline & Cedar Creek & Well & & & $70-140$ & $140-230$ & $230-430$ & $430-500$ \\
\hline $12 \mathrm{db}$ & Manke \#5 & W 1365 & 680 & & $0-120$ & $120-250$ & $250-350$ & $350-640$ \\
\hline 14 & Haraden & Y1665 & & & & $0-120$ & & \\
\hline $14 \mathrm{CC}$ & Rolfs & Y 885 & 835 & & $0-110$ & $110-200$ & $200-310$ & $310-430$ \\
\hline $15 a c$ & Pelling & Y 1678 & 520 & & $0-110$ & $110-230$ & $230-380$ & \\
\hline $22 \mathrm{ad}$ & Kurisa & Y 1675 & 520 & & & & . & $0-180$ \\
\hline & & \multicolumn{2}{|c|}{ (repeat: : } & & & $180-215$ & & \\
\hline $\begin{array}{l}22 a d \\
22 a c\end{array}$ & Conway & & 530 & $\cdot$ & & & & $0-190$ \\
\hline $2 \mathrm{ac}$ & Tucker & & 310 & & & $0-10$ & $10-170$ & \\
\hline
\end{tabular}


TABLE XII

STRATIGRAPHIC DIVISIONS OF WELLS MEASURED BY THE OWRD

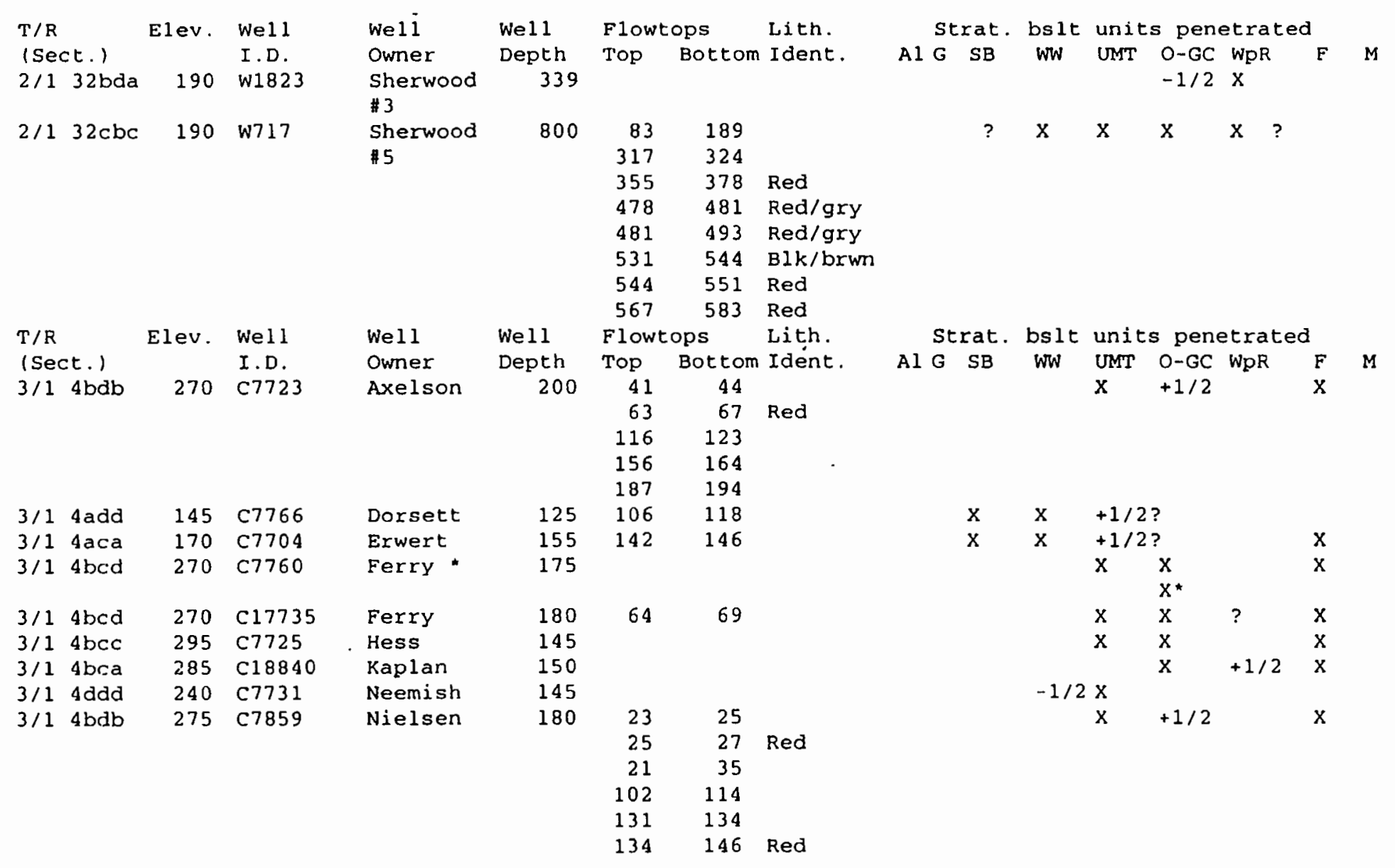


TABLE XII

STRATIGRAPHIC DIVISIONS OF WELLS MEASURED BY THE OWRD CONT INUED

\begin{tabular}{|c|c|c|c|c|c|c|c|c|c|c|c|c|c|c|c|c|}
\hline & & & & & & $\begin{array}{l}163 \\
172\end{array}$ & $\begin{array}{l}172 \\
178\end{array}$ & & & & & & & & & \\
\hline $3 / 1$ & $4 \mathrm{bca}$ & 275 & C7722 & Phil & 205 & & & & & & & $\mathrm{x}$ & $+1 / 2$ & & $x$ & \\
\hline $3 / 1$ & $4 \mathrm{dab}$ & 180 & C17819 & Sheehan & 145 & & & & & $-1 / 2$ & $x$ & $+1 / 2$ & & & $\mathrm{x}$ & \\
\hline $3 / 1$ & $4 \mathrm{dba}$ & 250 & $C 7743$ & Stevens & 185 & & & & & & & $-1 / 2$ & $+1 / 2$ & & & \\
\hline$T / R$ & & Elev. & Well & We11 & Wel1 & Flowt & ops & Lith. & St & rat. & bslt & unit & :s pene & etratec & & \\
\hline ( Sec & $c t)$. & & I.D. & Owner & Depth & Top & Bottom & Ident. & $A 1 G$ & $\mathrm{SB}$ & WW & UMT & O-GC & WpR & $\mathbf{F}$ & M \\
\hline $3 / 1$ & $5 \mathrm{ccb}$ & 610 & C7822 & Bancroft & 155 & 63 & 118 & & & & & & & & & \\
\hline & & & & & 360 & $\begin{array}{l}142 \\
306\end{array}$ & $\begin{array}{l}146 \\
342\end{array}$ & & & $-1 / 2$ & $x$ & $\mathrm{X}$ & $\mathrm{X}$ & B & & \\
\hline $3 / 1$ & $5 a d a$ & 310 & $c 07842$ & Base1 & 122 & & & & & $-1 / 2$ & & $+1 / 2$ & & & & \\
\hline $3 / 1$ & $5 \mathrm{bac}$ & 405 & C7799 & Cairns & 410 & $\begin{array}{r}95 \\
382\end{array}$ & $\begin{array}{l}102 \\
398\end{array}$ & Red & & & & & & & & \\
\hline $3 / 1$ & $5 \mathrm{cad}$ & 440 & C7781 & Coe & 245 & & & & & & $-1 / 2$ & $\mathrm{x}$ & $+1 / 2$ & & & \\
\hline $3 / 1$ & $5 a a b$ & 345 & C7807 & $E d y$ & 170 & $\begin{array}{r}64 \\
152\end{array}$ & $\begin{array}{r}72 \\
164\end{array}$ & & & & $\mathrm{x}$ & $\mathrm{x}$ & $+1 / 2$ & & & \\
\hline $3 / 1$ & $5 b d b$ & 405 & C 18432 & Eppich & 320 & 292 & 314 & & & & & $-1 / 2$ & $x$ & $+1 / 2$ & & \\
\hline $3 / 1$ & $5 b d c$ & 370 & $c 7782$ & Fifield & 144 & & & & & & & $-1 / 2$ & $+1 / 2$ & & & \\
\hline $3 / 1$ & $5 \mathrm{bca}$ & 395 & $C 7824$ & Garstka & 245 & $\begin{array}{l}106 \\
226\end{array}$ & $\begin{array}{l}142 \\
238\end{array}$ & & & & & $-1 / 2$ & $x$ & $+1 / 2$ & & \\
\hline $3 / 1$ & $5 \mathrm{bcd}$ & 410 & C7829 & Garstka & 230 & 104 & 142 & & & & & $-1 / 2$ & $x$ & $+1 / 2$ & & \\
\hline $3 / 1$ & $5 \mathrm{bcd}$ & 415 & C7828 & Garstka & 260 & & & & & & & $-1 / 2$ & $x$ & $+1 / 2$ & & \\
\hline $3 / 1$ & $5 \mathrm{cad}$ & 440 & C7808 & Holst & 140 & & & & & & $-1 / 2$ & $\mathrm{x}$ & $\mathrm{x}$ & $+1 / 2$ & & \\
\hline $3 / 1$ & $5 \mathrm{bcd}$ & 445 & C7809 & Moore & 260 & & & & & & & $-1 / 2$ & $\mathrm{x}$ & $+1 / 2$ & & \\
\hline $3 / 1$ & $5 \mathrm{bcd}$ & 425 & C7830 & Owens & 200 & 178 & 192 & & & & $-1 / 2$ & $\mathrm{x}$ & $\mathrm{x}$ & $+1 / 2$ & & \\
\hline & & & & & 324 & & & & & & $-1 / 2$ & $\mathrm{x}$ & $\mathrm{x}$ & $\mathrm{x}$ & & \\
\hline $3 / 1$ & $5 b d b$ & 413 & C7840 & Pitney & 114 & & & & & & & $-1 / 2$ & $x$ & B- & & \\
\hline & & & & & 230 & & & & & & & $-1 / 2$ & $x$ & $\mathrm{x}$ & & \\
\hline $3 / 1$ & $5 \mathrm{ccc}$ & 610 & C7828 & Radke & 245 & 194 & 214 & & & $-1 / 2$ & $x$ & $\mathrm{x}$ & $\mathrm{B}$ & & & \\
\hline & & & & & 585 & & & & & $-1 / 2$ & $x$ & $\mathrm{x}$ & $x$ & $x$ & & \\
\hline $\begin{array}{l}3 / 1 \\
3 / 1\end{array}$ & $\begin{array}{l}5 \mathrm{ccb} \\
5 \mathrm{aba}\end{array}$ & $\begin{array}{l}595 \\
390\end{array}$ & C7817 & $\begin{array}{l}\text { Richards } \\
\text { Schmeer }\end{array}$ & 600 & & & & & & $x$ & $x$ & $x$ & $\mathrm{x}$ & & \\
\hline $3 / 1$ & $5 c a a$ & 410 & C7864 & $\begin{array}{l}\text { Skeeters } \\
\# 2\end{array}$ & 315 & & & & & & $B-$ & $x$ & $x$ & $+1 / 2$ & & \\
\hline
\end{tabular}




\section{STRATIGRAPHIC DIVISIONS OF WELLS MEASURED BY THE OWRD} CONTINUED

\begin{tabular}{|c|c|c|c|c|c|c|c|c|}
\hline $3 / 1$ & 5 caa & 425 & C12324 & $\begin{array}{l}\text { skeeters } \\
\# 2\end{array}$ & 323 & & & \\
\hline $3 / 1$ & 5 daa & 310 & C7841 & Smith & 165 & & & \\
\hline $3 / 1$ & $5 \mathrm{cba}$ & 440 & C7797 & Vanlac & 320 & & & \\
\hline $3 / 1$ & 5 & 310 & $c 7802$ & Voss & 315 & 292 & 307 & \\
\hline $3 / 1$ & $5 a b a$ & 390 & C7889 & Wirfs-Bro & 167 & 153 & 167 & Red \\
\hline $3 / 1$ & $5 c c d$ & 610 & C7887 & Woodcock & 570 & $\begin{array}{l}182 \\
317 \\
348 \\
484 \\
556\end{array}$ & $\begin{array}{l}243 \\
322 \\
391 \\
515 \\
562\end{array}$ & \\
\hline $3 / 1$ & 5 & 450 & & Wozniak & 90 & $\begin{array}{r}25 \\
56 \\
446\end{array}$ & $\begin{array}{r}38 \\
91 \\
458\end{array}$ & S.S. \\
\hline $3 / 1$ & 5 & 450 & & Wozniak & 462 & $\begin{array}{r}82 \\
118\end{array}$ & $\begin{array}{r}90 \\
135\end{array}$ & $\begin{array}{l}\text { Red } \\
\text { S.S. }\end{array}$ \\
\hline $\mathrm{T} / \mathrm{R}$ & & Elev. & Well & Wel 1 & Well & Flowtc & ops & Lith. \\
\hline ( Sec & $=t .1$ & & I.D. & Owner & Depth & Top & Bottom & Ident. \\
\hline $3 / 1$ & $6 \mathrm{dbd}$ & 427 & W1 360 & Hansen & 345 & & & \\
\hline $3 / 1$ & $6 \mathrm{dbc}$ & 340 & W1894 & Mueller & 230 & & & \\
\hline $3 / 1$ & $6 \mathrm{bbd}$ & 205 & W1855 & Sadler & 165 & & & \\
\hline $3 / 1$ & $6 a b b$ & 210 & W864 & Scott & 200 & & & \\
\hline $3 / 1$ & $6 \mathrm{dbd}$ & 340 & W1904 & Troudt & $\begin{array}{l}230 \\
290\end{array}$ & 206 & 224 & \\
\hline $3 / 1$ & $6 \mathrm{bbd}$ & 190 & W1881 & Ulrich & 110 & & & \\
\hline$T / R$ & & Elev. & Well & Well & Well & Flowto & ops & Lith. \\
\hline ( Sec & $=(t)$. & & I.D. & Owner & Depth & Top & Bottom & Ident. \\
\hline $\begin{array}{l}3 / 1 \\
3 / 1\end{array}$ & $\begin{array}{l}7 \mathrm{dbc} \\
7 \mathrm{dbb}\end{array}$ & $\begin{array}{l}820 \\
880\end{array}$ & $\begin{array}{l}\text { W1929 } \\
\text { W1942 }\end{array}$ & $\begin{array}{l}\text { Auel } \\
\text { Bach }\end{array}$ & $\begin{array}{l}485 \\
200\end{array}$ & & & \\
\hline $3 / 1$ & $7 \mathrm{dab}$ & 780 & W1930 & Barron \#1 & 110 & & & \\
\hline $3 / 1$ & $7 \mathrm{dab}$ & 750 & W1939 & Barron \#2 & 492 & & & \\
\hline $3 / 1$ & $7 a d b$ & 805 & W1920 & Bennett & 410 & & & \\
\hline $3 / 1$ & $7 \mathrm{aad}$ & 775 & W3458 & Bitzenbur & 712 & $\begin{array}{l}500 \\
600\end{array}$ & $\begin{array}{l}510 \\
620\end{array}$ & \\
\hline
\end{tabular}

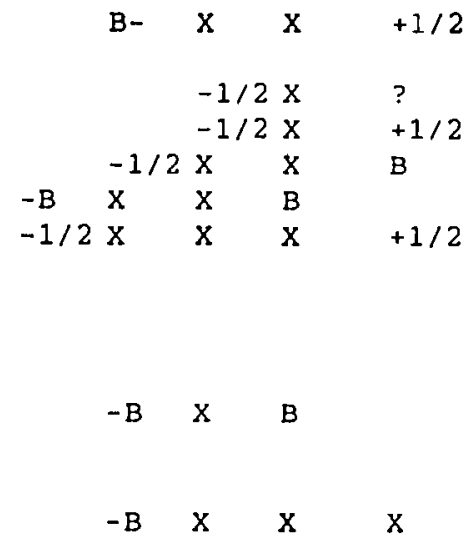

strat. bslt units penetrated $A \perp G$ SB WW UMT O-GC WpR $F \quad M$

$$
\begin{array}{llll} 
& \text { X } & \text { X } & \text { B } \\
& & & \\
-B & X & X & B \\
-B & X & X & 1 / 2
\end{array}
$$

Strat. bslt units penetrated $A l G$ SB WW UMT O-GC WpR $F \quad M$

$\begin{array}{lllllll}X & X & X & X & X & B\end{array}$

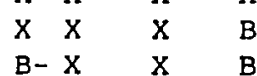

$B-X \quad X \quad B$

$\begin{array}{lllll}-X & X & X & X & B\end{array}$

$\begin{array}{lllll}X & X & X & 1 / 2 & \\ -B & X & X & X & X\end{array}$ 
TABLE XII

STRATIGRAPHIC DIVISIONS OF WELLS MEASURED BY THE OWRD CONTINUED

\begin{tabular}{|c|c|c|c|c|c|c|c|c|}
\hline $3 / 1$ & 7 aad & 730 & W8 68 & Briggs & 715 & & & \\
\hline $3 / 1$ & $7 c d d$ & 825 & W1806 & Bulloch & 430 & & & \\
\hline $3 / 1$ & $7 a a a$ & 720 & W3150 & Burton & 260 & & & \\
\hline $3 / 1$ & $7 \mathrm{adc}$ & 825 & W1923 & Butler & 605 & & & \\
\hline $3 / 1$ & $7 \mathrm{dac}$ & 735 & W1947 & Engels & 530 & & & \\
\hline $3 / 1$ & 7 aaa & 710 & W1945 & Hix & 685 & & & \\
\hline $3 / 1$ & 7 dac & 755 & W1943 & Hoftiezer & 570 & & & \\
\hline $3 / 1$ & $7 \mathrm{cab}$ & 962 & W1807 & Husband & 710 & & & \\
\hline $3 / 1$ & 7 daa & 700 & W1 158 & Imbrie & 505 & & & \\
\hline $3 / 1$ & $7 \mathrm{aad}$ & 760 & W1949 & Johnson & 805 & & & \\
\hline $3 / 1$ & $7 c a b$ & 985 & W1937 & Kimble & 640 & $\begin{array}{l}460 \\
600\end{array}$ & $\begin{array}{l}475 \\
640\end{array}$ & \\
\hline $3 / 1$ & 7dda & 685 & & Landis & & & & \\
\hline $3 / 1$ & $7 \mathrm{bac}$ & 708 & W1 361 & Manke \#1 & 760 & & & \\
\hline $3 / 1$ & $7 \mathrm{bad}$ & 572 & W1363 & Manke \#2 & 622 & & & \\
\hline $3 / 1$ & $7 \mathrm{bba}$ & 506 & W1 366 & Manke $\# 3$ & 573 & $\begin{array}{l}135 \\
421 \\
454\end{array}$ & $\begin{array}{l}185 \\
424 \\
485\end{array}$ & S.S.-like \\
\hline $3 / 1$ & $7 \mathrm{bbc}$ & 659 & W1 364 & Manke \#4 & 650 & $\begin{array}{l}498 \\
597\end{array}$ & $\begin{array}{l}591 \\
625\end{array}$ & \\
\hline $3 / 1$ & 7 bac & 659 & W1 362 & Manke \#6 & 562 & & & \\
\hline $3 / 1$ & $7 c d c$ & 880 & W1915 & Miller & 436 & & & \\
\hline $3 / 1$ & $7 \mathrm{cbd}$ & 1010 & W865 & Montague & 705 & & & \\
\hline $3 / 1$ & $7 \mathrm{cbd}$ & 1020 & W1948 & Mozenico & 735 & & & \\
\hline $3 / 1$ & $7 a a c$ & 780 & W1946 & Nixon & 515 & & & \\
\hline $3 / 1$ & $7 \mathrm{cdb}$ & 905 & W1926 & Paulson & 615 & & & \\
\hline $3 / 1$ & $7 \mathrm{daa}$ & 790 & W1938 & Puderbaug: & $\begin{array}{l}531 \\
665\end{array}$ & & & \\
\hline $3 / 1$ & $7 \mathrm{aaa}$ & 710 & W1913 & Rieger & 520 & & & \\
\hline $3 / 1$ & $7 \mathrm{ddb}$ & 740 & W1941 & Roberg & 480 & 455 & 480 & \\
\hline $3 / 1$ & $7 \mathrm{ccd}$ & 910 & W1912 & Smith & 475 & & & \\
\hline $3 / 1$ & $7 \mathrm{adc}$ & 805 & W1927 & Southwel 1 & 615 & $\begin{array}{r}55 \\
60 \\
494\end{array}$ & $\begin{array}{r}60 \\
67 \\
496\end{array}$ & S.S. \\
\hline
\end{tabular}

\begin{tabular}{|c|c|c|c|c|c|c|}
\hline & & $x$ & $x$ & $x$ & $x$ & \\
\hline & $-1 / 2$ & $x$ & $x$ & $\mathrm{x}$ & $+1 / 2$ & \\
\hline & & $x$ & $x$ & $+1 / 2$ & & $x$ \\
\hline & $x$ & $x$ & $x$ & $x$ & B & \\
\hline B- & $x$ & $x$ & $x$ & $x$ & $+1 / 2$ & \\
\hline & & $x$ & $x$ & $x$ & $x$ & \\
\hline & $\mathrm{X}$ & $x$ & $x$ & $x$ & $+1 / 2$ & \\
\hline & $-1 / 2$ & $x$ & $x$ & $x$ & $x$ & \\
\hline & B- & $x$ & $x$ & $x$ & $+1 / 2$ & \\
\hline & & $x$ & $x$ & $x$ & $\mathrm{x}$ & \\
\hline & $-B$ & $x$ & $x$ & $x$ & $+1 / 2$ & $x$ \\
\hline$x$ & $x$ & $x$ & $x$ & $x$ & $+1 / 2$ & \\
\hline & & $x$ & $x$ & $x$ & $x$ & \\
\hline & & & $x$ & $x$ & $x$ & \\
\hline & & & $x$ & $x$ & $x$ & \\
\hline & & & $x$ & $x$ & $x$ & \\
\hline & & $x$ & $x$ & $x$ & $x$ & \\
\hline & $-1 / 2$ & $x$ & $x$ & $x$ & B & \\
\hline & $-1 / 2$ & $x$ & $x$ & $x$ & $x$ & \\
\hline & B- & $x$ & $x$ & $x$ & B & \\
\hline & $-1 / 2$ & $x$ & $x$ & $x$ & $x x$ & \\
\hline & $-1 / 2$ & $x$ & $x$ & $x$ & & \\
\hline & $-1 / 2$ & $x$ & $x$ & $x$ & $1 / 2$ & \\
\hline & & $1 / 2$ & $x$ & $x$ & $\mathrm{x}$ & $x$ \\
\hline$x$ & $x$ & $x$ & $x$ & $x$ & B & \\
\hline$x$ & $x$ & $x$ & $x$ & $1 / 2$ & & \\
\hline & $-1 / 2$ & $x$ & $x$ & $x$ & $+1 / 2$ & \\
\hline
\end{tabular}


TABLE XII

STRATIGRAPHIC DIVISIONS OF WELLS MEASURED BY THE OWRD CONTINUED

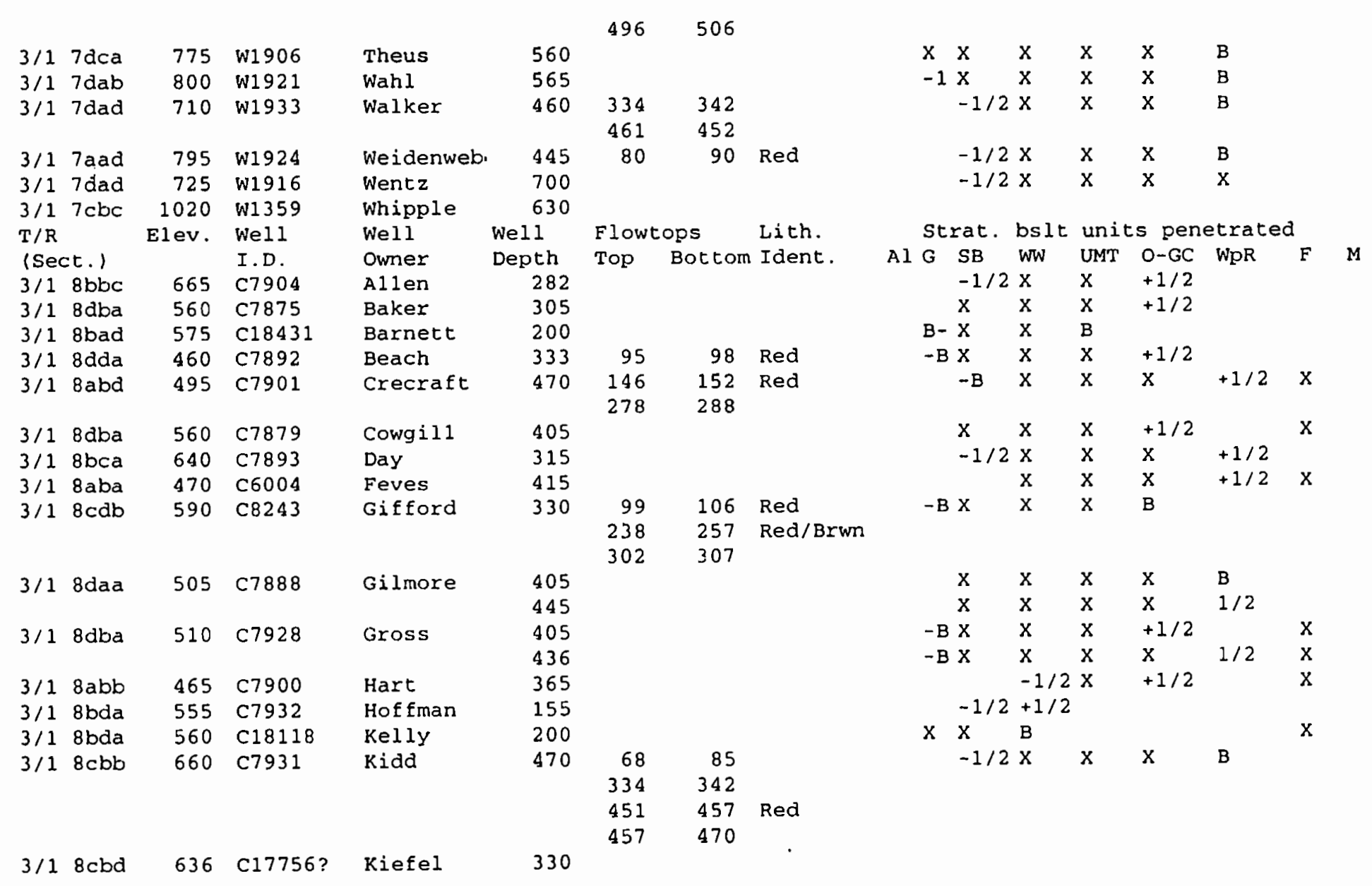


TABLE XII

STRATIGRAPHIC DIVISIONS OF WELLS MEASURED BY THE OWRD CONTINUED

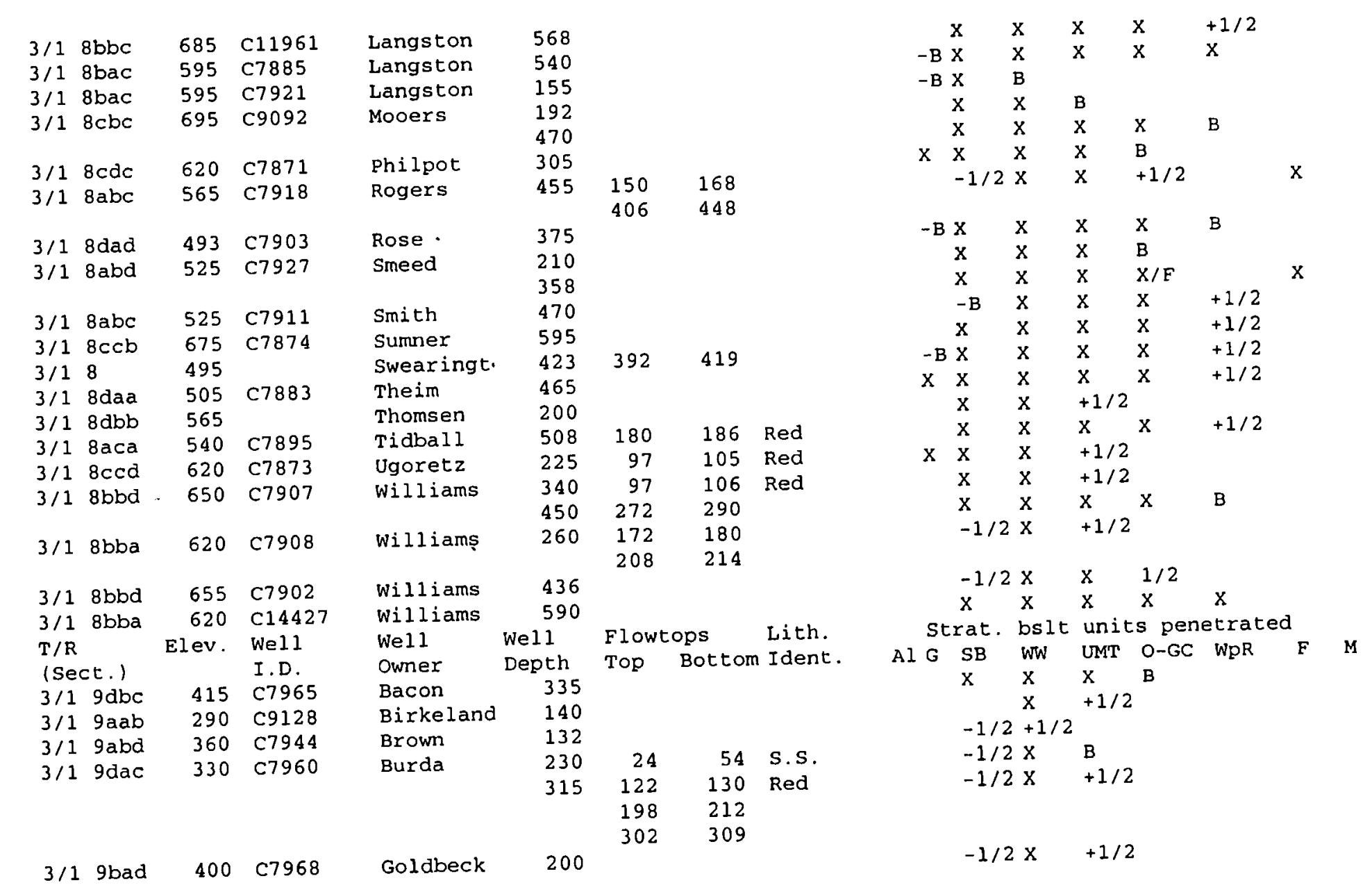


TABLE XII

STRATIGRAPHIC DIVISIONS OF WELLS MEASURED BY THE OWRD CONT INUED

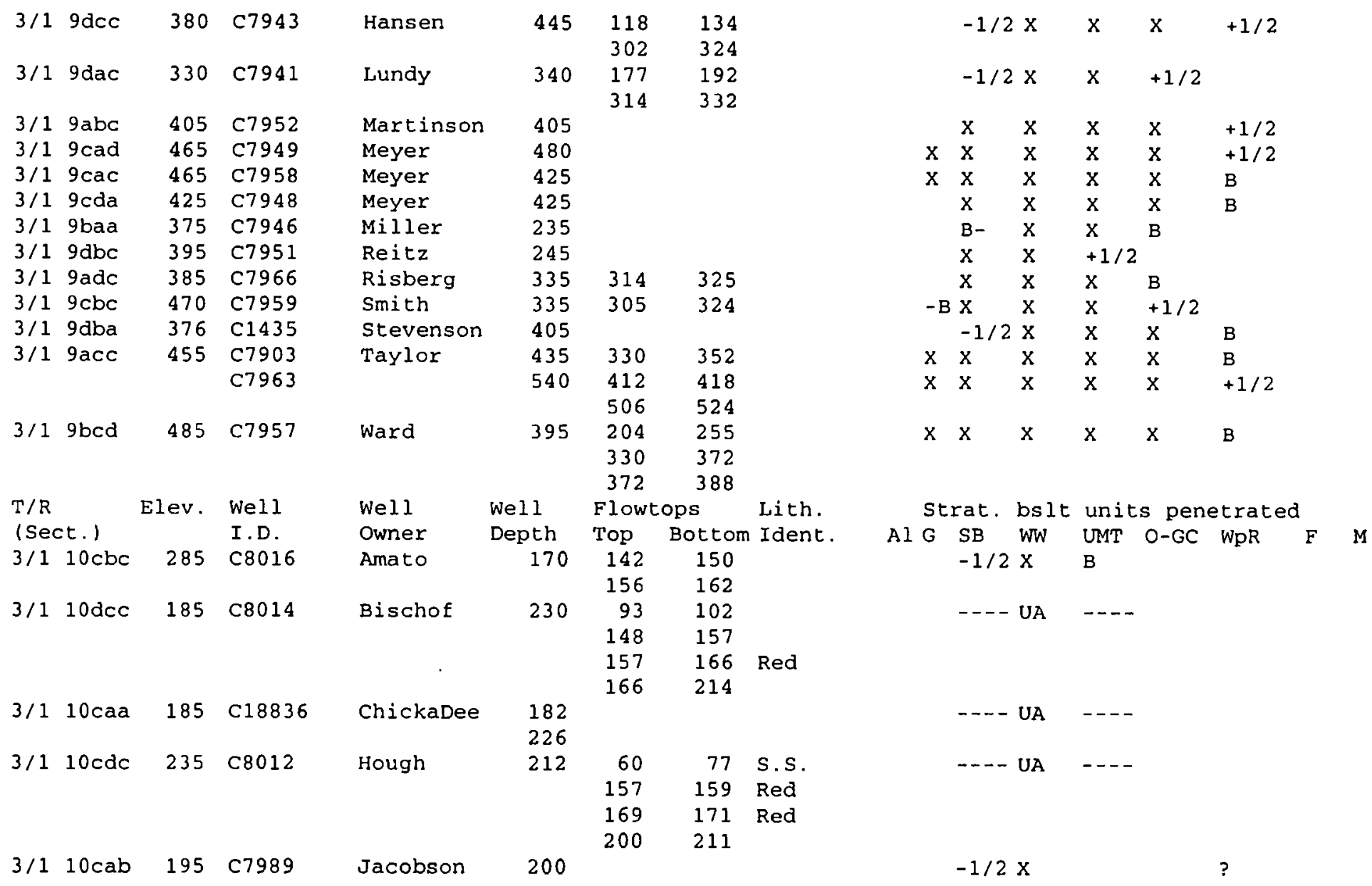




\section{STRATIGRAPHIC DIVISIONS OF WELLS MEASURED BY THE OWRD CONTINUED}

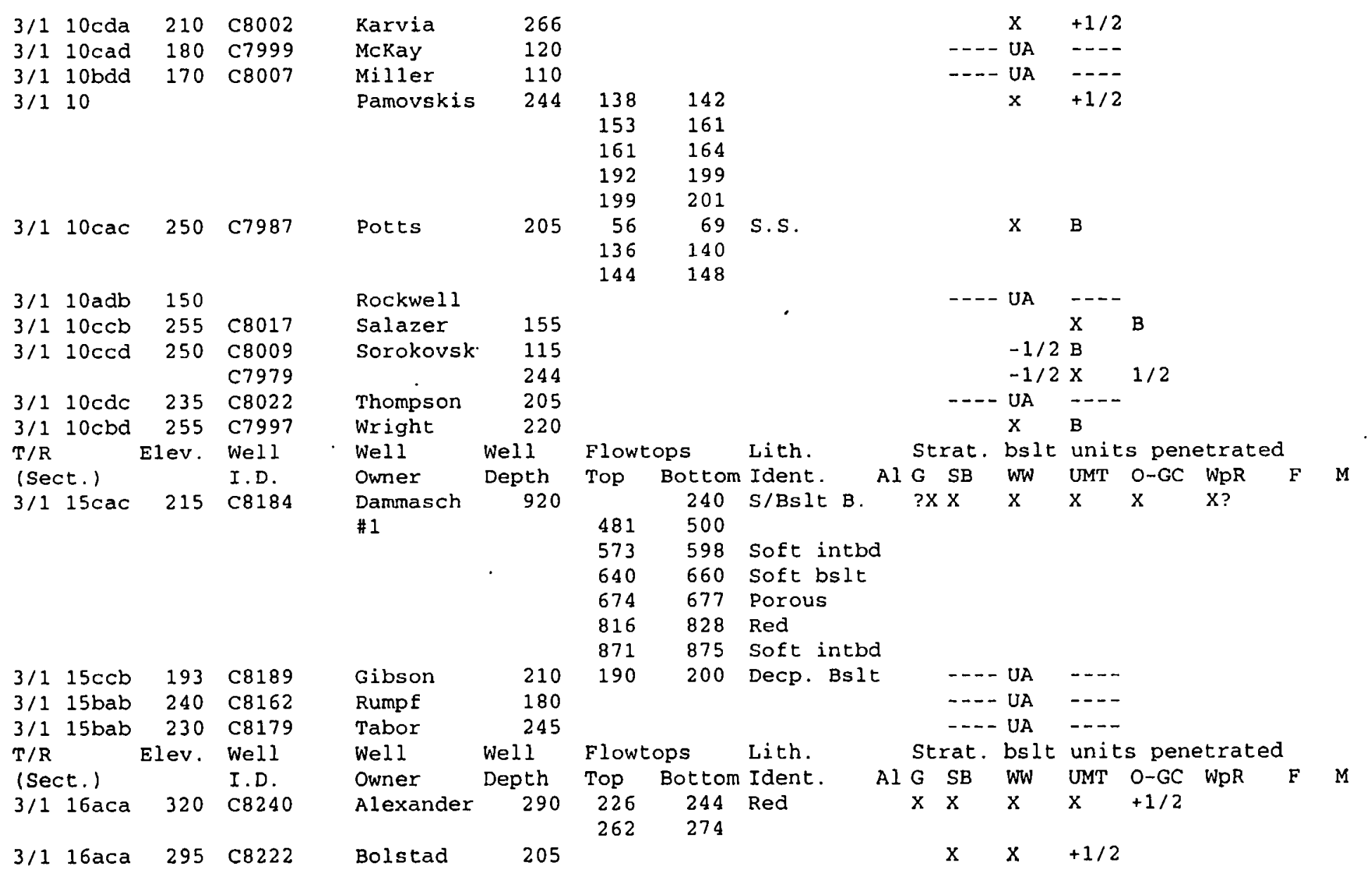


STRATIGRAPHIC DIVISIONS OF WELLS MEASURED BY THE OWRD CONTINUED

\begin{tabular}{|c|c|c|c|c|c|c|c|c|c|c|c|c|c|c|c|c|}
\hline $3 / 1$ & $16 \mathrm{dcc}$ & 180 & & Calkins & & & & & & $-\cdots$ & UA & \multirow{2}{*}{\multicolumn{5}{|c|}{$-\cdots-$}} \\
\hline $3 / 1$ & $16 a a a$ & 250 & C8172 & cleek & 150 & & & & & & $\mathrm{x}$ & \multicolumn{4}{|l|}{ B } & \\
\hline $3 / 1$ & $16 \mathrm{ddd}$ & 185 & $C 8231$ & $\begin{array}{l}\text { Dammasch } \\
\# 2\end{array}$ & 1000 & & & & & $-\cdots-$ & UA & \multicolumn{5}{|l|}{---} \\
\hline $3 / 1$ & $16 \mathrm{bad}$ & 315 & C8229 & Dugan & 173 & 86 & 90 & Soft & & $-1 / 2$ & $x$ & \multicolumn{5}{|c|}{$+1 / 2$} \\
\hline & & & C189 & & 295 & $\begin{array}{l}123 \\
280\end{array}$ & $\begin{array}{l}128 \\
295\end{array}$ & Soft & & $-1 / 2$ & $x$ & $x$ & $x$ & B & & \\
\hline $3 / 1$ & $16 \mathrm{cda}$ & 150 & C8230 & Garrett & 105 & & & & & & & \multicolumn{2}{|c|}{$-1 / 2 \mathrm{~B}$} & & $x$ & \\
\hline $3 / 1$ & $16 \mathrm{caa}$ & 235 & & Jones \#1 & 113 & & & & & & $x$ & \multicolumn{3}{|c|}{$1 / 2$} & & \\
\hline $3 / 1$ & $16 \mathrm{caa}$ & 235 & C18057 & Jones \#2 & 198 & 147 & 171 & Soft brwn & & & $x$ & $\mathrm{x}$ & $\mathrm{B}$ & & & \\
\hline $3 / 1$ & $16 \mathrm{dbb}$ & 220 & C8209 & Mason & 300 & 260 & $\begin{array}{l}250 \\
270\end{array}$ & $\begin{array}{l}\text { S/Bslt B. } \\
\text { Red }\end{array}$ & & & $x$ & $x$ & $x$ & \multicolumn{2}{|l|}{$+1 / 2$} & \\
\hline $3 / 1$ & $16 \mathrm{dba}$ & 210 & C8214 & Mcgee & 245 & $\begin{array}{l}154 \\
230\end{array}$ & $\begin{array}{l}176 \\
238\end{array}$ & & & & $x$ & $x$ & $x$ & B & & \\
\hline$T / R$ & & Elev. & Well & Wel 1 & We11 & Flowt & ops & Lith. & & rat. & bslt & \multicolumn{5}{|c|}{ units penetrated } \\
\hline $\begin{array}{l}\text { lSec } \\
3 / 1\end{array}$ & $\begin{array}{l}\text { ct. } 1 \\
17 \mathrm{aac}\end{array}$ & 350 & $\begin{array}{l}\text { I.D. } \\
\text { C8283 }\end{array}$ & $\begin{array}{l}\text { Owner } \\
\text { Adams \#1 }\end{array}$ & $\begin{array}{r}\text { Depth } \\
285\end{array}$ & Top & Bottom & Ident. & Al G & $\mathrm{SB}$ & $\begin{array}{l}W W \\
X\end{array}$ & $\begin{array}{l}\mathrm{UMT} \\
\mathrm{x}\end{array}$ & $\begin{array}{l}O-G C \\
B\end{array}$ & WpR & $\mathbf{F}$ & $\mathbf{M}$ \\
\hline $3 / 1$ & 17 aac & 280 & C17780 & Adams \#2 & 184 & & & & & & & $\mathrm{x}$ & $\mathrm{B}$ & & & \\
\hline $3 / 1$ & 17 bad & 530 & C8253 & Arkless & 505 & & & & $\mathrm{x}$ & $\mathrm{x}$ & $\mathrm{x}$ & $\mathrm{x}$ & $\mathrm{x}$ & $x$ & & \\
\hline $3 / 1$ & $17 \mathrm{bbd}$ & 560 & $\mathrm{C} 8297$ & Barrows & 440 & & & & & $\mathrm{x}$ & $x$ & $x$ & $\mathrm{x}$ & $1 / 2$ & & \\
\hline $3 / 1$ & $17 \mathrm{bba}$ & 610 & C8298 & Benson & 545 & & & & $\mathrm{x}$ & $\mathrm{x}$ & $\mathrm{x}$ & $\mathrm{x}$ & $\mathrm{x}$ & $1 / 2$ & & \\
\hline $3 / 1$ & $17 \mathrm{bbd}$ & 565 & C8269 & Bethune & 525 & & & & & $x$ & $\mathrm{x}$ & $x$ & $x$ & $+1 / 2$ & & \\
\hline $3 / 1$ & $17 \mathrm{bcd}$ & 510 & C8303 & Biles & 380 & 102 & 105 & Red & & $-B$ & $\mathrm{x}$ & $x$ & $\mathrm{x}$ & B & & \\
\hline $3 / 1$ & $17 \mathrm{ddc}$ & 200 & C17781 & Bisenius & 123 & & & & & $-1 / 2$ & $\mathrm{x}$ & $1 / 2$ & & & & \\
\hline $3 / 1$ & $17 a c a$ & 455 & C18317 & Cogger & 140 & 282 & 306 & & $\mathrm{x}$ & $\mathrm{x}$ & $x$ & $\mathrm{x}$ & $+1 / 2$ & & & \\
\hline & & & & & $\begin{array}{l}240 \\
380\end{array}$ & 352 & 374 & & & & & & & & & \\
\hline $3 / 1$ & $17 \mathrm{cab}$ & 400 & $C 8270$ & Fullmer & 305 & & & - & & $-1 / 2$ & $x$ & $\mathrm{x}$ & $1 / 2$ & & & \\
\hline $3 / 1$ & $17 \mathrm{cdc}$ & 170 & C8402 & Handy & 95 & & & & & & & & & $x$ & $x$ & \\
\hline $3 / 1$ & 17 aaa & 335 & C8282 & $\mathrm{Hi} 11$ & 268 & $\begin{array}{r}75 \\
209\end{array}$ & $\begin{array}{l}121 \\
250\end{array}$ & Porous & & & $-1 / 2$ & $x$ & $x$ & B & & \\
\hline $3 / 1$ & 17 add & 265 & & Langer & & & & & & --- & UA & $\rightarrow-\infty$ & & & & \\
\hline $3 / 1$ & 17 baa & 570 & C8280 & Leith & 405 & & & & $x$ & $x$ & $x$ & $\mathrm{x}$ & $+1 / 2$ & & & \\
\hline $3 / 1$ & $17 \mathrm{cac}$ & 280 & C1073 & Lewis & 216 & 0 & 30 & S.S. & & & & $\mathrm{x}$ & $\mathrm{x}$ & $\mathrm{B}$ & & \\
\hline
\end{tabular}


STRATIGRAPHIC DIVISIONS OF WELLS MEASURED BY THE OWRD CONT INUED

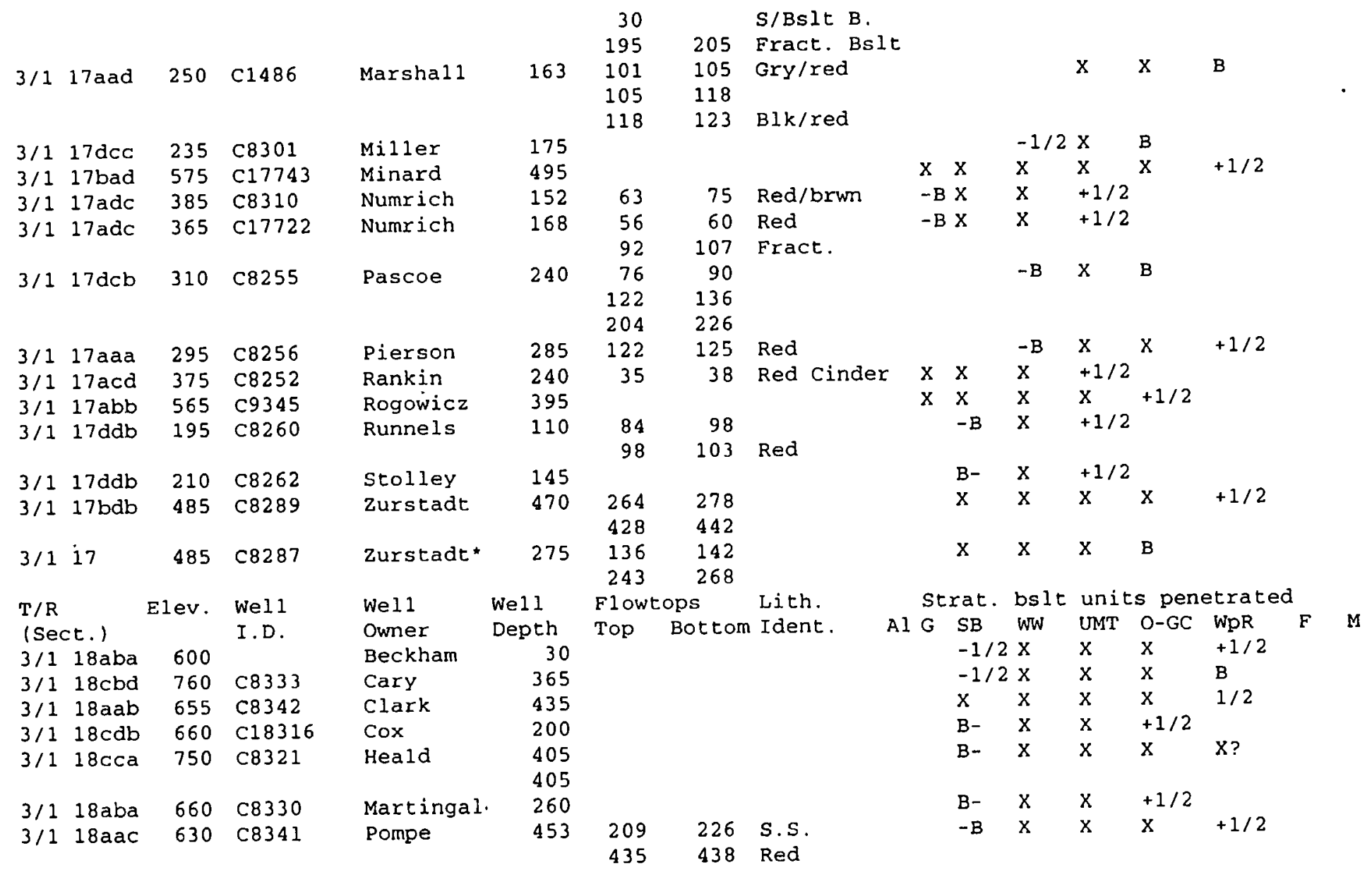


TABLE XII

\section{STRATIGRAPHIC DIVISIONS OF WELLS MEASURED BY THE OWRD CONTINUED}

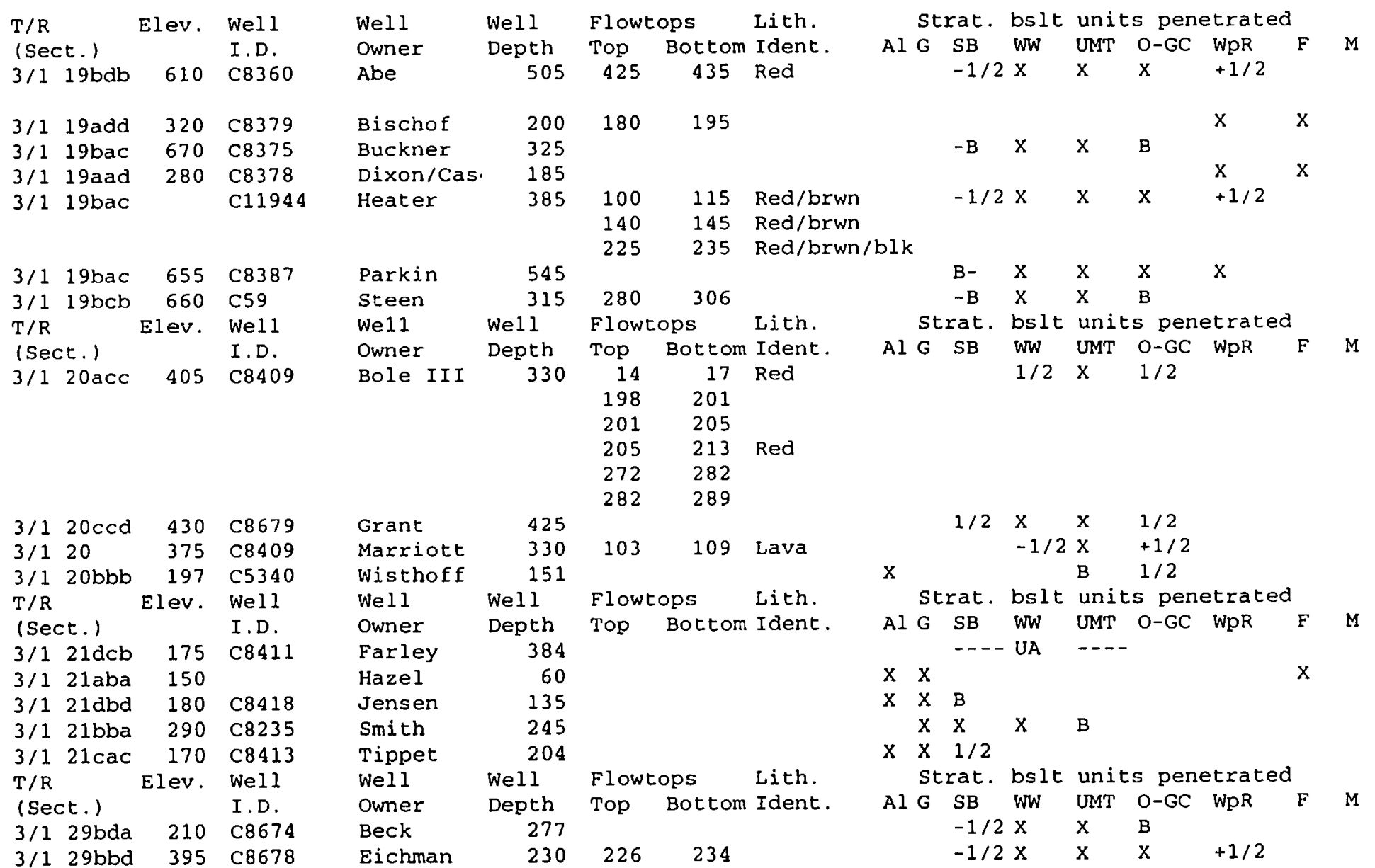


TABLE XII

STRATIGRAPHIC DIVISIONS OF WELLS MEASURED BY THE OWRD CONTINUED

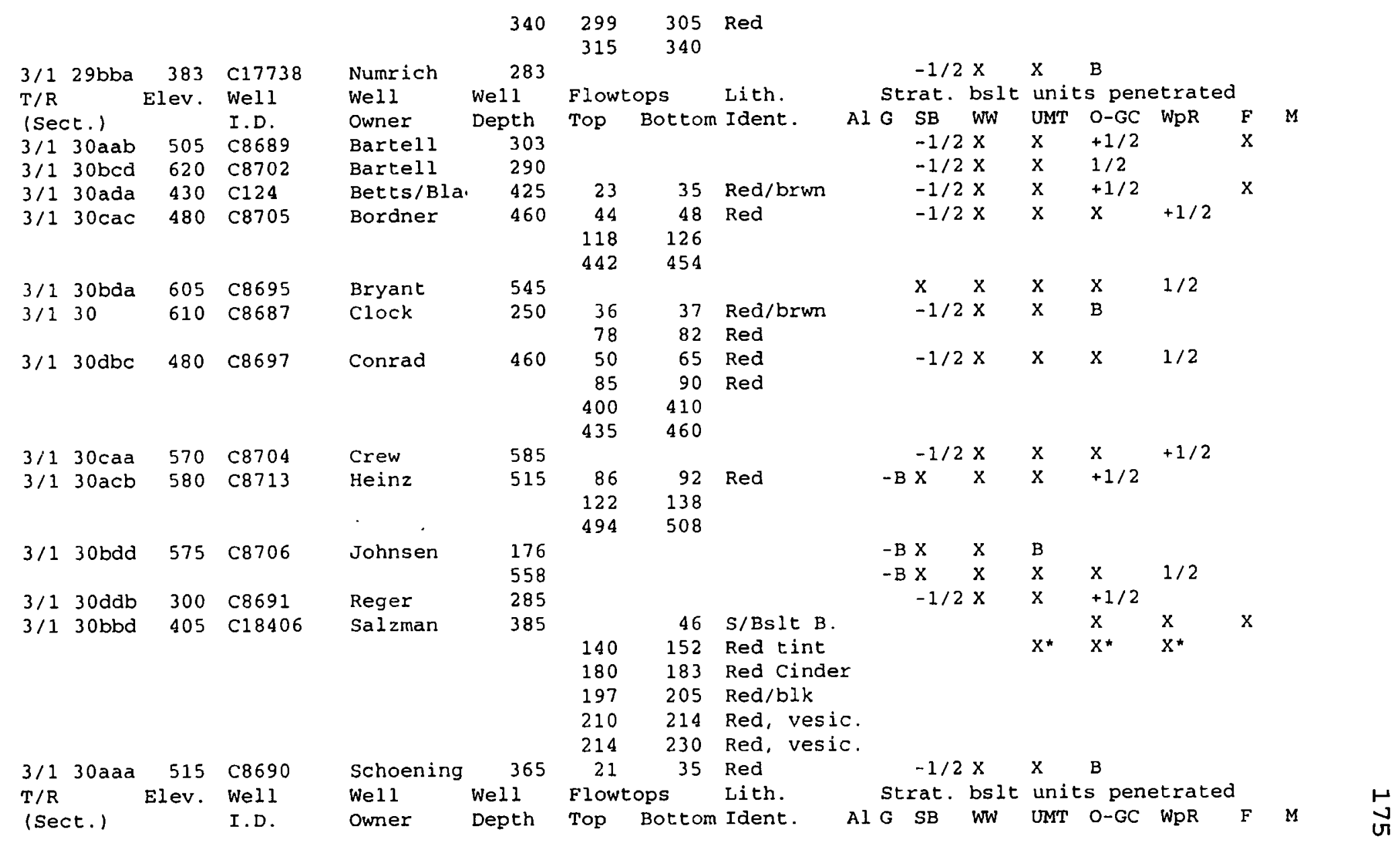


STRATIGRAPHIC DIVISIONS OF WELLS MEASURED BY THE OWRD CONTINUED

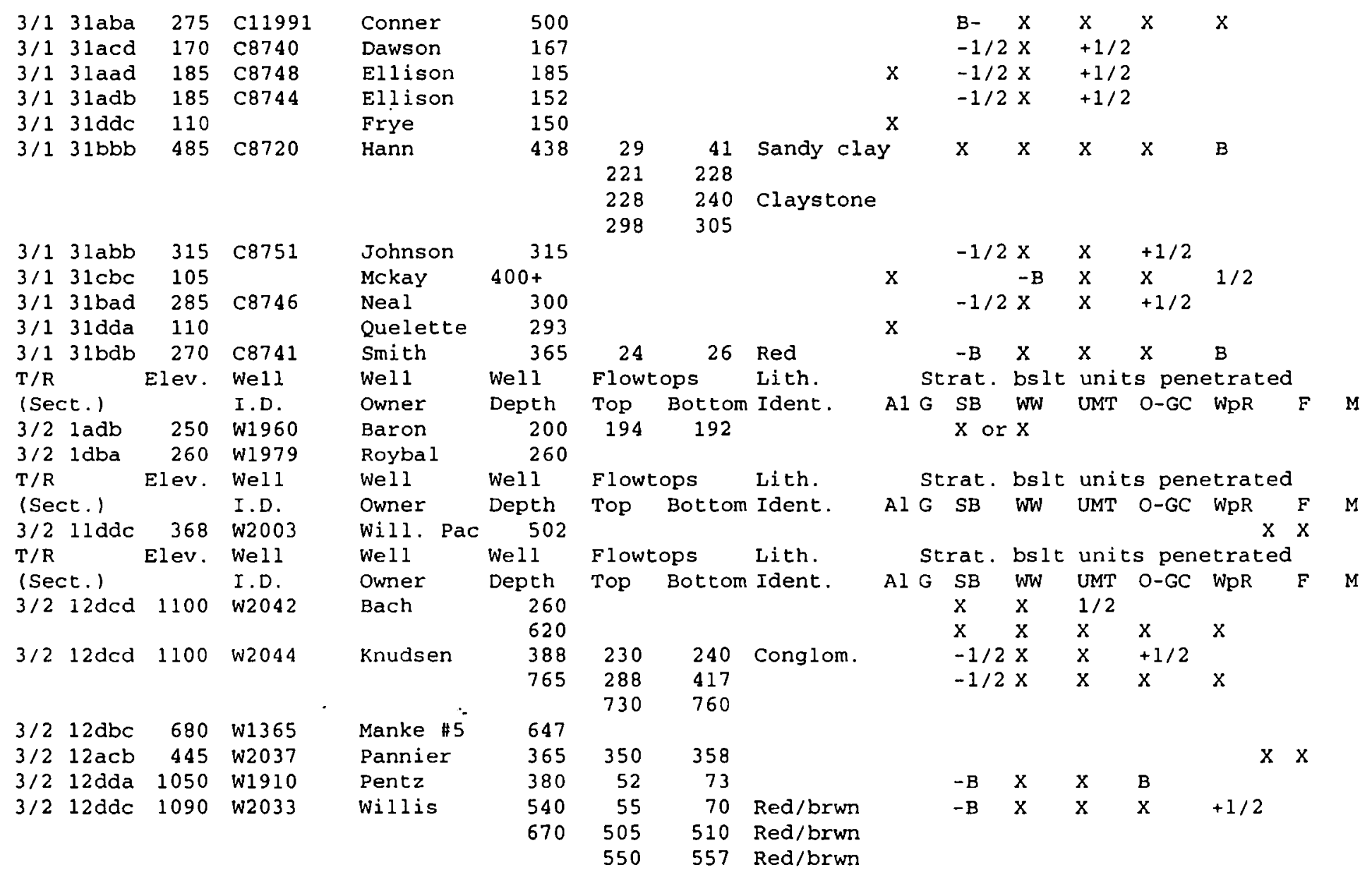


TABLE XII

STRATIGRAPHIC DIVISIONS OF WELLS MEASURED BY THE OWRD CONTINUED

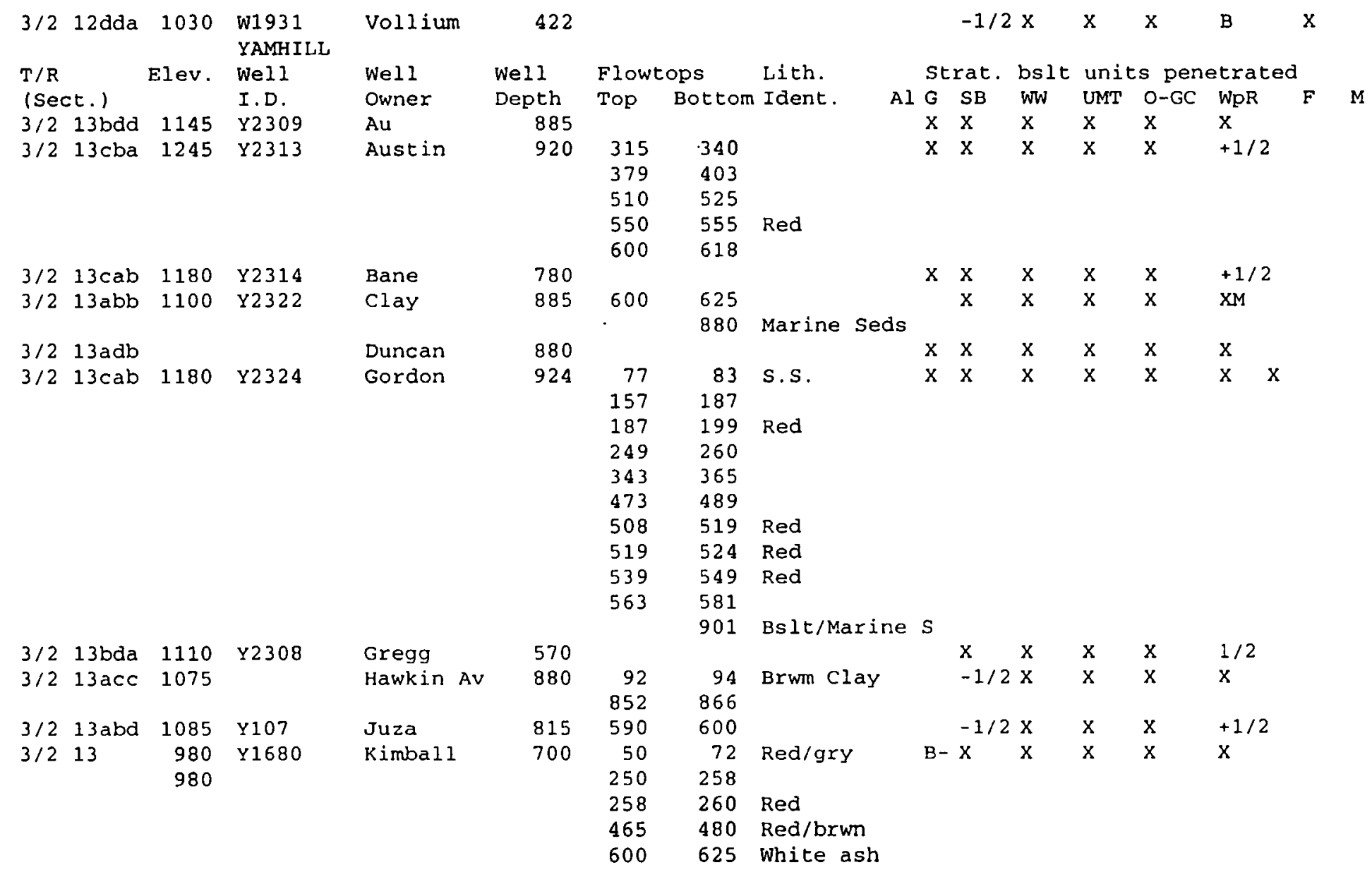


TABLE XII

STRATIGRAPHIC DIVISIONS OF WELLS MEASURED BY THE OWRD CONT INUED

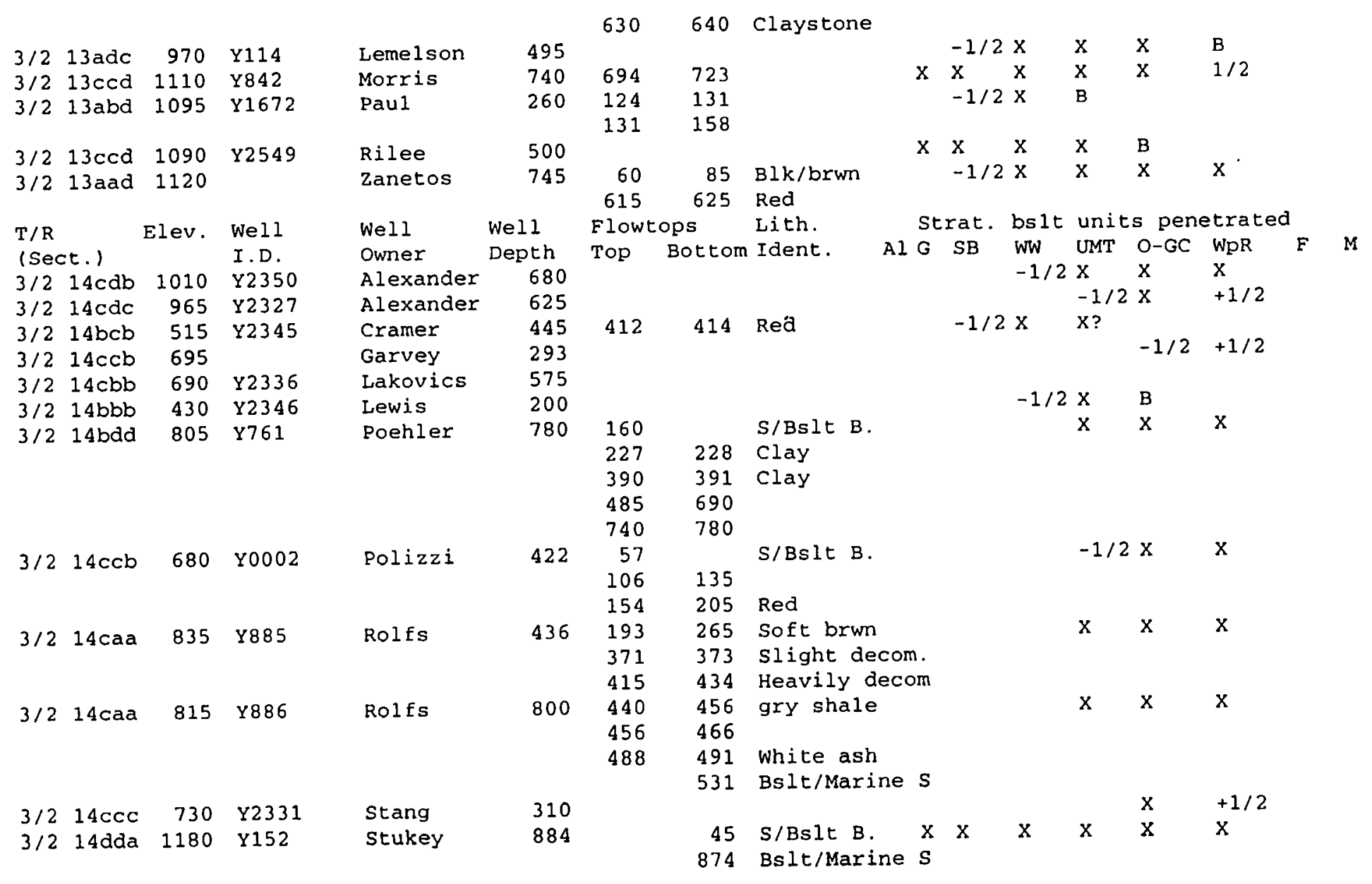


TABLE XII

STRATIGRAPHIC DIVISIONS OF WELLS MEASURED BY THE OWRD CONTINUED

$\begin{array}{llrl}3 / 2 & 14 \mathrm{caa} & 830 & \text { Y2340 } \\ 3 / 2 & 14 \mathrm{aad} & 835 & \text { Y } 680 \\ 3 / 2 & 14 \mathrm{bdb} & 680 & \text { Y292 } \\ \text { T/R } & \text { Elev. } & \text { Wel1 } \\ \text { (Sect.) } & & \text { I.D. } \\ 3 / 2 & 15 \mathrm{dbb} & 210 & \text { Y2381 } \\ 3 / 2 & 15 \mathrm{dad} & 615 & \text { Y2412 } \\ 3 / 2 & 15 \mathrm{aac} & 495 & \text { Y2379 } \\ 3 / 2 & 15 \mathrm{ada} & 510 & \text { Y2378 } \\ 3 / 2 & 15 \mathrm{dbb} & 230 & \text { Y2371 } \\ 3 / 2 & 15 \mathrm{dda} & 600 & \text { Y2380 } \\ \text { T/R } & \text { Elev. } & \text { Wel1 } \\ \text { (Sect.) } & & \text { I.D. } \\ 3 / 2 & 22 \mathrm{acb} & 305 & \\ 3 / 2 & 22 \mathrm{aaa} & 555 & \text { Y2522 } \\ 3 / 2 & 22 \mathrm{aca} & 330 & \text { Y2518 } \\ & & & \\ 3 / 2 & 22 \mathrm{aab} & 505 & \text { Y2512 } \\ 3 / 2 & 22 \mathrm{ddc} & 280 & \text { Y2509 } \\ 3 / 2 & 22 \mathrm{cad} & 222 & \text { Y2501 } \\ \text { T/R } & \text { Elev. } & \text { Wel1 } \\ \text { (Sect.) } & & \text { I.D. } \\ 3 / 2 & 23 \mathrm{dca} & 665 & \text { Y2532 } \\ 3 / 2 & 23 \mathrm{dcc} & 830 & \text { Y2536 } \\ 3 / 2 & 23 \mathrm{cac} & 705 & \text { Y2535 } \\ 3 / 2 & 23 & 720 & \\ & & & \end{array}$

$3 / 223 \mathrm{bba} \quad 760 \quad Y 168$

$3 / 2 \quad 23 \mathrm{bbb} \quad 691 \quad Y 167$

$\begin{array}{lrrrl}\text { Town } & 482 & 99 & 103 & \text { Clay } \\ \text { Walsh } & 495 & & 488 & \text { Marine Sed } \\ \text { Wissusik } & 560 & & & \\ \text { Well } & \text { Well } & \text { Flowtops } & \text { Lith. } \\ \text { Owner } & \text { Depth } & \text { Top } & \text { Bottom Ident. Al } \\ \text { Hermanson } & 140 & & & \\ \text { Mueller } & 348 & & & \\ \text { Schaad } & 530 & 506 & 520 & \\ \text { Schaad } & 485 & 448 & 476 & \\ \text { Scholz } & 103 & & & \\ \text { Zauner } & 255 & & & \\ \text { Well } & \text { Well } & \text { Flowtops } & \text { Lith. } \\ \text { Owner } & \text { Depth } & \text { Top Bottom Ident. Al }\end{array}$

Owner

Craft

$\begin{array}{lr}\text { Darby } & 165 \\ \text { Friedman } & 97\end{array}$

Seitz

Hendren 245

Renne 165

Siefken 145

Well Well

Owner Depth

Bauer $\quad 403$

Bauer $\quad 586$

Ferris (\# 581

Ferris (\# 600

Flowtops Lith.

Top Bottom Ident.

Par. Mt. 600

Est. \#1 285 
TABLE XII

STRATIGRAPHIC DIVISIONS OF WELLS MEASURED BY THE OWRD CONTINUED

\begin{tabular}{|c|c|c|c|c|c|c|c|c|c|c|c|c|c|c|c|c|c|}
\hline \multicolumn{3}{|c|}{ (Sect.) } & \multirow{2}{*}{\multicolumn{2}{|c|}{$\begin{array}{l}\text { I.D. } \\
\text { Y2683 }\end{array}$}} & \multirow{2}{*}{$\begin{array}{l}\text { Owner } \\
\text { Bryson }\end{array}$} & \multirow{2}{*}{$\begin{array}{l}\text { Depth } \\
586\end{array}$} & \multirow[t]{2}{*}{ Top } & \multirow[t]{2}{*}{ Bottom } & \multirow[t]{2}{*}{ Ident. } & \multirow[t]{2}{*}{ Al G } & \multirow[t]{2}{*}{ SB } & \multirow[t]{2}{*}{ WW } & \multirow[t]{2}{*}{ UMT } & \multirow[t]{2}{*}{$O-G C$} & \multirow[t]{2}{*}{ WpR } & \multirow[t]{2}{*}{$F$} & \multirow[t]{2}{*}{$\mathbf{M}$} \\
\hline $3 / 2$ & $35 \mathrm{bbd}$ & 265 & & & & & & & & & & & & & & & \\
\hline \multirow{2}{*}{\multicolumn{2}{|c|}{$(\operatorname{sect})}}$. & Elev. & Well & & well & Well & \multicolumn{2}{|c|}{ Flowtops } & Lith. & \multicolumn{2}{|c|}{ strat. } & bslt & \multicolumn{4}{|c|}{ units penetrated } & \\
\hline & & & I.D. & & Owner & Depth & Top. & Bottom & Ident. & $A 1 G$ & $S B$ & WW & UMT & $0-G C$ & WpR & $F$ & $M$ \\
\hline $3 / 2$ & $36 a c d$ & 445 & & & Acott & 147 & & & & & $-1 / 2$ & $x$ & $+1 / 2$ & & & & \\
\hline $3 / 2$ & $36 \mathrm{acd}$ & 445 & $Y 2686$ & & Acote & 545 & & & & & $-1 / 2$ & $x$ & $\mathrm{x}$ & $\mathrm{x}$ & $\mathrm{x}$ & & \\
\hline \multirow[t]{2}{*}{$3 / 2$} & $36 a c a$ & 520 & Y 2697 & & Brown & 350 & 237 & 258 & Red & & $-1 / 2$ & $x$ & $x$ & $x$ & B & & \\
\hline & & & & & & 450 & & & & & $-1 / 2$ & $x$ & $x$ & $\mathrm{x}$ & $+1 / 2$ & & \\
\hline $3 / 2$ & $36 \mathrm{acc}$ & 515 & $Y 2716$ & & Cole & 493 & & & & & $-1 / 2$ & $x$ & $x$ & $x$ & $+1 / 2$ & & \\
\hline $3 / 2$ & $36 \mathrm{aba}$ & 560 & $Y 2703$ & & $\operatorname{cox}$ & 280 & 175 & 190 & Red/blk & & & $\mathrm{x}$ & $x$ & $x$ & $+1 / 2$ & & \\
\hline \multirow[t]{2}{*}{$3 / 2$} & $36 \mathrm{aad}$ & 490 & $Y 2709$ & & Dickensen & 207 & & & & & $-1 / 2$ & $x$ & $+1 / 2$ & & & & \\
\hline & & & & & & 450 & & & & & $-1 / 2$ & $x$ & $\mathrm{x}$ & $x$ & $+1 / 2$ & & \\
\hline $3 / 2$ & $36 \mathrm{abb}$ & 610 & $Y 2714$ & & Kroger & 285 & & & & & & $-1 / 2$ & $x$ & $x$ & $\mathrm{~B}$ & & \\
\hline $3 / 2$ & $36 a c a$ & 500 & $Y 2685$ & & McCaferey & 545 & & & & & -12 & $\mathrm{x}$ & $\mathrm{x}$ & $x$ & $x$ & & \\
\hline \multirow[t]{2}{*}{$3 / 2$} & $36 \mathrm{aad}$ & 520 & Y2708 & & sterrett & 147 & & & & & $-1 / 2$ & $\mathrm{x}$ & $x$ & $\mathrm{~B}$ & & & \\
\hline & & & & & & 260 & & & & & $-1 / 2$ & $x$ & $x$ & $\mathrm{x}$ & $\mathrm{B}$ & & \\
\hline $3 / 2$ & $36 \mathrm{dab}$ & 390 & Y 2687 & & Whitaker & 505 & & & & & $-1 / 2$ & $x$ & $x$ & $\mathrm{x}$ & $x$ & & \\
\hline $3 / 2$ & $36 \mathrm{abb}$ & 625 & $Y 2565$ & & Wise & 550 & & & & & & $-1 / 2$ & $x$ & $x$ & $x$ & & \\
\hline $3 / 2$ & $36 a b b$ & 650 & $Y 2555$ & . & Wise & 743 & & & & & & $-1 / 2$ & $\mathrm{x}$ & $x$ & $x$ & & \\
\hline \multirow{2}{*}{$3 / 2$} & $36 a c a$ & 500 & Y2706 & & Wood & 155 & 56 & 62 & Red & & $-1 / 2$ & $x$ & B & & & & \\
\hline & - & & & & & & 122 & 136 & & & & & & & & & \\
\hline $3 / 2$ & $36 \mathrm{acc}$ & 520 & $Y 2700$ & & Wood & 545 & $\begin{array}{r}45 \\
450\end{array}$ & $\begin{array}{r}50 \\
455\end{array}$ & Red & & $-1 / 2$ & $x$ & $x$ & $x$ & $x$ & & \\
\hline
\end{tabular}


TABLE XII

\section{STRATIGRAPHIC DIVISIONS OF WELLS MEASURED BY THE OWRD} CONTINUED

\begin{tabular}{|c|c|c|c|}
\hline $3 / 2$ & $23 \mathrm{bcb}$ & 620 & \\
\hline $3 / 2$ & $23 \mathrm{bac}$ & 765 & $Y 2539$ \\
\hline $3 / 2$ & $23 \mathrm{bac}$ & 660 & Y2339 \\
\hline$T / R$ & & Elev. & Well \\
\hline (Sec & $(t)$. & & I.D. \\
\hline $3 / 2$ & $24 \mathrm{bdb}$ & 960 & $Y 2548$ \\
\hline $3 / 2$ & $24 \mathrm{bdc}$ & 920 & $Y 2550$ \\
\hline $3 / 2$ & $24 \mathrm{bad}$ & 1000 & Y2544 \\
\hline $3 / 2$ & $24 \mathrm{dbd}$ & 750 & \\
\hline$T / R$ & & Elev. & Well \\
\hline I Sec & t. . & & I.D. \\
\hline $3 / 2$ & $25 a c a$ & 470 & $Y 2566$ \\
\hline $3 / 2$ & $25 \mathrm{cbc}$ & 850 & $Y 2574$ \\
\hline $3 / 2$ & $25 a a a$ & 615 & \\
\hline $3 / 2$ & $25 \mathrm{bad}$ & 495 & Y2559 \\
\hline$T / R$ & & Elev. & Well \\
\hline (Sec & t. . & & I.D. \\
\hline $3 / 2$ & $26 a a b$ & 625 & $Y 2528$ \\
\hline $3 / 2$ & $26 \mathrm{bda}$ & 640 & Y2599 \\
\hline $3 / 2$ & $26 \mathrm{bab}$ & 700 & $Y 2563$ \\
\hline $3 / 2$ & $26 \mathrm{bba}$ & 655 & $Y 2592$ \\
\hline $3 / 2$ & $26 \mathrm{bdb}$ & 610 & Y2609 \\
\hline $3 / 2$ & $26 \mathrm{daa}$ & 855 & $Y 2596$ \\
\hline $3 / 2$ & $26 \mathrm{abb}$ & 830 & Y316 \\
\hline$T / R$ & & Elev. & Well \\
\hline
\end{tabular}

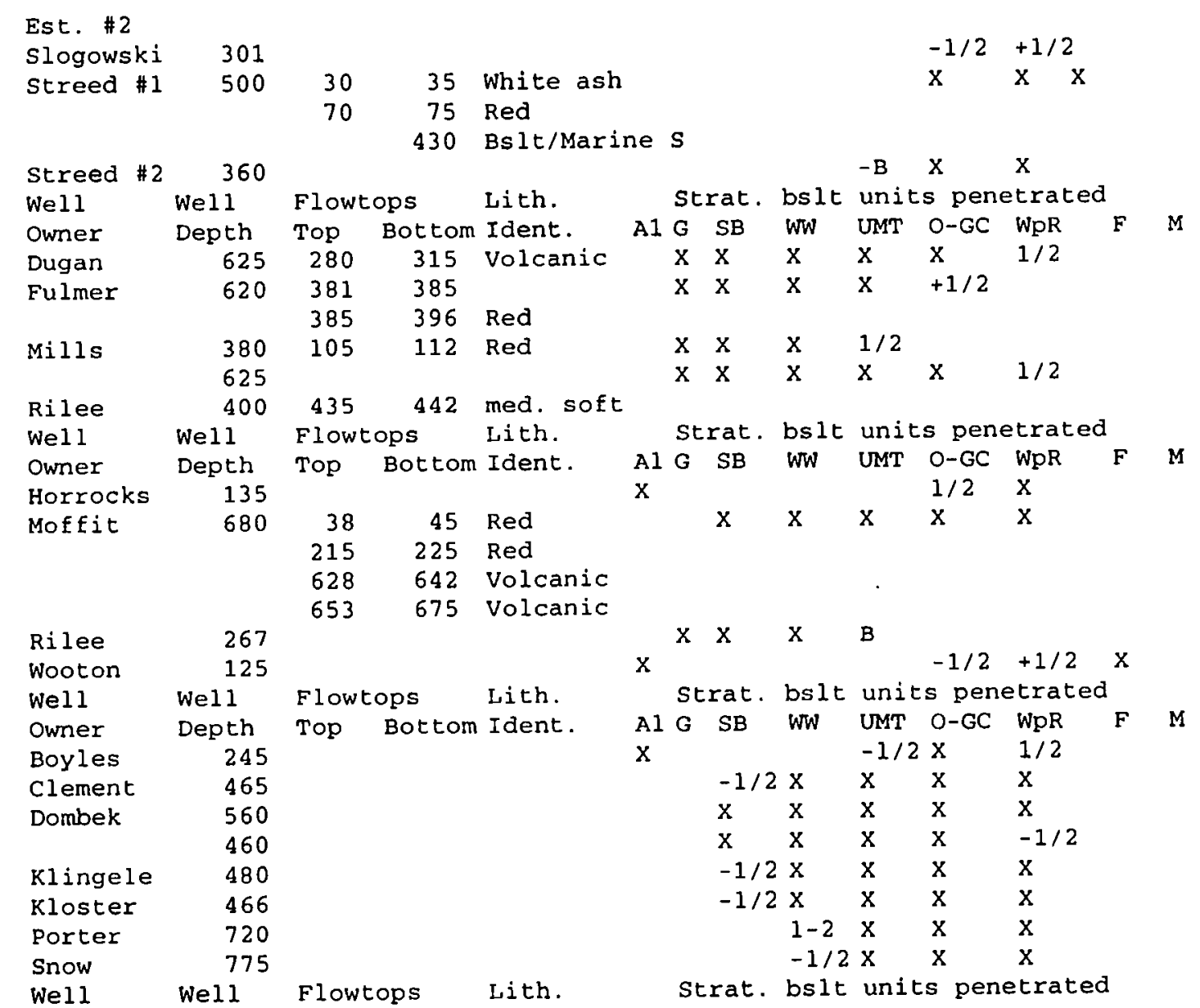


Guidelines for Table XII

TABLE XIII

DESIGNATION OF BASALT UNIT PENETRATION BY A WATER WELL

$X$ - full penetration of the unit
$-1 / 2$ - lower portion of the unit is penetrated
$+1 / 2$ - upper portion of the unit is penetrated
B - upper basalt flow boundary is penetrated
$-B$ - lower basalt flow boundary is penetrated

TABLE XIV

LIST OF INITIALS FOR BASALT UNIT BOUNDARIES

Basalt Flow

Boundaries

Ginkgo/Sentinel Bluffs

Sentinel Bluffs/Sentinel Bluffs

Sentinel Bluffs/Winter Water

Winter Water/Winter Water

Winter Water/Umtanum

Umtanum/Umtanum

Umtanum/Ortley-Grouse Creek

Ortley-Grouse Creek \#1/Ortley-Grouse Creek \#2

Ortley-Grouse Creek \#2/Ortley-Grouse Creek \#3

Ortley-Grouse Creek/Wapshilla Ridge

Within the Wapshilla Ridge
Basalt Boundary Designation

$\mathrm{G} / \mathrm{SB}$

$\mathrm{SB} / \mathrm{SB}$

$\mathrm{SB} / \mathrm{WW}$

$\mathrm{WW} / \mathrm{WW}$

$\mathrm{WW} / \mathrm{U}$

$\mathrm{U} / \mathrm{U}$

$\mathrm{U} / \mathrm{OGC}$

OGC2

OGC3

OGC/WpR

$\mathrm{WpR}$ 
APPENDIX B

HYDROLOGIC DATA

* hydrologic data provided by Miller and others (1994) 
TABLE XV

\section{PARRETT MOUNTAIN HYDROLOGIC DATA}

$T / R$

(Sect.)

$2 / 132 \mathrm{bda}$
Elev. Well Well I.D. Owner

190 W1823 Sherwood \#3
Well Yield St. Wate: Date of Measured Water Bear. Corresp Depth 339

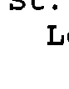


TABLE XV

PARRETT MOUNTAIN HYDROLOGIC DATA CONTINUED

$2506 / 01 / 66$ OWRD

$2507 / 05 / 66$ OWRD

$3607 / 27 / 66$ OWRD

$2508 / 03 / 66$ OWRD

$2509 / 04 / 66$ OWRD

66 10/04/66 OWRD

$4010 / 25 / 66$ OWRD

$2511 / 01 / 66$ OWRD

$2512 / 06 / 66$ OWRD

$3402 / 01 / 67$ OWRD

$24 \quad 04 / 25 / 67$ OWRD

$4107 / 18 / 67$ OWRD

$4410 / 18 / 67$ OWRD

$4211 / 01 / 67$ OWRD

$3812 / 05 / 67$ OWRD

$3801 / 03 / 68$ OWRD

$2801 / 16 / 68$ OWRD

$2702 / 06 / 68$ OWRD

$26.504 / 16 / 68$ OWRD

$3707 / 17 / 68$ OWRD

$3308 / 28 / 68$ OWRD

$40.510 / 15 / 68$ OWRD

$2711 / 29 / 68$ OWRD

$3501 / 21 / 69$ OWRD

$3502 / 03 / 69$ OWRD

$2503 / 04 / 69$ OWRD

$2604 / 04 / 69$ OWRD

$41.507 / 15 / 69$ OWRD

$48 \quad 10 / 15 / 69$ OWRD

$59.501 / 15 / 70$ OWRD

$4401 / 19 / 70$ OWRD

$4302 / 02 / 70$ OWRD

$3903 / 12 / 70$ OWRD

$39.504 / 14 / 70$ OWRD 
TABLE XV

PARRETT MOUNTAIN HYDROLOGIC DATA CONTINUED

$\begin{array}{rl}46 & 06 / 23 / 70 \text { OWRD } \\ 54 & 07 / 21 / 70 \text { OWRD } \\ 54 & 08 / 04 / 70 \text { OWRD } \\ 52.5 & 10 / 20 / 70 \text { OWRD } \\ 47 & 12 / 29 / 70 \text { OWRD } \\ 46 & 01 / 25 / 71 \text { OWRD } \\ 45 & 02 / 18 / 71 \text { OWRD } \\ 44 & 04 / 20 / 71 \text { OWRD } \\ 45 & 07 / 19 / 71 \text { OWRD } \\ 54 & 09 / 02 / 71 \text { OWRD } \\ 52 & 10 / 14 / 71 \text { OWRD } \\ 43 & 12 / 20 / 71 \text { OWRD } \\ 44 & 02 / 21 / 72 \text { OWRD } \\ 42 & 03 / 06 / 72 \text { OWRD } \\ 39 & 04 / 11 / 72 \text { OWRD } \\ 53 & 05 / 19 / 72 \text { OWRD } \\ 57 & 07 / 05 / 72 \text { OWRD } \\ 67 & 08 / 07 / 72 \text { OWRD } \\ 63 & 02 / 14 / 73 \text { OWRD } \\ 59 & 04 / 12 / 73 \text { OWRD } \\ 46 & 07 / 12 / 73 \text { OWRD } \\ 52 & 07 / 31 / 52 \text { OWRD } \\ 47 & 10 / 04 / 73 \text { OWRD } \\ 45 & 12 / 07 / 73 \text { OWRD } \\ 43 & 01 / 03 / 74 \text { OWRD } \\ 40 & 03 / 04 / 74 \text { OWRD } \\ 37 & 04 / 19 / 74 \text { OWRD } \\ 46 & 09 / 30 / 74 \text { OWRD } \\ 42 & 01 / 13 / 75 \text { OWRD } \\ 38 & 03 / 31 / 75 \text { OWRD } \\ 40 & 06 / 30 / 75 \text { OWRD } \\ 63 & 10 / 06 / 75 \text { OWRD } \\ 42 & 01 / 05 / 76 \text { OWRD } \\ 39 & 04 / 05 / 76 \text { OWRD }\end{array}$


TABLE XV

PARRETT MOUNTAIN HYDROLOGIC DATA CONTINUED

$\begin{array}{rl}40 & 07 / 09 / 76 \text { OWRD } \\ 63 & 07 / 08 / 77 \text { OWRD } \\ 46 & 09 / 26 / 77 \text { OWRD } \\ 61 & 01 / 09 / 78 \text { OWRD } \\ 39 & 04 / 03 / 78 \text { OWRD } \\ 23 & 04 / 23 / 79 \text { OWRD } \\ 61.5 & 04 / 15 / 80 \text { OWRD } \\ 50 & 10 / 01 / 80 \text { OWRD } \\ 51.49 & 10 / 02 / 80 \text { OWRD } \\ 46.81 & 04 / 16 / 81 \text { OWRD } \\ 51.5 & 10 / 23 / 81 \text { OWRD } \\ 65.35 & 10 / 01 / 82 \text { OWRD } \\ 67.7 & 10 / 13 / 82 \text { OWRD } \\ 42.8 & 03 / 08 / 83 \text { OWRD } \\ 47 & 10 / 20 / 83 \text { OWRD } \\ 43.98 & 05 / 21 / 84 \text { OWRD } \\ 68.82 & 10 / 17 / 84 \text { OWRD } \\ 51.49 & 04 / 05 / 85 \text { OWRD } \\ 51.49 & 04 / 25 / 85 \text { OWRD } \\ 58.42 & 10 / 24 / 85 \text { OWRD } \\ 71.7 & 04 / 28 / 86 \text { OWRD } \\ 51.7 & 04 / 12 / 88 \text { OWRD } \\ 57.7 & 07 / 22 / 88 \text { OWRD } \\ 56 & 11 / 01 / 89 \text { SHERWOOD } \\ 60 & 12 / 01 / 89 \text { SHERWOOD } \\ 52 & 01 / 01 / 90 \text { SHERWOOD } \\ 52 & 02 / 01 / 90 \text { SHERWOOD } \\ 55 & 03 / 01 / 90 \text { SHERWOOD } \\ 68 & 04 / 01 / 90 \text { SHERWOOD } \\ 50 & 05 / 01 / 90 \text { SHERWOOD } \\ 55 & 06 / 01 / 90 \text { SHERWOOD } \\ 52 & 07 / 01 / 90 \text { SHERWOOD } \\ 56 & 08 / 01 / 90 \text { SHERWOOD } \\ 52 & 09 / 01 / 90 \text { SHERWOOD }\end{array}$


TABLE XV

PARRETT MOUNTAIN HYDROLOGIC DATA CONTINUED

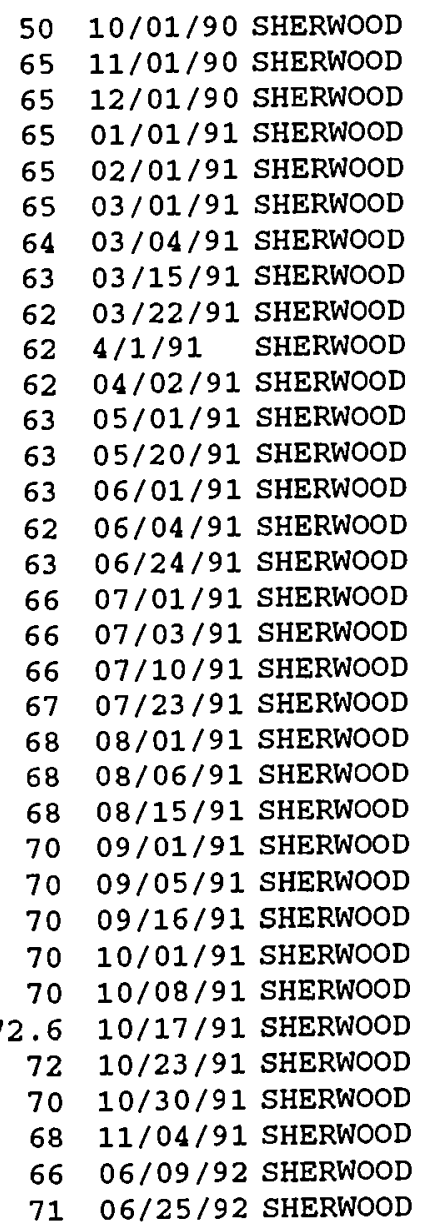


TABLE XV

\section{PARRETT MOUNTAIN HYDROLOGIC DATA} CONTINUED

$2 / 132 \mathrm{cbc}$ 190 W717

Sherwood \#5

$\begin{array}{rl}67 & 07 / 17 / 92 \text { SHERWOOD } \\ 68 & 08 / 14 / 92 \text { SHERWOOD } \\ 62 & 11 / 01 / 92 \text { SHERWOOD } \\ 62 & 12 / 01 / 92 \text { SHERWOOD } \\ 63 & 01 / 18 / 93 \text { SHERWOOD } \\ 60 & 02 / 12 / 93 \text { SHERWOOD } \\ 60 & 03 / 12 / 93 \text { SHERWOOD } \\ 57.5 & 03 / 30 / 93 \text { SHERWOOD } \\ 57 & 04 / 15 / 93 \text { SHERWOOD } \\ 57 & 05 / 15 / 93 \text { SHERWOOD } \\ 57 & 06 / 15 / 93 \text { SHERWOOD } \\ 57 & 07 / 15 / 93 \text { SHERWOOD } \\ 57 & 08 / 19 / 93 \text { SHERWOOD } \\ 3.2 & 10 / 21 / 93 \text { OWRD } \\ 48 & 10 / 25 / 84 \text { drilIE } \\ 53 & 11 / 01 / 89 \text { SHERWOOD } 253 \\ 57 & 12 / 01 / 89 \text { SHERWOOD } \\ 55 & 01 / 01 / 90 \text { SHERWOOD } \\ 55 & 02 / 01 / 90 \text { SHERWOOD } \\ 52 & 03 / 01 / 90 \text { SHERWOOD } \\ 52 & 04 / 01 / 90 \text { SHERWOOD } \\ 52 & 05 / 01 / 90 \text { SHERWOOD } \\ 52 & 06 / 01 / 90 \text { SHERWOOD } \\ 52 & 07 / 01 / 90 \text { SHERWOOD } \\ 67 & 08 / 01 / 90 \text { SHERWOOD } \\ 63 & 09 / 01 / 90 \text { SHERWOOD } \\ 65 & 10 / 01 / 90 \text { SHERWOOD } \\ 5.6 & 11 / 01 / 90 \text { SHERWOOD } \\ 8.6 & 12 / 01 / 90 \text { SHERWOOD } \\ 58 & 02 / 01 / 91 \text { SHERWOOD } \\ 58 & 03 / 01 / 91 \text { SHERWOOD } \\ 55 & 04 / 01 / 91 \text { SHERWOOD } \\ 54 & 05 / 01 / 91 \text { SHERWOOD } \\ \end{array}$

139 
TABLE XV

\section{PARRETT MOUNTAIN HYDROLOGIC DATA} CONTINUED

$\begin{array}{rl}55 & 06 / 01 / 91 \text { SHERWOOD } \\ 58 & 07 / 01 / 91 \text { SHERWOOD } \\ 60 & 08 / 01 / 91 \text { SHERWOOD } \\ 62.5 & 09 / 01 / 91 \text { SHERWOOD } \\ 62.5 & 10 / 01 / 91 \text { SHERWOOD } \\ 61 & 11 / 01 / 91 \text { SHERWOOD } \\ 58.5 & 12 / 01 / 91 \text { SHERWOOD } \\ 54.91 & 01 / 10 / 92 \text { OWRD } \\ 62.5 & 01 / 20 / 92 \text { SHERWOOD } \\ 56 & 03 / 02 / 92 \text { SHERWOOD } \\ 60 & 03 / 20 / 92 \text { SHERWOOD } \\ 60 & 04 / 17 / 92 \text { SHERWOOD } \\ 57.5 & 05 / 18 / 92 \text { SHERWOOD } \\ 64.5 & 06 / 09 / 92 \text { SHERWOOD } \\ 62 & 07 / 17 / 92 \text { SHERWOOD } \\ 63 & 08 / 14 / 92 \text { SHERWOOD } \\ 55 & 11 / 01 / 92 \text { SHERWOOD } \\ 55 & 12 / 01 / 92 \text { SHERWOOD } \\ 60 & 01 / 18 / 93 \text { SHERWOOD } \\ 55 & 02 / 12 / 93 \text { SHERWOOD } \\ 55 & 03 / 12 / 93 \text { SHERWOOD } \\ 52 & 03 / 30 / 93 \text { SHERWOOD } \\ 52 & 04 / 15 / 93 \text { SHERWOOD } \\ 51 & 05 / 14 / 93 \text { SHERWOOD } \\ 52 & 06 / 15 / 93 \text { SHERWOOD } \\ 52 & 07 / 15 / 93 \text { SHERWOOD } \\ 57 & 08 / 19 / 93 \text { SHERWOOD } \\ 57.54 & 10 / 21 / 93 \text { OWRD } \\ W & 0469\end{array}$

$T / R$

(Sect.)

$3 / 14 \mathrm{bdb}$
Elev.

$270 \quad C 7723$
Well

Owmer

Axelson
Well

Depth

200

$D$

st.

$$
\begin{array}{rl}
55 & 06 / 01 / 91 \text { SHERWOOD } \\
58 & 07 / 01 / 91 \text { SHERWOOD } \\
60 & 08 / 01 / 91 \text { SHERWOOD } \\
62.5 & 09 / 01 / 91 \text { SHERWOOD } \\
62.5 & 10 / 01 / 91 \text { SHERWOOD } \\
61 & 11 / 01 / 91 \text { SHERWOOD } \\
58.5 & 12 / 01 / 91 \text { SHERWOOD } \\
54.91 & 01 / 10 / 92 \text { OWRD } \\
62.5 & 01 / 20 / 92 \text { SHERWOOD } \\
56 & 03 / 02 / 92 \text { SHERWOOD } \\
60 & 03 / 20 / 92 \text { SHERWOOD } \\
60 & 04 / 17 / 92 \text { SHERWOOD } \\
57.5 & 05 / 18 / 92 \text { SHERWOOD } \\
64.5 & 06 / 09 / 92 \text { SHERWOOD } \\
62 & 07 / 17 / 92 \text { SHERWOOD } \\
63 & 08 / 14 / 92 \text { SHERWOOD } \\
55 & 11 / 01 / 92 \text { SHERWOOD } \\
55 & 12 / 01 / 92 \text { SHERWOOD } \\
60 & 01 / 18 / 93 \text { SHERWOOD } \\
55 & 02 / 12 / 93 \text { SHERWOOD } \\
55 & 03 / 12 / 93 \text { SHERWOOD } \\
52 & 03 / 30 / 93 \text { SHERWOOD } \\
52 & 04 / 15 / 93 \text { SHERWOOD } \\
51 & 05 / 14 / 93 \text { SHERWOOD } \\
52 & 06 / 15 / 93 \text { SHERWOOD } \\
52 & 07 / 15 / 93 \text { SHERWOOD } \\
57 & 08 / 19 / 93 \text { SHERWOOD } \\
57.54 & 10 / 21 / 93 \text { OWRD } \\
695 & 096901 \text { MeE }
\end{array}
$$

- Wate:Date of Measured

90 07/13/92 driller

$71.5910 / 22 / 92$ OWRD

to

Water $B$

Bear. Corresp Est.

$116123 \quad U / U$

156164 fault

$187 \quad 194$ OGC? /OGC gpm

2

6
12
Design. Main Aquifer 198 OGC/WpR 


\section{TABLE XV}

PARRETT MOUNTȦIN HYDROLOGIC DATA

\section{CONT INUED}

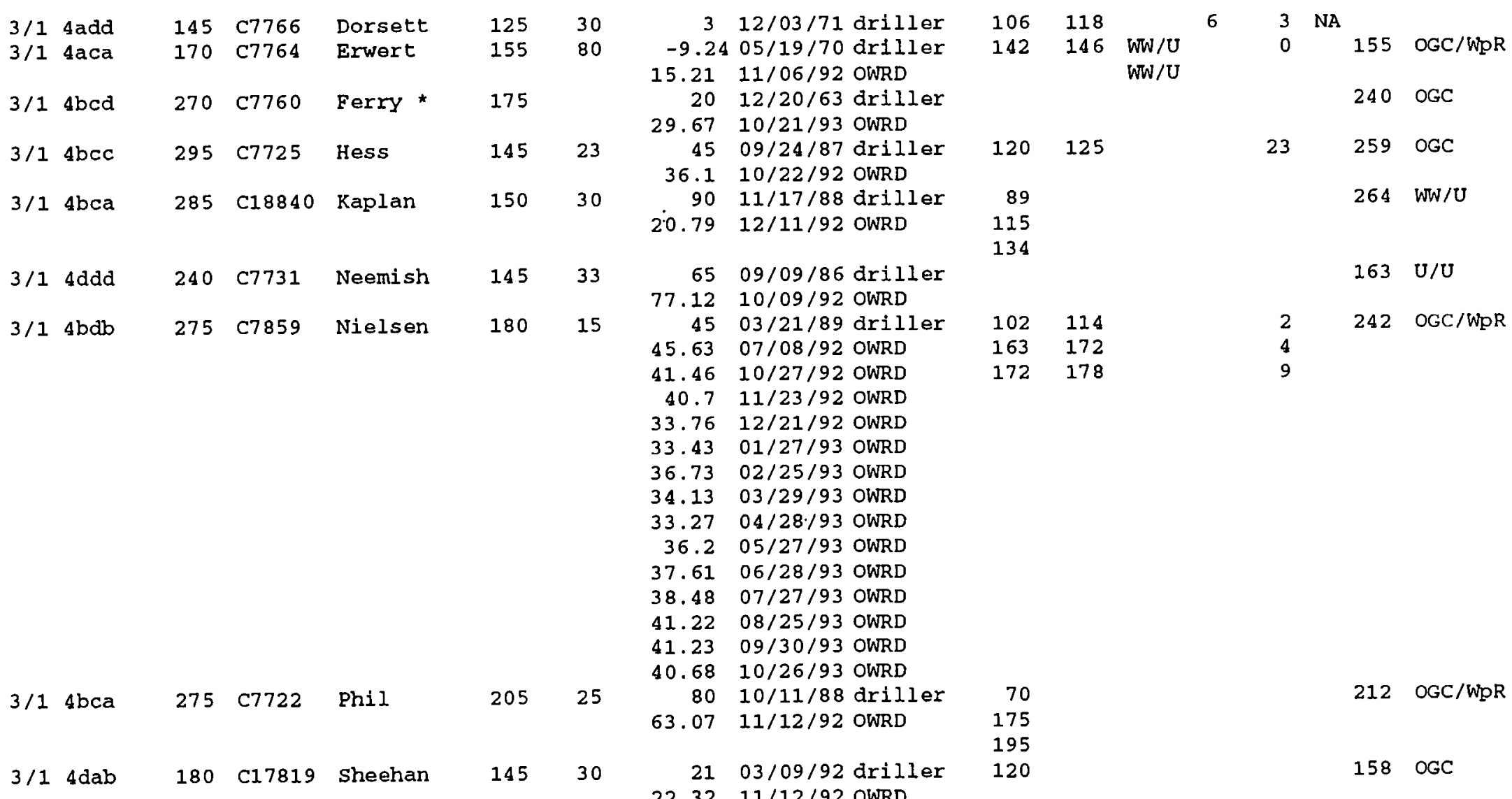


PARRETT MOUNTAIN HYDROLOGIC DATA

CONTINUED

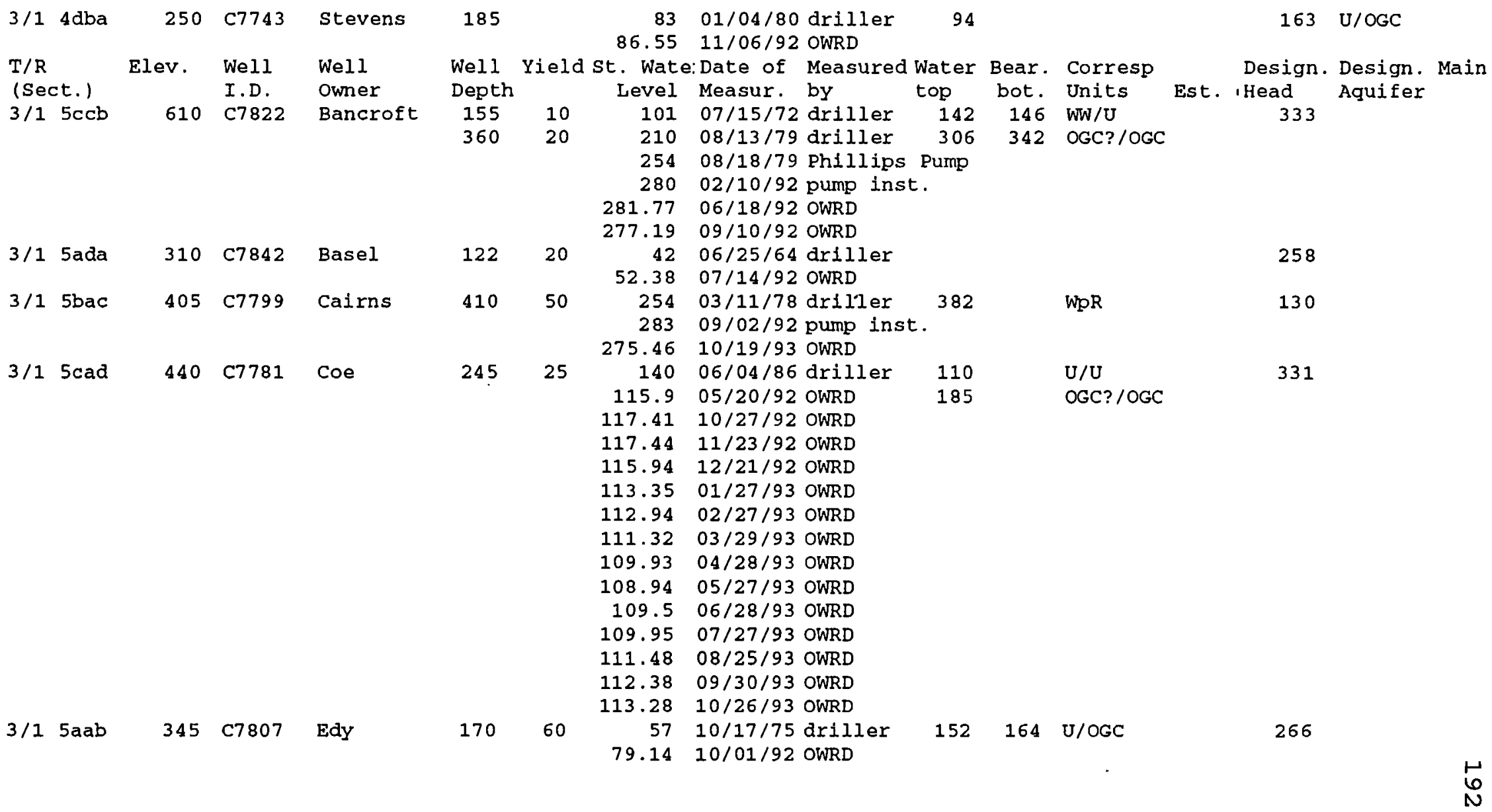


TABLE XV

PARRETT MOUNTAIN HYDROLOGIC DATA CONT INUED

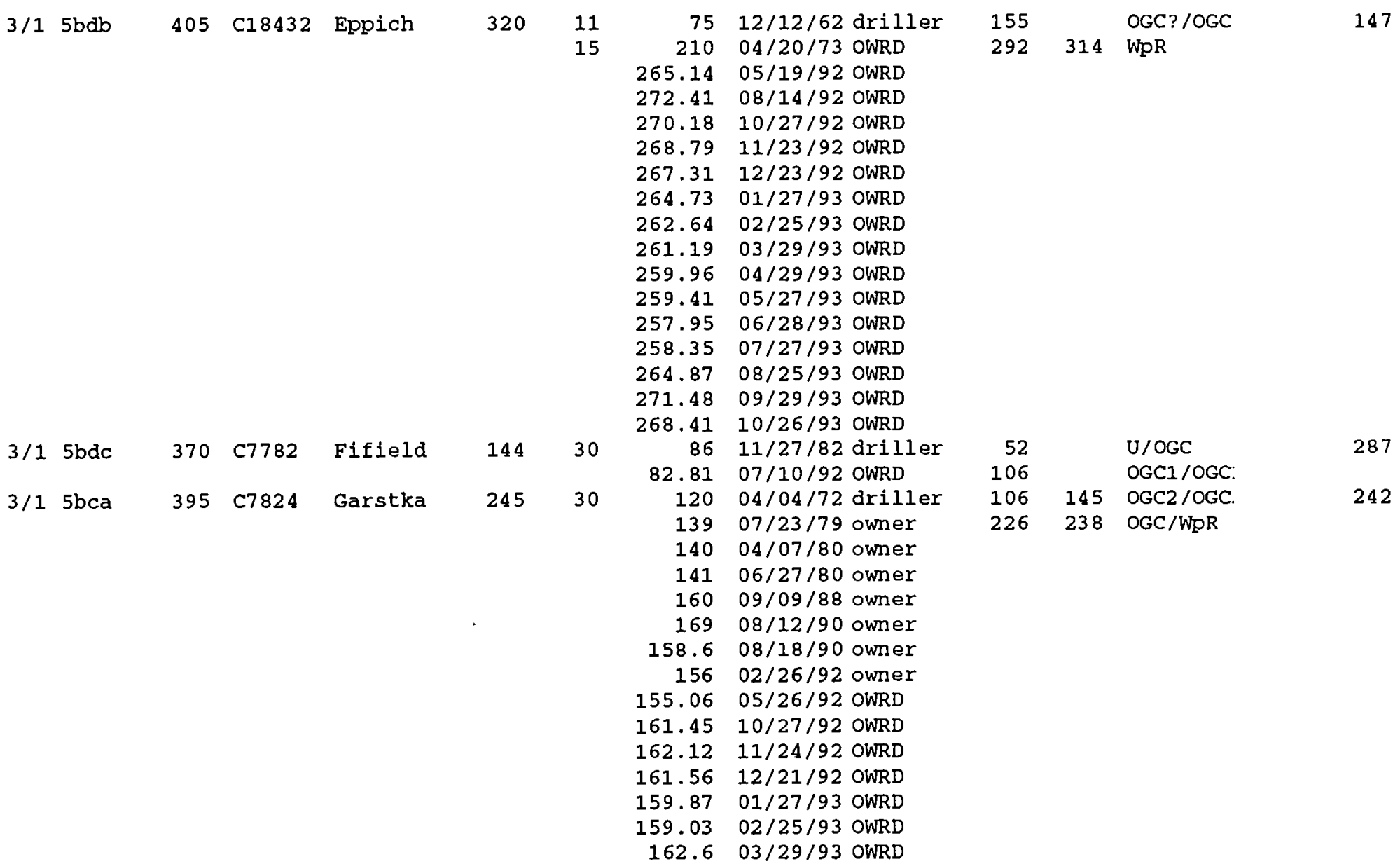


PARRETT MOUNTAIN HYDROLOGIC DATA

\section{CONTINUED}

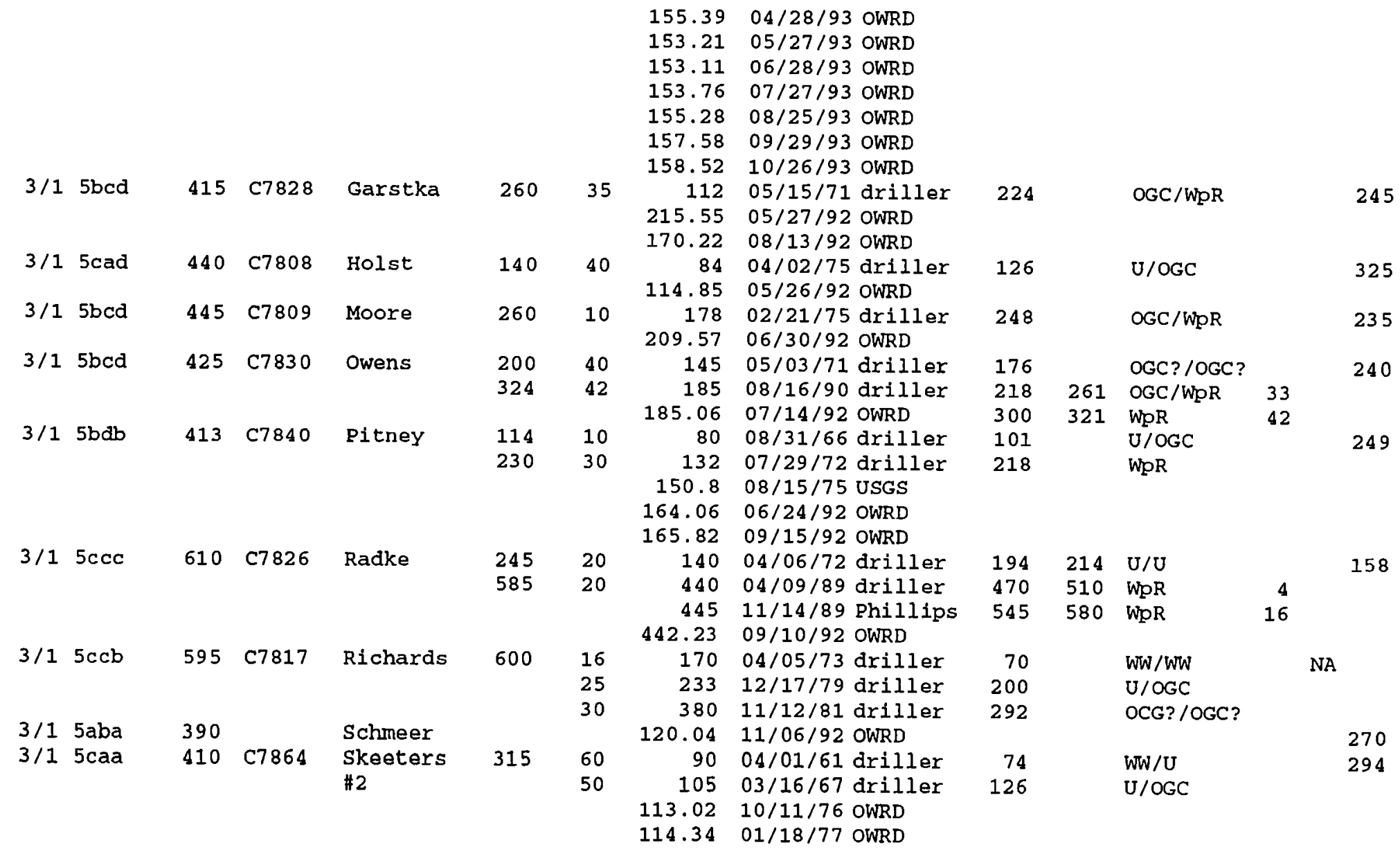


TABLE XV

PARRETT MOUNTAIN HYDROLOGIC DATA

$\begin{array}{lllll}3 / 1 & \text { caa } & 425 & \text { C12324 } & \begin{array}{l}\text { Skeeters } \\ \# 2\end{array} \\ 3 / 1 & 5 \text { daa } & 310 & \text { C7841 } & \text { Smith } \\ 3 / 15 \mathrm{cba} & 440 & \mathrm{C7797} & \text { Vanlac } \\ 3 / 15 & 310 & \mathrm{c} 7802 & \text { Voss }\end{array}$

\section{CONTINUED}

$113.0204 / 18 / 77$ OWRD

$115.807 / 19 / 77$ OWRD

$115.2610 / 10 / 77$ OWRD

$107.8101 / 27 / 78$ OWRD

$109.5804 / 11 / 78$ OWRD

$116.0710 / 09 / 78$ OWRD

$110.4604 / 19 / 79$ OWRD

$108.1504 / 02 / 80$ OWRD

$114.4509 / 16 / 80$ OWRD

$114.210 / 07 / 81$ OWRD

$106.404 / 15 / 82$ OWRD

$112.609 / 29 / 82$ OWRD

$105.504 / 29 / 83$ OWRD

$111.68 \quad 09 / 22 / 83$ OWRD

$107.0805 / 17 / 84$ OWRD

$108.8906 / 05 / 85$ OWRD

$113.6710 / 03 / 85$ OWRD

$111.906 / 04 / 86$ OWRD

$115.306 / 16 / 87$ OWRD

$111.3706 / 13 / 88$ OWRD

$111.2605 / 15 / 91$ OWRD

$115.6608 / 13 / 92$ OWRD

$323 \quad 37 \quad 11909 / 05 / 91$ driller $210 \quad$ OGC?/OGC?

$123.0708 / 13 / 92$ OWRD $278 \quad$ OGC/WpR

$40 \quad 05 / 17 / 65$ driller $125 \quad \mathrm{U} / \mathrm{U}$

$\mathrm{U} /$ OGC

OGC/WpR

$60.9608 / 13 / 92$ OWRD

$18410 / 07 / 78$ driller 246

196 05/07/83 Phillips Pump

196.33 01/24/86 Phililps Pump

$18805 / 19 / 92$ OWRD

292307 OGC/WpR
302 OGC , OGC/WpR

249 OGC/WpR

252 WpR

OGC/WpR 
TABLE XV

\section{PARRETT MOUNTAIN HYDROLOGIC DATA CONTINUED}

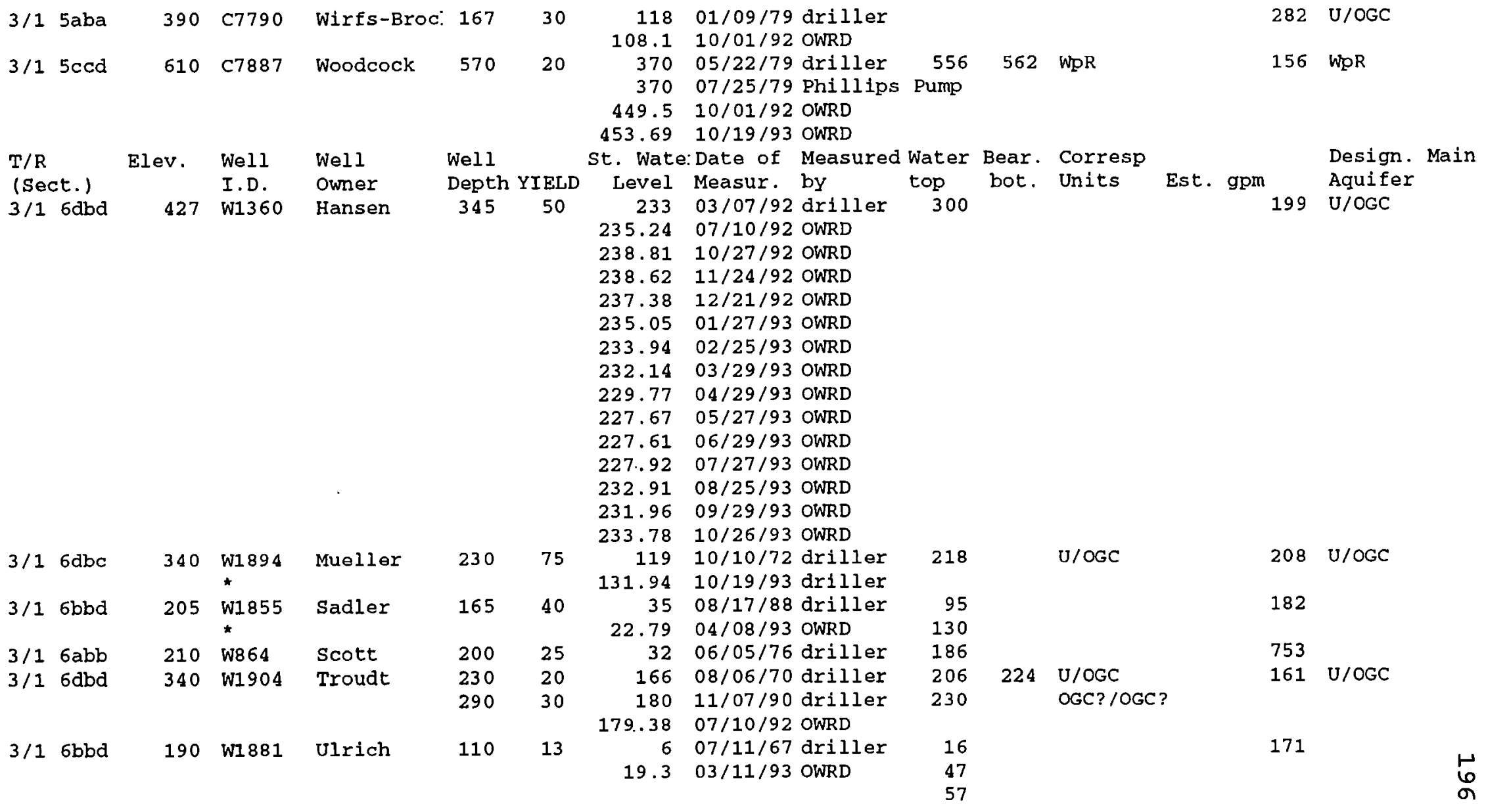


TABLE XV

\section{PARRETT MOUNTAIN HYDROLOGIC DATA CONTINUED}

75

\begin{tabular}{|c|c|c|c|c|c|c|c|c|c|c|}
\hline \multirow{2}{*}{\multicolumn{2}{|c|}{$\begin{array}{l}\text { T/R } \\
\text { (Sect.) }\end{array}$}} & \multirow{2}{*}{ Elev. } & \multirow{2}{*}{$\begin{array}{l}\text { Well } \\
\text { I.D. }\end{array}$} & \multirow{3}{*}{$\begin{array}{l}\text { Well } \\
\text { Owner } \\
\text { Auel }\end{array}$} & \multirow{3}{*}{$\begin{array}{l}\text { Well } \\
\text { Depth } \\
485\end{array}$} & Yield st. & \multicolumn{2}{|c|}{ - Wate: Date of } & \multicolumn{2}{|c|}{ Measured Water } \\
\hline & & & & & & & Level & Measur. & by & top \\
\hline & & 820 & W1929 & & & 30 & $\begin{array}{l}335 \\
330\end{array}$ & $\begin{array}{l}11 / 11 / 86 \\
08 / 03 / 87\end{array}$ & $\begin{array}{l}\text { drillex } \\
\text { Phillips }\end{array}$ & $\begin{array}{l}115 \\
415\end{array}$ \\
\hline & & & & & & & 330.67 & $09 / 10 / 92$ & OWRD & \\
\hline /1 & $7 \mathrm{dbb}$ & 880 & W1942 & Bach & 200 & 10 & 158 & $04 / 28 / 78$ & driller & 178 \\
\hline & & & & & & & 125 & $05 / 11 / 78$ & Phillips & Pump \\
\hline & & & & & & & 144 & $08 / 25 / 92$ & OWRD & \\
\hline & & & & & & & 146.93 & $10 / 27 / 92$ & OWRD & \\
\hline & & & & & & & 148.48 & $11 / 24 / 92$ & OWRD & \\
\hline & & & & & & & 148.47 & $12 / 21 / 92$ & OWRD & \\
\hline & & & & & & & 142.86 & $01 / 28 / 93$ & OWRD & \\
\hline & & & & & & & 139.66 & $02 / 25 / 93$ & OWRD & \\
\hline & & & & & & & 141.49 & $03 / 30 / 93$ & OWRD & \\
\hline & & & & & & & 134.11 & $04 / 25 / 93$ & OWRD & \\
\hline & & & & & & & 131.95 & $05 / 28 / 93$ & OWRD & \\
\hline & & & & & & & 133.47 & $06 / 29 / 93$ & OWRD & \\
\hline & & & & & & & 134.65 & $07 / 28 / 93$ & OWRD & \\
\hline & & & & & & & 137.85 & $08 / 26 / 93$ & OWRD & \\
\hline & & & & & & & 142.6 & $09 / 30 / 93$ & OWRD & \\
\hline & & & & & & & 144.66 & $10 / 26 / 93$ & OWRD & \\
\hline $3 / 1$ & $7 \mathrm{dab}$ & 780 & W1930 & Barron \#1 & 110 & 4 & 50 & $0.5 / 01 / 86$ & driller & 67 \\
\hline $3 / 1$ & $7 \mathrm{dab}$ & 750 & W1939 & Barron \#2 & 492 & 15 & 400 & $07 / 07 / 86$ & driller & 458 \\
\hline $3 / 1$ & $7 \mathrm{adb}$ & 805 & W1 920 & Bennett & 410 & 20 & 335 & $02 / 13 / 75$ & driller & 399 \\
\hline & & & & & & & 348.28 & $10 / 09 / 92$ & OWRD & \\
\hline $3 / 1$ & $7 \mathrm{aad}$ & 775 & W3458 & Bitzenb. & 712 & 9 & 509 & $11 / 19 / 70$ & driller & 500 \\
\hline & & & & & & & 590 & $05 / 13 / 93$ & Phillips & 694 \\
\hline $3 / 1$ & 7 aad & 730 & W868 & Briggs & 715 & 7.5 & 430 & $06 / 17 / 83$ & driller & 240 \\
\hline & & & & & & & 430 & $10 / 18 / 83$ & Phillips & Pump \\
\hline $3 / 1$ & $7 \mathrm{cdd}$ & 825 & W1806 & Bulloch & 430 & 25 & 338 & $06 / 25 / 74$ & driller & 92 \\
\hline & & & & & & & 208 & $03 / 31 / 88$ & OWRD & 230 \\
\hline & & & & & & & & & & 360 \\
\hline
\end{tabular}

Bear. Corresp Design. Design. Main bot. Units Est. Head Aquifer $\begin{array}{rrr}\text { Units } & \text { Est. 'Head } & \text { Aquifer } \\ \text { WW/WW } & 489 & \text { OGC/WpR }\end{array}$ OGC? /OGC?

WW $/ U$

$748 W W / U$

\begin{tabular}{|c|c|c|c|}
\hline & $S B / W W$ & NA & WW/U \\
\hline & OGC/WpR & $\mathrm{NA}$ & OGC / WpR \\
\hline & OGC? /OGC? & 457 & OGC \\
\hline \multirow[t]{7}{*}{510} & OGC/WpR & 185 & WpR \\
\hline & WpR & & \\
\hline & U/OGC & NA & OGC/WpR \\
\hline & WW/WW & $\mathrm{NA}$ & OGC/WpR \\
\hline & OGC? /OGC? & & \\
\hline & OGC/WpR & & \\
\hline & WpR & & \\
\hline
\end{tabular}


TABLE XV

PARRETT MOUNTAIN HYDROLOGIC DATA CONTINUED

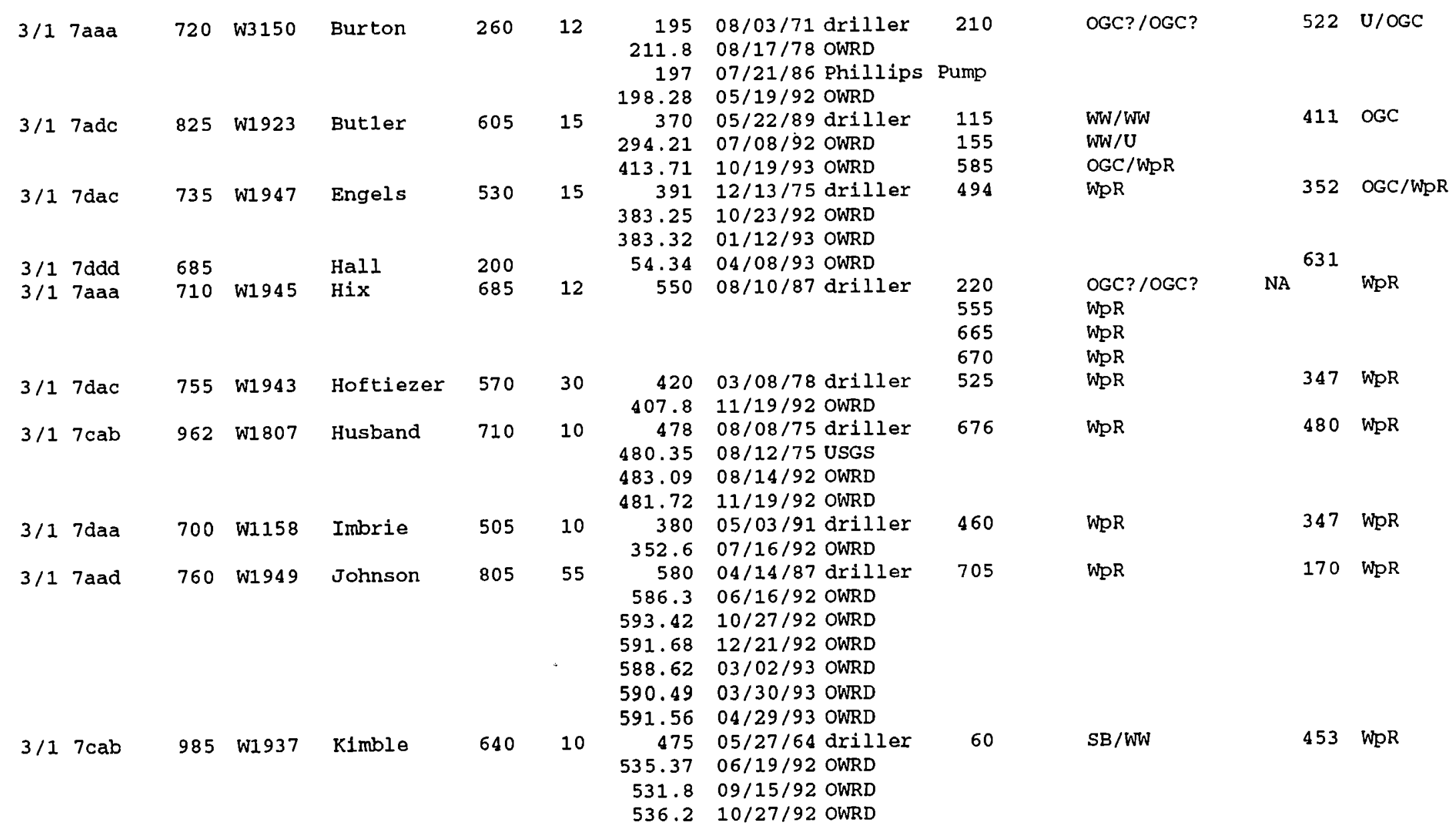


TABLE XV

PARRETT MOUNTAIN HYDROLOGIC DATA CONT INUED

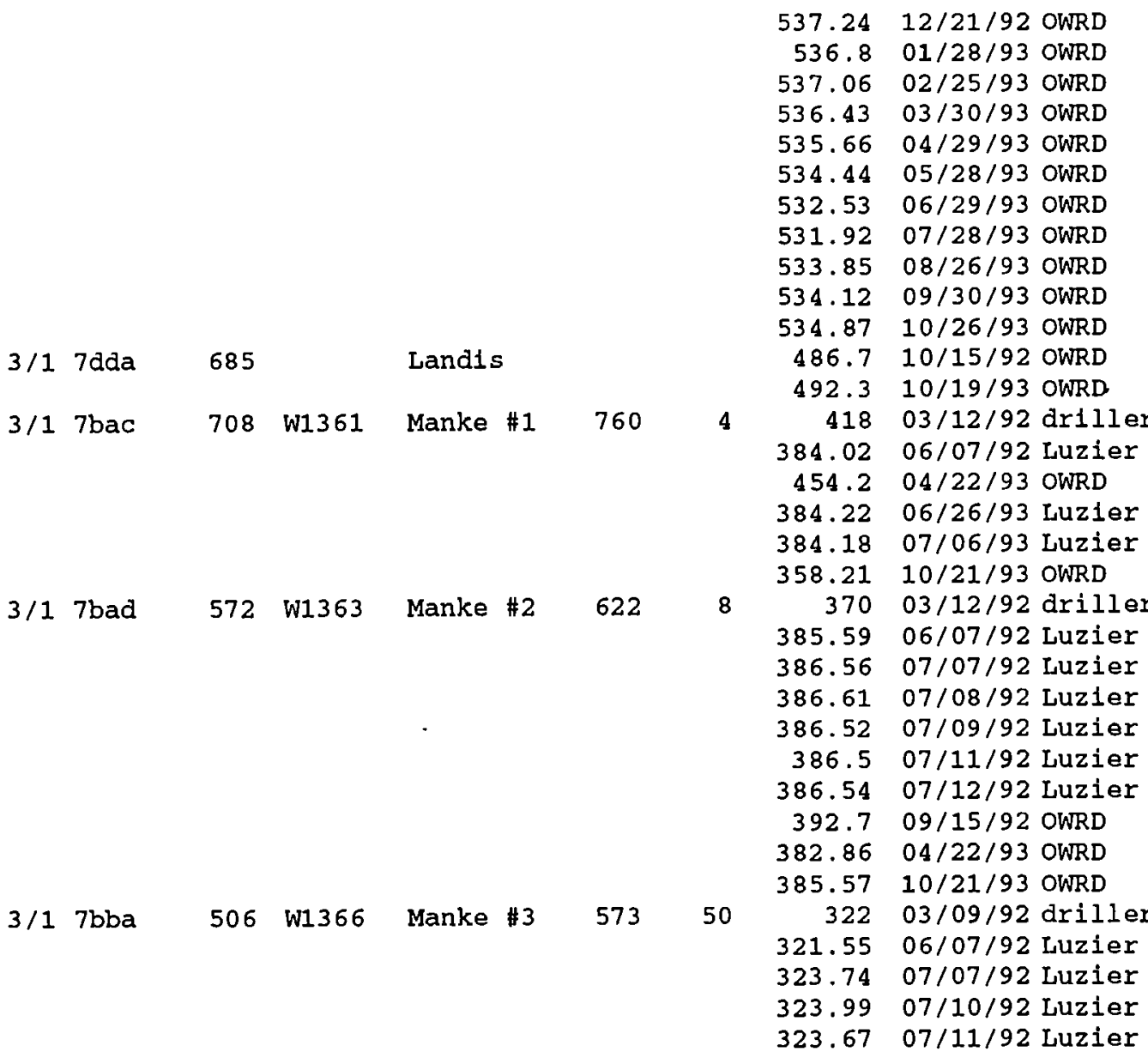

$193 W p R$

350 OGC/WpR, WpR

461

480

$189 \mathrm{WpR}$

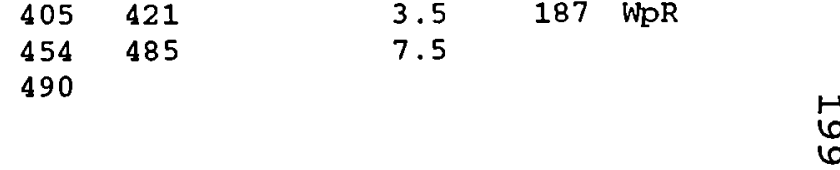


PARRETT MOUNTAIN HYDROLOGIC DATA CONTINUED

$3 / 17 \mathrm{bbc}$ 659 W1364 Manke \#4

650

22

$3 / 17 \mathrm{bac}$ 65
Manke \#6

562
$323.7807 / 12 / 92$ Luzier

$326.9609 / 15 / 92$ OWRD

$318.9504 / 22 / 93$ OWRD

$322.8310 / 21 / 93$ OWRD

$34603 / 12 / 92$ driller

$474.503 / 14 / 92$ driller

$469.8803 / 15 / 92 \mathrm{JEL}$

472.17 06/07/92 Luzier

$474.306 / 29 / 92$ OWRD

$479.3409 / 25 / 92$ OWRD

$470.2404 / 22 / 93$ OWRD

$473.210 / 21 / 93$ OWRD

$39603 / 12 / 92$ driller
$344.903 / 15 / 92 \mathrm{JEL}$

$318.3506 / 07 / 92$ JEL

$315.7807 / 08 / 92 \mathrm{JEL}$

$315.5207 / 09 / 92 \mathrm{JEL}$

$315.0207 / 11 / 92 \mathrm{JEL}$

$314.907 / 12 / 90 \mathrm{JEL}$

$314.9907 / 13 / 92$ JEL

$296.9104 / 22 / 93$ OWRD

$291.7510 / 21 / 93$ OWRD

$37503 / 09 / 72$ driller

$379.608 / 12 / 75$ USGS

$376.1108 / 13 / 92$ OWRD

$43508 / 10 / 84$ driller

$444.5910 / 23 / 92$ driller

460 04/18/86 driller

$\begin{array}{lllll}3 / 17 \mathrm{cbd} \quad 1020 & \text { w1948 Mozenico } & 735 & 15\end{array}$

$3 / 1$ 7aac 780 W1946 Nixon
$515 \quad 6$

355 11/09/87 driller

340 12/04/89 Phillips

350 05/28/92 Phillips

$335.3406 / 30 / 92$ OWRD

$\begin{array}{ll}348 & 360 \\ 558 & 590 \\ 597 & 613\end{array}$

9

15

367 WpR

530

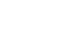

425

OGC/WpR

504 OGC/WpR

OGC? / OGC

565 WPR

OGC? /OGC

OGC? /OGC

OGC? /OGC?

OGC? /OGC?

OGC? /OGC?

OGC/WpR 
PARRETT MOUNTAIN HYDROLOGIC DATA

CONTINUED

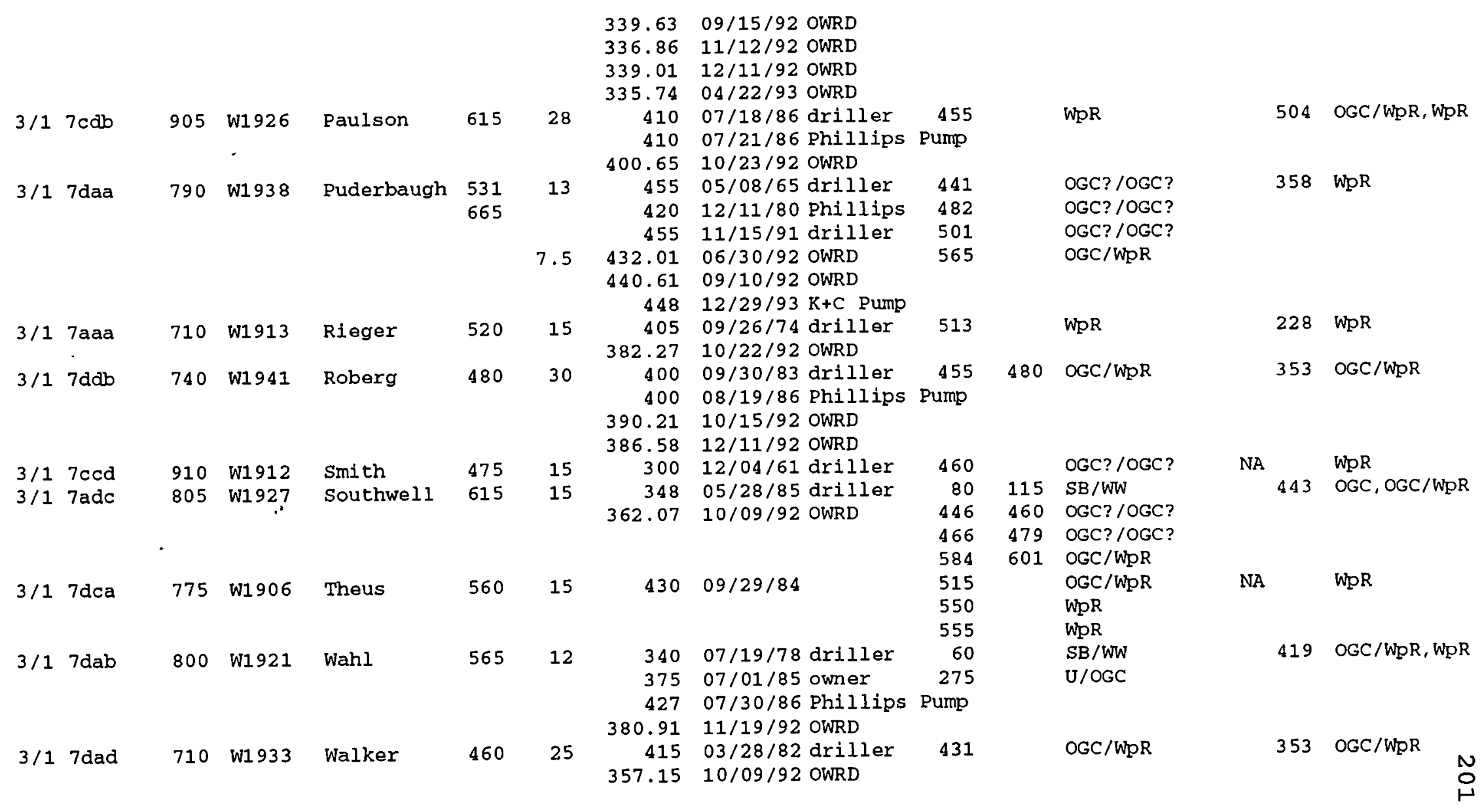




\title{
PARRETT MOUNTAIN HYDROLOGIC DATA
}

\author{
CONTINUED
}

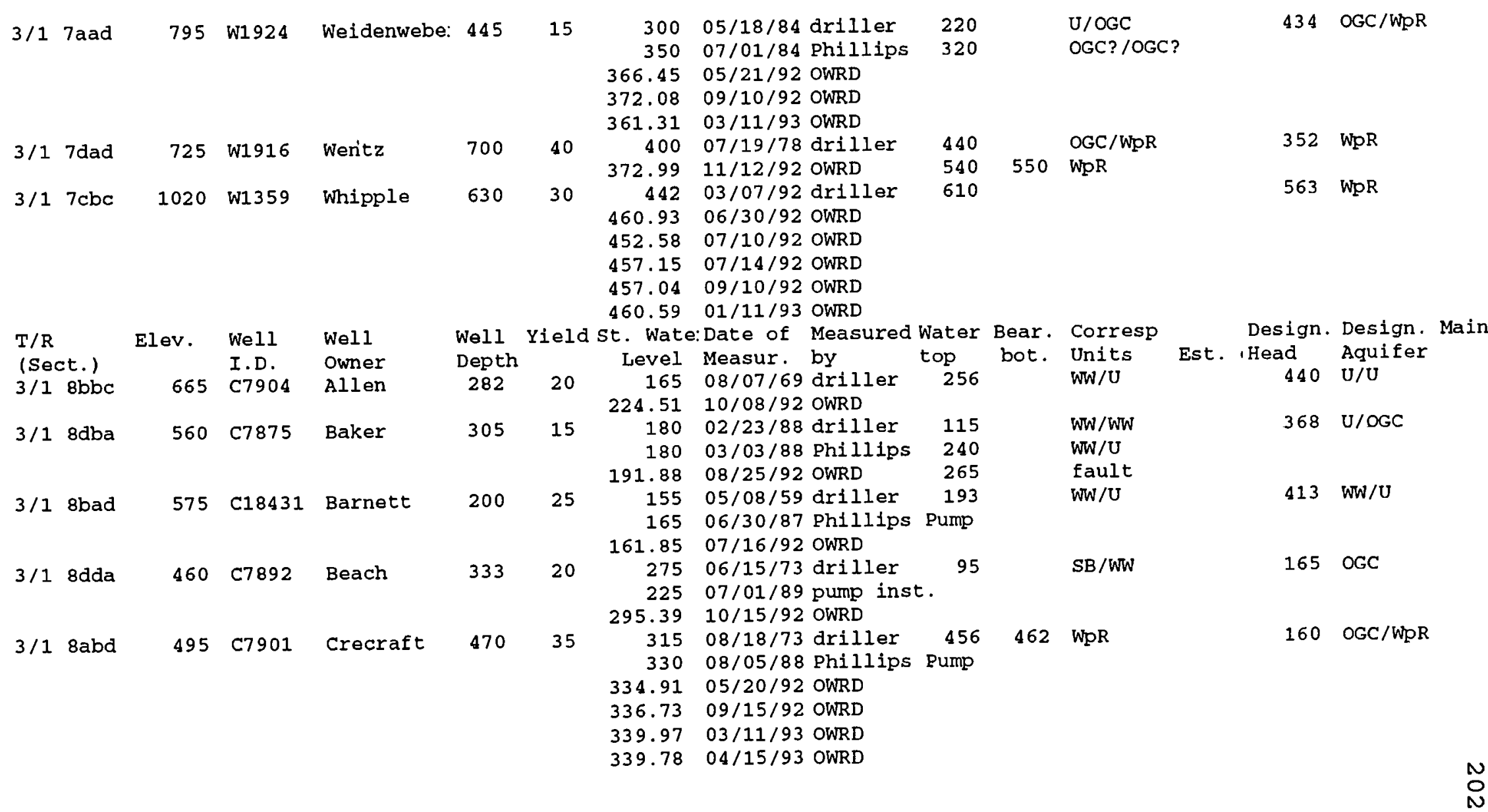


TABLE XV

PARRETT MOUNTAIN HYDROLOGIC DATA

CONTINUED

\begin{tabular}{|c|c|c|c|c|c|c|c|c|c|c|c|c|c|c|}
\hline $3 / 1$ & $8 \mathrm{dba}$ & 560 & C7879 & Cowgill & 405 & 16 & $\begin{array}{r}110 \\
117 \\
195.4\end{array}$ & $\begin{array}{l}\text { 07/09/87 driller } \\
\text { 09/21/87 Phillips } \\
\text { 10/01/92 OWRD }\end{array}$ & $\begin{array}{l}115 \\
150 \\
305 \\
355 \\
390\end{array}$ & $\begin{array}{l}135 \\
180 \\
315 \\
365 \\
400\end{array}$ & $\begin{array}{l}\text { WW/WW } \\
\text { WW/U } \\
\text { U/OGC } \\
\text { fault } \\
\text { U/OGC }\end{array}$ & $\begin{array}{l}3 \\
1 \\
4 \\
9 \\
3\end{array}$ & 365 & OGC/WpR \\
\hline $3 / 1$ & $8 \mathrm{bca}$ & 640 & C7893 & Day & 315 & 40 & 240 & $06 / 27 / 73$ driller & 305 & & $\mathrm{U} / \mathrm{OGC}$ & & NA & $\mathrm{U} /$ OGC \\
\hline $3 / 1$ & 8aba & 470 & C6004 & Feves & 415 & 20 & $\begin{array}{r}315 \\
304.61\end{array}$ & $\begin{array}{l}\text { 04/24/91 driller } \\
07 / 16 / 92 \text { OWRD }\end{array}$ & $\begin{array}{l}340 \\
365\end{array}$ & & $\begin{array}{l}\text { OGC? /OGC? } \\
\text { OGC? /OGC? }\end{array}$ & & 165 & OGC/WpR \\
\hline $3 / 1$ & $8 c d b$ & 590 & C8243 & Gifford & 330 & 22 & $\begin{array}{r}210 \\
226.76\end{array}$ & $\begin{array}{l}07 / 10 / 89 \text { driller } \\
10 / 01 / 92 \text { OWRD }\end{array}$ & $\begin{array}{l}257 \\
302 \\
315\end{array}$ & $\begin{array}{l}265 \\
307 \\
322\end{array}$ & $\begin{array}{l}U / U \\
\text { OGC? / OGC } \\
\text { OGC? / OGC }\end{array}$ & $\begin{array}{r}6 \\
12 \\
4\end{array}$ & 363 & OGC \\
\hline $3 / 1$ & 8daa & 505 & C7888 & G1lmore & $\begin{array}{l}405 \\
445\end{array}$ & $\begin{array}{l}15 \\
15\end{array}$ & $\begin{array}{r}110 \\
340 \\
342.44\end{array}$ & $\begin{array}{l}\text { 03/17/78 driller } \\
\text { 09/04/90 driller } \\
\text { 09/10/92 OWRD }\end{array}$ & $\begin{array}{l}120 \\
440\end{array}$ & & $\begin{array}{l}\text { SB/WW } \\
\text { WpR }\end{array}$ & & 163 & OGC/WpR \\
\hline $3 / 2$ & $8 d \mathrm{ba}$ & 510 & C7928 & Gross & $\begin{array}{l}405 \\
436\end{array}$ & $\begin{array}{l}10 \\
10\end{array}$ & $\begin{array}{r}200 \\
350.08 \\
318\end{array}$ & $\begin{array}{l}\text { 06/14/76 driller } \\
08 / 14 / 92 \text { OWRD } \\
09 / 17 / 92 \text { driller }\end{array}$ & 187 & & $\mathrm{U} / \mathrm{U}$ & & 160 & WpR \\
\hline $3 / 1$ & $8 a b b$ & 465 & C7900 & Hart & 365 & 12 & $\begin{array}{r}292 \\
290 \\
303 \\
299.85\end{array}$ & $\begin{array}{l}\text { 02/06/78 driller } \\
04 / 10 / 78 \text { Phillips } \\
\text { 10/31/86 Phillips } \\
01 / 11 / 93 \text { OWRD }\end{array}$ & $\begin{array}{l}344 \\
\text { Pump } \\
\text { Purmp }\end{array}$ & & OGC?/OGC? & & 165 & OGC \\
\hline $3 / 1$ & $8 \mathrm{bda}$ & 555 & C7932 & Hoffman & 155 & 36 & $\begin{array}{r}74 \\
100 \\
77 \\
100 \\
100 \\
104.71\end{array}$ & $\begin{array}{l}\text { 10/24/67 driller } \\
07 / 28 / 85 \text { Phillips } \\
07 / 01 / 87 \text { owner recc } \\
09 / 01 / 91 \text { owner reco } \\
02 / 18 / 92 \text { Pump inst } \\
10 / 01 / 92 \text { OwRD }\end{array}$ & $\begin{array}{l}136 \\
\text { Pump } \\
\text { oll. } \\
\text { oll. } \\
\text {. }\end{array}$ & & $\mathrm{SB} / \mathrm{WW}$ & & 450 & $W W / W W$ \\
\hline $3 / 1$ & $8 \mathrm{bda}$ & 560 & C18118 & Kelly & 200 & 14 & $\begin{array}{r}55 \\
54.85\end{array}$ & $\begin{array}{l}\text { 06/24/80 driller } \\
10 / 09 / 92 \text { OWRD }\end{array}$ & $\begin{array}{r}54 \\
112\end{array}$ & & $\begin{array}{l}\text { fault } \\
W W / U\end{array}$ & & 505 & $W W / U$ \\
\hline $3 / 1$ & $8 \mathrm{cbb}$ & 660 & C7931 & Kidd & 470 & 15 & $\begin{array}{r}312 \\
305.65 \\
307.15\end{array}$ & $\begin{array}{l}03 / 07 / 69 \text { driller } \\
08 / 14 / 75 \text { USGS } \\
08 / 13 / 92 \text { OWRD }\end{array}$ & $\begin{array}{l}334 \\
457\end{array}$ & 342 & $\begin{array}{l}\text { OGC?/OGC? } \\
\text { WpR }\end{array}$ & & 353 & OGC/WpR \\
\hline
\end{tabular}


PARRETT MOUNTAIN HYDROLOGIC DATA CONTINUED

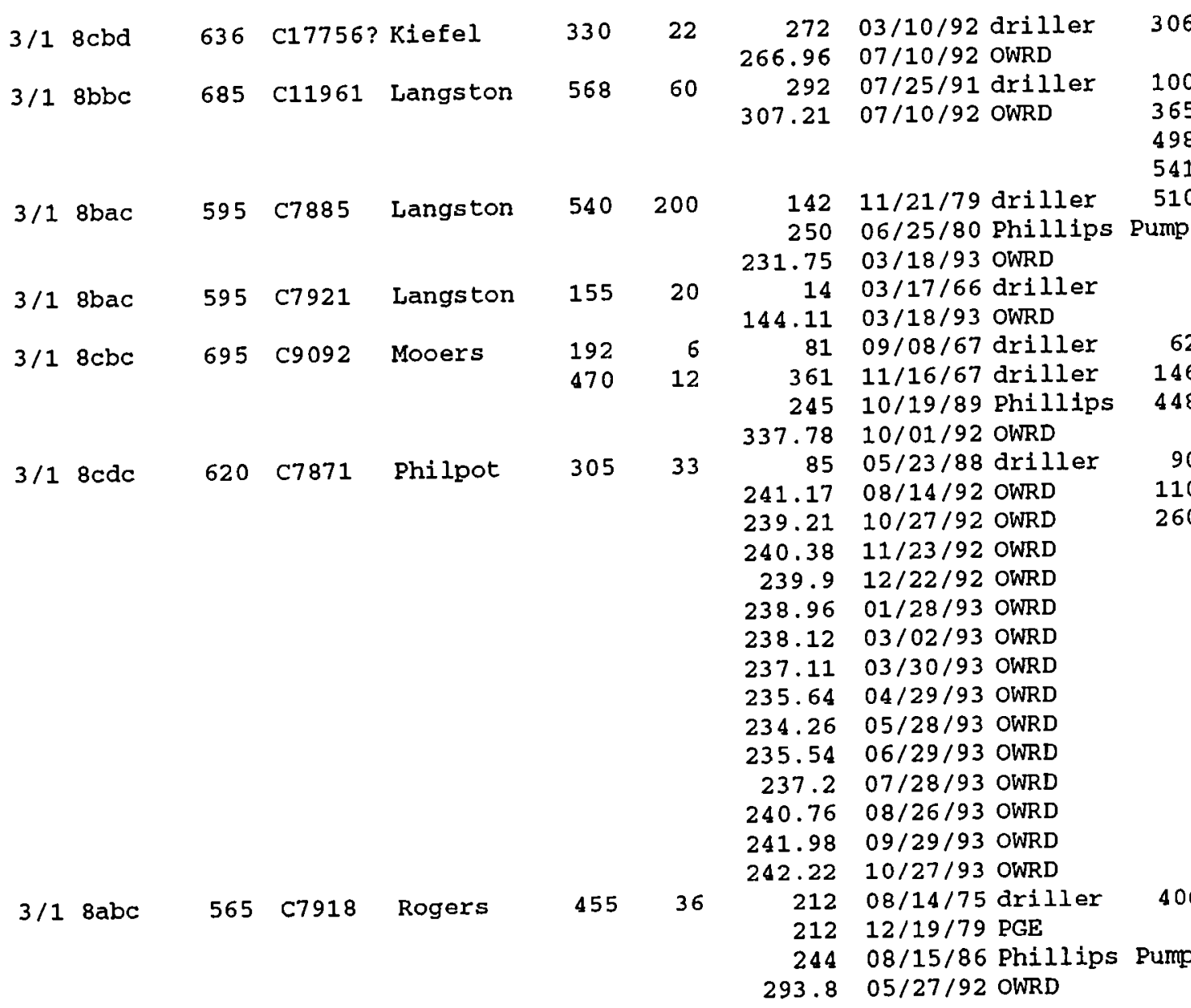

$369 \mathrm{U} / \mathrm{OGC}$

$\mathrm{SB} / \mathrm{SB}$

$\mathrm{U} / \mathrm{OGC}$

OGC?/OGC?

WpR

WpR

363 WpR

$451 W W / W W$

357 OGC/WpR

$S B / W W$

$\mathrm{U} / \mathrm{U}$

OGC/WpR

SB /WW

$\mathrm{U} / \mathrm{U}$

$386 \mathrm{WW} / \mathrm{U}$

$\mathrm{U} / \mathrm{U}$

378 OGC/WpR, WpR 
TABLE XV

PARRETT MOUNTAIN HYDROLOGIC DATA

CONTINUED

\begin{tabular}{|c|c|c|c|c|c|c|}
\hline $3 / 1$ & 8dad & 493 & C7903 & Rose & 375 & 24 \\
\hline $3 / 1$ & $8 a b d$ & 525 & C7927 & Smeed & $\begin{array}{l}210 \\
358\end{array}$ & \\
\hline $3 / 1$ & $8 a b c$ & 525 & C7911 & Smith & 470 & 12 \\
\hline $3 / 1$ & $8 \mathrm{ccb}$ & 675 & C7874 & Sumner & 595 & 8 \\
\hline $\begin{array}{l}3 / 1 \\
3 / 1\end{array}$ & $\begin{array}{l}8 \\
8 \text { daa }\end{array}$ & $\begin{array}{l}495 \\
505\end{array}$ & C7883 & $\begin{array}{l}\text { Swearingto } \\
\text { Theim }\end{array}$ & $\begin{array}{l}423 \\
465\end{array}$ & $\begin{array}{l}44 \\
18\end{array}$ \\
\hline $3 / 1$ & $8 \mathrm{dbb}$ & 565 & & Thomsen & 200 & \\
\hline $3 / 1$ & 8aca & 540 & C7895 & Tidball & 508 & 12 \\
\hline $3 / 1$ & $8 \mathrm{ccd}$ & 620 & C7873 & Ugoretz & 225 & 20 \\
\hline
\end{tabular}

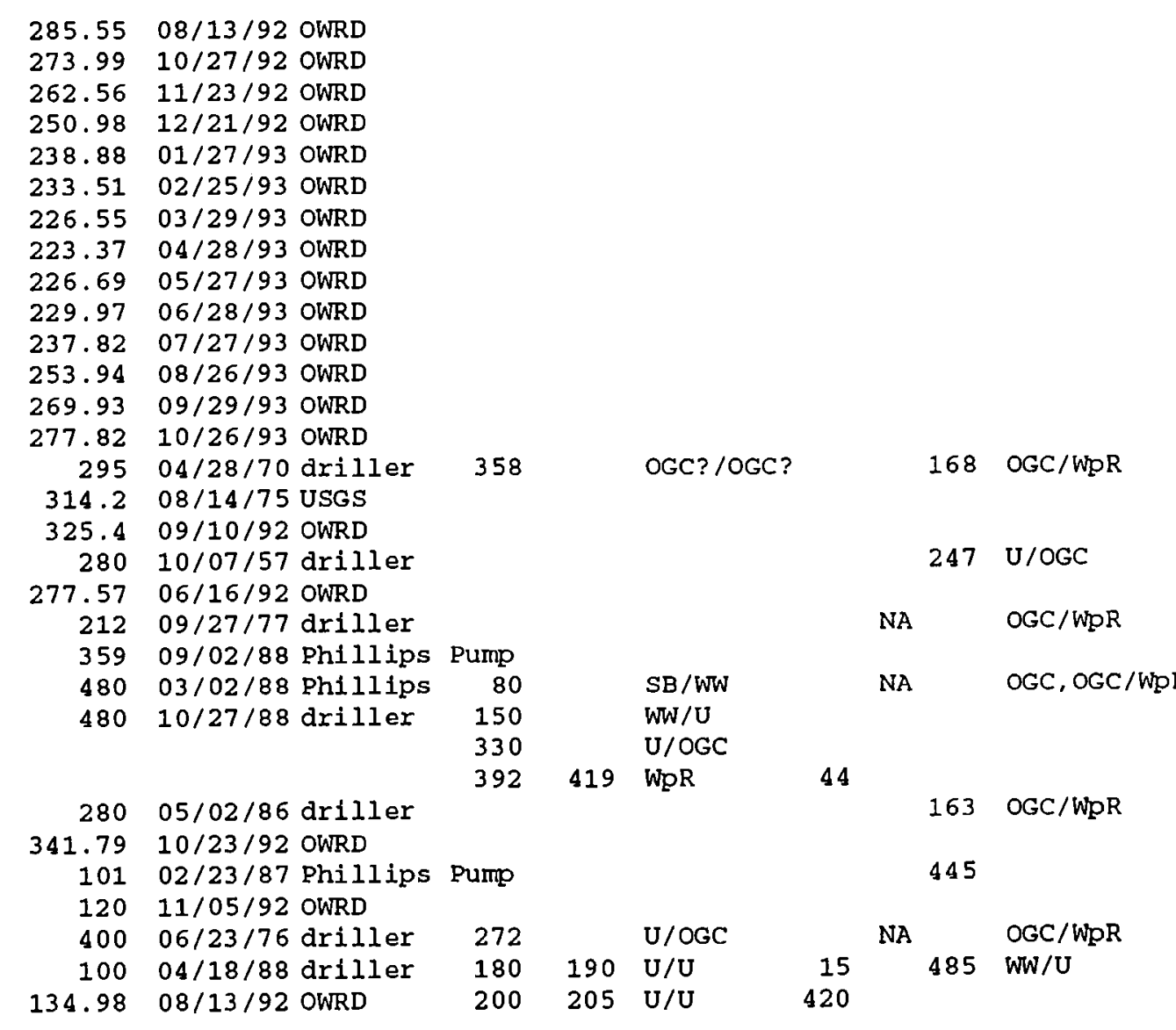


TABLE XV

PARRETT MOUNTAIN HYDROLOGIC DATA

CONTINUED

\begin{tabular}{|c|c|c|c|c|c|c|c|c|c|c|}
\hline \multirow[t]{4}{*}{$3 / 18 \mathrm{bbd}$} & 650 & C7907 & Williams & $\begin{array}{l}340 \\
450\end{array}$ & $\begin{array}{r}15 \\
200\end{array}$ & $\begin{array}{r}93 \\
179\end{array}$ & $\begin{array}{l}\text { 07/30/71 driller } \\
08 / 17 / 78 \text { OWRD }\end{array}$ & $\begin{array}{l}290 \\
424\end{array}$ & 308 & $\begin{array}{l}\mathrm{U} / \mathrm{U} \\
\mathrm{OGC} / \mathrm{WpR}\end{array}$ \\
\hline & & & & & & 195 & 08/17/79 OWRD & & & \\
\hline & & & & & & $\begin{array}{r}241 \\
244.5\end{array}$ & $\begin{array}{l}05 / 06 / 83 \text { driller } \\
09 / 22 / 83 \text { OWRD }\end{array}$ & & & \\
\hline & & & & & & 271.31 & $04 / 08 / 93$ OWRD & & & \\
\hline \multirow[t]{28}{*}{$3 / 18 \mathrm{bba}$} & 620 & C7908 & Williams & 260 & 50 & 146 & 07/31/71 driller & 243 & 254 & $\mathrm{U} / \mathrm{U}$ \\
\hline & & & & & & 181.85 & $08 / 17 / 79$ OWRD & & & \\
\hline & & & & & & 190.6 & $04 / 02 / 80$ OWRD & & & \\
\hline & & & & & & 203.51 & $09 / 16 / 80$ OWRD & & & \\
\hline & & & & & & 192.93 & $04 / 23 / 81$ OWRD & & & \\
\hline & & & & & & 202.33 & 10/07/81 OWRD & & & \\
\hline & & & & & & 200.53 & 05/15/82 OWRD & & & \\
\hline & & & & & & 205.1 & $09 / 29 / 82$ OWRD & & & \\
\hline & & & & & & 196.85 & $04 / 29 / 83$ OWRD & & & \\
\hline & & & & & & 202.6 & $09 / 22 / 83$ OWRD & & & \\
\hline & & & & & & 197.34 & $05 / 17 / 84$ OWRD & & & \\
\hline & & & & & & 201.79 & $06 / 05 / 85$ OWRD & & & \\
\hline & & & & & & 202.65 & $10 / 03 / 85$ OWRD & & & \\
\hline & & & & & & 197.41 & $06 / 04 / 86$ OWRD & & & \\
\hline & & & & & & 201.55 & $06 / 16 / 87$ OWRD & & & \\
\hline & & & & & & 211.6 & $06 / 17 / 88$ OWRD & & & \\
\hline & & & & & & 208.55 & $10 / 27 / 88$ OWRD & & & \\
\hline & & & & & & 205.68 & $05 / 30 / 90$ OWRD & & & \\
\hline & & & & & & 197.79 & 05/15/91 OWRD & & & \\
\hline & & & & & & 235.48 & $10 / 27 / 92$ OWRD & & & \\
\hline & & & & & & 237.2 & $11 / 30 / 92$ OWRD & & & \\
\hline & & & & & & 237.44 & $12 / 21 / 92$ OWRD & & & \\
\hline & & & & & & 238.31 & 01/27/93 OWRD & & & \\
\hline & & & & & & 238.96 & $03 / 02 / 93$ OWRD & & & \\
\hline & & & & & & 239.43 & $03 / 29 / 93$ OWRD & & & \\
\hline & & & & & & 239.24 & $04 / 28 / 93$ OWRD & & & \\
\hline & & & & & & 238.98 & $05 / 27 / 93$ OWRD & & & \\
\hline & & & & & & 239.96 & $06 / 28 / 93$ OWRD & & & \\
\hline
\end{tabular}

379 OGC/WpR

385 U/OGC 


\section{PARRETT MOUNTAIN HYDROLOGIC DATA}

\section{CONTINUED}

\begin{tabular}{|c|c|c|c|c|c|c|c|c|c|c|c|c|c|c|c|}
\hline & & & & & & $\begin{array}{l}240.72 \\
242.24 \\
243.95 \\
245.25\end{array}$ & $\begin{array}{l}07 / 27 / 93 \\
08 / 25 / 93 \\
09 / 30 / 93 \\
10 / 26 / 93\end{array}$ & $\begin{array}{l}\text { OWRD } \\
\text { OWRD } \\
\text { OWRD } \\
\text { OWRD }\end{array}$ & & & & & & & \\
\hline $3 / 18 \mathrm{bbd}$ & 655 & C7902 & Williams & 436 & 200 & $\begin{array}{r}212 \\
273.94\end{array}$ & $\begin{array}{l}07 / 03 / 81 \\
04 / 08 / 93\end{array}$ & $\begin{array}{l}\text { driller } \\
\text { OWRD }\end{array}$ & 418 & & OGC? /OGC? & & 381 & OGC & \\
\hline $3 / 18 \mathrm{bba}$ & 620 & C14427 & Williams & 590 & 100 & $\begin{array}{l}250 \\
268\end{array}$ & $\begin{array}{l}10 / 29 / 93 \\
07 / 27 / 93\end{array}$ & $\begin{array}{l}\text { driller } \\
\text { OWRD }\end{array}$ & $\begin{array}{l}328 \\
465 \\
565\end{array}$ & & $\begin{array}{l}U / O G C \\
\text { OGC/WpR } \\
\text { WpR }\end{array}$ & & 356 & OGC/WpR, h & WpR \\
\hline $\begin{array}{l}T / R \\
\text { (Sect.) } \\
3 / 19 \mathrm{dbc}\end{array}$ & $\begin{array}{l}\text { Elev. } \\
415\end{array}$ & $\begin{array}{l}\text { Wel1 } \\
\text { I.D. } \\
\text { C7965 }\end{array}$ & $\begin{array}{l}\text { Well } \\
\text { Owner } \\
\text { Bacon }\end{array}$ & $\begin{array}{l}\text { Well } \\
\text { Depth } \\
335\end{array}$ & $\begin{array}{c}\text { Yield } \\
12\end{array}$ & $\begin{array}{r}\text { St. Wate } \\
\text { Level } \\
165 \\
242.45\end{array}$ & $\begin{array}{l}\text { Date of } \\
\text { Measur. } \\
06 / 15 / 74 \\
10 / 15 / 92\end{array}$ & $\begin{array}{l}\text { Measured } \\
\text { by } \\
\text { driller } \\
\text { OWRD }\end{array}$ & $\begin{array}{l}\text { Water } \\
\text { top } \\
302\end{array}$ & $\begin{array}{c}\text { Bear. } \\
\text { bot. }\end{array}$ & $\begin{array}{l}\text { Corresp } \\
\text { Units } \\
U / U\end{array}$ & Est. & $\begin{array}{l}\text { Design. } \\
\text { :Head } \\
173\end{array}$ & $\begin{array}{l}\text { Design. } \\
\text { Aquifer } \\
\text { U/OGC }\end{array}$ & Main \\
\hline $3 / 19 a a b$ & 290 & C9128 & Birkeland & 140 & 12 & $\begin{array}{r}52 \\
109.46\end{array}$ & $\begin{array}{l}08 / 11 / 59 \\
10 / 08 / 92\end{array}$ & $\begin{array}{l}\text { driller } \\
\text { OWRD }\end{array}$ & 125 & & WW/U & & 181 & WW/U & \\
\hline $3 / 19 a b d$ & 360 & C7944 & Brown & 132 & $\begin{array}{r}20 \\
5.5\end{array}$ & $\begin{array}{r}67 \\
65 \\
67.76\end{array}$ & $\begin{array}{l}05 / 26 / 77 \\
11 / 07 / 91 \\
11 / 12 / 92\end{array}$ & $\begin{array}{l}\text { driller } \\
\text { Phillips } \\
\text { OWRD }\end{array}$ & $\begin{array}{l}125 \\
\text { Pump }\end{array}$ & & $W W / W W$ & & 292 & $W W / W W$ & \\
\hline $3 / 1$ 9dac & 330 & C7960 & Burda & $\begin{array}{l}230 \\
315\end{array}$ & $\begin{array}{l}20 \\
45\end{array}$ & $\begin{array}{r}156 \\
162.8 \\
162 \\
178.8\end{array}$ & $\begin{array}{l}04 / 27 / 71 \\
08 / 14 / 75 \\
07 / 07 / 81 \\
10 / 21 / 93\end{array}$ & $\begin{array}{l}\text { driller } \\
\text { OWRD } \\
\text { driller } \\
\text { OWRD }\end{array}$ & $\begin{array}{l}198 \\
302\end{array}$ & $\begin{array}{l}212 \\
309\end{array}$ & $\begin{array}{l}W W / U \\
\text { U/OGC }\end{array}$ & & 151 & U/OGC & \\
\hline $3 / 19 \mathrm{bad}$ & 400 & C7968 & Goldbeck & 200 & 36 & $\begin{array}{r}105 \\
94.3 \\
119.27 \\
119.97 \\
119.23 \\
119.54 \\
118.72 \\
112.84 \\
113.66 \\
119.3 \\
115.82 \\
118.53\end{array}$ & $\begin{array}{l}07 / 02 / 64 \\
08 / 14 / 75 \\
07 / 19 / 76 \\
10 / 10 / 76 \\
10 / 11 / 76 \\
01 / 18 / 77 \\
04 / 18 / 77 \\
01 / 27 / 78 \\
04 / 11 / 78 \\
10 / 09 / 78 \\
04 / 19 / 79 \\
10 / 08 / 92\end{array}$ & $\begin{array}{l}\text { driller } \\
\text { OWRD } \\
\text { OWRD } \\
\text { OWRD } \\
\text { OWRD } \\
\text { OWRD } \\
\text { OWRD } \\
\text { OWRD } \\
\text { OWRD } \\
\text { OWRD } \\
\text { OWRD } \\
\text { OWRD }\end{array}$ & 165 & & WW/U & & 281 & WW/U & $\stackrel{N}{O}$ \\
\hline
\end{tabular}


TABLE XV

PARRETT MOUNTAIN HYDROLOGIC DATA

CONTINUED

\begin{tabular}{|c|c|c|c|c|c|c|c|c|c|c|c|c|c|c|}
\hline $3 / 1$ & $9 \mathrm{dcc}$ & 380 & C7943 & Hansen & 445 & 30 & $\begin{array}{r}240 \\
208.19\end{array}$ & $\begin{array}{l}\text { 02/12/80 driller } \\
11 / 05 / 92 \text { OWRD }\end{array}$ & $\begin{array}{l}2 \% 0 \\
302\end{array}$ & 324 & $\begin{array}{l}U / U \\
U / O G C\end{array}$ & & 172 & $\mathrm{U} / \mathrm{OGC}$ \\
\hline $3 / 1$ & 9 dac & 330 & C7941 & Lundy & 340 & 35 & $\begin{array}{r}150 \\
180.03\end{array}$ & $\begin{array}{l}\text { 07/07/81 driller } \\
10 / 09 / 92 \text { OWRD }\end{array}$ & 314 & 332 & $\mathrm{U} / \mathrm{OGC}$ & & 150 & $\mathrm{U} / \mathrm{OGC}$ \\
\hline $3 / 1$ & $9 a b c$ & 405 & C7952 & Martinson & 405 & 40 & $\begin{array}{r}206 \\
241.29\end{array}$ & $\begin{array}{l}05 / 11 / 77 \text { driller } \\
10 / 22 / 92 \text { OWRD }\end{array}$ & 384 & & OGC/WpR & & 164 & OGC/WpR \\
\hline $3 / 1$ & $9 \mathrm{cad}$ & 465 & C7949 & Meyer & 480 & 12 & $\begin{array}{r}281 \\
304.36\end{array}$ & $\begin{array}{l}07 / 10 / 69 \text { dr1ller } \\
10 / 22 / 92 \text { OWRD }\end{array}$ & 432 & & DGC/WpR & & 161 & OGC/WpR \\
\hline $\begin{array}{l}3 / 1 \\
3 / 1\end{array}$ & $\begin{array}{l}9 \mathrm{cac} \\
9 \mathrm{cda}\end{array}$ & $\begin{array}{l}465 \\
425\end{array}$ & $\begin{array}{l}C 7958 \\
\text { C7948 }\end{array}$ & $\begin{array}{l}\text { Meyer } \\
\text { Meyer }\end{array}$ & $\begin{array}{l}425 \\
425\end{array}$ & $\begin{array}{l}75 \\
37\end{array}$ & $\begin{array}{r}280 \\
240 \\
260.99\end{array}$ & $\begin{array}{l}08 / 10 / 78 \text { driller } \\
11 / 22 / 69 \text { driller } \\
10 / 22 / 92 \text { OWRD }\end{array}$ & 320 & & $\mathrm{U} / \mathrm{OGC}$ & $\mathrm{NA}$ & 164 & $\begin{array}{l}\text { U/OGC, OGC } \\
\text { OGC/WpR }\end{array}$ \\
\hline $3 / 1$ & $9 \mathrm{baa}$ & 375 & C7946 & Miller & 235 & 10 & $\begin{array}{r}136 \\
140 \\
140.8\end{array}$ & $\begin{array}{l}05 / 20 / 71 \text { driller } \\
06 / 30 / 87 \text { Phillips } \\
10 / 15 / 92 \text { OWRD }\end{array}$ & $\begin{array}{l}70 \\
\text { Pump }\end{array}$ & & WW/WW & & 234 & $\mathrm{U} / \mathrm{OGC}$ \\
\hline $3 / 1$ & $9 \mathrm{dbc}$ & 395 & C7951 & Re1tz & 245 & 13 & $\begin{array}{r}134 \\
133.09\end{array}$ & $\begin{array}{l}04 / 28 / 63 \text { driller } \\
11 / 19 / 91 \text { OWRD }\end{array}$ & & & & & 262 & $W W / U$ \\
\hline $3 / 1$ & 9 adc & 385 & C7966 & Risberg & 335 & 24 & $\begin{array}{r}224 \\
233.67 \\
220.07 \\
218.87 \\
226.71 \\
235.28 \\
221.61 \\
220.52 \\
218.67 \\
220.48 \\
218.51 \\
219 \\
222.38 \\
219.4 \\
223.3 \\
219.4 \\
223.85 \\
220\end{array}$ & $\begin{array}{l}06 / 22 / 73 \text { driller } \\
06 / 29 / 76 \text { OWRD } \\
10 / 11 / 76 \text { OWRD } \\
01 / 18 / 77 \text { OWRD } \\
04 / 18 / 77 \text { OWRD } \\
07 / 19 / 77 \text { OWRD } \\
10 / 10 / 77 \text { OWRD } \\
01 / 24 / 78 \text { OWRD } \\
04 / 03 / 78 \text { OWRD } \\
10 / 08 / 78 \text { OWRD } \\
04 / 19 / 79 \text { OWRD } \\
04 / 02 / 80 \text { OWRD } \\
09 / 17 / 80 \text { OWRD } \\
04 / 16 / 81 \text { OWRD } \\
10 / 07 / 81 \text { OWRD } \\
04 / 15 / 82 \text { OWRD } \\
09 / 30 / 82 \text { OWRD } \\
04 / 29 / 83 \text { Phillips }\end{array}$ & Pump & 328 & $\mathrm{U} / \mathrm{U}$ & & 160 & $\mathrm{U} / \mathrm{OGC}$ \\
\hline
\end{tabular}


TABLE XV

PARRETT MOUNTAIN HYDROLOGIC DATA CONTINUED

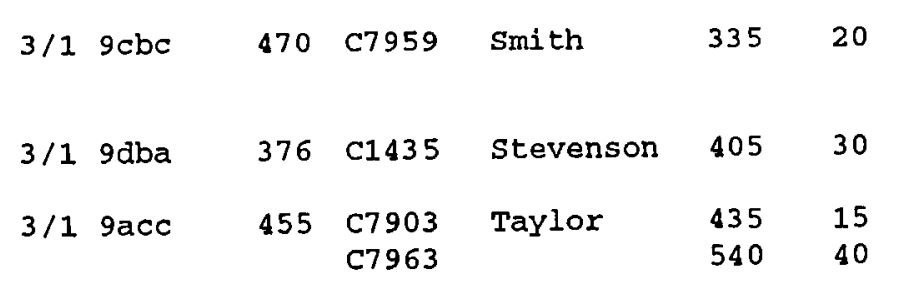

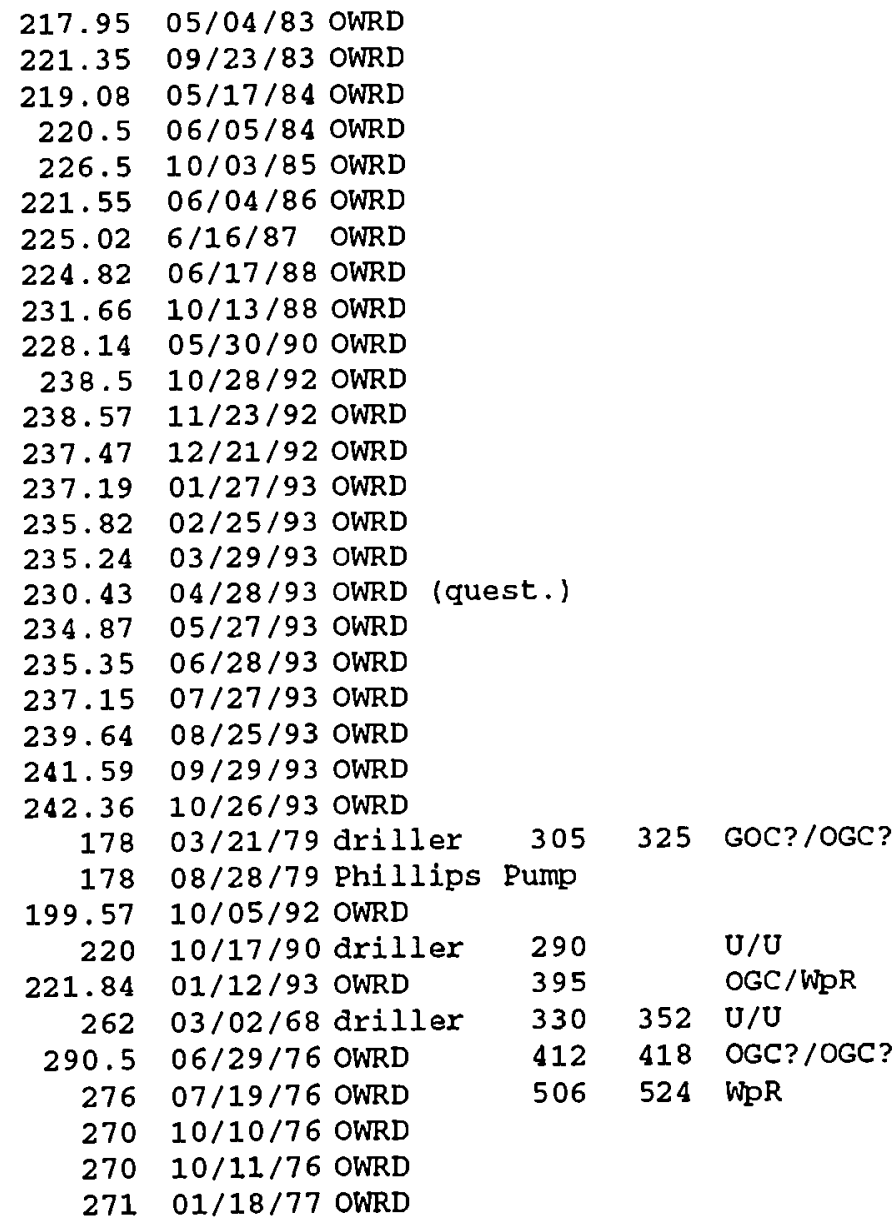

$270 \mathrm{U} / \mathrm{OGC}, \mathrm{OGC}$

154 OGC/WpR

180 OGC / WOR, WPR 
TABLE XV

\section{PARRETT MOUNTAIN HYDROLOGIC DATA}

\section{CONTINUED}

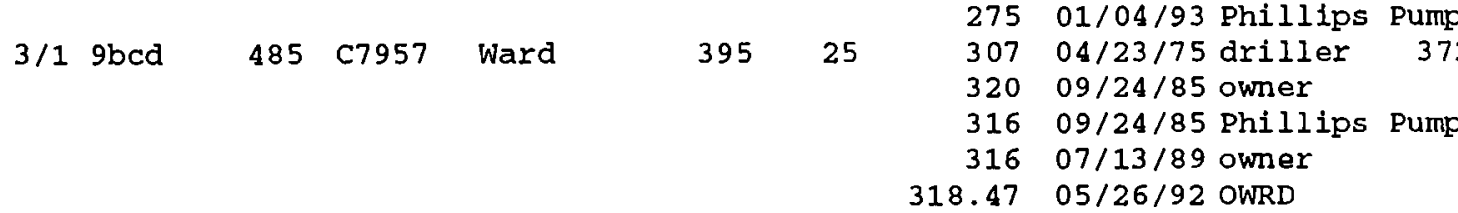

T/R Elev. Well Wel

(Sect.)

$3 / 110 \mathrm{cbc}$

I. D

Well

Well Yield St.

$3 / 1$ 10dcc

$285 \mathrm{C} 8016$

$185 \quad \mathrm{C} 8014$

Amato

Depth

170

12
60

St. Wev

$26904 / 18 / 77$ OWRD

$27001 / 27 / 78$ OWRD

$26904 / 11 / 78$ OWRD

$27010 / 09 / 78$ OWRD

$26704 / 19 / 79$ OWRD

440 06/27/83 driller

268 06/28/83 Phillips Pump

$27504 / 04 / 92$ owner

$274.7507 / 08 / 92$ OWRD

275 01/04/93 Phillips Pump

$320 \quad 09 / 24 / 85$ owner

388 OGC?/OGC?

167 OGC

$31607 / 13 / 89$ owner

Level Measur of Meas

Water Bear. Corresp

$3906 / 02 / 70$ driller

$166 \quad 214$

162
214

Head

. Design. Main

$41.7301 / 18 / 77$ OWRD

$41.6104 / 18 / 77$ OWRD

$39.101 / 27 / 78$ OWRD

$40.0904 / 11 / 78$ OWRD

$41.8110 / 09 / 78$ OWRD

$45.9211 / 12 / 91$ OWRD

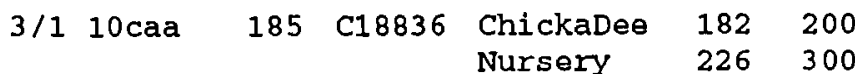

30 01/14/69 driller

118

$19.512 / 01 / 75$ DEEP

136

$19.106 / 29 / 76$ OWRD

$18.8510 / 11 / 76$ OWRD

182

$16.6101 / 18 / 77$ OWRD

219

$14.8904 / 18 / 77$ OWRD

$23.6607 / 19 / 77$ OWRD

$21.09 \quad 10 / 10 / 77$ OWRD

$14.601 / 27 / 78$ OWRD 


\section{PARRETT MOUNTAIN HYDROLOGIC DATA} CONTINUED

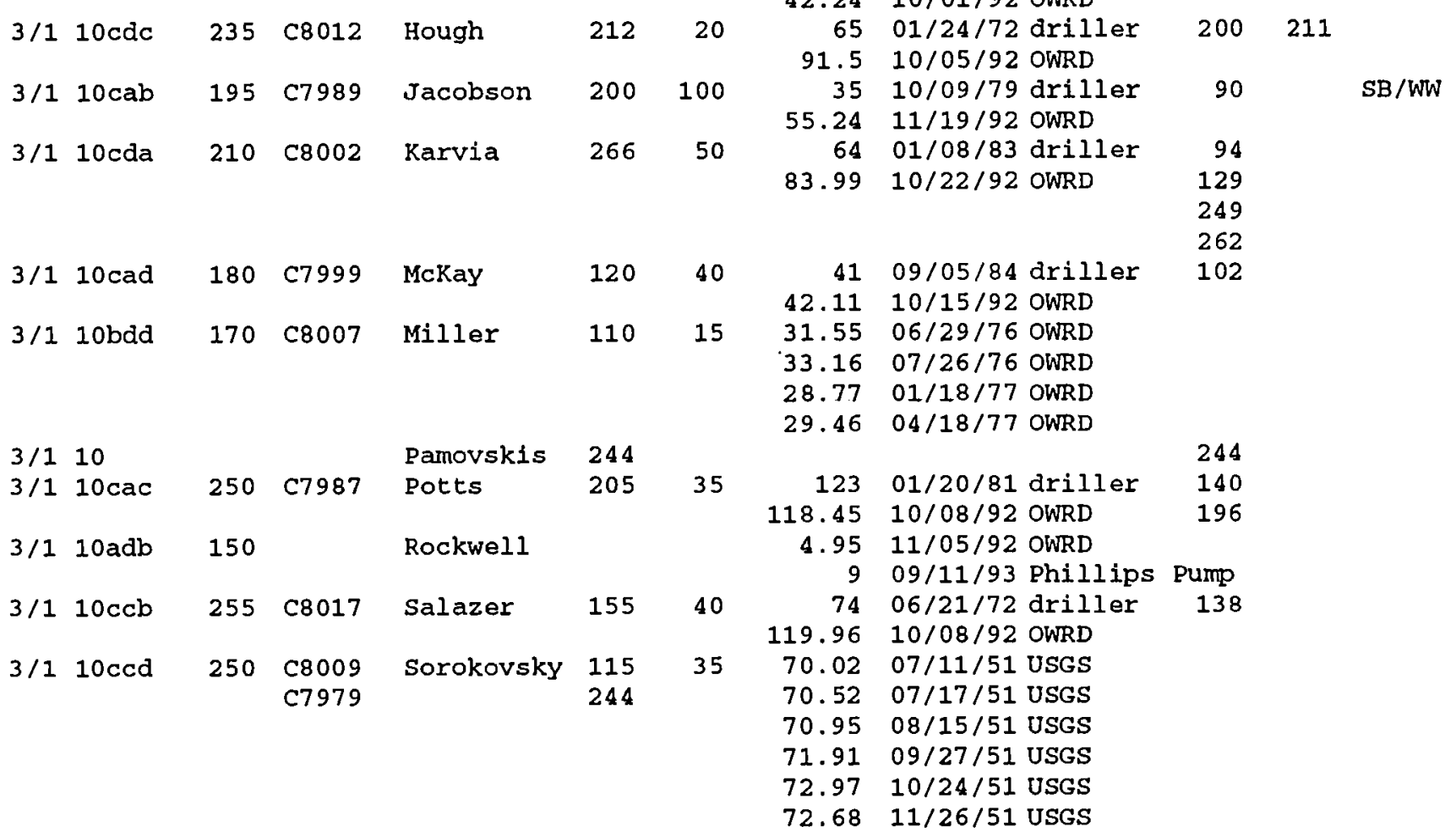

\begin{tabular}{|c|c|c|c|c|c|c|c|}
\hline 16.26 & $04 / 11 / 78$ OWRD & & & & & & \\
\hline 19.93 & 10/09/78 OWRD & & & & & & \\
\hline 14.93 & $04 / 19 / 79$ OWRD & & & & & & \\
\hline 34 & $10 / 13 / 88$ OWRD & & & & & & \\
\hline 30.01 & $05 / 30 / 90$ OWRD & & & & & & \\
\hline 28.17 & $05 / 31 / 91$ OWRD & & & & & & \\
\hline 42.24 & $10 / 01 / 92$ OWRD & & & & & & \\
\hline 65 & $01 / 24 / 72$ ariller & 200 & 211 & & & 144 & $W W / U$ \\
\hline 91.5 & $10 / 05 / 92$ OWRD & & & & & & \\
\hline 35 & 10/09/79 driller & 90 & & $\mathrm{SB} / \mathrm{WW}$ & & 140 & \\
\hline 55.24 & $11 / 19 / 92$ OWRD & & & & & & \\
\hline 64 & 01/08/83 driller & 94 & & & & 136 & $U / U$ \\
\hline \multirow[t]{3}{*}{83.99} & $10 / 22 / 92$ OWRD & 129 & & & & & \\
\hline & & 249 & & & & & \\
\hline & & 262 & & & & & \\
\hline 41 & 09/05/84 driller & 102 & & & & 138 & $\mathrm{WW} / \mathrm{U}$ \\
\hline 42.11 & $10 / 15 / 92$ OWRD & & & & & & \\
\hline 31.55 & $06 / 29 / 76$ OWRD & & & & & NA & $\mathrm{WW} / \mathrm{U}$ \\
\hline 33.16 & $07 / 26 / 76$ OWRD & & & & & & \\
\hline 28.77 & $01 / 18 / 77$ OWRD & & & & & & \\
\hline \multirow[t]{2}{*}{29.46} & $04 / 18 / 77$ OWRD & & & & & & \\
\hline & & 244 & & & 20 & & \\
\hline 123 & 01/20/81 driller & 140 & & & & 132 & $W W / U$ \\
\hline 18.45 & $10 / 08 / 92$ OWRD & 196 & & & & & \\
\hline 4.95 & $11 / 05 / 92$ OWRD & & & & & NA & $\mathrm{WW} / \mathrm{U}$ \\
\hline 9 & 09/11/93 Phillips & Pump & & & & & \\
\hline 74 & $06 / 21 / 72$ driller & 138 & & & & 135 & $W W / U$ \\
\hline 19.96 & 10/08/92 OWRD & & & & & & \\
\hline 70.02 & $07 / 11 / 51$ USGS & & & & & 148 & $W W / U$ \\
\hline
\end{tabular}


TABLE XV

PARRETT MOUNTAIN HYDROLOGIC DATA CONTINUED

$$
\begin{aligned}
& 71.1106 / 25 / 57 \text { USGS } \\
& 73.6909 / 25 / 57 \text { USGS } \\
& 73.9410 / 11 / 57 \text { USGS } \\
& 74.1812 / 16 / 57 \text { USGS } \\
& 74.301 / 09 / 58 \text { USGS } \\
& 71.2904 / 02 / 58 \text { USGS } \\
& 71.8904 / 21 / 58 \text { USGS } \\
& 71.4105 / 01 / 58 \text { USGS } \\
& 71.605 / 29 / 58 \text { USGS } \\
& 71.9705 / 30 / 58 \text { USGS } \\
& 72.1407 / 08 / 58 \text { USGS } \\
& 73.2708 / 07 / 58 \text { USGS } \\
& 76.2609 / 03 / 58 \text { USGS } \\
& 74.58 \quad 09 / 29 / 58 \text { USGS } \\
& 74.9509 / 30 / 58 \text { USGS } \\
& 75.2610 / 28 / 58 \text { USGS } \\
& 75.8211 / 26 / 58 \text { USGS } \\
& 75.2512 / 22 / 58 \text { USGS } \\
& 75.2201 / 13 / 59 \text { USGS } \\
& 75.0401 / 14 / 59 \text { USGS } \\
& 74.5501 / 30 / 59 \text { USGS } \\
& 73.0603 / 10 / 59 \text { USGS } \\
& 72.4 \quad 04 / 07 / 59 \text { USGS } \\
& 71.9404 / 20 / 59 \text { USGS } \\
& 71.9404 / 22 / 59 \text { USGS } \\
& 71.98 \quad 05 / 07 / 59 \text { USGS } \\
& 71.8206 / 02 / 59 \text { USGS } \\
& 71.806 / 23 / 59 \text { USGS } \\
& 74.5506 / 30 / 59 \text { USGS } \\
& 72.307 / 23 / 59 \text { USGS } \\
& 73.6808 / 25 / 59 \text { USGS } \\
& 73.3809 / 04 / 59 \text { USGS } \\
& 74.4110 / 06 / 59 \text { USGS } \\
& 75.5611 / 24 / 59 \text { USGS }
\end{aligned}
$$


TABLE XV

PARRETT MOUNTAIN HYDROLOGIC DATA CONTINUED

$$
\begin{aligned}
& 72.24 \quad 12 / 19 / 51 \text { USGS } \\
& 71.9801 / 15 / 52 \text { USGS } \\
& 70.84 \quad 02 / 20 / 51 \text { USGS } \\
& 70.08 \quad 03 / 19 / 52 \text { USGS } \\
& 70.04 \quad 04 / 28 / 52 \text { USGS } \\
& 71.0707 / 01 / 52 \text { USGS } \\
& 71.708 / 01 / 52 \text { USGS } \\
& 72.03 \quad 08 / 22 / 52 \text { USGS } \\
& 72.9409 / 27 / 52 \text { USGS } \\
& 73.6110 / 30 / 52 \text { USGS } \\
& 74.0611 / 28 / 52 \text { USGS } \\
& 74.912 / 23 / 52 \text { USGS } \\
& 74.08 \quad 02 / 04 / 53 \text { USGS } \\
& 72.9703 / 02 / 53 \text { USGS } \\
& 71.7305 / 05 / 53 \text { USGS } \\
& 72.08 \quad 06 / 02 / 53 \text { USGS } \\
& 72.0407 / 01 / 53 \text { USGS } \\
& 73.4109 / 01 / 53 \text { USGS } \\
& 73.7410 / 05 / 53 \text { USGS } \\
& 74.5612 / 07 / 53 \text { USGS } \\
& 72.5602 / 04 / 54 \text { USGS } \\
& 70.5504 / 20 / 54 \text { USGS } \\
& 71.0507 / 15 / 54 \text { USGS } \\
& 72.6709 / 29 / 54 \text { USGS } \\
& 71.94 \quad 03 / 22 / 55 \text { USGS } \\
& 70.9105 / 29 / 55 \text { USGS } \\
& 72.1108 / 03 / 55 \text { USGS } \\
& 72.8 \quad 09 / 06 / 55 \text { USGS } \\
& 73.4111 / 25 / 55 \text { USGS } \\
& 72.2712 / 20 / 55 \text { USGS } \\
& 69.4602 / 18 / 56 \text { USGS } \\
& 68.4205 / 12 / 56 \text { USGS } \\
& 70.6508 / 20 / 56 \text { USGS } \\
& 72.87 \quad 12 / 23 / 56 \text { USGS }
\end{aligned}
$$


TABLE XV

PARRETT MOUNTAIN HYDROLOGIC DATA CONTINUED

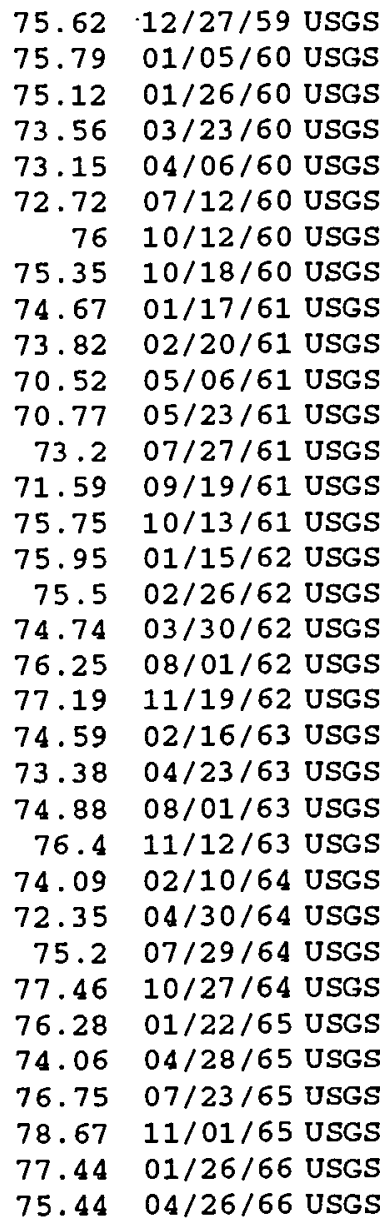


TABLE XV

PARRETT MOUNTAIN HYDROLOGIC DATA CONTINUED

$\begin{array}{rl}79.28 & 07 / 27 / 66 \text { USGS } \\ 80.35 & 10 / 25 / 66 \text { USGS } \\ 78.68 & 01 / 31 / 67 \text { USGS } \\ 76.32 & 04 / 25 / 67 \text { USGS } \\ 79.45 & 07 / 18 / 67 \text { USGS } \\ 81.15 & 10 / 18 / 67 \text { USGS } \\ 80.42 & 01 / 16 / 68 \text { USGS } \\ 77.75 & 04 / 16 / 68 \text { USGS } \\ 79.21 & 07 / 17 / 68 \text { USGS } \\ 80.46 & 10 / 15 / 68 \text { USGS } \\ 76.26 & 01 / 21 / 69 \text { USGS } \\ 74.62 & 04 / 15 / 69 \text { USGS } \\ 76.55 & 07 / 15 / 69 \text { USGS } \\ 80.36 & 10 / 15 / 69 \text { USGS } \\ 79.1 & 01 / 27 / 70 \text { USGS } \\ 75.65 & 04 / 14 / 70 \text { USGS } \\ 80.45 & 07 / 21 / 70 \text { USGS } \\ 82.46 & 10 / 20 / 70 \text { USGS } \\ 81.25 & 01 / 25 / 71 \text { USGS } \\ 77.42 & 04 / 20 / 71 \text { USGS } \\ 78.83 & 07 / 21 / 71 \text { USGS } \\ 82.3 & 10 / 14 / 71 \text { USGS } \\ 80.55 & 01 / 18 / 72 \text { USGS } \\ 80.98 & 09 / 08 / 72 \text { USGS } \\ 83.33 & 01 / 18 / 73 \text { USGS } \\ 83.14 & 06 / 04 / 73 \text { USGS } \\ 81.36 & 07 / 16 / 74 \text { USGS } \\ 91.26 & 10 / 17 / 74 \text { USGS } \\ 85.07 & 01 / 21 / 75 \text { USGS } \\ 81.36 & 04 / 14 / 75 \text { USGS } \\ 84.29 & 07 / 14 / 75 \text { USGS } \\ 88.48 & 10 / 21 / 75 \text { USGS } \\ 85.59 & 01 / 19 / 76 \text { USGS } \\ 82.21 & 04 / 20 / 76 \text { USGS }\end{array}$


TABLE XV

PARRETT MOUNTAIN HYDROLOGIC DATA

CONTINUED

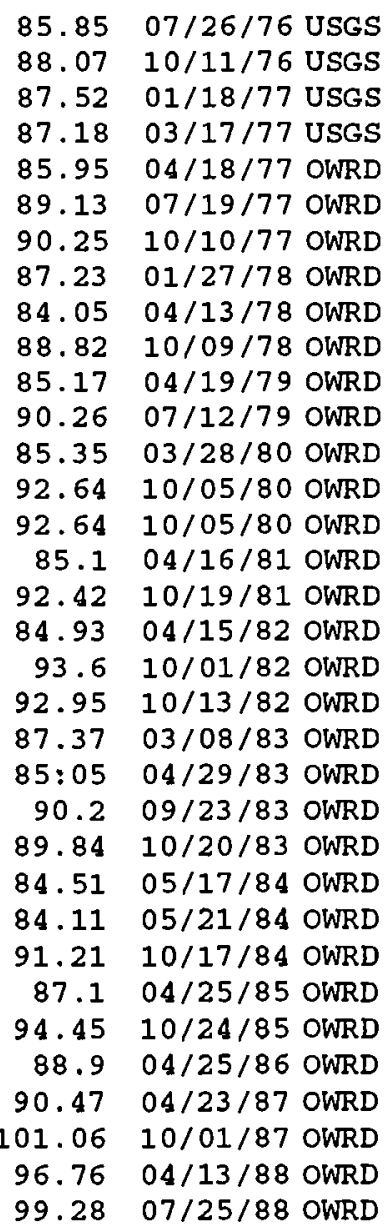


TABLE XV

PARRETT MOUNTAIN HYDROLOGIC DATA CONTINUED

$\begin{array}{rl}100.23 & 07 / 30 / 88 \text { OWRD } \\ 101.42 & 08 / 10 / 88 \text { OWRD } \\ 102.6 & 07 / 18 / 88 \text { OWRD } \\ 106 & 09 / 07 / 88 \text { dr1ller } \\ 104.53 & 10 / 10 / 88 \text { OWRD } \\ 96.79 & 04 / 20 / 89 \text { OWRD } \\ 102.06 & 04 / 11 / 90 \text { OWRD } \\ 104.66 & 02 / 15 / 91 \text { OWRD } \\ 110.17 & 09 / 20 / 91 \text { OWRD } \\ 104.13 & 02 / 19 / 92 \text { OWRD } \\ 103.4 & 04 / 01 / 92 \text { OWRD } \\ 110.03 & 07 / 22 / 92 \text { OWRD } \\ 111.53 & 10 / 21 / 92 \text { OWRD } \\ 111.08 & 10 / 28 / 92 \text { OWRD } \\ 111.1 & 11 / 23 / 92 \text { OWRD } \\ 109.58 & 12 / 21 / 92 \text { OWRD } \\ 109.91 & 01 / 22 / 93 \text { OWRD } \\ 108.22 & 01 / 29 / 93 \text { OWRD } \\ 107.32 & 02 / 25 / 93 \text { OWRD } \\ 105.78 & 03 / 29 / 93 \text { OWRD } \\ 105.13 & 04 / 05 / 93 \text { OWRD } \\ 103.61 & 04 / 28 / 93 \text { OWRD } \\ 101.96 & 05 / 27 / 93 \text { OWRD } \\ 101.52 & 06 / 28 / 93 \text { OWRD } \\ 103.3 & 07 / 26 / 93 \text { OWRD } \\ 111.95 & 10 / 14 / 93 \text { OWRD } \\ 111.54 & 10 / 26 / 93 \text { OWRD } \\ 73 & 09 / 20 / 78 \text { driller } \\ 92.37 & 10 / 08 / 92 \text { OWRD } \\ 60 & 02 / 25 / 79 \text { driller } \\ 85.46 & 10 / 23 / 92 \text { OWRD }\end{array}$

\begin{tabular}{|c|c|c|c|c|c|c|c|}
\hline $3 / 110 \mathrm{cdc}$ & 235 & $\mathrm{C} 8022$ & Thompson & 205 & 33 & 73 & 09/20/78 driller \\
\hline & & & & & & 92.37 & 10/08/92 OWRD \\
\hline $3 / 1 \quad 10 \mathrm{cbd}$ & 255 & C7997 & Wright & 220 & 60 & $\begin{array}{r}60 \\
85.46\end{array}$ & $\begin{array}{l}\text { 02/25/79 driller } \\
10 / 23 / 92 \text { OWRD }\end{array}$ \\
\hline
\end{tabular}


TABLE XV

\section{PARRETT MOUNTAIN HYDROLOGIC DATA}

CONTINUED

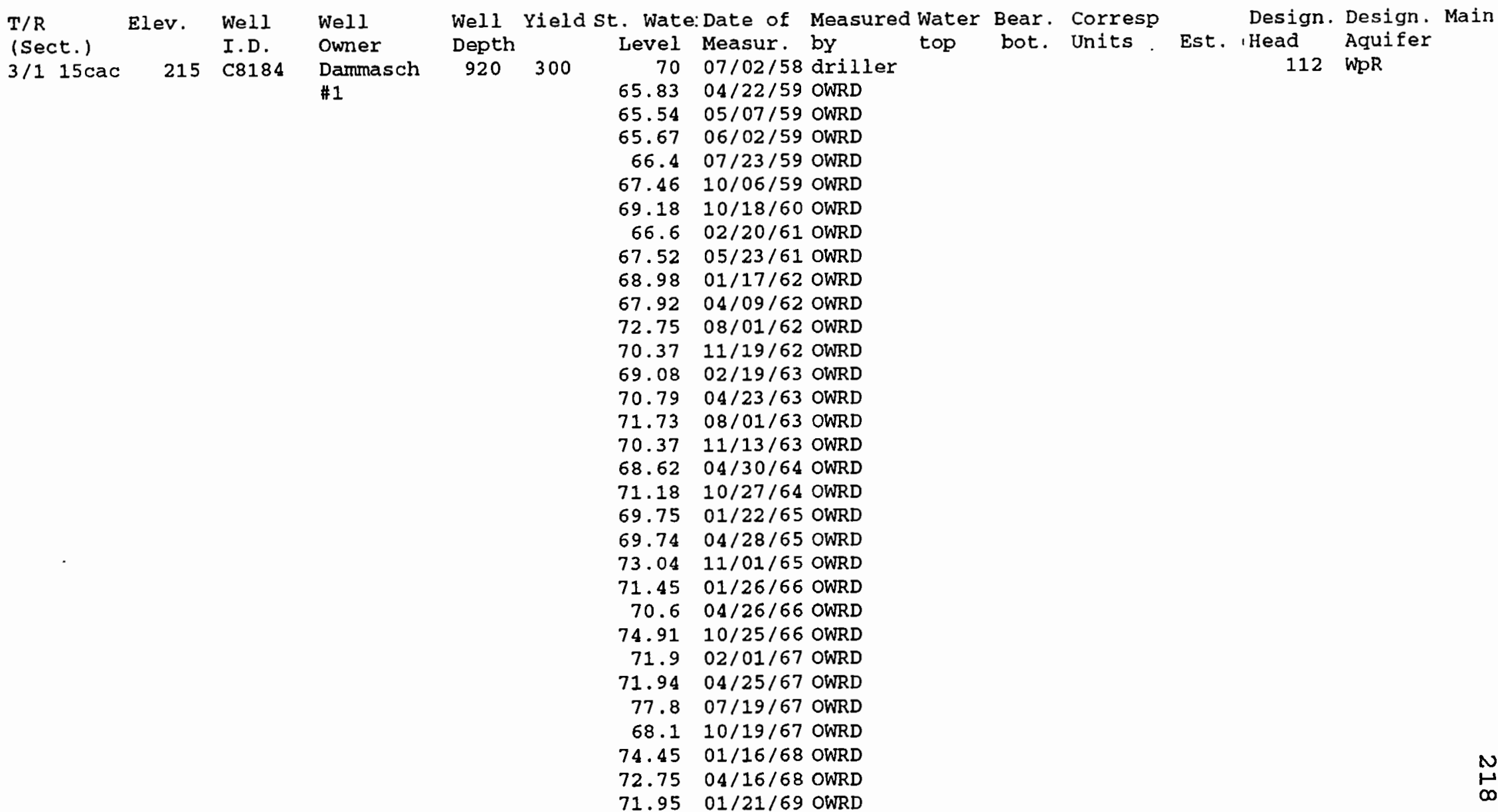


TABLE XV

PARRETT MOUNTAIN HYDROLOGIC DATA

CONTINUED

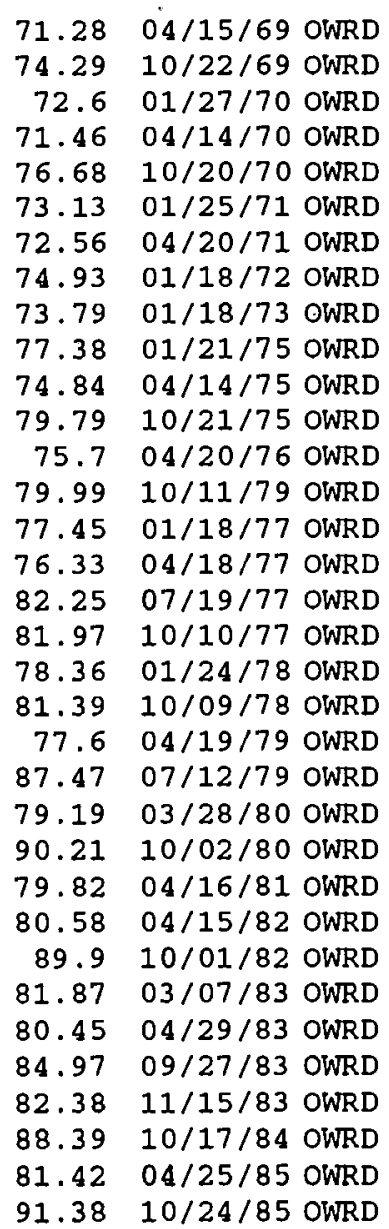


TABLE XV

\section{PARRETT MOUNTAIN HYDROLOGIC DATA}

CONTINUED

$\begin{array}{rl}99.5 & 10 / 16 / 86 \text { OWRD } \\ 94.28 & 05 / 07 / 87 \text { OWRD } \\ 97.95 & 04 / 13 / 88 \text { OWRD } \\ 292.27 & 07 / 22 / 88 \text { OWRD, ppg } \\ 107.02 & 10 / 10 / 88 \text { OWRD } \\ 98.88 & 04 / 20 / 89 \text { OWRD } \\ 108.46 & 01 / 18 / 90 \text { OWRD } \\ 104.15 & 04 / 11 / 90 \text { OWRD } \\ 120 & 10 / 10 / 90 \text { OWRD } \\ 103.84 & 02 / 15 / 91 \text { OWRD } \\ 105.17 & 06 / 06 / 91 \text { OWRD, ppg } \\ 123.72 & 09 / 20 / 91 \text { OWRD } \\ 103.57 & 02 / 19 / 92 \text { OWRD } \\ 102.51 & 04 / 01 / 92 \text { OWRD } \\ 116.7 & 07 / 29 / 92 \text { OWRD } \\ 117.81 & 10 / 21 / 92 \text { OWRD } \\ 116.53 & 10 / 28 / 92 \text { OWRD } \\ 115.65 & 11 / 12 / 92 \text { OWRD } \\ 113.4 & 12 / 21 / 92 \text { OWRD } \\ 111.7 & 01 / 22 / 93 \text { OWRD } \\ 111.61 & 01 / 29 / 93 \text { OWRD } \\ 111.05 & 02 / 25 / 93 \text { OWRD } \\ 106.3 & 03 / 29 / 93 \text { OWRD } \\ 105.72 & 04 / 05 / 93 \text { OWRD } \\ 104.64 & 04 / 28 / 93 \text { OWRD } \\ 103.28 & 05 / 27 / 93 \text { OWRD } \\ 103.33 & 06 / 28 / 93 \text { OWRD } \\ 108.57 & 07 / 27 / 93 \text { OWRD } \\ 108.25 & 07 / 28 / 93 \text { OWRD } \\ 112.51 & 08 / 25 / 93 \text { OWRD } \\ 114.21 & 09 / 29 / 93 \text { OWRD } \\ 237.6 & 10 / 14 / 93 \text { OWRD, ppg } \\ 113.88 & 10 / 26 / 93 \text { OWRD } \\ & \end{array}$


TABLE XV

\section{PARRETT MOUNTAIN HYDROLOGIC DATA}

CONTINUED

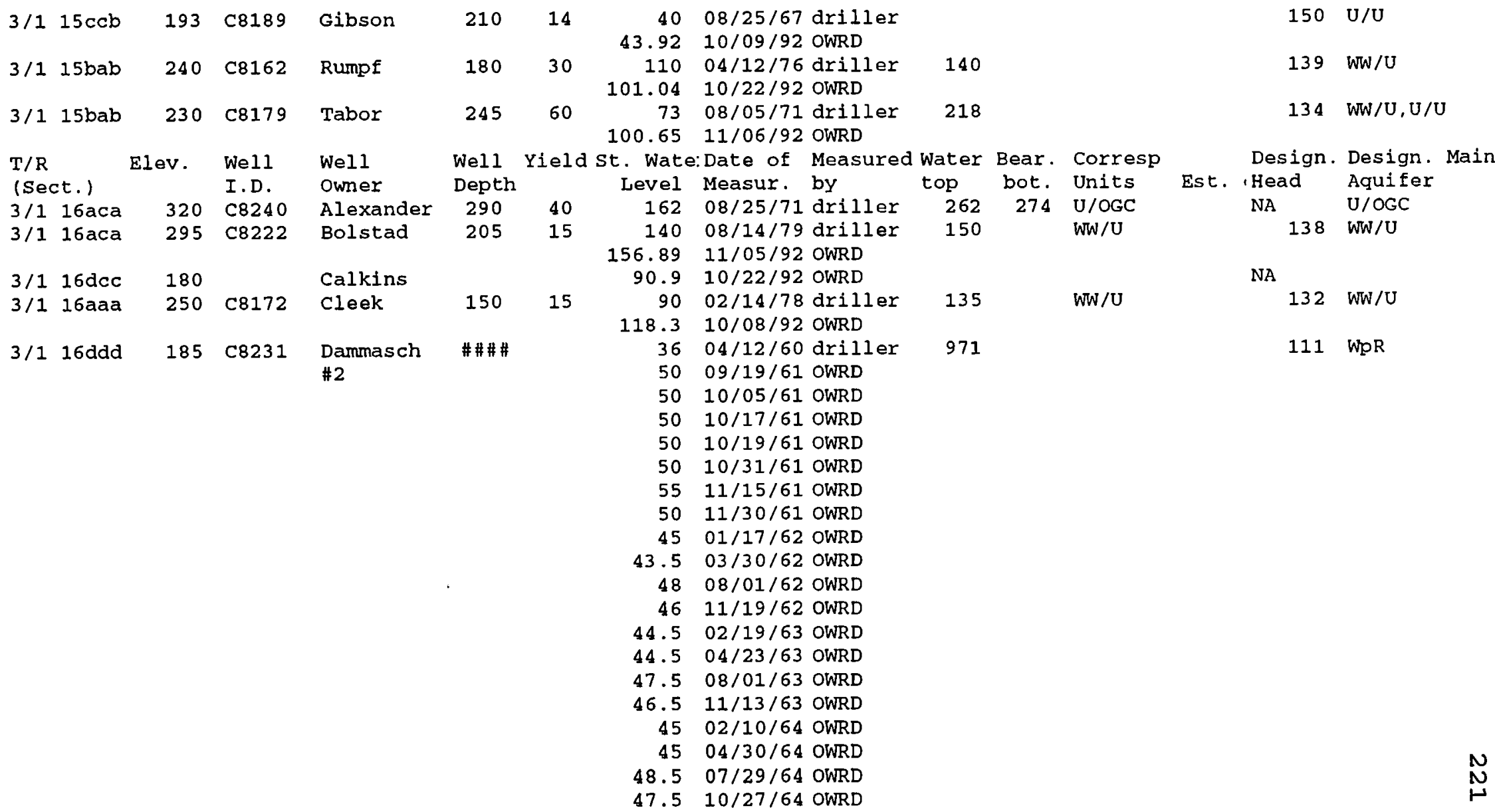


TABLE XV

PARRETT MOUNTAIN HYDROLOGIC DATA CONTINUED

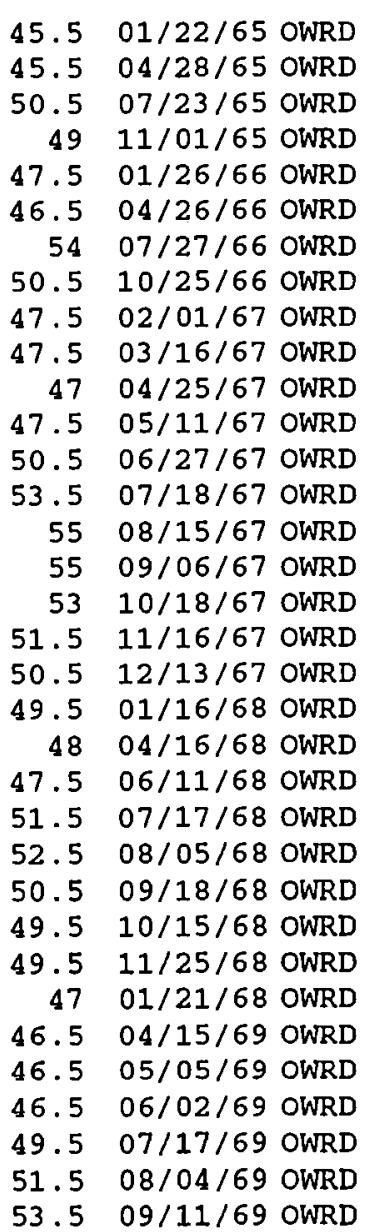


TABLE XV

PARRETT MOUNTAIN HYDROLOGIC DATA

CONTINUED

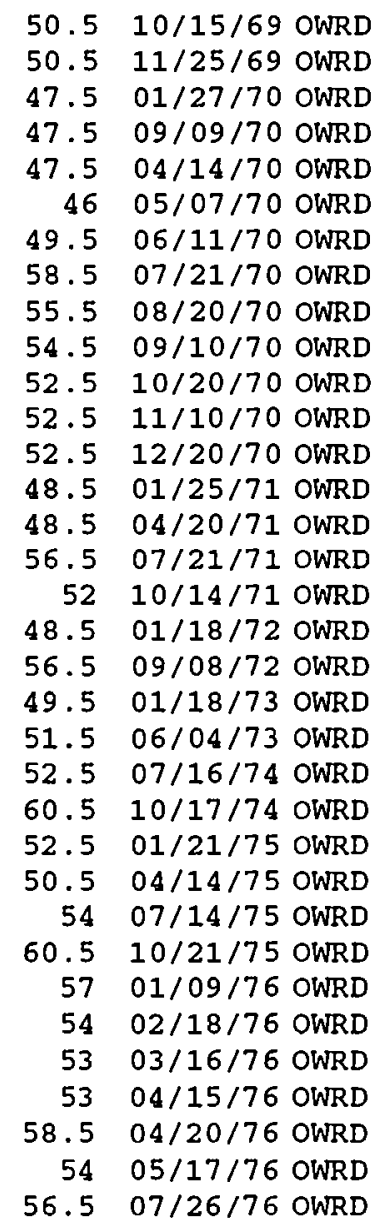


TABLE XV

\section{PARRETT MOUNTAIN HYDROLOGIC DATA}

CONTINUED

$$
\begin{array}{rr}
56.5 & 10 / 11 / 76 \text { OWRD } \\
54 & 01 / 18 / 77 \text { OWRD } \\
53.5 & 04 / 18 / 77 \text { OWRD } \\
60 & 07 / 19 / 77 \text { OWRD } \\
68.5 & 10 / 10 / 77 \text { OWRD } \\
55 & 01 / 24 / 78 \text { OWRD } \\
53.5 & 04 / 13 / 78 \text { OWRD } \\
58.5 & 10 / 09 / 78 \text { OWRD } \\
55 & 04 / 19 / 79 \text { OWRD } \\
53.5 & 03 / 28 / 80 \text { OWRD } \\
64 & 10 / 05 / 80 \text { OWRD } \\
52.4 & 04 / 16 / 81 \text { OWRD } \\
62.25 & 10 / 01 / 81 \text { OWRD } \\
54.75 & 04 / 15 / 82 \text { OWRD } \\
64.25 & 10 / 01 / 82 \text { OWRD } \\
56.17 & 03 / 07 / 83 \text { OWRD } \\
56.17 & 04 / 29 / 83 \text { OWRD } \\
61.94 & 09 / 23 / 83 \text { OWRD } \\
62.25 & 10 / 20 / 83 \text { OWRD } \\
54.17 & 05 / 21 / 84 \text { OWRD } \\
64.56 & 10 / 17 / 84 \text { OWRD } \\
56.48 & 04 / 25 / 85 \text { OWRD } \\
66.41 & 10 / 24 / 85 \text { OWRD } \\
59.94 & 04 / 24 / 86 \text { OWRD } \\
86.5 & 10 / 01 / 87 \text { OWRD } \\
68.9 & 04 / 13 / 88 \text { OWRD } \\
80.73 & 10 / 10 / 88 \text { OWRD } \\
70.9 & 04 / 20 / 89 \text { OWRD } \\
85.3 & 01 / 18 / 90 \text { OWRD } \\
85.3 & 04 / 11 / 90 \text { OWRD } \\
.99 & 08 / 01 / 90 \text { OWRD } \\
73.8 & 02 / 15 / 91 \text { OWRD } \\
96.9 & 09 / 20 / 91 \text { OWRD } \\
73.8 & 02 / 19 / 92 \text { OWRD }
\end{array}
$$




\section{PARRETT MOUNTAIN HYDROLOGIC DATA}

CONTINUED

\begin{tabular}{|c|c|c|c|c|}
\hline $3 / 1$ & $16 \mathrm{bad}$ & 315 & $\begin{array}{l}\text { C8229 } \\
\text { C189 }\end{array}$ & Dugan \\
\hline $3 / 1$ & $16 \mathrm{cda}$ & 150 & $\mathrm{C} 8230$ & Garrett \\
\hline$/ 1$ & $16 \mathrm{caa}$ & 235 & & Jones \#1 \\
\hline & $16 \mathrm{caa}$ & 235 & C18057 & Jones $\# 2$ \\
\hline
\end{tabular}

\begin{tabular}{|c|c|c|c|c|c|}
\hline $3 / 1$ & $16 \mathrm{dbb}$ & 220 & C8209 & Mason & 300 \\
\hline $3 / 1$ & $16 \mathrm{dba}$ & 210 & C8214 & Mcgee & 245 \\
\hline
\end{tabular}

$\begin{array}{rl}73.8 & 04 / 01 / 92 \text { OWRD } \\ 87.66 & 07 / 29 / 92 \text { OWRD } \\ 96.9 & 10 / 21 / 92 \text { OWRD } \\ 96.9 & 01 / 22 / 93 \text { OWRD } \\ 78.42 & 04 / 04 / 93 \text { OWRD } \\ 77.25 & 04 / 16 / 93 \text { OWRD } \\ 79.54 & 07 / 28 / 93 \text { OWRD } \\ 85.35 & 10 / 14 / 93 \text { OWRD } \\ 138 & 12 / 14 / 65 \text { driller } \\ 143.72 & 08 / 13 / 75 \text { USGS } \\ 158 & 08 / 22 / 90 \text { driller } \\ 152.54 & 09 / 15 / 92 \text { OWRD } \\ 30 & 09 / 01 / 65 \text { driller } \\ 41.63 & 08 / 13 / 75 \text { USGS } \\ 34.45 & 11 / 05 / 92 \text { OWRD } \\ 94.85 & 06 / 19 / 92 \text { OWRD } \\ 72 & 07 / 25 / 92 \text { driller } \\ 100.48 & 10 / 28 / 92 \text { OWRD } \\ 99.6 & 11 / 23 / 92 \text { OWRD } \\ 97.87 & 12 / 21 / 92 \text { OWRD } \\ 96.31 & 01 / 27 / 93 \text { OWRD } \\ 96.05 & 02 / 25 / 93 \text { OWRD } \\ 95.36 & 03 / 29 / 93 \text { OWRD } \\ 90.58 & 04 / 28 / 93 \text { OWRD } \\ 93.73 & 05 / 27 / 93 \text { OWRD } \\ 93.58 & 06 / 28 / 93 \text { OWRD } \\ 94.15 & 07 / 27 / 93 \text { OWRD } \\ 95.58 & 08 / 25 / 93 \text { OWRD } \\ 98 & 09 / 29 / 93 \text { OWRD } \\ 98.59 & 10 / 26 / 93 \text { OWRD } \\ 70 & 08 / 27 / 77 \text { driller } \\ 68.75 & 10 / 15 / 92 \text { OWRD } \\ 70 & 06 / 16 / 77 \text { driller } \\ 72.28 & 10 / 05 / 92 \text { OWRD }\end{array}$

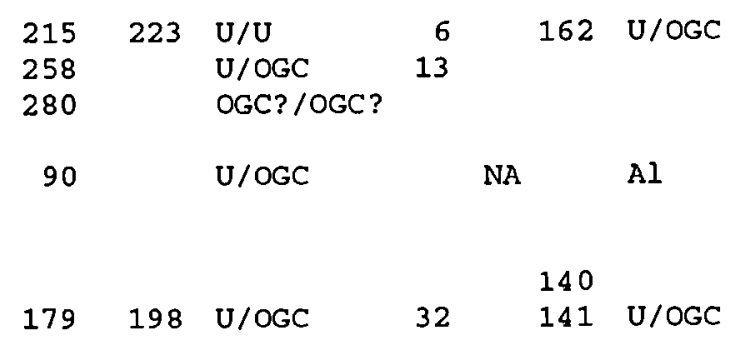

$3 / 116 \mathrm{dba}$

,

\begin{tabular}{|c|c|c|c|c|}
\hline 150 & & Al/Bas. & 151 & OGC/WpR, WpR \\
\hline 230 & 238 & OGC? /OGC? & 138 & $\mathrm{U} / \mathrm{OGC}$ \\
\hline
\end{tabular}


TABLE XV

\section{PARRETT MOUNTAIN HYDROLOGIC DATA}

CONTINUED

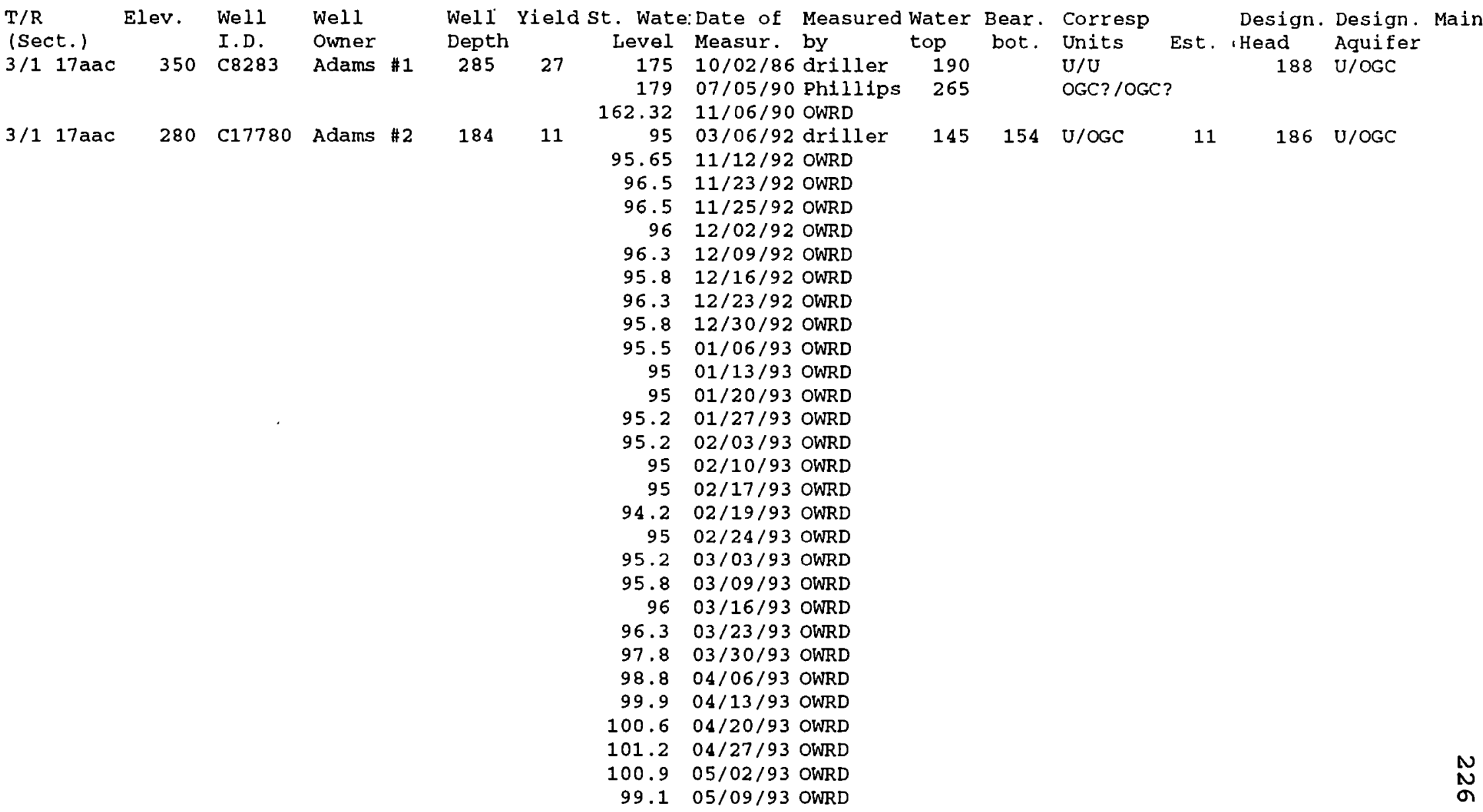


TABLE XV

\title{
PARRETT MOUNTAIN HYDROLOGIC DATA
} CONTINUED

\author{
$99.405 / 16 / 93$ OWRD \\ $99.905 / 23 / 93$ OWRD \\ $100.105 / 30 / 93$ OWRD \\ $100.406 / 06 / 93$ OWRD \\ $100.906 / 13 / 93$ OWRD \\ $100.906 / 20 / 93$ OWRD \\ $100.906 / 27 / 93$ OWRD \\ $101.4 \quad 07 / 04 / 93$ OWRD \\ $102.207 / 11 / 93$ OWRD \\ $101.907 / 18 / 93$ OWRD \\ $101.907 / 25 / 93$ OWRD \\ $101.908 / 01 / 93$ OWRD \\ $101.908 / 08 / 93$ OWRD \\ $102.208 / 15 / 93$ OWRD \\ $102.208 / 22 / 93$ OWRD \\ $102.708 / 29 / 93$ OWRD \\ $102.709 / 05 / 93$ OWRD \\ $102.409 / 12 / 93$ OWRD \\ $102.209 / 19 / 93$ OWRD \\ $102.209 / 26 / 93$ OWRD \\ $101.910 / 03 / 93$ OWRD \\ $101.710 / 10 / 93$ OWRD \\ $101.4 \quad 10 / 17 / 93$ OWRD \\ $101.210 / 24 / 93$ OWRD \\ $100.611 / 07 / 93$ OWRD \\ $100.911 / 14 / 93$ OWRD \\ $100.111 / 21 / 93$ OWRD \\ $100.411 / 28 / 93$ OWRD \\ $101.1311 / 30 / 93$ OWRD \\ $322.8705 / 18 / 84$ OWRD \\ $325.8210 / 19 / 93$ OWRD \\ $34509 / 27 / 79$ Phillips \\ 115 \\ 375 \\ 420
}

$3 / 117 \mathrm{bad} 530 \quad \mathrm{C} 8253$ Arkless $505 \quad 22 \quad 325 \quad 06 / 17 / 82$ driller

$3 / 117 \mathrm{bbd} \quad 560 \quad \mathrm{C} 8297$ Barrows $440 \quad 9 \quad 310 \quad 02 / 11 / 71$ driller

$S B / W W$

U/OGC

OGC/WpR
204 OGC, OGC/WDR

NA OGC/WpR N N 


\section{PARRETT MOUNTAIN HYDROLOGIC DATA}

CONTINUED

\begin{tabular}{|c|c|c|c|c|c|c|c|c|c|c|c|c|c|c|}
\hline $3 / 1$ & $17 \mathrm{bba}$ & 610 & C8298 & Benson & 545 & 15 & $\begin{array}{r}416 \\
412.25\end{array}$ & $\begin{array}{l}\text { 09/10/73 driller } \\
\text { 10/19/93 OWRD }\end{array}$ & 495 & & WpR & & 198 & WpR \\
\hline \multirow[t]{2}{*}{$3 / 1$} & $17 \mathrm{bbd}$ & 565 & C8269 & Bethune & 525 & 18 & $\begin{array}{l}340 \\
346\end{array}$ & $\begin{array}{l}\text { 03/29/78 driller } \\
06 / 26 / 89 \text { Phillips }\end{array}$ & $\begin{array}{l}397 \\
518\end{array}$ & & $\begin{array}{l}\mathrm{OGC} / \mathrm{WpR} \\
\mathrm{WPR}\end{array}$ & & 218 & WpR \\
\hline & & & & & & & 347.47 & $03 / 11 / 93$ OWRD & & & & & & \\
\hline \multirow[t]{2}{*}{$3 / 1$} & $17 \mathrm{bcd}$ & 510 & C8303 & Biles & 380 & 15 & 260 & $09 / 30 / 76$ driller & 150 & & $\mathrm{U} / \mathrm{U}$ & & 212 & OGC/WpR \\
\hline & & & & & & & 298.13 & $11 / 19 / 92$ OWRD & & & & & & \\
\hline \multirow[t]{2}{*}{$3 / 1$} & $17 \mathrm{ddc}$ & 200 & C17781 & Bisenius & 123 & 15 & 67 & 03/06/92 driller & 98 & & WW/U & & 131 & $\mathrm{U} / \mathrm{U}$ \\
\hline & & & & & & & 68.83 & $01 / 11 / 93$ OWRD & & & & & & \\
\hline \multirow[t]{17}{*}{$3 / 1$} & $17 \mathrm{aca}$ & 455 & C18317 & Cogger & 140 & 12 & 100 & $07 / 29 / 60$ driller & 115 & & $W W / U$ & & 203 & $\mathrm{U} / \mathrm{OGC}, \mathrm{OGC}$ \\
\hline & & & & & 240 & 40 & $\begin{array}{l}125 \\
310\end{array}$ & $\begin{array}{l}04 / 25 / 77 \text { driller } \\
10 / 24 / 77 \text { driller }\end{array}$ & 352 & 374 & OGC? /OGC? & & & \\
\hline & & & & & & & 280 & $06 / 10 / 80$ Phillips & Pump & & & & & \\
\hline & & & & & & & 242.18 & $06 / 30 / 90$ OWRD & & & & & & \\
\hline & & & & & & & 243.22 & $10 / 28 / 92$ OWRD & & & & & & \\
\hline & & & & & & & 243.89 & $11 / 23 / 92$ OWRD & & & & & & \\
\hline & & & & & & & 243.24 & $12 / 22 / 92$ OWRD & & & & & & \\
\hline & & & & & & & 242.53 & $01 / 28 / 93$ OWRD & & & & & & \\
\hline & & & & & & & 242.02 & $03 / 02 / 93$ OWRD & & & & & & \\
\hline & & & & & & & 242.49 & $03 / 30 / 93$ OWRD & & & & & & \\
\hline & & & & & & & 244.41 & $04 / 29 / 93$ OWRD & & & & & & \\
\hline & & & & & & & 244.24 & $05 / 28 / 93$ OWRD & & & & & & \\
\hline & & & & & & & 244.83 & $06 / 30 / 93$ OWRD & & & & & & \\
\hline & & & & & & & 245.16 & $07 / 28 / 93$ OWRD & & & & & & \\
\hline & & & & & & & 246.54 & $08 / 25 / 93$ OWRD & & & & & & \\
\hline & & & & & & & 247.07 & $09 / 29 / 93$ OWRD & & & & & & \\
\hline & & & & & & & 248.34 & $10 / 27 / 93$ OWRD & & & & & & \\
\hline \multirow[t]{2}{*}{$3 / 1$} & $17 \mathrm{cab}$ & 400 & $\mathrm{C} 8270$ & Fullmer & 305 & 25 & 199 & 04/03/78 driller & 262 & & $\mathrm{U} / \mathrm{OGC}$ & & 195 & OGC \\
\hline & & & & & & & 204.8 & $12 / 30 / 92$ OWRD & & & & & & \\
\hline \multirow[t]{2}{*}{$3 / 1$} & $17 \mathrm{cdc}$ & 170 & $\mathrm{C} 8402$ & Handy & 95 & 35 & 12 & $06 / 12 / 75$ driller & 50 & & WpR & & 155 & WpR \\
\hline & & & & & & & 15.43 & $12 / 11 / 92$ OWRD & & & & & & \\
\hline \multirow[t]{2}{*}{$3 / 1$} & 17 aaa & 335 & C8282 & $\mathrm{H} 111$ & 268 & 42 & 151 & $03 / 31 / 87$ driller & 121 & 202 & OGC?/OGC & 5 & 170 & OGC/WpR \\
\hline & & & & & & & 165.11 & $11 / 12 / 92$ OWRD & 238 & 268 & OGC/WpR & 47 & & \\
\hline $3 / 1$ & 17 add & 265 & & Langer & & & 91.77 & $11 / 12 / 92$ OWRD & & & & & 173 & \\
\hline
\end{tabular}


PARRETT MOUNTAIN HYDROLOGIC DATA CONTINUED

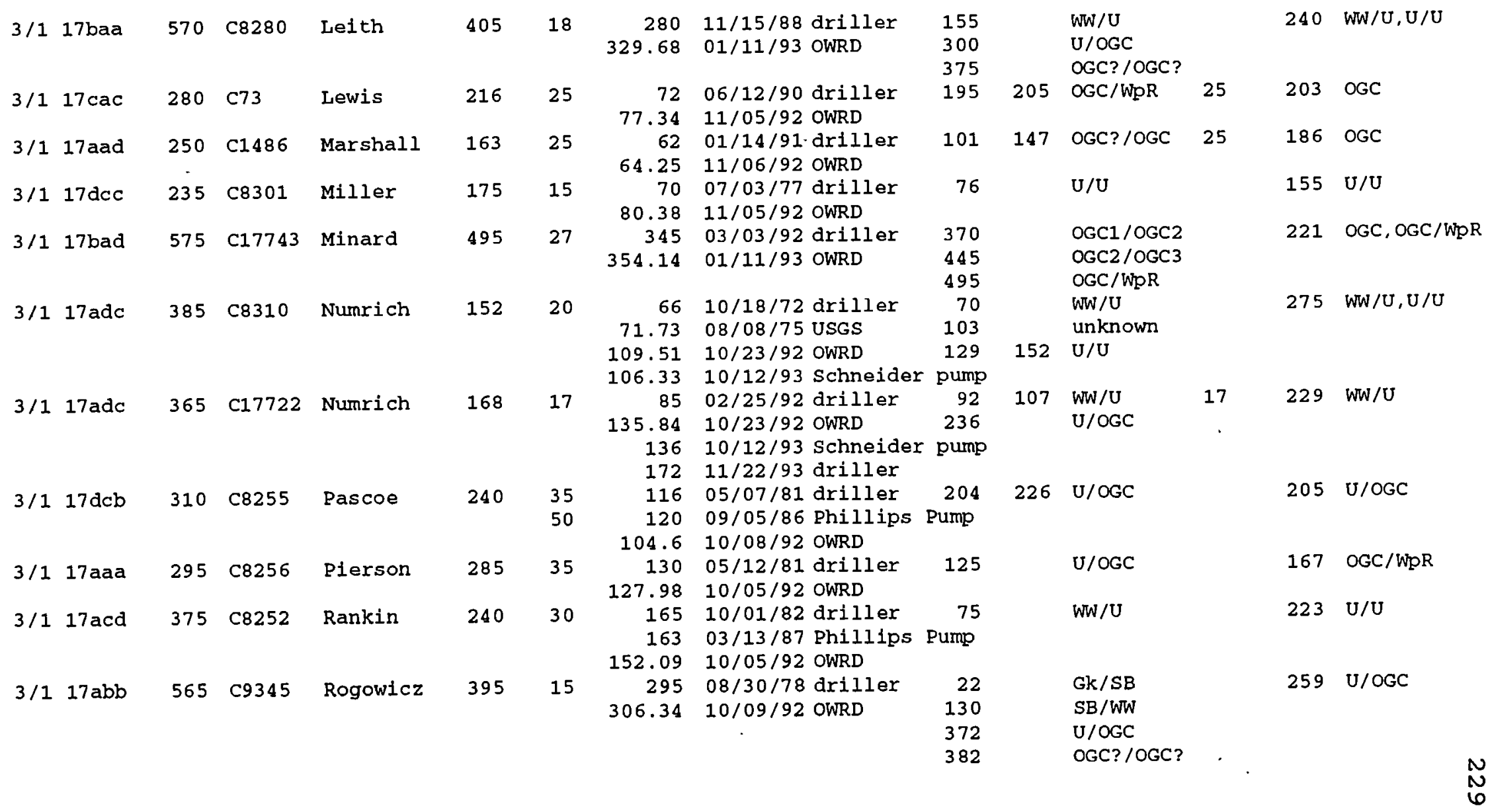


TABLE XV

PARRETT MOUNTAIN HYDROLOGIC DATA CONTINUED

\begin{tabular}{|c|c|c|c|c|c|c|c|c|c|c|c|c|c|c|c|c|}
\hline $3 / 1$ & $17 \mathrm{ddb}$ & 195 & $C 8260$ & Runnels & 110 & 60 & $\begin{array}{l}6 \\
0\end{array}$ & $\begin{array}{l}11 / 08 / 78 \\
11 / 01 / 91\end{array}$ & $\begin{array}{l}\text { driller } \\
\text { owner }\end{array}$ & $\begin{array}{l}84 \\
98\end{array}$ & 103 & $\begin{array}{l}U / U \\
U / U\end{array}$ & & 195 & $\mathrm{U} / \mathrm{U}$ & \\
\hline $3 / 1$ & $17 \mathrm{ddb}$ & 210 & C8262 & stolley & 145 & 75 & $\begin{array}{r}0.38 \\
15 \\
7.64\end{array}$ & $\begin{array}{l}10 / 15 / 92 \\
05 / 01 / 76 \\
01 / 11 / 93\end{array}$ & $\begin{array}{l}\text { OWRD } \\
\text { ariller } \\
\text { OWRD }\end{array}$ & $\begin{array}{r}50 \\
118 \\
135\end{array}$ & & $\begin{array}{l}\text { unknown } \\
\mathrm{U} / \mathrm{U} \\
\mathrm{U} / \mathrm{U}\end{array}$ & & 202 & $\mathrm{U} / \mathrm{U}$ & \\
\hline $3 / 1$ & $17 \mathrm{bdb}$ & 485 & C8289 & Zurstadt & 470 & 10 & $\begin{array}{r}301 \\
285.75\end{array}$ & $\begin{array}{l}03 / 03 / 77 \\
10 / 09 / 92\end{array}$ & $\begin{array}{l}03 / 03 / 77 \\
10 / 09 / 92\end{array}$ & 428 & 442 & OGC/WPR & & 199 & OGC/WPR & \\
\hline $3 / 1$ & 17 & 485 & $\mathrm{C} 8287$ & Zurstadt & 275 & & & & & 243 & 268 & & & & & \\
\hline $\begin{array}{l}\mathrm{T} / \mathrm{R} \\
1 \mathrm{Sec} \\
3 / 1\end{array}$ & $\begin{array}{l}\text { 18aba } \\
\text { ct.) }\end{array}$ & $\begin{array}{l}\text { Elev. } \\
600\end{array}$ & $\begin{array}{l}\text { Well } \\
\text { I.D. }\end{array}$ & $\begin{array}{l}\text { Well } \\
\text { Owner } \\
\text { Beckham }\end{array}$ & $\begin{array}{c}\text { Well } \\
\text { Depth } \\
30\end{array}$ & Yield & $\begin{array}{c}\text { St. Wate } \\
\text { Level } \\
10\end{array}$ & $\begin{array}{l}\text { Date of } \\
\text { Measur. } \\
02 / 04 / 93\end{array}$ & $\begin{array}{l}\text { Measured } \\
\text { by } \\
\text { owner }\end{array}$ & $\begin{array}{l}\text { Water } \\
\text { top }\end{array}$ & $\begin{array}{c}\text { Bear. } \\
\text { bot. }\end{array}$ & $\begin{array}{l}\text { Corresp } \\
\text { Units }\end{array}$ & Est. & $\begin{array}{l}\text { Design. } \\
\text { - Head } \\
\text { NA }\end{array}$ & $\begin{array}{l}\text { Design. } \\
\text { Aquifer }\end{array}$ & Main \\
\hline $3 / 1$ & $18 \mathrm{cbd}$ & 760 & C8333 & Cary & 365 & 18 & $\begin{array}{r}245 \\
248.22\end{array}$ & $\begin{array}{l}10 / 13 / 78 \\
01 / 12 / 93\end{array}$ & $\begin{array}{l}\text { driller } \\
\text { OWRD }\end{array}$ & 315 & & $\mathrm{U} / \mathrm{U}$ & & 512 & OGC/WpR & \\
\hline $3 / 1$ & $18 \mathrm{aab}$ & 655 & $\mathrm{C} 8342$ & Clark & 435 & 30 & $\begin{array}{r}230 \\
320.43\end{array}$ & $\begin{array}{l}10 / 03 / 75 \\
02 / 04 / 93\end{array}$ & $\begin{array}{l}\text { driller } \\
\text { OWRD }\end{array}$ & 160 & & $\mathrm{U} / \mathrm{U}$ & & 335 & OGC/WpR & \\
\hline $3 / 1$ & $18 \mathrm{cdb}$ & 660 & C18316 & $\operatorname{Cox}$ & 200 & 12 & $\begin{array}{r}85 \\
78.73 \\
88.31\end{array}$ & $\begin{array}{l}08 / 21 / 74 \\
08 / 07 / 75 \\
06 / 24 / 92\end{array}$ & $\begin{array}{l}\text { driller } \\
\text { USGS } \\
\text { OWRD }\end{array}$ & 45 & & $\mathrm{WW} / \mathrm{U}$ & & 572 & $\mathrm{U} / \mathrm{U}$ & \\
\hline $3 / 1$ & $18 \mathrm{cca}$ & 750 & C8321 & Heald & $\begin{array}{l}405 \\
405\end{array}$ & $\begin{array}{l}3 \\
6\end{array}$ & $\begin{array}{l}320 \\
250 \\
240 \\
240\end{array}$ & $\begin{array}{l}04 / 17 / 81 \\
11 / 18 / 81 \\
08 / 15 / 89 \\
11 / 28 / 89\end{array}$ & $\begin{array}{l}\text { driller } \\
\text { Phillips } \\
\text { Phillips } \\
\text { driller }\end{array}$ & $\begin{array}{l}325 \\
\text { Pump } \\
\text { Pump }\end{array}$ & & $\mathrm{U} / \mathrm{OGC}$ & & NA & OGC/WpR & \\
\hline $3 / 1$ & $18 a b a$ & 660 & C8330 & Martingale & 260 & 16 & $\begin{array}{r}89 \\
90 \\
90.98\end{array}$ & $\begin{array}{c}04 / 23 / 81 \\
05 / 01 / 92 \\
0.0043\end{array}$ & $\begin{array}{l}\text { driller } \\
\text { pump } \\
\text { OWRD }\end{array}$ & 244 & & $\mathrm{U} / \mathrm{OGC}$ & & 569 & U/OGC & \\
\hline $3 / 1$ & $18 \mathrm{aac}$ & 630 & C8341 & Pompe & 453 & 20 & $\begin{array}{r}320 \\
293.69 \\
297.1 \\
297.46 \\
297.17 \\
298 \\
296.4 \\
296.27\end{array}$ & $\begin{array}{l}05 / 07 / 76 \\
05 / 19 / 92 \\
10 / 28 / 92 \\
11 / 23 / 92 \\
12 / 22 / 93 \\
01 / 28 / 93 \\
03 / 02 / 93 \\
03 / 30 / 93\end{array}$ & $\begin{array}{l}\text { driller } \\
\text { OWRD } \\
\text { OWRD } \\
\text { OWRD } \\
\text { OWRD } \\
\text { OWRD } \\
\text { OWRD } \\
\text { OWRD }\end{array}$ & 390 & & OGC/WpR & & 337 & OGC/WpR & $\begin{array}{l}N \\
\omega\end{array}$ \\
\hline
\end{tabular}


PARRETT MOUNTAIN HYDROLOGIC DATA CONTINUED

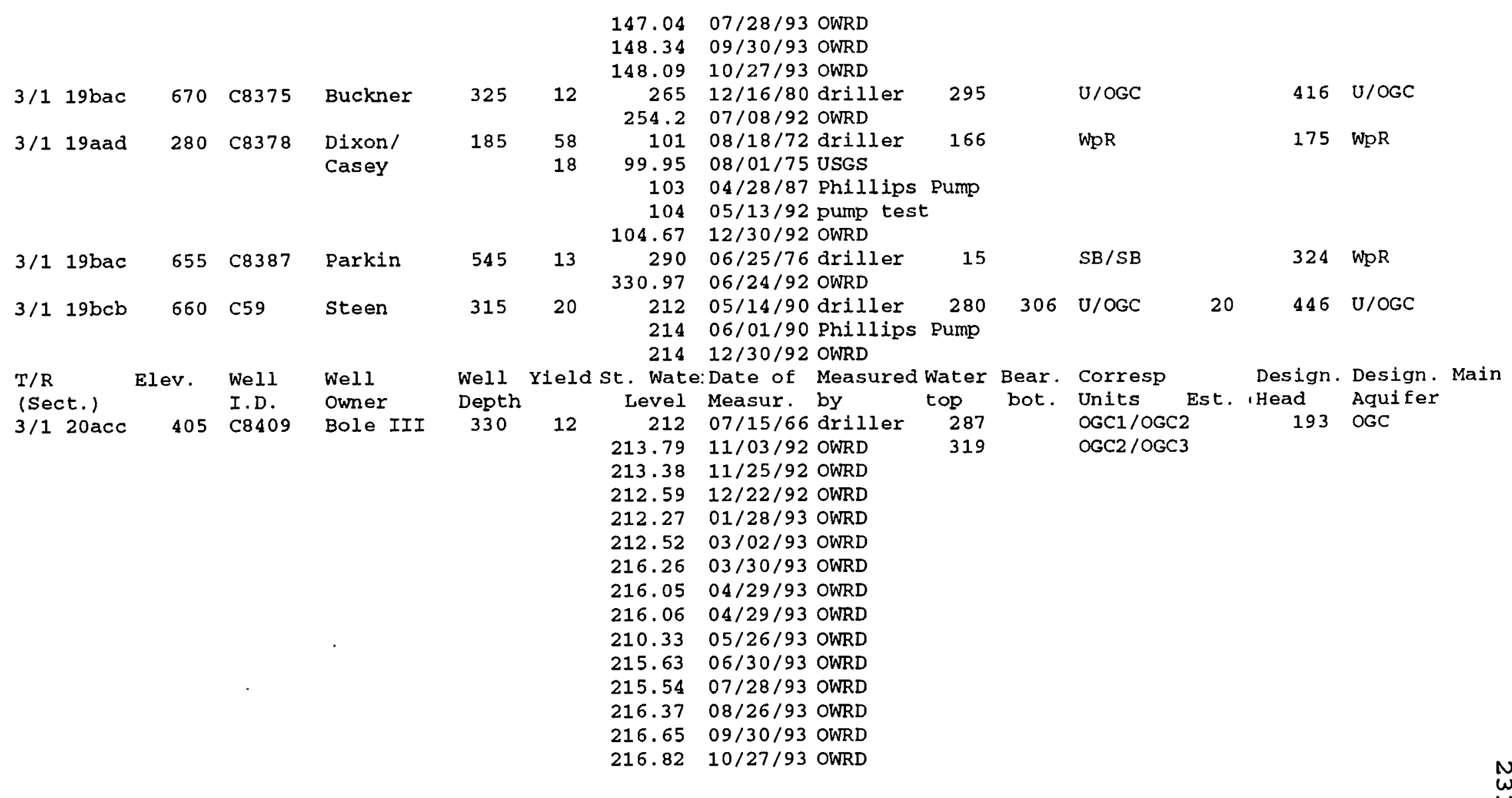


PARRETT MOUNTAIN HYDROLOGIC DATA

$T / R$

(Sect.)

Elev. Well

I.D.

$3 / 119 \mathrm{bdb}$ 610

$3 / 1 \quad 19$ add

320

C8379
Bischof

Well

Owner

Abe

Bischof

\section{CONTINUED}

$$
\begin{array}{rr}
294.98 & 04 / 29 / 93 \text { OWRD } \\
293.72 & 05 / 28 / 93 \text { OWRD } \\
293.04 & 06 / 30 / 93 \text { OWRD } \\
292.58 & 07 / 28 / 93 \text { OWRD } \\
293.86 & 08 / 26 / 93 \text { OWRD } \\
294.12 & 09 / 30 / 93 \text { OWRD } \\
294.5 & 10 / 27 / 93 \text { OWRD }
\end{array}
$$

Well Yield St. Wate:Date of Measured Water Bear. Corresp Design. Design. Main

Depth Level Measur. by

top bot. Units

Est. :Head Aquifer

$34510 / 08 / 86$ driller

258 WpR

$352.2101 / 19 / 93$ OWRD

$200 \quad 30$

143

$148.9605 / 01 / 75$ OWRD

$148.8608 / 01 / 75$ OWRD

$143.8 \quad 04 / 02 / 80$ OWRD

$145.1209 / 16 / 80$ OWRD

$142.8804 / 23 / 81$ OWRD

$145.1510 / 06 / 81$ OWRD

$142.8904 / 15 / 82$ OWRD

$145.109 / 29 / 82$ OWRD

$141.805 / 04 / 83$ OWRD

$144.9709 / 27 / 83$ OWRD

$143.5706 / 05 / 85$ OWRD

$145.1806 / 16 / 87$ OWRD

$144.3406 / 17 / 88$ OWRD

$147.8910 / 28 / 92$ OWRD

$148.3611 / 25 / 92$ OWRD

$147.6212 / 22 / 92$ OWRD

$147.1501 / 28 / 93$ OWRD

$147.0603 / 02 / 93$ OWRD

$146.6603 / 30 / 93$ OWRD

$146.3804 / 29 / 93$ OWRD

$146.2605 / 26 / 93$ OWRD 


\section{PARRETT MOUNTAIN HYDROLOGIC DATA}

\section{CONTINUED}

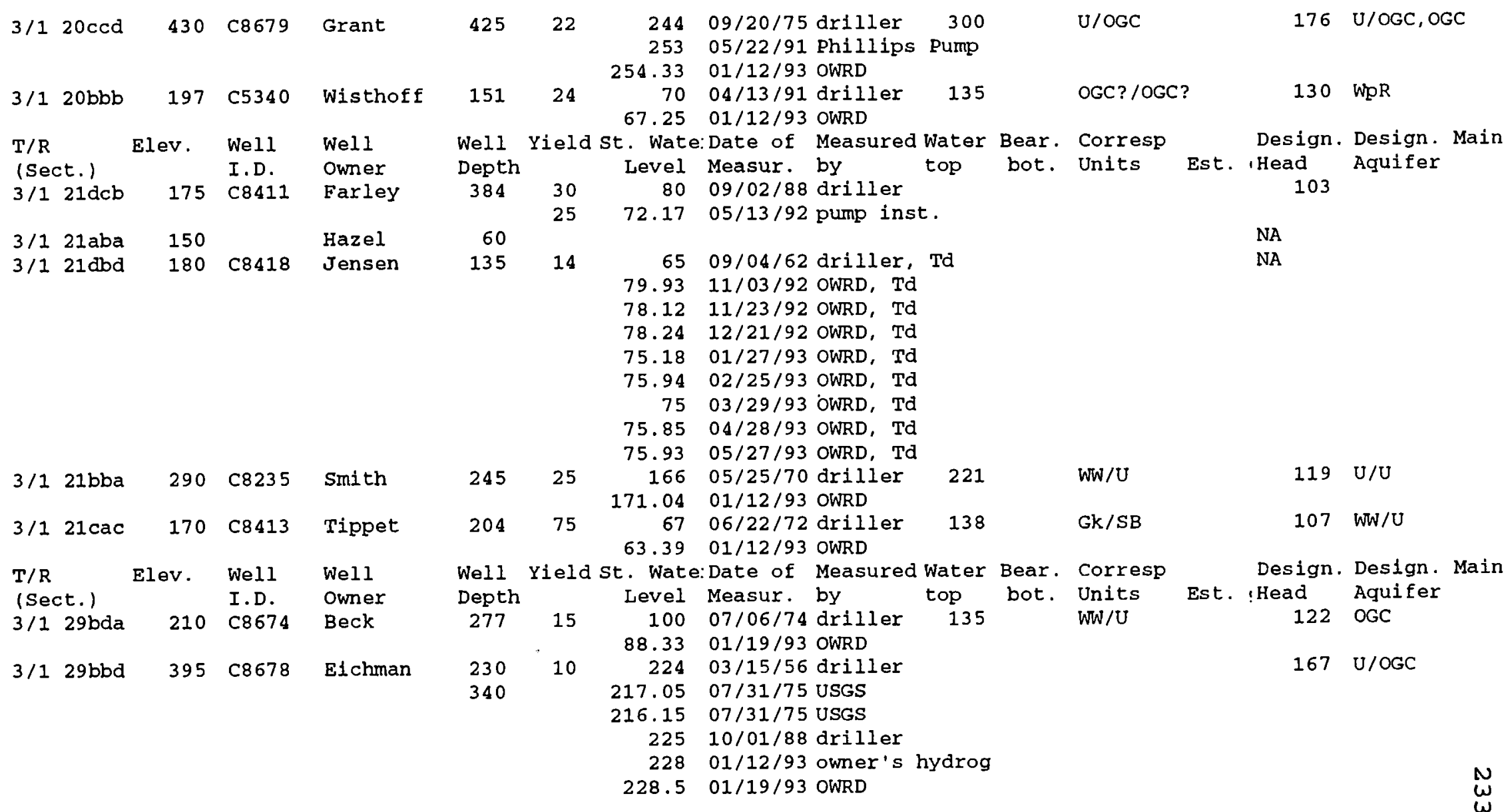


TABLE XV

PARRETT MOUNTAIN HYDROLOGIC DATA

CONTINUED

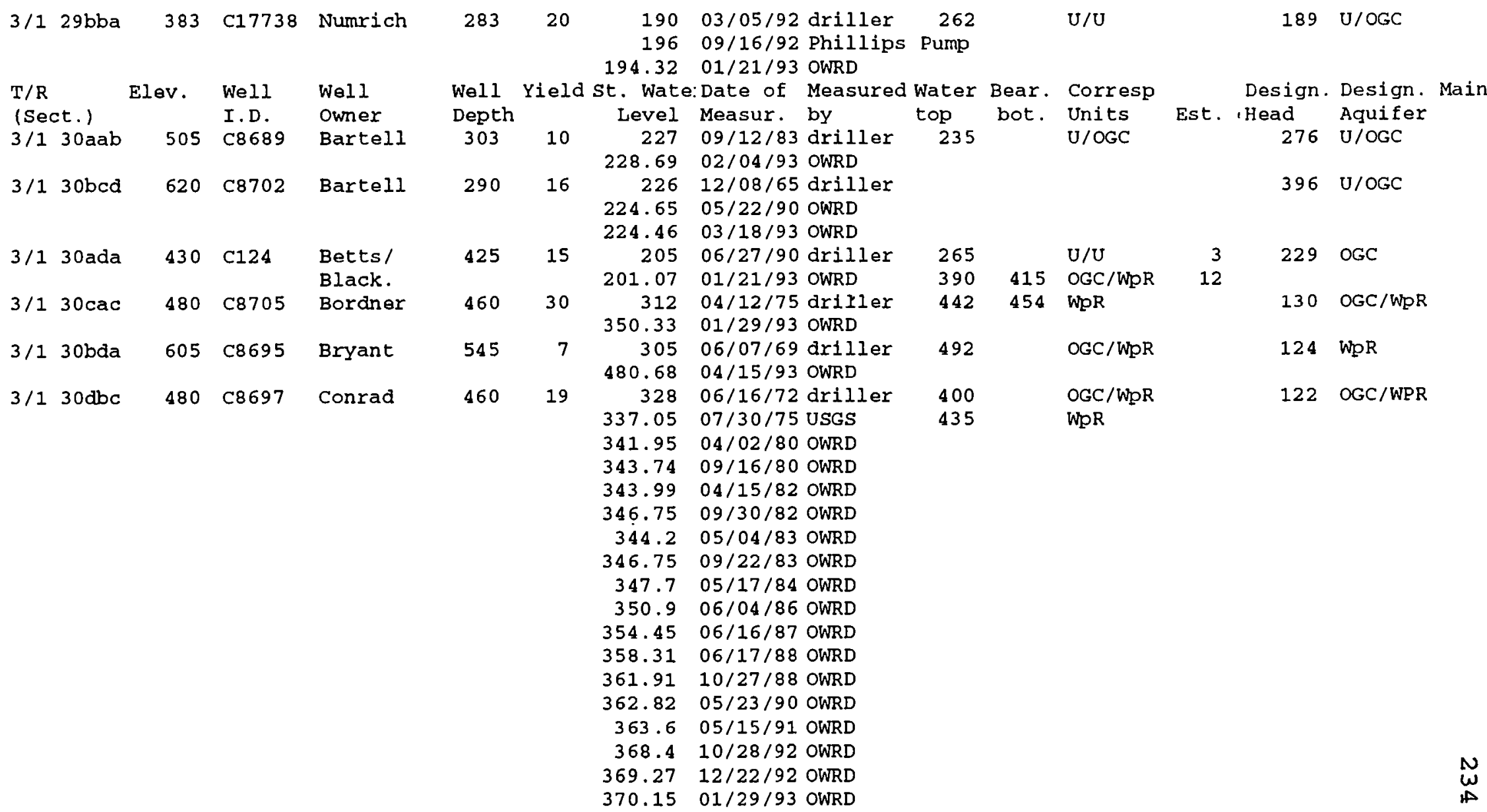


PARRETT MOUNTAIN HYDROLOGIC DATA CONTINUED

\begin{tabular}{|c|c|c|c|c|c|c|c|c|c|c|c|c|c|}
\hline & & & & & . & & 370 & $03 / 02 / 93$ OWRD & & & & & \\
\hline & & & & & & & 369.59 & $03 / 30 / 93$ OWRD & & & & & \\
\hline & & & & & & & 369.16 & $04 / 30 / 93$ OWRD & & & & & \\
\hline & & & & & & & 368.98 & $05 / 26 / 93$ OWRD & & & & & \\
\hline & & & & & & & 369.26 & $06 / 30 / 93$ OWRD & & & & & \\
\hline & & & & & & & 369.29 & $07 / 28 / 93$ OWRD & & & & & \\
\hline & & & & & & & 370.17 & $08 / 26 / 93$ OWRD & & & & & \\
\hline & & & & & & & 371.28 & $09 / 30 / 93$ OWRD & & & & & \\
\hline & & & & & & & 371.32 & $10 / 27 / 93$ OWRD & & & & & \\
\hline $3 / 1$ & $30 \mathrm{caa}$ & 570 & $\mathrm{C} 8704$ & Crew & 585 & 10 & 412 & $07 / 27 / 78$ driller & 164 & & WW/U & 122 & $\omega p R$ \\
\hline & & & & & & & 447.67 & $03 / 25 / 93$ OWRD & 545 & & & & \\
\hline $3 / 1$ & $30 \mathrm{acb}$ & 580 & $\mathrm{C} 8713$ & Heinz & 515 & 12 & 372 & 09/03/73 driller & 494 & 508 & WpR & 119 & WpR \\
\hline & & & & & & & 460.75 & $03 / 25 / 93$ OWRD & & & & & \\
\hline $3 / 1$ & $30 \mathrm{bdd}$ & 575 & C8706 & Johnsen & 176 & 9 & 108 & $08 / 16 / 65$ driller & 485 & & WpR & 126 & WpR \\
\hline & & & & & 558 & 9 & 465 & $08 / 14 / 73$ driller & & & & & \\
\hline & & & & & & & 470 & $02 / 11 / 93$ OWRD & & & & & \\
\hline & & & & & & & 448.71 & $04 / 15 / 93$ OWRD & & & & & \\
\hline $3 / 1$ & $30 \mathrm{ddb}$ & 300 & C8691 & Reger & 285 & 15 & 140 & 10/19/81 driller & 65 & & $S B / W W$ & 127 & $\mathrm{U} / \mathrm{OGC}$ \\
\hline & & & & & & & 172.64 & $07 / 09 / 92$ OWRD & & & & & \\
\hline $3 / 1$ & $30 \mathrm{bbd}$ & 405 & C18406 & Salzman & 385 & 30 & 190 & 10/16/92 driller & 37 & & OGC? /OGC? & 216 & WpR \\
\hline & & & & & & & 191.05 & $12 / 11 / 92$ OWRD & 190 & & fault & & \\
\hline & & & & & & & 190.78 & $12 / 22 / 92$ OWRD & & & & & \\
\hline & & & & & & & 190.89 & $01 / 28 / 93$ OWRD & & & & & \\
\hline & & & & & & & 189.97 & $03 / 02 * 93$ OWRD & & & & & \\
\hline & & & & & & & 190.66 & $03 / 30 / 93$ OWRD & & & & & \\
\hline & & & & & & & 190.27 & $04 / 29 / 93$ OWRD & & & & & \\
\hline & & & & & & & 189.33 & $05 / 26 / 93$ OWRD & & & & & \\
\hline & & & & & & & 189.46 & $06 / 30 / 93$ OWRD & & & & & \\
\hline $3 / 1$ & $30 a a a$ & 515 & $\mathrm{C} 8690$ & Schoening & 365 & 14 & 235 & $07 / 20 / 83$ driller & 65 & & SB/SB & 273 & U/OGC \\
\hline & & & & & & & 235 & 07/25/83 Phillips & 120 & & $\mathrm{SB} / \mathrm{WW}$ & & \\
\hline & & & & & & & 241.89 & 02/04/93 OWRD & 238 & & $\mathrm{U} / \mathrm{U}$ & & \\
\hline
\end{tabular}


PARRETT MOUNTAIN HYDROLOGIC DATA

CONTINUED

\begin{tabular}{|c|c|c|c|c|c|c|c|c|c|c|c|}
\hline $\begin{array}{l}\text { T/R } \\
\text { (Sect.) } \\
3 / 1 \text { 31aba }\end{array}$ & Elev. & $\begin{array}{l}\text { Well } \\
\text { I.D. } \\
\text { C11991 }\end{array}$ & $\begin{array}{l}\text { Well } \\
\text { Owner } \\
\text { Conner }\end{array}$ & $\begin{array}{l}\text { Well } \\
\text { Depth } \\
500\end{array}$ & Yield & $\begin{array}{r}\text { St. Wate } \\
\text { Level } \\
154 \\
152.13\end{array}$ & $\begin{array}{l}\text { Date of } \\
\text { Measur. } \\
08 / 02 / 67 \\
03 / 11 / 93\end{array}$ & $\begin{array}{l}\text { Measured } \\
\text { by } \\
\text { driller } \\
\text { OWRD }\end{array}$ & $\begin{array}{l}\text { Water } \\
\text { top }\end{array}$ & $\begin{array}{l}\text { Bear. } \\
\text { bot. }\end{array}$ & $\begin{array}{l}\text { Corresp } \\
\text { Units }\end{array}$ \\
\hline $3 / 131 \mathrm{acd}$ & 170 & $C 8740$ & Dawson & 167 & 20 & $\begin{array}{r}70 \\
64.88\end{array}$ & $\begin{array}{l}06 / 05 / 63 \\
01 / 21 / 93\end{array}$ & $\begin{array}{l}\text { driller } \\
\text { OWRD }\end{array}$ & 151 & & $\mathrm{U} / \mathrm{U}$ \\
\hline $3 / 1$ 31aad & 185 & $C 8748$ & Ellison & 185 & $\begin{array}{l}18 \\
18\end{array}$ & $\begin{array}{r}88 \\
88.82\end{array}$ & $\begin{array}{l}06 / 24 / 77 \\
02 / 11 / 93\end{array}$ & $\begin{array}{l}\text { driller } \\
\text { OWRD }\end{array}$ & $\begin{array}{r}94 \\
131\end{array}$ & & $\begin{array}{l}\text { WW/U } \\
\mathrm{U} / \mathrm{U}\end{array}$ \\
\hline $3 / 131 \mathrm{adb}$ & 185 & $C 8744$ & Ellison & 152 & & $\begin{array}{r}66 \\
73.68\end{array}$ & $\begin{array}{l}06 / 10 / 62 \\
02 / 11 / 93\end{array}$ & $\begin{array}{l}\text { driller } \\
\text { OWRD }\end{array}$ & & & \\
\hline $3 / 131 d d c$ & 110 & & Frye & 150 & & 50.04 & $02 / 11 / 93$ & OWRD & & & \\
\hline $3 / 131 \mathrm{bbb}$ & 485 & C8720 & Hann & 438 & 12 & $\begin{array}{r}320 \\
299.32\end{array}$ & $\begin{array}{l}04 / 30 / 85 \\
02 / 04 / 93\end{array}$ & $\begin{array}{l}\text { driller } \\
\text { OWRD }\end{array}$ & $\begin{array}{l}305 \\
426\end{array}$ & 438 & $\begin{array}{l}\mathrm{U} / O G C \\
\text { OGC / WpR }\end{array}$ \\
\hline $3 / 131 \mathrm{abb}$ & 315 & C8751 & Johnson & 315 & & $\begin{array}{r}129 \\
171 \\
197.98\end{array}$ & $\begin{array}{l}05 / 27 / 60 \\
02 / 02 / 84 \\
03 / 11 / 93\end{array}$ & $\begin{array}{l}\text { driller } \\
\text { Phillips } \\
\text { OWRD }\end{array}$ & Pump & & \\
\hline $3 / 131 \mathrm{cbc}$ & 105 & & Mckay & $400+$ & & $\begin{array}{r}4 \\
22\end{array}$ & $01 / 12 / 93$ & OWRD & & & \\
\hline $3 / 1$ 31bad & 285 & $C 8746$ & Neal & 300 & 60 & $\begin{array}{r}140 \\
141.44\end{array}$ & $\begin{array}{l}09 / 29 / 78 \\
03 / 11 / 93\end{array}$ & $\begin{array}{l}\text { driller } \\
\text { OWRD }\end{array}$ & & & \\
\hline 3/1 31dda & 110 & & Quelette & 293 & & $\begin{array}{r}40 \\
45.32\end{array}$ & $\begin{array}{l}07 / 01 / 46 \\
01 / 12 / 93\end{array}$ & $\begin{array}{l}\text { owner } \\
\text { OWRD }\end{array}$ & & & \\
\hline $3 / 131 \mathrm{bdb}$ & 270 & $C 8741$ & Smith & 365 & 18 & $\begin{array}{r}195 \\
213.57 \\
191.83 \\
193.49 \\
189.56 \\
189.84 \\
188.85 \\
190.12 \\
184.14 \\
184.75 \\
189.69 \\
201.78\end{array}$ & $\begin{array}{l}09 / 23 / 77 \\
08 / 14 / 92 \\
10 / 29 / 92 \\
11 / 25 / 92 \\
12 / 56 / 92 \\
01 / 29 / 93 \\
03 / 02 / 93 \\
03 / 30 / 93 \\
04 / 30 / 93 \\
05 / 26 / 93 \\
06 / 30 / 93 \\
08 / 25 / 93\end{array}$ & $\begin{array}{l}\text { driller } \\
\text { OWRD } \\
\text { OWRD } \\
\text { OWRD } \\
\text { OWRD } \\
\text { OWRD } \\
\text { OWRD } \\
\text { OWRD } \\
\text { OWRD } \\
\text { OWRD } \\
\text { OWRD } \\
\text { OWRD }\end{array}$ & $\begin{array}{l}305 \\
345\end{array}$ & & $\begin{array}{l}\text { OGC/WpR } \\
\text { WpR }\end{array}$ \\
\hline
\end{tabular}

Design. Design. Main Est. IHead Aquifer 123 WpR $105 \mathrm{WW} / \mathrm{U}$ $96 W W / U, U / U$ $111 \mathrm{WW} / \mathrm{U}$

NA 186 OGC/WpR 117 OGC 93 $144 \mathrm{U} / \mathrm{OGC}, \mathrm{OGC}$ NA 86 OGC / WpR 
TABLE XV

\section{PARRETT MOUNTAIN HYDROLOGIC DATA}

CONT INUED

\begin{tabular}{|c|c|c|c|}
\hline $\begin{array}{l}T / R \\
\text { (Sect.) } \\
3 / 131 \mathrm{cbc}\end{array}$ & $\begin{array}{l}\text { Elev. } \\
105\end{array}$ & $\begin{array}{l}\text { Well } \\
\text { I.D. }\end{array}$ & $\begin{array}{l}\text { Well } \\
\text { Owner } \\
\text { Mckay }\end{array}$ \\
\hline $\begin{array}{l}T / R \\
\text { (Sect.) } \\
3 / 2 \text { ladb }\end{array}$ & $\begin{array}{l}\text { Elev. } \\
250\end{array}$ & $\begin{array}{l}\text { Well } \\
\text { I.D. } \\
\text { W1960 }\end{array}$ & $\begin{array}{l}\text { Well } \\
\text { Owner } \\
\text { Baron }\end{array}$ \\
\hline
\end{tabular}

$3 / 21 \mathrm{dba}$
260 W1979 Roybal

\begin{tabular}{|c|c|c|c|c|c|c|c|c|c|c|c|}
\hline & & $\begin{array}{l}203.29 \\
191.11\end{array}$ & $\begin{array}{l}09 / 30 / 93 \\
10 / 27 / 93\end{array}$ & $\begin{array}{l}\text { OWRD } \\
\text { OWRD }\end{array}$ & & & & & & & \\
\hline $\begin{array}{l}\text { Well } \\
\text { Depth }\end{array}$ & Yield & $\begin{array}{c}\text { St. Wate } \\
\text { Level }\end{array}$ & $\begin{array}{l}\text { Date of } \\
\text { Measur. }\end{array}$ & $\begin{array}{l}\text { Measured } \\
\text { by }\end{array}$ & $\begin{array}{l}\text { d Water } \\
\text { top }\end{array}$ & $\begin{array}{l}\text { Bear. } \\
\text { bot. }\end{array}$ & $\begin{array}{l}\text { Corresp } \\
\text { Units }\end{array}$ & Est. & $\begin{array}{l}\text { Design. } \\
\text { Head }\end{array}$ & $\begin{array}{l}\text { Design. } \\
\text { Aquifer }\end{array}$ & Main \\
\hline \multirow[t]{2}{*}{$400+$} & & 4 & & & & & & \multicolumn{4}{|c|}{93} \\
\hline & & 22 & $01 / 12 / 93$ & OWRD & & & & & & & \\
\hline Well & Yield & st. Wate & Date of & Measured & d Water & Bear. & Corresp & & Design. & Design. & Main \\
\hline Depth & & Level & Measur. & by & top & bot. & Units & Est. & ! Head & Aquifer & \\
\hline \multirow[t]{14}{*}{200} & 20 & 28 & $12 / 29 / 79$ & driller & 184 & 192 & & & 219 & & \\
\hline & & 34 & $05 / 20 / 92$ & OWRD & & & & & & & \\
\hline & & 42.49 & $10 / 28 / 92$ & OWRD & & & & & & & \\
\hline & & 39.42 & $11 / 24 / 92$ & OWRD & & & & & & & \\
\hline & & 35.43 & $12 / 21 / 92$ & OWRD & & & & & & & \\
\hline & & 32.75 & $01 / 27 / 93$ & OWRD & & & & & & & \\
\hline & & 34.3 & $02 / 25 / 93$ & OWRD & & & & & & & \\
\hline & & 33.08 & $03 / 29 / 93$ & OWRD & & & & & & & \\
\hline & & 30.86 & $04 / 29 / 93$ & OWRD & & & & & & & \\
\hline & & 34.51 & $05 / 27 / 93$ & OWRD & & & & & & & \\
\hline & & 35.51 & $06 / 29 / 93$ & OWRD & & & & & & & \\
\hline & & 37.96 & $07 / 27 / 93$ & OWRD & & & & & & & \\
\hline & & 41.86 & $09 / 29 / 93$ & OWRD & & & & & & & \\
\hline & & 39.61 & $10 / 26 / 93$ & OWRD & & & & & & & \\
\hline \multirow[t]{12}{*}{260} & 10 & 60 & $02 / 22 / 74$ & DEEP & 196 & & & & NA & & \\
\hline & & 61.43 & $07 / 10 / 75$ & GW RPT \# & $\# 27$ & & & & & & \\
\hline & & 62.1 & $04 / 02 / 80$ & OWRD & & & & & & & \\
\hline & & 65.17 & $09 / 16 / 80$ & OWRD & & & & & & & \\
\hline & & 65.1 & $09 / 11 / 81$ & OWRD & & & & & & & \\
\hline & & 61.1 & $05 / 12 / 82$ & OWRD & & & & & & & \\
\hline & & 63.7 & $09 / 30 / 82$ & OWRD & & & & & & & \\
\hline & & 60.6 & $05 / 04 / 83$ & OWRD & & & & & & & \\
\hline & & 61 & $09 / 22 / 83$ & OWRD & & & & & & & \\
\hline & & 59.4 & $05 / 17 / 84$ & OWRD & & & & & & & \\
\hline & & 60.97 & $06 / 05 / 85$ & OWRD & & & & & & & $\omega$ \\
\hline & & 62.15 & $04 / 18 / 86$ & OWRD & & & & & & & $\checkmark$ \\
\hline
\end{tabular}


TABLE XV

\section{PARRETT MOUNTAIN HYDROLOGIC DATA CONTINUED}

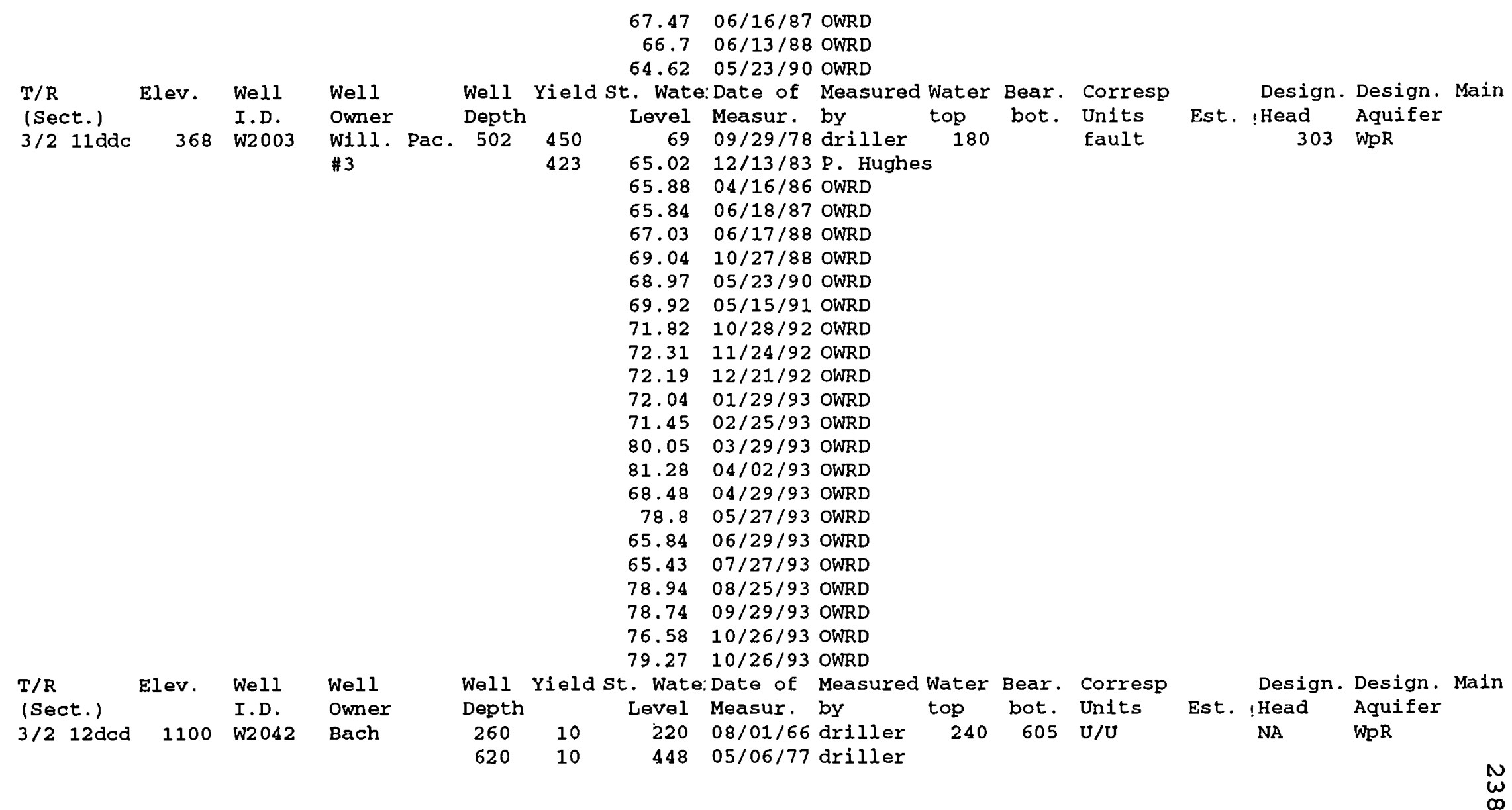


PARRETT MOUNTAIN HYDROLOGIC DATA CONTINUED

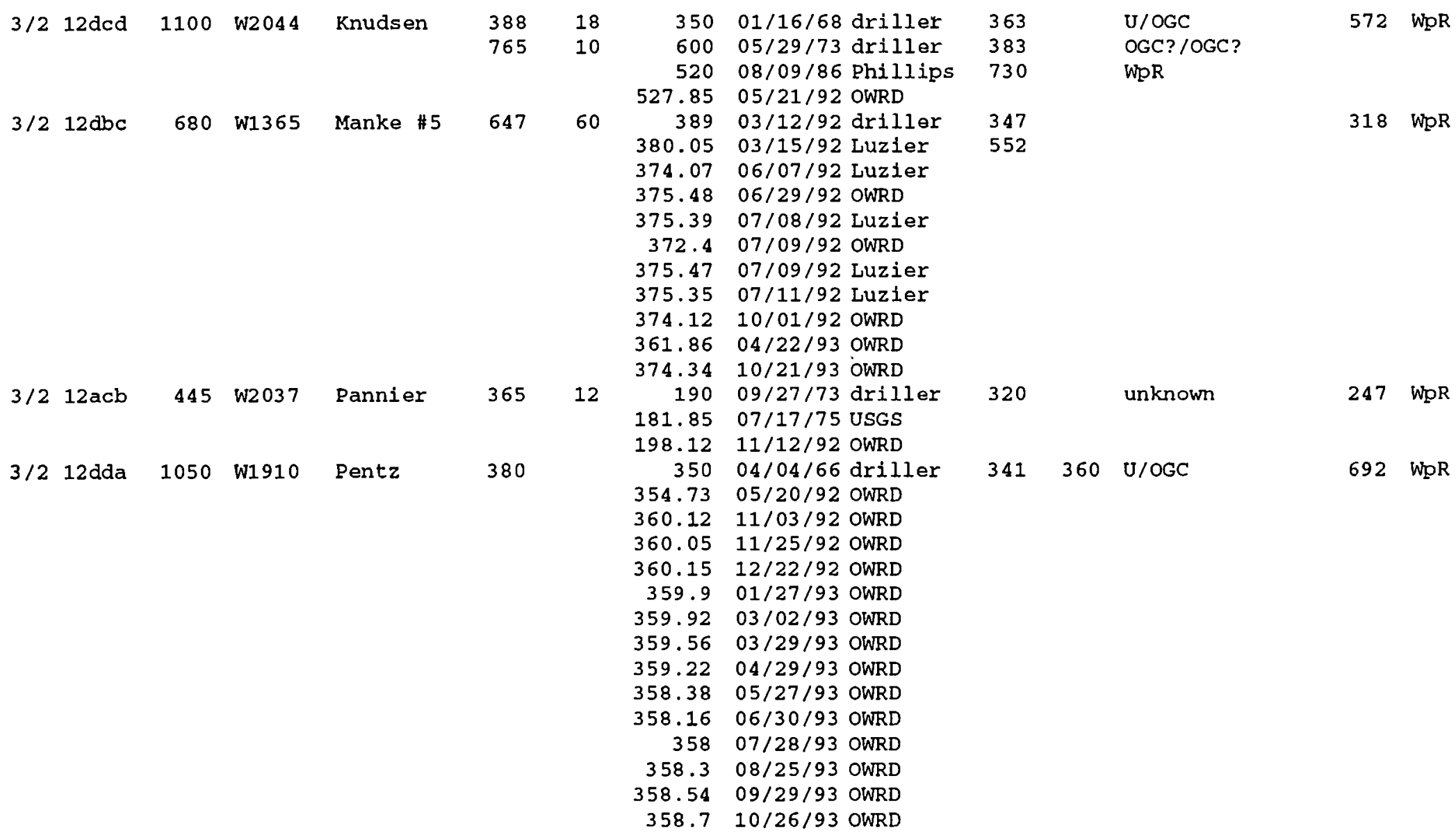


TABLE XV

PARRETT MOUNTAIN HYDROLOGIC DATA

CONTINUED

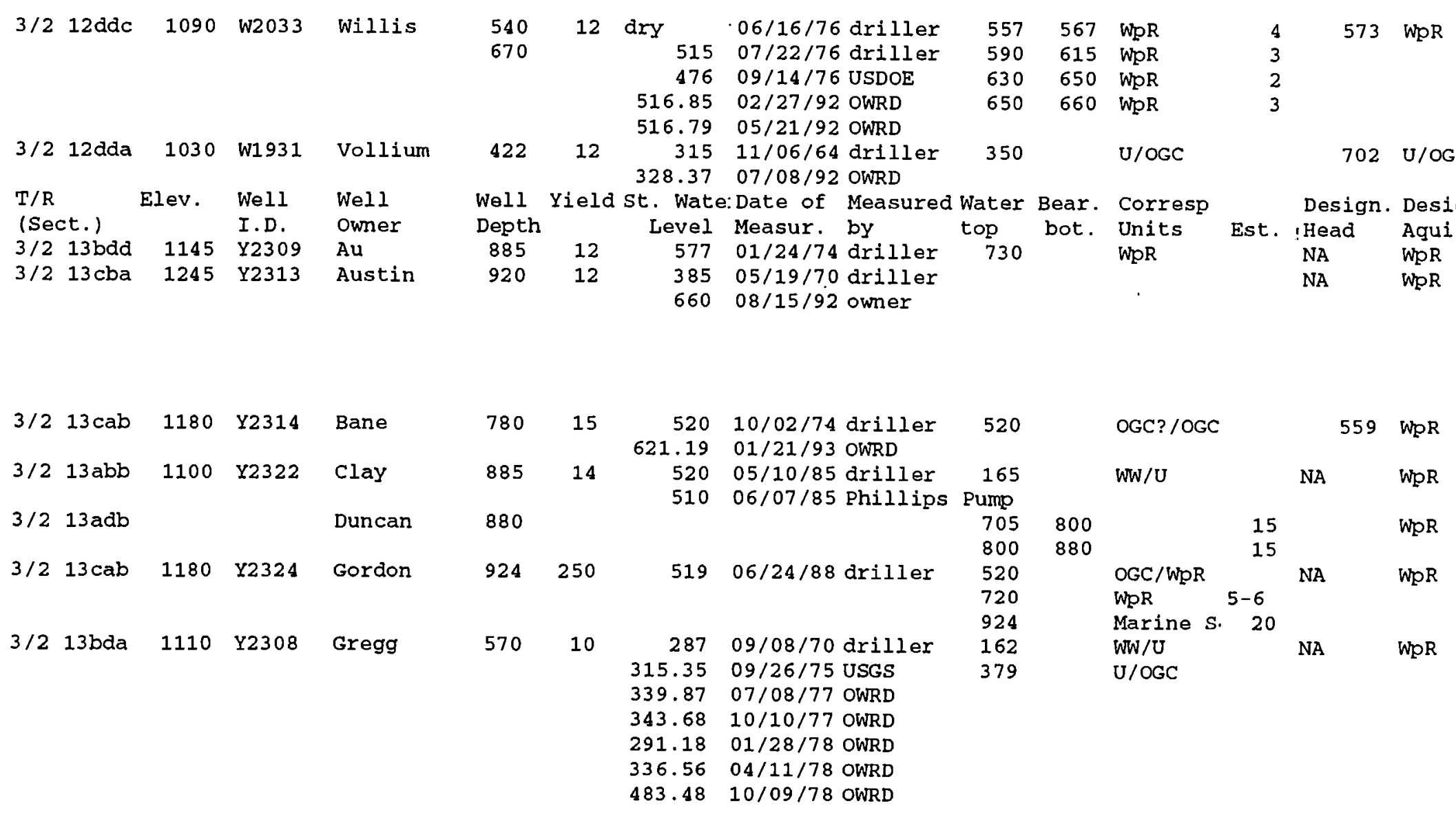




\section{PARRETT MOUNTAIN HYDROLOGIC DATA}

CONTINUED

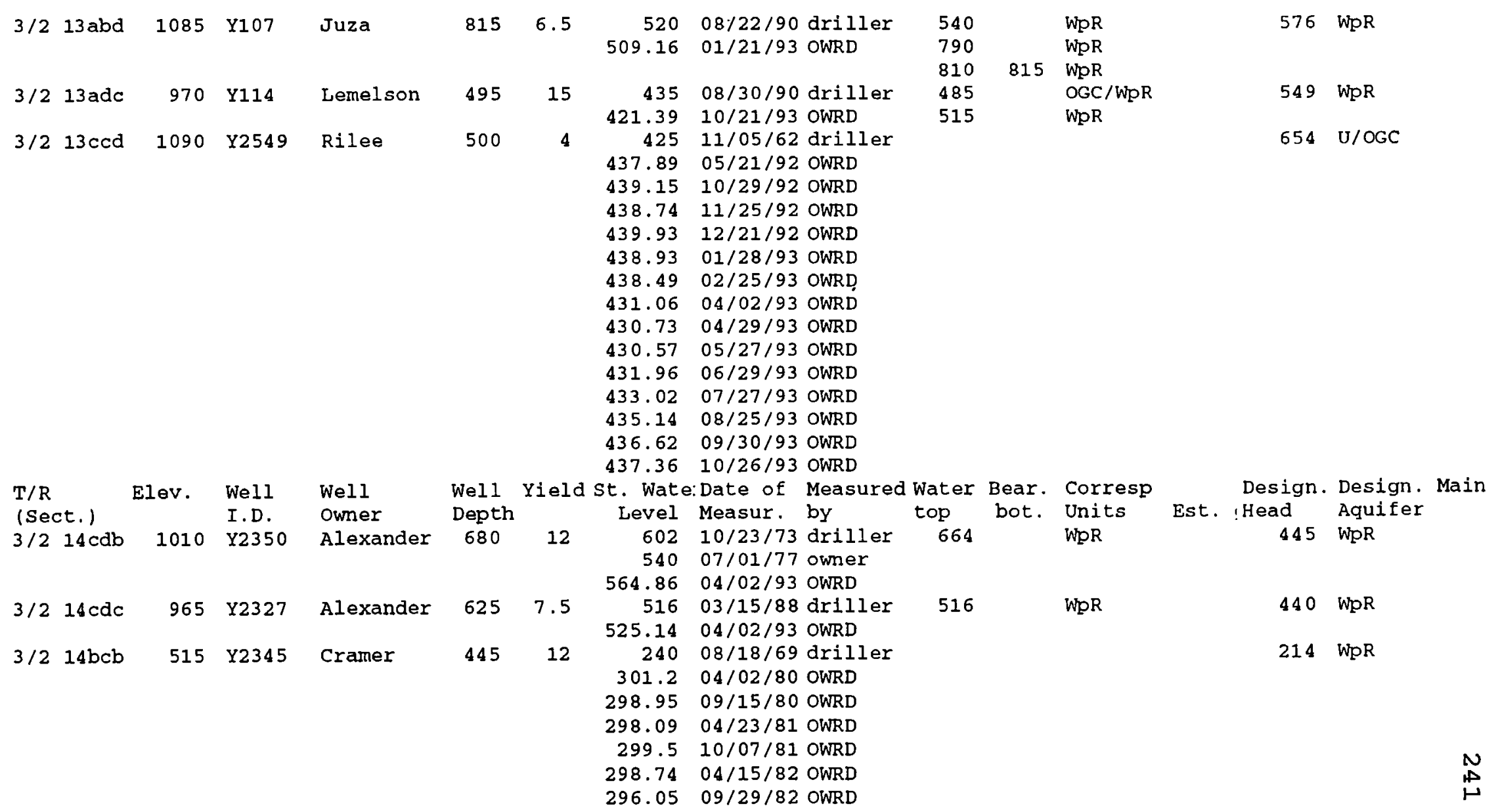




\section{PARRETT MOUNTAIN HYDROLOGIC DATA} CONTINUED

$\begin{array}{llllll}3 / 2 & 14 \mathrm{ccb} & 695 & & \text { Garvey } & 293 \\ 3 / 214 \mathrm{cbb} & 690 & \text { Y2336 } & \text { Lakovics } & 575 & 12 \\ & & & & & \\ 3 / 2 & 14 \mathrm{bbb} & 430 & \text { Y2346 } & \text { Lewis } & 200\end{array}$

$3 / 214 \mathrm{bbb}$

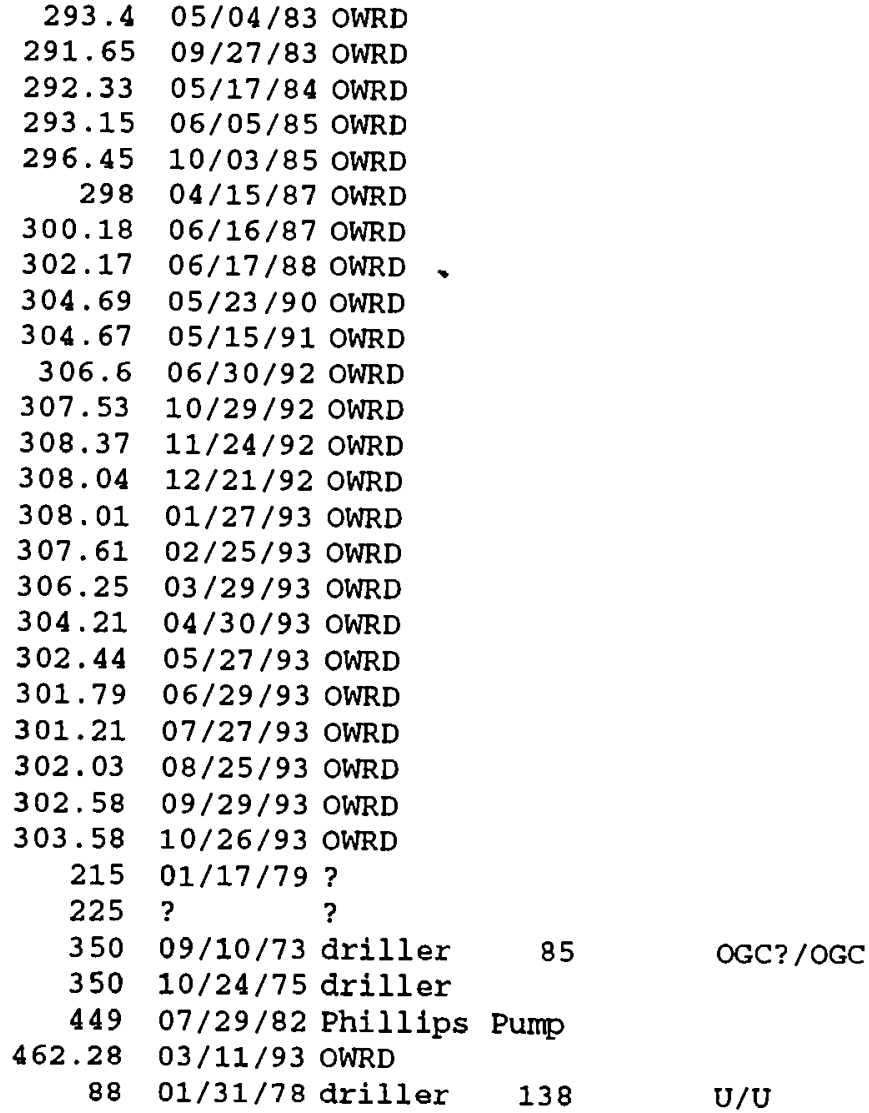




\title{
PARRETT MOUNTAIN HYDROLOGIC DATA
}

\author{
CONTINUED
}

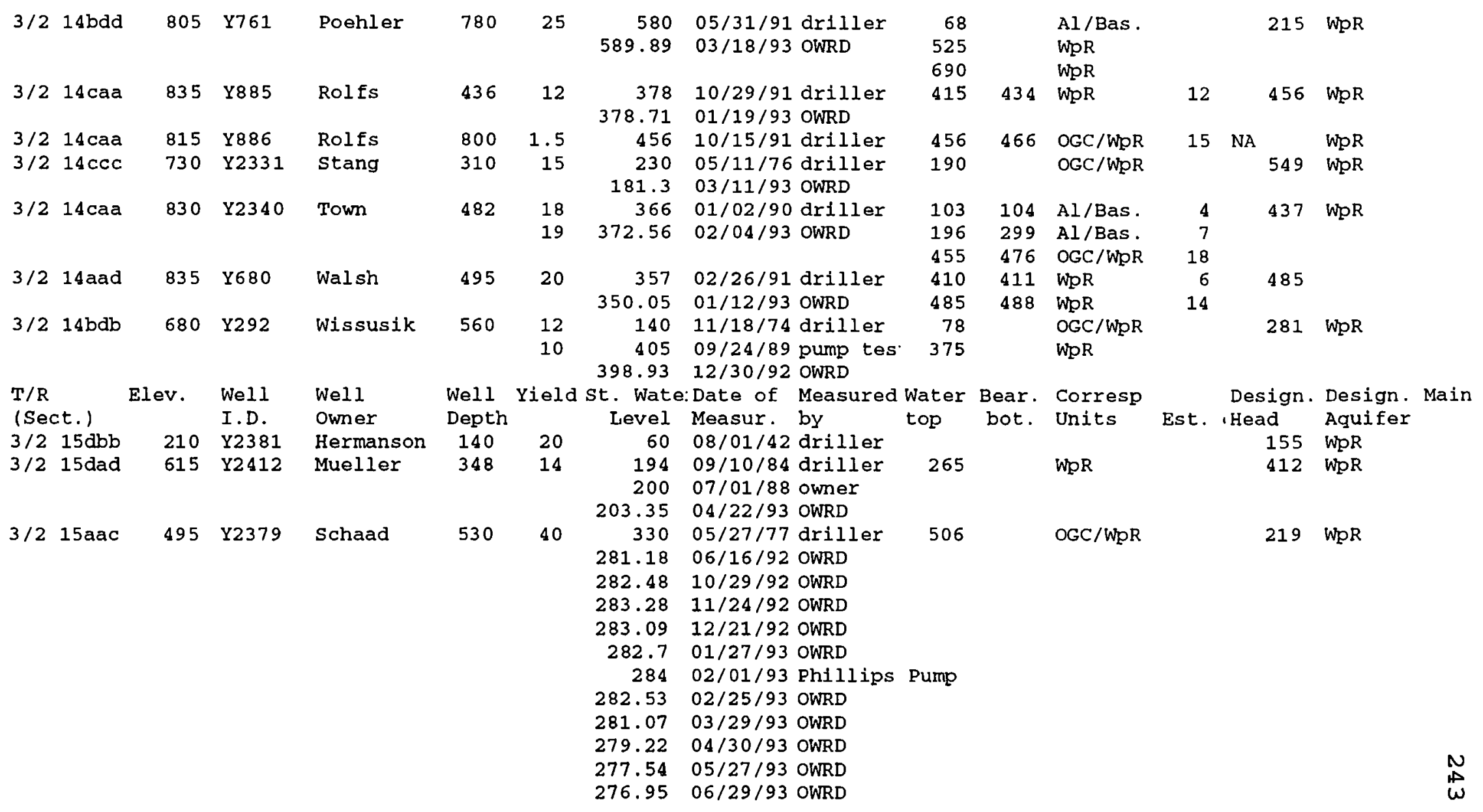




\section{PARRETT MOUNTAIN HYDROLOGIC DATA} CONTINUED

\begin{tabular}{|c|c|c|c|c|c|c|c|c|c|c|c|c|c|c|c|c|}
\hline & & & & & & & $\begin{array}{l}276.46 \\
277.44 \\
277.97 \\
278.81\end{array}$ & $\begin{array}{l}07 / 27 / 93 \\
08 / 25 / 93 \\
09 / 29 / 93 \\
10 / 26 / 93\end{array}$ & $\begin{array}{l}\text { OWRD } \\
\text { OWRD } \\
\text { OWRD } \\
\text { OWRD }\end{array}$ & & & & & & & \\
\hline $3 / 2$ & 15ada & 510 & Y2378 & Schaad & 485 & 40 & $\begin{array}{r}302 \\
300.28\end{array}$ & $\begin{array}{l}08 / 15 / 77 \\
03 / 25 / 93\end{array}$ & $\begin{array}{l}\text { driller } \\
\text { OWRD }\end{array}$ & 448 & & OGC? /OGC & & 210 & WpR & \\
\hline $3 / 2$ & $15 \mathrm{dbb}$ & 230 & Y2371 & Scholz & 103 & 20 & $\begin{array}{r}21 \\
27.37\end{array}$ & $\begin{array}{l}04 / 06 / 67 \\
04 / 15 / 93\end{array}$ & $\begin{array}{l}\text { driller } \\
\text { OWRD }\end{array}$ & 91 & & WpR & & 203 & WpR & \\
\hline $3 / 2$ & 15dda & 600 & $Y 2380$ & Zauner & 255 & 18 & $\begin{array}{r}164 \\
176.78\end{array}$ & $\begin{array}{l}08 / 15 / 78 \\
04 / 15 / 93\end{array}$ & $\begin{array}{l}\text { driller } \\
\text { OWRD }\end{array}$ & 177 & & WpR & & 423 & WpR & \\
\hline $\begin{array}{l}T / R \\
\text { (Sec } \\
3 / 2\end{array}$ & $\begin{array}{l}\text { ct.) } \\
22 \mathrm{acb}\end{array}$ & $\begin{array}{l}\text { Elev. } \\
305\end{array}$ & $\begin{array}{l}\text { Well } \\
\text { I.D. }\end{array}$ & $\begin{array}{l}\text { Well } \\
\text { Owner } \\
\text { Craft }\end{array}$ & $\begin{array}{l}\text { Well } \\
\text { Depth } \\
38\end{array}$ & & $\begin{array}{r}\text { St. Wate } \\
\text { Level } \\
9 \\
6.9\end{array}$ & $\begin{array}{l}\text { Date of } \\
\text { Measur. } \\
08 / 92 \\
04 / 08 / 93\end{array}$ & $\begin{array}{l}\text { Measured } \\
\text { by } \\
\text { owner } \\
\text { OWRD }\end{array}$ & $\begin{array}{l}\text { Water } \\
\text { top }\end{array}$ & $\begin{array}{c}\text { Bear. } \\
\text { bot. }\end{array}$ & $\begin{array}{l}\text { Corresp } \\
\text { Units }\end{array}$ & Est. & $\begin{array}{l}\text { Design. } \\
\text { !Head } \\
\text { NA }\end{array}$ & $\begin{array}{l}\text { Design. } \\
\text { Aquifer } \\
\text { WpR }\end{array}$ & Main \\
\hline $3 / 2$ & $22 \mathrm{aaa}$ & 555 & Y2522 & Darby & 165 & 13 & $\begin{array}{r}71 \\
86.62\end{array}$ & $\begin{array}{l}08 / 03 / 71 \\
04 / 02 / 93\end{array}$ & driller & 100 & & WpR & & 468 & $W p R$ & \\
\hline $3 / 2$ & $22 \mathrm{aca}$ & 330 & Y2518 & $\begin{array}{l}\text { Friedman / } \\
\text { Seitz }\end{array}$ & 97 & $\begin{array}{l}14 \\
14\end{array}$ & $\begin{array}{r}35 \\
37 \\
37.61\end{array}$ & $\begin{array}{l}11 / 22 / 61 \\
05 / 27 / 88 \\
03 / 18 / 93\end{array}$ & $\begin{array}{l}\text { driller } \\
\text { pump tes } \\
\text { OWRD }\end{array}$ & 52 & & $\mathrm{U} / \mathrm{OGC}$ & & 292 & WpR & \\
\hline $3 / 2$ & $22 a a b$ & 505 & Y2512 & Hendren & 245 & 37 & $\begin{array}{r}78 \\
112.13 \\
109.01\end{array}$ & $\begin{array}{l}08 / 10 / 68 \\
03 / 18 / 93 \\
04 / 22 / 93\end{array}$ & $\begin{array}{l}\text { driller } \\
\text { OWRD } \\
\text { OWRD }\end{array}$ & & & & & 396 & WpR & \\
\hline $3 / 2$ & $22 d d c$ & 280 & Y2509 & Renne & 165 & 30 & $\begin{array}{r}70 \\
55.31\end{array}$ & $\begin{array}{l}02 / 13 / 79 \\
04 / 15 / 93\end{array}$ & $\begin{array}{l}\text { driller } \\
\text { OWRD }\end{array}$ & 112 & & fault & & 225 & WpR & \\
\hline $3 / 2$ & $22 \mathrm{cad}$ & 222 & Y2501 & Siefken & 145 & 100 & $\begin{array}{r}31 \\
31.54 \\
28.45 \\
31.48 \\
28.29 \\
31.1 \\
27.72 \\
31.3 \\
27.45 \\
30.72\end{array}$ & $\begin{array}{l}09 / 21 / 74 \\
07 / 23 / 75 \\
04 / 02 / 80 \\
09 / 15 / 80 \\
04 / 23 / 81 \\
10 / 07 / 81 \\
04 / 15 / 82 \\
09 / 30 / 82 \\
05 / 04 / 83 \\
09 / 23 / 83\end{array}$ & $\begin{array}{l}\text { driller } \\
\text { USGS } \\
\text { OWRD } \\
\text { OWRD } \\
\text { OWRD } \\
\text { OWRD } \\
\text { OWRD } \\
\text { OWRD } \\
\text { OWRD } \\
\text { OWRD }\end{array}$ & 105 & & WpR & & 194 & WpR & $\underset{A}{N}$ \\
\hline
\end{tabular}


TABLE XV

PARRETT MOUNTAIN HYDROLOGIC DATA

CONTINUED

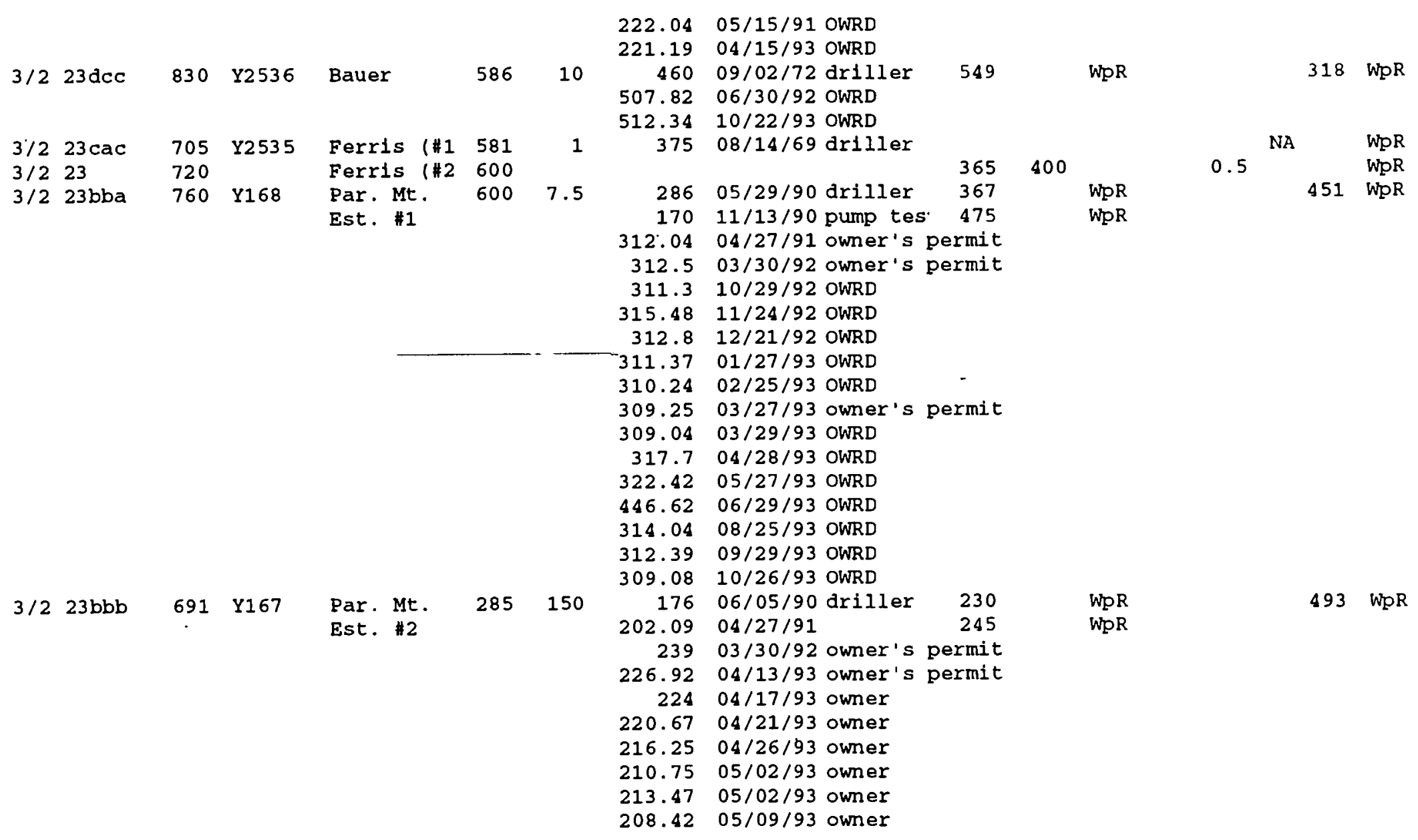


TABLE XV

\section{PARRETT MOUNTAIN HYDROLOGIC DATA}

CONTINUED

T/R Elev. Well Well

(Sect.) I.D. Owner

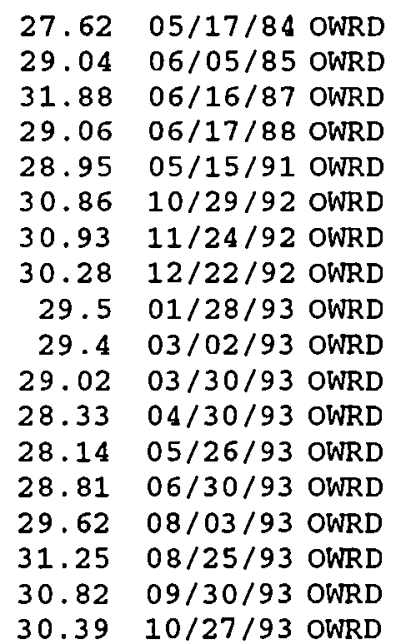

Well Yield St. Wate:Date of Measured Water Bear. Corresp Design. Design. Main

Depth Level Measur. by top bot. Units Est. !Head Aquifer

$23806 / 21 / 75$ driller

154

WpR

444 WpR

$$
\begin{array}{rr}
228.25 & 07 / 23 / 75 \text { USGS } \\
226.25 & 04 / 02 / 80 \text { OWRD } \\
232.85 & 09 / 23 / 80 \text { OWRD } \\
221.65 & 04 / 23 / 81 \text { OWRD } \\
227.3 & 10 / 07 / 81 \text { OWRD } \\
227.1 & 04 / 15 / 82 \text { OWRD } \\
231.7 & 09 / 30 / 82 \text { OWRD } \\
218.7 & 04 / 05 / 83 \text { OWRD } \\
228.72 & 09 / 23 / 83 \text { OWRD } \\
219.05 & 05 / 18 / 84 \text { OWRD } \\
229.6 & 06 / 16 / 87 \text { OWRD } \\
237.67 & 06 / 17 / 88 \text { OWRD } \\
247 & 09 / 12 / 88 \text { OWRD }
\end{array}
$$


TABLE XV

\section{PARRETT MOUNTAIN HYDROLOGIC DATA}

\section{CONTINUED}

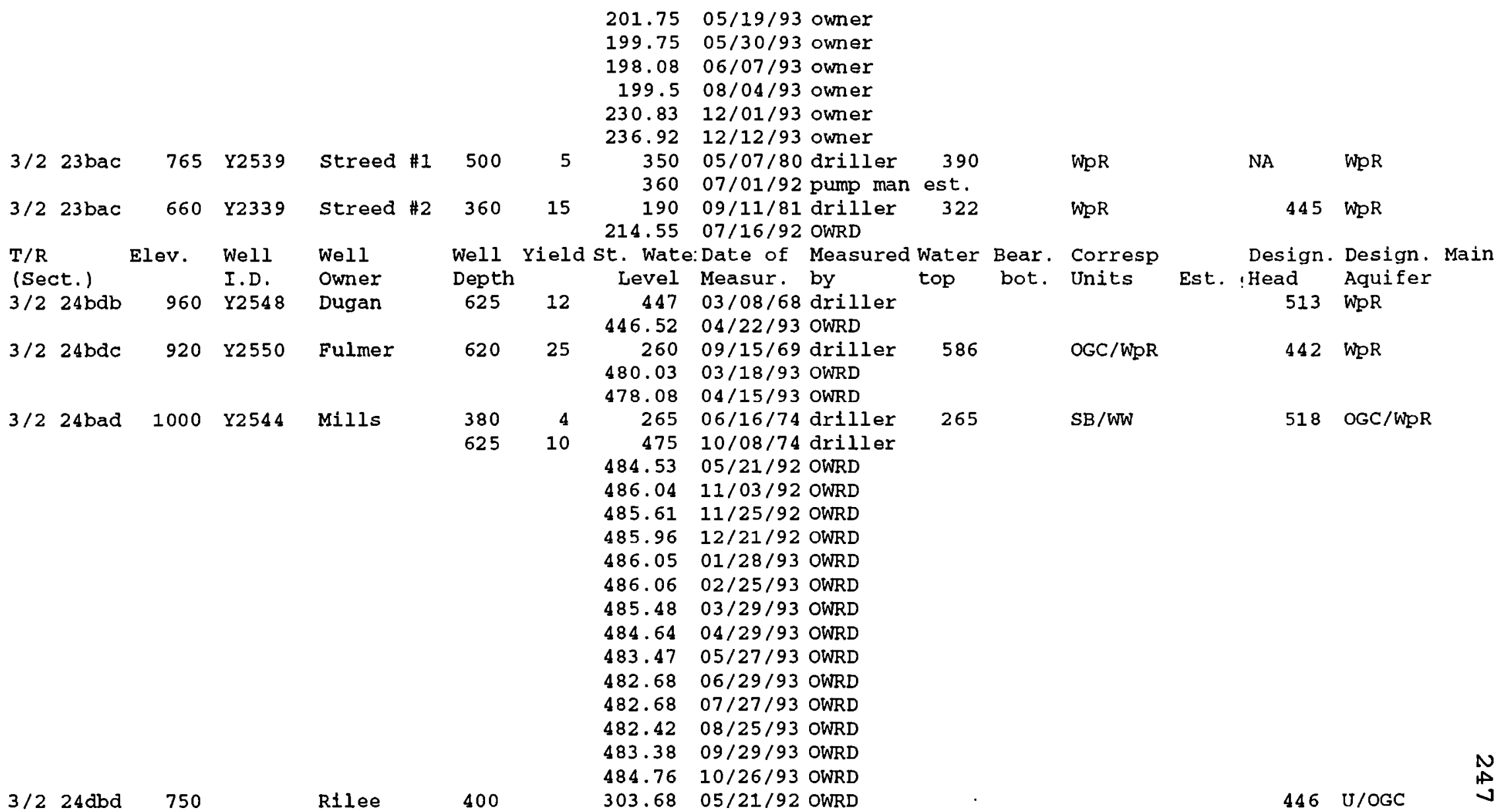




\section{PARRETT MOUNTAIN HYDROLOGIC DATA} CONT INUED

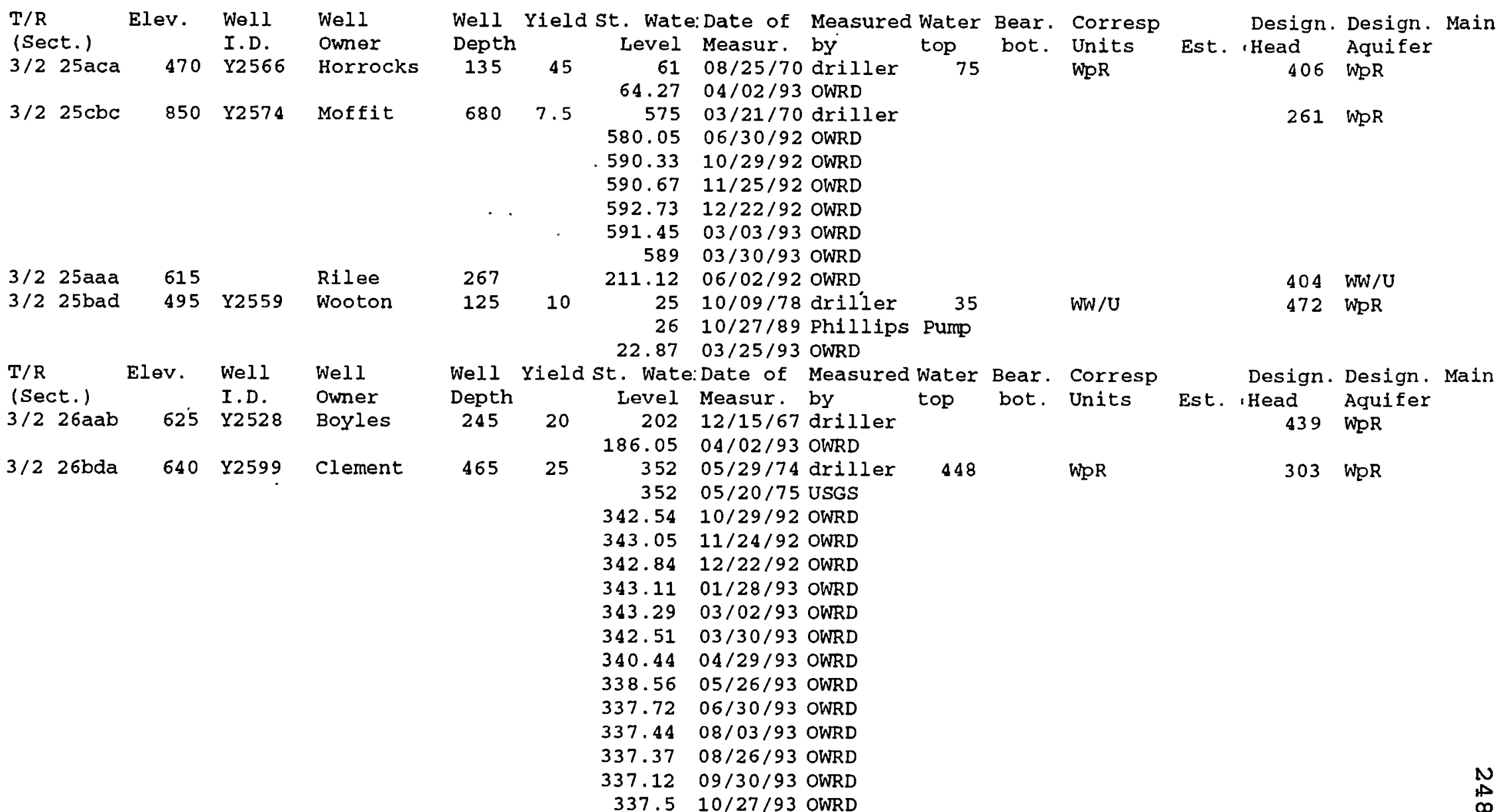




\title{
TABLE XV
}

\section{PARRETT MOUNTAIN HYDROLOGIC DATA}

\author{
CONTINUED
}

\begin{tabular}{|c|c|c|c|c|c|c|c|c|c|c|c|c|c|c|}
\hline \multirow[t]{2}{*}{$3 / 2$} & $26 \mathrm{bab}$ & 700 & Y2 563 & Dombek & $\begin{array}{l}560 \\
460\end{array}$ & $\begin{array}{l}20 \\
14\end{array}$ & $\begin{array}{l}150 \\
410\end{array}$ & $\begin{array}{l}07 / 19 / 72 \\
07 / 01 / 74\end{array}$ & $\begin{array}{l}\text { driller } \\
\text { pump shop }\end{array}$ & 497 & & WpR & 285 & WPR \\
\hline & & & & & & & 414.68 & $02 / 11 / 93$ & OWRD & & & & & \\
\hline \multirow[t]{2}{*}{$3 / 2$} & $26 \mathrm{bba}$ & 655 & Y2592 & Klingele & 480 & 22 & 350 & $07 / 20 / 74$ & driller & 460 & & $W p R$ & 293 & WpR \\
\hline & & & & & & 20 & 361.99 & $03 / 18 / 93$ & OWRD & & & & & \\
\hline \multirow[t]{2}{*}{$3 / 2$} & $26 b d b$ & 610 & Y2609 & Kloster & 466 & 30 & 310 & $04 / 15 / 87$ & driller & 410 & & WpR & 282 & WpR \\
\hline & & & & & & & 327.57 & $03 / 25 / 93$ & OWRD & 440 & & WpR & & \\
\hline \multirow[t]{8}{*}{$3 / 2$} & $26 d a a$ & 855 & Y2596 & Porter & 720 & 9.5 & 535 & $12 / 31 / 76$ & driller & 670 & & WpR & 267 & WpR \\
\hline & & & & & & & 595.07 & $04 / 02 / 93$ & OWRD & & & & & \\
\hline & & & & & & & 591.69 & $05 / 26 / 93$ & OWRD & & & & & \\
\hline & & & & & & & 590.25 & $06 / 30 / 93$ & OWRD & & & & & \\
\hline & & & & & & & 592.69 & $08 / 03 / 93$ & OWRD & & & & & \\
\hline & & & & & & & 588.25 & $08 / 26 / 93$ & OWRD & & & & & \\
\hline & & & & & & & 587.98 & $09 / 30 / 93$ & OWRD & & & & & \\
\hline & & & & & & & 588.61 & $10 / 27 / 93$ & OWRD & & & & & \\
\hline \multirow[t]{2}{*}{$3 / 2$} & $26 \mathrm{abb}$ & 830 & Y316 & Snow & 775 & 12 & 550 & $09 / 13 / 85$ & driller & 550 & & WpR & 306 & $\omega p R$ \\
\hline & & & & & & & 523.51 & $03 / 25 / 93$ & OWRD & 605 & & WpR & & \\
\hline \multirow{3}{*}{$\begin{array}{l}\text { T/R } \\
\text { (Sec } \\
3 / 2\end{array}$} & & Elev. & Well & Well & Well & Yield & St. Wate: & Date of & Measured & Water & Bear. & Corresp & Design. & Design. Main \\
\hline & $=t)$. & & I.D. & Owner & Depth & & Level & Measur. & by & top & bot. & Units & Est. 'Head & Aquifer \\
\hline & $35 \mathrm{bbd}$ & 265 & Y2683 & Bryson & 586 & 60 & $\begin{array}{r}132 \\
135.21\end{array}$ & $\begin{array}{l}04 / 18 / 80 \\
10 / 22 / 93\end{array}$ & $\begin{array}{l}\text { driller } \\
\text { OWRD }\end{array}$ & 238 & & WpR & 130 & WpR \\
\hline \multirow{2}{*}{$\begin{array}{l}\mathrm{T} / \mathrm{R} \\
\text { (Sec }\end{array}$} & & Elev. & Well & Well & Well & & St. Wate: & Date of & Measured & Water & Bear. & Corresp & & Design. Main \\
\hline & $=t .1$ & & I.D. & Owner & Depth & YIELD & Level & Measur. & by & top & bot. & Units & Est. gpm & Aquifer \\
\hline & $36 a c d$ & 445 & & Acott & 147 & & 138.9 & $04 / 02 / 93$ & owner & & & & $\mathrm{NA}$ & \\
\hline $3 / 2$ & $36 \mathrm{acd}$ & 445 & $Y 2686$ & Acott & 545 & 30 & $\begin{array}{r}412 \\
340.74\end{array}$ & $\begin{array}{l}02 / 26 / 90 \\
04 / 02 / 93\end{array}$ & $\begin{array}{l}\text { driller } \\
\text { OWRD }\end{array}$ & 505 & & $W p R$ & 104 & WpR \\
\hline \multirow[t]{2}{*}{$3 / 2$} & $36 \mathrm{aca}$ & 520 & Y2697 & Brown & $\begin{array}{l}350 \\
450\end{array}$ & $\begin{array}{r}8 \\
15\end{array}$ & $\begin{array}{r}90 \\
308\end{array}$ & $\begin{array}{l}10 / 20 / 81 \\
06 / 15 / 82\end{array}$ & $\begin{array}{l}\text { driller } \\
\text { driller }\end{array}$ & $\begin{array}{l}130 \\
403\end{array}$ & & $\begin{array}{l}\text { WW/U } \\
W p R\end{array}$ & 195 & OGC/WpR, WpR \\
\hline & & & & & & & 325.06 & $08 / 25 / 92$ & OWRD & & & & & \\
\hline \multirow[t]{2}{*}{$3 / 2$} & $36 a c c$ & 515 & Y2716 & Cole & 493 & 14 & 400 & $09 / 24 / 71$ & driller & 480 & & WpR & 97 & WpR \\
\hline & & & & & & & 418 & $02 / 11 / 93$ & OWRD & & & & & \\
\hline \multirow[t]{2}{*}{$3 / 2$} & $36 a b a$ & 560 & Y2703 & $\operatorname{Cox}$ & 280 & 14 & 212 & $08 / 30 / 76$ & driller & 245 & & WpR & 354 & WpR \\
\hline & & & & & & & $\begin{array}{l}211.72 \\
211.85\end{array}$ & $\begin{array}{l}06 / 19 / 92 \\
10 / 29 / 92\end{array}$ & $\begin{array}{l}\text { OWRD } \\
\text { OWRD }\end{array}$ & 250 & & WpR & & to \\
\hline
\end{tabular}


PARRETT MOUNTAIN HYDROLOGIC DATA CONTINUED

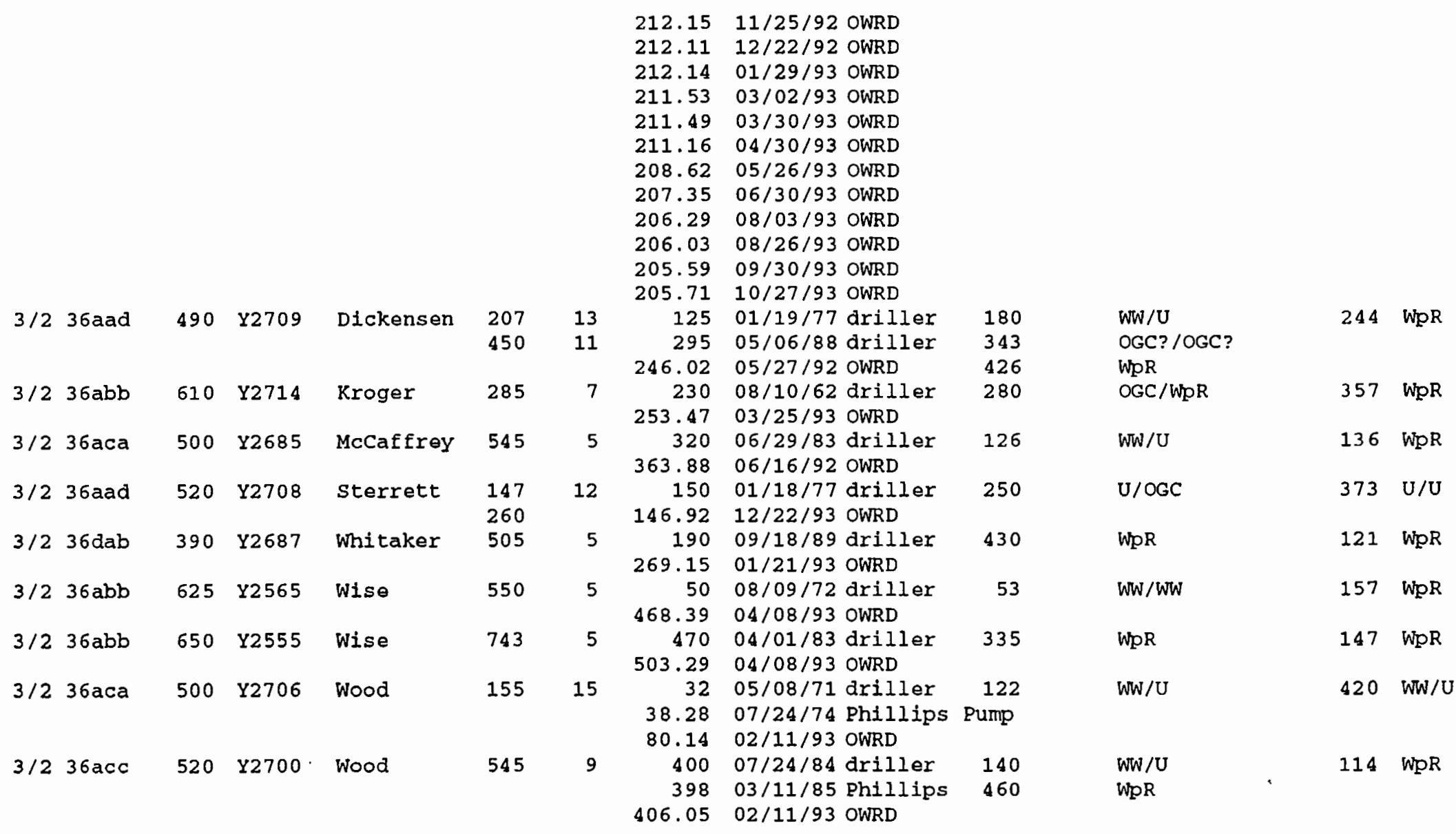


TABLE XVI

QUARTER - QUARTER - POTENTIOMETRIC HEAD VALUES FOR PARRETT MOUNTAIN

Section 31

$\begin{array}{llll}\text { aa) } & \text { ba) } & c a) & \text { da) } \\ \text { ab) } 139^{\prime} & \text { bb) } & c b) & \text { db) } \\ \text { ac) } & \text { bc) } & \text { cc) } & \text { dc) } \\ \text { ad) } 162^{\prime} & \text { bd) } & c d) & \text { dd) }\end{array}$

Section 32

$\begin{array}{llll}\text { aa) } & \text { ba) } & c a) & d a) \\ \text { ab) } & \text { bb) } & c b) ~ 139^{\prime} & \text { db) } \\ \text { ac) } & \text { bc) } & c c) & \text { dc) } \\ \text { ad) } & \text { bd) 133' } & \text { cd) } & \text { dd) }\end{array}$

Section 33

$\begin{array}{llll}\text { aa) } & \text { ba) } 139^{\prime} & c a) & d a) \\ \mathrm{ab}) & \mathrm{bb}) & \mathrm{cb} & \mathrm{db}) \\ \mathrm{ac}) & \mathrm{bc}) & \mathrm{cc} & \mathrm{dc}) \\ \mathrm{ad} & \mathrm{bd} & \mathrm{cd} & \mathrm{dd})\end{array}$

Section 4

T3S RIW

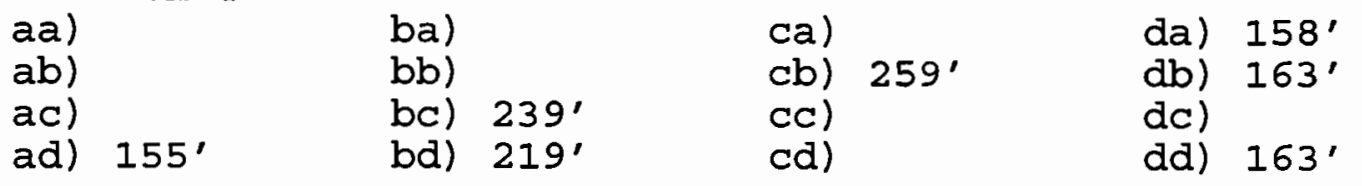

Section 5

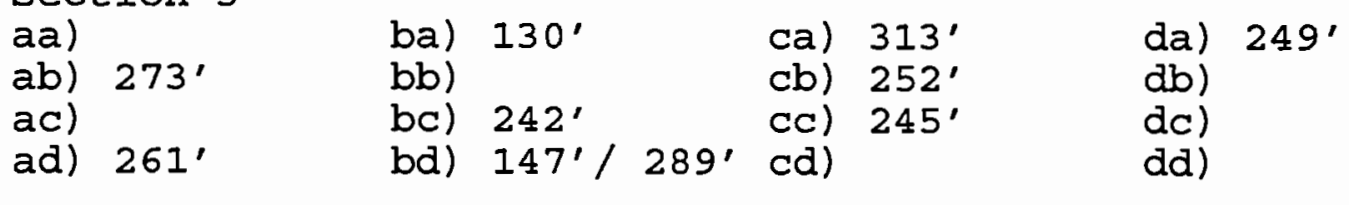

Section 6

\begin{tabular}{|c|c|c|c|c|c|c|}
\hline $\begin{array}{l}\text { aa) } \\
\text { ab) 153' } \\
\text { ac) } \\
\text { ad) }\end{array}$ & $\begin{array}{l}\text { ba) } \\
\text { bb) } \\
\text { bc) } \\
\text { bd) }\end{array}$ & $176^{\prime}$ & $\begin{array}{l}\text { ca) } \\
\mathrm{cb}) \\
\mathrm{cc}) \\
\mathrm{cd})\end{array}$ & & $\begin{array}{l}\text { da) } \\
d b) \\
d c) \\
d d)\end{array}$ & $\begin{array}{l}199^{\prime} \\
184^{\prime}\end{array}$ \\
\hline Section 7 & & & & & & \\
\hline $\begin{array}{l}\text { aa) } 332^{\prime} \\
\mathrm{ab)} \\
\mathrm{ac)} \\
\mathrm{ad)} 397^{\prime}\end{array}$ & $\begin{array}{l}\text { ba) } \\
\text { bb) } \\
\text { bc) } \\
\text { bd) }\end{array}$ & $\begin{array}{l}189^{\prime} / 358^{\prime} \\
188^{\prime}\end{array}$ & $\begin{array}{l}\text { ca) } \\
c b) \\
c c) \\
c d)\end{array}$ & $\begin{array}{l}169^{\prime} \\
564^{\prime} \\
504^{\prime}\end{array}$ & $\begin{array}{l}\text { da) } \\
d b) \\
d c) \\
d d)\end{array}$ & $\begin{array}{l}419^{\prime} / 350^{\prime} \\
748^{\prime} \\
489^{\prime} \\
393^{\prime}\end{array}$ \\
\hline
\end{tabular}


Section 8

\begin{tabular}{|c|c|c|c|c|c|c|c|}
\hline $\begin{array}{l}a a) \\
a b) \\
a c) \\
a d)\end{array}$ & $205^{\prime} / 360^{\prime}$ & $\begin{array}{l}\text { ba) } \\
\text { bb) } \\
\text { bc) } \\
\text { bd) }\end{array}$ & $\begin{array}{l}409^{\prime} \\
386^{\prime} \\
450^{\prime}\end{array}$ & $\begin{array}{l}\text { ca) } \\
\mathrm{cb}) \\
\mathrm{cc)} \\
\mathrm{cd})\end{array}$ & $\begin{array}{l}357^{\prime} \\
485^{\prime} \\
378^{\prime}\end{array}$ & $\begin{array}{l}\text { da) } \\
d b) \\
d c) \\
d d)\end{array}$ & $\begin{array}{l}164^{\prime} \\
393^{\prime} \\
165^{\prime}\end{array}$ \\
\hline Sect & Eion 9 & & & & & & \\
\hline $\begin{array}{l}a a) \\
a b) \\
a c) \\
a d)\end{array}$ & $\begin{array}{l}181^{\prime} \\
228^{\prime} \\
180^{\prime} \\
160^{\prime}\end{array}$ & $\begin{array}{l}\text { ba) } \\
\text { bb) } \\
\text { bc) } \\
\text { bd) }\end{array}$ & $\begin{array}{l}258^{\prime} \\
167^{\prime}\end{array}$ & $\begin{array}{l}\mathrm{ca}) \\
\mathrm{cb}) \\
\mathrm{cc}) \\
\mathrm{cd})\end{array}$ & $\begin{array}{l}161^{\prime} \\
270^{\prime} \\
164^{\prime}\end{array}$ & $\begin{array}{l}d a) \\
d b) \\
d c) \\
d d)\end{array}$ & $\begin{array}{l}150^{\prime} \\
218^{\prime} \\
172^{\prime}\end{array}$ \\
\hline
\end{tabular}

Section 10

$\begin{array}{ll}\text { aa) } & \text { ba) } \\ \mathrm{ab}) & \mathrm{bb}) \\ \mathrm{ac}) & \mathrm{bc}) \\ \mathrm{ad}) & \mathrm{bd})\end{array}$

ca) $138^{\prime}$ da)

cb) $170^{\prime} \mathrm{db}$ )

cc) 142' dc)

cd) 144' dd)

Section 15

$\begin{array}{llll}\text { aa) } & \text { ba) } 136^{\prime} & c a) & d a) \\ \text { ab) } & \text { bb) } & \text { cb) } & \text { db) } \\ \text { ac) } & \text { bc) } & \text { cc) 150' } & \text { dc) } \\ \text { ad) } & \text { bd) } & \text { cd) 112' } & \text { dd) }\end{array}$

Section 16

\begin{tabular}{|c|c|c|c|}
\hline $\begin{array}{l}\text { aa) } 132^{\prime} \\
\mathrm{ab)}\end{array}$ & $\begin{array}{l}\text { ba) } 162^{\prime} \\
\text { bb) }\end{array}$ & $\begin{array}{l}\text { ca) 144' } \\
\text { cb) }\end{array}$ & $\begin{array}{l}d a) \\
d b)\end{array}$ \\
\hline $\begin{array}{l}\text { ac) } 138^{\prime} \\
\text { ad) }\end{array}$ & $\begin{array}{l}\text { bc) } \\
\text { bd) }\end{array}$ & $\begin{array}{l}\text { cc) } \\
\text { cd) }\end{array}$ & $\begin{array}{l}\text { dc) } \\
\text { dd) }\end{array}$ \\
\hline
\end{tabular}

Section 17

$\begin{array}{llll}\text { aa) } 178^{\prime} & \text { ba) } 229^{\prime} & \text { ca) } 195^{\prime} & \text { da) } \\ \text { ab) 259'} & \text { bb) } 208^{\prime} & \text { cb) } & \text { db) } \\ \text { ac) } & \text { bc) } 212^{\prime} & \text { cc) } & \text { dc) } 180^{\prime} \\ \text { ad) } & \text { bd) } 201^{\prime} & \text { cd) } 179^{\prime} & \text { dd) } 176^{\prime}\end{array}$

Section 18

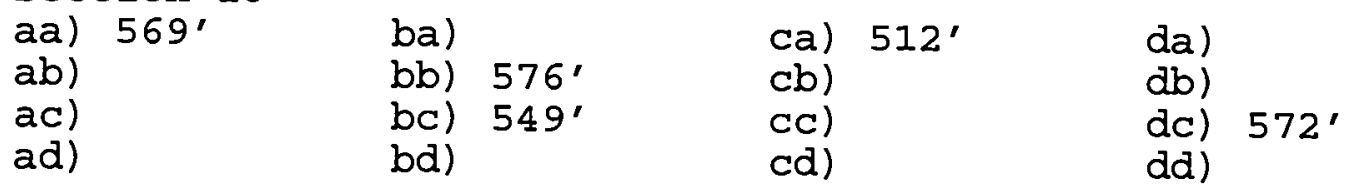

Section 19

$\begin{array}{llll}\text { aa) } & \text { ba) } 370^{\prime} & \text { ca) } & \text { da) } \\ \text { ab) } & \text { bb) } & \text { cb) } & \text { db) } \\ \text { ac) } & \text { bc) } 446^{\prime} & c c) & \text { dc) } \\ \text { ad) 174' } & \text { bd) } 258^{\prime} & c d) & \text { dd) }\end{array}$


Section 20

$\begin{array}{ll}\text { aa) } & \text { ba) } \\ \text { ab) } & \text { bb) } \\ \text { ac) 193, } & \text { bc) } \\ \text { ad) } & \text { bd) }\end{array}$

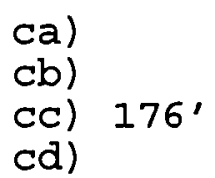

da)

$\mathrm{db})$

dc)

dd)

Section 21

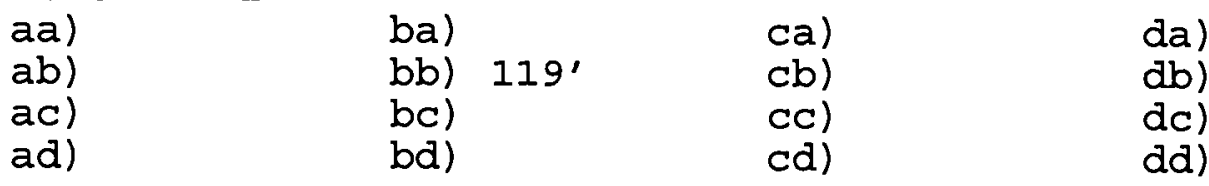

Section 29

$\begin{array}{ll}\text { aa) } & \text { ba) } \\ \text { ab) } & \text { bb) 173' } \\ \text { ac) } & \text { bc) } \\ \text { ad) } & \text { bd) 122' }\end{array}$

ca)

da)

cb) $\mathrm{db}$ )

cc) dc)

ad)

cd)

dd)

Section 30

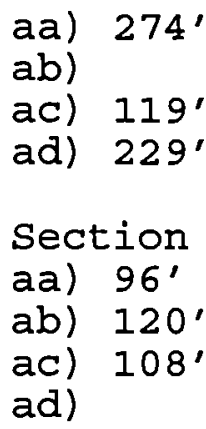

ba)

bb) $216^{\prime}$

ca) $128^{\prime}$

da)

bc) $396^{\prime}$

cb)

cc)

db) 122'

bd) $123^{\prime}$

cd)

dc)

dd) 127'

Section 31
ab) $120^{\prime}$
ac) 108'

ba) $144^{\prime}$

ca)

da)

bb) 186'

bc)

cb)

$\mathrm{db})$

bd) $86^{\prime}$

cc)

dc)

cd)

dd)

T3S R2W

Section 1

$\begin{array}{llll}\text { aa) } & \mathrm{ba}) & \mathrm{ca} & \mathrm{da}) 219^{\prime} \\ \mathrm{ab}) & \mathrm{bb} & \mathrm{cb}) & \mathrm{db}) \\ \mathrm{ac}) & \mathrm{bc}) & \mathrm{cc}) & \mathrm{dc}) \\ \mathrm{ad}) & \mathrm{bd}) & \mathrm{cd}) & \mathrm{dd})\end{array}$

Section 11

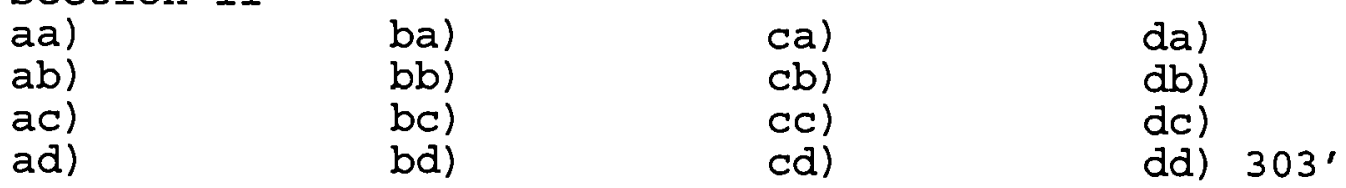

Section 12

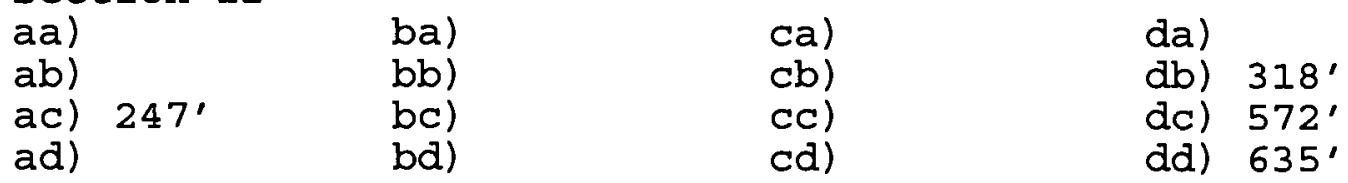


Section 13

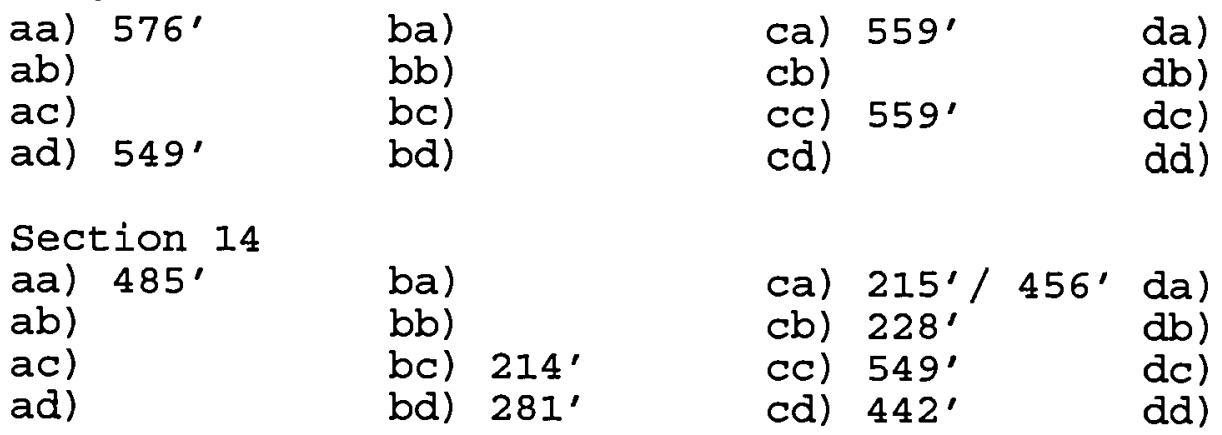

Section 15

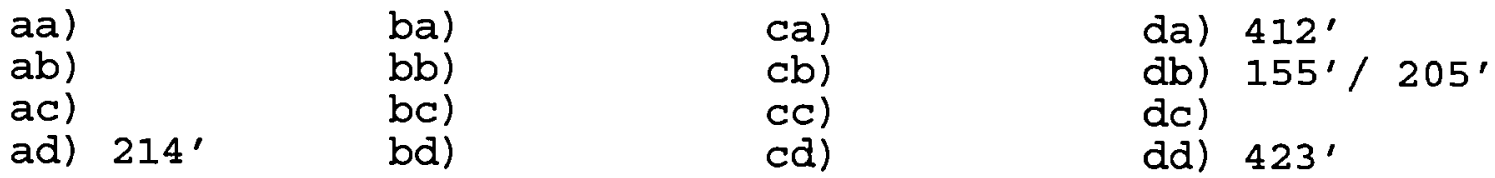

Section 22

aa) $\left.396^{\prime} / 468^{\prime} \mathrm{ba}\right)$

$\mathrm{ab}) \mathrm{bb}$ )

ca) 194' da)

ac) 292'

bc)

$\mathrm{cb)}$

$\mathrm{db})$

ad)

bd)

cc)

dc) $215^{\prime}$

cd)

dd)

Section 23

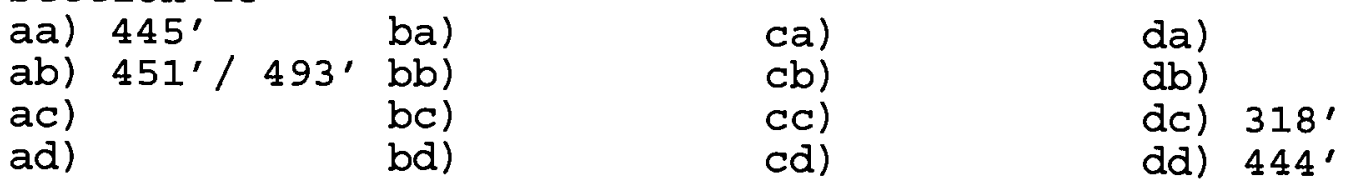

Section 24

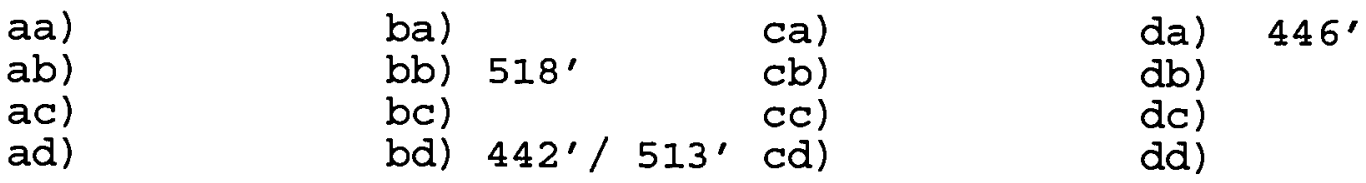

Section 25

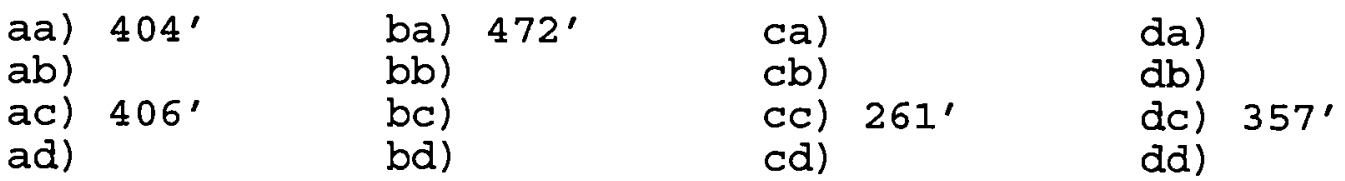

Section 26

\begin{tabular}{|c|c|c|c|c|}
\hline $\begin{array}{l}\text { aa) } 439^{\prime} \\
\text { ab) } 306^{\prime} \\
\text { ac) } \\
\text { ad) }\end{array}$ & $\begin{array}{l}\text { ba) } \\
\text { bb) } \\
\text { bc) } \\
\text { bd) }\end{array}$ & $\begin{array}{l}285^{\prime} \\
293^{\prime} \\
282^{\prime} \\
303^{\prime}\end{array}$ & $\begin{array}{l}\text { ca) } \\
c b) \\
c c) \\
c d)\end{array}$ & $\begin{array}{l}\text { da) } \\
d b) \\
d c) \\
d d)\end{array}$ \\
\hline
\end{tabular}


Section 35

\begin{tabular}{|c|c|c|c|}
\hline $\begin{array}{l}\text { aa) } \\
\text { ab) } \\
\text { ac) } \\
\text { ad) }\end{array}$ & $\begin{array}{l}\text { ba) } \\
\text { bb) } 130^{\prime} \\
\text { bc) } \\
\text { bd) }\end{array}$ & $\begin{array}{l}\text { ca) } \\
\text { cb) } \\
\text { cc) } \\
\text { cd) }\end{array}$ & $\begin{array}{l}\text { da) } \\
d b) \\
\text { dc) } \\
\text { dd) }\end{array}$ \\
\hline $\begin{array}{l}\text { Section } 36 \\
\text { aa) } 308^{\prime} / 354^{\prime} \\
\text { ab) } 152^{\prime} \\
\text { ac) } 106^{\prime} / 202^{\prime} \\
\text { ad) }\end{array}$ & $\begin{array}{l}\text { ba) } \\
\text { bb) } \\
\text { bc) } \\
\text { bd) }\end{array}$ & $\begin{array}{l}\text { ca) } \\
\mathrm{cb}) \\
\mathrm{cc}) \\
\mathrm{cd})\end{array}$ & $\begin{array}{l}\text { da) } \\
d b) \\
d c) \\
d d)\end{array}$ \\
\hline
\end{tabular}


APPENDIX C

HYDROGRAPHS

* hydrographs provided by the OWRD 
KENNERLY WELL (WASH 3448)

T2S/R TW-31 dbd

WELL DEPTH - 215 FEET

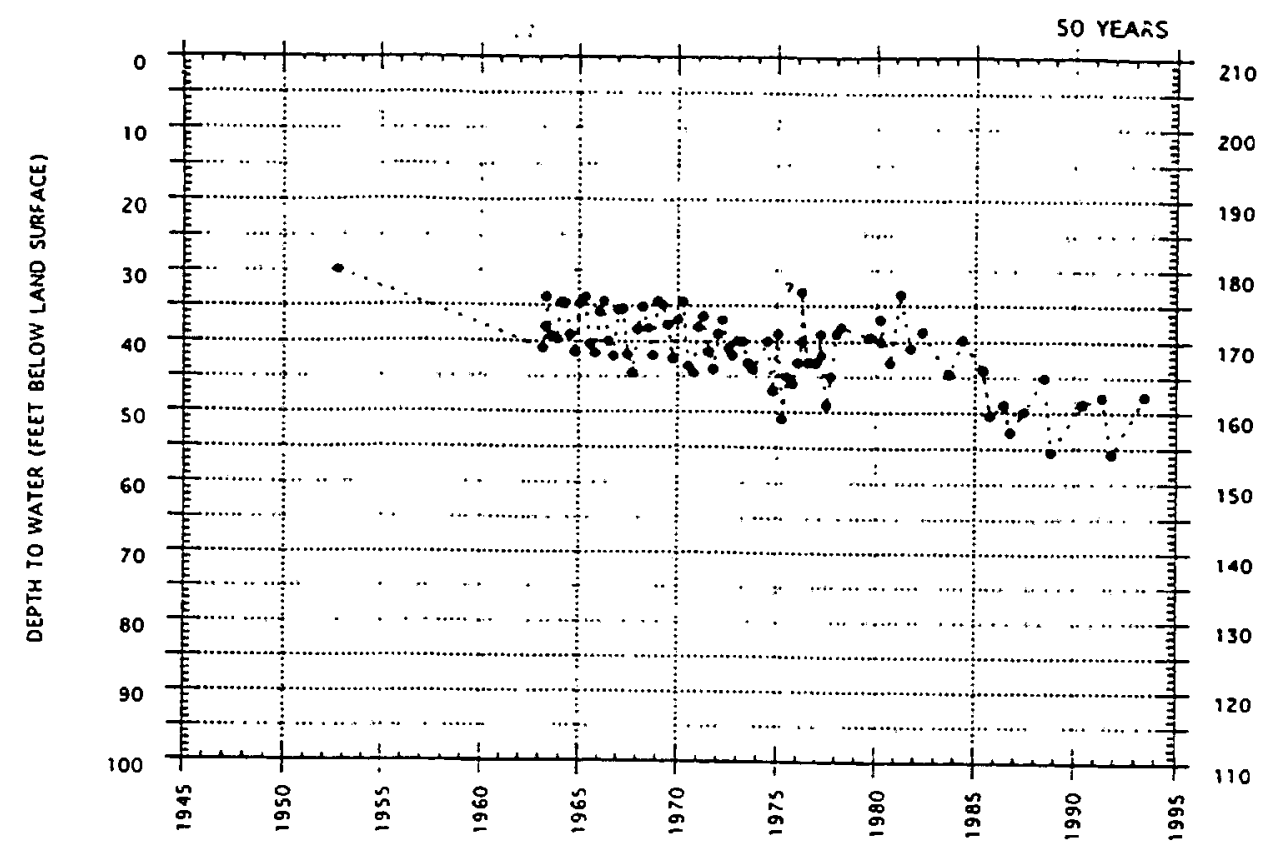

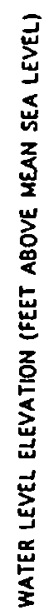

CITY OF SHERWOOD WELL \#4 (WASH 3447)

$T 2 S / R 1 W-31$ aba

WELL DEPTH - 458 FEET

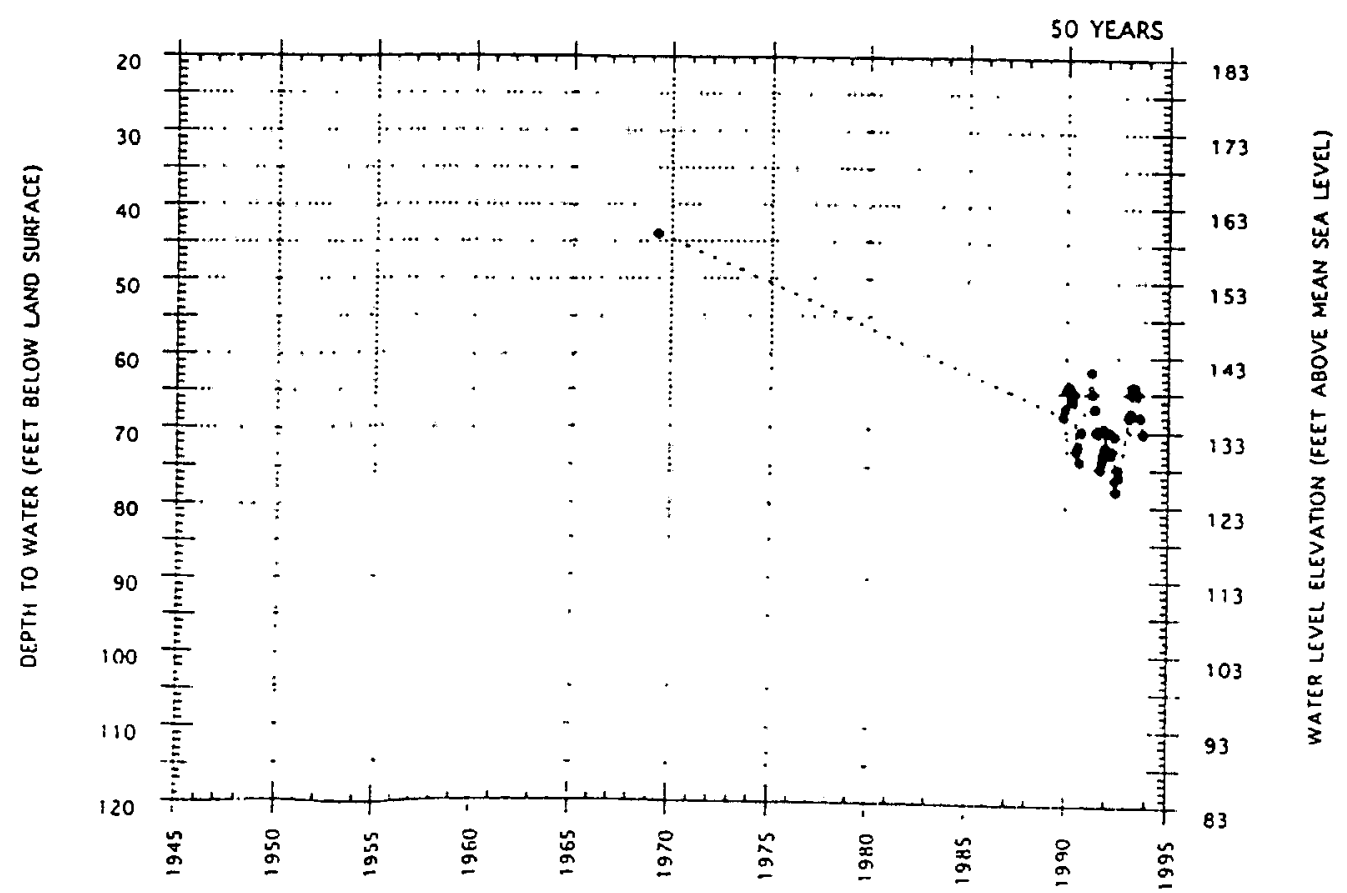


CITY OF SHERWOOD WELL \#3 (WASH 1823)

T2S/RIW-32bdd

WELL DEPTH - 339 FEET

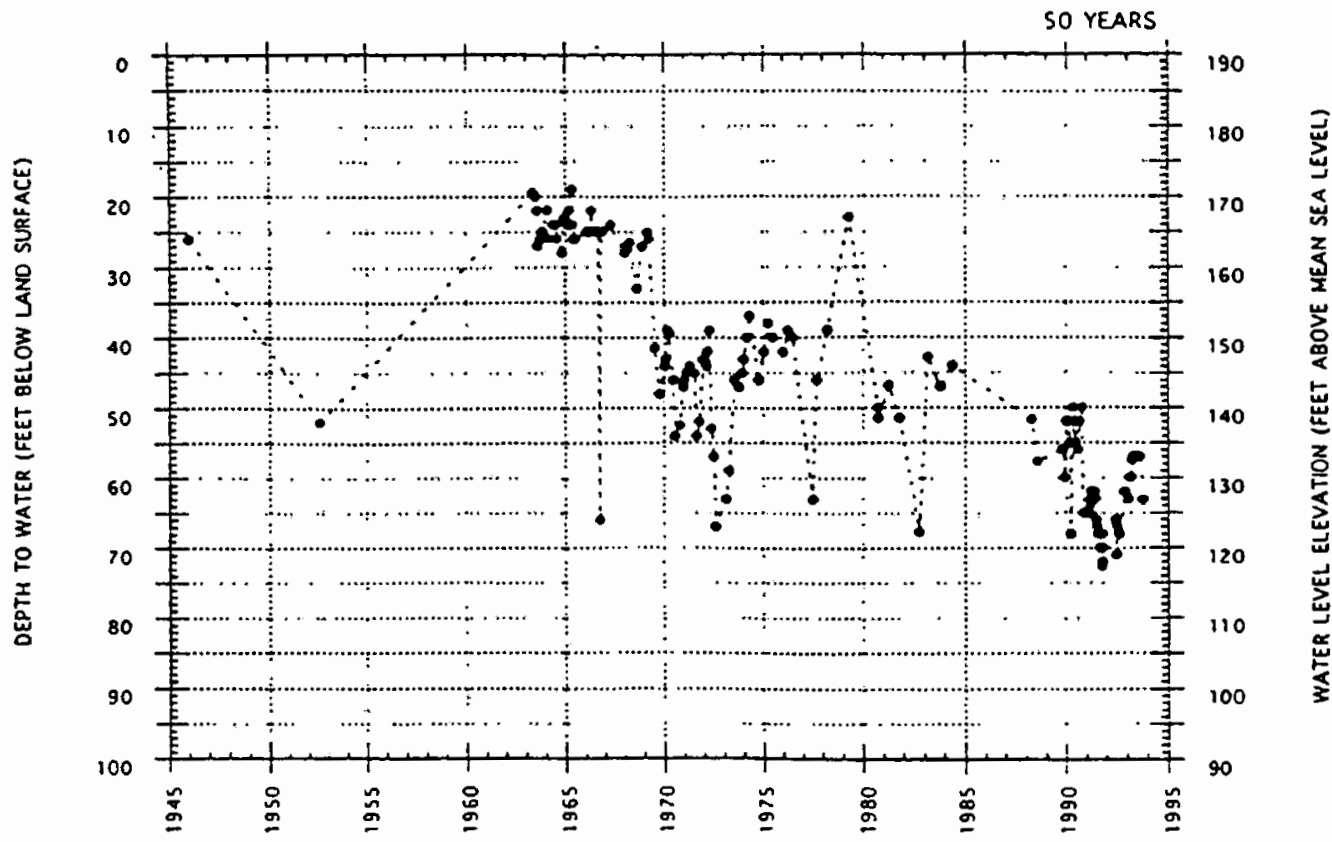

CITY OF SHERWOOO WELL \#5 (WASH 717)

T2S/RIW-32 CbC

WELL DEPTH -800 FEET

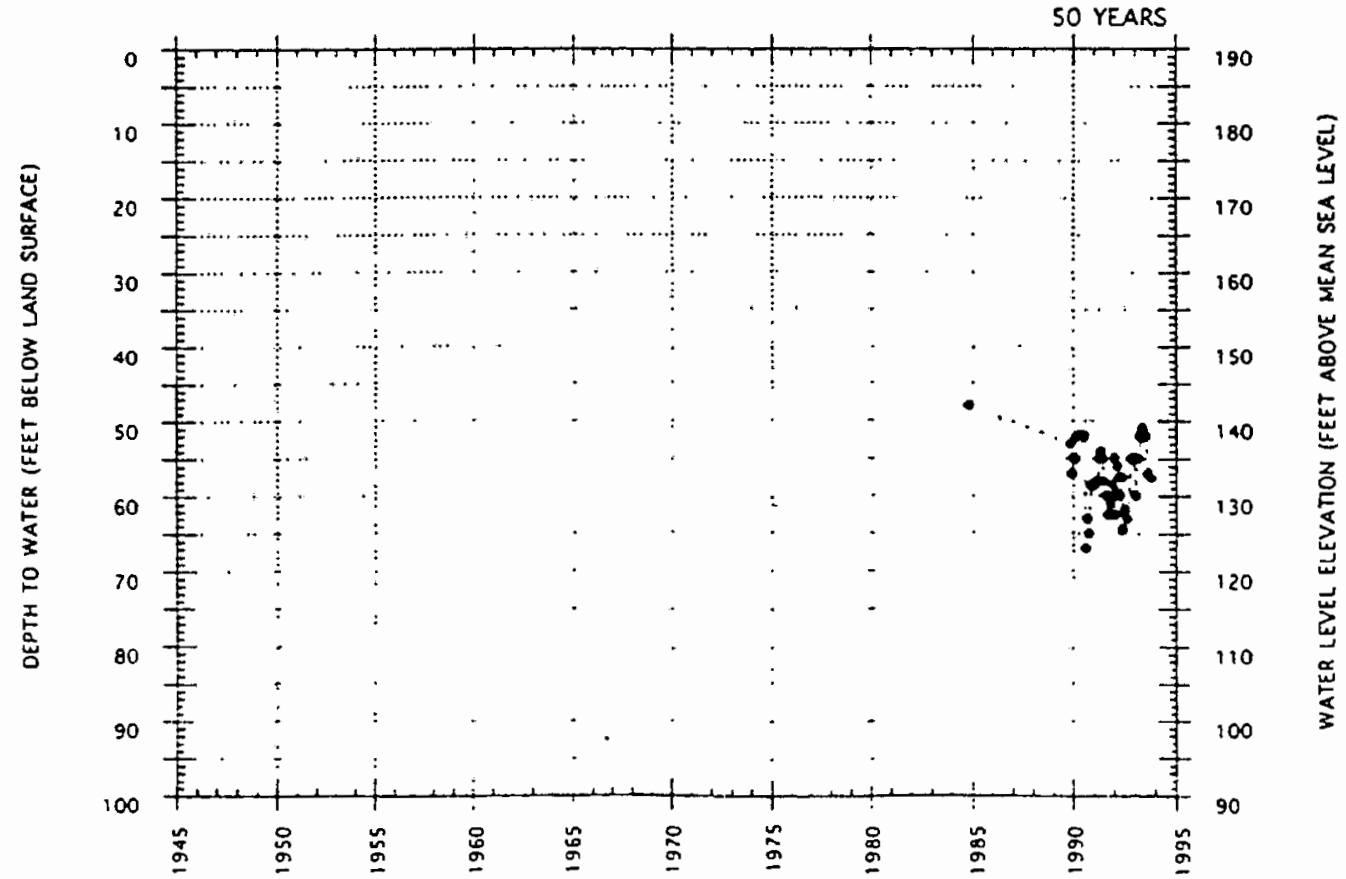


TRI-COUNTY GUN CLUB WELL (WASH 1847)

T2S/RIW-33dda

ORIGINAL WELL DEPTH - 109 FEET

DEEPENED TO $230 \cdot(2 / 9 / 73)$

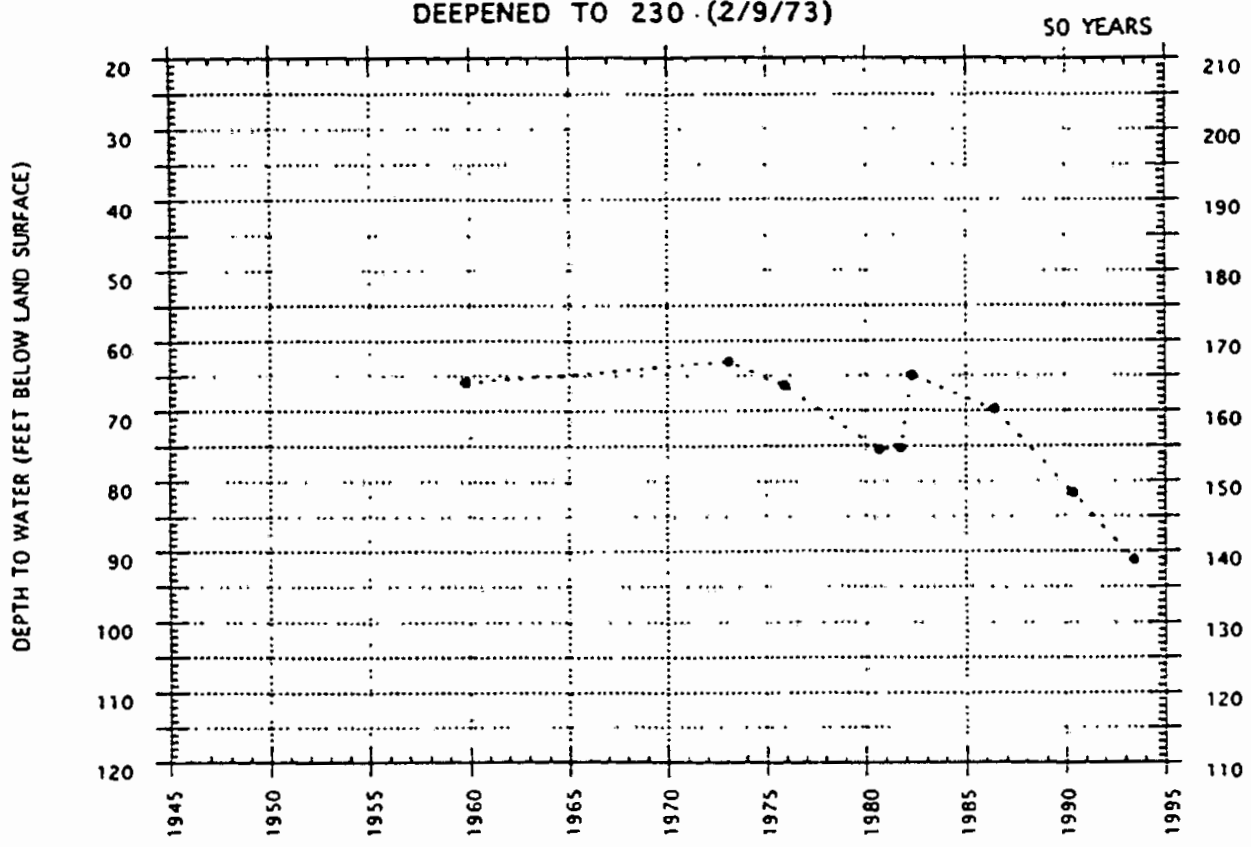

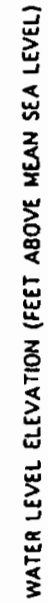

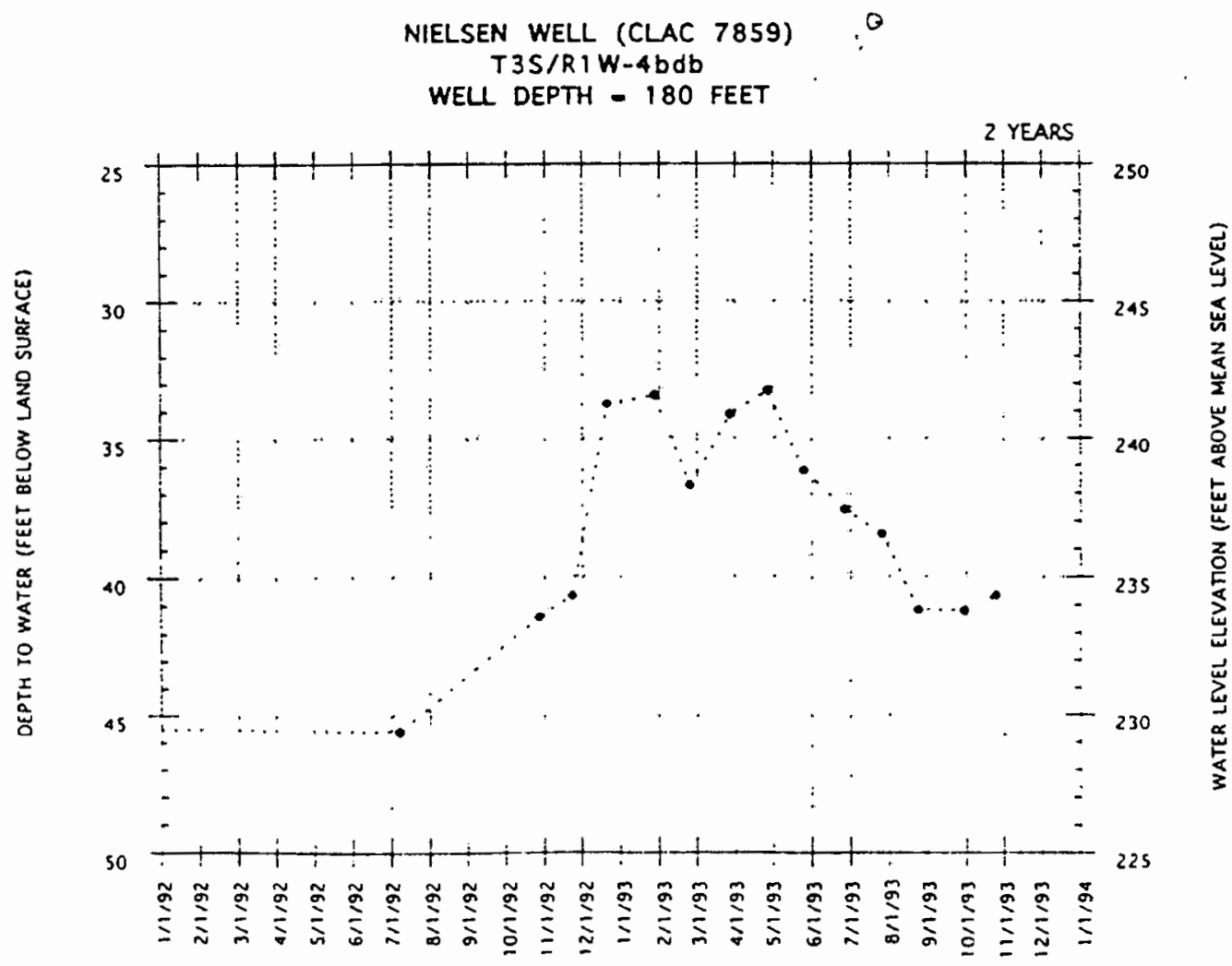




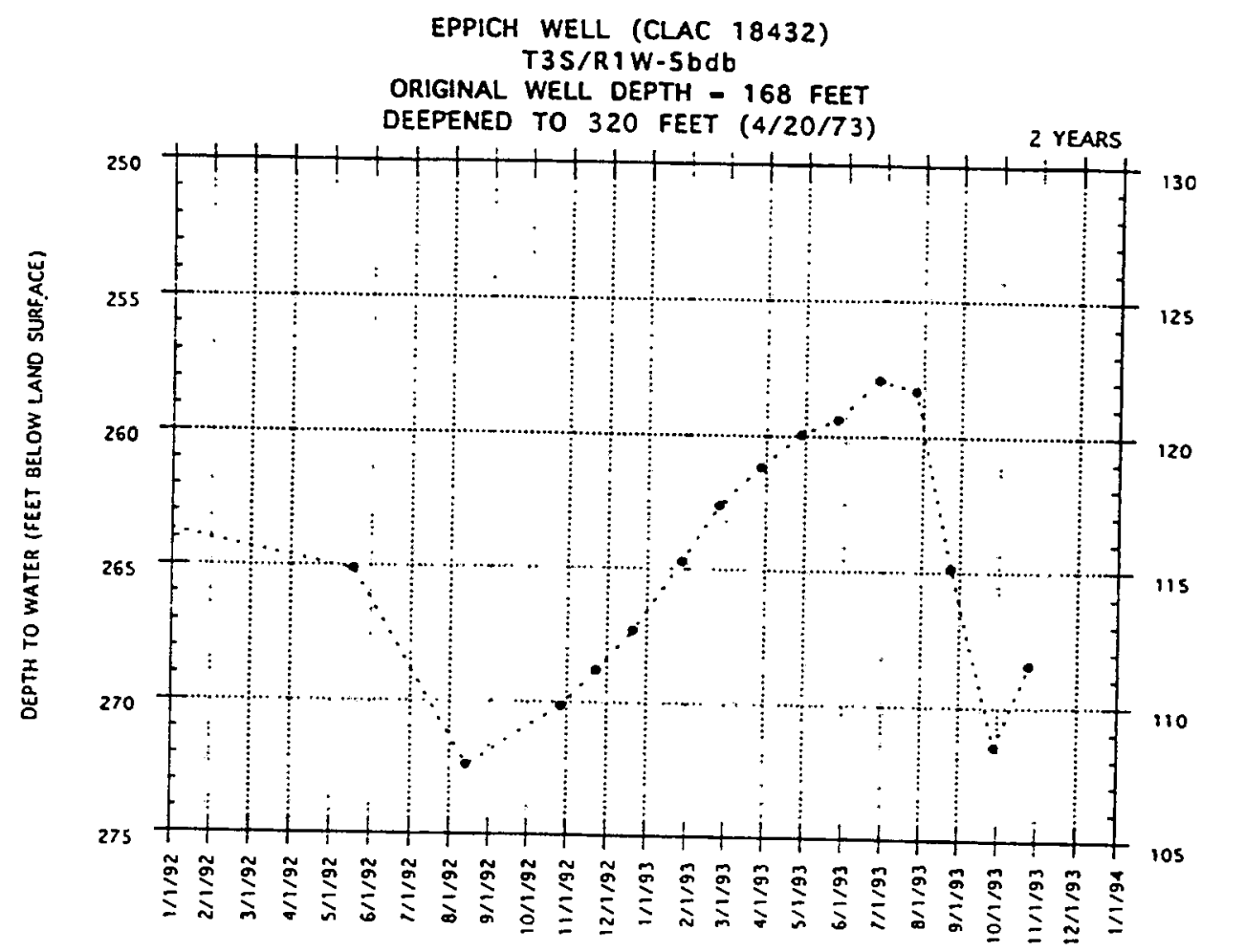

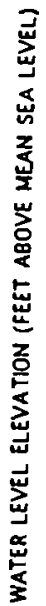

COE WELL (CLAC 7781)

T3S/RIW-5Cad

WELL DEPTH - 245 FEET

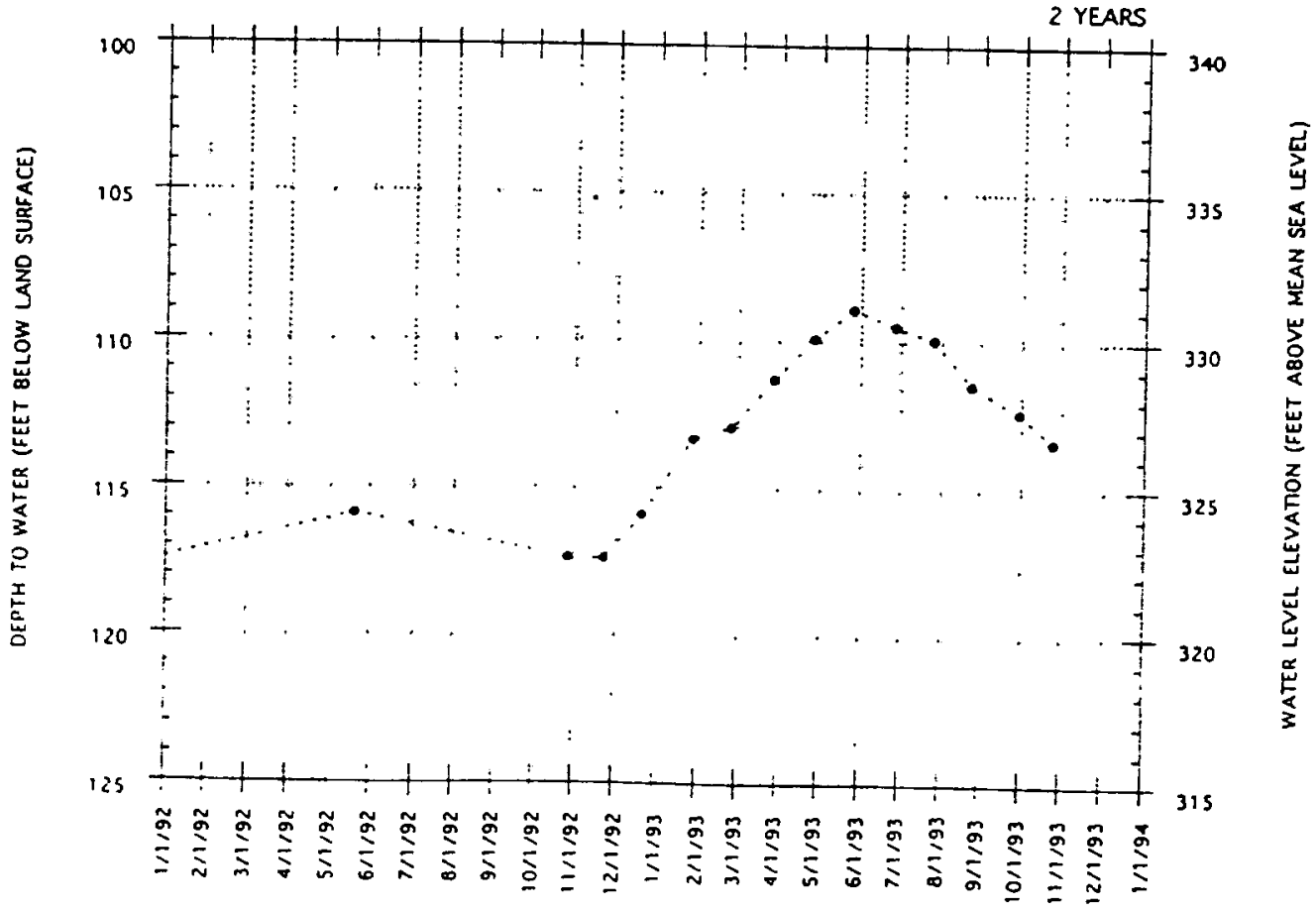




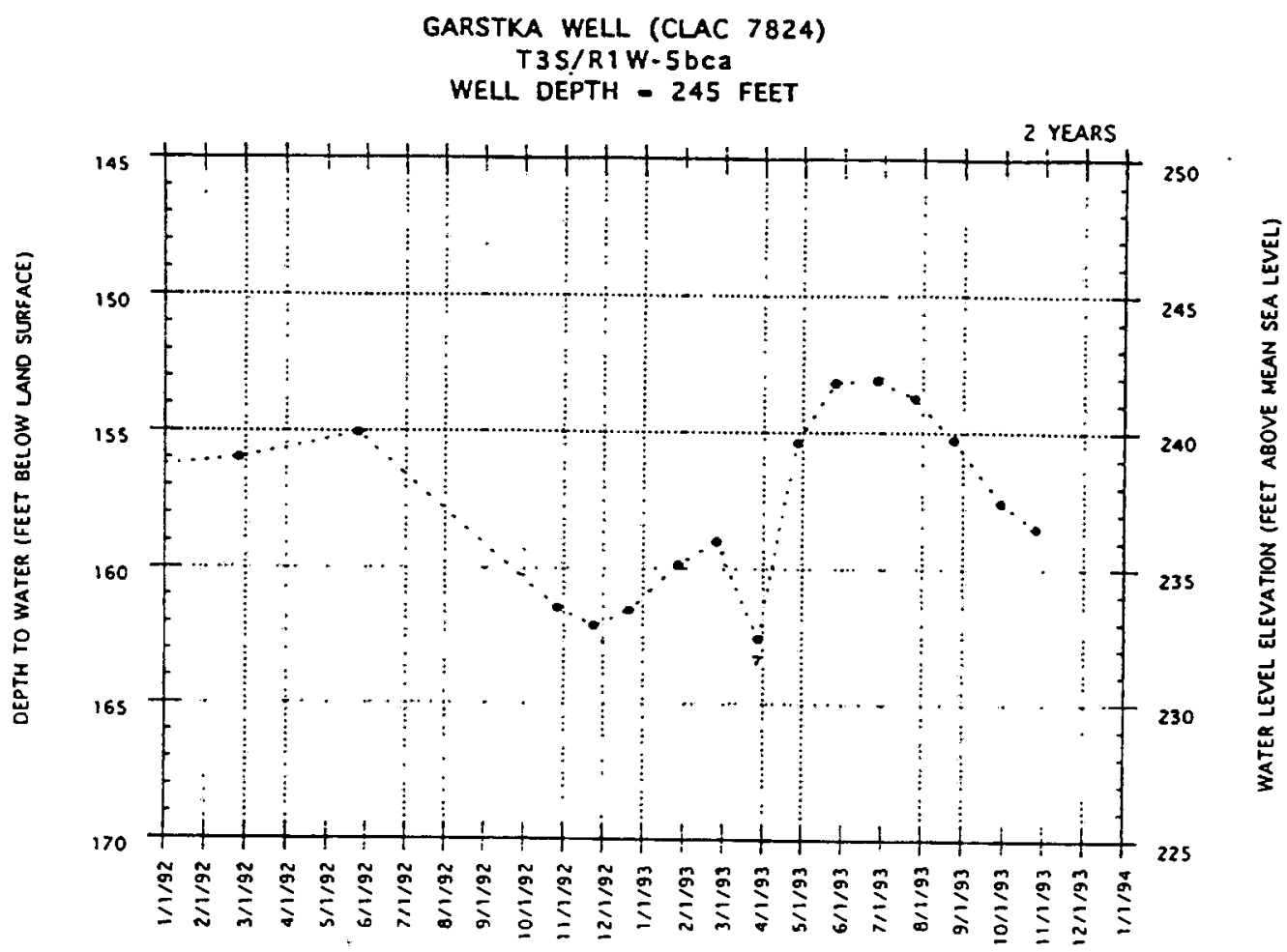

GARSTKA WELL (CLAC 7824)

T3S/R $1 W-5$ bca

WELL DEPTH - 245 FEET

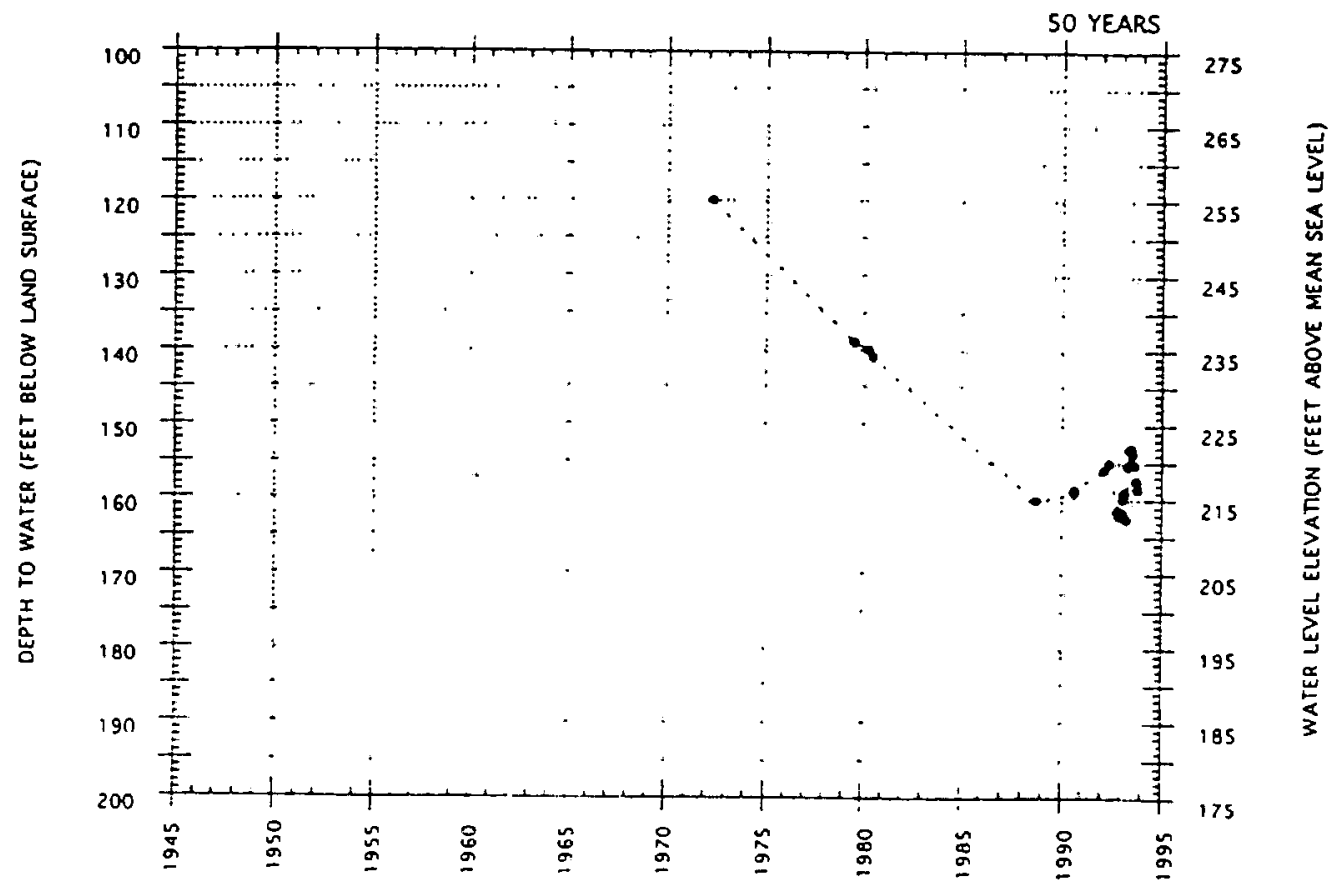



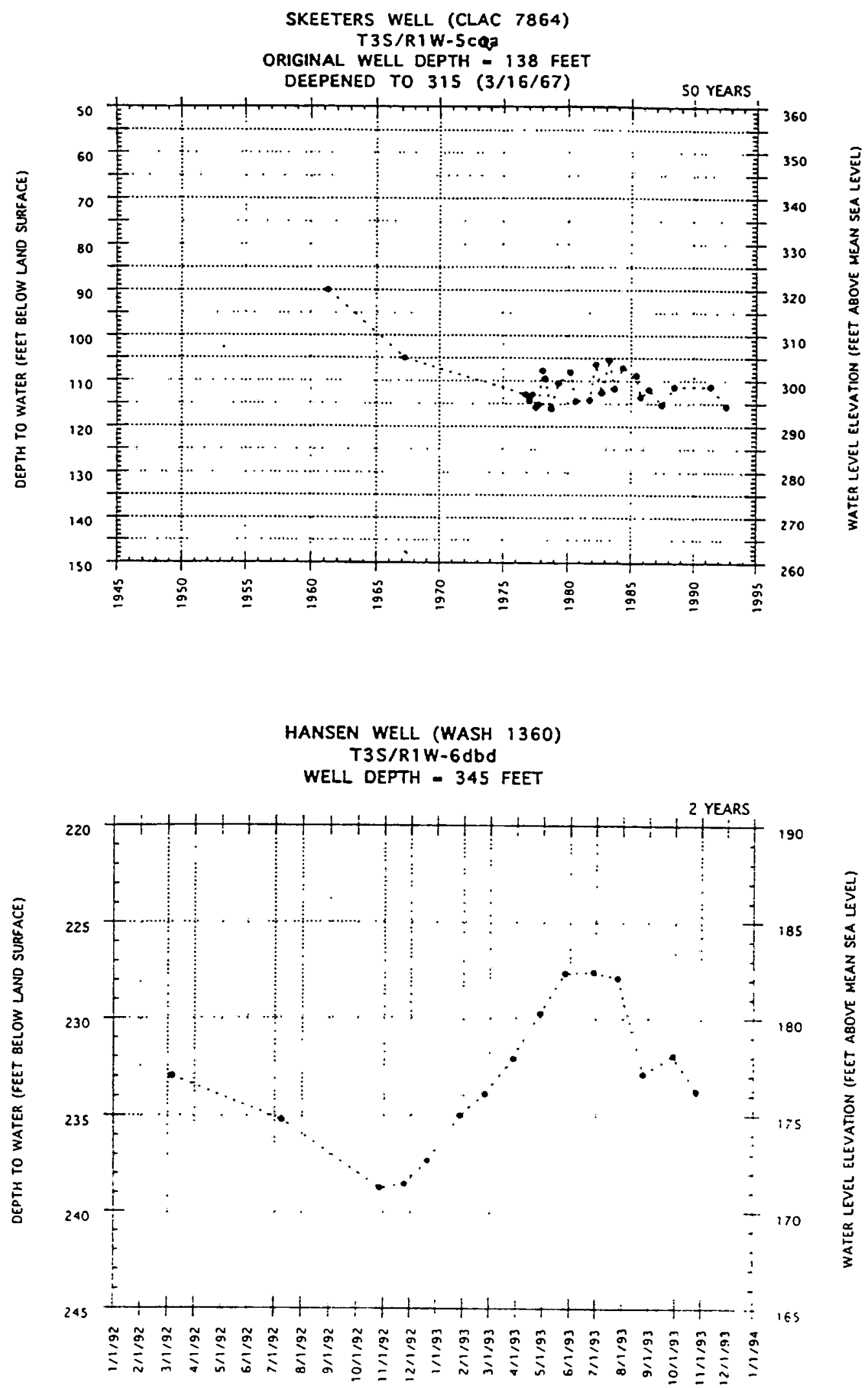


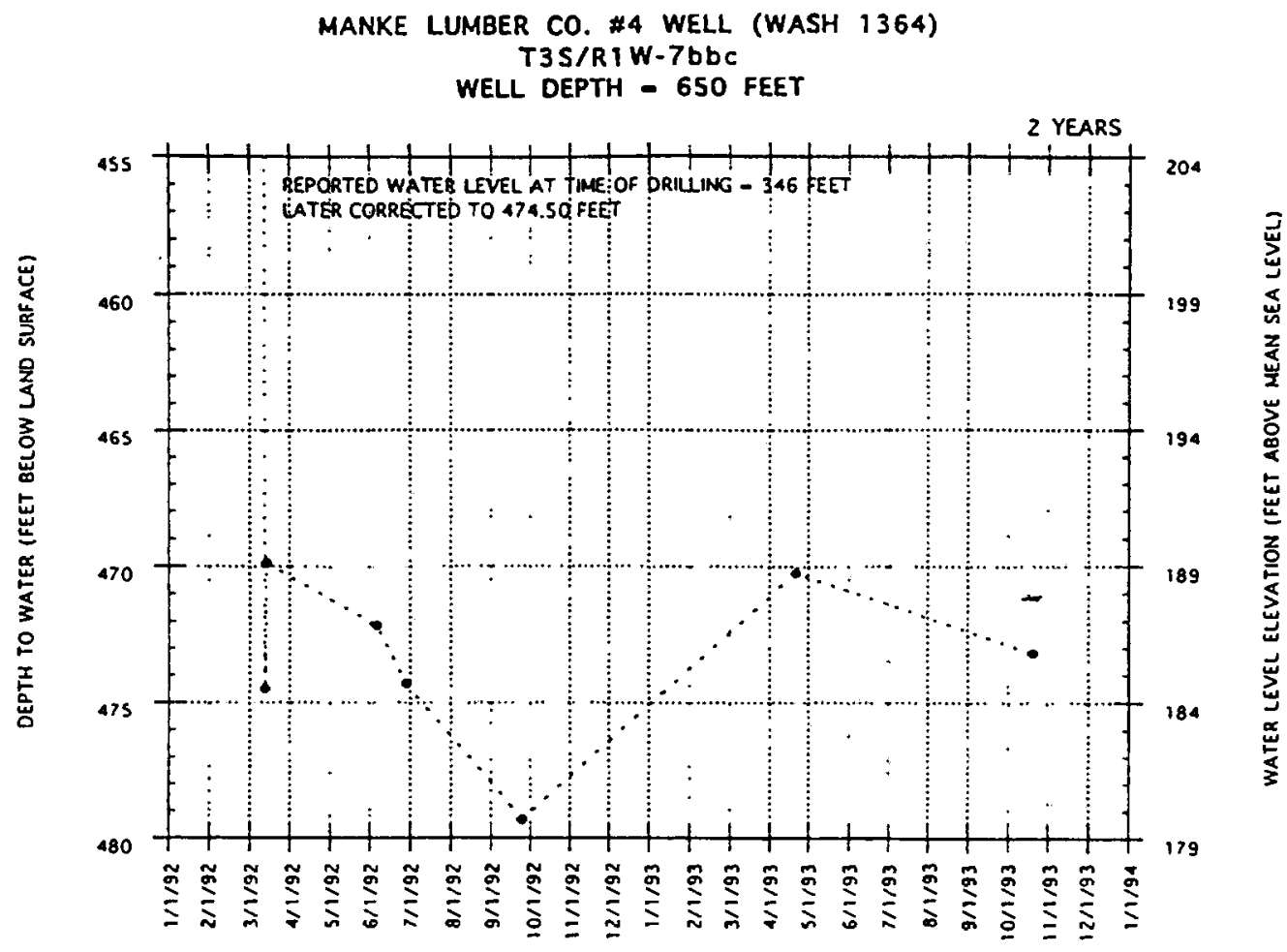

MANKE LUMBER CO. \#6 WELL (WASH 1362) T3S/R $1 W-7$ bac

WELL DEPTH - 562 FEET

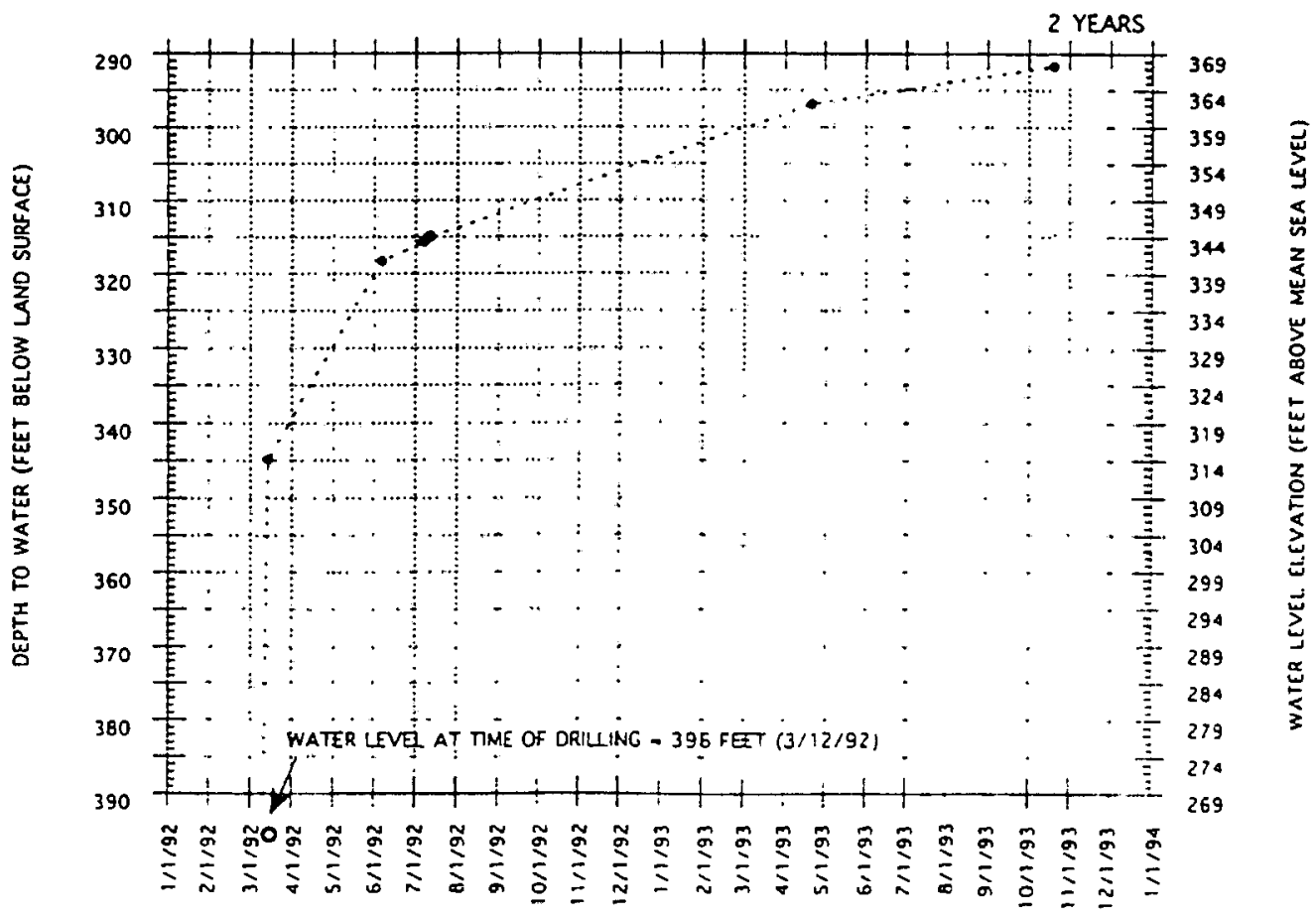




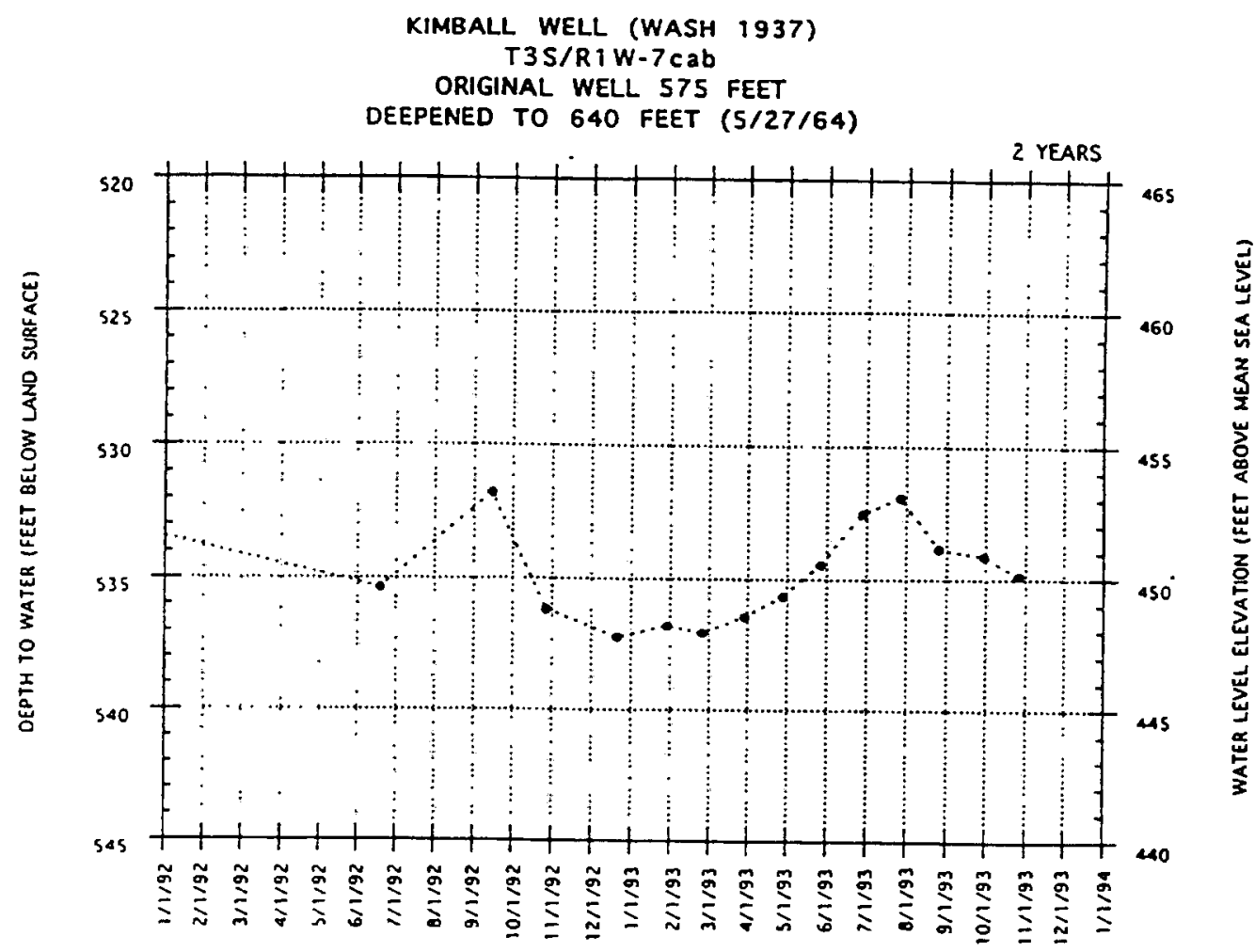

MANKE LUMBER CO. \#3 WELL (WASH 1366)

T3S/RIW-7bba

WELL DEPTH - 573 FEET

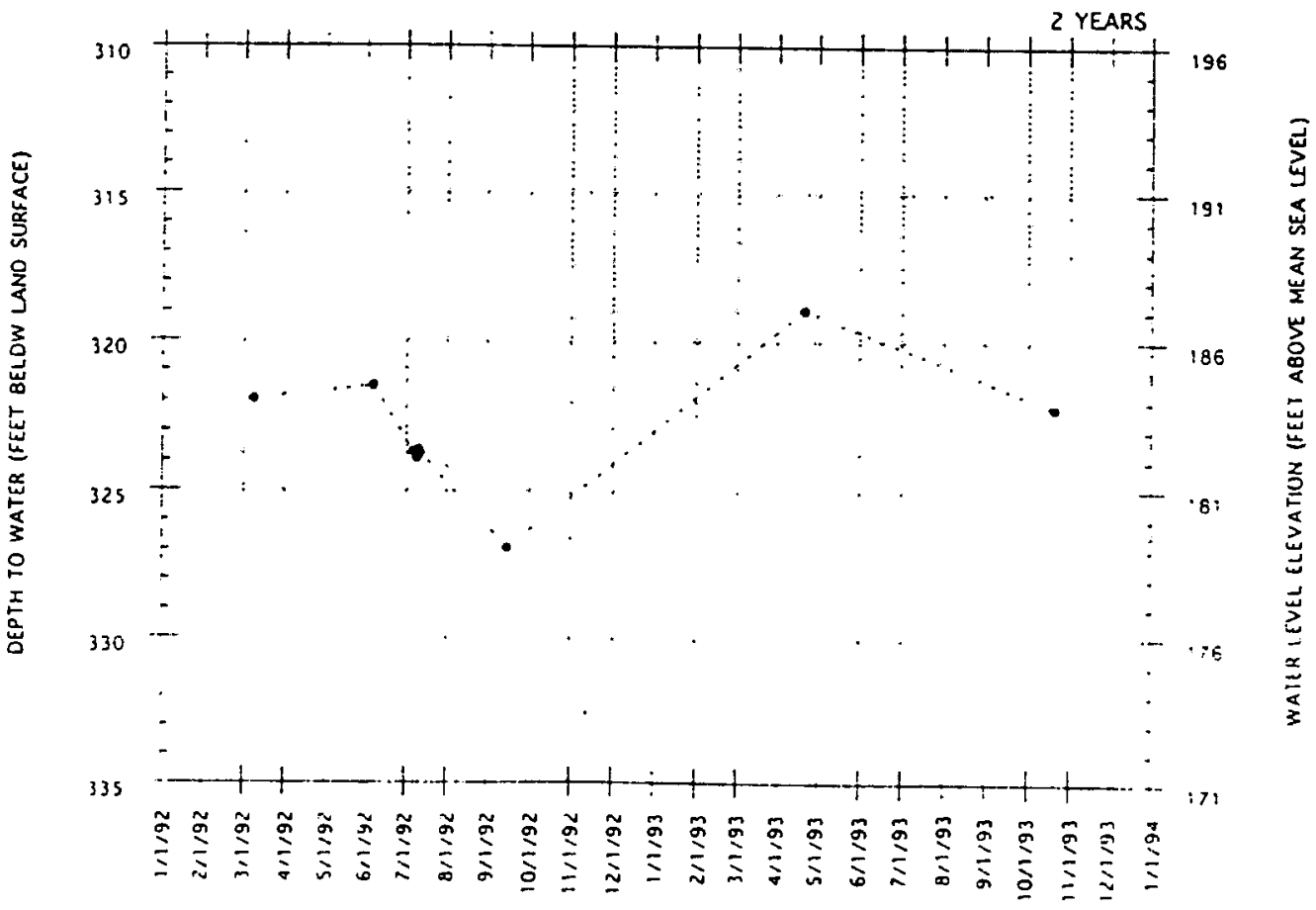



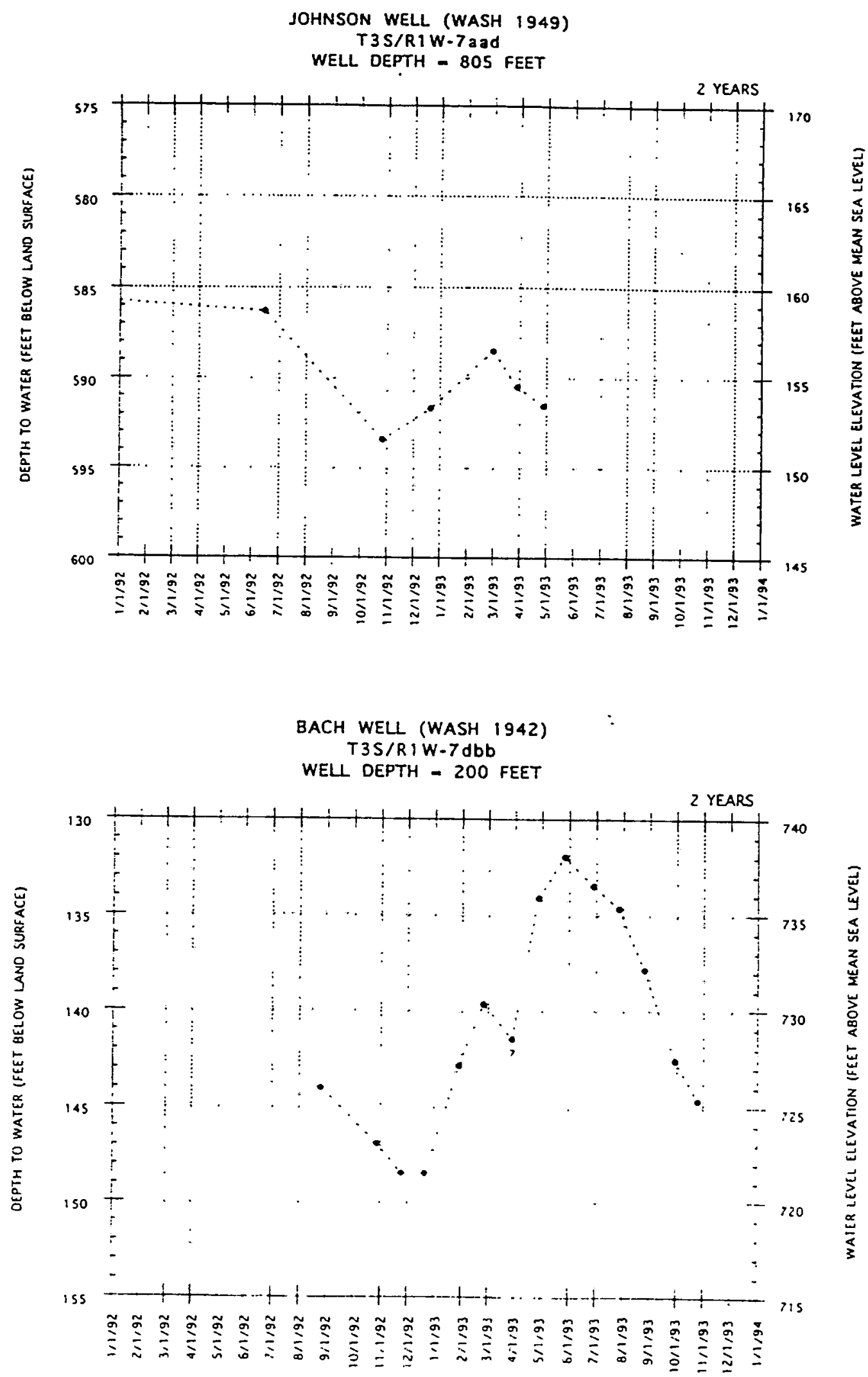
PHILPOT WELL (CLAC 7871)

T3S/RIW-8CdC

WELL DEPTH - 305 FEET

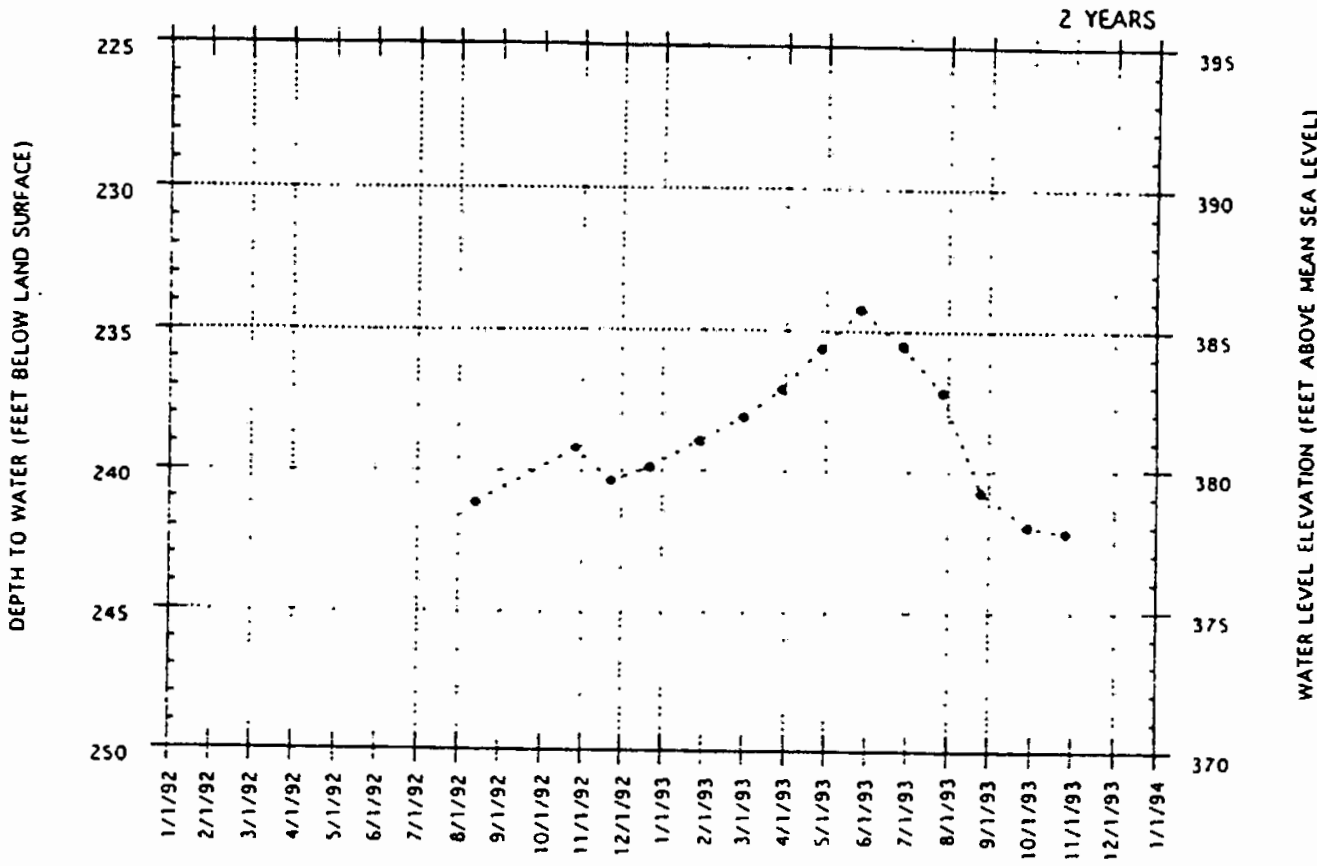

ROGERS WELL (CLAC 7918)

T3S/R IW-8abC

WELL DEPTH - 455 FEET

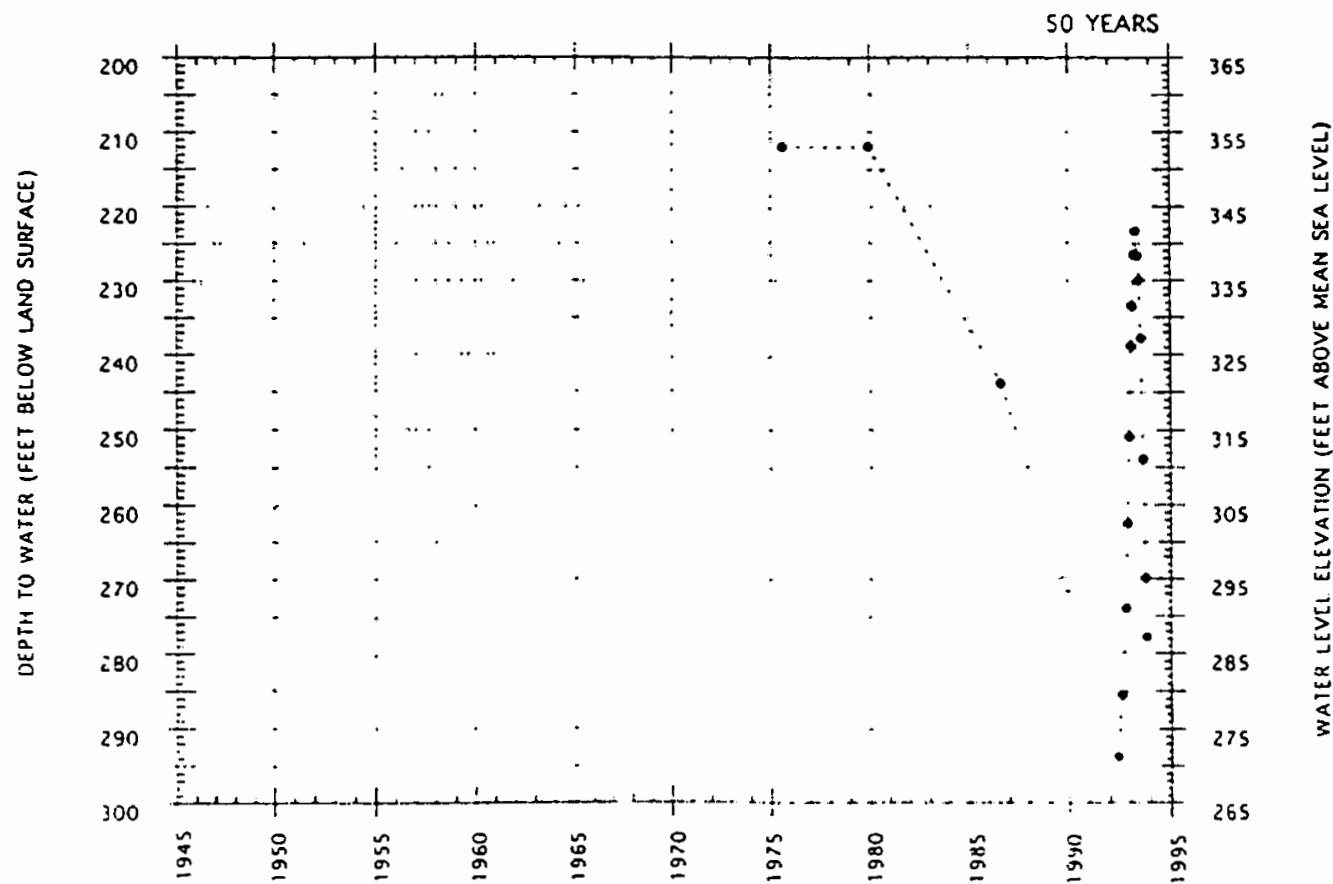




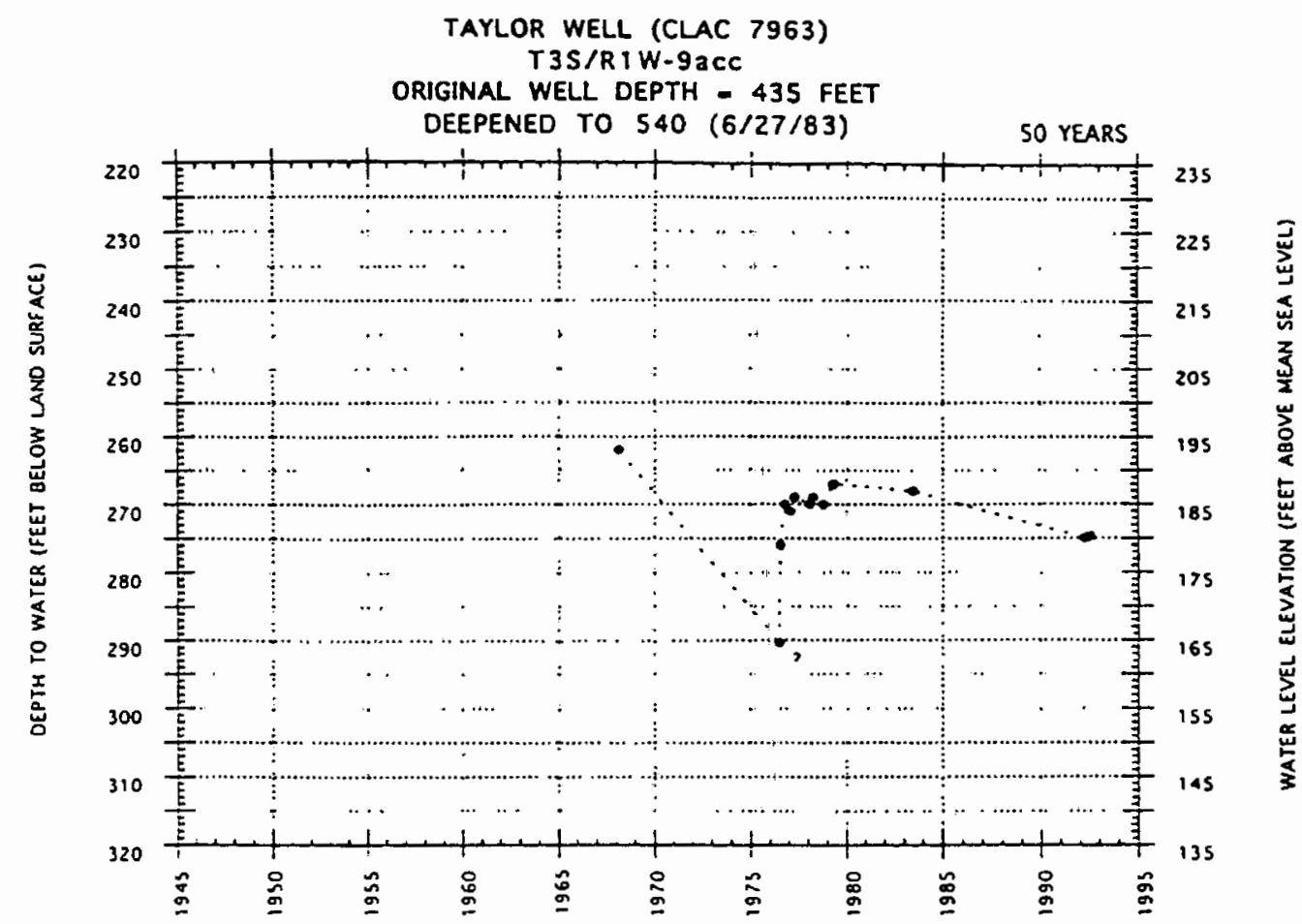

GOLDBECK WELL (CLAC 7968)

T3S/RIW-9bad

WELL DEPTH - 200 FEET

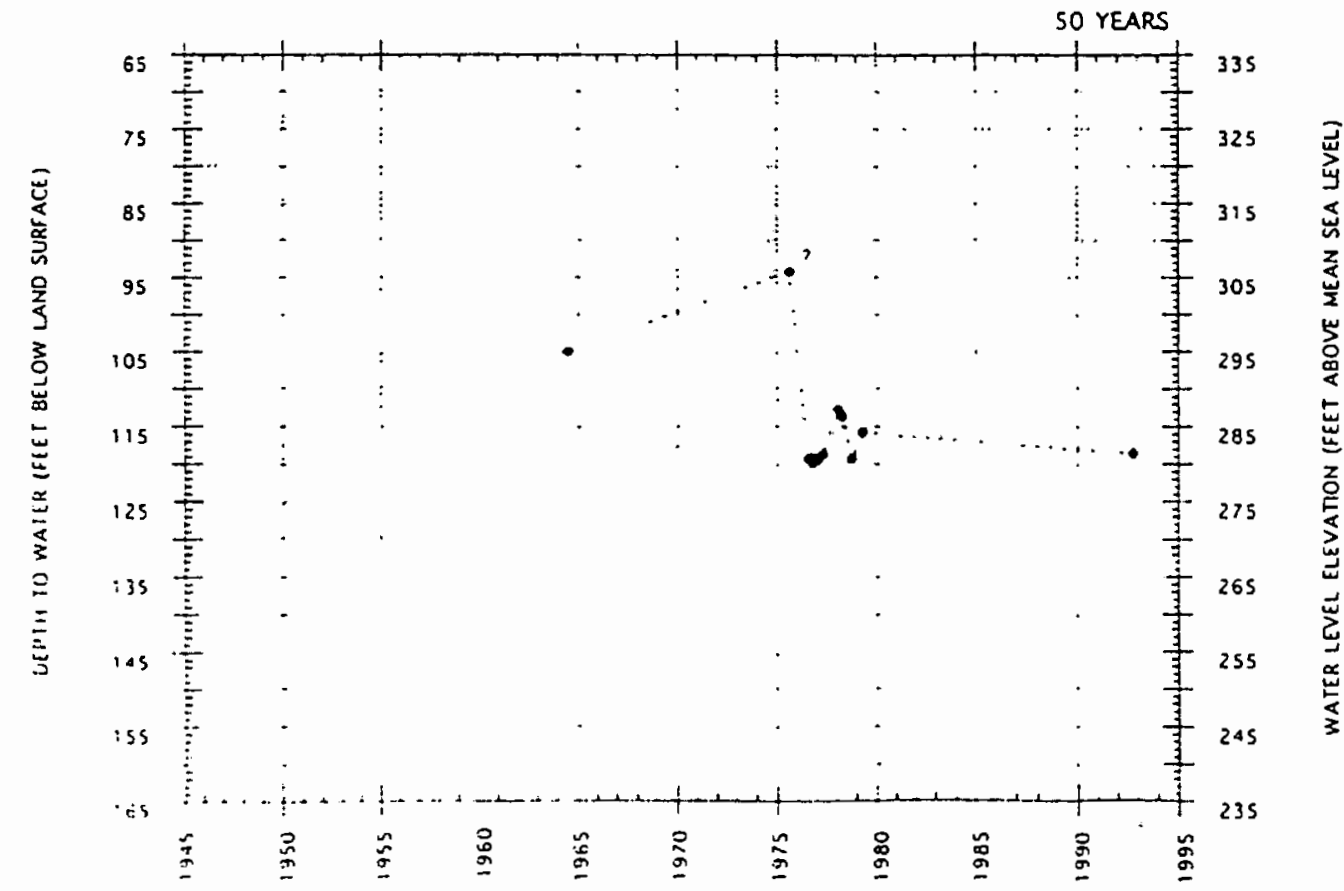



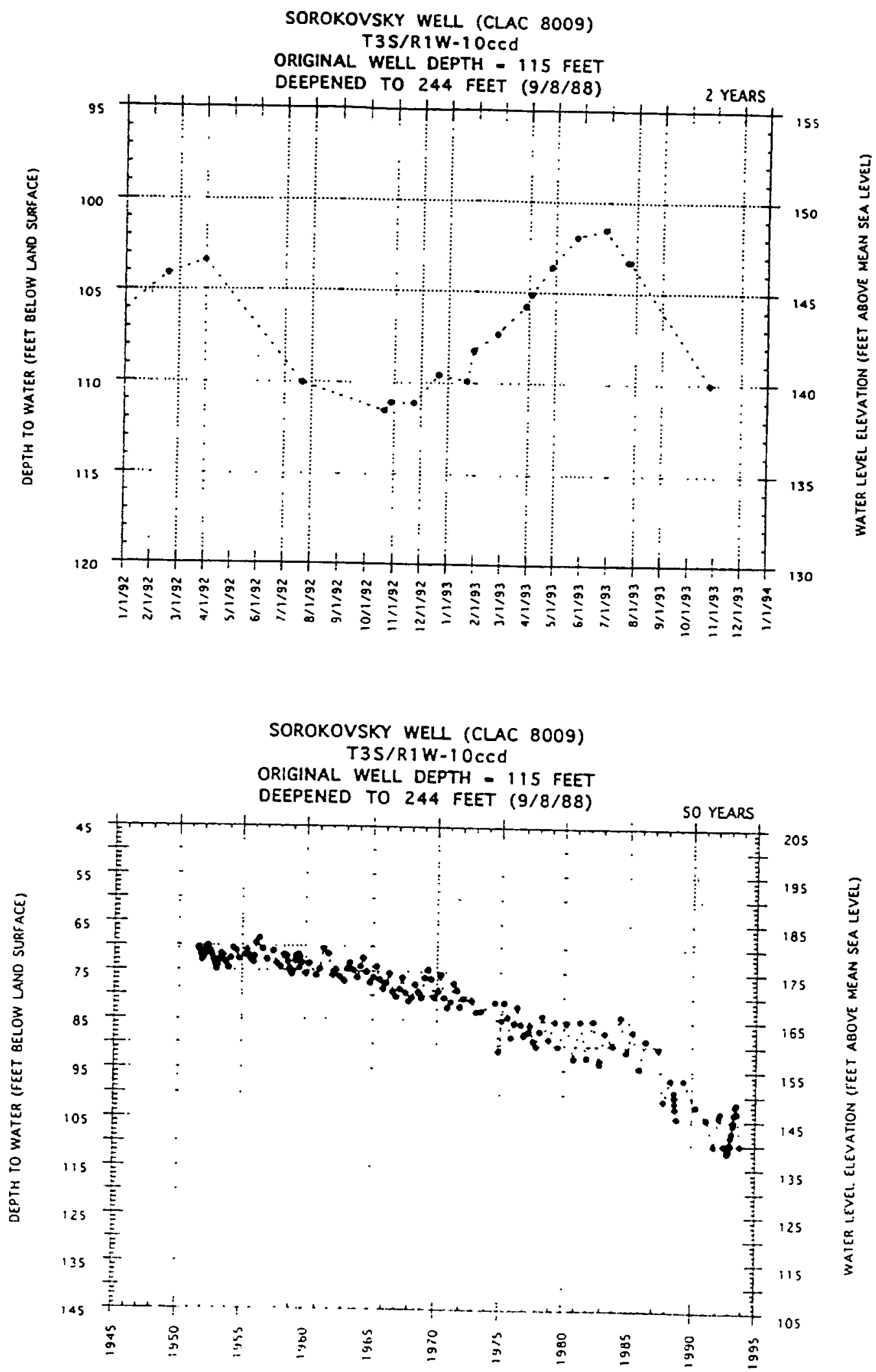

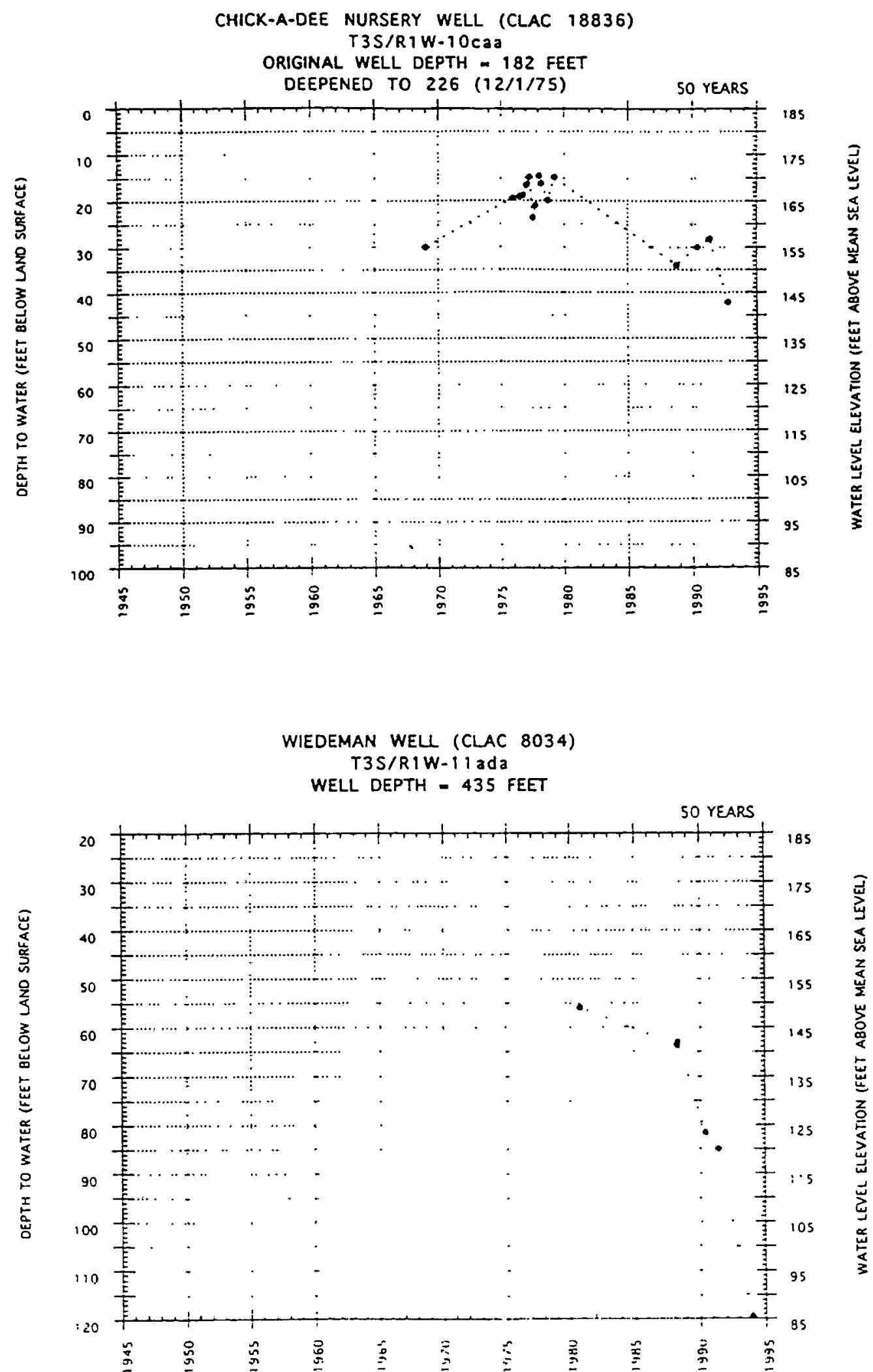

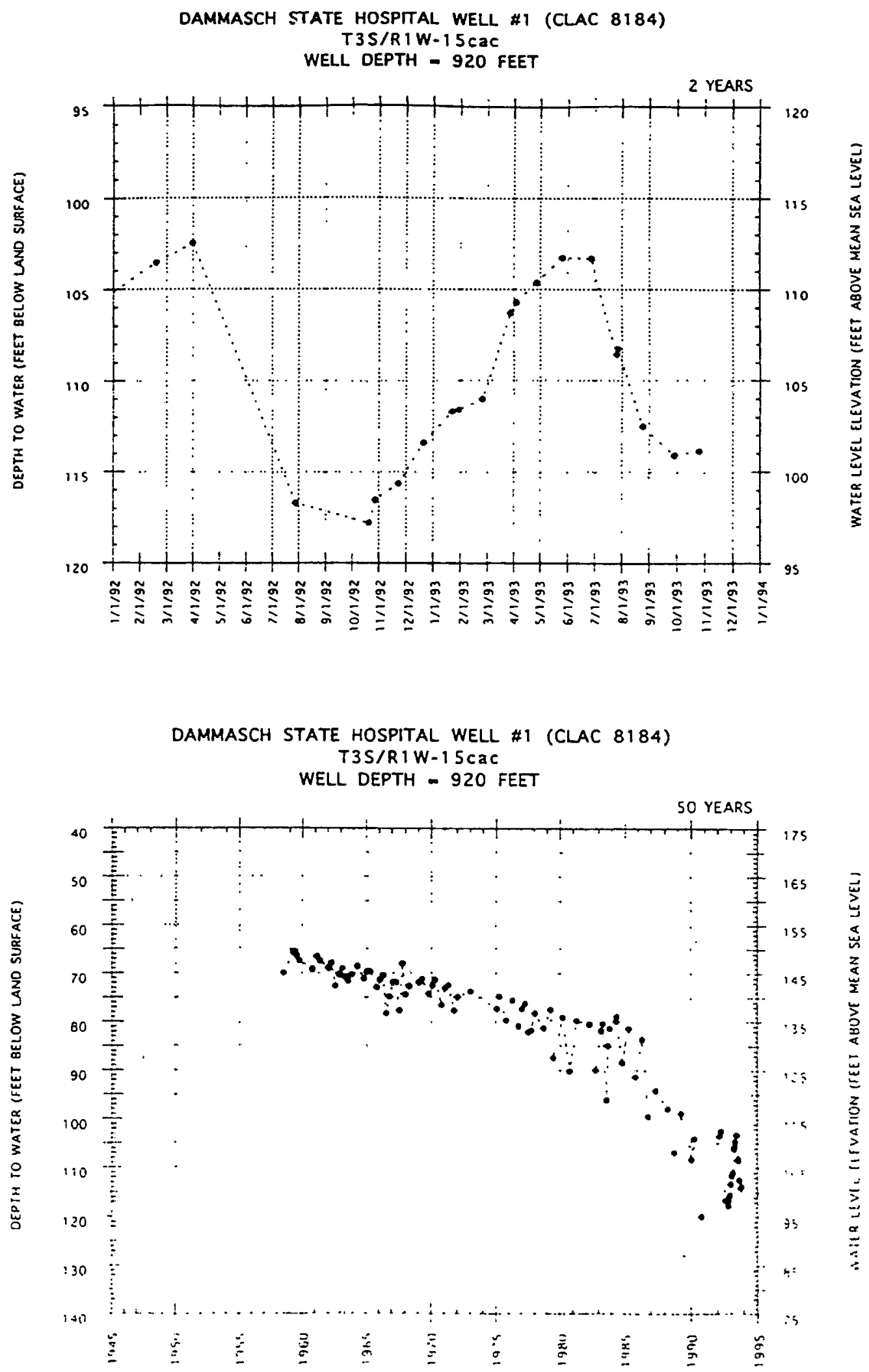


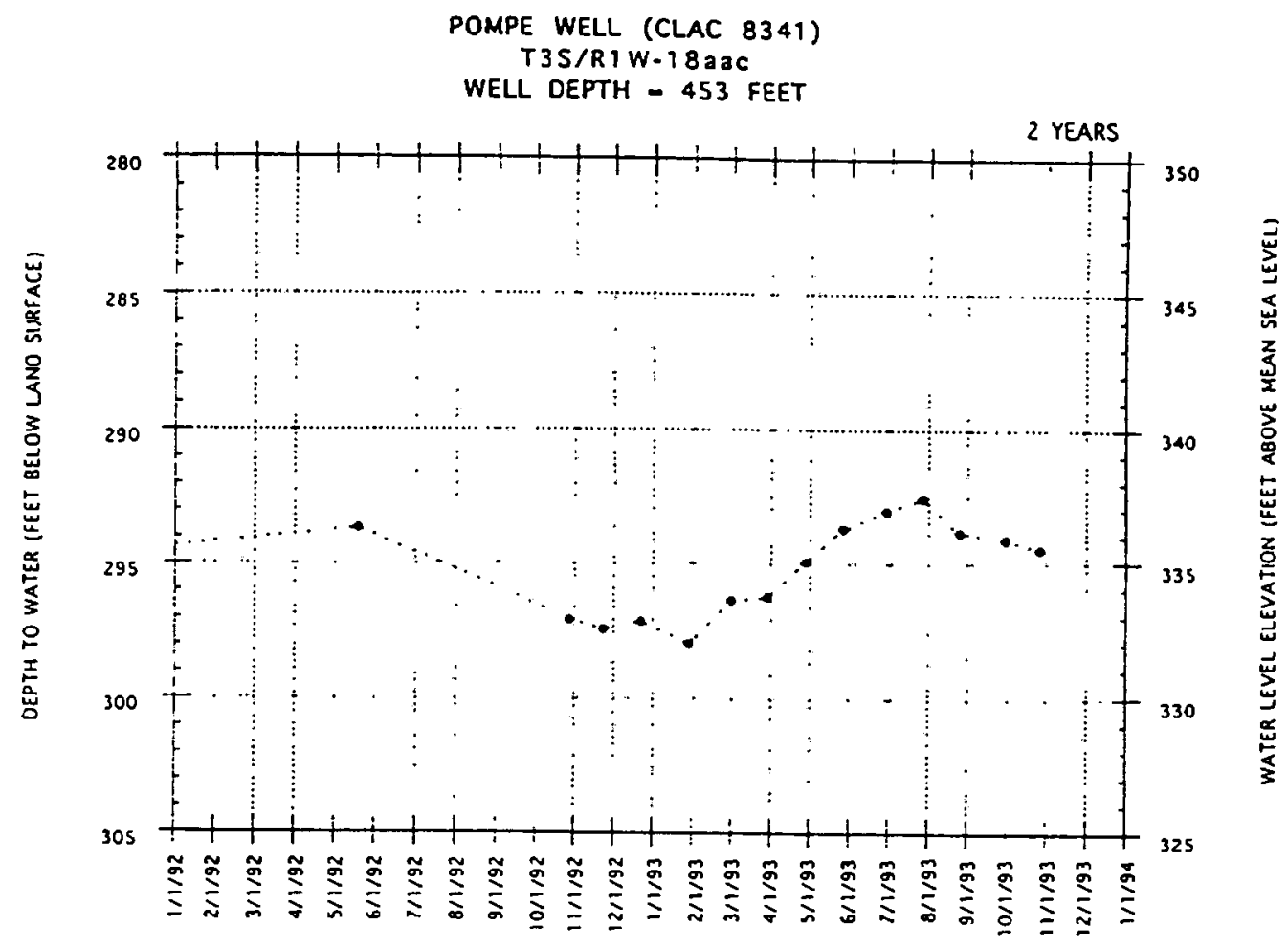



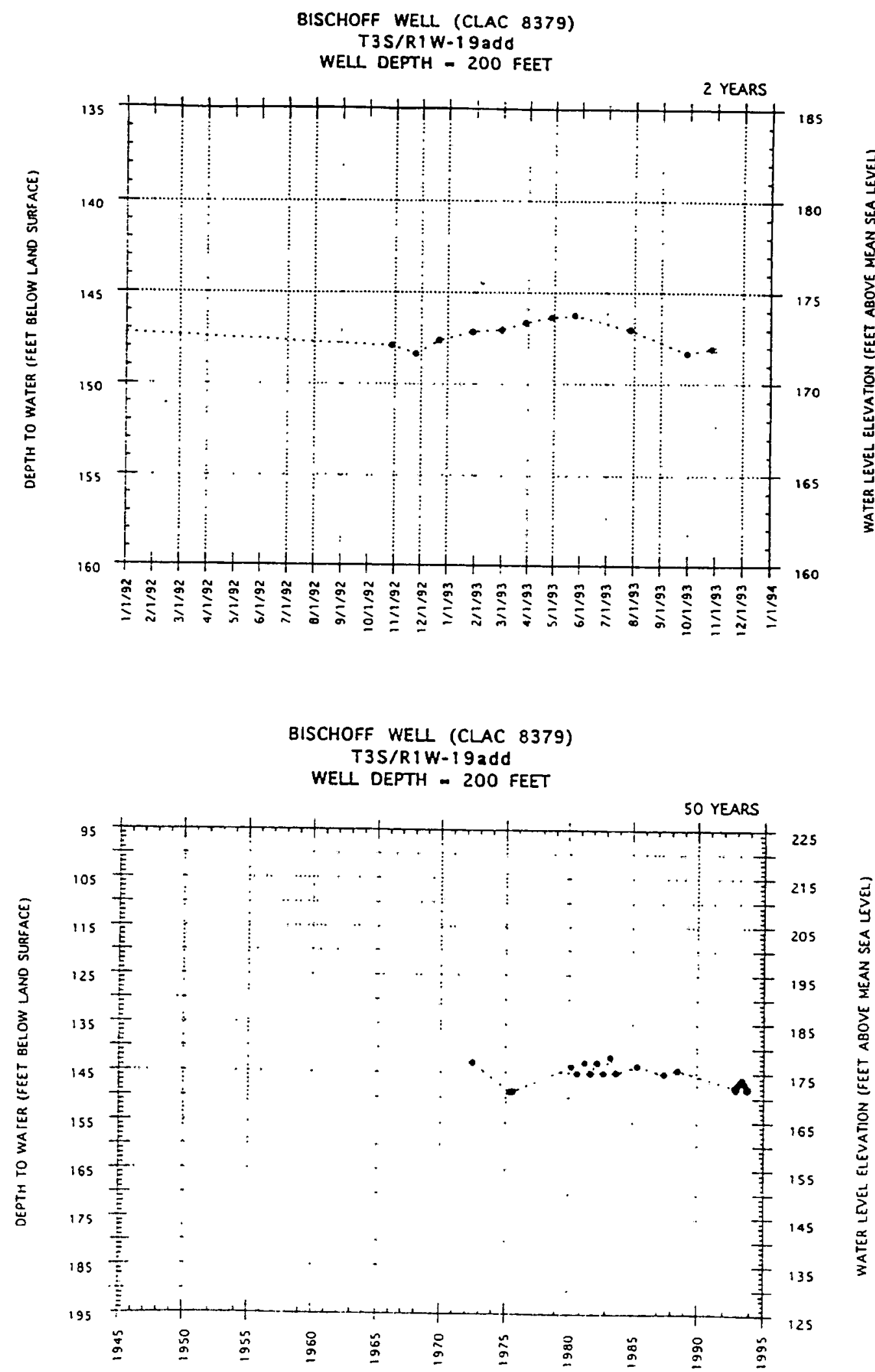

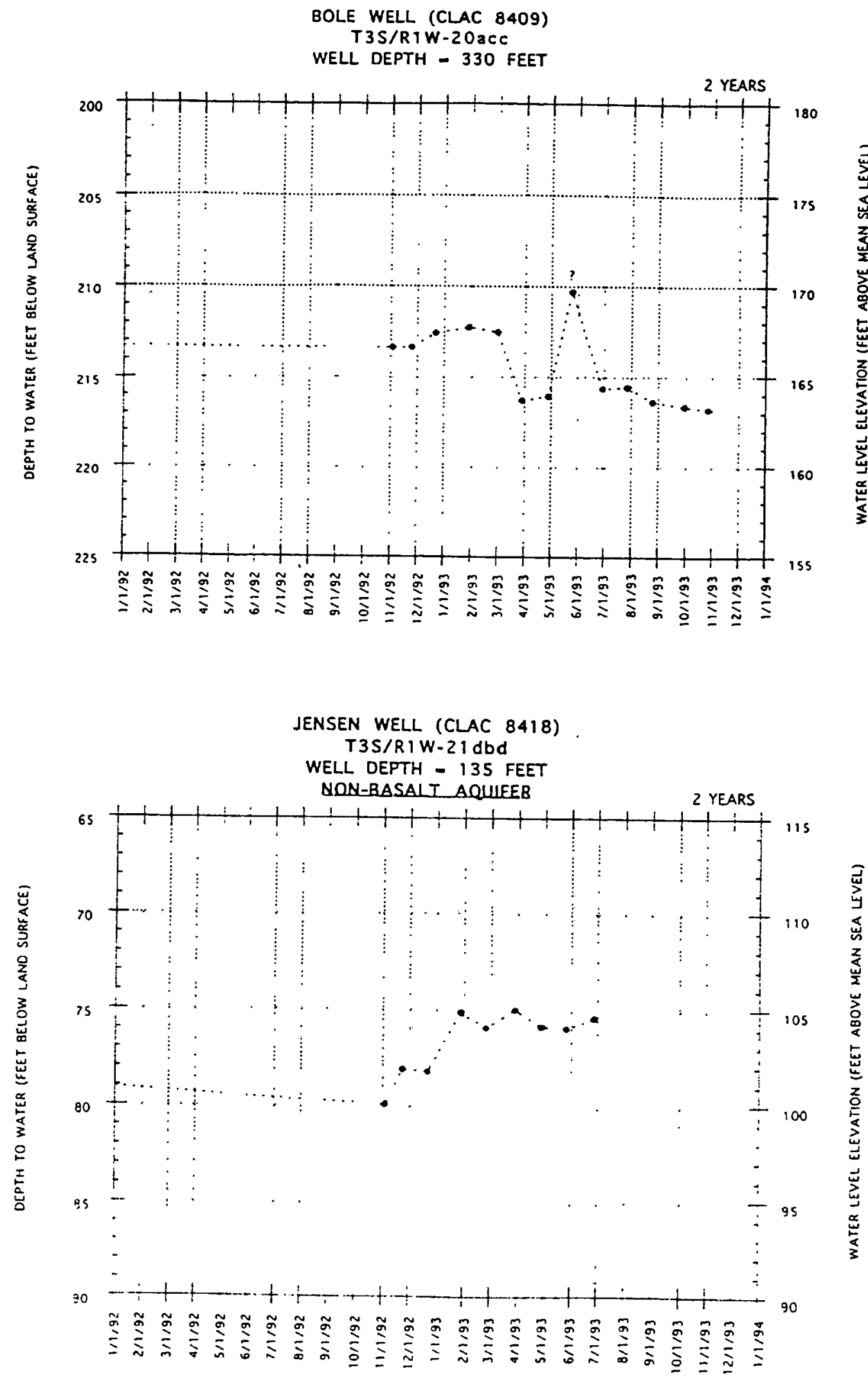


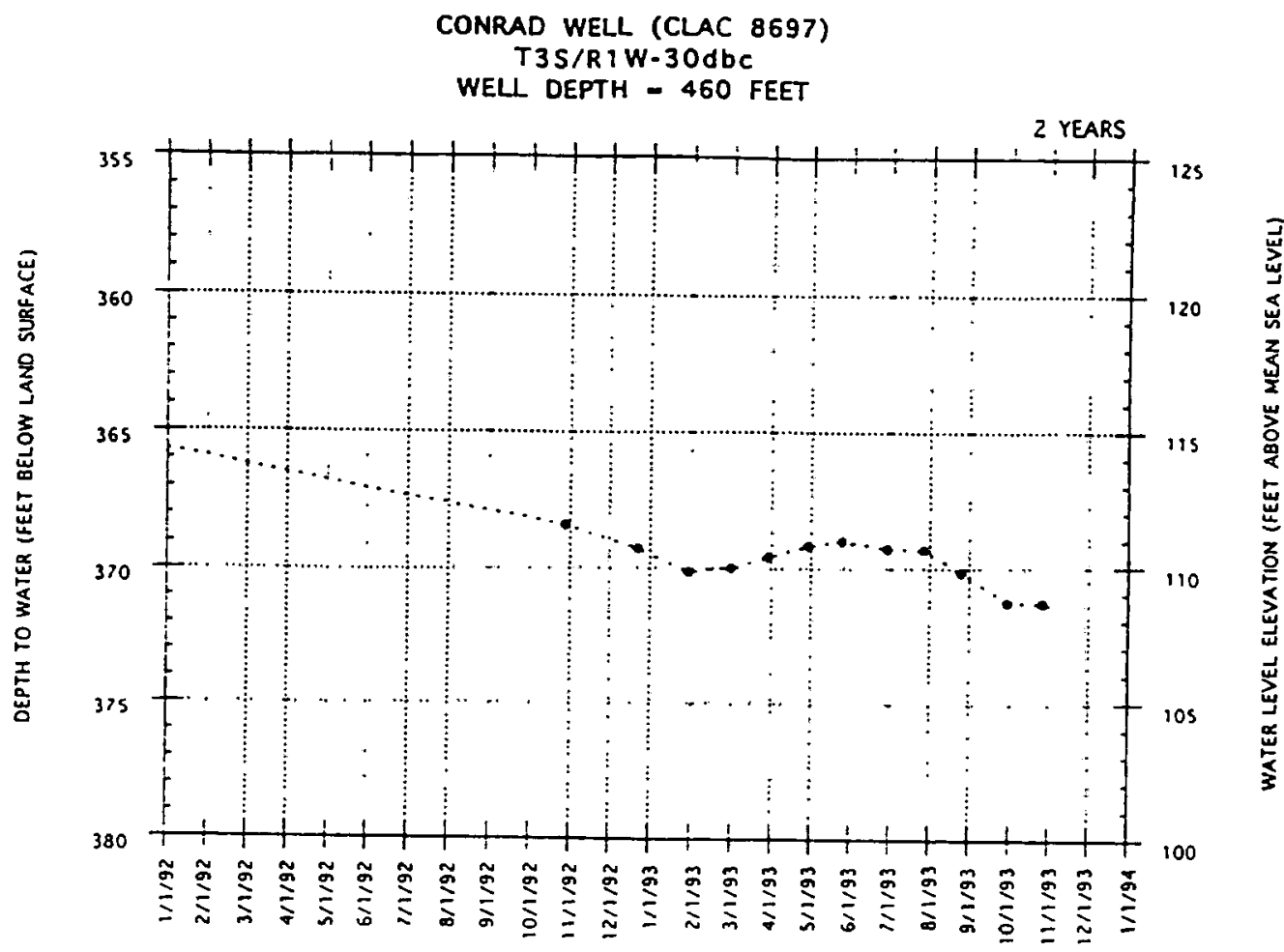

CONRAD WELL (CLAC 8697)

T3S/R1W-30dbc

WELL DEPTH - 460 FEET

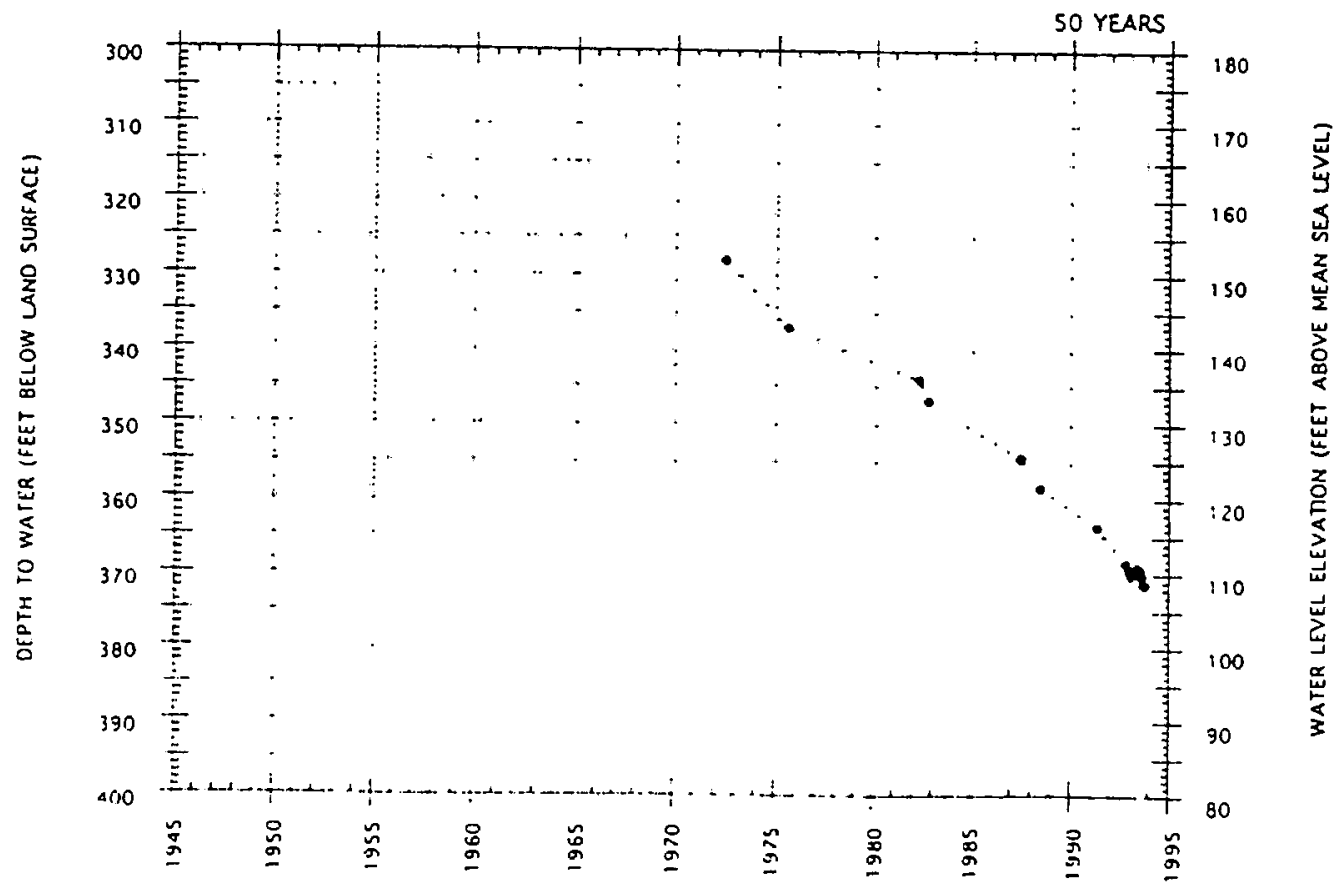




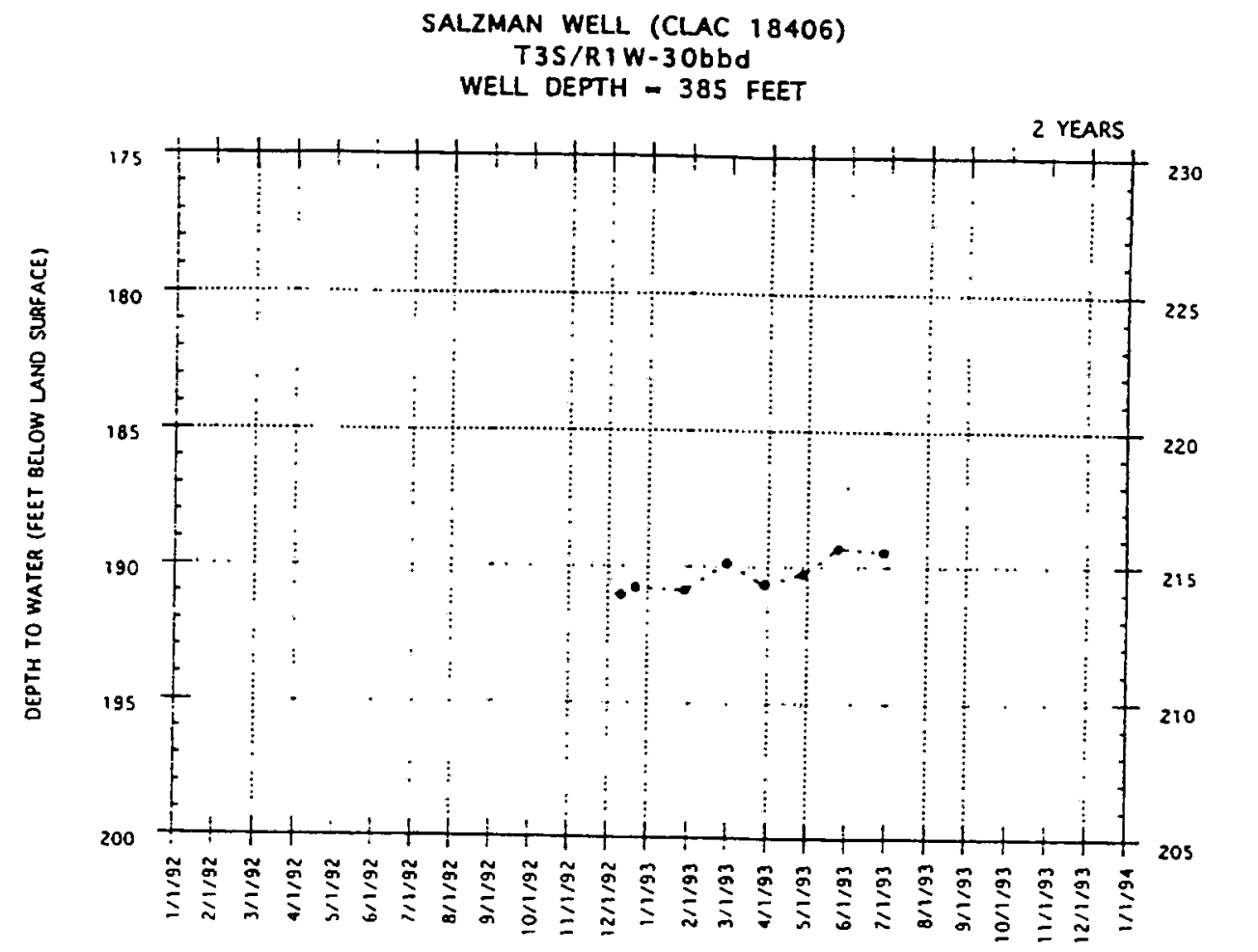

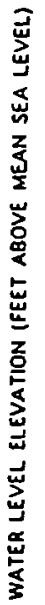

SMITH WEL (CLAC 8741)

T3S/R IW-31 bdb

WELL DEPTH - 365 FEET

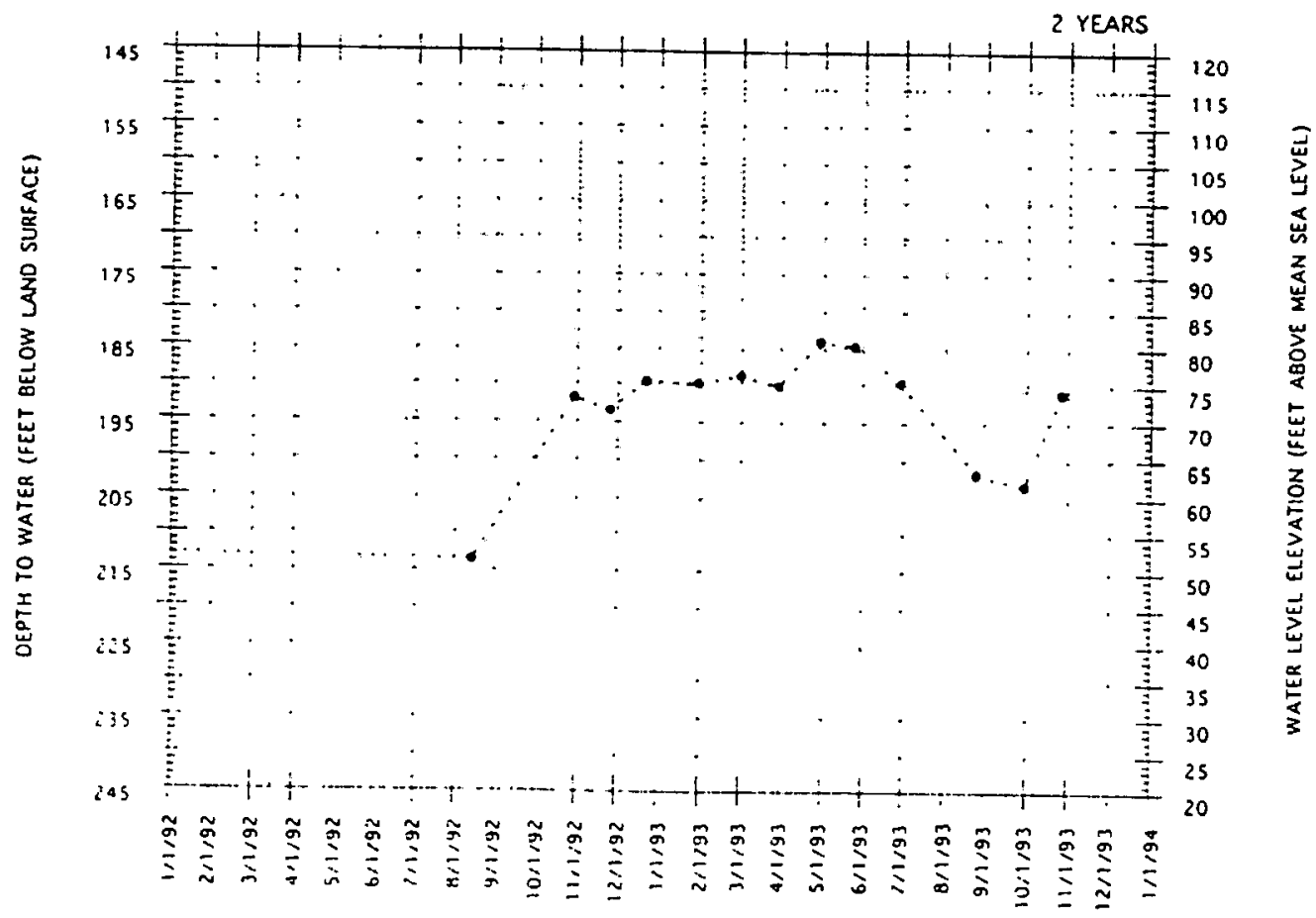



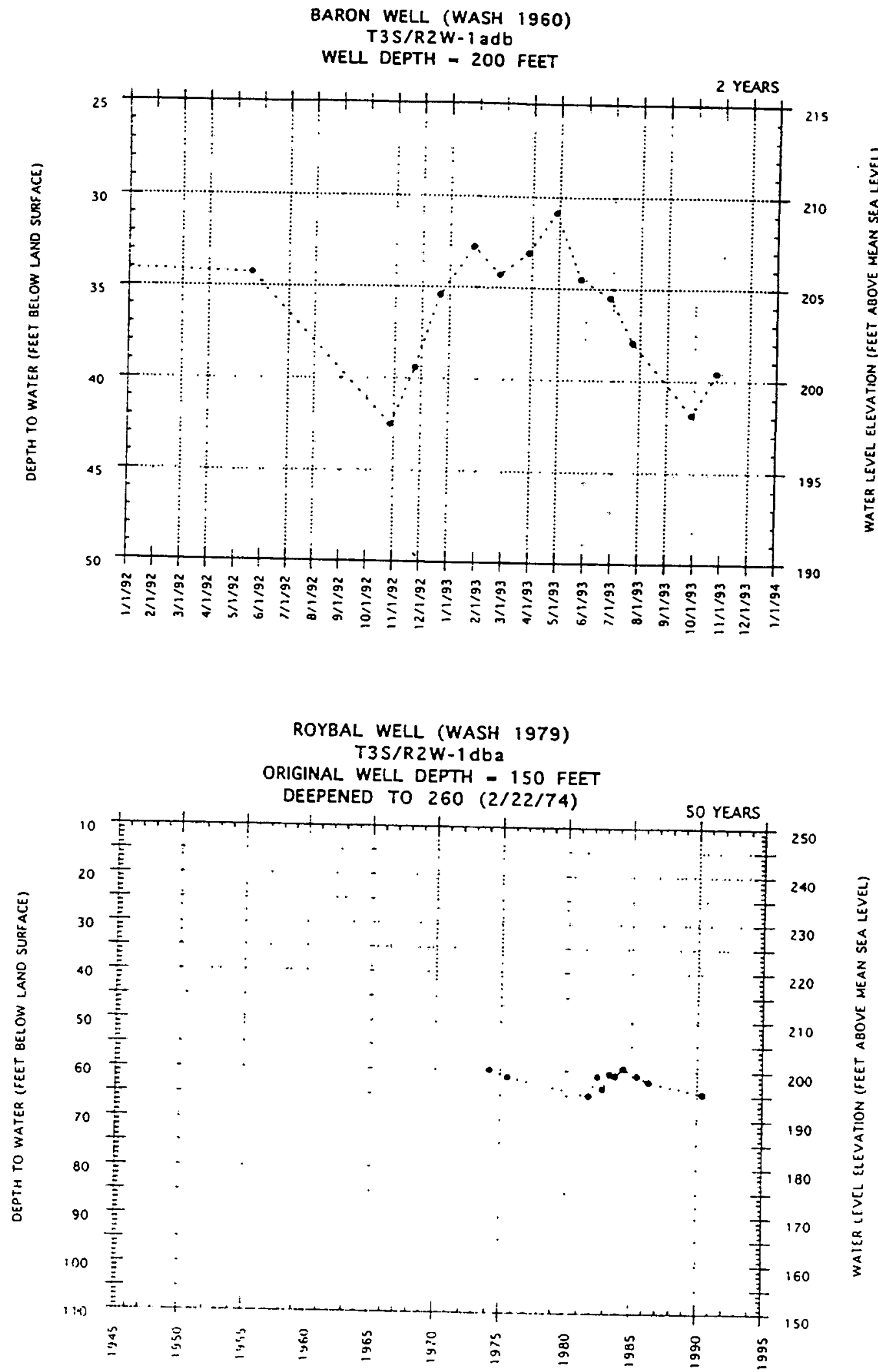


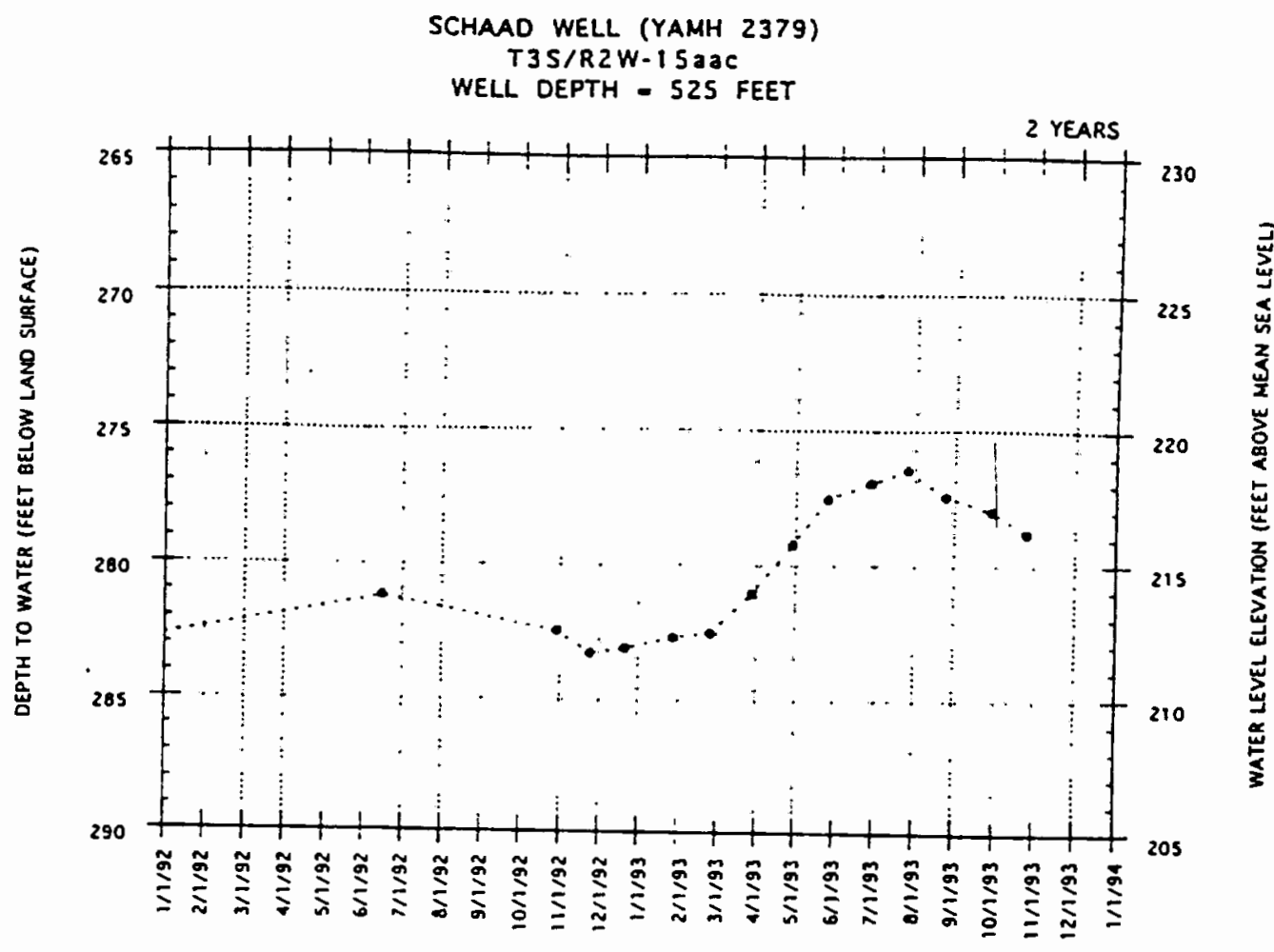



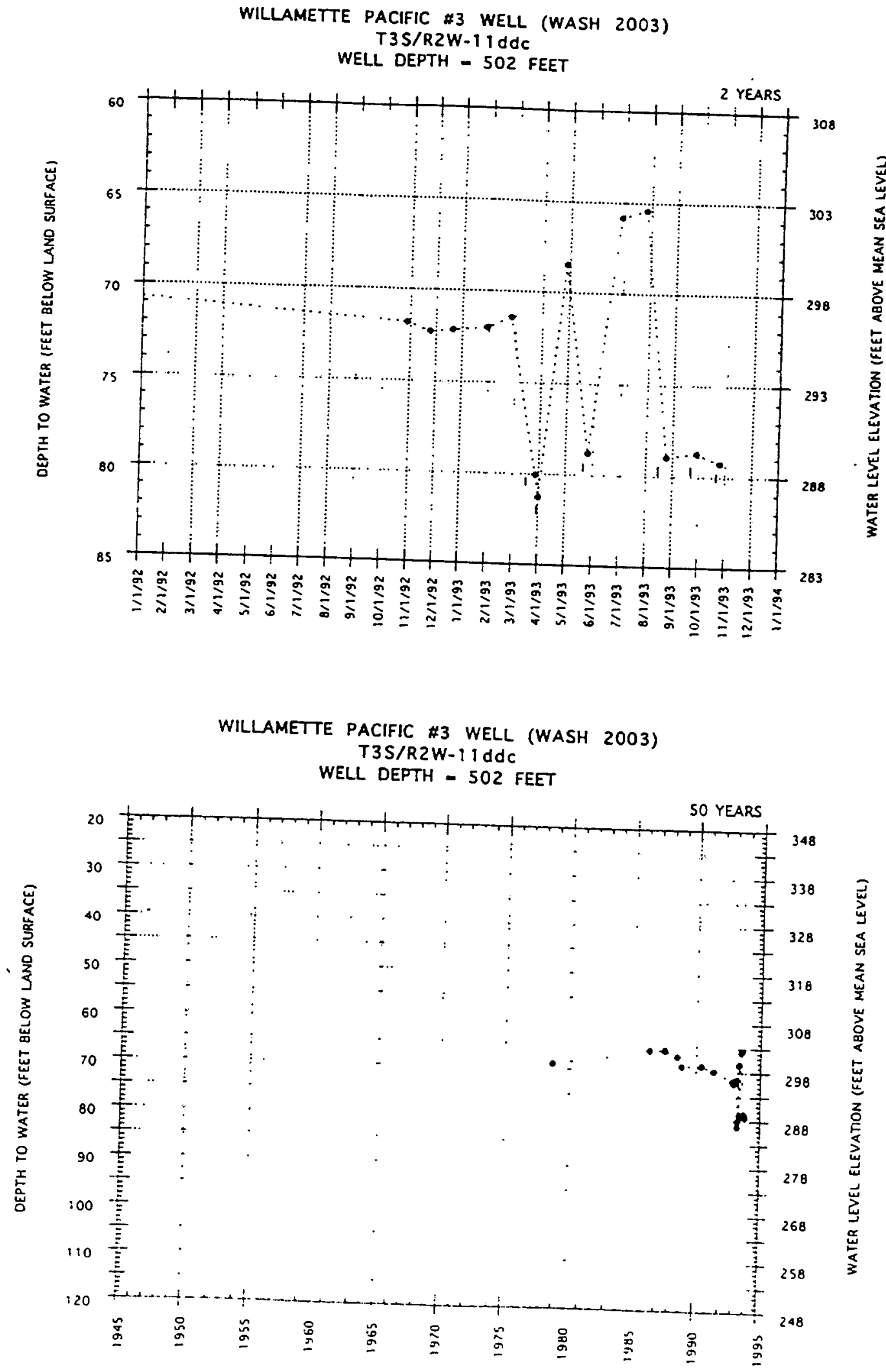

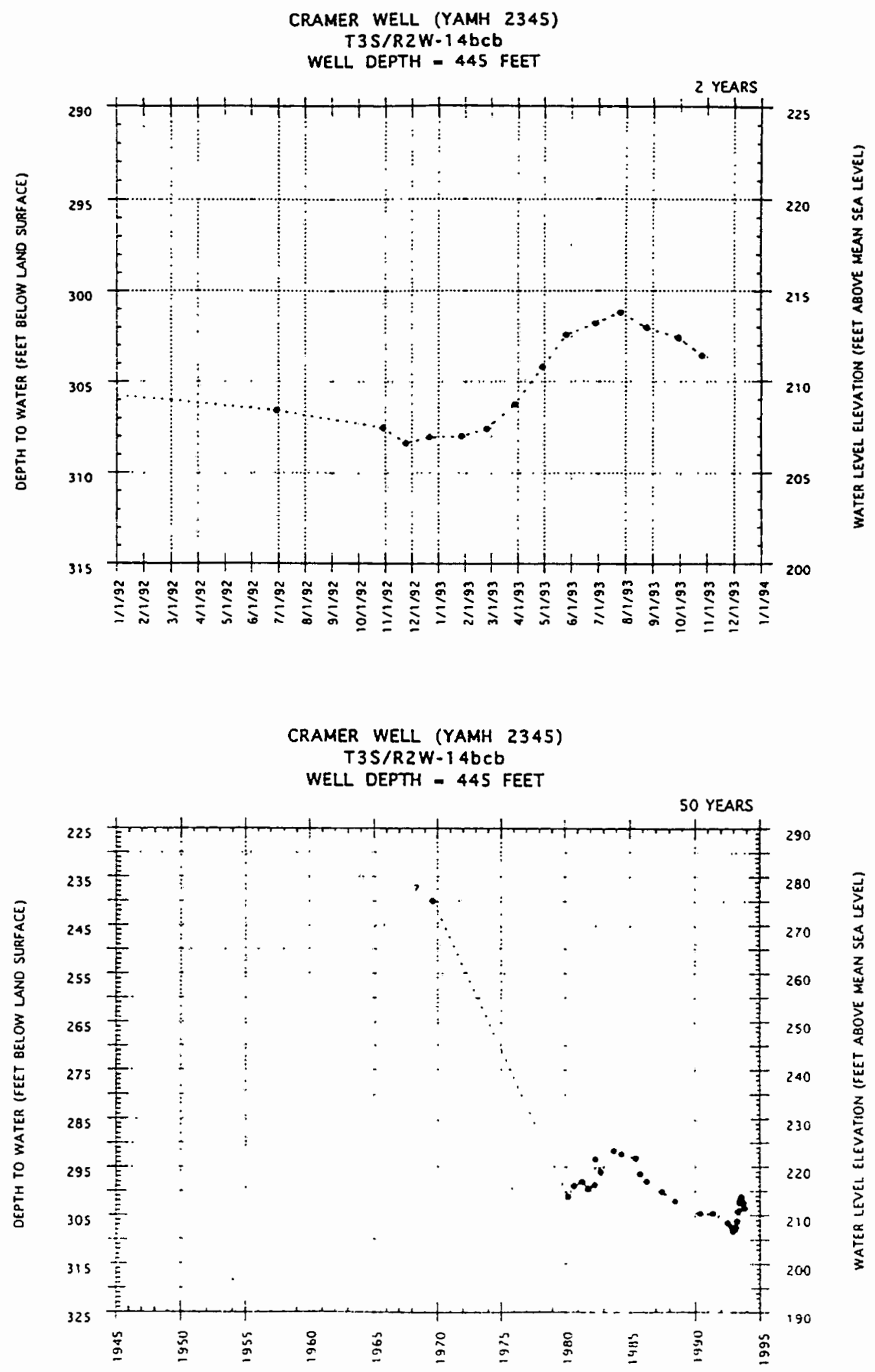

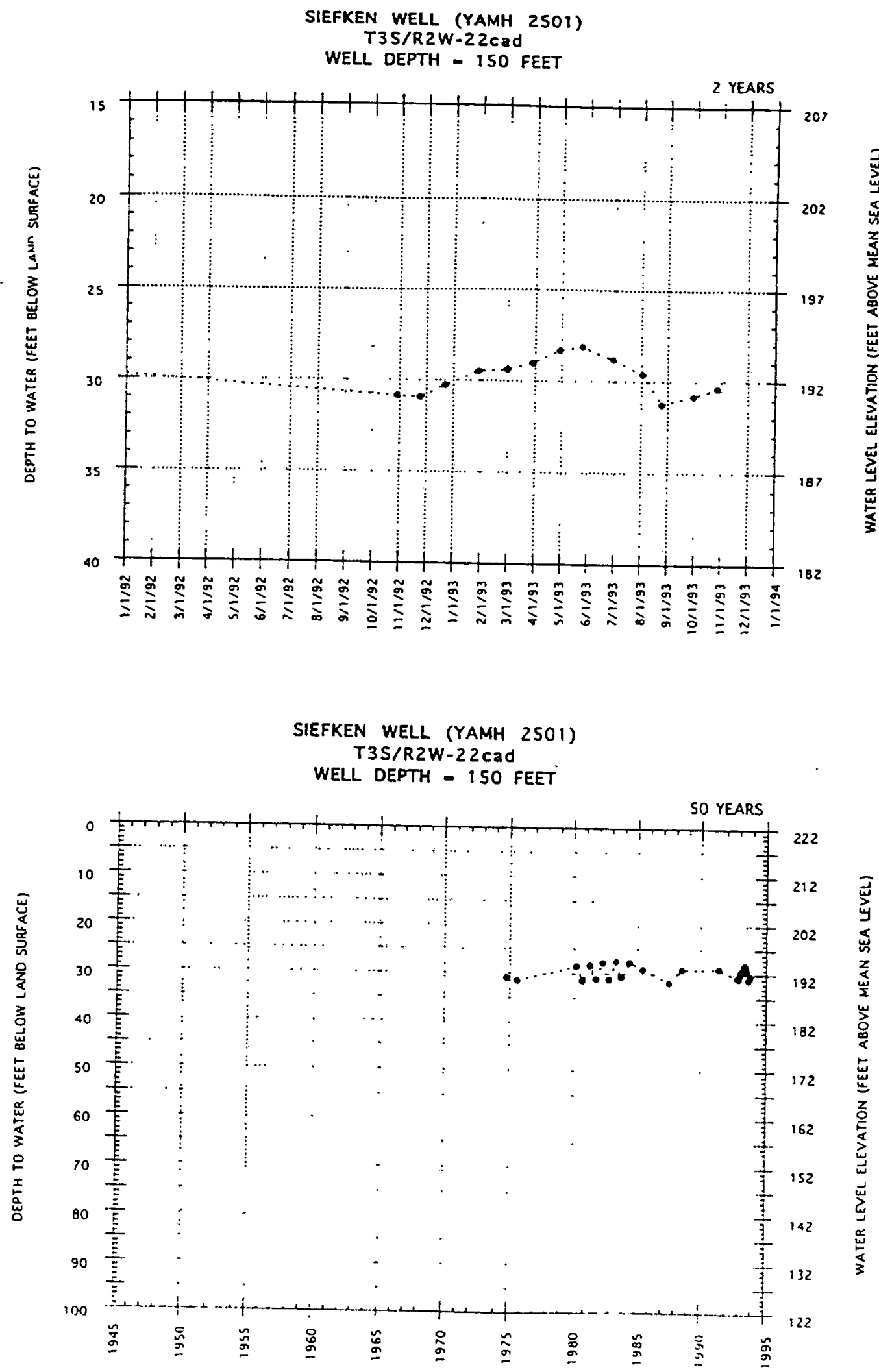


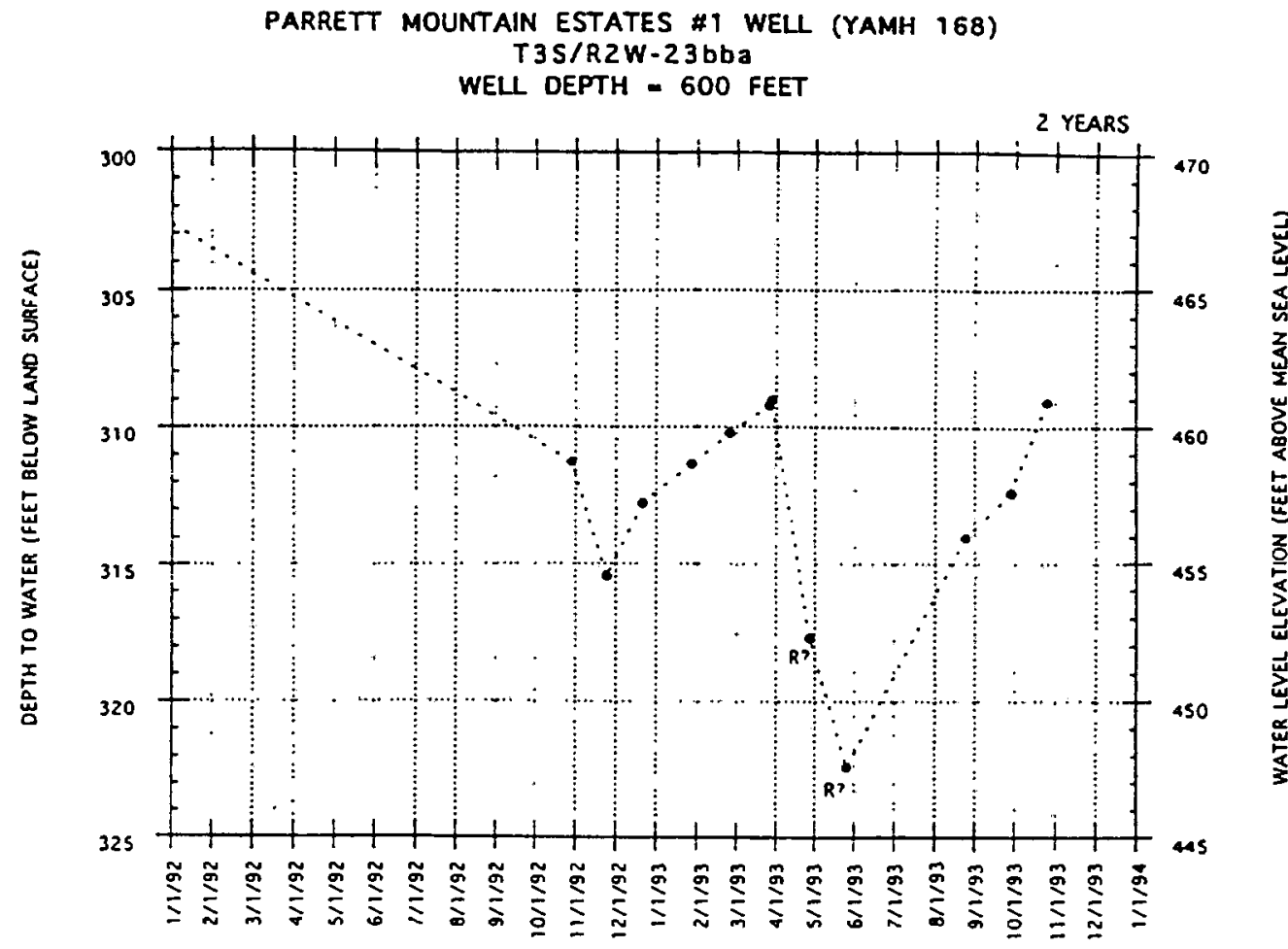

BAUER WELL (YAMH 2532)

T3S/R2W-23dca

WELI DEPTH - 403 FEET

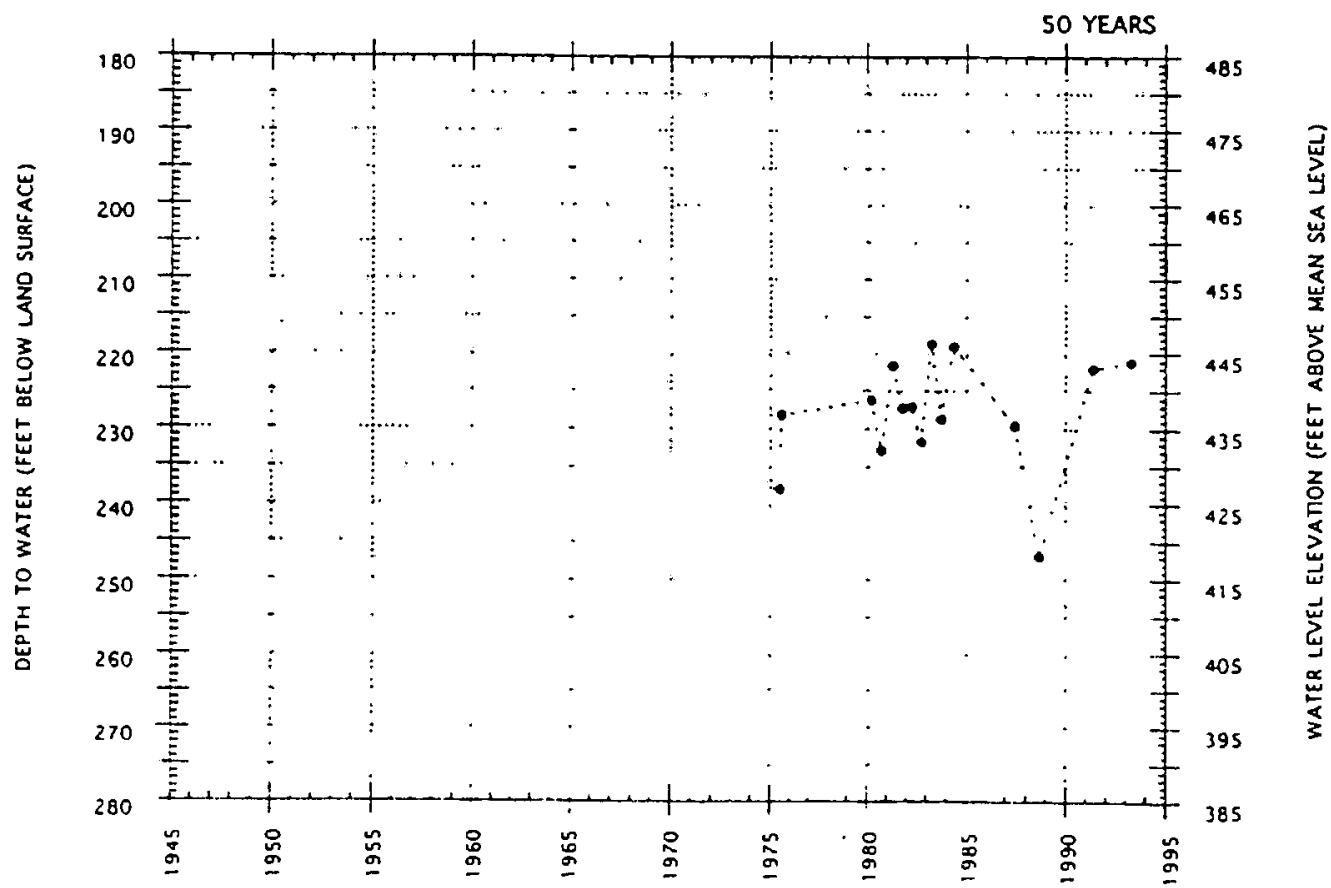



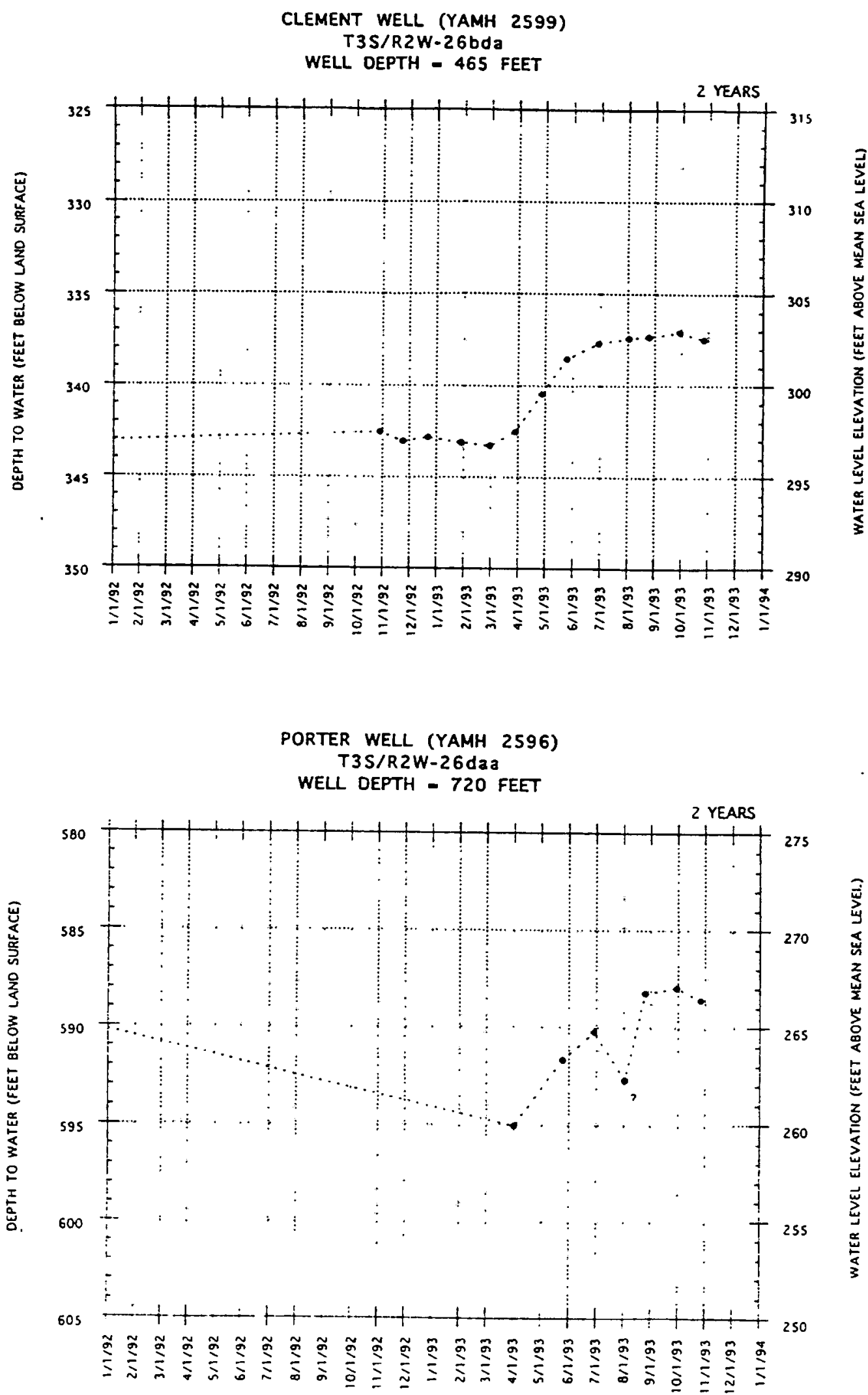


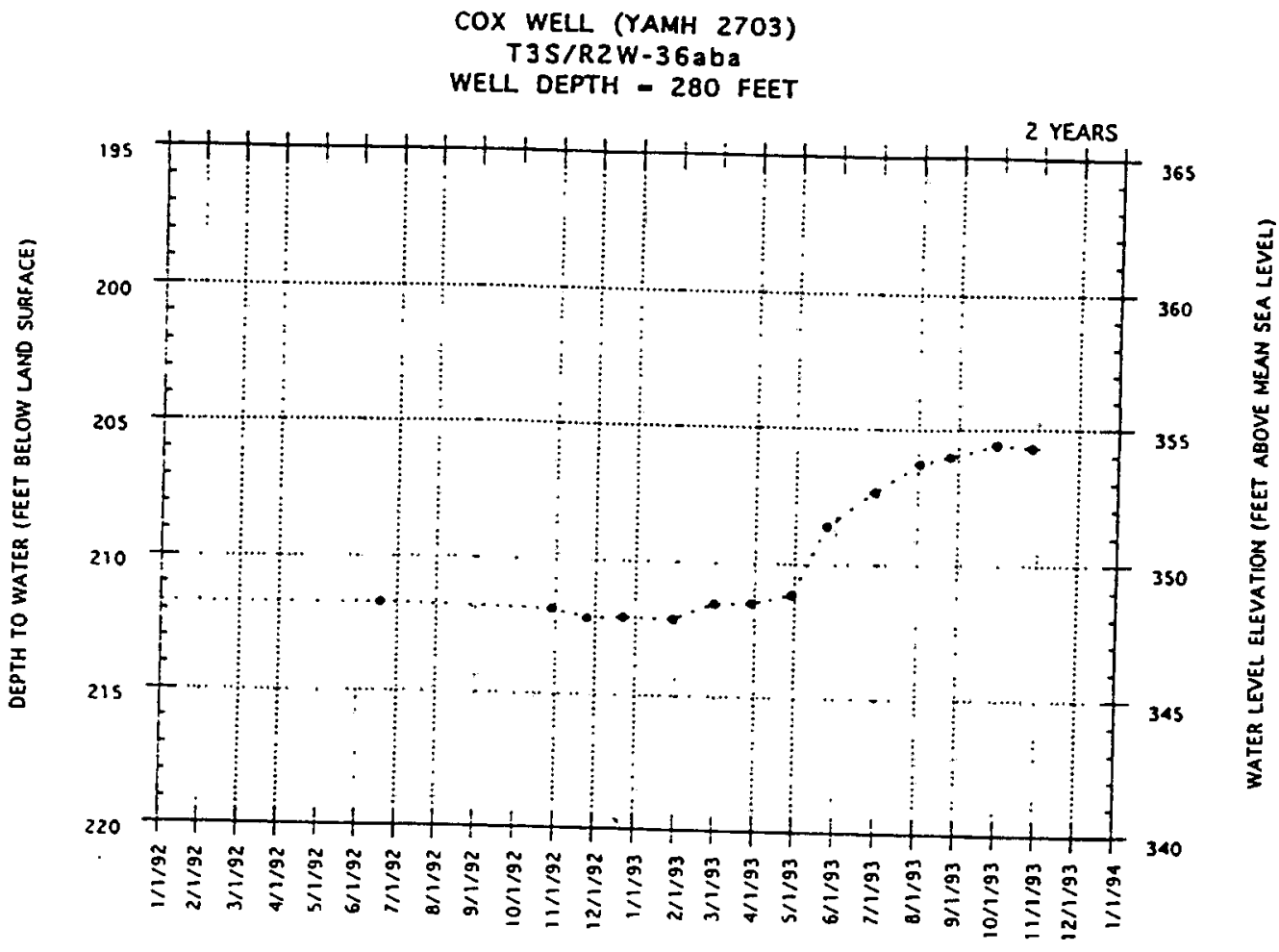

